\title{
Hydrogeological and Groundwater Flow Model for C, K, L, and P Reactor Areas, Savannah River Site, Aiken, South Carolina
}

by

G. P. Flach

Westinghouse Savannah River Company

Savannah River Site

Aiken, South Carolina 29808

M. K. Harris

R. A. Hiergesell

A. D. Smits

K. L. Hawkins

DOE Contract No. DE-AC09-96SR18500

This paper was prepared in connection with work done under the above contract number with the U.S. Department of Energy. By acceptance of this paper, the publisher and/or recipient acknowledges the U.S. Government's right to retain a nonexclusive, royalty-free license in and to any copyright covering this paper, along with the right to reproduce and to authorize others to reproduce all or part of the copyrighted paper. 
WSRC-TR-98-00285

Rev. 0

\section{Hydrogeological and Groundwater Flow Model for C, K, L, and P Reactor Areas, Savannah River Site, Aiken, South Carolina (U)}

Gregory P. Flach, Mary K. Harris, Robert A. Hiergesell, Andrew D. Smits

and Kelley L. Hawkins

September 1998

Prepared by:

Westinghouse Savannah River Company

Savannah River Site

Aiken, SC 29808

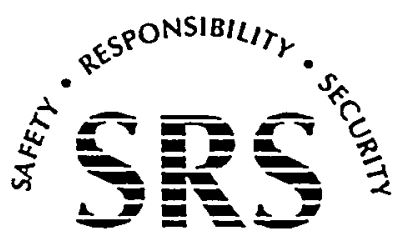

SAVANNAH RIVER SITE

Prepared for the U.S. Department of Energy Under

Contract Number DE-AC09-96SR18500 


\section{DISCLAMMER}

This report was prepared as an account of work sponsored by an agency of the United States Government. Neither the United States Government nor any agency thereof, nor any of their employees, makes any warranty, express or implied, or assumes any legal liability or responsibility for the accuracy, completeness, or usefulness of any information, apparatus, product, or process disclosed, or represents that its use would not infringe privately owned rights. Reference herein to any specific commercial product, process, or service by trade name, trademark, manufacturer, or otherwise does not necessarily constitute or imply its endorsement, recommendation, or favoring by the United States Government or any agency thereof. The views and opinions of authors expressed herein do not necessarily state or reflect those of the United States Government or any agency thereof.

This report has been reproduced directly from the best available copy.

Available to DOE and DOE contractors from the Office of Scientific and Technical Information, P.O. Box 62, Oak Ridge, TN 37831; prices available from (615) 576-8401.

Available to the public from the National Technical Information Service, U.S. Department of Commerce, 5285 Port Royal Road, Springfield, VA 22161.

Printed in the United States of America

Prepared For

U.S. Department of Energy

And

Westinghouse Savannah River Company 


\section{DISCLAIMER}

Portions of this document may be illegible in electronic image products. Images are produced from the best available original document. 


\section{Hydrogeological and Groundwater Flow Model for C, K, L, and P Reactor Areas, Savannah River Site, Aiken, South Carolina (U)}

Gregory P. Flach, Mary K. Harris, Robert A. Hiergesell, Andrew D. Smits

and Kelley L. Hawkins

September 1998

Prepared by:

Westinghouse Savannah River Company

Savannah River Site

Aiken, SC 29808

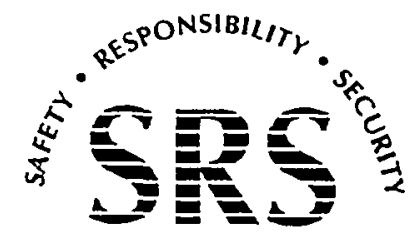

SAVANNAH RIVER SITE

Prepared for the U.S. Department of Energy Under

Contract Number DE-AC09-96SR18500 
Hydrogeological and Groundwater Flow Model for C, K, L, and P Reactor Areas, Savannah River Site, Aiken, South Carolina (U)

Authentication and Approvals:
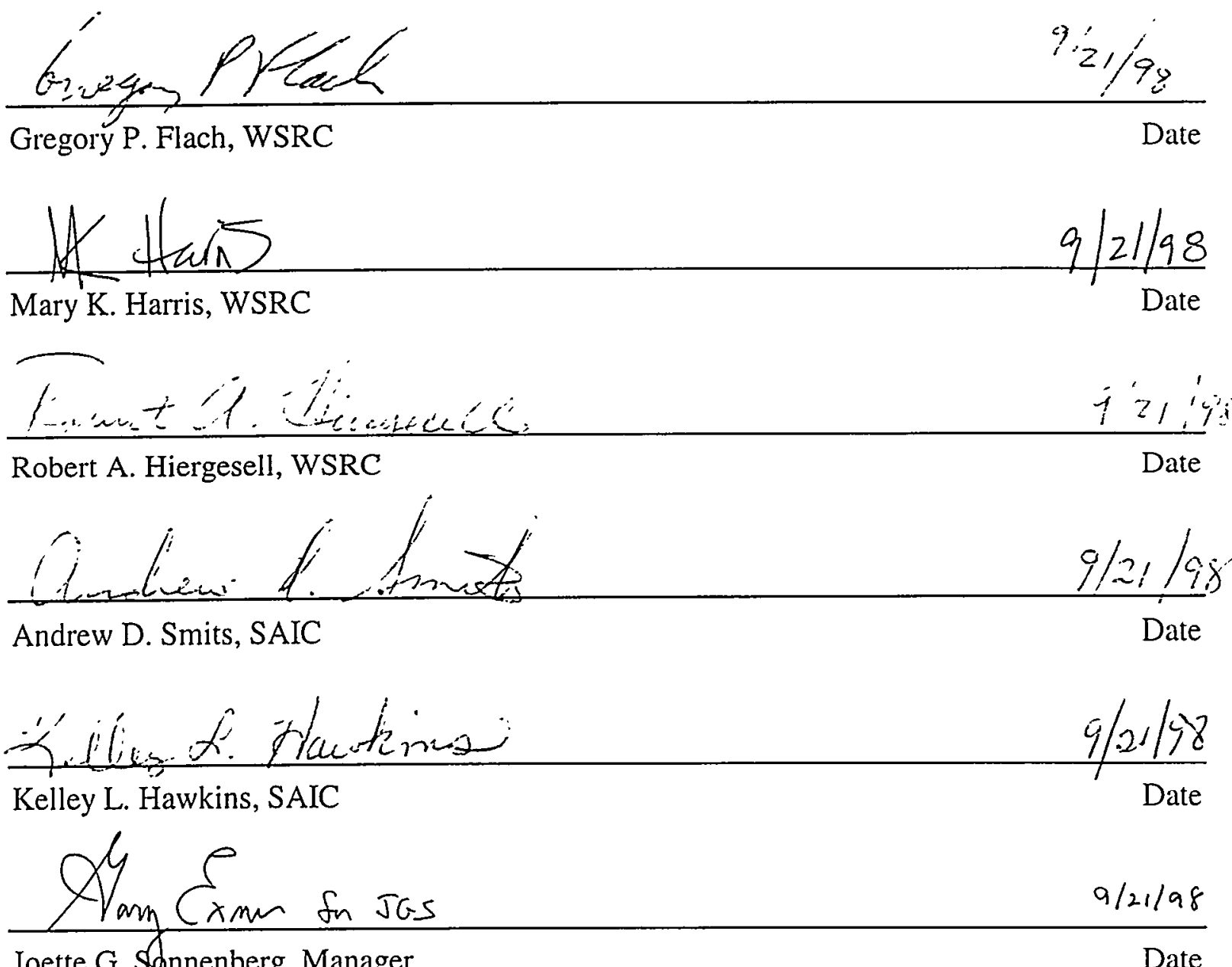

Joette G. Sonnenberg, Manager

Date 


\begin{abstract}
A regional groundwater flow model encompassing approximately $100 \mathrm{mi}^{2}$ surrounding the $\mathrm{C}$. $\mathrm{K}, \mathrm{L}$, and $\mathrm{P}$ reactor areas has been developed. The reactor flow model is designed to meet the planning objectives outlined in the General Groundwater Strategy for Reactor Area Projects by providing a common framework for analyzing groundwater flow, contaminant migration and remedial alternatives within the Reactor Projects team of the Environmental Restoration Department. The model provides a quantitative understanding of groundwater flow on a regional scale within the near surface aquifers and deeper semi-confined to confined aquifers. The model incorporates historical and current field characterization data up through Spring 1998. Model preprocessing is automated so that future updates and modifications can be performed quickly and efficiently. The CKLP regional reactor model can be used to guide characterization, perform scoping analyses of contaminant transport, and serve as a common base for subsequent finer-scale transport and remedial/feasibility models for each reactor area.
\end{abstract}

\title{
MODEL SUMMARY
}

The current groundwater flow model for $\mathrm{C}, \mathrm{K}, \mathrm{L}$, and $\mathrm{P}$ reactor areas simulates groundwater flow within the area bounded to the north by Upper Three Runs, to the west by the Savannah River, to the south by Steel Creek and Meyers Branch, and to the east by a line between McQueen Branch and Par Pond. Vertically the model extends from ground surface to the top of the Meyers Branch confining system. The model confirms that groundwater flow in upper aquifers at the Savannah River Site is recharge driven, with streams intercepting flow from higher elevations. The underlying Gordon aquifer is strongly influenced by and discharges to the Savannah River and Upper Three Runs. Nearly all recharge within the CKLP reactor region discharges to streams within or bounding the same area, usually the nearest stream, with the balance entering the Gordon aquifer. Simulated flow directions agree with the conceptual model of groundwater flow. Model calibration targets include groundwater recharge estimates, stream baseflow data and estimates, and water level measurements from more than 1000 wells. Model conductivity values in the Gordon aquifer and confining units are set directly to prior estimates based on field data. For the Upper Three Runs aquifer unit, conductivity values are defined through calibration to the groundwater flow and hydraulic head targets.

The chosen areal grid is 70,000 feet on a side, with a horizontal resolution of 500 square feet. The grid consists of 140 elements along each horizontal axis. The vertical resolution varies 
depending on hydrogeologic unit and terrain/hydrostratigraphic surface variations. The top surface of the mesh conforms to the ground surface. The bottom surface of the mesh coincides with the bottom of the Gordon aquifer unit. Interior node layers conform to the other stratigraphic surfaces. The "upper" aquifer zone of the Upper Three Runs aquifer includes the vadose zone and is represented by 3 finite-elements in the vertical direction. The "lower" aquifer zone of the Upper Three Runs aquifer contains 2 finite-elements. while the "tan clay" confining zone of the Upper Three Runs aquifer is represented by a single model element. The Gordon confining unit and Gordon aquifer unit are each assigned to one element, for a total of 8 vertical elements from ground surface to the bottom of the Gordon aquifer. The three-dimensional mesh is therefore $140 \times 140 \times 8$ with 156.800 elements or $141 \times 141 \times 9$ with 178,929 nodes. The finer vertical resolution in the "upper" zone of the Upper Three Runs aquifer is designed to support subsequent. finer-scale contaminant transport analyses.

Horizontal conductivity in the Gordon aquifer is set to $35 \mathrm{ft} /$ day based on the extensive field data from wells at the SRS and in the region surrounding the site. The vertical conductivity of the Gordon confining unit is set to $10^{-4} \mathrm{ft} / \mathrm{day}$ in accordance with field measurements. Conductivity values within Upper Three Runs aquifer zones are set through model calibration to measured water levels. Horizontal conductivity in the "lower" and "upper" aquifer zones is nominally $5.6 \mathrm{ft} / \mathrm{day}$, and varies from 1.6 to $9.6 \mathrm{ft} /$ day. Vertical conductivity for the "tan clay" confining zone is nominally $4 \times 10^{-3} \mathrm{ft} /$ day, and varies between $4 \times 10^{-4}$ and $4 \times 10^{-2}$ $\mathrm{ft} /$ day. The ratio of horizontal to vertical conductivity is assumed to be 100 to 1 . Approximate soil characteristic curves are adopted for the vadose zone in the numerical model. An effective porosity value of $25 \%$ is assumed when computing the pore velocity field. 


\section{TABLE OF CONTENTS}

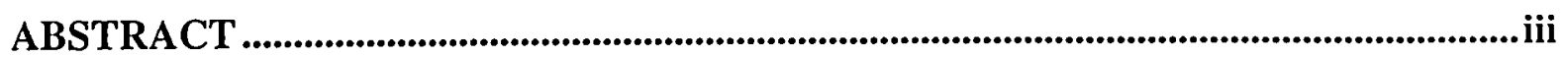

MODEL SUMMARY ….............................................................................................................ii

LIST OF FIGURES ........................................................................................................................ vii

APPENDICES ................................................................................................................................ $\mathrm{xi}$

1.0 INTRODUCTION .............................................................................................................. 1

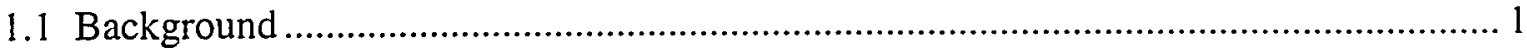

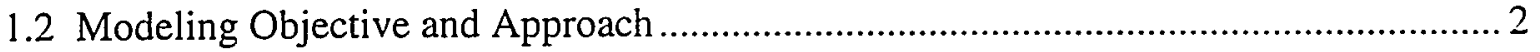

1.3 Description of the Study Area.........................................................................................

2.0 HYDROGEOLOGIC DATA AND CONCEPTUAL MODEL....................................9

2.1 SRS Geology

2.2 SRS Hydrostratigraphic Units and Properties......................................................... 9

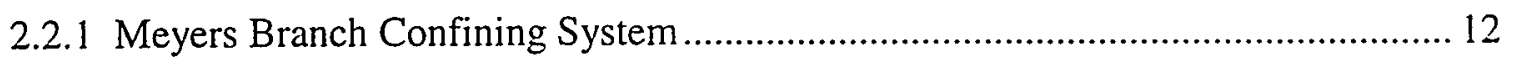

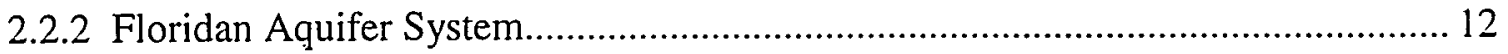

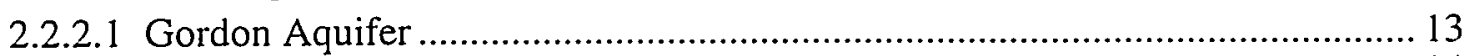

2.2.2.2 Gordon Confining Unit .......................................................................... 14

2.2.2.3 Upper Three Runs Aquifer ..................................................................... 15

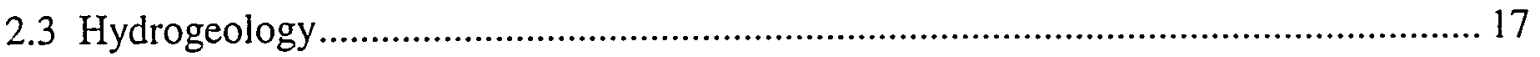

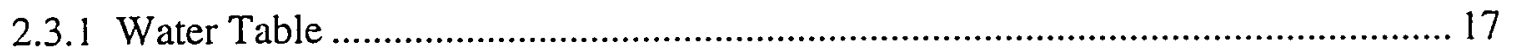

2.3.2 Gordon Aquifer Potentiometric Surface ............................................................ 18

2.3.3 Hydraulic Head Targets ................................................................................... 18

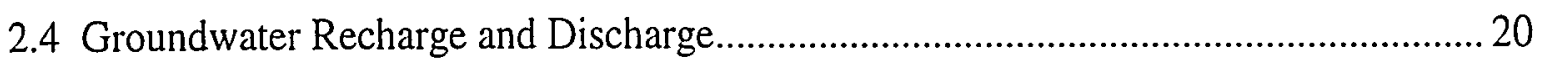

2.5 Conceptual Model of Groundwater Flow ................................................................. 21

2.6 Hydrologic Properties ................................................................................................ 22

2.6.1 Soil Characteristic Curves ................................................................................. 23

2.6.2 Effective (Kinematic) Porosity ...................................................................... 24

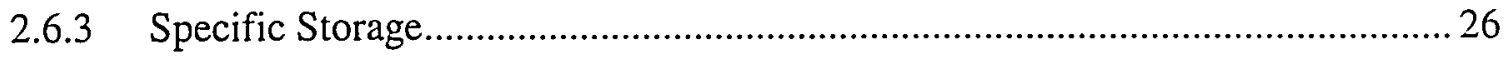

3.0 GROUNDWATER FLOW MODEL DEVELOPMENT .........................................69

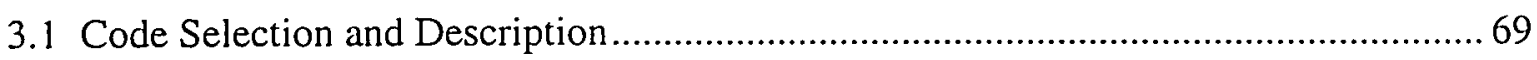

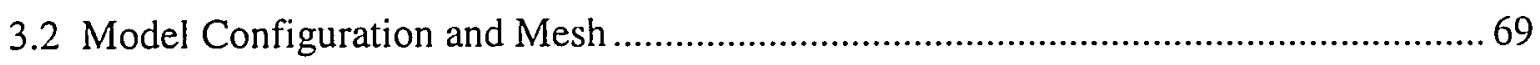

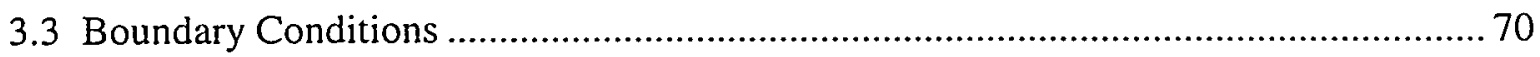

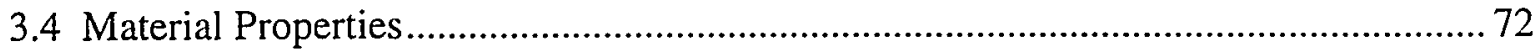

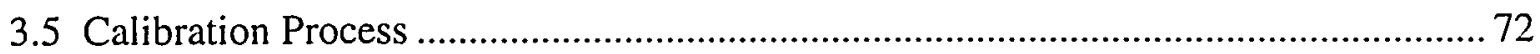


4.0 GROUNDWATER FLOW MODEL RESULTS ............................................................ 80

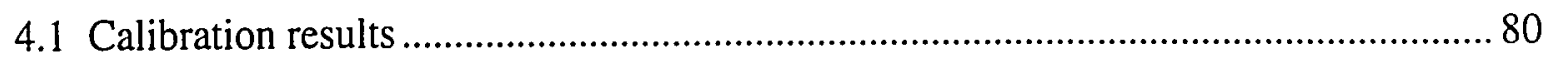

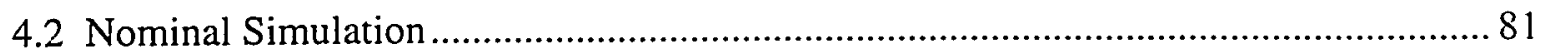

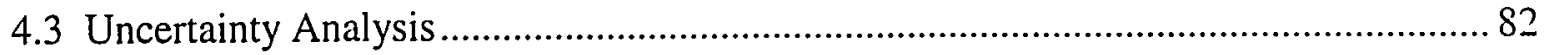

5.0 SUMMARY AND RECOMMENDATIONS .............................................................. 116

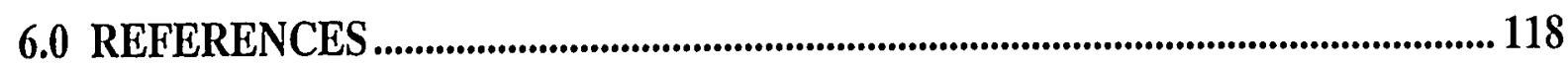




\section{LIST OF FIGURES}

1-1 Location of the Savannah River Site and Model Area ............................................. 4

1-2 Location of Groundwater Basins at the Savannah River Site …................................

1-3 Location of Major Streams and Rivers in Model Area. Model Boundary Shown in Red.

2-1 Comparison of Lithostratigraphic and Hydrostratigraphic Units at SRS .................... 23

2-2 Conceptual Hydrostratigraphic Model .................................................................. 24

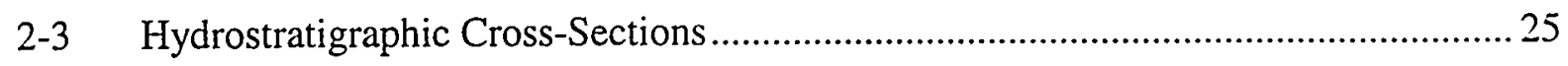

2-4 Altitude-Contour Map of the Top of the Meyers Branch Confining System .............. 26

2-5 Altitude-Contour Map of the Top of the Gordon Aquifer......................................... 27

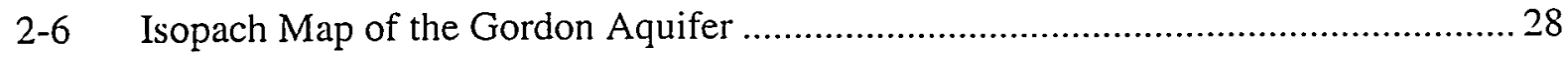

2-7 Altitude-Contour Map of the Top of the Gordon Confining Unit................................2 29

2-8 Isopach Map of the Gordon Confining Unit ……................................................... 30

2-9 Altitude-Contour Map of the Top of the "Lower" Aquifer Zone ................................. 31

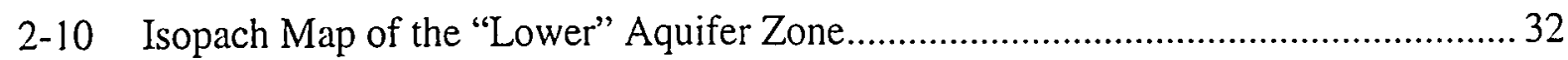

2-11 Altitude-Contour Map of the Top of the "Tan Clay" Confining Zone......................... 33

2-12 Isopach Map of the "Tan Clay" Confining Zone ....................................................... 34

2-13 Topographic Surface of the "Upper" Aquifer Zone ................................................... 35

2-14 Water Table Map of CKLP Model Area .................................................................... 36

2-15 Location of Stream Baseflow Measurements for 1998 Field Study ........................... 37

2-16 Water Table Map for C Reactor Area ………….................................................... 38

2-17 Water Table Map for K Reactor Area .......................................................................... 39 


\section{LIST OF FIGURES (continued)}

2-18 Water Table Map for L Reactor Area........................................................................ 40

2-19 Water Table Map for P Reactor Area.......................................................... 41

2-20 Gordon Potentiometric Surface in the CKLP Model Area.......................................... 42

2-21 Map of Live (Perennial) Stream Reaches as Determined by Field Observations ....... 43

2-22 Approximate Soil Characteristic Curves................................................................. 44

3-1 Plan View of Model Domain and Finite-Element Mesh .........................................54

3-2 Typical Cross-Sectional Slice through Finite-Element Mesh ...................................55

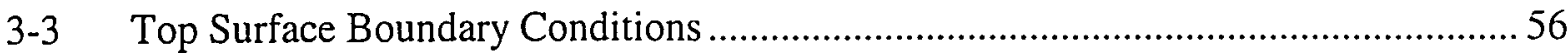

3-4 Boundary Conditions for Gordon Aquifer Between the Top and Bottom Nodal

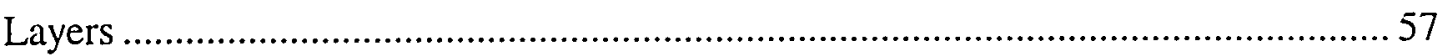

3-5 Boundary Conditions for Upper Three Runs Aquifer Between the Top and

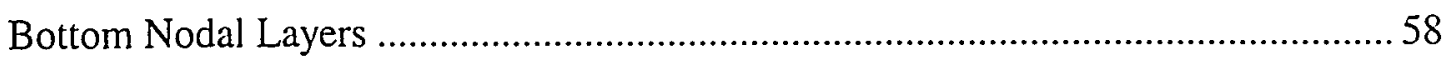

4-1 Simulated Versus Measured Head for Each Aquifer Zone .......................................... 63

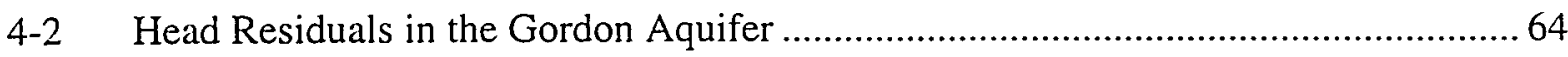

4-3 Head Residuals in the "Lower" UTR Aquifer Zone .................................................... 65

4-4 Head Residuals in the "Upper" UTR Aquifer Zone ...................................................... 66

4-5 Horizontal Conductivity in the Gordon Aquifer (Element Layer 1) ..........................67

4-6 Vertical Conductivity in the Gordon Confining Unit (Element Layer 2)..................... 68

4-7 Horizontal Conductivity in the Lower Half of the "Lower" UTR Aquifer Zone

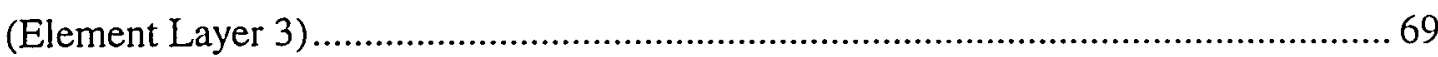

4-8 Horizontal Conductivity in the Upper Half of the "Lower" UTR Aquifer Zone (Element Layer 4) 


\section{LIST OF FIGURES (continued)}

4-9 Vertical Conductivity in the "Tan Clay" Confining Zone (Element Layer 5)............. 71

4-10 Horizontal Conductivity in the Lower Third of the "Upper" UTR Aquifer Zone (Element Layer 6; Transmissive Zone in K-Area)

4-11 Horizontal Conductivity in the Middle Third of the "Upper" UTR Aquifer Zone (Element Layer 7; AA Horizon in K-Area).

4-12 Horizontal Conductivity in the Upper Third of the "Upper" UTR Aquifer Zone (Element Layer 8; A Horizon in K-Area)................................................................ 74

4-13 Horizontal Conductivity Along a Cross-Section Through K-Area ............................. 75

4-14 Simulated Hydraulic Head in the Gordon Aquifer................................................ 76

4-15 Simulated Hydraulic Head in the "Lower" UTR Aquifer ............................................. 77

4-16 Simulated Hydraulic Head in the "Upper" UTR Aquifer ..................................... 78

4-17 Simulated Hydraulic Head in the Aquifer Zone Containing the Water Table ............ 79

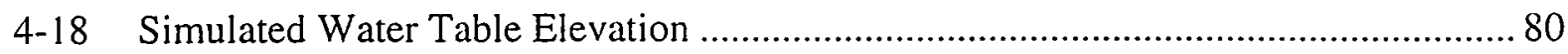

4-19 Simulated Flow Directions in the Gordon Aquifer ................................................. 81

4-20 Simulated Flow Directions in the "Lower" UTR Aquifer.......................................... 82

4-21 Simulated Flow Directions in the "Upper" UTR Aquifer............................................ 83

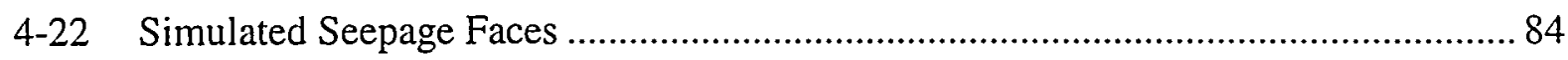

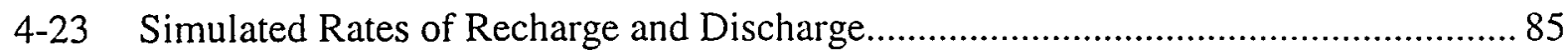

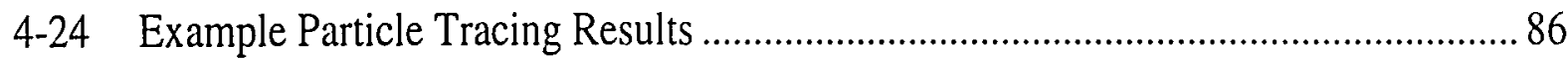

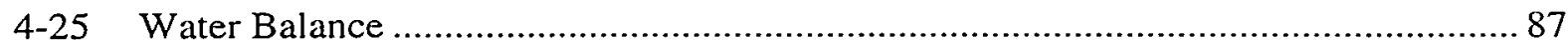




\section{LIST OF TABLES}

2-1 Summary of Permeability Measurements ............................................................. 45

2-2 Base Flow Estimates Based on Hydrograph Separation of USGS Gauging

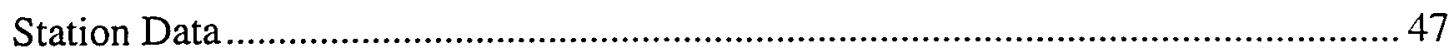

4-1 Calibration Summary for Groundwater Flow Targets................................................ 88

4-2 Calibration Summary for Hydraulic Head Targets.................................................... 89

4-3 Calibration Summary for Hydraulic Conductivity ................................................... 90

4-4 Summary of Uncertainty Cases ....................................................................... 91

4-5 Calibration Summary for Uncertainty Cases........................................................... 92 


\section{APPENDICES}

APPENDIX A DATA COLLECTION AND HYDROGEOLOGIC MODEL METHODOLOGY

APPENDIX B HYDROSTRATIGRAPHIC DATA

B-1 Locations of Sites within the Model Area

B-2 Hydrostratigraphic Boundaries

B-3 Summary of 2-Dimensional grids

APPENDIX CPERMEABILITY DATA

C-1 Permeability Values Recorded from Pumping Tests

C-2 Permeability Values Recorded from Slug Tests

C-3 Permeability Values Recorded from Laboratory Tests

APPENDIX D DATA REFERENCES

APPENDIX E STREAM BASEFLOW DATA AND ESTIMATES

E-1 Stream Base Flow Estimates Based on USGS Gauging Station Data

E-2 Summary of Stream Baseflow and Water Table Work Conducted in Support of the R-Reactor and K-Reactor Groundwater Modeling Efforts (SRT-EST98-110)

APPENDIX F HYDRAULIC HEAD TARGET AND RESIDUAL DATA

APPENDIX G UNCERTAINTY ANALYSIS 
This Page Intentionally Left Blank 


\subsection{INTRODUCTION}

\subsection{Background}

The Savannah River Site (SRS) is a U.S. Department of Energy (DOE) facility occupying 300 square miles within Aiken, Barnwell, and Allendale counties in southwestern South Carolina (Figure 1-1). The SRS was set aside in 1950 as a controlled area to produce nuclear materials for national defense. The DOE and its contractors are responsible for the operation of the SRS. Westinghouse Savannah River Company (WSRC) is currently contracted to manage and operate the site.

The SRS operated five reactors to produce special radioactive materials during the Cold War period. R Reactor was the first production reactor to go on-line, achieving criticality in December 1953. P Reactor achieved criticality in February of 1954, followed by L Reactor in August 1954, K Reactor in October 1954, and C Reactor in March 1955. The reactors produced primarily plutonium-238, plutonium-239, and tritium for uses related to national defense, but also generated special isotopes for non-defense research, medical uses, and space programs. These special isotopes included cobalt-60. polonium-210, uranium-233, curium-244, and californium-252.

The past disposal practices associated with SRS reactor operations created waste units within and adjacent to the five reactor areas. Reactor area waste units include seepage basins, Bingham pump outage pits, burning/rubble pits, rubble piles, acid/caustic basins, coal pile runoff basins, and coal ash basins. WSRC (1997) provides a detailed discussion of these waste units.

The reactor areas lie within five major drainage systems (groundwater basins). These include the Fourmile Branch, Pen Branch, Steel Creek, Lower Three Runs and Upper Three Runs groundwater basins (Figure 1-2). SRS facilities are normally situated on well-drained, topographically high areas (divides) which separate the groundwater basins. This arrangement commonly places the waste units associated with a reactor within both of the adjacent groundwater basins. For example, L-Reactor waste units lie within the Pen Branch and Steel Creek groundwater basins and P-Reactor waste units lie within the Steel Creek and Lower Three Runs groundwater basins. 


\subsection{Modeling Objective and Approach}

The primary objective of this modeling effort is to establish a regional groundwater flow model to encompass the waste units associated with $\mathrm{C}, \mathrm{K}, \mathrm{L}$, and $\mathrm{P}$ reactor areas. The RReactor waste units are addressed in previous modeling efforts (HydroGeoLogic, 1997, 1998) and are not included in this report.

This model will provide a basic understanding of the groundwater flow behavior for these areas on a regional scale. This capability is important because of the various groundwater flow directions in the near surface aquifers and deeper semi-confined to confined aquifers, and enables tracking of contaminant plumes from the source to surface discharge potentially as far as the Savannah River and Upper Three Runs. The reactor areas model has been constructed to assist in scoping characterization and remedial activities by providing a common base for the subsequent smaller scale transport and remedial/feasibility models for each of these areas. In addition, waste units that are in close proximity'to one another can be addressed comprehensively to look at the possibility of commingled plumes and the effects of one waste unit on the other.

The model is designed to meet the planning objectives described in Section 4.2 of the General Groundwater Strategy for Reactor Area Projects (WSRC, 1997). The model incorporates all available data from geological and hydrological field characterizations into a project database that can be easily updated as additional field measurements are taken. This is consistent with the interactive approach described in WSRC (1997). The model will be able to incorporate new data as it is collected, providing quick and cost-effective updates. The model can be evaluated to determine whether the available information is adequate to address a remediation issue. If not, the model can assist in determining what types of data are needed and from where they should be collected.

The reactors groundwater flow model uses EarthVision ${ }^{\circledR}$ proprietary software to calculate two-dimensional grids, maps, and cross-sections of hydrostratigraphic surfaces. The groundwater flow modeling is performed using the Flow And Contaminant Transport (FACT) code. The FACT code is a finite-element code developed by the Savannah River Technology Center (SRTC) (Hamm and others, 1997). 


\subsection{Description of the Study Area}

The SRS is centered 22.5 miles southeast of Augusta, Georgia, approximately 100 miles from the Atlantic Coast within the Upper Atlantic Coastal Plain Physiographic Province. The Savannah River forms the southwest boundary of the SRS (Figure 1-1). The SRS is situated on the Aiken Plateau of the Atlantic Coastal Plain at an approximate elevation of 300 feet above mean sea level ( $\mathrm{ft} \mathrm{msl}$ ). Overall, the plateau has a highly dissected surface and is characterized by broad inter-fluvial areas with narrow, steep-sided valleys. Local relief can attain 280 feet (Siple, 1967). The Aiken plateau is generally well-drained, although many poorly drained sinks and depressions exist.

The model area, herein referred to as the $\mathrm{C}, \mathrm{K}, \mathrm{L}$, and P Groundwater Model Area (CKLP GWMA) comprises approximately 100 square miles within the central and southern portions of the Savannah River Site. The CKLP GWMA has low to moderate topographic relief and is drained by perennial and intermittent streams (Figure 1-3). The CKLP GWMA is bounded to the north by Upper Three Runs, to the west by the Savannah River, to the south by Steel Creek and Meyers Branch, and to the east by a line between McQueen Branch and Par Pond (Figure 1-3). Upper Three Runs forms the northern boundary of the study area with an average elevation of $150 \mathrm{ft}$ msl., the Savannah River forms the western boundary with an average elevation of 85-90 feet msl., and Steel Creek and Meyers Branch forms the southsoutheastern boundary with elevations ranging from 100 to $105 \mathrm{ft} \mathrm{msl}$. Beyond the headwaters of Meyers Branch, the southern boundary extends southeast to Par Pond south of $P$ Area. There is no single natural drainage at the eastern margin of the area. A line running southeast from McQueen Branch, through the headwaters of Fourmile Branch, to Par Pond (Figure 1-3) defines an eastern boundary. 


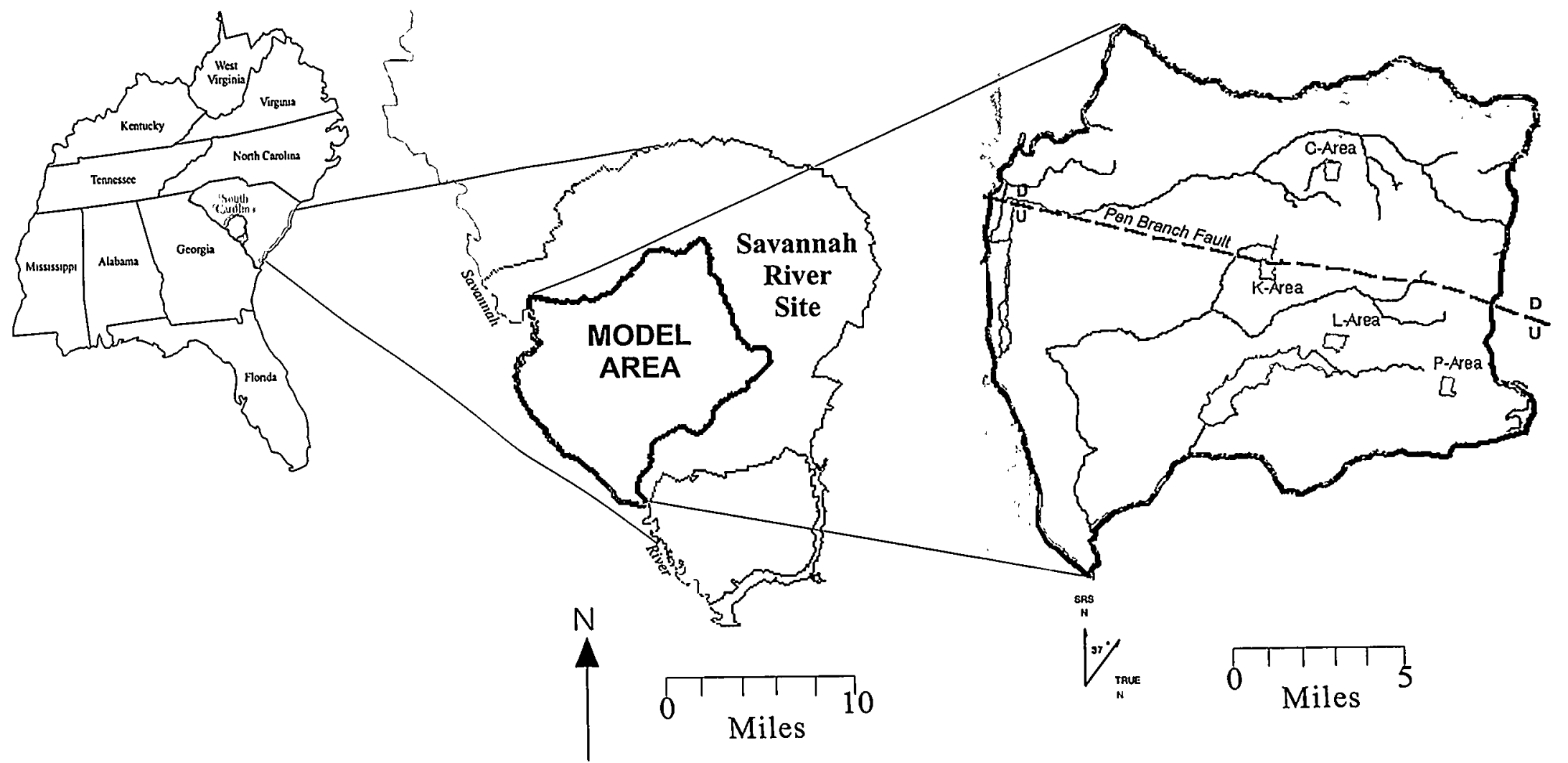

Figure 1-1. Location of the Savannah River Site and Model Area. 


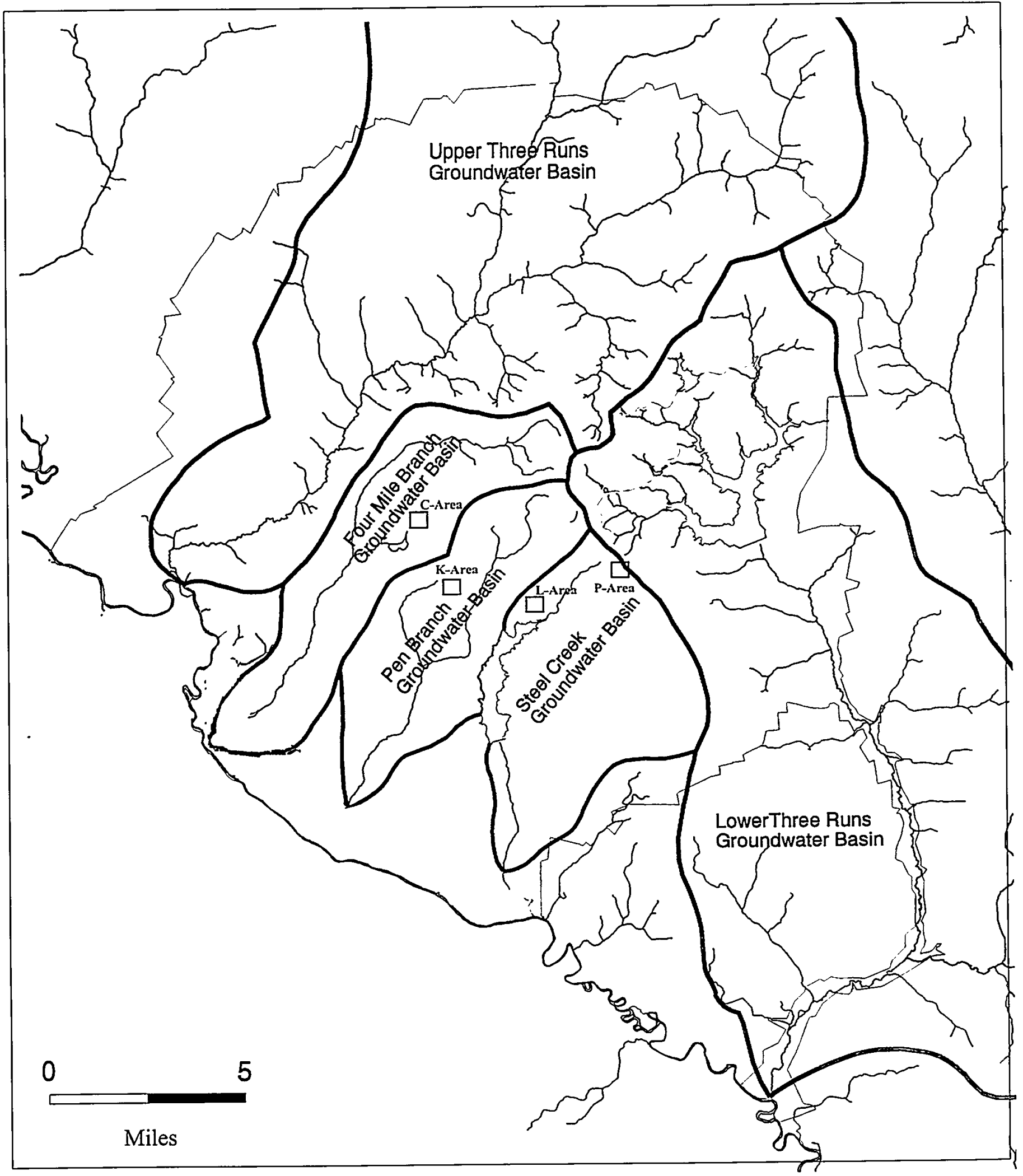

Figure 1-2. Location of Groundwater Basins at the Savannah River Site 

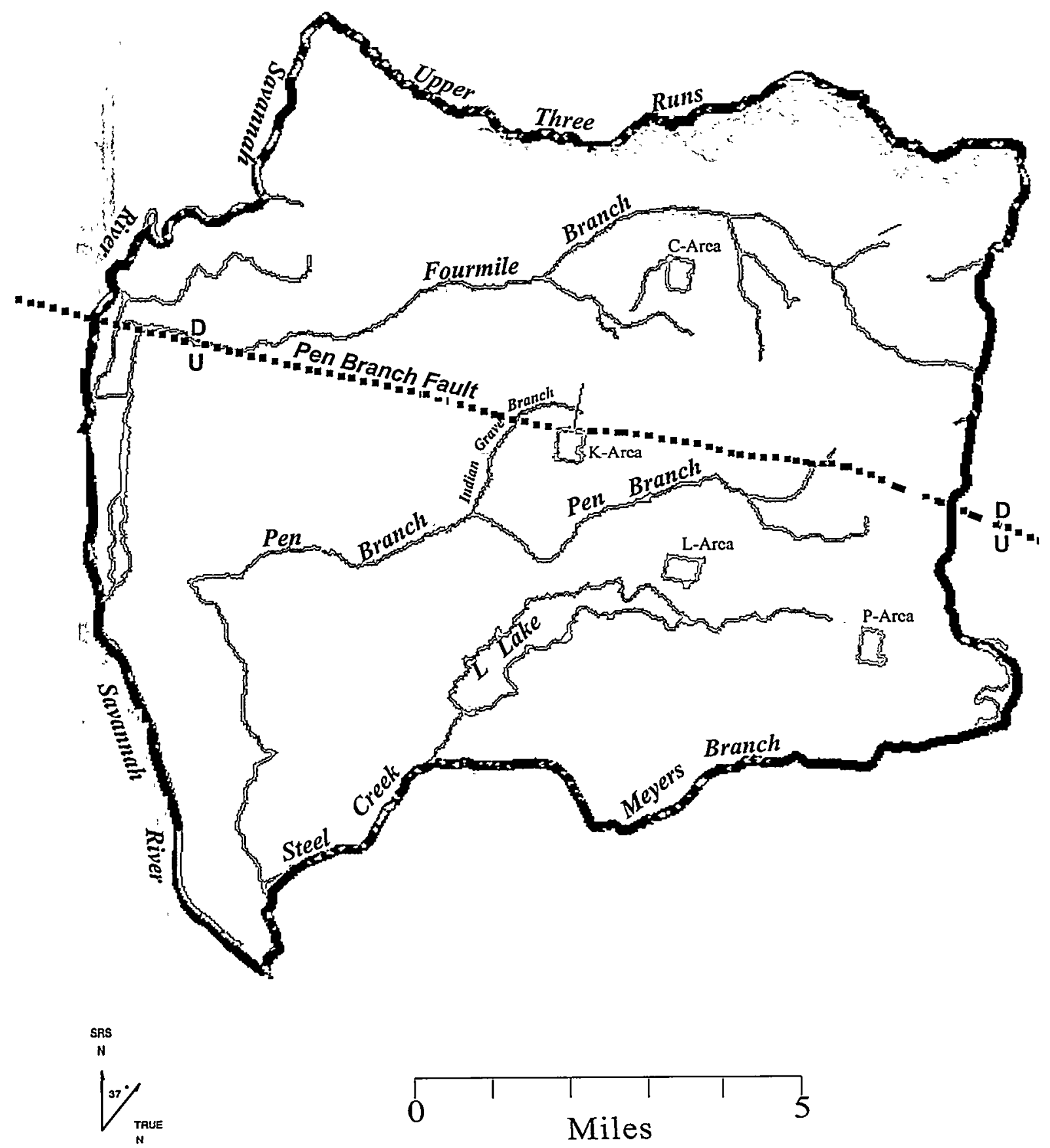

Figure 1-3. Location of Major Streams and Rivers in Model Area. Model Boundary Shown in Red. 


\subsection{Hydrogeologic Data and Conceptual Model}

\subsection{SRS Geology}

The SRS lies within the Atlantic Coastal Plain, a southeast-dipping wedge of unconsolidated and semi-consolidated sediment that extends from its contact with the Piedmont Province at the Fall Line to the edge of the continental shelf. The sediment ranges from Late Cretaceous to Miocene in age and comprises layers of sand, muddy sand. and mud with minor amounts of calcareous sediment (Fallaw and Price, 1995). The Coastal Plain sediment rests unconformably on Triassic-aged sedimentary rock of the Dunbarton Basin and Paleozoicaged crystalline rock of the Appalachian orogen.

The Pen Branch Fault (PBF) offsets basement rock and Late Cretaceous to Tertiary-aged sediment beneath the CKLP GWMA (Figure 1-1). Seismic studies and stratigraphic correlation indicate that the Pen Branch Fault is a sub-vertical growth fault with down-to-thenorthwest movement sense. The PBF probably represents reactivation of a border fault in the basement rock along the north margin of the Dunbarton Basin (Snipes and others. 1993; Stieve and Stephenson, 1995).

\subsection{SRS Hydrostratigraphic Units and Properties}

The hydrostratigraphy of the SRS has been the subject of several different classification schemes. This report incorporates the hydrostratigraphic nomenclature currently established for the SRS region by Aadland and others (1995), who present a thorough review and description of the units. Figure 2-1 correlates the hydrostratigraphic nomenclature with the local lithostratigraphy as defined by Fallaw and Price (1995). This report addresses the up-dip part of the Floridan aquifer system and the top of the Meyers Branch confining system as defined by Aadland and others (1995).

The conceptual hydrostratigraphic model depicted on Figure 2-2 and the cross-sections in Figure 2-3 illustrate the relationship between the hydrostratigraphic units, the topography, and the recent alluvial material deposited in the Savannah River valley. The lateral and vertical extent of the hydrostratigraphic units and the recent alluvium are very important hydrologically. The topography is a major factor in controlling the distribution of surface

water and the configuration of the water table. Major tributaries of the Savannah River incise the hydrostratigraphic units down to the "tan clay" confining zone and, to a lesser extent, to the "lower" aquifer zone of the Upper Three Runs aquifer. The Savannah River and Upper Three Runs cut down into the Gordon aquifer. The depth to which the streams and river 
incise underlying hydrostratigraphic units is an important factor in the localized and regional flow systems in the study area. Leeth and Nagle (1996) performed a series of borings along the Savannah River in the vicinity of SRS to determine the shallow subsurface geology of the Savannah River. Their results were used as a guide in determining the lateral and vertical extent of the alluvium in the CKLP GWMA. The thickness of the recent alluvial material in the river valley varies, and attains a maximum thickness of approximately $50 \mathrm{ft}$ (Leeth and Nagle, 1996). Figures 2-2 and 2-3 depict the conceptual hydrostratigraphic model used for the CKLP GWMA and illustrate the extent to which the Savannah River has incised the hydrostratigraphic units. The Savannah River has cut down to the Gordon aquifer at the northern and southern ends of the valley but does not incise the Meyers Branch Confining System within the model area. This relationship of the alluvial valley to the hydrostratigraphic units is also illustrated in Figure 2-1.

The following sections describe the lithologic characteristics along with the configuration of the tops and thickness of the hydrostratigraphic units mapped for this study. It should be noted that the tops of the hydrostratigraphic units correspond closely with recognized unconformities in the SRS region (Fallaw and Price, 1995). All of the altitude contour maps have patterns that are consistent with the south-southeast dip of the Coastal Plain strata in this region (Fallaw and Price, 1995). Isopach contours indicate variability in thickness, which is related to the varying degrees of erosion at the unconformable surfaces and structural relations with the Pen Branch Fault. Both the altitude contour maps and isopach maps have been constructed to depict down cutting and deposition of recent alluvial material by the Savannah River. All of the maps exhibit contour patterns that reflect the variability in data density across the area.

The project database includes permeability data from aquifer pumping tests. borehole permeability tests (slug tests), and laboratory tests of core samples from locations within the CKLP GWMA. Table 2-1 presents a summary of the permeability data collected for this study. The summary incorporates only data from locations that have hydrostratigraphic boundaries established as part of this study. Statistical calculations were made using averaged values from multi-well pumping tests and the average values from wells with results from both rising and falling-head slug tests. 
Appendix A presents a summary of the data collection and modeling methods that were utilized for this investigation. Appendix B presents locations of data points, hydrostratigraphic boundaries, and a summary of the two-dimensional grids calculated from the boundaries. Appendix $C$ presents permeability data from locations within the model area. Appendix D lists source documents for the data presented in Appendices B and C and summarized in Table 2-1.

\subsubsection{Meyers Branch Confining System}

The Meyers Branch confining system (MBCS) defines the base of the Floridan aquifer system in the study area. In the CKLP GWMA, the top of the MBCS is delineated by the laterally continuous, dense, gray to black, clay and sandy clay of the Lang Syne Formation of the Black Mingo Group (Figure 2-1) (Aadland and others, 1991 and 1995).

The configuration of the top of the MBCS is illustrated with altitude contours in Figure 2-4. The MBCS exhibits a relatively gentle dip in a south-southeast direction. Vertical offset along this unit is approximately 40 feet along the PBF. The Savannah River has not incised the MBCS.

Laboratory tests of 38 undisturbed samples taken from the MBCS indicate vertical permeability ranges from $4.26 \mathrm{E}-06$ to $3.40 \mathrm{E}-01$ feet per day (ft/day)(Table 2-1). Tests of 27 undisturbed samples yield horizontal permeability values that range from $1.1 \mathrm{E}-05$ to $1.5 \mathrm{E}+00$ $\mathrm{ft} /$ day within this unit. These data show an arithmetic mean of 1.39E-02 ft/day for vertical permeability and 8.63E-02 ft/day for horizontal permeability, and a geometric mean of 2.47E$04 \mathrm{ft} /$ day for vertical permeability and 5.52E-04 ft/day for horizontal permeability. The standard deviation is $5.65 \mathrm{E}-02$ for vertical permeability and $3.12 \mathrm{E}-01$ for horizontal permeability.

\subsubsection{Floridan Aquifer System}

The Floridan Aquifer System overlies the MBCS and includes the Gordon aquifer, Gordon confining unit, and Upper Three Runs aquifer within the CKLP GWMA (Figure 2-1). Groundwater maintains a downward component of flow from the Upper Three Runs aquifer into the Gordon aquifer. The Upper Three Runs aquifer is recharged primarily by precipitation (Hiergesell, 1998a). 


\subsubsection{Gordon Aquifer}

The Gordon aquifer constitutes the basal unit of the Floridan aquifer system beneath the CKLP GWMA and is the lowermost unit characterized in this report (Figure 2-1). Within the study area, the Gordon aquifer includes loose sand and clayey sand of the Congaree Formation and, where present, the sandy parts of the underlying Fourmile Branch and Snapp Formations (Figure 2-1), (Harris and others, 1990; Aadland and others, 1991 and 1995). The sand within the Gordon aquifer is yellowish to grayish orange and is sub- to well-rounded. moderately to poorly sorted, and medium- to coarse-grained. Pebbly layers and zones of iron and silica cemented sand are common. Interbeds of light tan to gray clay up to three feet in thickness are rare. The Gordon aquifer contains a small amount of sporadically distributed calcareous sediment. Stringers of clay less than 6 inches in thickness are common near the base of this unit.

The configuration of the top of the Gordon aquifer is illustrated in Figure 2-5. An isopach map is presented in Figure 2-6. The Gordon aquifer exhibits the same structural pattern as the MBCS with a regional dip to the south-southeast. Vertical offset along this unit is approximately 40 feet along the PBF. The thickness of this unit is variable, ranging from approximately 60 feet to 160 feet. This variability is believed to be related to structural relations with overlying and underlying units and the presence of unconformities above and below the unit. In addition, the Gordon aquifer is incised along the Savannah River primarily in the vicinity of the PBF and along Upper Three Runs (Figure 2-5).

Laboratory tests of 23 undisturbed samples taken from the Gordon aquifer indicate vertical permeability ranges from $3.12 \mathrm{E}-06$ to $3.62 \mathrm{E}+01 \mathrm{ft} /$ day (Table 2-1). Tests of 24 undisturbed samples yield horizontal permeability values that range from $2.06 \mathrm{E}-05$ to $3.26 \mathrm{E}+01 \mathrm{ft} /$ day within this unit. These data show an arithmetic mean of $1.66 \mathrm{E}+00 \mathrm{ft} /$ day for vertical permeability and $5.25 \mathrm{E}+00 \mathrm{ft} /$ day for horizontal permeability and a geometric mean of 7.73E$04 \mathrm{ft} /$ day for vertical permeability and 1.05E-02 ft/day for horizontal permeability. The standard deviation calculated from these data is $7.54 \mathrm{E}+00 \mathrm{ft} /$ day for vertical permeability and $1.12 \mathrm{E}+01 \mathrm{ft} /$ day for horizontal permeability.

Results from 47 slug tests conducted on wells screened within the Gordon aquifer indicate permeability ranges from $5.00 \mathrm{E}-03$ to $3.32 \mathrm{E}+01 \mathrm{ft} /$ day (Table 2-1). The arithmetic mean from these data is $3.78 \mathrm{E}+00 \mathrm{ft} /$ day and the geometric mean is $9.81 \mathrm{E}-01 \mathrm{ft} /$ day. The standard deviation calculated from these results is $6.15 \mathrm{E}+00 \mathrm{ft} /$ day. The permeability results were averaged for wells with both rising and falling-head tests. 
Thirteen pumping tests performed on wells screened within the Gordon aquifer indicate permeability ranges from $8.20 \mathrm{E}-01$ to $1.43 \mathrm{E}+02 \mathrm{ft} /$ day (Table 2-1). The arithmetic mean is $2.92 \mathrm{E}+01 \mathrm{ft} /$ day and the geometric mean is $1.04 \mathrm{E}+01 \mathrm{ft} /$ day. The standard deviation calculated from these results is $3.92 \mathrm{E}+01 \mathrm{ft} /$ day. Aadland and others (1995) present additional information on pumping tests conducted within the Gordon aquifer.

\subsubsection{Gordon Confining Unit}

The Gordon confining unit (GCU) separates the Gordon aquifer from the Upper Three Runs aquifer. This unit is commonly referred to as the "green clay" in previous SRS literature and includes sediment of the Warley Hill Formation (Figure 2-1). The unit comprises interbedded silty and clayey sand, sandy clay and clay. The clay is stiff to hard and is commonly fissile. Glauconite is a common constituent and imparts a distinctive greenish cast to the sediment, hence the informal name of "green clay" given to this unit. Zones of silicacemented sand and clay are present within the GCU in some cores taken from the GSA. In the vicinity of the CKLP GWMA, the GCU includes some calcareous sediment and limestone, primarily calcarenaceous sand and clayey sand with subordinate calcarenaceous clay, micritic clay, and sandy micrite and limestone.

The GCU dips toward the south-southeast, increasing from approximately 10 feet to 80 feet in thickness (Figures 2-7 and 2-8). The southeastward thickening is primarily due to an increase in the quantity of fine-grained calcareous material within this unit beneath the southern half of the study area. The GCU is incised along the Savannah River to the north and south of the PBF and also incised along the southern boundary of Upper Three Runs (Figure 2-7).

Laboratory tests of 41 undisturbed samples taken from the GCU indicate vertical permeability ranges from $1.14 \mathrm{E}-06$ to $4.27 \mathrm{E}-01 \mathrm{ft} /$ day (Table 2-1). Tests of 25 undisturbed samples yield horizontal permeability values that range from $5.40 \mathrm{E}-06$ to $1.22 \mathrm{E}-01 \mathrm{ft} / \mathrm{day}$ within this unit. These data show an arithmetic mean of $1.20 \mathrm{E}-02 \mathrm{ft} /$ day for vertical permeability and $1.06 \mathrm{E}-02 \mathrm{ft} /$ day for horizontal permeability and a geometric mean of $1.15 \mathrm{E}-$ $04 \mathrm{ft} /$ day for vertical permeability and 1.62E-04 ft/day for horizontal permeability. The standard deviation calculated from these data is $6.68 \mathrm{E}-02 \mathrm{ft} /$ day for vertical permeability and 3.09E-02 ft/day for horizontal permeability. Aadland and others (1995) discuss leakance estimates derived from multiple well pumping tests. 


\subsubsection{Upper Three Runs Aquifer}

The Upper Three Runs aquifer (UTRA), as defined in this report. includes all strata from the ground surface to the top of the Gordon confining unit. The UTRA includes the informally named "upland" unit, Tobacco Road Sand, Dry Branch Formation, Clinchfield Formation, and Santee Limestone (Figure 2-1). For the purposes of hydrostratigraphic analysis, the UTRA aquifer is often locally divided into informal "lower" and "upper" aquifer zones separated by the "tan clay" confining zone (Figure 2-1).

"Lower" Aquifer Zone. The "lower" aquifer zone (LAZ) of the UTRA beneath the CKLP GWMA consists of the dominantly fine-grained, well-sorted sand and clayey sand of the Santee Formation and parts of the Dry Branch Formation beneath the "tan clay" confining zone (Figure 2-1). The bulk of the carbonate sediment beneath the CKLP GWMA is contained within the Santee and lower part of the Dry Branch and is included in the LAZ. Descriptions of drill core indicate that the carbonate sediment in this vicinity has a siliciclastic component, and consists of calcarenaceous sand, micritic sand, shelly sand, and minor amounts of sandy calcarenite and shelly limestone.

The altitude-contour map and isopach for the LAZ are presented in Figures 2-9 and 2-10. The configuration of the top of the LAZ is similar to the GCU. The thickness of the LAZ ranges from approximately 30 feet to 110 feet. The variability is attributed primarily to erosion on the overlying and underlying unconformities. The LAZ is deeply incised by the Savannah River and Upper Three Runs within the model area (Figure 2-9).

Laboratory tests of 33 undisturbed samples taken from the LAZ indicate vertical permeability ranges from 4.54E-06 to $3.42 \mathrm{E}+00 \mathrm{ft} / \mathrm{day}$ (Table 2-1). Tests of 31 undisturbed samples yield horizontal permeability values that range from $1.59 \mathrm{E}-05$ to $1.11 \mathrm{E}+01 \mathrm{ft} /$ day within this unit. These data show an arithmetic mean of $1.77 \mathrm{E}-01 \mathrm{ft} /$ day for vertical permeability and $6.45 \mathrm{E}-$ $01 \mathrm{ft} /$ day for horizontal permeability and a geometric mean of $2.82 \mathrm{E}-03 \mathrm{ft} /$ day for vertical permeability and 1.02E-02 ft/day for horizontal. The standard deviation calculated from these data is $6.19 \mathrm{E}-01 \mathrm{ft} /$ day for vertical permeability and $2.03 \mathrm{E}+00 \mathrm{ft} /$ day for horizontal permeability.

Results from 25 slug tests conducted within the LAZ indicate permeability ranges from $1.30 \mathrm{E}-01$ to $2.44 \mathrm{E}+01 \mathrm{ft} / \mathrm{day}$ (Table $2-1$ ). The arithmetic mean from these data is $3.90 \mathrm{E}+00$ $\mathrm{ft} / \mathrm{day}$ and the geometric mean is $1.67 \mathrm{E}+00 \mathrm{ft} / \mathrm{day}$. The standard deviation calculated from these results is $6.09 \mathrm{E}+00 \mathrm{ft} /$ day. 
Three pumping tests of wells screened within the LAZ indicate permeability ranges from $1.23 \mathrm{E}+00$ to $2.10 \mathrm{E}+00 \mathrm{ft} /$ day (Table 1 ). The arithmetic mean is $1.67 \mathrm{E}+00 \mathrm{ft} / \mathrm{day}$ and the geometric mean is $1.63 \mathrm{E}+00 \mathrm{ft} /$ day (Table 1). The standard deviation calculated from these results is $4.35 \mathrm{E}-01 \mathrm{ft} /$ day.

"Tan Clay" Confining Zone. The "tan clay" confining zone (TCCZ) of the UTRA is equivalent to the "tan clay" zone referred to in previous SRS reports. The "tan clay" confining zone includes sediment of the Dry Branch Formation (Figure 2-1). The zone contains light-yellowish tan to orange clay and sandy clay interbedded with clayey sand and sand. Clay layers are dispersed vertically and horizontally throughout the confining zone and are probably not laterally continuous over distances greater than 100 to 200 feet (Harris and others, 1990; Aadland and others, 1991).

The configuration of the top of the TCCZ is illustrated in Figure 2-11 and an isopach map of the unit is presented in Figure 2-12. The configuration of the top of the TCCZ is very similar to that of the underlying LAZ. The thickness of the TCCZ ranges from approximately 10 feet to 20 feet. The TCCZ is deeply incised by the Savannah River, Upper Three Runs, Fourmile Branch, and Steel Creek and Meyers Branch within the model area (Figure 2-11).

Laboratory tests of 37 undisturbed samples taken from the TCCZ indicate vertical permeability ranges from $3.70 \mathrm{E}-08$ to $9.66 \mathrm{E}-02 \mathrm{ft} /$ day (Table 2-1). Tests of 24 undisturbed samples yield horizontal permeability values that range from $1.45 \mathrm{E}-05$ to $1.70 \mathrm{E}-01 \mathrm{ft} / \mathrm{day}$ within this unit. These data show an arithmetic mean of $4.62 \mathrm{E}-03 \mathrm{ft} /$ day for vertical permeability and $8.49 \mathrm{E}-03 \mathrm{ft} /$ day for horizontal permeability and a geometric mean of $5.93 \mathrm{E}-05 \mathrm{ft} /$ day for vertical permeability and $2.60 \mathrm{E}-04 \mathrm{ft} /$ day for horizontal permeability. The standard deviation calculated from these data is $1.91 \mathrm{E}-02 \mathrm{ft} /$ day for vertical permeability and 3.47E-02 ft/day for horizontal permeability.

"Upper" Aquifer Zone. The "upper" aquifer zone (UAZ) of the UTRA includes all strata from the ground surface to the top of the "tan clay" confining zone. The UAZ includes the "upland" unit, Tobacco Road Sand, and part of the Dry Branch Formation (Figure 2-1). The UAZ characterized by sand and clayey sand with minor interbeds of clay. The sediment within the "upland" unit is commonly very dense and clayey and often contains gravely sand.

The top of the UAZ is represented by the present-day topographic surface (Figure 2-13). As with the underlying units, the UAZ has been heavily influenced by the incision of the Savannah River, Upper Three Runs, and other major tributaries within the model area. 
Permeability results from eleven laboratory tests taken from undisturbed samples in the UAZ indicate vertical permeability ranges from $9.20 \mathrm{E}-05$ to $2.77 \mathrm{E}+01 \mathrm{ft} /$ day (Table 2-1). Tests of twelve undisturbed samples yield horizontal permeability values that range from $2.24 \mathrm{E}-04$ to $6.04 \mathrm{E}+00 \mathrm{ft} /$ day within this unit. These data show an arithmetic mean of $2.68 \mathrm{E}+00 \mathrm{ft} /$ day for vertical permeability and $1.21 \mathrm{E}+00 \mathrm{ft} /$ day for horizontal permeability and a geometric mean of $1.04 \mathrm{E}-02 \mathrm{ft} /$ day for vertical permeability and $6.19 \mathrm{E}-02 \mathrm{ft} /$ day for horizontal permeability. The standard deviation calculated from these data is $8.31 \mathrm{E}+00 \mathrm{ft} /$ day for vertical permeability and $2.24 \mathrm{E}+00 \mathrm{ft} /$ day for horizontal permeability.

Results from twelve slug tests conducted within the UAZ indicate permeability ranges from $1.40 \mathrm{E}-01$ to $1.22 \mathrm{E}+01 \mathrm{ft} /$ day (Table 2-1). The arithmetic mean from these data is $1.88 \mathrm{E}+00$ $\mathrm{ft} /$ day and the geometric mean is $7.36 \mathrm{E}-01 \mathrm{ft} /$ day. The standard deviation calculated from these results is $3.46 \mathrm{E}+00 \mathrm{ft} /$ day.

Results from one multi-well pumping test performed on a well screened within the UAZ indicate permeability is at least $5.16 \mathrm{E}+01 \mathrm{ft} /$ day (Table 1 ). The test included 4 observation wells with permeability results. These results were averaged to obtain one permeability value.

\subsection{Hydrogeology}

\subsubsection{Water Table}

The water table aquifer is contained within the UTRA and includes all saturated material from the water table to the top of the GCU. The water table aquifer is commonly divided into the informal UAZ and LAZ, separated by the TCCZ. For this report, no distinction is made for the upper and lower zones because the majority of well data is from the upper zone as there are very few wells screened in the lower part of the water table aquifer within the model area at this time. A water table map of the reactor areas model domain is shown in Figure 2-14.

The configuration of the water table is tightly controlled by the local topography and drainage system. Wells are scarce in the reactors area with the majority of the wells located around the reactor facilities. Therefore, for this project a study was conducted to characterize stream baseflow and supplement water table configuration along Indian Grave Branch and the upper part of Pen Branch within the model domain (Figure 2-15; Appendix E), (Hiergesell, $1998 \mathrm{~b}, \mathrm{c})$. Water level measurements were obtained from selected wells along with careful 
examination of flowing reaches of the headwater segments of the streams. The water table map (Figure 2-14) was further refined with this data.

In addition to the regional water table map for the area, Figures 2-16 through 2-19 illustrate the water table configuration in $\mathrm{C}, \mathrm{K}, \mathrm{L}$, and $\mathrm{P}$ reactor areas. For further discussion of the water table in the reactor areas the reader is referred to (Hiergesell, 1988a).

\subsubsection{Gordon Aquifer Potentiometric Surface}

The Gordon aquifer is the lowermost aquifer of interest in this study and represents the basal unit of the Floridan aquifer system in the CKLP GWMA (Figure 2-1). Figure 2-20 illustrates the Gordon aquifer potentiometric surface in the model domain. Data is limited for the Gordon aquifer in the CKLP GWMA. The Gordon aquifer discharges to the Upper Three Runs valley to the north-northwest and to the Savannah River valley to the west-southwest.

\subsubsection{Hydraulic Head Targets}

In addition to constructing potentiometric maps for conceptual understanding of groundwater flow and boundary condition specification (e.g. Figures 2-14 and 2-20). hydraulic head data are valuable model calibration targets. Because steady-state groundwater flow is the focus of this effort, long-term, time-averaged head data are of most interest as model calibration targets. The primary source of uncertainty in mean water level is transient fluctuation in individual readings that are on the order of a few feet. Surveying errors, measurement errors, etc. are generally very small in comparison.

Water level data for most wells at the SRS are available from the Geochemical Information Management System (GIMS), which can be accessed through the Savannah River Information Network Environment (ShRINE). The data are also published in periodic well inventory and monitoring reports; see Environmental Protection Department and Exploration Resources, Inc. (1996a, b) for example. GIMS archives data obtained through a groundwater monitoring program administered by the Environmental Monitoring Section (EMS) of the Environmental Protection Department (EPD). The GIMS database is known to contain erroneous entries. Outliers were identified as single readings that deviated from the average value by more than $20 \mathrm{ft}$ and eliminated. With the remaining data, the sample standard deviation of the mean value was computed as (Walpole and Myers, 1978, section 5.5)

$$
s_{m}=\frac{s}{\sqrt{n}}=\frac{1}{\sqrt{n}} \times\left[\frac{1}{n-1} \sum_{i=1}^{n}\left(h_{1}-\bar{h}\right)^{2}\right]^{1 / 2}
$$


Mean values with an uncertainty exceeding $3 \mathrm{ft}$ at $95 \%$ confidence $\left(2 \mathrm{~s}_{\mathrm{m}}>3 \mathrm{ft}\right)$ were eliminated, with the idea that uncertainty in a hydraulic head target should not exceed the calibration goal. Previous models covering relatively small areas of the SRS have generally achieved a root-mean-square residual of $3 \mathrm{ft}$ (e.g. Camp Dresser \& McKee. 1989: GeoTrans. 1992; Flach and Harris, 1997). Given the large scale and coarse resolution anticipated for CKLP model, a calibration goal of $3 \mathrm{ft}$ may be too low. Sample standard deviations could not be computed for wells with a single reading, and the single reading was accepted as the target for steady-state flow calibration.

Valuable data from wells not included in the EMS monitoring program are also available. The Environmental Science and Technology Department (ES\&TD) has monitored the Pseries wells and other SRS wells for several years (Hiergesell. 1998). Water level data are also available from Environmental Restoration Department (ERD) documents, such as the RFI/RI/BRA for the CMP Pits (WSRC, 1996). These data supplement the head targets derived from the GIMS database.

Appendix $\mathrm{F}$ includes the resulting list of hydraulic head targets. Each well was assigned to the appropriate hydrostratigraphic unit as defined by the grids presented in section 2.2. Category 1 includes wells screened within the Gordon aquifer, category 2 includes those within the "lower" UTRA, and category 3 includes those within the "upper" UTRA. Wells screened into or across the Gordon confining unit or across the "tan clay" confining zone are assigned to category 4 (other). Within the model domain, there are 124 Gordon aquifer targets, 356 "lower" UTRA targets, 658 "upper" UTRA targets, and 65 indeterminate targets.

\subsection{Groundwater Recharge and Discharge}

Groundwater flow in upper aquifers at the Savannah River Site is driven by recharge, with streams intercepting flow from areas of higher groundwater elevations (Figures 2-14 and 220). Nearly all recharge within the CKLP model area discharges to streams within or bounding the same area, usually the nearest stream. For this type of groundwater flow system, recharge and discharge estimates, coupled with head measurements and confining unit leakance estimates, define the overall horizontal conductivity values of upper aquifers required to calibrate a numerical flow model. Because conductivity data at the model scale are typically non-existent, groundwater flow estimates are important model calibration targets. 
At least three independent investigations of surface groundwater recharge have been performed in or near the SRS. Parizek and Root (1986) conducted a detailed hydrologic budget study of the McQueen Branch basin. They estimated average recharge for the basin at 15.6 in/yr. Parizek and Root (1986) computed this value by dividing the total volumetric rate of recharge by the total basin area. The average recharge rate excluding seepage/wetland areas would therefore be somewhat larger. Hubbard $(1984,1986)$ conducted a multi-year lysimeter study at the SRS burial grounds in the General Separations Area and measured an average recharge of about $16 \mathrm{in} / \mathrm{yr}$ for grass cover. Based on lysimeters with small pine trees growing within them, Hubbard (1986) estimated recharge to be 6 in/yr for forested areas. Hubbard (1986) also reported that Denehy and McMahon (1985) measured $15 \mathrm{in} / \mathrm{yr}$ of recharge at the Chem-Nuclear site in Barnwell, South Carolina. Parizek and Root (1986) and Looney and others (1987) report that Cahill (1982) estimated recharge to be about $15 \mathrm{in} / \mathrm{yr}$ at the Low Level Radioactive Solid Waste Burial Site near Barnwell, South Carolina (ChemNuclear). It is unclear from the literature cited here whether the Denehy and McMahon (1985), and Cahill (1982) studies are related, apart from being conducted at the same location.

From these studies, the average recharge over the Savannah River Site is estimated to be about $15 \mathrm{in} / \mathrm{yr}$. The average rate excluding groundwater discharge areas would be somewhat higher. This estimate may be high due to a bias toward analysis of developed areas that tend to be less forested and flatter. The data for forested conditions are difficult to reconcile. Hubbard (1985) estimated recharge at $6 \mathrm{in} / \mathrm{yr}$ for forested areas. On the other hand, the vegetation of McQueen Branch basin studied by Parizek and Root (1986) study was 85\% evergreen and deciduous forest, and produced an estimate of nearly $16 \mathrm{in} / \mathrm{yr}$. The average of these two estimates is $10 \mathrm{in} / \mathrm{yr}$. Considering that the area of interest in this study is relatively undeveloped and heavily forested, perhaps a reasonable range to consider for groundwater flow modeling sensitivity studies is 10 to $16 \mathrm{in} / \mathrm{yr}$.

To support this and subsequent modeling efforts in the $\mathrm{C}, \mathrm{K}, \mathrm{L}$ and $\mathrm{P}$ areas, stream base flow was estimated by analyzing U. S. Geological Survey (USGS) stream gauging station data (Cooney and others, 1998, for example) and measuring stream flow rate under low flow conditions (Hiergesell, 1998b, 1998c). The USGS data provide large-scale estimates of base flow. Complementing these estimates, Hiergesell (1998b, 1998c) measured base flow for small streams. Appendix E-1 presents the data of Hiergesell (1998). Appendix E-2 describes the simple hydrograph separation techniques that were used to estimate the long-term average rate of groundwater discharge to large-scale stream reaches within the CKLP reactor area. 
The results are summarized in Table 2-1. Hiergesell (1998b, 1998c) also estimated the point of effluence along small streams and refined an ARC/INFO USGS coverage of live stream reaches, as illustrated by Figure 2-21.

The Steel Creek, Pen Branch and Fourmile Branch base flow estimates may be the most reliable calibration targets. For Meyers Branch and Upper Three Runs, there is added uncertainty in the fraction of base flow that can be attributed to the modeled area. Overall, the base flow calibration targets may have an uncertainty of 15 to 25\% (Appendix E). The Steel Creek base flow estimate is negative and indicates a losing reach, reflecting artificial flow to L-Lake to maintain a historic level of $190 \mathrm{ft} \mathrm{msl}$.

\subsection{Conceptual Model of Groundwater Flow}

From Figure 2-14, groundwater flow in the Upper Three Runs aquifer is seen to be driven by recharge, with nearby streams intercepting flow from higher elevations. The underlying Gordon aquifer is strongly influenced by the Savannah River and Upper Three Runs, which appear to completely drain the aquifer and function as no-flow lines (Figure 2-20). Except for reactor area outfalls and the lower portion of L Lake, surface water bodies gain from groundwater discharge. Aadland and others (1995, Plate 17) gives the leakance of the Crouch Branch confining unit (of the Meyers Branch confining system) as roughly $3 \times 10^{-6}$ day $^{-1}$, which corresponds to $0.13 \mathrm{in} / \mathrm{yr}$ for every $10 \mathrm{ft}$ of head difference. The head difference across the Crouch Branch confining unit is centered near zero (Aadland and others, 1995, Figure 30). Flow across the unit is therefore a small fraction of total recharge, and could probably be neglected. A representative leakance coefficient for the Gordon confining unit in the study area appears to be roughly $10^{-5}$ day $^{-1}$ (Aadland and others. 1995, Plate 13). The head difference across the Gordon confining is highly variable due to large variation in the water table. Supposing a head difference of $50 \mathrm{ft}$ for example, the Darcy velocity through the unit would be $2.2 \mathrm{in} / \mathrm{yr}$ or $15 \%$ of surface recharge. Therefore, groundwater flow in the Gordon aquifer appears to be influenced significantly by recharge from the overlying UTR aquifer, and lateral flow into the model domain, mainly from the east. L-Lake and Par Pond are major lakes that have an important influence on nearby groundwater flow (Figure 2-14). The Site Utilities Department well database on ShRINE indicates that no more than three producing wells are screened in the Gordon aquifer (905-136G, 905-126G. and 905-103G). These wells serve small facilities and have a maximum capacity of $25 \mathrm{gpm}$ or less. Considering that actual usage would be much lower, the impact of these wells is insignificant at the regional scale. The impact of the Pen Branch fault on confining unit leakance is uncertain. 
Solute groundwater contamination originating in the $C, K$. $L$ or $P$ areas is expected to be confined to the Upper Three Runs and Gordon aquifers. Most surface recharge discharges to the nearest stream, with the balance entering the Gordon aquifer. As groundwater in the Gordon aquifer flows toward the Savannah River or Upper Three Runs, the gradient between the Crouch Branch and Gordon aquifers becomes upward ensuring ultimate discharge to the Savannah River or Upper Three Runs. Contamination is not expected to enter the Crouch Branch aquifer.

\subsection{Hydrologic Properties}

In addition to the unit-specific hydraulic conductivity data discussed above. soil characteristic curves, effective porosity, and specific storage data are needed for model development. The steady-state hydraulic head and Darcy velocity fields in the saturated zone are affected only by horizontal and vertical hydraulic conductivity, making these remaining properties less critical to model development. Soil characteristic curves (capillary suction and relative permeability as a function of water saturation) affect the flow solution in unsaturated regions. Effective porosity affects groundwater "particle" tracing results, which rely on the pore velocity field. Specific storage affects transient flow only, and then only in confined aquifer systems for practical purposes. Characterization data available for defining these hydraulic properties in the model are identified below. Given the general scarcity and uncertainty in the data, generic estimates to be applied model-wide are appropriate.

\subsubsection{Soil Characteristic Curves}

Relative permeability and capillary suction head as a function of water saturation are referred to as soil characteristic curves. These relationships are difficult to measure accurately, and testing is expensive. Very little data are available for SRS unconsolidated sediments. O'Brien \& Gere (1991) obtained a small set of water retention (capillary suction versus saturation) data for M-Area sediment samples. The data have been plotted by Flach and others (1996, Figures 11 and 12). Yu and others (1993) obtained both relative permeability and water retention data for remolded GSA sediments to be used for Environmental Restoration construction projects. Recently, Amidon (1996) obtained water retention data from 3 undisturbed soil samples collected from the vadose zone around the Burial Grounds Complex. According to Looney and others (1987), Gruber (1981, 1983) and Parizek and Root (1986) measured soil water content in the vadose zone and suggested the average water content is approximately $30 \%$ (water volume/total volume). Given the scarcity of the data and lacking a specific need for accurate vadose zone modeling in a regional scale model, a 
simplified approach for defining soil characteristic curves is taken as shown in Figure 2-22. The curves are chosen to align with data for sandy sediments as opposed to clayey sediments (see Flach and others (1996), Figures 11 and 12). These "pseudo-soil" characteristic curves are adequate for transporting water and contaminants through the vadose zone to the water table, provided detailed, accurate information about the unsaturated zone is not needed. The most important aspect of these curves is the assumed residual saturation value (40\%), which has the strongest effect on average vadose zone saturation. Groundwater travel times through the vadose zone are affected by saturation through pore velocity.

\subsubsection{Effective (Kinematic) Porosity}

Aadland and others (1995, p. 44) analyzed laboratory data from 83 selected sediment samples taken from various low permeability beds within the Upper Three Runs aquifer. For 28 "clayey to very clayey, often silty, sand" samples the total porosity averaged $40 \%$. For 55 "sandy, often silty clay, and clay" samples, the average total porosity is $41 \%$. Aadland and others (1995, Table 3) also calculated the total porosity of the sandy portions of the Upper Three Runs aquifer using the Beard and Weyl (1973) method, and arrived at an average total porosity of 35\%. For the Gordon aquifer, the result is 34\% (Aadland and others, 1995, Table 7). More recently, Smits and others (1997) compiled a database of porosity measurements for the General Separations Area. The arithmetic average of these values, mostly from low permeability samples, is $45 \%$. From these data and analyses, total porosity in aquifer zones appears to average about $40 \%$.

An "effective" porosity value, smaller than the total porosity, is commonly used for transport simulations and particle tracing related to contaminant migration. As discussed by De Marsily (1986, Chapter 2), two types of porosity are commonly and unfortunately referred to as "effective porosity". The first is specific yield or drainage porosity of an unsaturated soil, $\omega_{\mathrm{d}}$, and the second is kinematic porosity of a saturated medium, $\omega_{\mathrm{c}}$. Section 2.3 .3 of De Marsily (1986) summarizes which porosity (total included) to use for which application. For saturated-zone particle tracing and transport simulations, the kinematic porosity is appropriate and the focus of effective porosity discussions in this report.

An effective porosity can be used to account for regions of relatively immobile water, ranging from grain-sized "dead-end" pores to macro-scale clay intervals, which do not effectively participate in contaminant transport. The presence of immobile water does not necessarily dictate the use of an effective porosity (De Marsily, 1986, p. 259). If the solute contaminant perfectly penetrates the immobile water $\left(K^{\prime}=1, C^{\prime}=C\right.$ in De Marsily (1986)) (or there is no 
immobile water), then total porosity is appropriate $(\omega)$. On the other hand, if a model block contains sub-regions of immobile water that a solute will not penetrate $\left(K^{\prime}=0, C^{\prime}=0\right)$, then a lower, "effective" porosity is appropriate (kinematic, $\omega_{\mathrm{c}}$ ).

Effective porosity can be estimated by assuming that only the largest scale regions of relatively immobile water are not effectively penetrated by contaminant. At smaller scales. contaminant is able to effectively diffuse into regions of immobile water. Macro-scale regions of immobile water can reasonably be defined as sediment intervals with more than $25 \%$ mud. For the General Separations Area, $32 \%$ of the nearly $40,000 \mathrm{ft}$ of sediment core contains greater than $25 \%$ mud, based on analysis of the lithologic data compiled by Smits and others (1997). This suggests that as low as 68\% of a typical aquifer is effectively available for contaminant transport, and that effective porosity is approximately $25 \%$ (68\% of $40 \%$ total porosity). This estimate may be a conservative (low) estimate for effective conductivity, because in reality some contamination would penetrate the lower conductivity intervals. This value is consistent with the recommendations of Looney and others (1987, p. 39), who recommend assuming an effective porosity of 0.2 for risk calculations. Transport sensitivity studies should consider an effective porosity range of approximately $25 \%$ to $40 \%$. 


\subsubsection{Specific Storage}

Specific storage is relevant only to transient flow simulations, and therefore has no effect on the steady-state results presented in later sections. Specific storage is defined by (Freeze and Cherry, 1979, p. 59)

$$
S_{s}=\rho g(\alpha+\eta \beta)
$$

where

$$
\begin{aligned}
S_{S} & \text { specific storage } \\
\rho & \text { density of water }\left(\sim 1000 \mathrm{~kg} / \mathrm{m}^{3}\right) \\
\mathrm{g} & \text { gravitational acceleration }\left(9.8 \mathrm{~m} / \mathrm{s}^{2}\right) \\
\alpha & \text { compressibility of porous medium } \\
\eta & \text { total porosity } \\
\beta & \text { compressibility of water }\left(4.4 \times 10^{-10} \mathrm{~m}^{2} / \mathrm{N}\right)
\end{aligned}
$$

Compressibility ranges from $10^{-6}$ to $10^{-8} \mathrm{~m}^{2} / \mathrm{N}$ for clay and from $10^{-7}$ to $10^{-9} \mathrm{~m}^{2} / \mathrm{N}$ for sand (Freeze and Cherry, 1979, Table 2.5). Assuming a nominal compressibility value of $5 \times 10^{-8} \mathrm{~m}^{2} / \mathrm{N}$ and a total porosity of $40 \%$ yields $1.5 \times 10^{-4} \mathrm{ft}^{-1}$ for specific storage. 


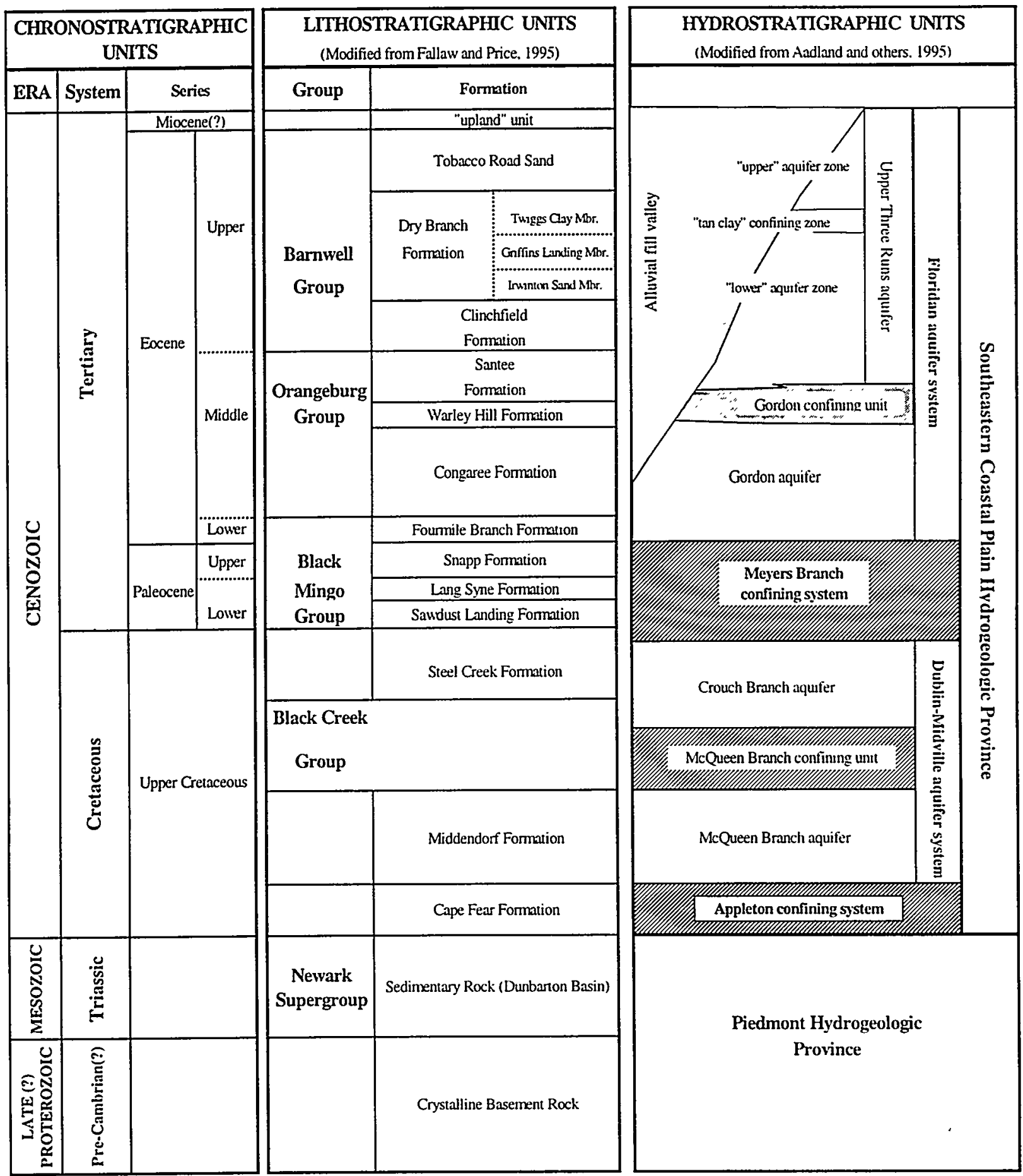

Figure 2-1. Comparison of Lithostratigraphic and Hydrostratigraphic Units at SRS 


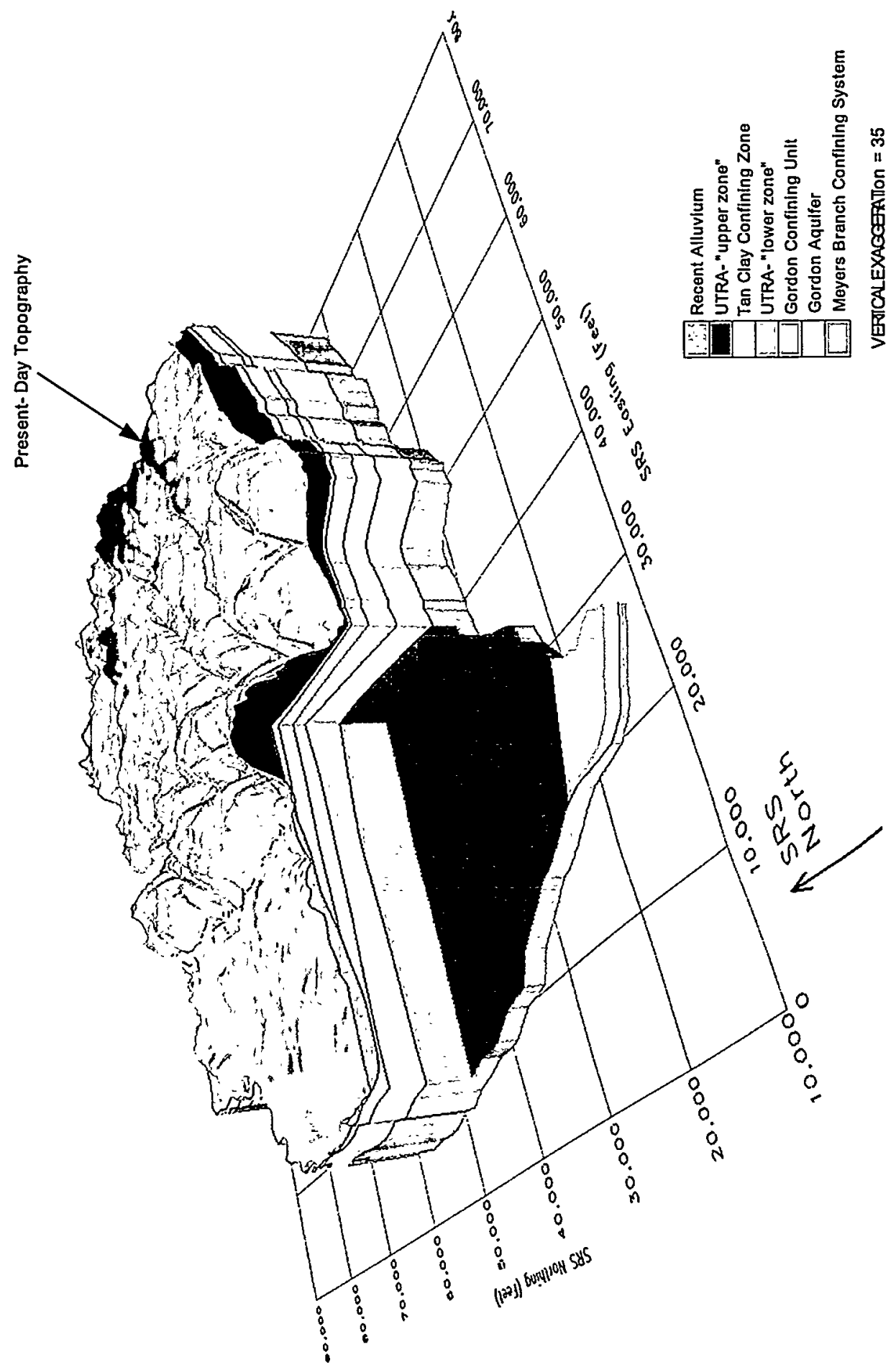

U 

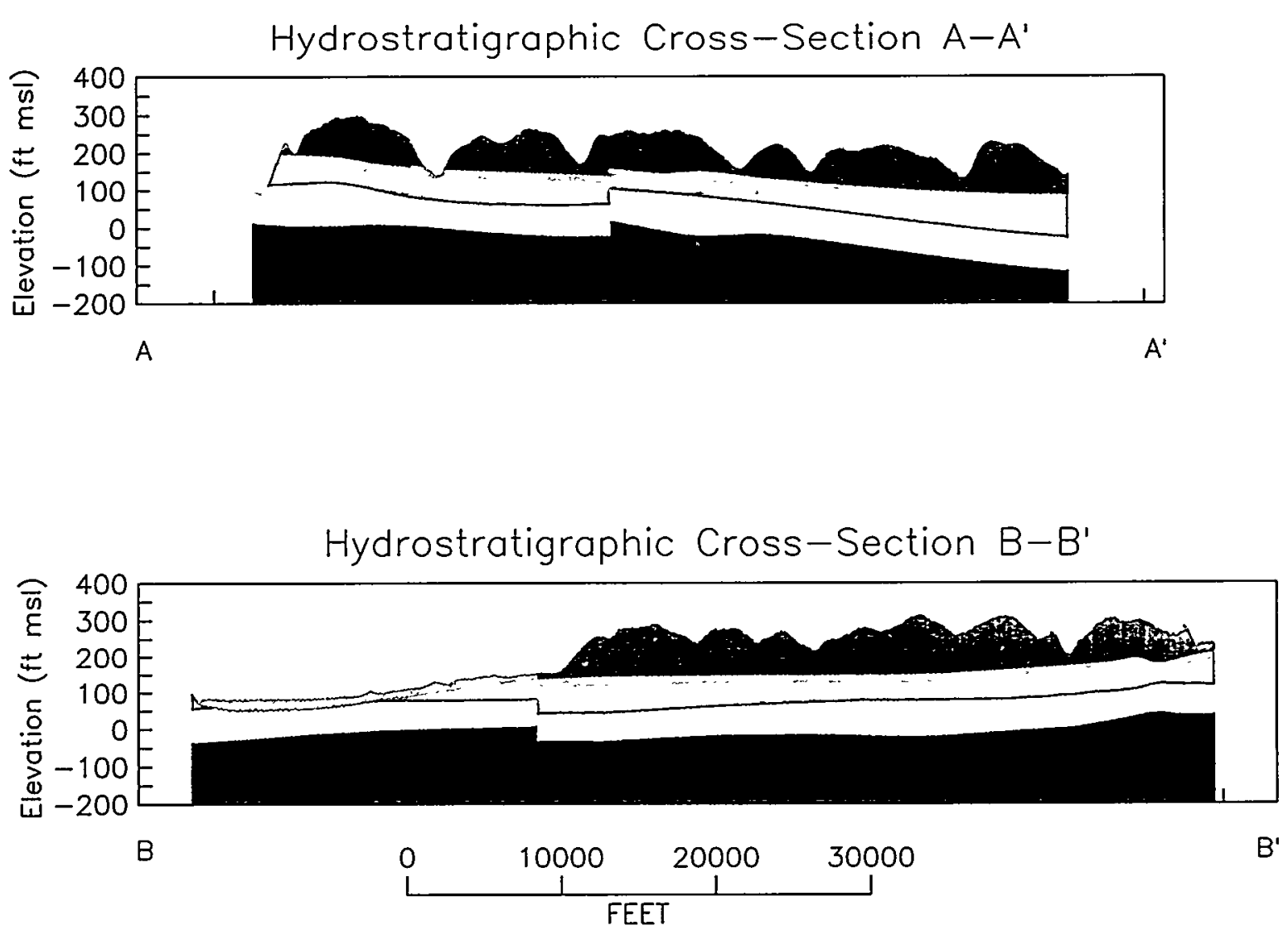

Vertical exaggeration $=25$
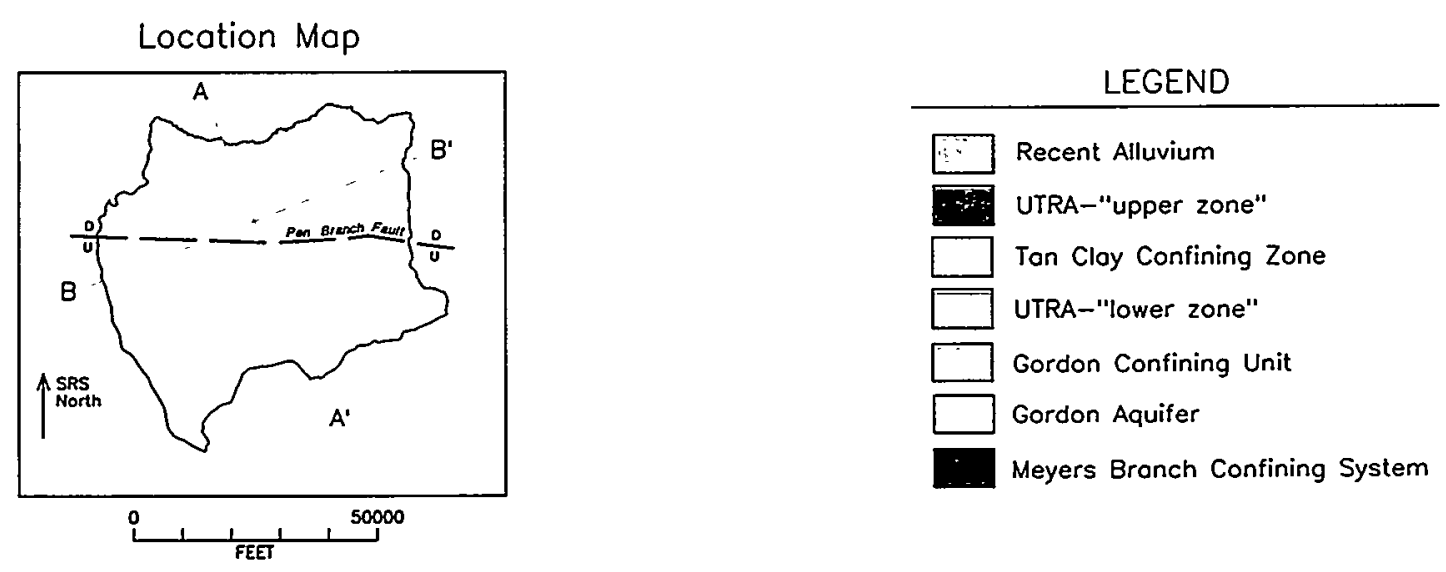

Figure 2-3. Hydrostratigraphic Cross-Sections 


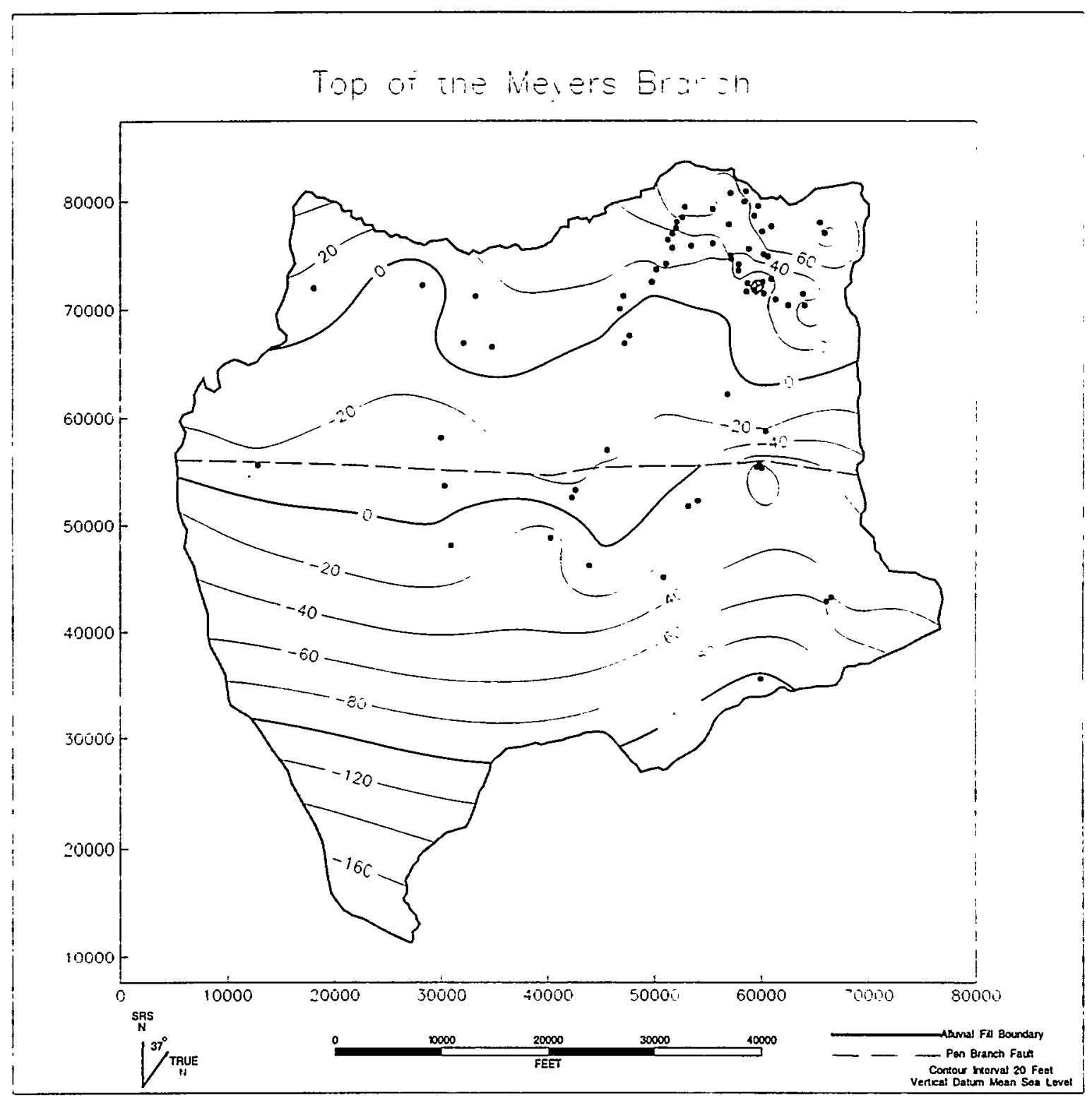

Figure 2-4. Altitude-Contour Map of the Top of the Meyers Branch Confining System 


\section{Top of Gordon Aquifer with Alluvial Fill Valley (AFV)}

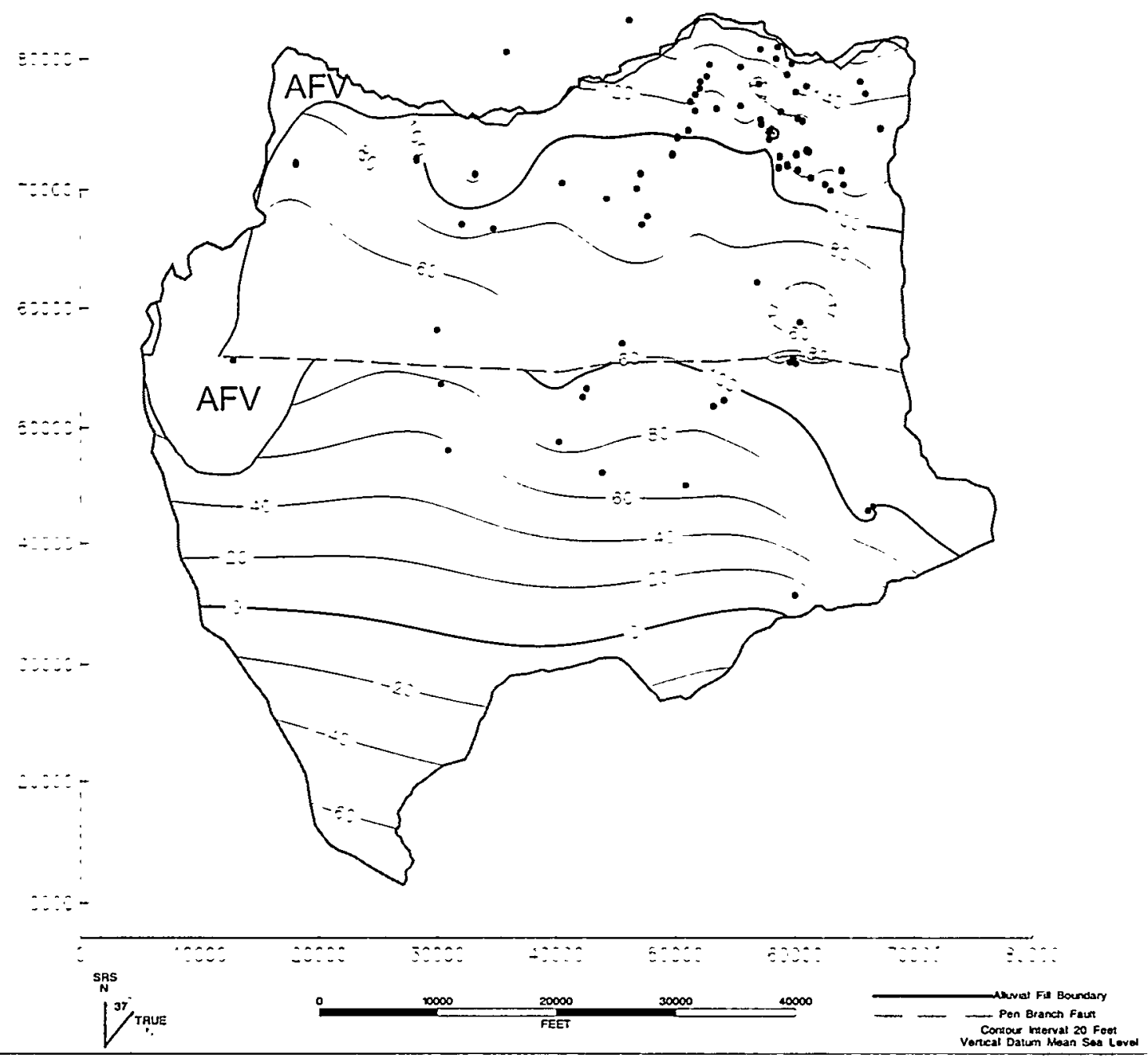




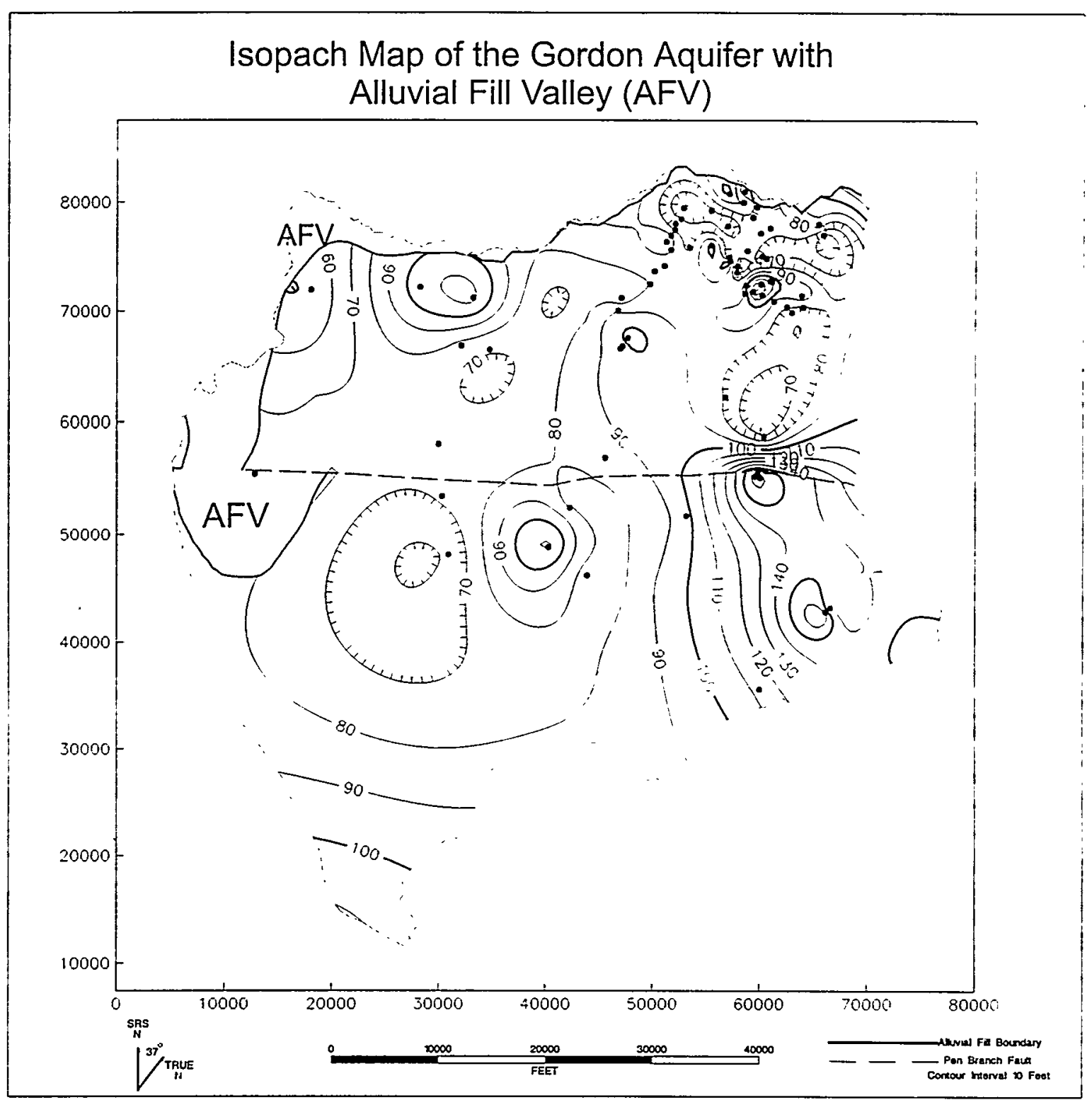

Figure 2-6. Isopach Map of the Gordon Aquifer 


\section{Top of the Gordon Confining Unit with Alluvial Valley Fill (AVF)}

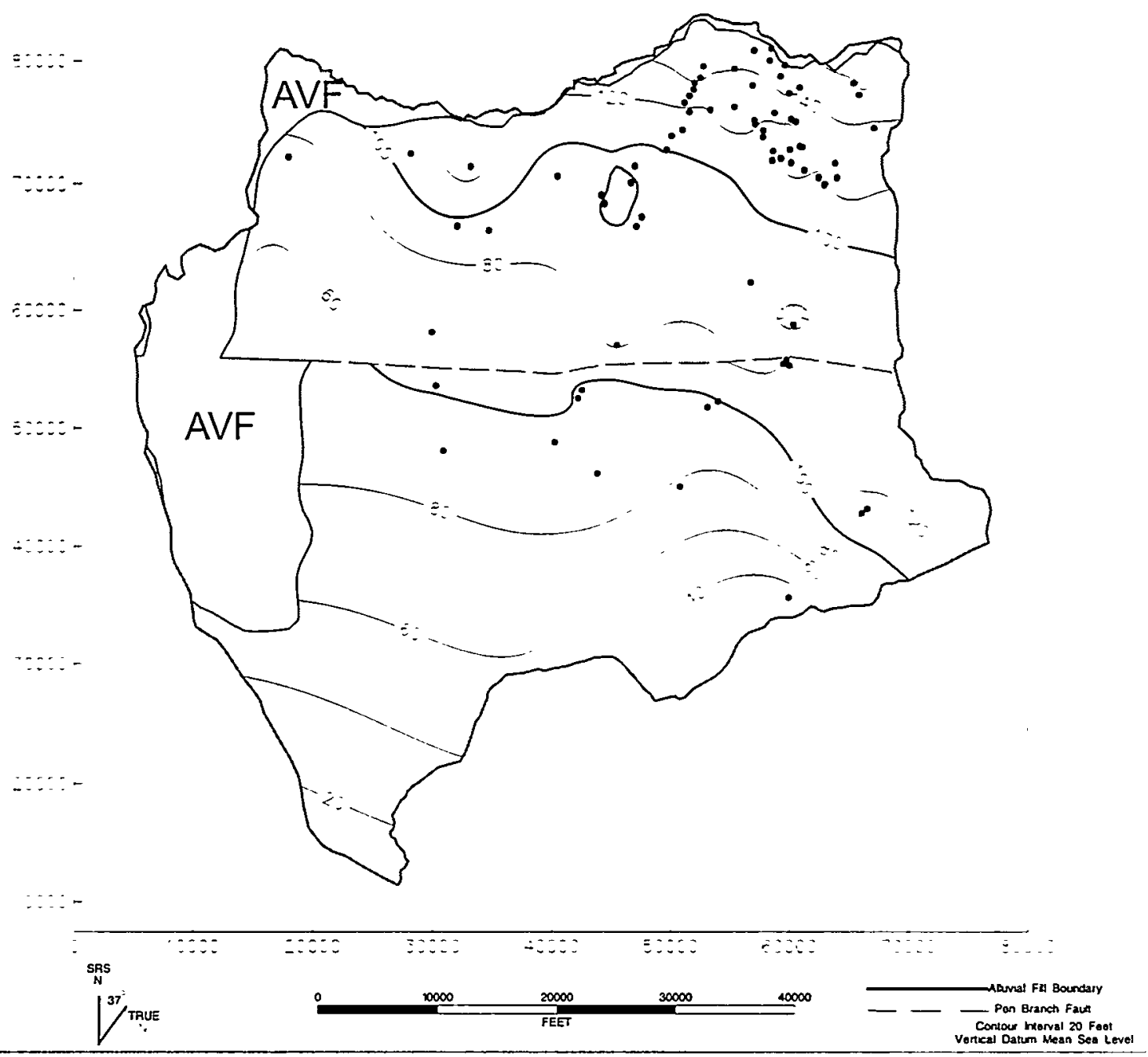

Figure 2-7. Altitude-Contour Map of the Top of the Gordon Confining Unit 


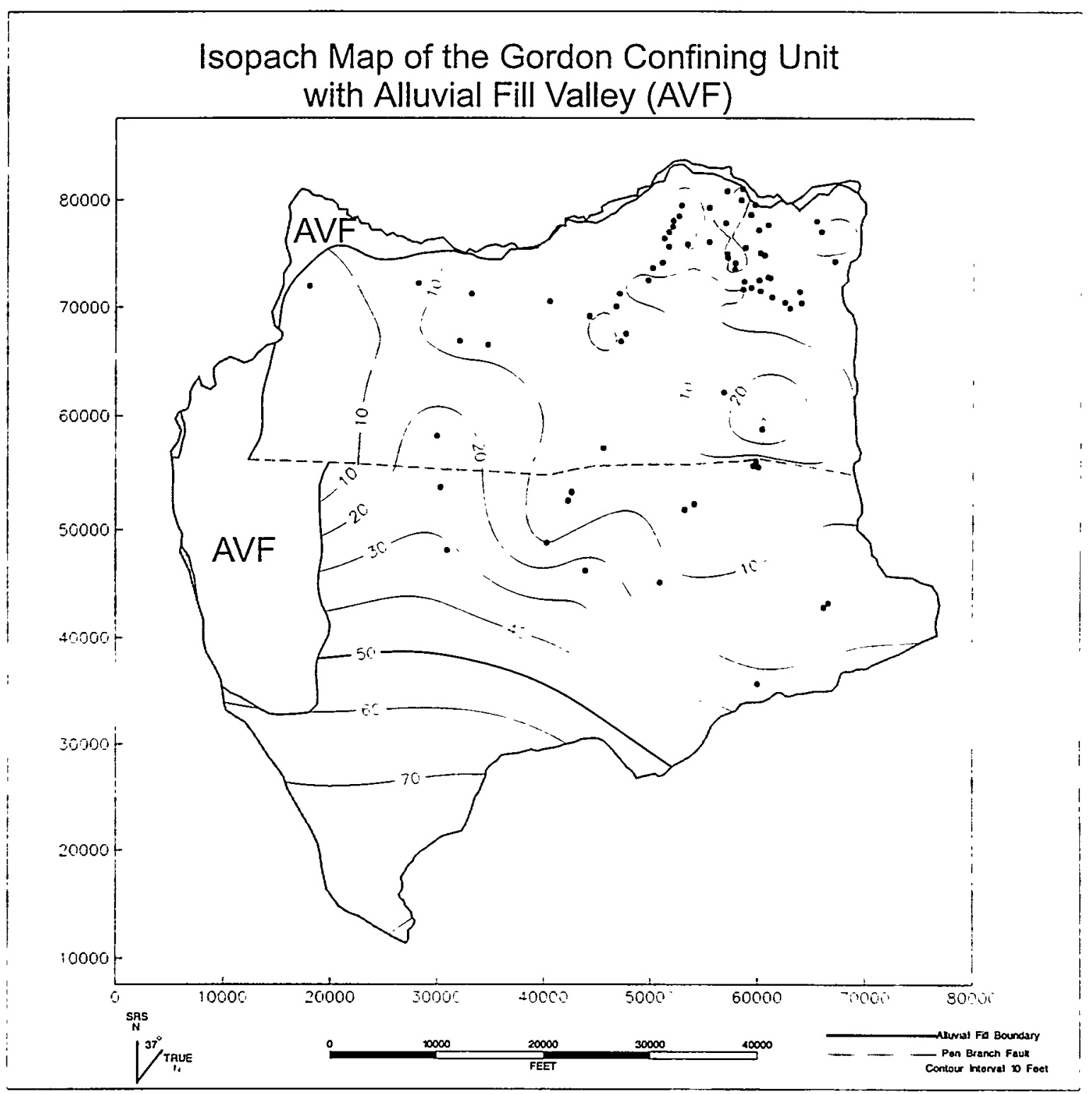

Figure 2-8. Isopach Map of the Gordon Confining Unit 


\section{Top of the "lower" aquifer zone with Alluvial Valley Fill (AVF)}

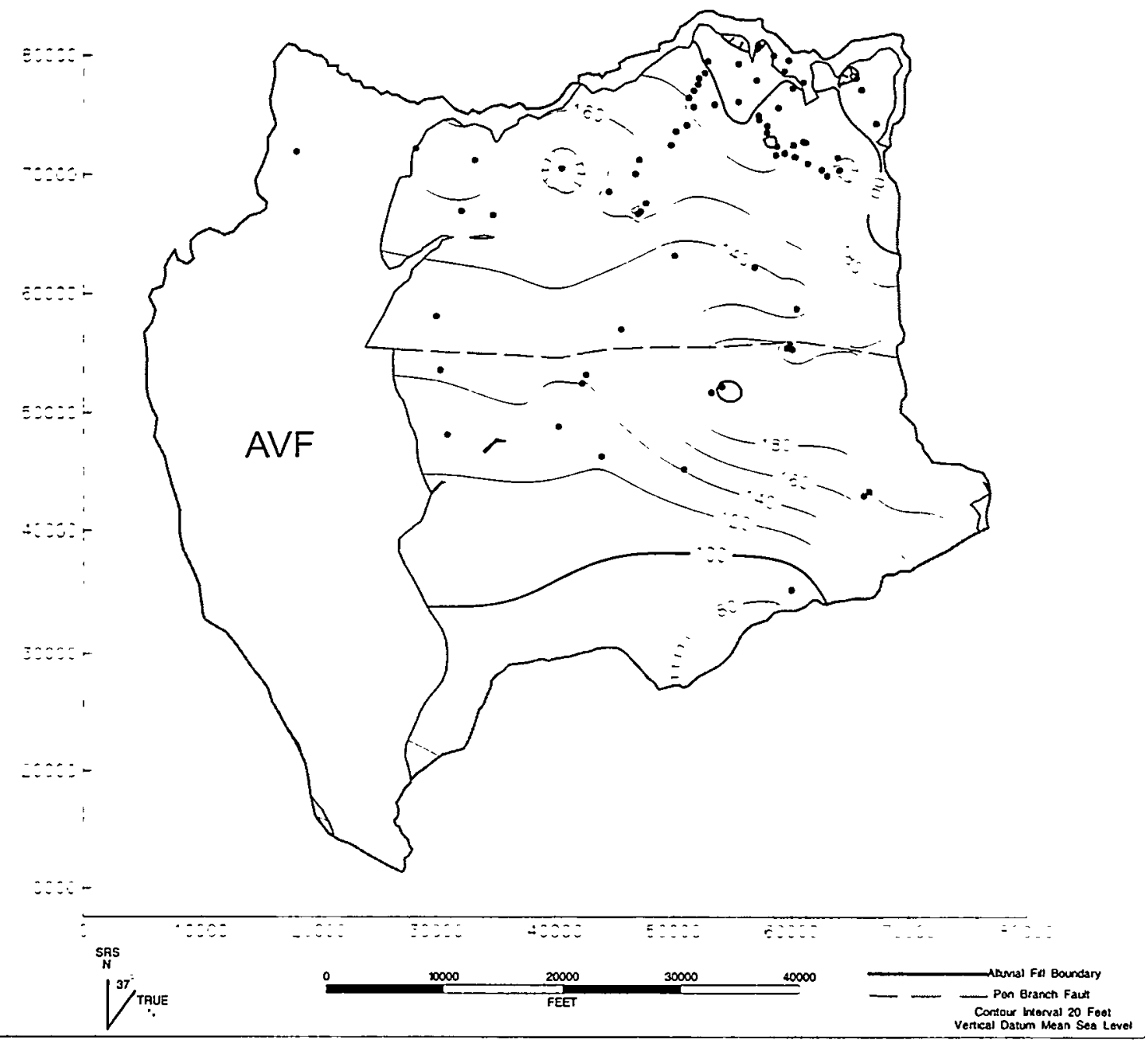




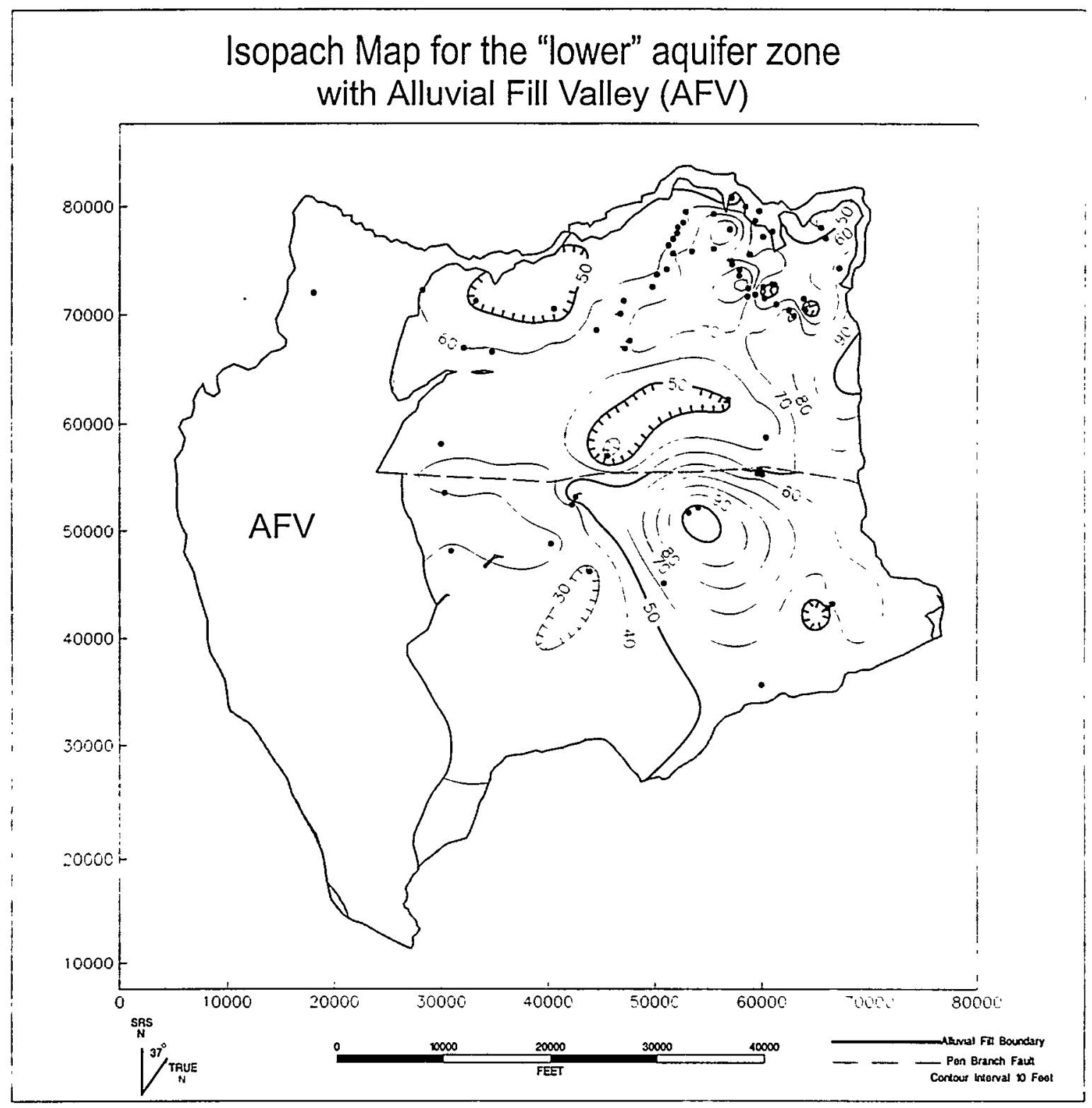

Figure 2-10. Isopach Map of the "Lower" Aquifer Zone 


\section{Top of the "Tan Clay" Confining Zone with Allluvial Valley Fill (AVF)}

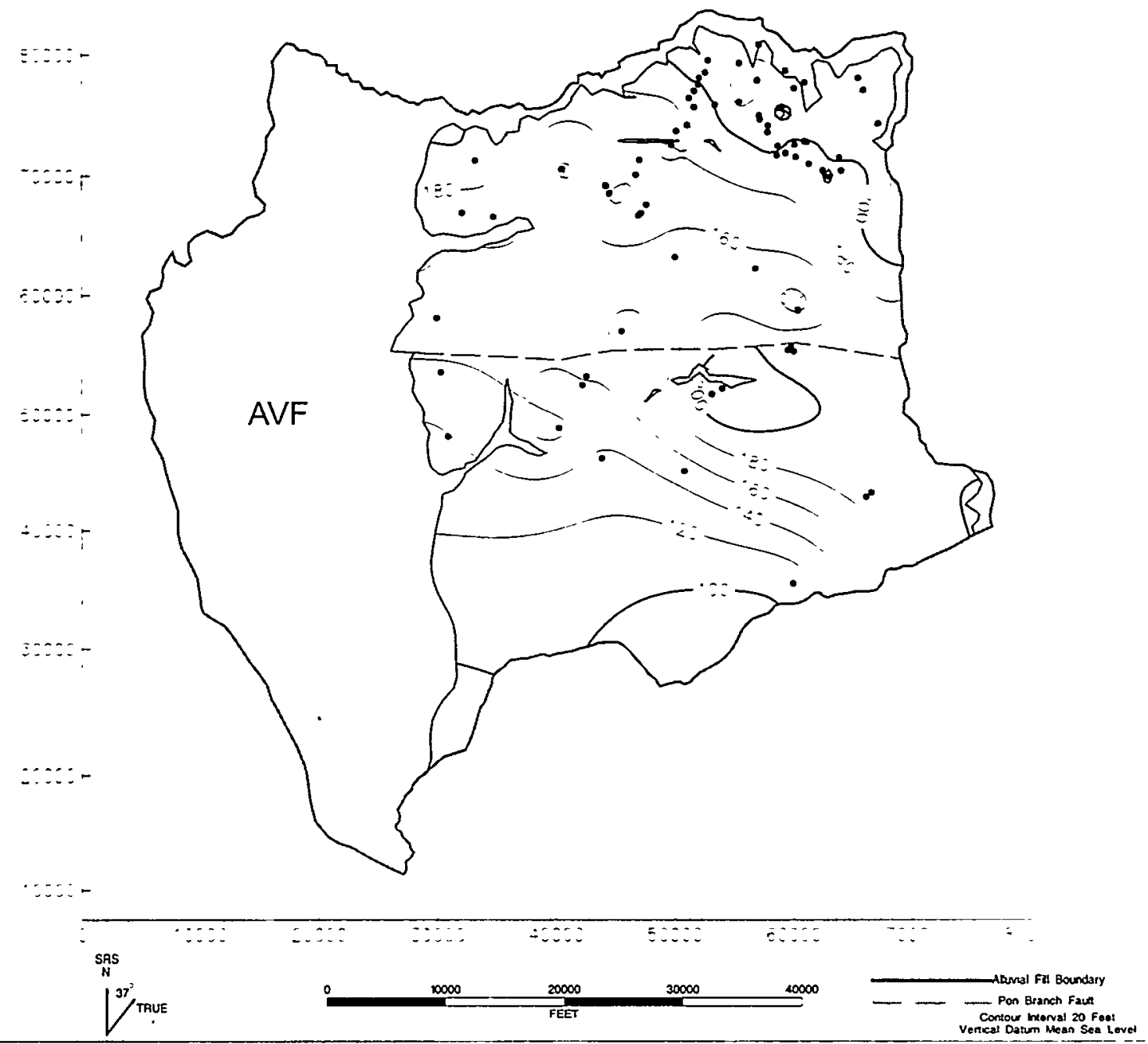

Figure 2-11. Altitude-Contour Map of the Top of the "Tan Clay" Confining Zone 


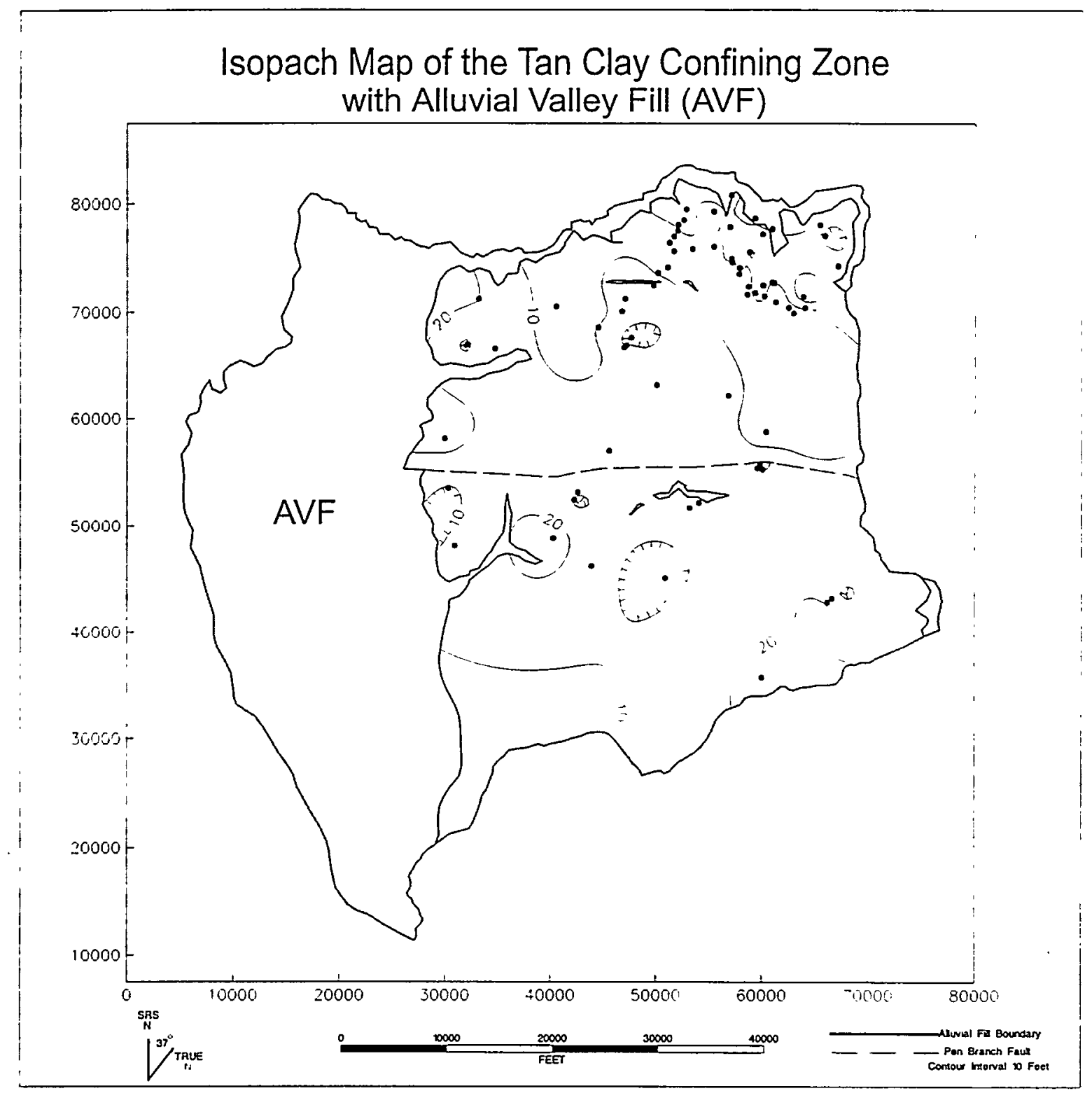

Figure 2-12. Isopach Map of the "Tan Clay" Confining Zone 


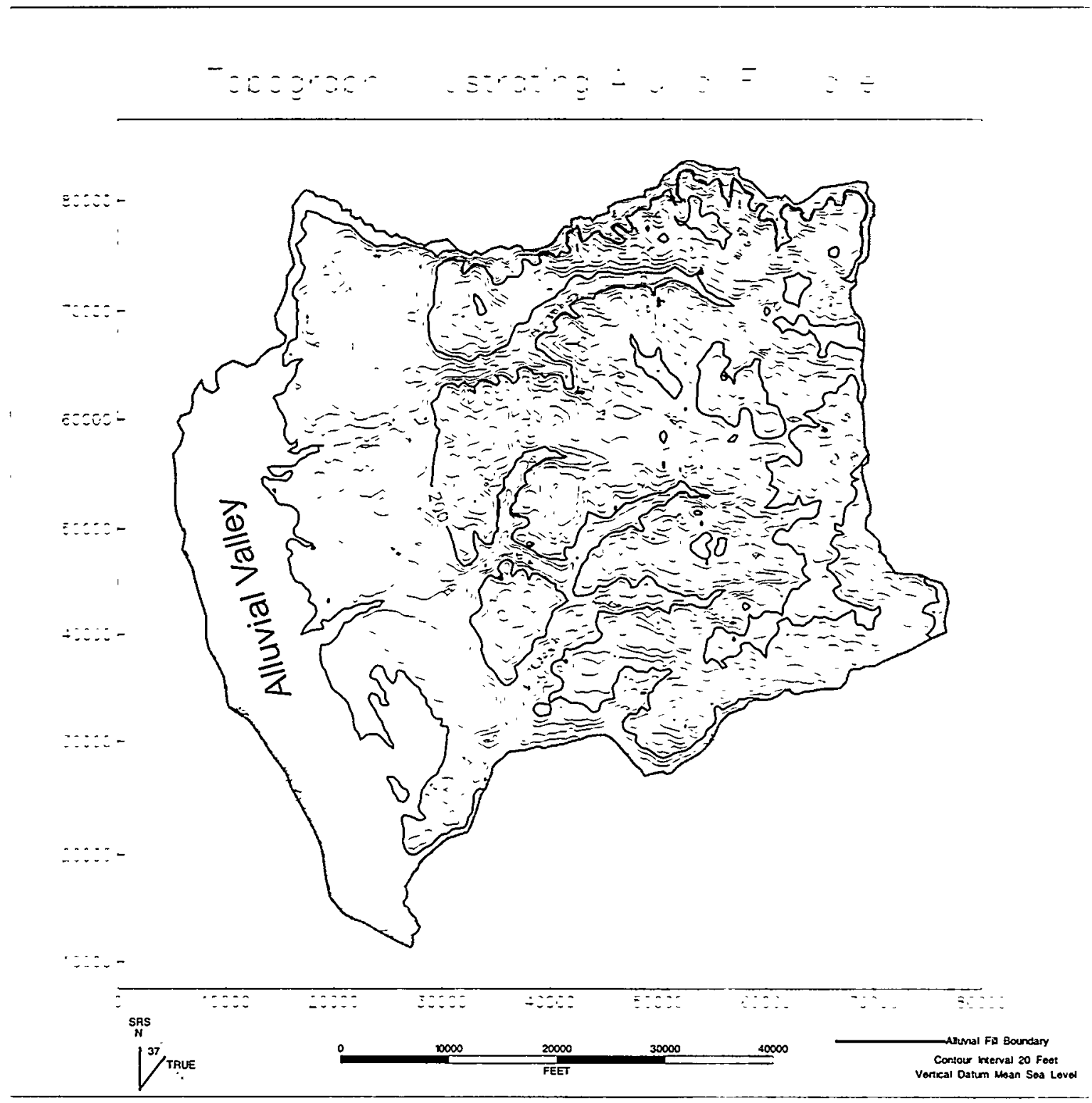

Figure 2-13. Topographic Surface of the "Upper" Aquifer Zone 


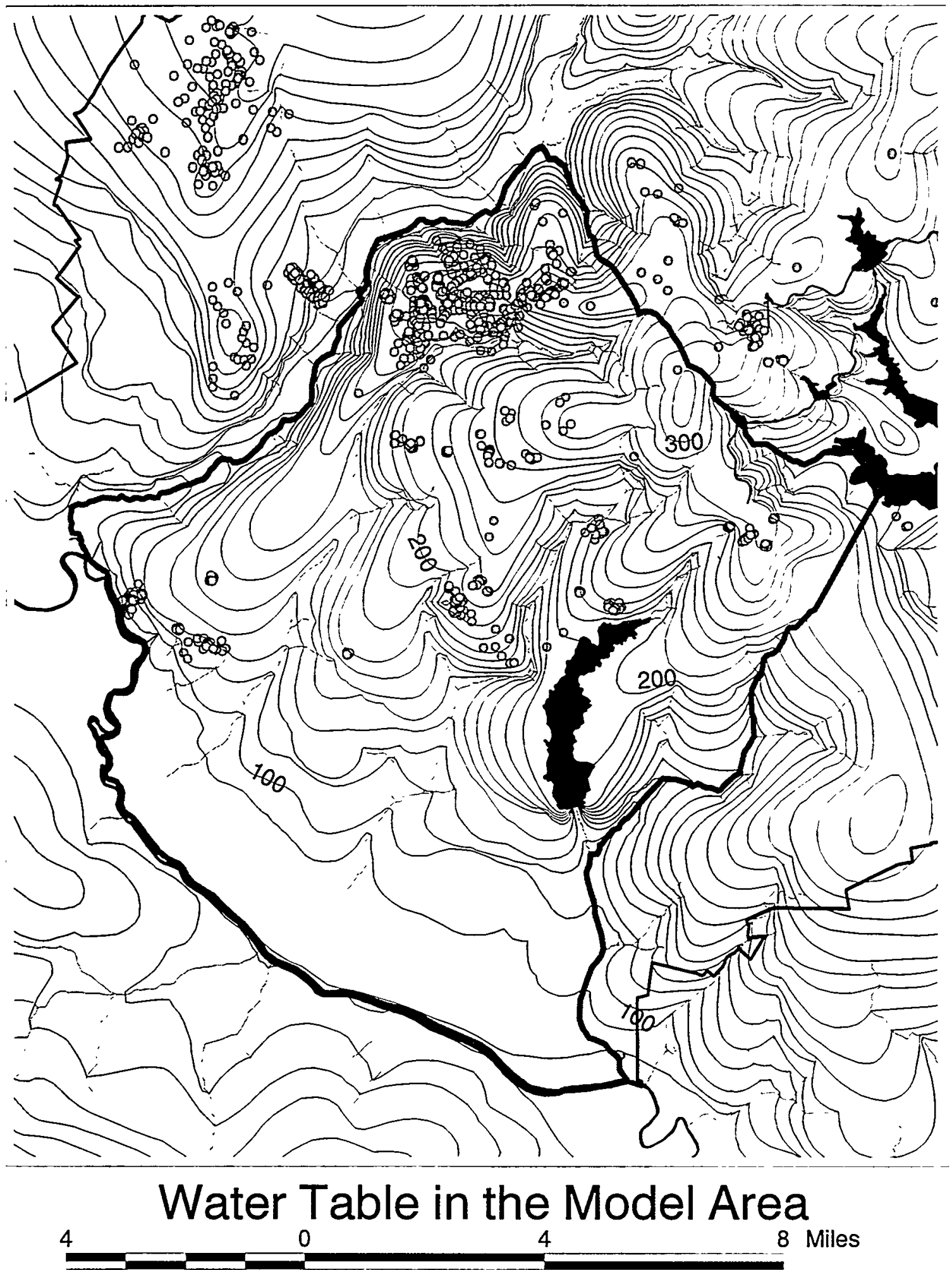

Figure 2-14. Water Table Map of CKLP Model Area 


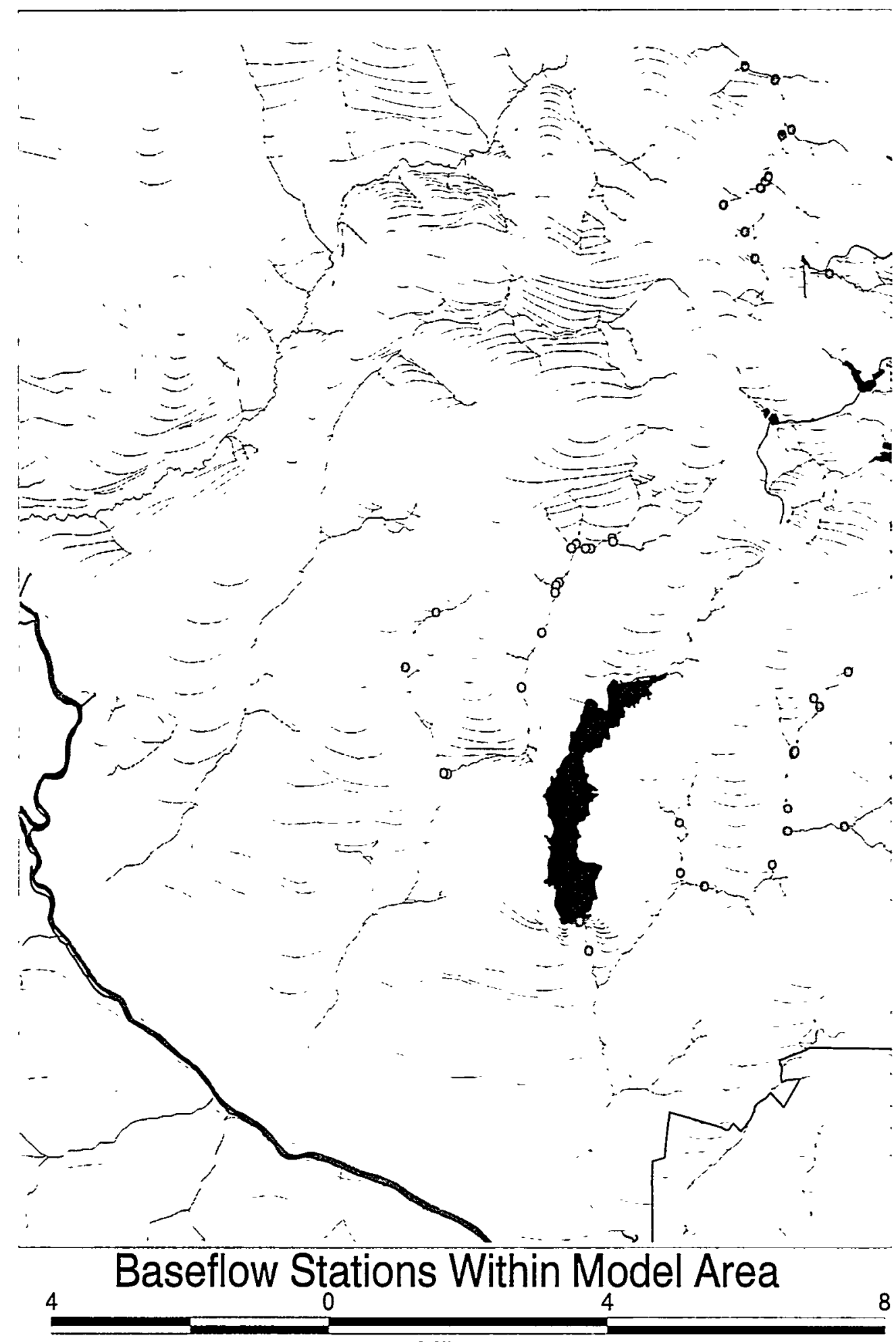

Miles

Figure 2-15. Location of Stream Baseflow Measurements for 1998 Field Study 

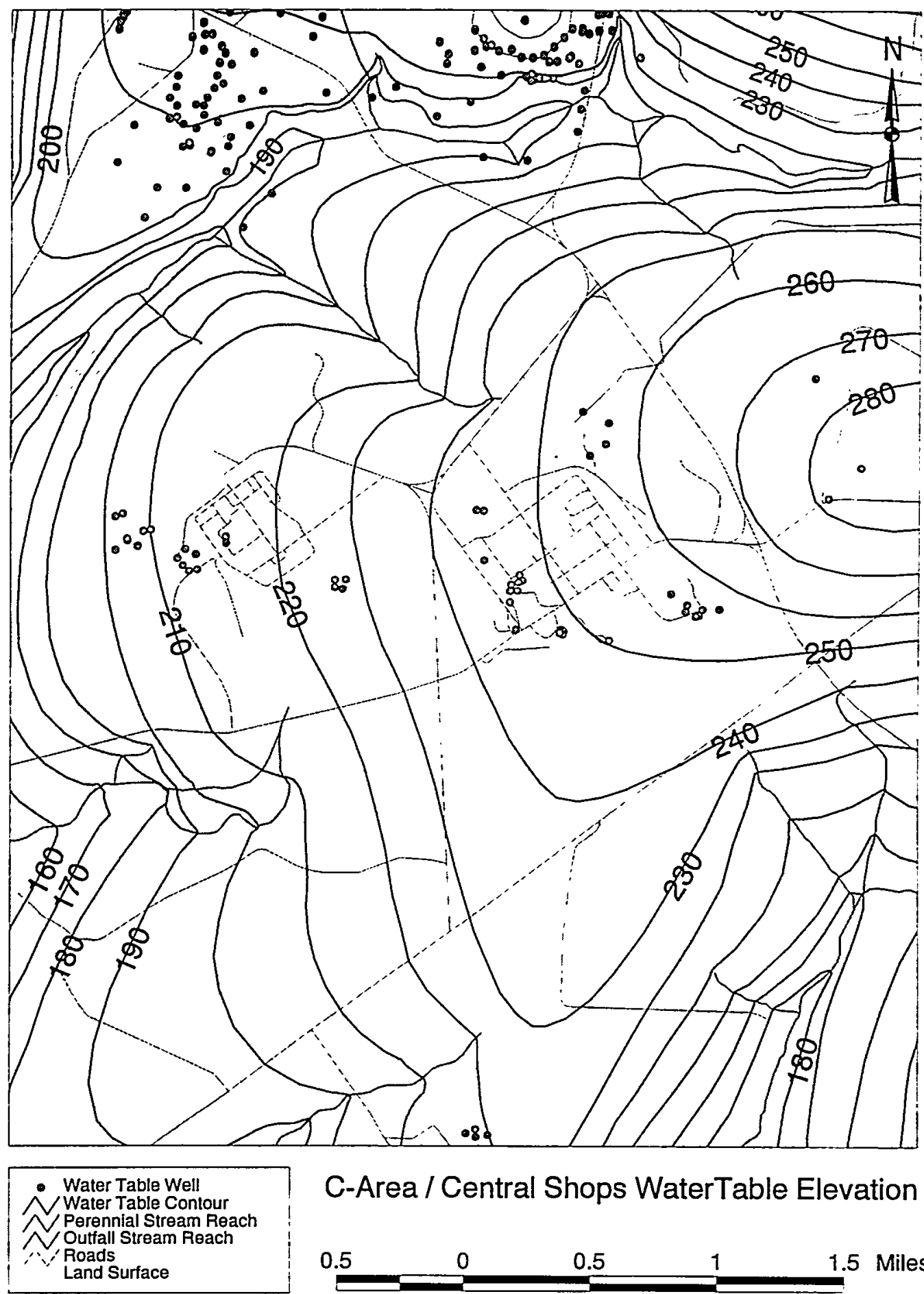

C-Area / Central Shops WaterTable Elevation

0.5 0 0.5 1 1.5 Miles

Figure 2-16. Water Table Map for C Reactor Area 


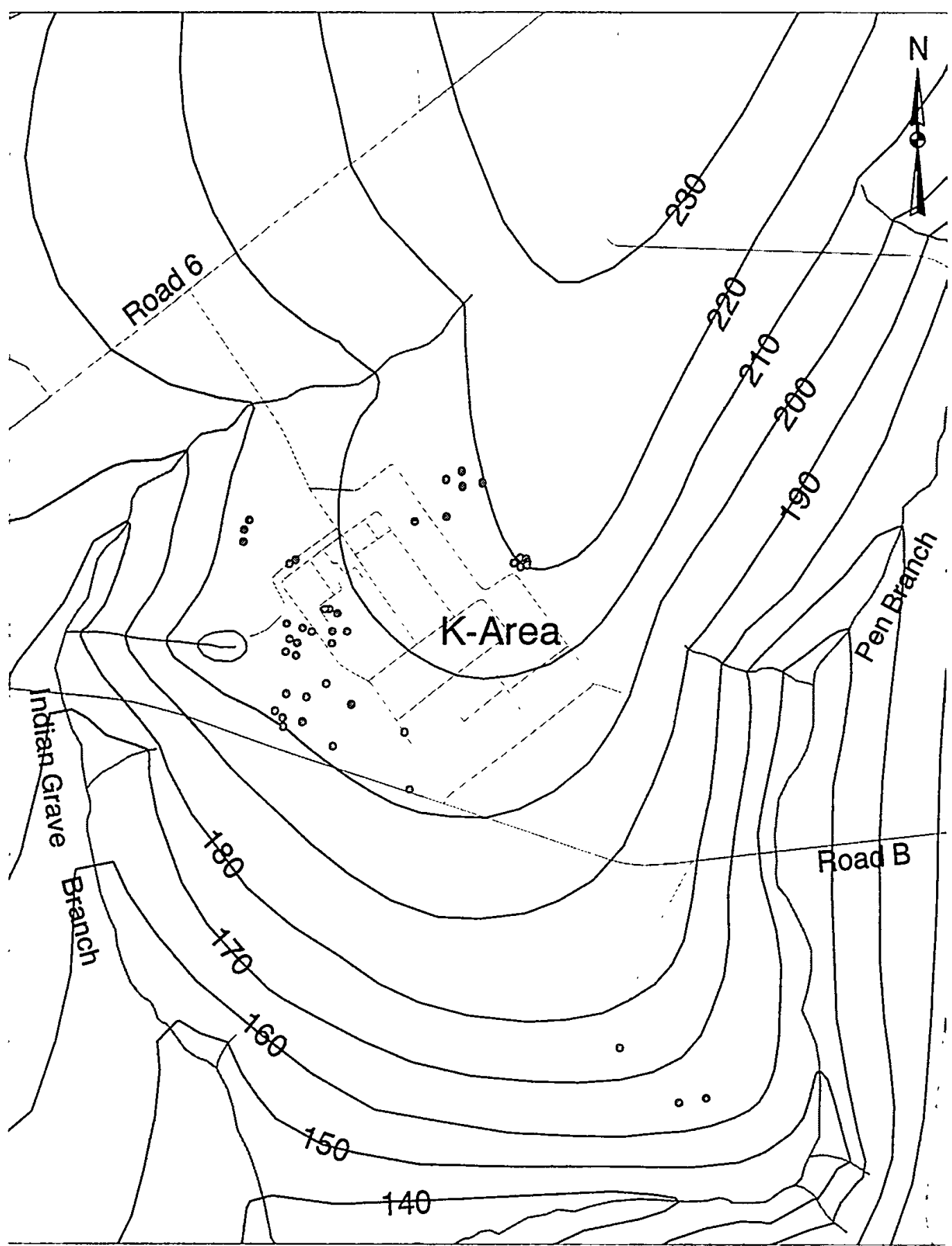

- Water Table Well Water Table Contour

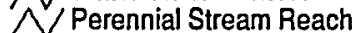
Outfall Stream Reach Roads

Land Surface

\section{K-Area Water Table Elevation}

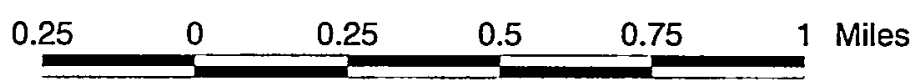

Figure 2-17. Water Table Map for K Reactor Area 

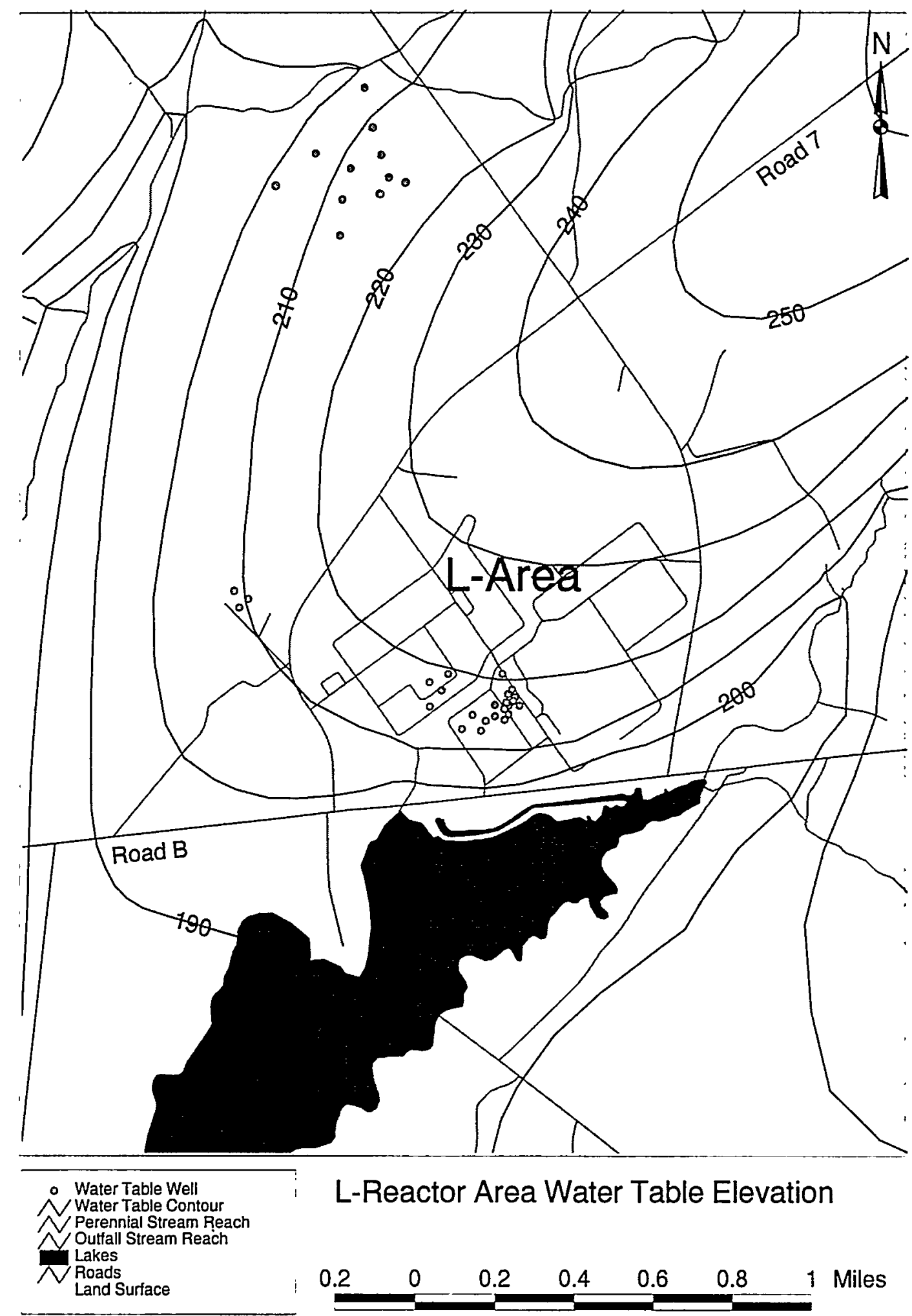

\section{L-Reactor Area Water Table Elevation}

$\begin{array}{llllllll}0.2 & 0 & 0.2 & 0.4 & 0.6 & 0.8 & 1 & \text { Miles }\end{array}$

Figure 2-18. Water Table Map for L Reactor Area 


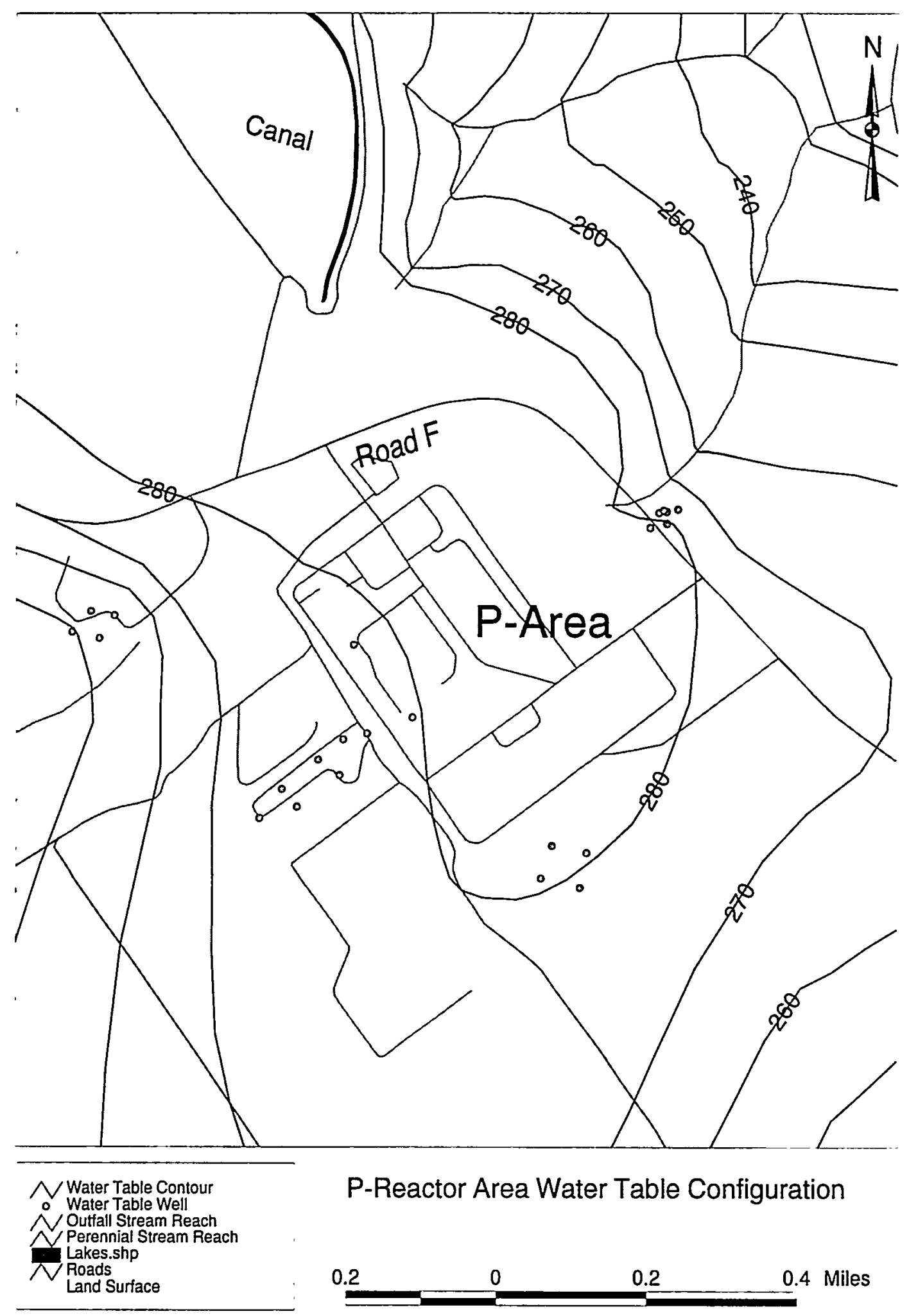

Figure 2-19. Water Table Map for P Reactor Area 


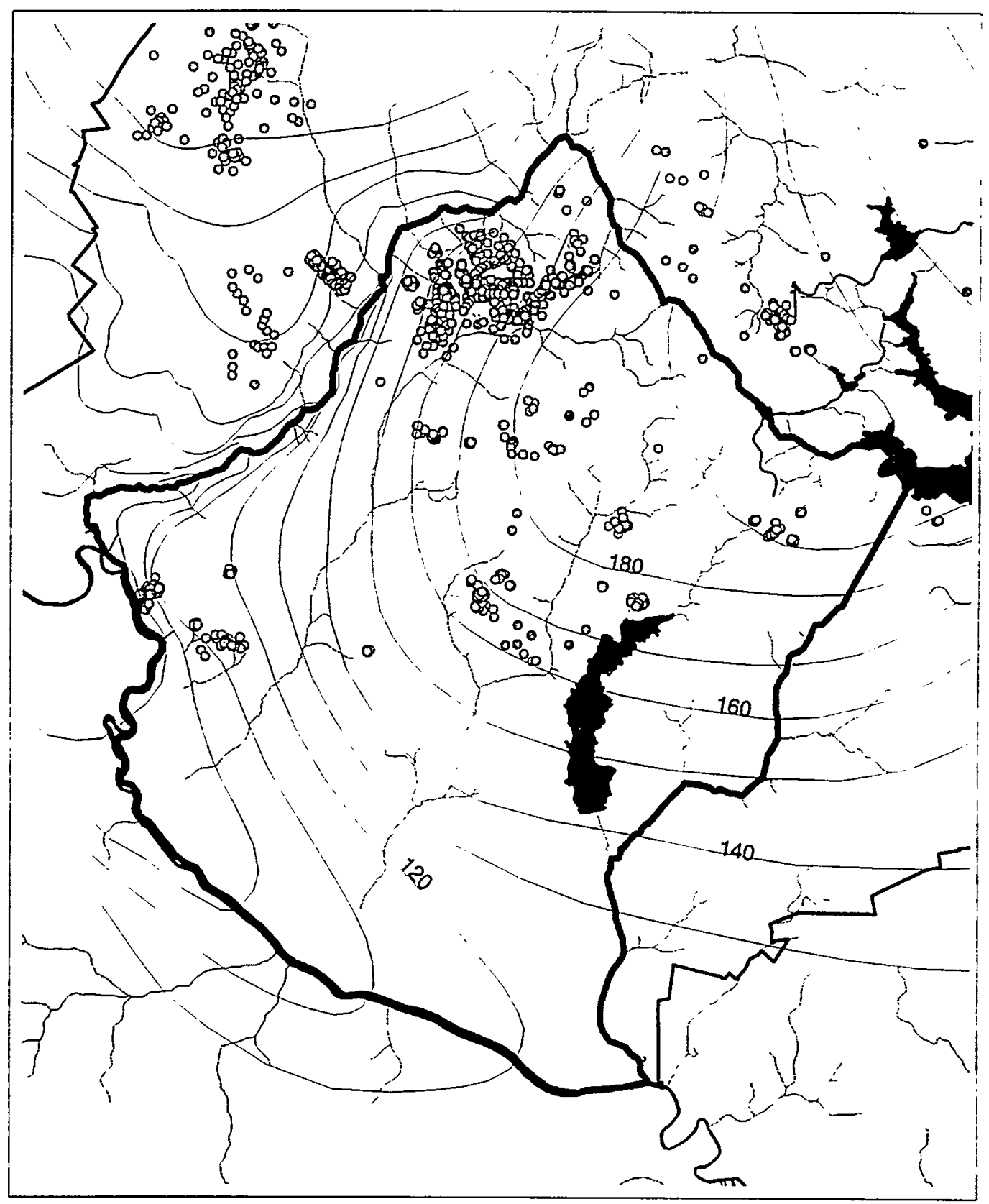

Gordon Potentiometric Level in Model Area $\begin{array}{rrrrrrr}2 & 0 & 2 & 4 & 6 & 8 & 10 \text { Miles }\end{array}$

Figure 2-20. Gordon Potentiometric Surface in the CKLP Model Area 


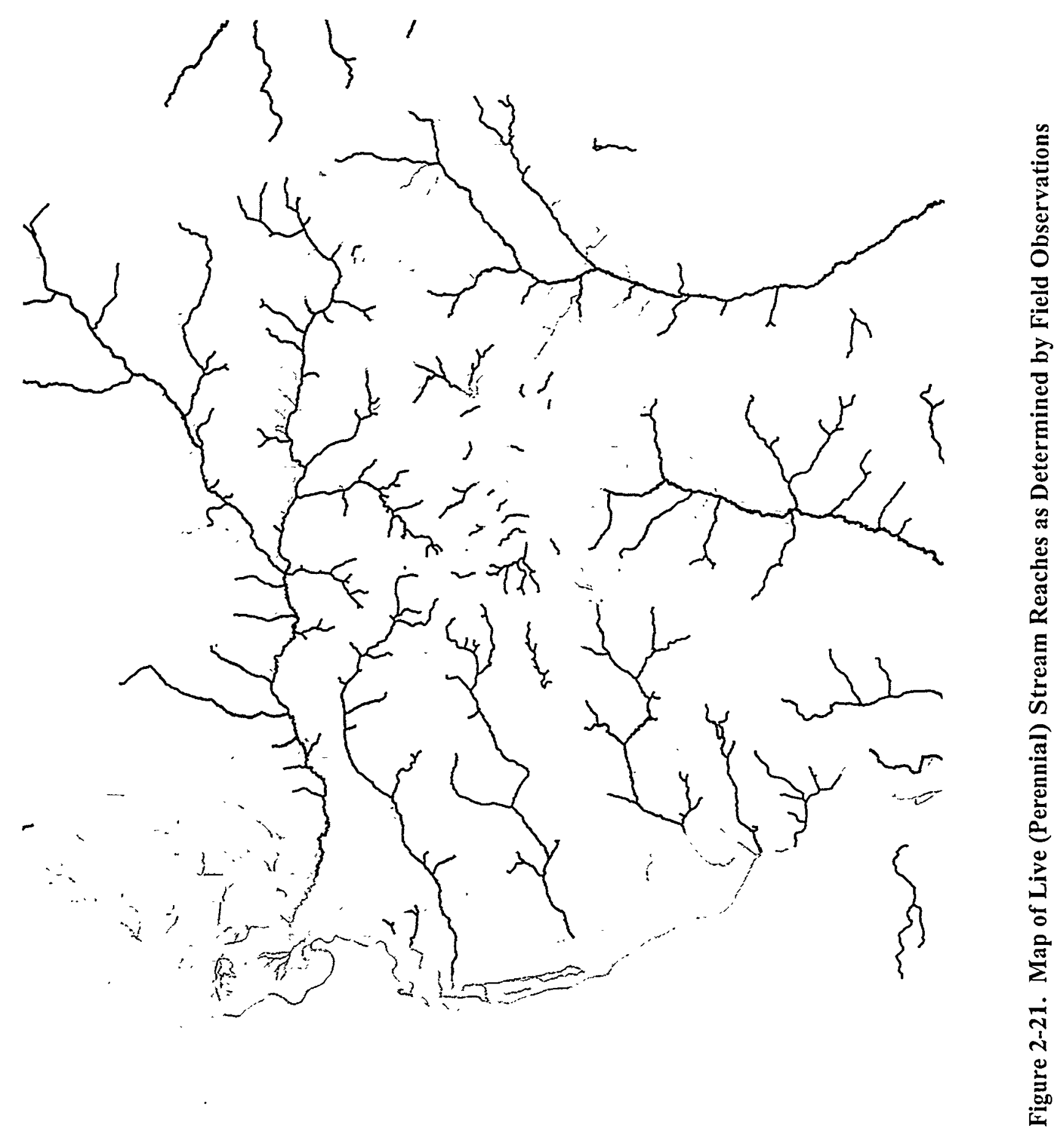




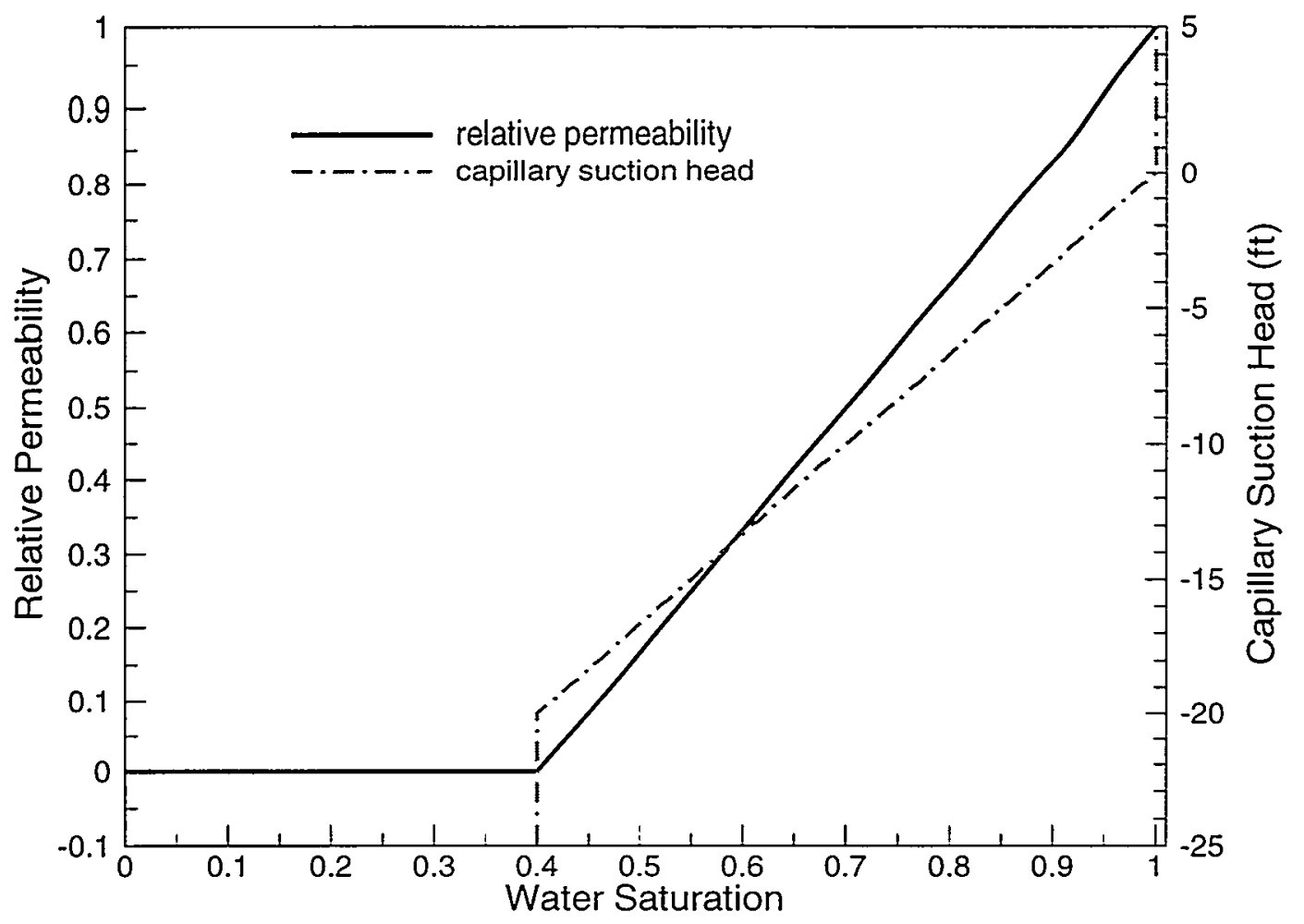

Figure 2-22. Approximate Soil Characteristic Curves 
Table 2-1. Summary of Permeability Measurements

\begin{tabular}{|c|c|c|c|c|}
\hline \multirow[b]{2}{*}{ Hydrostratigraphic Unit } & \multicolumn{2}{|c|}{ Laboratory Tests (ft/day) } & \multirow{2}{*}{$\begin{array}{c}\text { Slug } \\
\text { Tests (ft/day) }\end{array}$} & \multirow{2}{*}{$\begin{array}{c}\text { Pumping } \\
\text { Tests (ft/day) }\end{array}$} \\
\hline & Vertical & Horizontal & & \\
\hline \multicolumn{5}{|l|}{ "upper" aquifer zone } \\
\hline Number of Results & 11 & 12 & 12 & 1 \\
\hline Minimum & $9.20 \mathrm{E}-05$ & $2.24 \mathrm{E}-04$ & $1.40 \mathrm{E}-01$ & $5.16 \mathrm{E}+01$ \\
\hline Maximum & $2.77 \mathrm{E}+01$ & $6.04 \mathrm{E}+00$ & $1.22 \mathrm{E}+01$ & - \\
\hline Arithmetic Mean & $2.68 \mathrm{E}+00$ & $1.21 \mathrm{E}+00$ & $1.88 \mathrm{E}+00$ & - \\
\hline Geometric Mean & $1.04 \mathrm{E}-02$ & $6.19 \mathrm{E}-02$ & $7.36 \mathrm{E}-01$ & - \\
\hline Standard Deviation & $8.31 E+00$ & $2.24 \mathrm{E}+00$ & $3.46 \mathrm{E}+00$ & - \\
\hline \multicolumn{5}{|l|}{ "tan clay" confining zone } \\
\hline Number of Results & 37 & 24 & 0 & 0 \\
\hline Minimum & $3.70 \mathrm{E}-08$ & $1.45 \mathrm{E}-05$ & - & - \\
\hline Maximum & $9.66 \mathrm{E}-02$ & $1.70 \mathrm{E}-01$ & - & - \\
\hline Arithmetic Mean & 4.62E-03 & $8.49 \mathrm{E}-03$ & - & - \\
\hline Geometric Mean & $5.94 \mathrm{E}-05$ & $2.60 \mathrm{E}-04$ & - & - \\
\hline Standard Deviation & $1.91 \mathrm{E}-02$ & 3.47E-02 & - & - \\
\hline \multicolumn{5}{|l|}{ "lower" aquifer zone } \\
\hline Number of Results & 33 & 31 & 25 & 3 \\
\hline Minimum & 4.54E-06 & $1.59 \mathrm{E}-05$ & $1.30 \mathrm{E}-01$ & $1.23 \mathrm{E}+00$ \\
\hline Maximum & $3.42 \mathrm{E}+00$ & $1.11 \mathrm{E}+01$ & $2.44 E+01$ & $2.10 \mathrm{E}+00$ \\
\hline Arithmetic Mean & $1.77 \mathrm{E}-01$ & $6.45 \mathrm{E}-01$ & $3.90 \mathrm{E}+00$ & $1.67 \mathrm{E}+00$ \\
\hline Geometric Mean & $2.82 \mathrm{E}-03$ & $1.02 \mathrm{E}-02$ & $1.67 \mathrm{E}+00$ & $1.63 \mathrm{E}+00$ \\
\hline Standard Deviation & $6.19 \mathrm{E}-01$ & $2.03 E+00$ & $6.09 \mathrm{E}+00$ & 4.35E-01 \\
\hline \multicolumn{5}{|l|}{ Gordon Confining Unit } \\
\hline Number of Results & 41 & 25 & 0 & 0 \\
\hline Minimum & $1.14 \mathrm{E}-06$ & $5.40 \mathrm{E}-06$ & - & - \\
\hline Maximum & $4.27 \mathrm{E}-01$ & $1.22 \mathrm{E}-01$ & - & - \\
\hline Arithmetic Mean & $1.20 \mathrm{E}-02$ & $1.06 \mathrm{E}-02$ & - & - \\
\hline Geometric Mean & $1.15 \mathrm{E}-04$ & 1.62E-04 & - & - \\
\hline Standard Deviation & $6.68 \mathrm{E}-02$ & $3.09 \mathrm{E}-02$ & - & - \\
\hline
\end{tabular}


Table 2-1. Summary of Permeability Measurements (Continued)

\begin{tabular}{|c|c|c|c|c|}
\hline \multirow[b]{2}{*}{ Hydrostratigraphic Unit } & \multicolumn{2}{|c|}{ Laboratory Tests (ft/day) } & \multirow{2}{*}{$\begin{array}{c}\text { Slug } \\
\text { Tests (ft/day) }\end{array}$} & \multirow{2}{*}{$\begin{array}{c}\text { Pumping } \\
\text { Tests (ft/day) }\end{array}$} \\
\hline & Vertical & Horizontal & & \\
\hline \multicolumn{5}{|l|}{ Gordon Aquifer } \\
\hline Number of Results & 23 & 24 & 47 & 13 \\
\hline Minimum & $3.12 \mathrm{E}-06$ & $2.06 \mathrm{E}-05$ & $5.00 \mathrm{E}-03$ & $8.20 \mathrm{E}-01$ \\
\hline Maximum & $3.62 \mathrm{E}+01$ & $3.26 \mathrm{E}+0 \mathrm{I}$ & $3.32 E+01$ & $1.43 \mathrm{E}+02$ \\
\hline Arithmetic Mean & $1.66 \mathrm{E}+00$ & $5.25 \mathrm{E}+00$ & $3.78 \mathrm{E}+00$ & $2.92 \mathrm{E}+01$ \\
\hline Geometric Mean & 7.73E-04 & $1.05 \mathrm{E}-02$ & $9.81 \mathrm{E}-01$ & $1.04 E+01$ \\
\hline Standard Deviation & $7.54 \mathrm{E}+00$ & $1.12 \mathrm{E}+01$ & $6.15 E+00$ & $3.92 E+01$ \\
\hline \multicolumn{5}{|c|}{ Meyers Branch Confining System } \\
\hline Number of Results & 38 & 27 & 1 & 0 \\
\hline Minimum & $4.26 \mathrm{E}-06$ & $1.11 \mathrm{E}-05$ & $3.55 \mathrm{E}+01$ & - \\
\hline Maximum & $3.40 \mathrm{E}-01$ & $1.50 \mathrm{E}+00$ & - & . \\
\hline Arithmetic Mean & $1.39 \mathrm{E}-02$ & $8.63 \mathrm{E}-02$ & - & 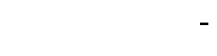 \\
\hline Geometric Mean & $2.47 \mathrm{E}-04$ & $5.52 \mathrm{E}-04$ & - & - \\
\hline Standard Deviation & $5.65 \mathrm{E}-02$ & $3.12 \mathrm{E}-01$ & - & - \\
\hline
\end{tabular}


Table 2-2. Base Flow Estimates Based on Hydrograph Separation of USGS Gauging Station Data

\begin{tabular}{|l|c|c|c|}
\hline Stream reach & $\begin{array}{c}\text { Estimated } \\
\text { base flow } \\
\text { (cfs) }\end{array}$ & $\begin{array}{c}\text { Estimated fraction of } \\
\text { reach within } \\
\text { CKLP model }\end{array}$ & $\begin{array}{c}\text { Base flow } \\
\text { target } \\
\text { (cfs) }\end{array}$ \\
\hline $\begin{array}{l}\text { Meyers Branch } \\
\text { (headwaters to Road 9) }\end{array}$ & 9.5 & $1 / 3$ & 3.2 \\
\hline $\begin{array}{l}\text { Steel Creek } \\
\text { (above Road B to Road A; } \\
\text { includes L-Lake) }\end{array}$ & 13.3 & 1 & -2.2 \\
\hline $\begin{array}{l}\text { Pen Branch } \\
\text { (headwaters to Road Al3; } \\
\text { includes Indian Grave Branch) }\end{array}$ & 14.1 & 1 & 13.3 \\
\hline $\begin{array}{l}\text { Fourmile Branch } \\
\text { (headwaters to Road A12) }\end{array}$ & 8.9 & $1 / 2$ & 4.5 \\
\hline $\begin{array}{l}\text { Upper Three Runs } \\
\text { (Road C to Road A) }\end{array}$ & & 14.1 \\
\hline
\end{tabular}




\subsection{Groundwater Flow Model Development}

The process used to transform the hydrogeologic data and conceptual model into a numerical groundwater flow is presented in this section.

\subsection{Code Selection and Description}

The Subsurface Flow and Contaminant Transport (FACT) code was selected for numerical flow simulations. FACT is a variably saturated, three-dimensional, finite-element groundwater flow and solute contaminant transport code developed by the Savannah River Technology Center (SRTC) (Hamm and others, 1997). FACT version 1.0 is an outgrowth of the SAFT3D code developed jointly by HydroGeoLogic, Inc. and SRTC (Huyakorn and others, 1991). Other distinguishing features of FACT include efficient memory management and numerical algorithms that make large grids feasible, and user-friendly boundary conditions. For example, the combination recharge/drain boundary condition automatically determines whether a surface node should receive recharge or be discharging groundwater, based on the head solution. The software has been extensively verification and validation (V\&V) tested, and successfully used to model other areas of the SRS. The reader is referred to the FACT User's Manual for a more thorough description of the code (Hamm and others, 1997). FACT was selected primarily because

1) the variably saturated formulation enables explicit modeling of the vadose zone, which may be important for subsequent modeling of contaminant transport or remedial actions using the present model or a derivative

2) the code meets the software Quality Assurance requirements of 1Q, 20-1 and E7, 2.32 (discontinued)

3) the authors have a strong working knowledge of the code

4) the source code is available.

\subsection{Model Configuration and Mesh}

As described in section 2.5, groundwater recharge over the greater CKLP GWMA is thought to potentially travel as deep as the Gordon aquifer before discharging to the Savannah River, Upper Three Runs, or tributary. Therefore contamination originating from $\mathrm{C}, \mathrm{K}, \mathrm{L}$ and $\mathrm{P}$ reactor facilities is expected to be confined to the Upper Three Runs and Gordon aquifer units between Upper Three Runs on the north, Steel Creek/Meyers Branch on the south, the 
Savannah River on the west, and an eastern line running from McQueen Branch to Par Pond. As shown in Figures 3-1 and 3-2, these are the boundaries chosen for the CKLP model. The rivers and streams bordering the selected domain also provide natural no-flow boundary conditions according to the conceptual model, and further motivation for choosing model boundaries as shown in Figure 3-1.

The chosen areal grid is $70,000 \mathrm{ft}$ on each side, with a resolution of 500 square feet(Figure 3-1). The mesh resolution is a compromise between the need to resolve topographic features that drive groundwater flow in the UTR aquifer, and computer memory, run-time, and storage limitations. There are 140 elements along the east-west and north-south model coordinate axes. The vertical resolution varies depending on hydrogeologic unit and stratigraphic variations (Figure 3-2). The top surface of the mesh conforms to the ground surface. The bottom surface of the mesh coincides with the bottom of the Gordon aquifer unit. Interior node layers conform to the other stratigraphic surfaces. The "upper" aquifer zone of the UTR aquifer unit is represented with 3 finite-elements in the vertical direction. The vadose zone is included in the model. The "lower" aquifer zone contains 2 finite-elements while the "tan clay" confining zone separating the aquifer zones is modeled with a single element. The Gordon confining and aquifer units each contain one element, for a total of 8 vertical elements from ground surface to the bottom of the Gordon aquifer. The three-dimensional mesh size is therefore $140 \times 140 \times 8=156,800$ elements or $141 \times 141 \times 9=178,929$ nodes. The finer vertical resolution in the "upper" UTR aquifer zone is designed to support subsequent contaminant transport analyses. Within $\mathrm{K}$ area, the 3 element layers in the "upper" UTR aquifer zone also conform to the transmissive zone, AA horizon, and $\mathrm{A}$ horizon/vadose zone, in a manner consistent with a recent model for the K Burning/Rubble Pit (KBRP) facility (HSI GeoTrans, 1998).

\subsection{Boundary Conditions}

The entire top surface of the mesh is assigned a combination recharge/drain boundary condition, except for the area covered by L Lake and Par Pond (Figure 3-3). This FACT code option automatically specifies a recharge boundary condition for nodes with a computed head below ground elevation, and a drain boundary condition for nodes with a computed head above ground surface, which is physically correct. The reader is referred to the FACT code manual for detailed information on how this boundary condition is numerically implemented in FACT (Hamm and others, 1997). Surface drain coefficients are set to 1.0 day $^{-1}$ model wide. The selected drain coefficient is sufficiently large to ensure that computed head will be only slightly greater than ground elevation in discharge areas. Streams and rivers can be 
represented with the FACT recharge/drain boundary condition, instead of general head or river boundary condition, because they are gaining according to the conceptual model. For gaining surface bodies, the FACT recharge/drain, general head. river, and drain boundaries all function as drains and are equivalent. The maximum local recharge rate is generally specified as $12.5 \mathrm{in} / \mathrm{yr}$ based on model calibration (to be discussed), which is consistent with the estimated range of 10 to $16 \mathrm{in} / \mathrm{yr}$ for recharge developed in section 2.4. Over the General Separations Area, recharge is set to $15 \mathrm{in} / \mathrm{yr}$ to reflect site-specific estimates of $15 \mathrm{in} / \mathrm{yr}$ recharge, less than average forest cover, and to be consistent with Flach and Harris (1997). However, recharge is set to $1.5 \mathrm{in} / \mathrm{yr}$ for capped areas within the Burial Ground Complex (E area).

The entire bottom surface of the mesh is assigned a general head boundary condition to account for flow into or out of the model domain across the Crouch Branch confining unit (Meyers Branch confining system). A leakance coefficient of $3 \times 10^{-6} \mathrm{~d}^{-1}$ is assumed based on Aadland and others (1995, plate 17). This value is supported by a scoping SRTC regional flow model for which model calibration indicates the leakance should be about $5 \times 10^{-6} \mathrm{~d}^{-1}$ (Hiergesell, 1997). Head distribution in the Crouch Branch aquifer is also taken from Aadland and others (1995, plate 45). General head boundary conditions are also specified for L Lake and Par Pond. L Lake is assumed to have a constant pool of $190 \mathrm{ft}$ and a drain coefficient of $1000 \mathrm{~d}^{-1}$. The drain coefficient is large enough that the lake and underlying aquifer have the same head along their boundary. Par Pond is similarly modeled as having a constant pool of $200 \mathrm{ft}$ and drain coefficient of $1000 \mathrm{~d}^{-1}$. Process water outfalls are not modeled because these features are too small to effectively resolve with a 500 -ft finiteelement size.

Boundary nodes between the top and bottom surfaces of the mesh are assigned either a noflow or prescribed head boundary condition. Consistent with the conceptual model, boundary nodes underlying major streams and rivers are assigned no-flow boundary conditions because no groundwater is assumed to cross beneath these features. No-flow boundary conditions are also specified in the vadose zone. Where no-flow boundary conditions are inappropriate in the saturated zone, head is prescribed consistent with the potentiometric maps presented in Figures 2-14 and 2-20. For the Gordon aquifer, the result is no flow conditions along the west (Savannah River) and north (Upper Three Runs) boundaries, and prescribed head along the east and south boundaries as shown in Figure 3-4. For the Upper Three Runs aquifer, head is prescribed from the headwaters of McQueen Branch south to Par Pond, and from the 
headwaters of Meyers Branch east to Par Pond (Figure 3-5). Elsewhere, no flow boundary conditions are specified for this unit.

\subsection{Material Properties}

Horizontal conductivity in the Gordon aquifer is set to $35 \mathrm{ft} /$ day based on the extensive field data from both on and off the Savannah River Site reviewed in section 2.2.2.1 and by Aadland and others (1995). The vertical conductivity of the Gordon confining unit is set to $10^{-4} \mathrm{ft} /$ day in accordance with the field data summarized in section 2.2.2.2 and by Aadland and others (1995). Conductivity values in the Upper Three Runs aquifer unit are set through model calibration to well water level data, according to the procedure described in the next section. The ratio of horizontal to vertical conductivity is assumed to be 100:1 model wide. The approximate soil characteristic curves shown in Figure 2-22 are adopted for the numerical model. An effective porosity value of $25 \%$ is assumed for the purpose of computing a pore velocity field that may be used later for particle tracing. The assumed porosity value is consistent with the general recommendation of Looney and others (1987, p. 39). However, the value does not affect the steady-state head and Darcy velocity solutions, or set precedence for subsequent transport simulations. For specific storage a nominal value of $10^{-4} \mathrm{ft}^{-1}$ is input to the FACT code, and would only be important for transient flow simulations within a confined aquifer.

\subsection{Calibration Process}

Groundwater recharge and discharge estimates, monitoring well water level data, large-scale measurements of hydraulic conductivity, previous modeling efforts, and a general knowledge of groundwater flow directions and timing were used as targets for calibrating the CKLP flow model. The main parameters selected for calibration adjustment are recharge, horizontal conductivity in UTR aquifer zones and vertical conductivity in confining zones, because the model is sensitive to these parameters, and each has significant uncertainty. Other input parameters have less impact on the steady-state flow results and/or lower uncertainty, and were set to their initial best-estimate value throughout calibration. For example, horizontal conductivity in the Gordon aquifer is relatively well known from extensive field-scale tests conducted both on and off the Savannah River Site. Therefore, the horizontal conductivity of the Gordon aquifer can be set to $35 \mathrm{ft} /$ day, and essentially held fixed during model calibration. The overall calibration procedure involves 4 sequential, steps: 
1) Set model recharge to a value consistent with the prior estimate, and such that simulated discharge agrees with prior baseflow estimates.

2) Adjust Gordon confining unit vertical conductivity to achieve agreement with measured head in the Gordon aquifer, while still agreeing with prior estimates.

3) Simultaneously adjust horizontal conductivity in the "lower" and "upper" UTR aquifer zones (assumed equal) and "tan clay" vertical conductivity to achieve agreement with head data in these zones.

4) Add zonal variation to UTR aquifer unit conductivity values as needed to achieve better agreement with head targets.

In practice, the above procedure is iterated during calibration. The model is most sensitive to recharge, as this parameter drives groundwater flow according to the conceptual model (section 2.5). As discussed in section 2.4, average recharge is thought to lie within the range of 10 to $16 \mathrm{in} / \mathrm{yr}$. Taking the best-estimate value as the mid-point of the range, $13 \mathrm{in} / \mathrm{yr}$, the uncertainty would be plus or minus $25 \%$. The uncertainty of stream base-flow targets ranges from $\pm 15 \%$ to $25 \%$ (Appendix $E$ ). In step 1, equal weight is given to satisfying recharge and discharge targets because these data have similar reliability.

Next in importance is leakance through the Gordon confining unit, which is adjusted in step 2. Groundwater flow in the Gordon aquifer is controlled by recharge through the Gordon confining unit, flow across the east and south model boundaries, and horizontal conductivity. Because the head boundary conditions and horizontal conductivity are relatively well known for this unit, Gordon confining unit vertical conductivity is adjusted to achieve agreement with head targets.

With recharge and Gordon confining unit vertical conductivity fixed through steps 1 and 2 , horizontal conductivity in UTR aquifer zones and "tan clay" vertical conductivity become the next calibration parameters. The model is sensitive to these parameters, which are highly uncertain relative to other factors (e.g. boundary conditions). Zonal variation is invoked as a last resort to achieving adequate agreement with head targets. Zonal variation in recharge is not considered because uncertainty is greater in the prior conductivity estimates.

The goal of the calibration process is to achieve as good of agreement with prior targets as possible, without resorting to unjustifiable zonal variation in conductivity or other parameters. A lower estimate for achievable calibration accuracy is the uncertainty level in 
the target data. That is, one should not expect to match calibration targets better than the "noise" level in the data. As discussed in section 2.3.3, head targets that are a result of time averaging have a "2-sigma" uncertainty less than or equal to $3 \mathrm{ft}$, with most being well below $3 \mathrm{ft}$ (Appendix F). However, there are also a significant number of one-time head readings that have much larger uncertainty, typically $\pm 5 \mathrm{ft}$, that inflate average uncertainty. The recharge and stream base flow targets have an uncertainty of roughly $\pm 25 \%$ (section 2.4; Appendix E). Previous models covering portions of the SRS have generally achieved a rootmean-square head residual of $3 \mathrm{ft}$ or so (e.g. Camp Dresser \& McKee, 1989; GeoTrans, 1992; Flach and Harris, 1997). Given the large scale, coarse mesh resolution. and relative uniformity of the conductivity field desired in the present model, a calibration goal of $3 \mathrm{ft}$ may be too low, especially for the more heterogeneous aquifer zones. A reasonable calibration goal for the largest head residual is sometimes defined as $5-10 \%$ of the total head variation in the modeled system. For the Gordon aquifer, the total variation is about $120 \mathrm{ft}$ (Figure 2-20) suggesting a calibration goal of 6 to $12 \mathrm{ft}$ for the maximum residual. For the Upper Three Runs aquifer, the total variation is about $330 \mathrm{ft}$ (Figure 2-14) for a calibration goal of 16 to $33 \mathrm{ft}$. 


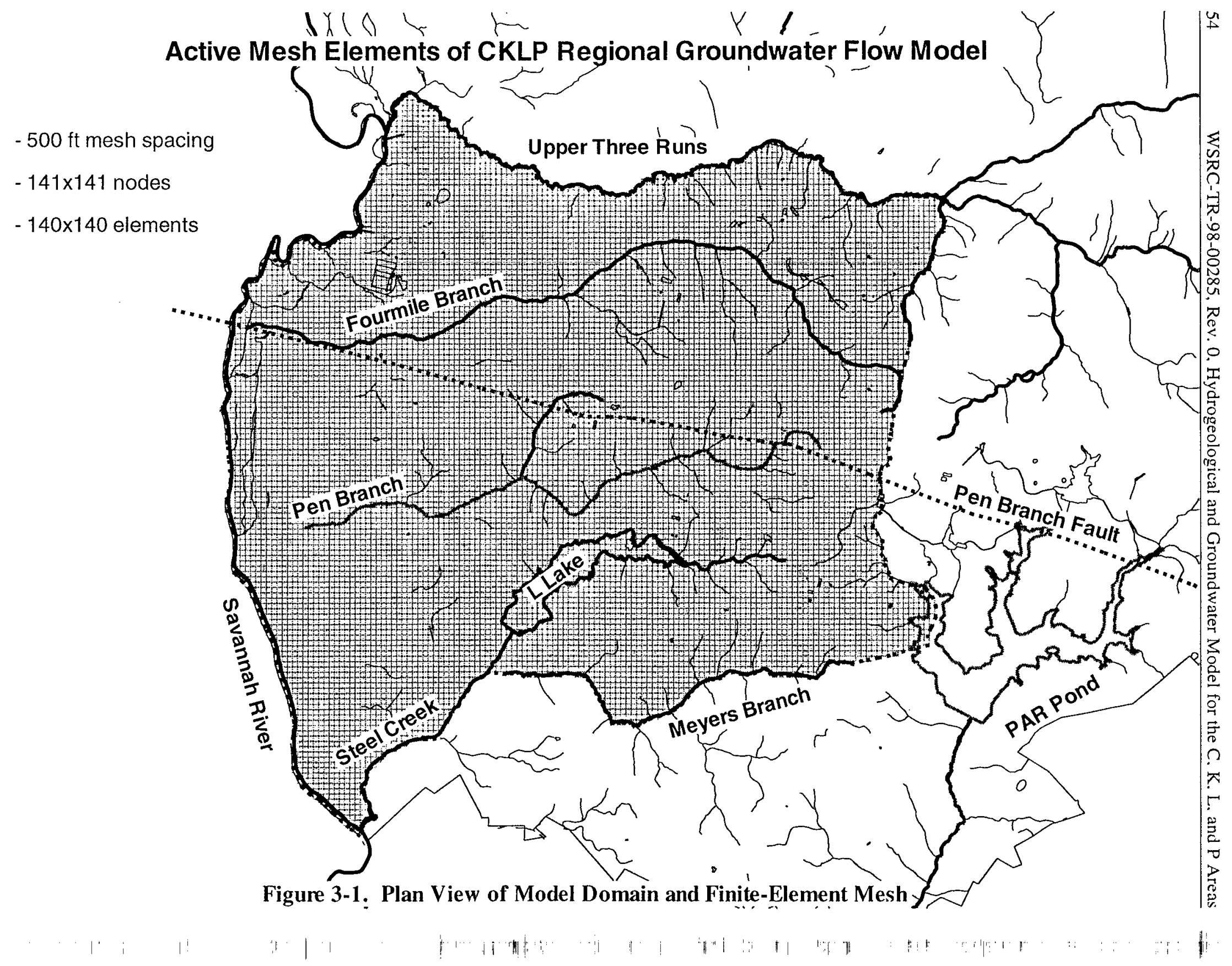




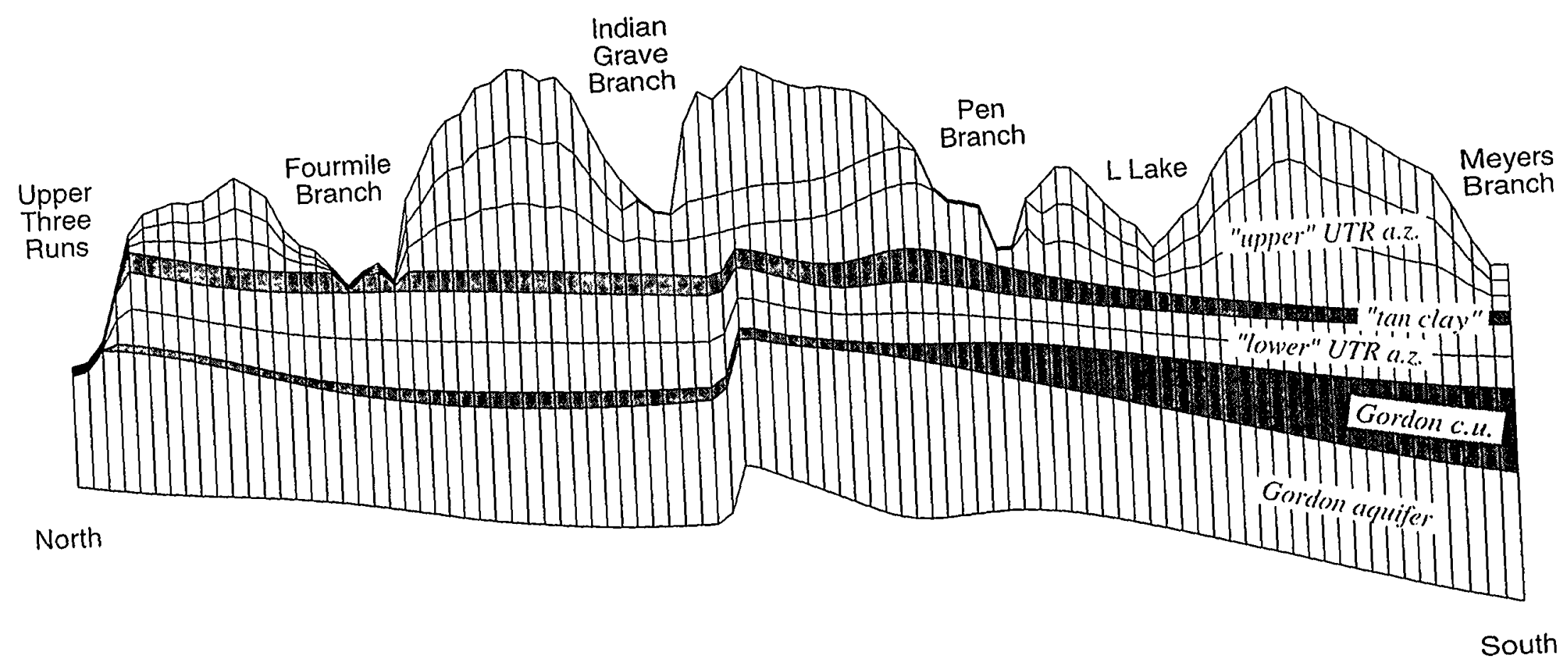

Typical Cross-Sectional Slice Through Finite-Element Mesh 


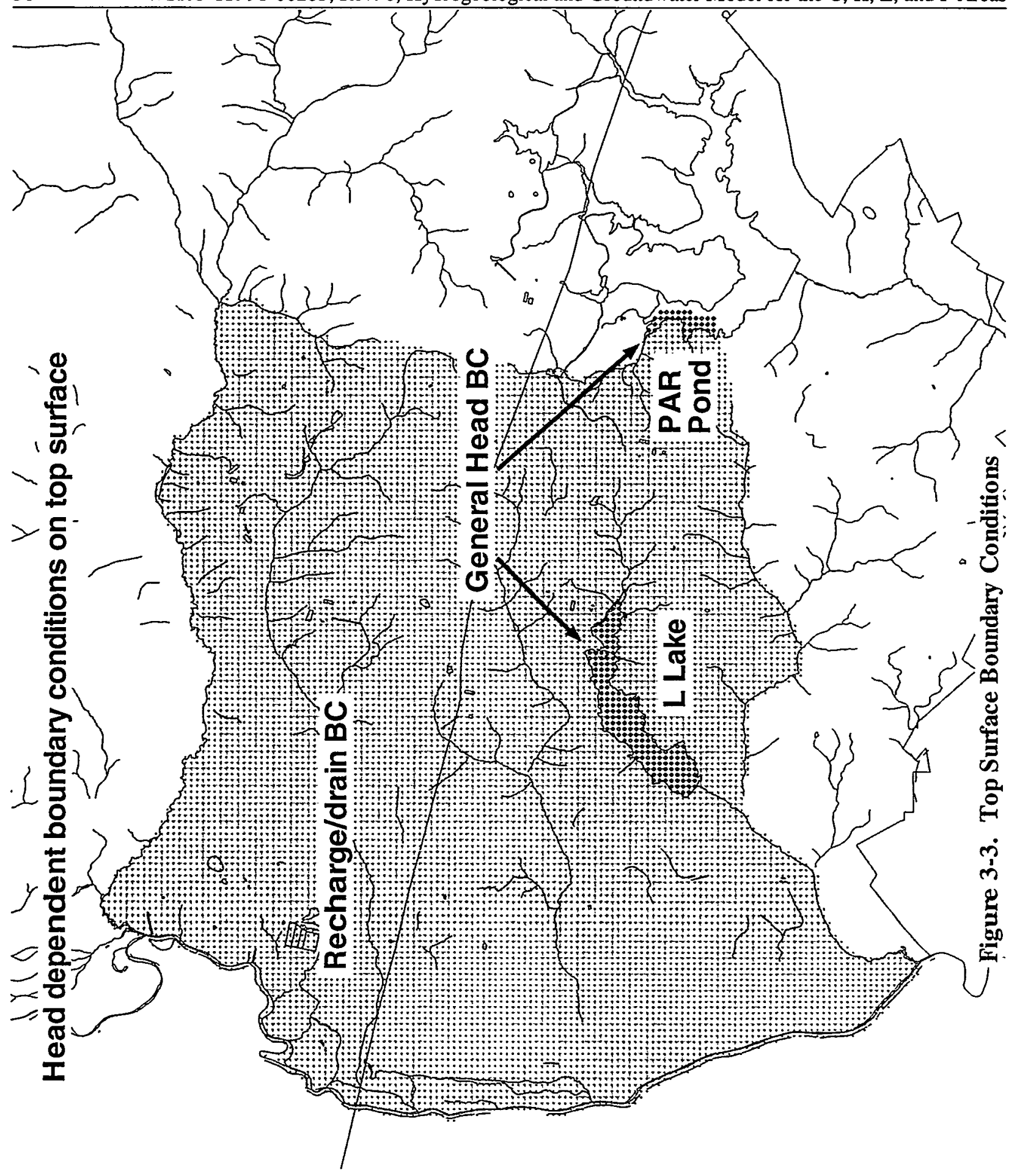




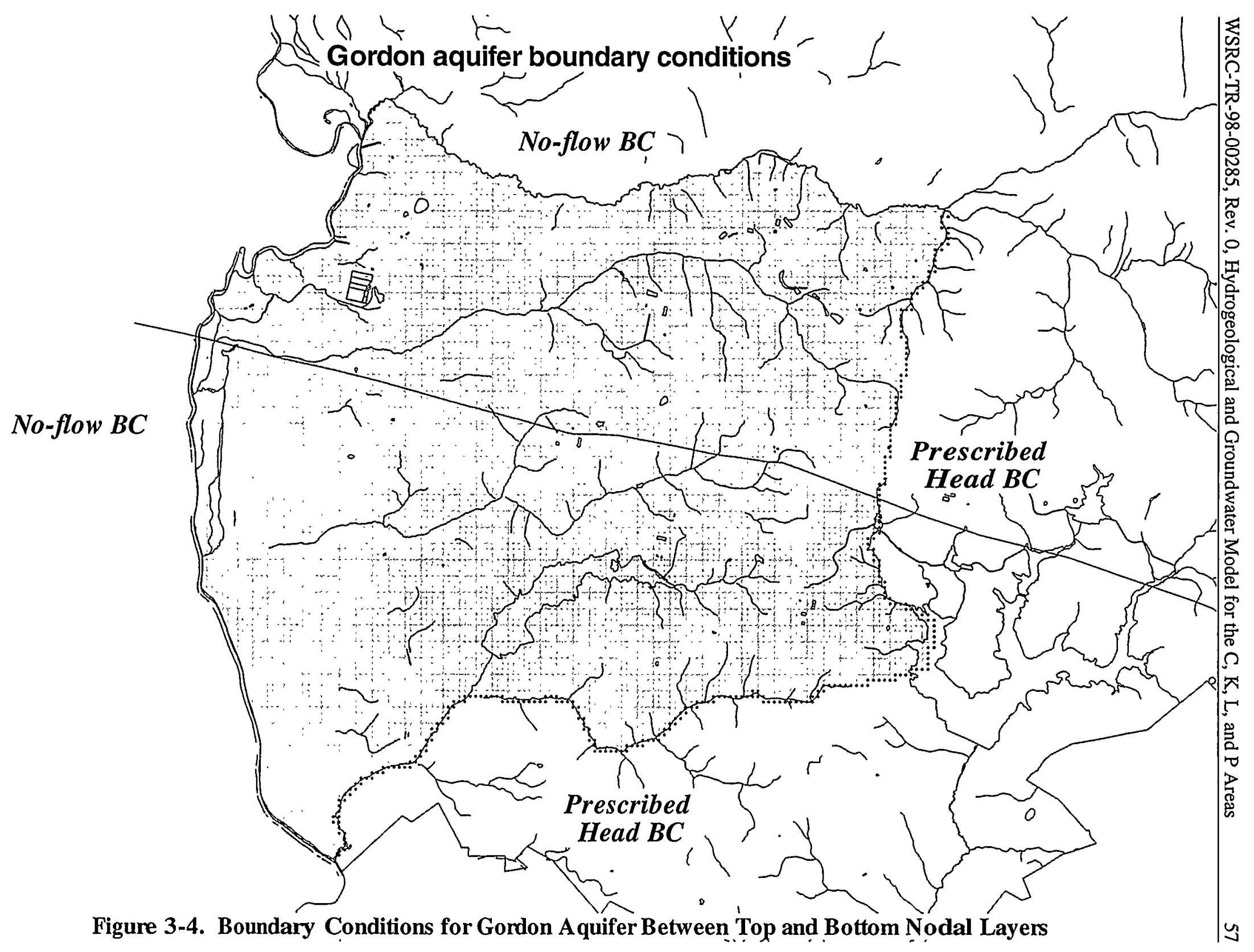




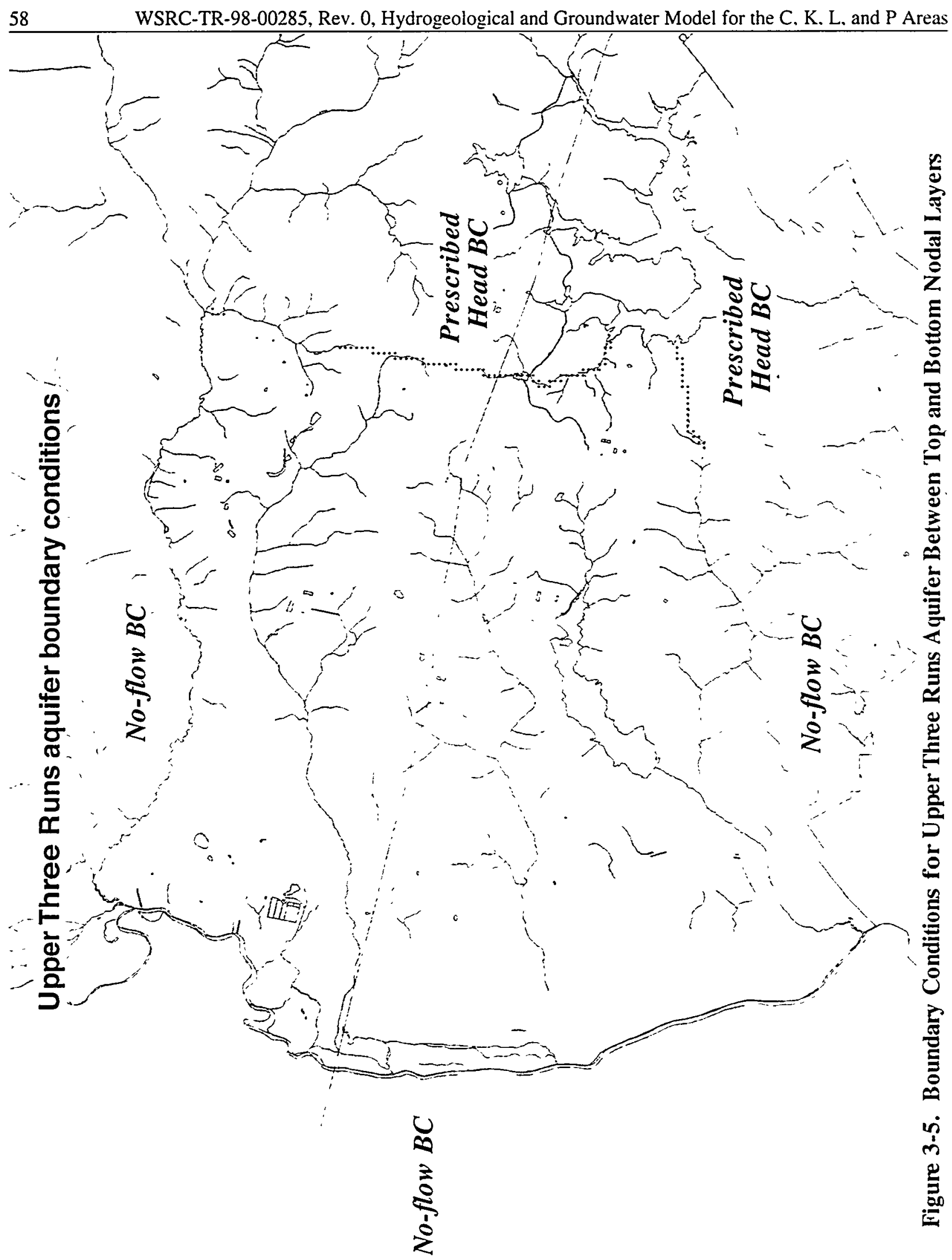




\subsection{GROUNDWATER FLOW MODEL RESULTS}

\subsection{Calibration results}

Table 4-1 summarizes the calibration results for groundwater flow targets. The maximum rate of local recharge is set to $12.5 \mathrm{in} / \mathrm{yr}$ in the FACT recharge/drain boundary condition. except for the General Separations Area (Section 3.3). The modeled rate is 17\% lower than the prior estimate of $15 \mathrm{in} / \mathrm{yr}$, but very close to the midpoint of the uncertainty range (13 in/yr). Based on total area, which includes the Savannah River flood plain and other wetland areas, the average recharge rate is $9.7 \mathrm{in} / \mathrm{yr}$. Excellent agreement is observed for Meyers Branch, Pen Branch and Fourmile Branch base flow. Simulated base flow to Upper Three Runs between Road C and Road A is 53\% higher than the prior estimate. A possible explanation is that Upper Three Runs receives significantly more base flow from the south side (model side), due to significantly steeper terrain and aquifer head gradients compared to the north side. The prior estimate is based on the assumption that base flow should be partitioned equally to each side. Another possibility is that the prior estimate has much larger uncertainty than estimated, because it results from taking the difference of two nearly equal flow rates (Appendix E). Or, the model may simply have an undetected bias. A large discrepancy is noted for the combined baseflow from Steel Creek and L Lake. The data suggests a large net loss of $2.2 \mathrm{ft} 3 / \mathrm{s}$ for this reach. While the model predicts $L$ Lake to be losing at a rate of $0.3 \mathrm{ft} 3 / \mathrm{s}$, Steel Creek gains at a rate of $4.1 \mathrm{ft} 3 / \mathrm{s}$ for a net gain of $3.8 \mathrm{ft}^{3} / \mathrm{s}$. The reason for the discrepancy is unclear. Like Upper Three Runs, the Steel Creek base flow estimate is the result of averaging small differences between large flows, and could have more uncertainty than initially thought. The small portion of Par Pond within the model domain is simulated to be gaining, as would be expected for an area away from the dam. Overall, calibration goals for groundwater flow are met. The most notable exception is base flow to Steel Creek/L Lake.

Table 4-2 summarizes the calibration results for hydraulic head targets. Figure 4-1 graphically compares simulated head with measured head for each aquifer zone. Figures 4-2 through 4-4 illustrate the spatial distribution of head residuals. Appendix F contains a detailed listing of head residual information. Agreement is excellent in the Gordon aquifer, except for 4 double-digit outliers. At TNX Area, the simulated heads for TBG-5B and P-26A are 15 to $18 \mathrm{ft}$ low, while the residual at nearby XSB-1A is only $-2.5 \mathrm{ft}$. The scale of the model appears to be too large to reproduce the sudden change in head in this area. In $\mathrm{K}$ Area, simulated head at $\mathrm{P}-25 \mathrm{~B}$ is $15 \mathrm{ft}$ low. A possible explanation is that the Gordon aquifer is experiencing high recharge through the Pen Branch Fault. Northeast of P-25B, the residual 
for PW-83N is $+11 \mathrm{ft}$. Here the large discrepancy may be due to the target value being a single reading that is not reflective of the long-term average water level. The average Gordon aquifer residual is biased low by $1.3 \mathrm{ft}$, mainly due to the very low residuals at TBG-5B and $\mathrm{P}-26 \mathrm{~A}$. In the "lower" UTR aquifer zone, the largest residuals $(\sim 30 \mathrm{ft})$ are located in the General Separations Area along the steep slopes adjacent to Upper Three Runs. The coarse resolution of the mesh may be hindering the ability of the model to reproduce gradients in this area. Flach and Harris (1997) also experienced difficulty in matching heads in this area. Significantly low values are also observed south and west of F Area near Fourmile Branch. and within $\mathrm{H}$ Area proper. Significantly high values are seen at the CMP Pits and in C Area. Maximum absolute value residuals in the "upper" aquifer zone of the UTRA are much smaller in magnitude compared to the "lower" zone. Predicted heads are systematically low west of F Area, and high in C Area. The average residuals in the "lower" and "upper" UTR aquifer zones show almost no bias (Table 4-2). The root-mean-square head residuals meet the overall calibration goals set in Section 3.5.

Table 4-3 summarizes the calibration results for hydraulic conductivity. Figures 4-5 through 4-12 show variation in conductivity for each model layer in plan view. Horizontal conductivity is shown for transmissive zones, and vertical conductivity for confining zones. Figure 4-13 illustrates a typical north-south vertical slice, in this case passing through $\mathrm{K}$ Area. The calibrated values are consistent with field data (Section 2.2) and previous groundwater flow models (e.g. HSI GeoTrans, 1998, Figure 4-6; HydroGeoLogic, 1998 (draft), Table 6.5; Flach, 1998, Table 4; Flach and Harris, 1997: GeoTrans, 1993, Table 4.1; GeoTrans, 1992, Table 3.6; Camp Dresser \& McKee, 1989, Table 3-3).

\subsection{Nominal Simulation}

Figures 4-14 through 4-16 illustrate simulated hydraulic head averaged over the entire thickness of the Gordon aquifer and "lower" and "upper" UTR aquifer zones. Simulated head in the aquifer zone containing the water table is shown in Figure 4-17, and Figure 4-18 illustrates simulated water table elevation. For comparison to Figure 4-15. see Figure 2-20 which shows the Gordon potentiometric surface as based on measured water levels. The estimated water table based directly on head data is shown in Figure 2-14, and can be compared to Figures 4-15 through 4-18. Figures 4-19 through 4-21 illustrate flow directions that are vertically averaged over the entire thickness of the aquifer zones. Figure 4-22 shows simulated seepage faces, and Figure 4-23 illustrates rates of recharge and discharge. Figures 4-22 and 4-23 can be compared to Figure 2-21, which is based on field observations. 
Example particle tracing results are shown in Figure 4-24. A water balance for the model is depicted in Figure 4-25.

\subsection{Uncertainty Analysis}

Uncertainty in the nominal model can be estimated by varying the input parameters within their uncertainty range, and in a correlated manner such that agreement with calibration targets is preserved as much as possible. The nominal model is sensitive to recharge, which drives overall groundwater flow in this system, and Gordon confining unit (GCU) vertical conductivity $\left(\mathrm{K}_{\mathrm{v}}\right)$, which controls recharge to the Gordon aquifer (equal to leakance from the Upper Three Runs aquifer). Both of these input parameters have significant uncertainty. Table 4-4 summarizes four variations of these two parameters within their estimated range of uncertainty. For each uncertainty case, the model is recalibrated to maintain agreement with the prior targets by adjusting conductivity values in the Upper Three Runs aquifer, and Gordon aquifer if necessary. Table 4-5 summarizes the calibration results for each sensitivity case.

Uncertainty cases 1 and 2 involve recharge perturbations of $\pm 20 \%$, except over the General Separations Area which is left unaltered at 15 in/yr. As seen in Table 4-5, the results for cases 1 and 2 show equivalent agreement to hydraulic head targets compared to the nominal or base case. For higher recharge (case 1), predicted base flows are biased high for Pen Branch and Fourmile Branch, the most reliable targets. For lower recharge (case 2), simulated base flows are low for these streams. Horizontal conductivities in the "upper" and "lower" UTRA aquifer zones were adjusted by $\pm 20 \%$ to compensate for the $\pm 20 \%$ variations in recharge for cases 1 and 2, respectively. The resulting Kh values for the uncertainty cases remain well within the data range. No changes were made to the Gordon aquifer unit horizontal conductivity, or vertical conductivity in confining units/zones.

Uncertainty cases 3 and 4 involve Gordon vertical conductivity increases and decreases by a factor of 5. For these cases, adjustment to Gordon aquifer unit horizontal conductivity in addition to UTRA Kh was required to maintain agreement with head targets to the extent possible. Despite model recalibration, uncertainty cases 3 and 4 show significantly poorer agreement to calibration targets compared to the nominal case. For higher Gordon confining unit leakance, head residuals are large, and Pen Branch and Fourmile Branch base flows are significantly biased low. Horizontal conductivities for both the Gordon and UTR aquifers are barely credible. For lower Gordon confining unit leakance, head residuals are similar to the base case, and uncertainty cases 1 and 2. Simulated base flows for Pen Branch and Fourmile 
Branch base flows are biased high. Reasonable horizontal conductivities are obtained for the UTR aquifer. However, the Gordon aquifer horizontal conductivity is significantly low compared to field data.

More detailed information about each uncertainty analysis case is presented in Appendix G. In the appendix, model results in various forms are reproduced for each uncertainty case for comparison to the nominal results (Figures 4-1 through 4-12, 4-14 through 4-18, and 4-22 through 4-24). Of particular interest are the particle tracing results presented in Figures G-120, G-2-20, G-3-20 and G-4-20. For variations in recharge (Figures G-1-20 and G-2-20), the simulated groundwater paths are similar to the nominal results (Figure 4-24). The largest deviation occurs for the pathline leaving the northeast corner of the P-area. Although time markers are not shown in these figures, groundwater travel times also vary roughly proportional to the recharge variation. The variations in Gordon confining unit leakance considered in uncertainty cases 3 and 4 produce significant changes to simulated groundwater flow paths (Figures G-3-20 and G-4-20). For increased leakance, groundwater from reactor areas migrates deeper, typically to the Gordon aquifer, and discharges to surface far from the facilities (Figure G-3-20). For decreased leakance, groundwater remains more shallow, typically above the Gordon aquifer, and discharges to nearby stream reaches.

The uncertainty results presented so far are generic. For specific applications of the model, additional uncertainty analysis should be performed, tailored to the sub-region and output parameter(s) of interest. For example, uncertainty cases 5 and 6 shown parenthetically in Table 4-4 would be useful for investigating uncertainty in plume migration, because they effectively provide upper and lower bounds on horizontal flow rates. Similarly, effective porosity should be considered for groundwater travel time and transport uncertainty analysis, because pore velocity is inversely proportional to this parameter. Specifically, transport sensitivity runs should include total porosity for an upper estimate ( 40\%), and a conservative (low) estimate for effective porosity $(\sim 25 \%)$. 

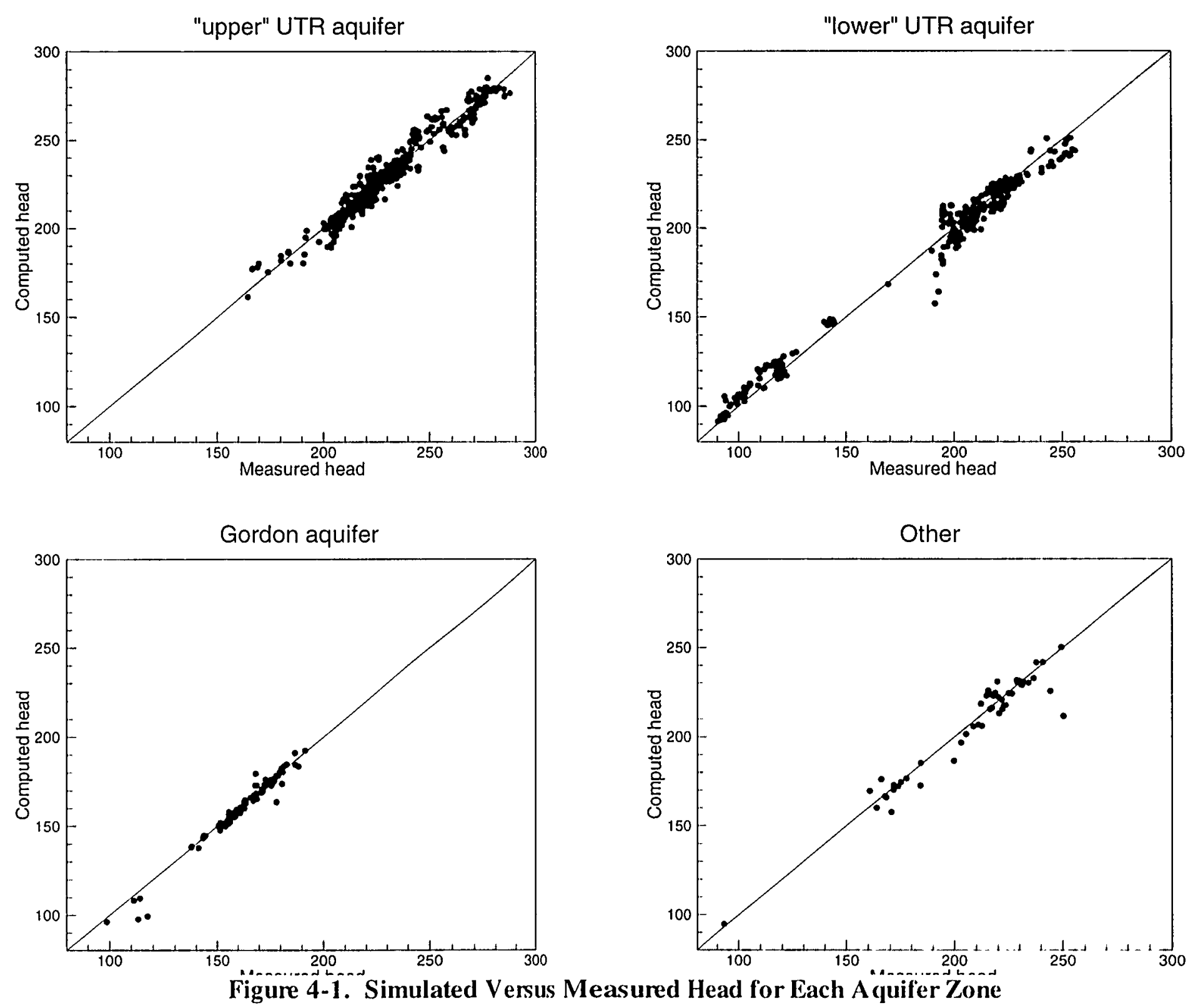

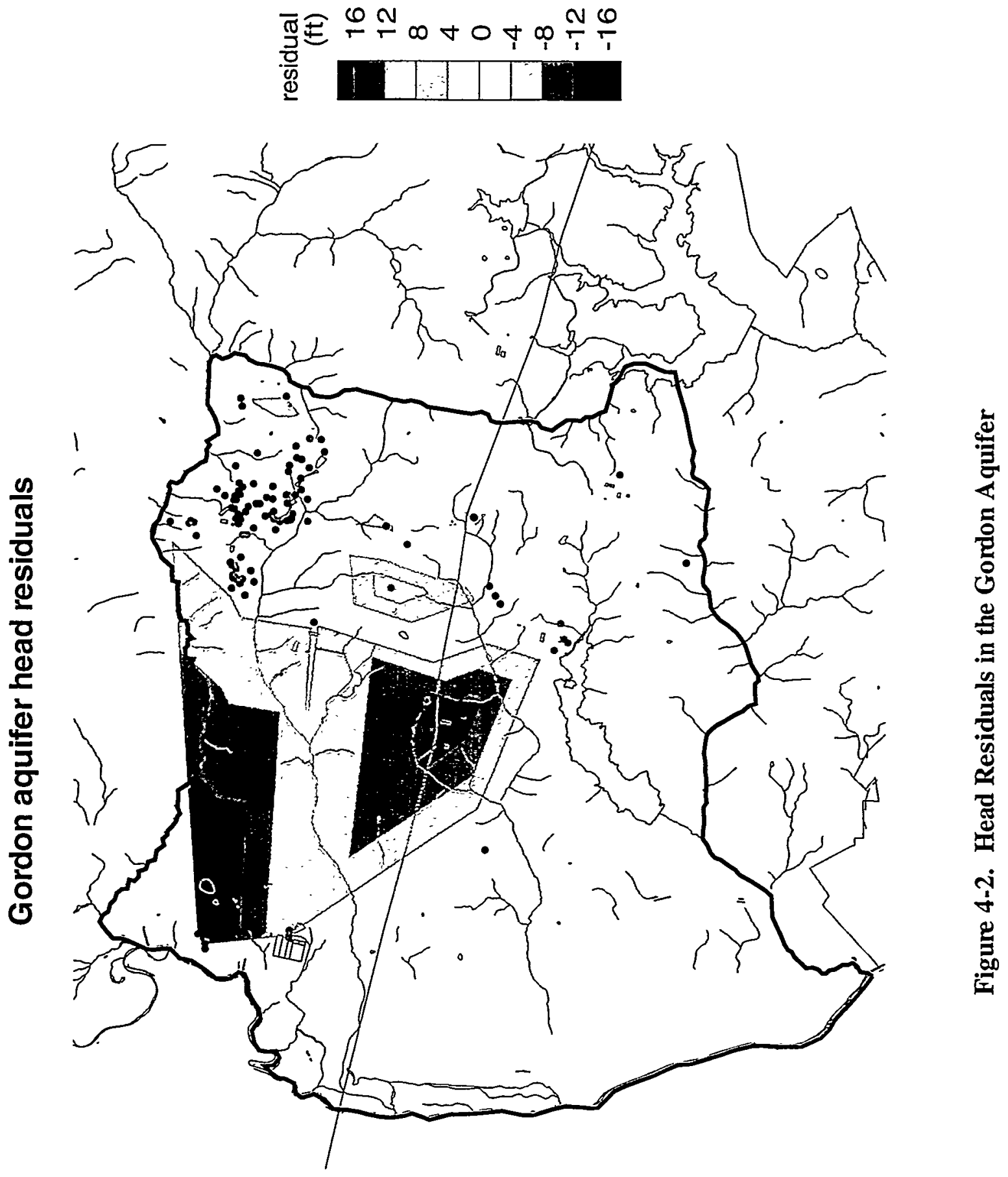


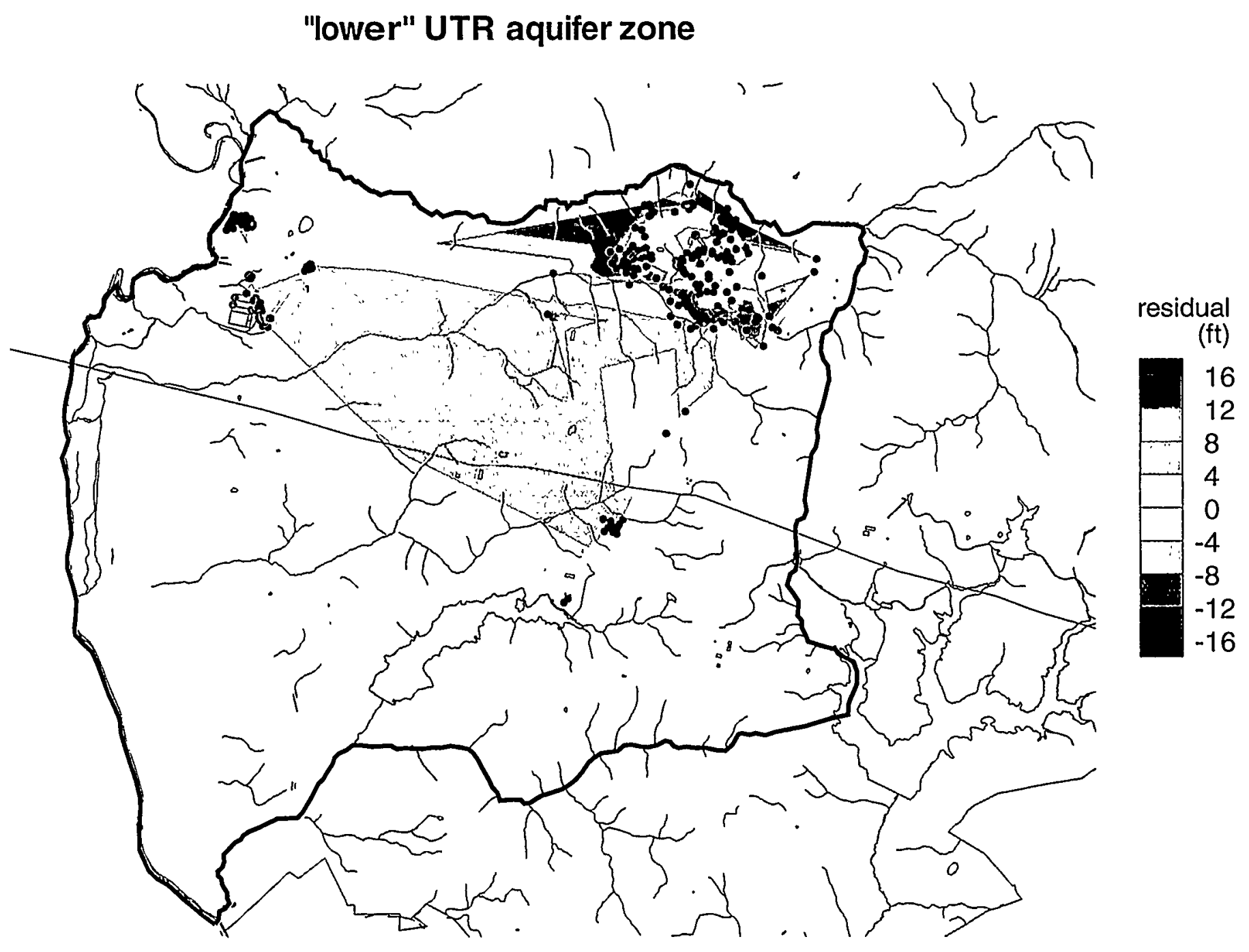

Figure 4-3. Head Residuals in the 'Lower" UTR Aquifer Zone

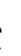



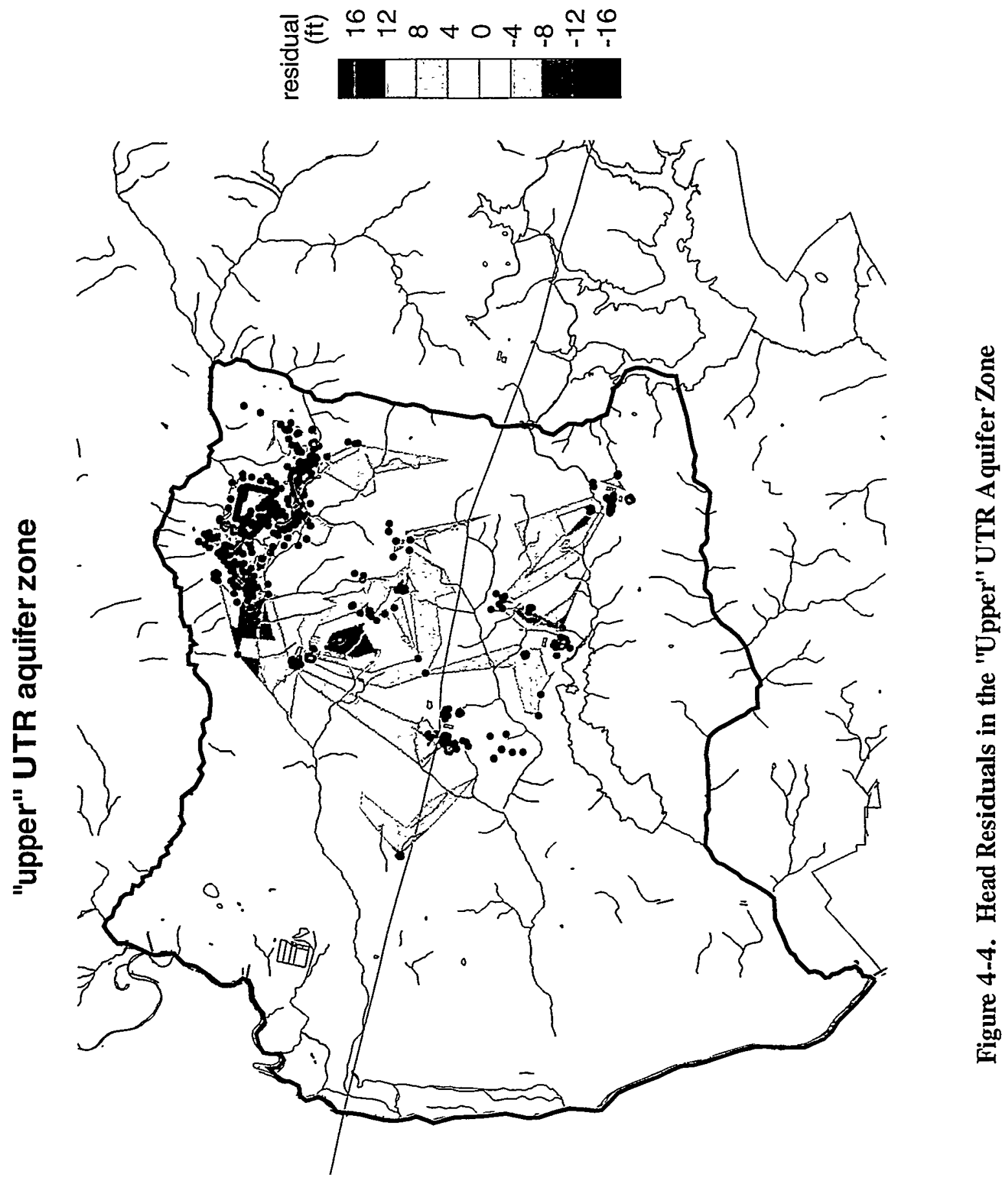


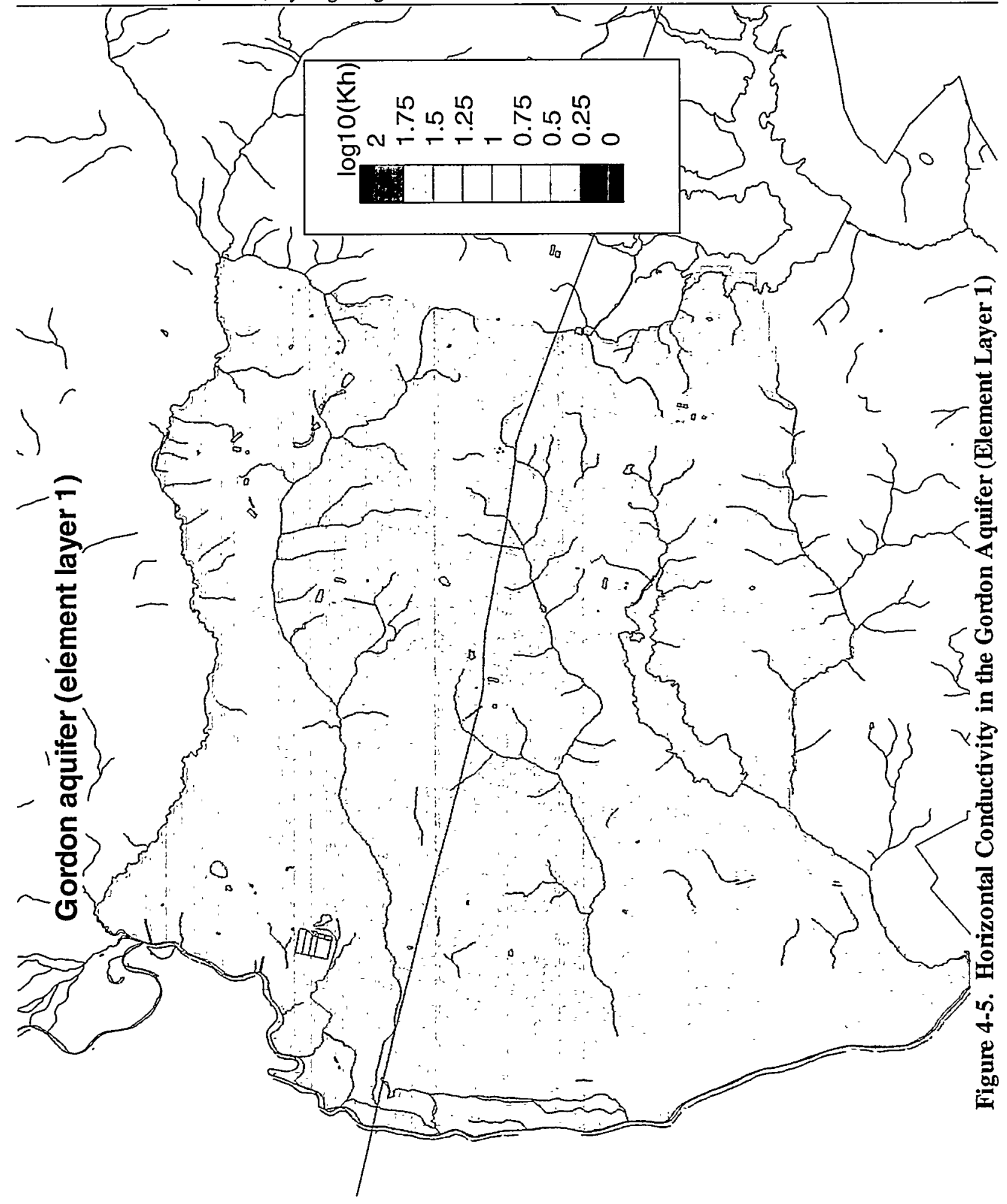


WSRC-TR-98-00285, Rev. 0, Hydrogeological and Groundwater Model for the C, K, L, and P Areas

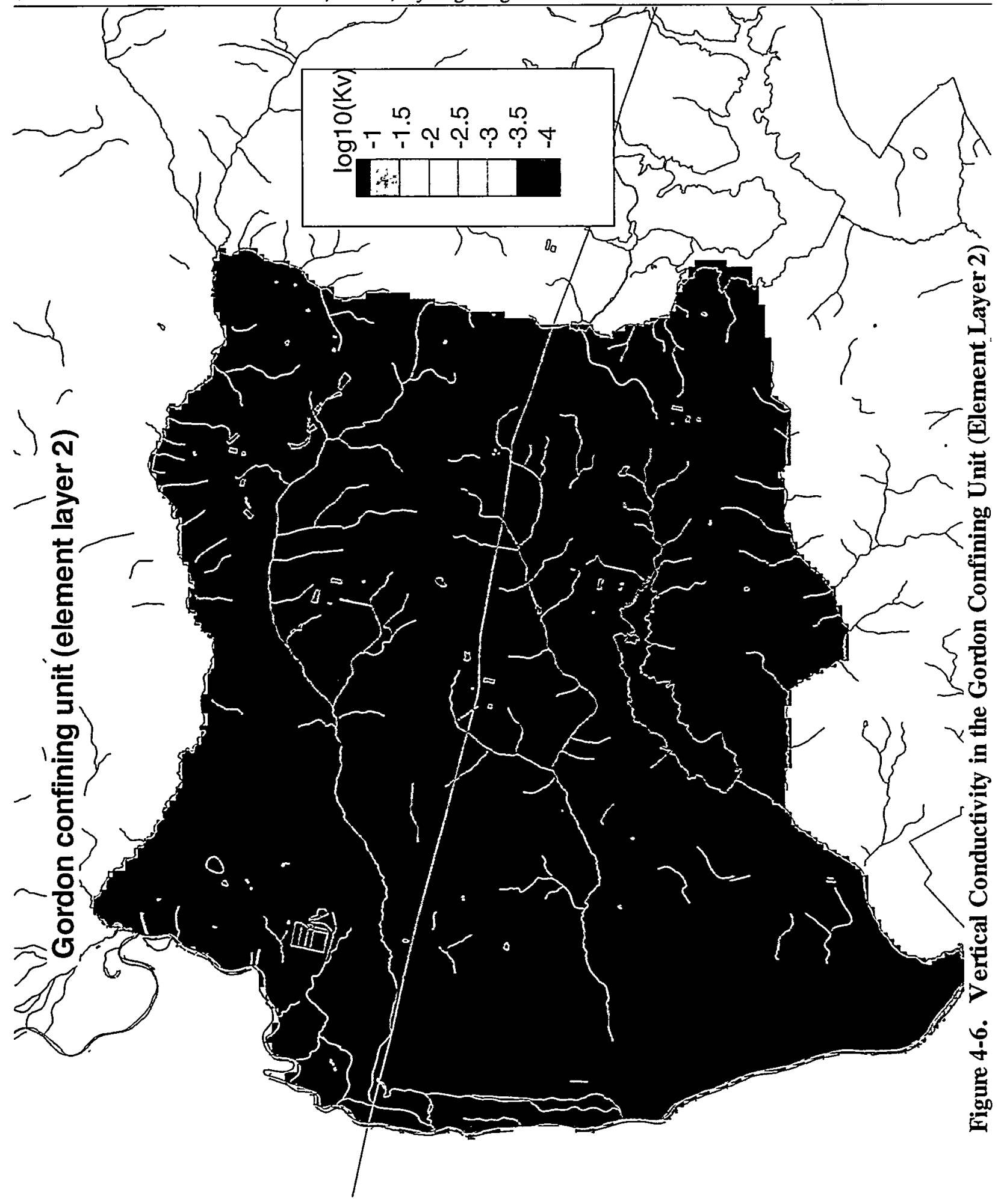




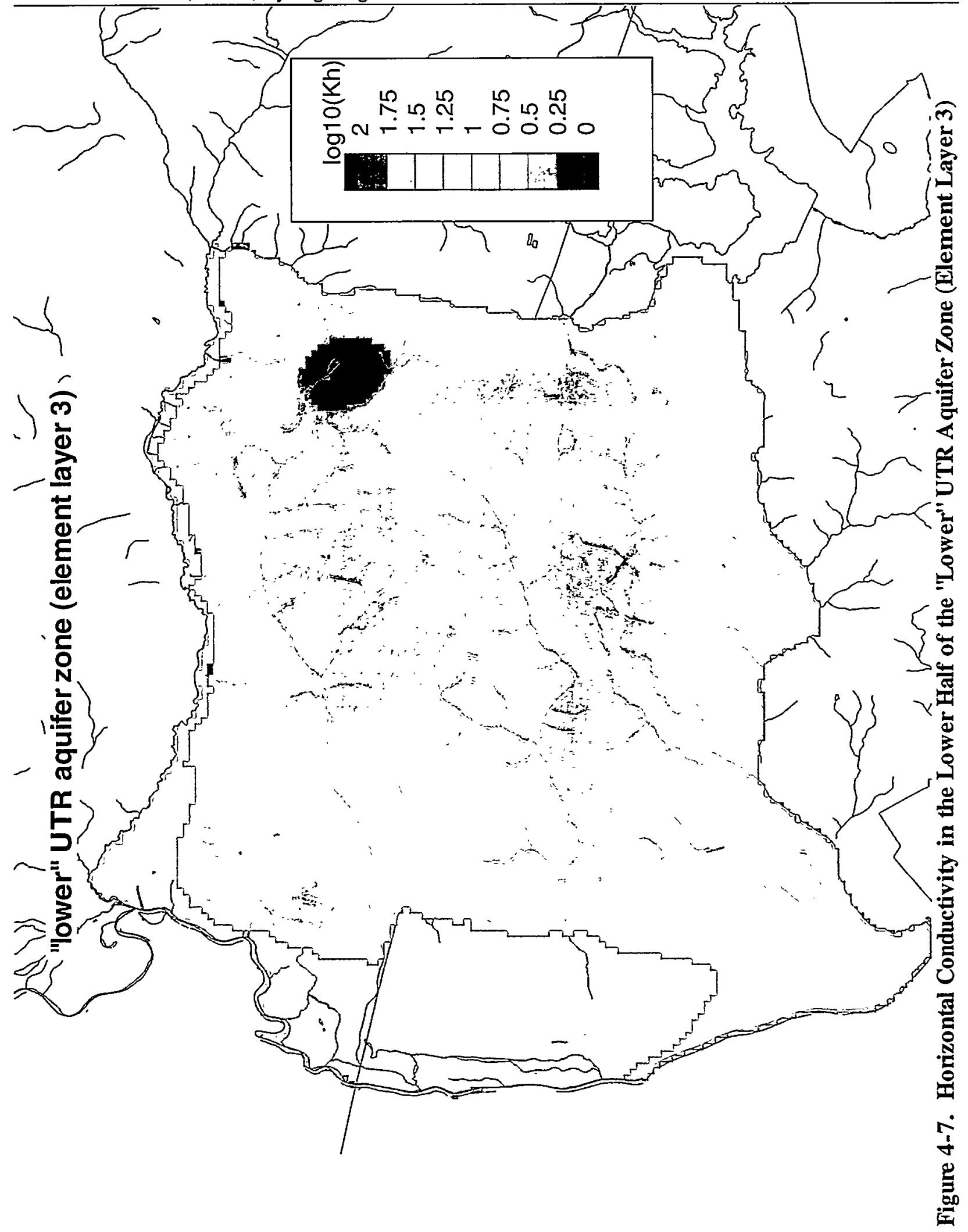




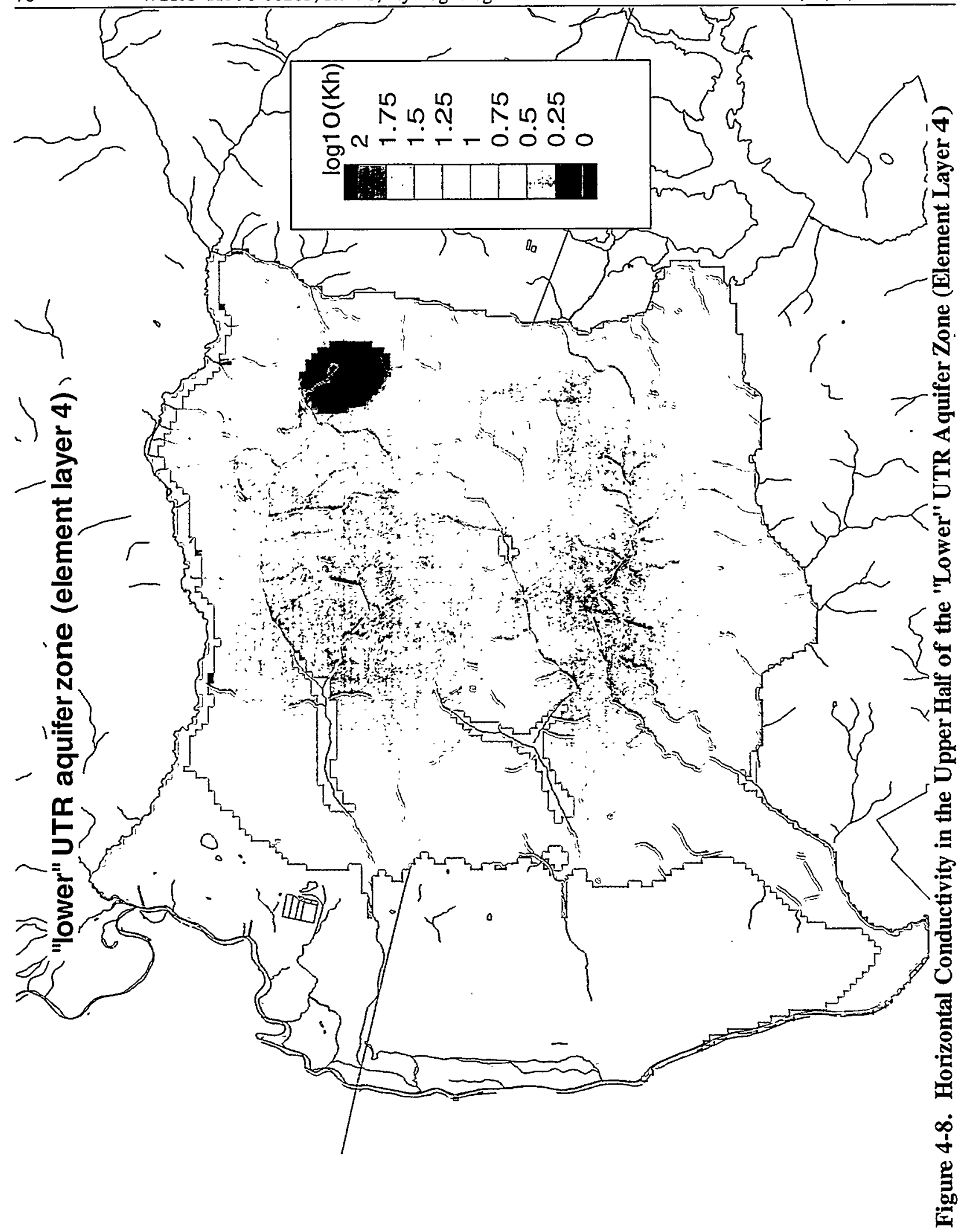




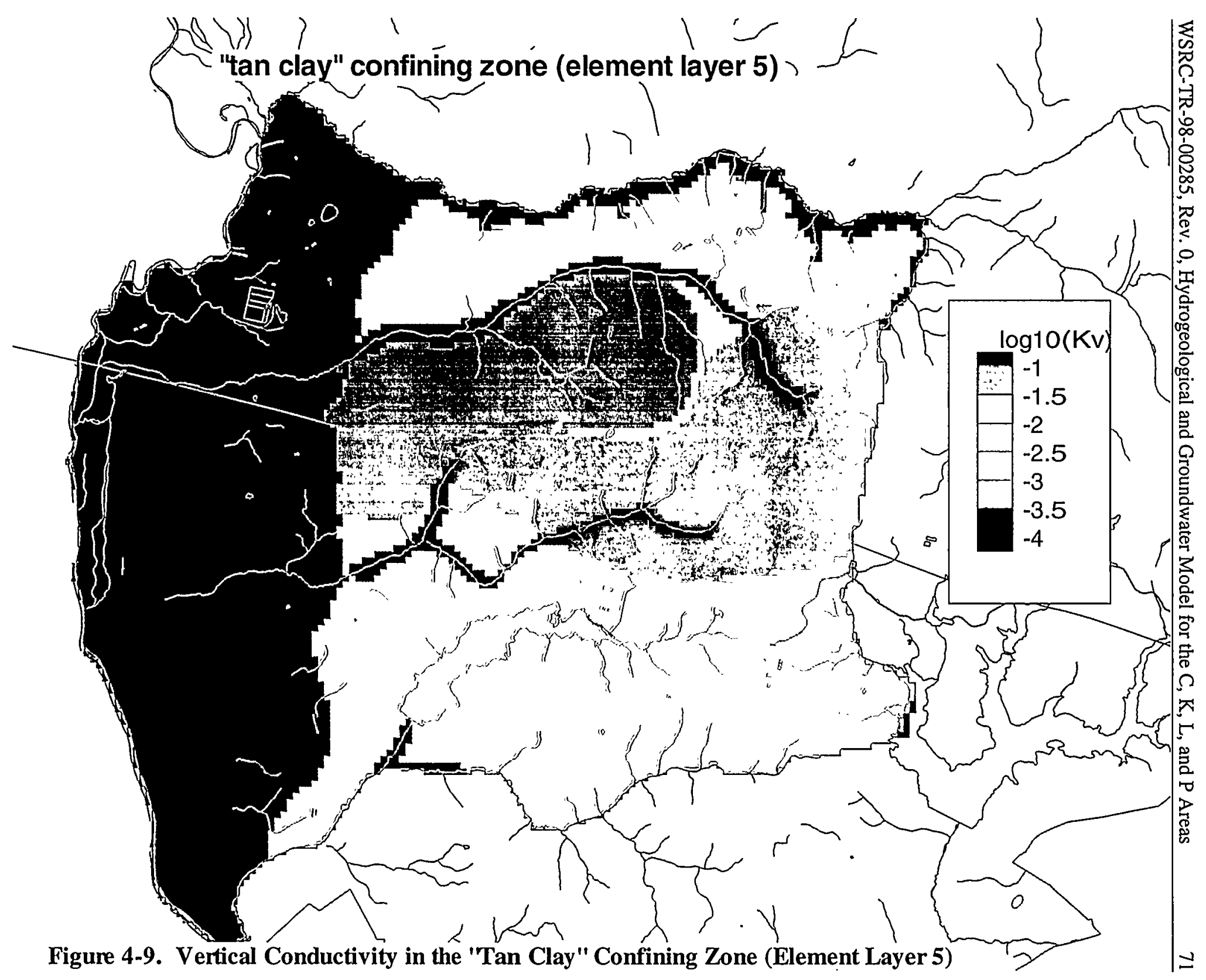




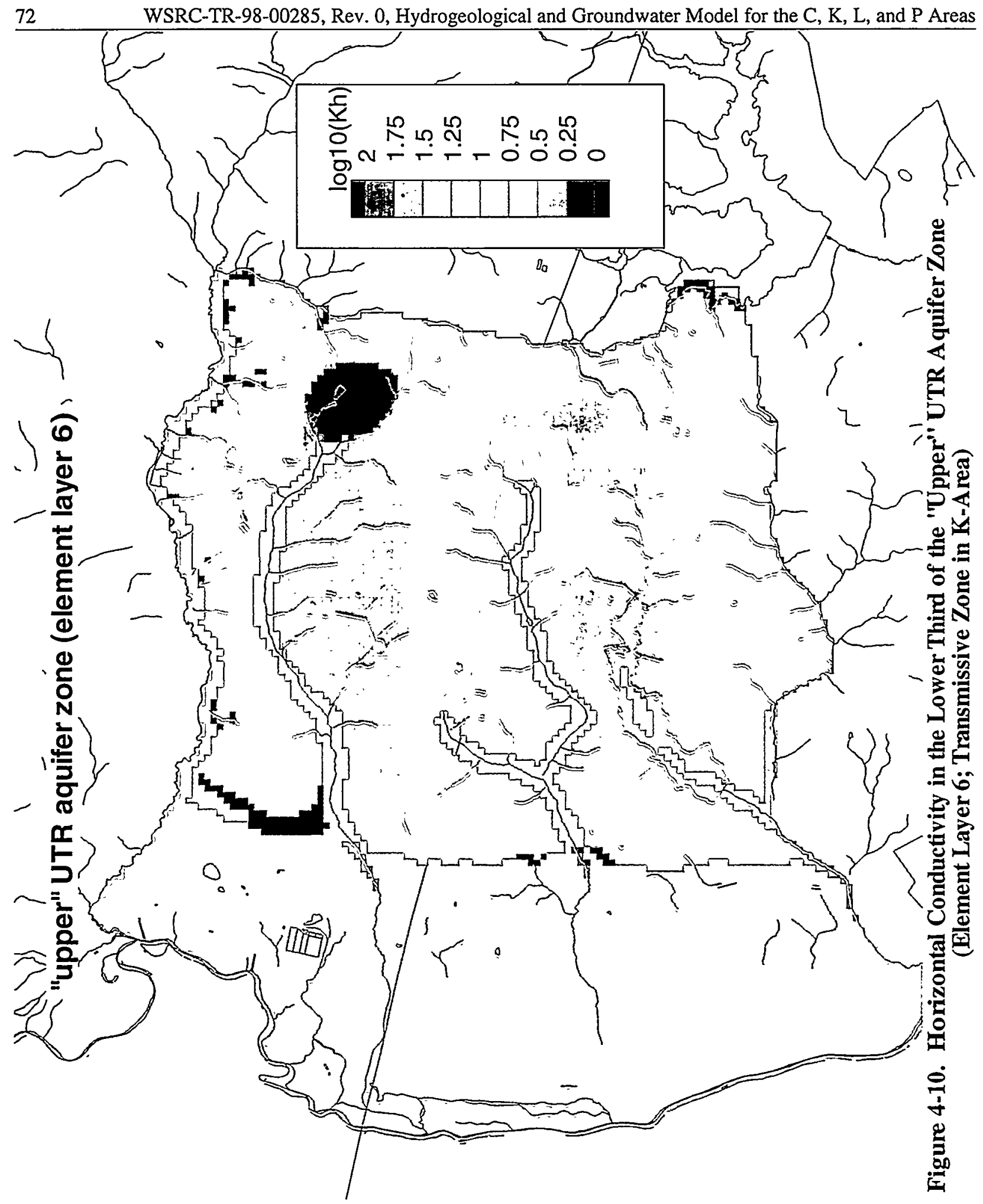




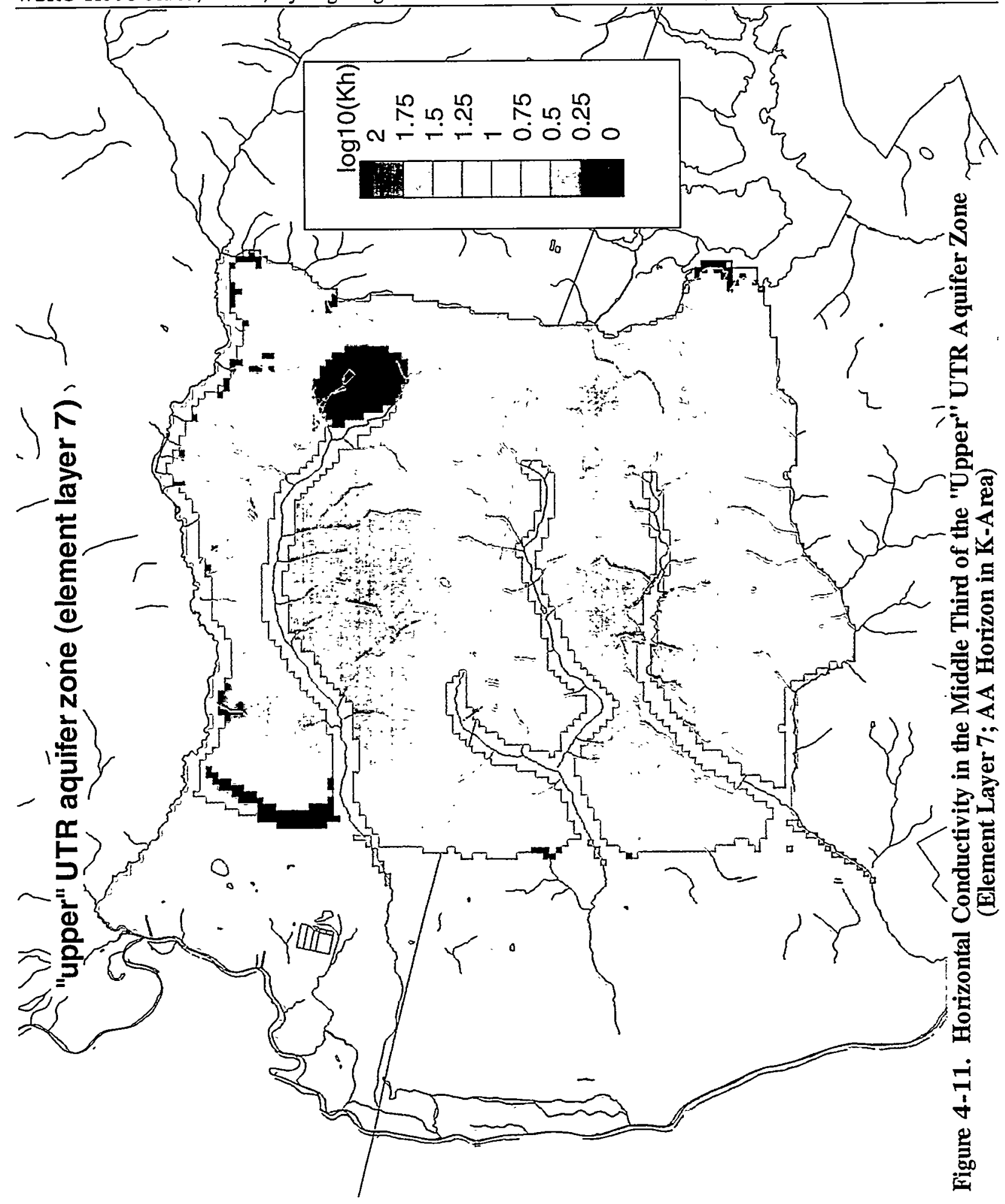




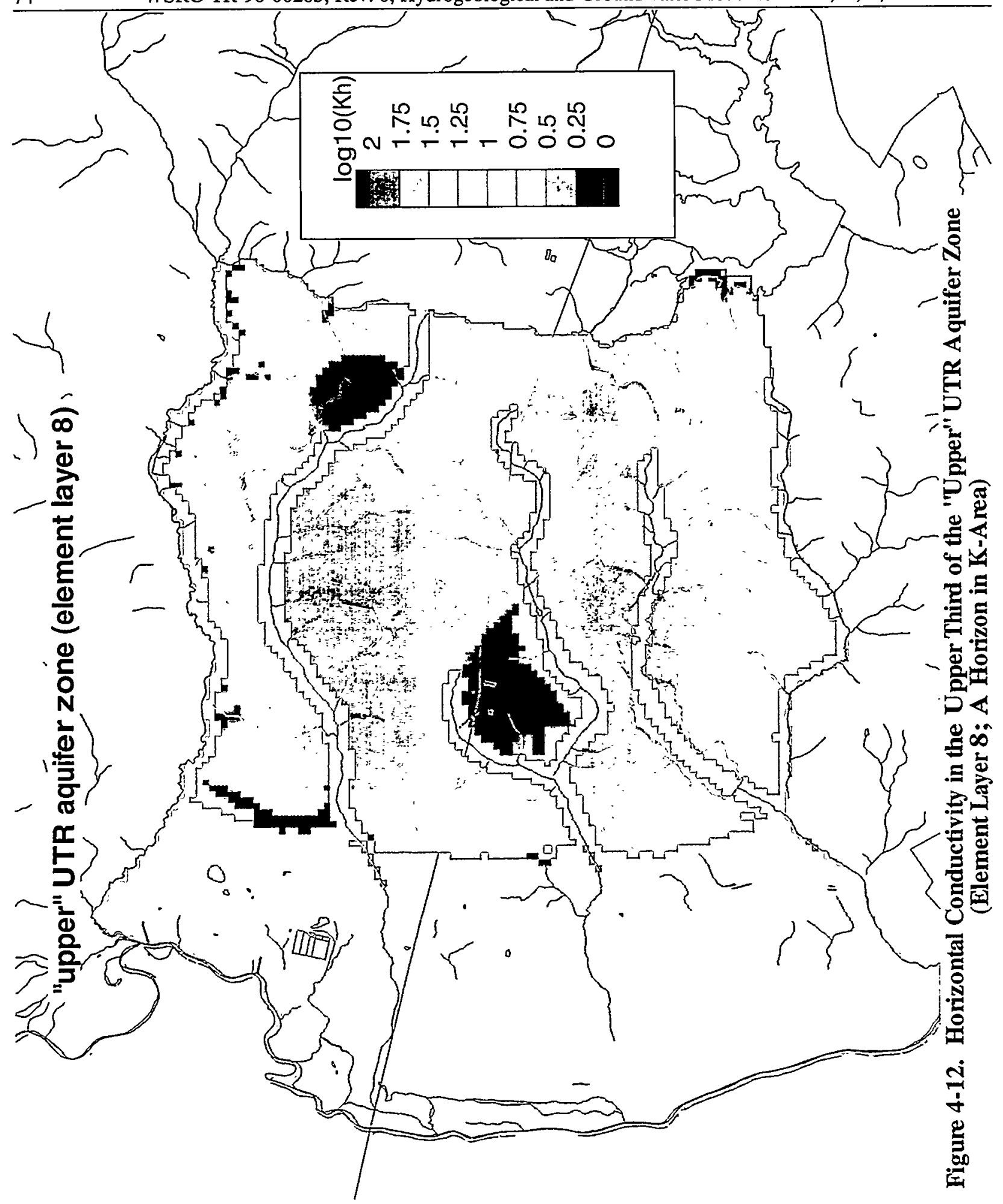



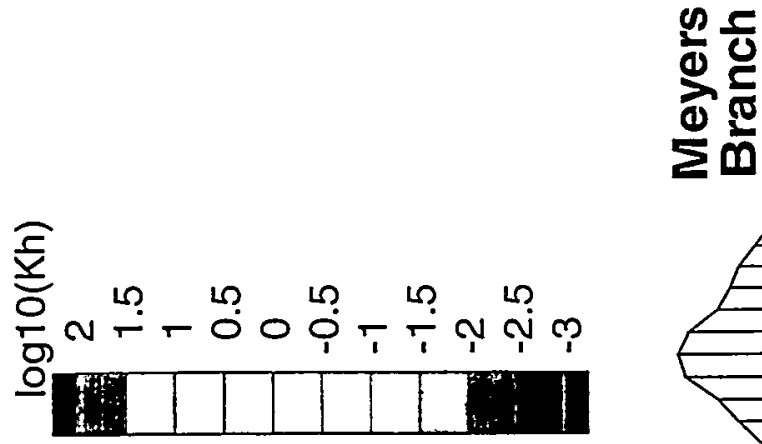

동
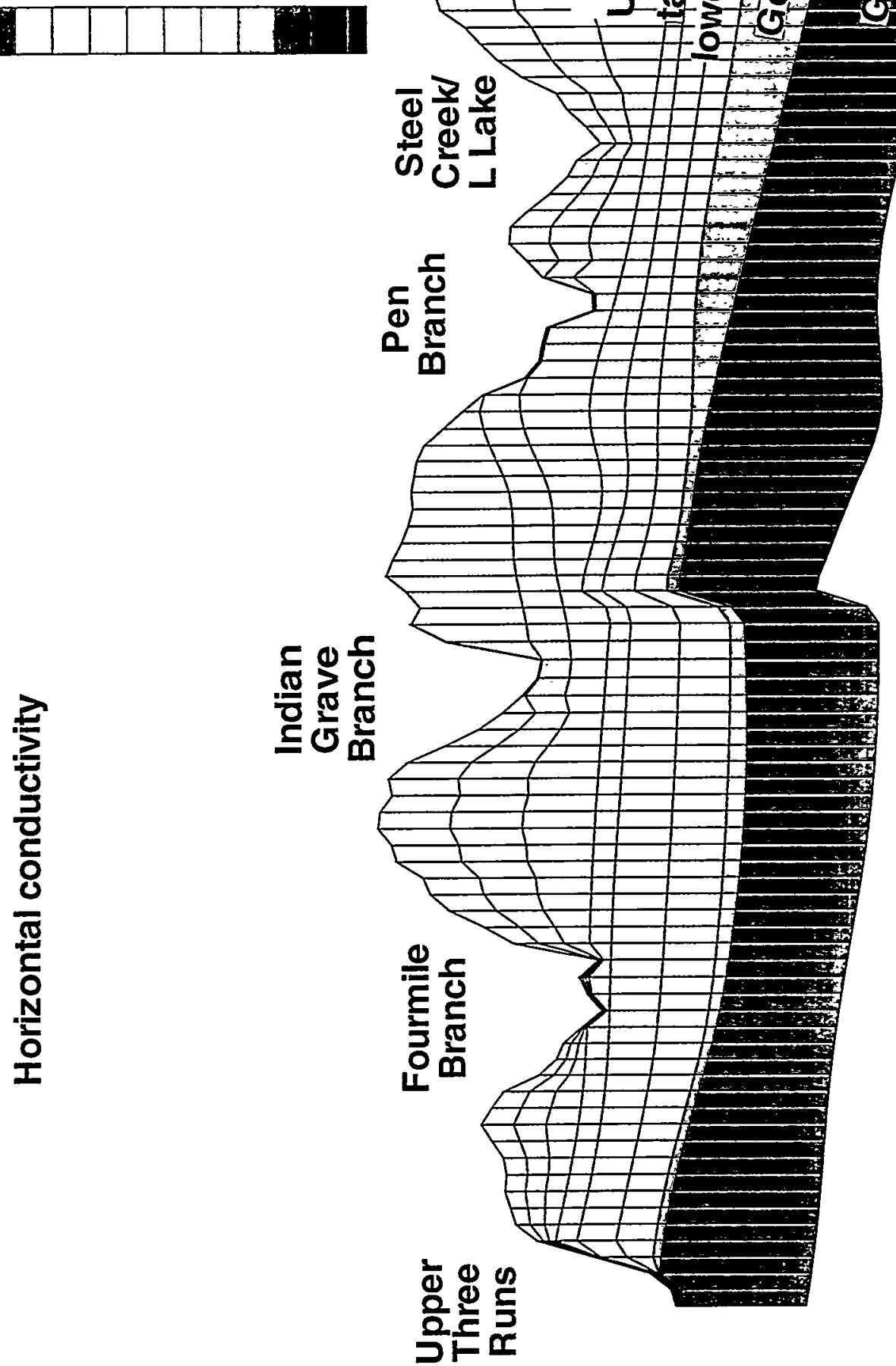

告

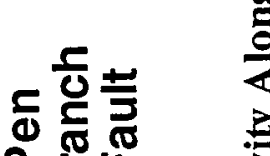

ต

릉

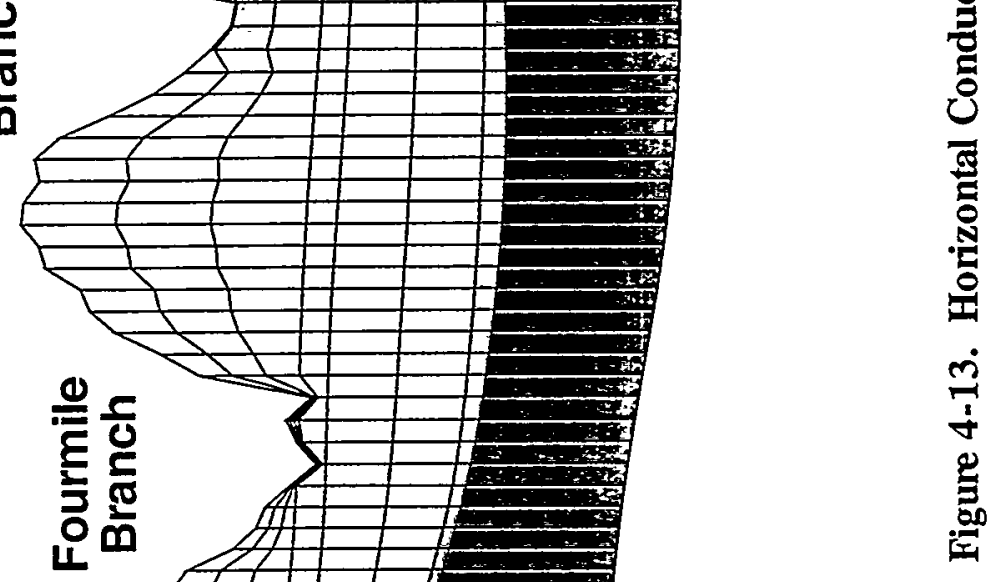


Simulated hydraulic head in Gordon aquifer

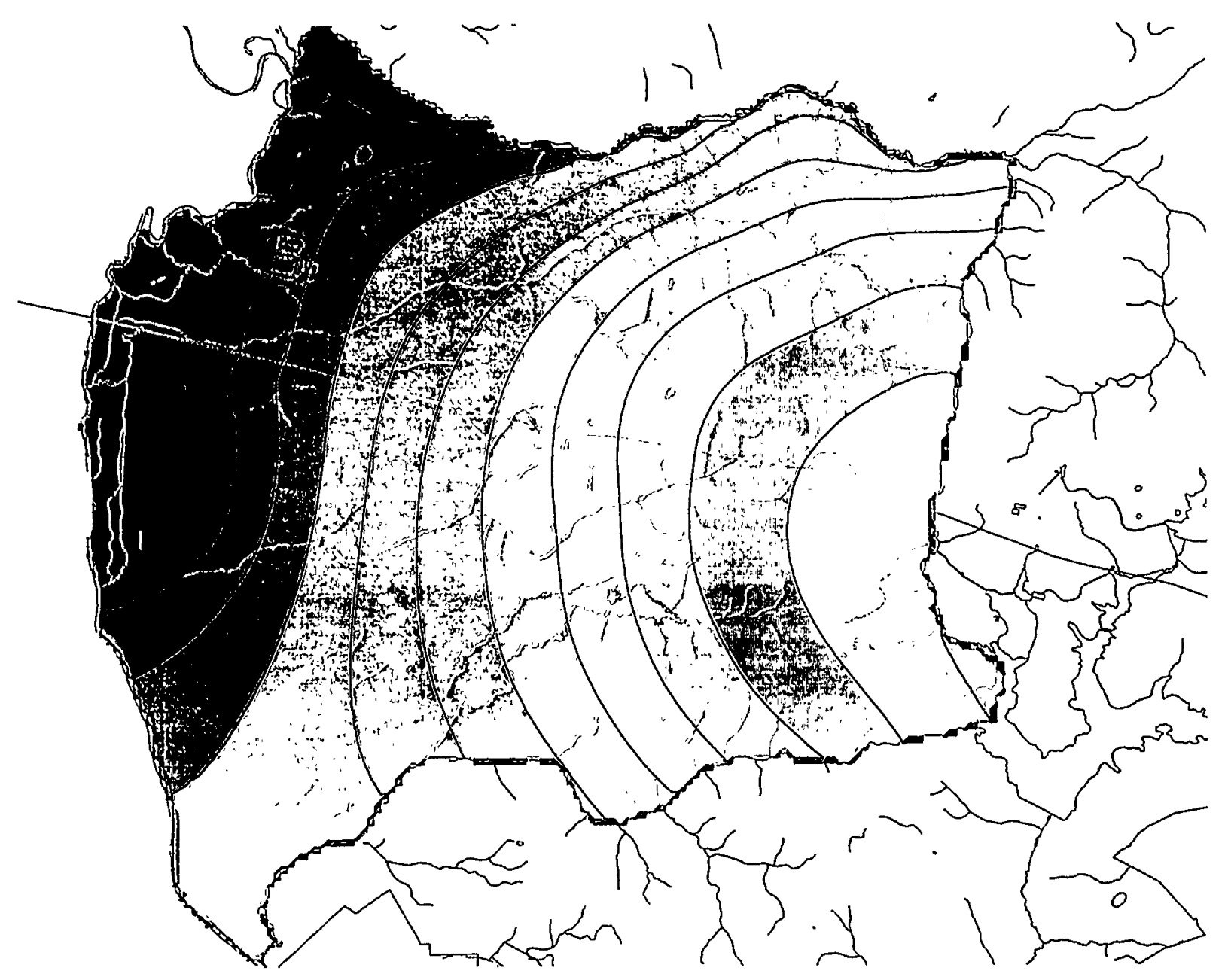

Figure 4-14. Simulated Hydraulic Head in the Gordon Aquifer 
Simulated hydraulic head in "lower" UTR aquifer zone

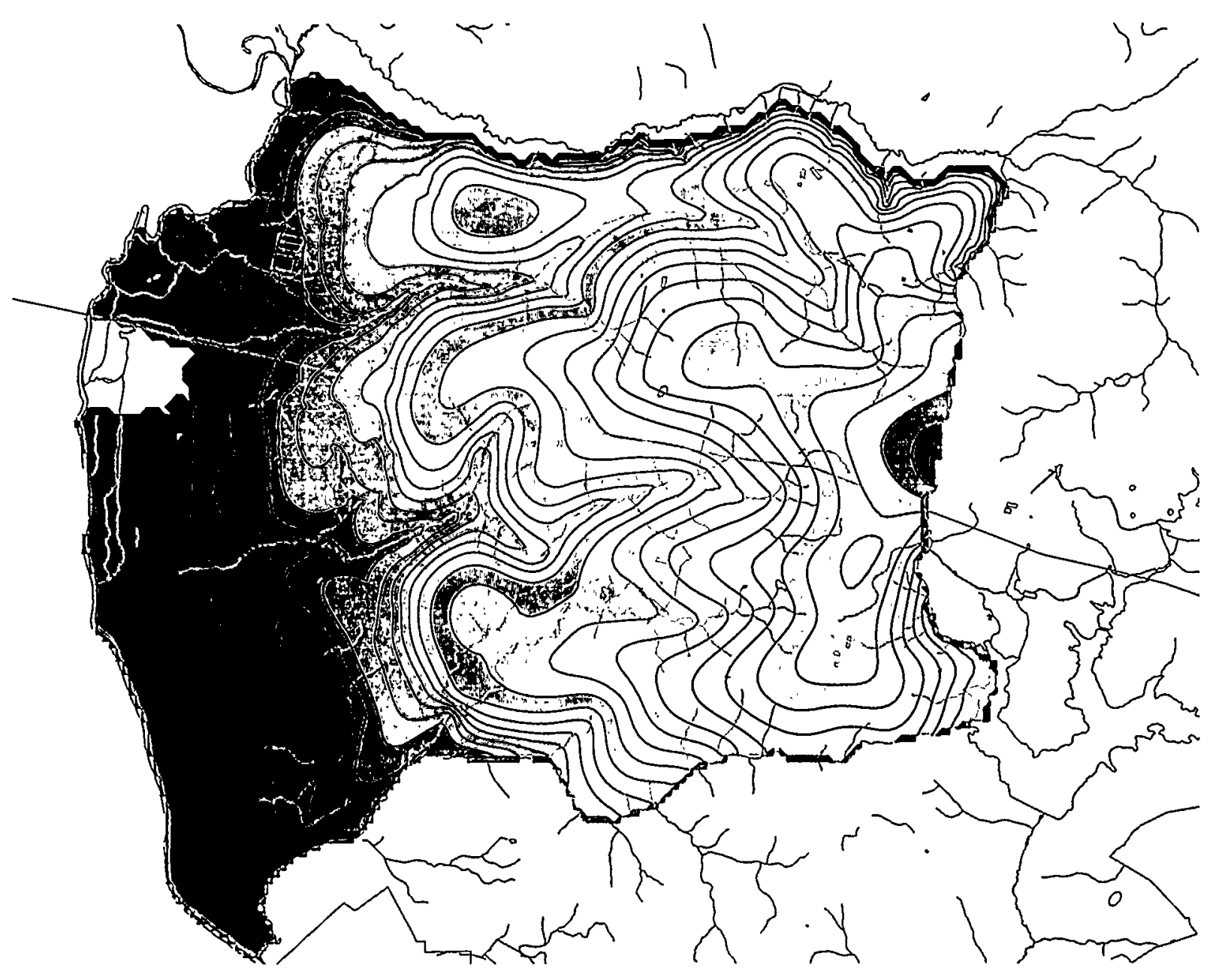


Simulated hydraulic head in "upper" UTR aquifer zone

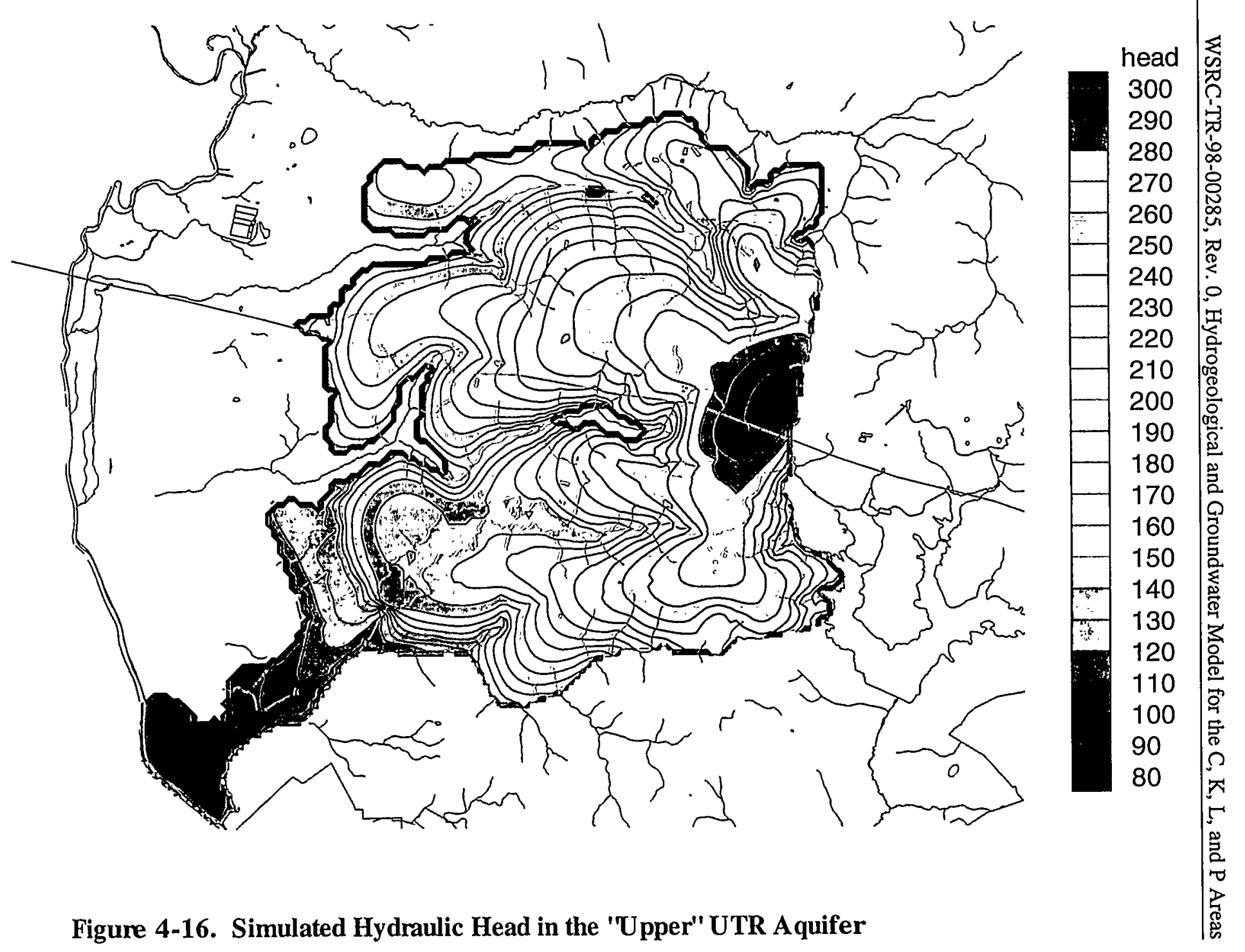




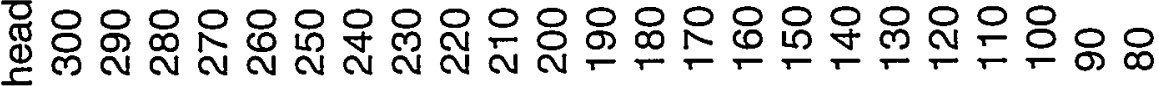

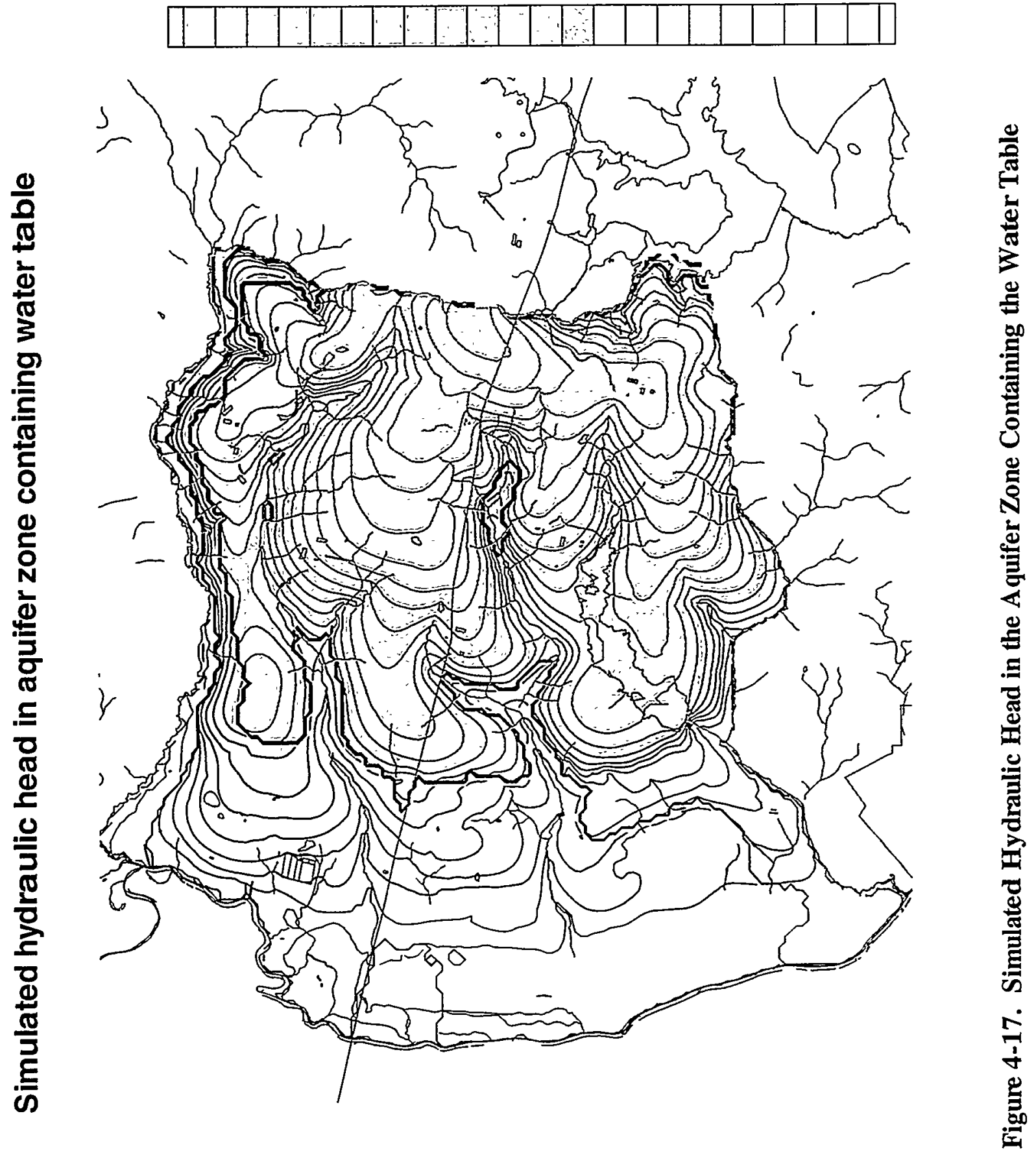




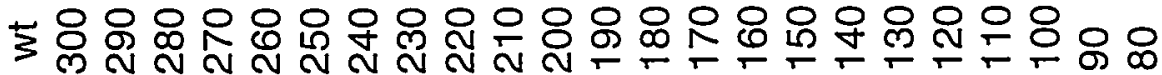

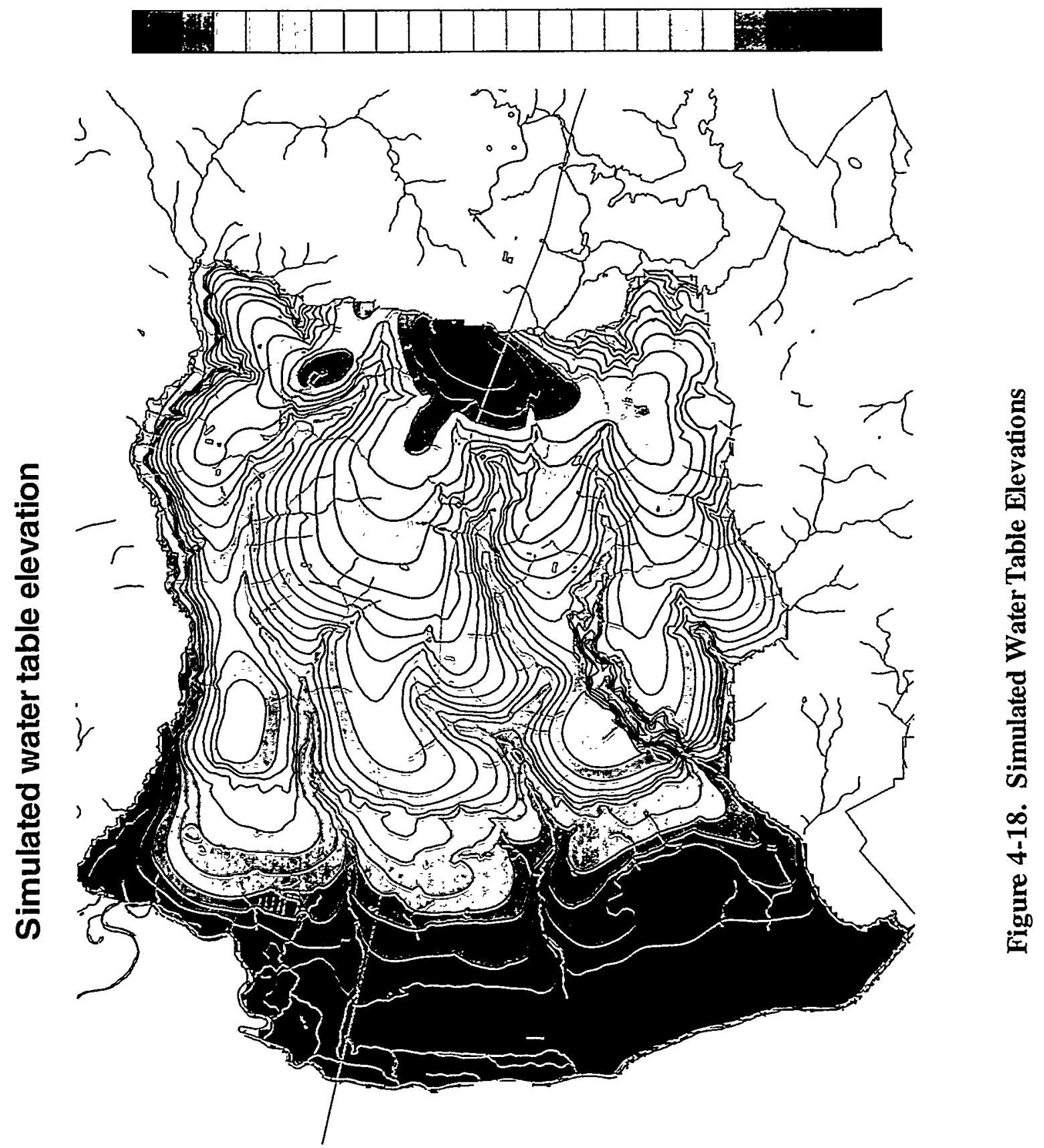




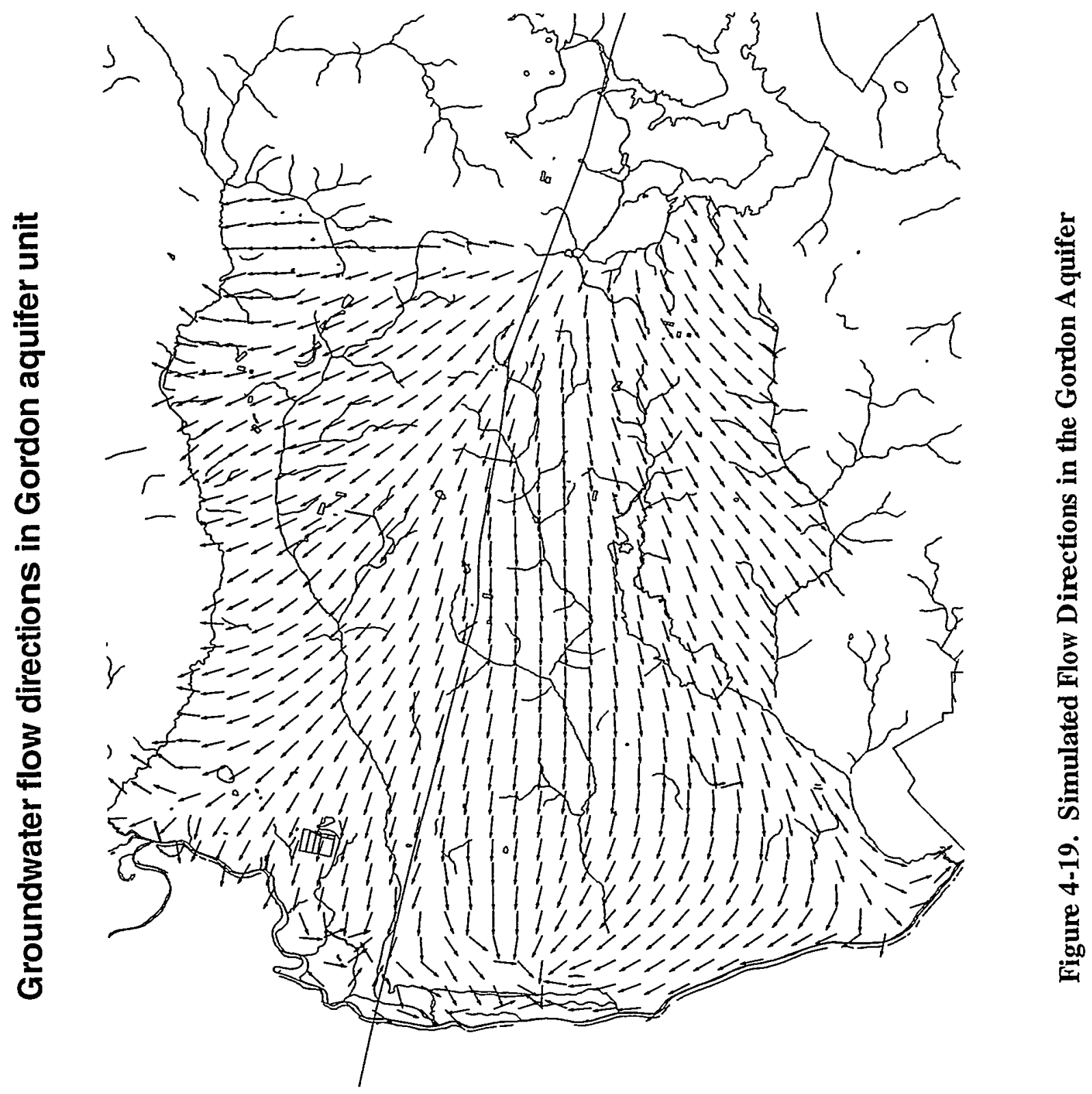




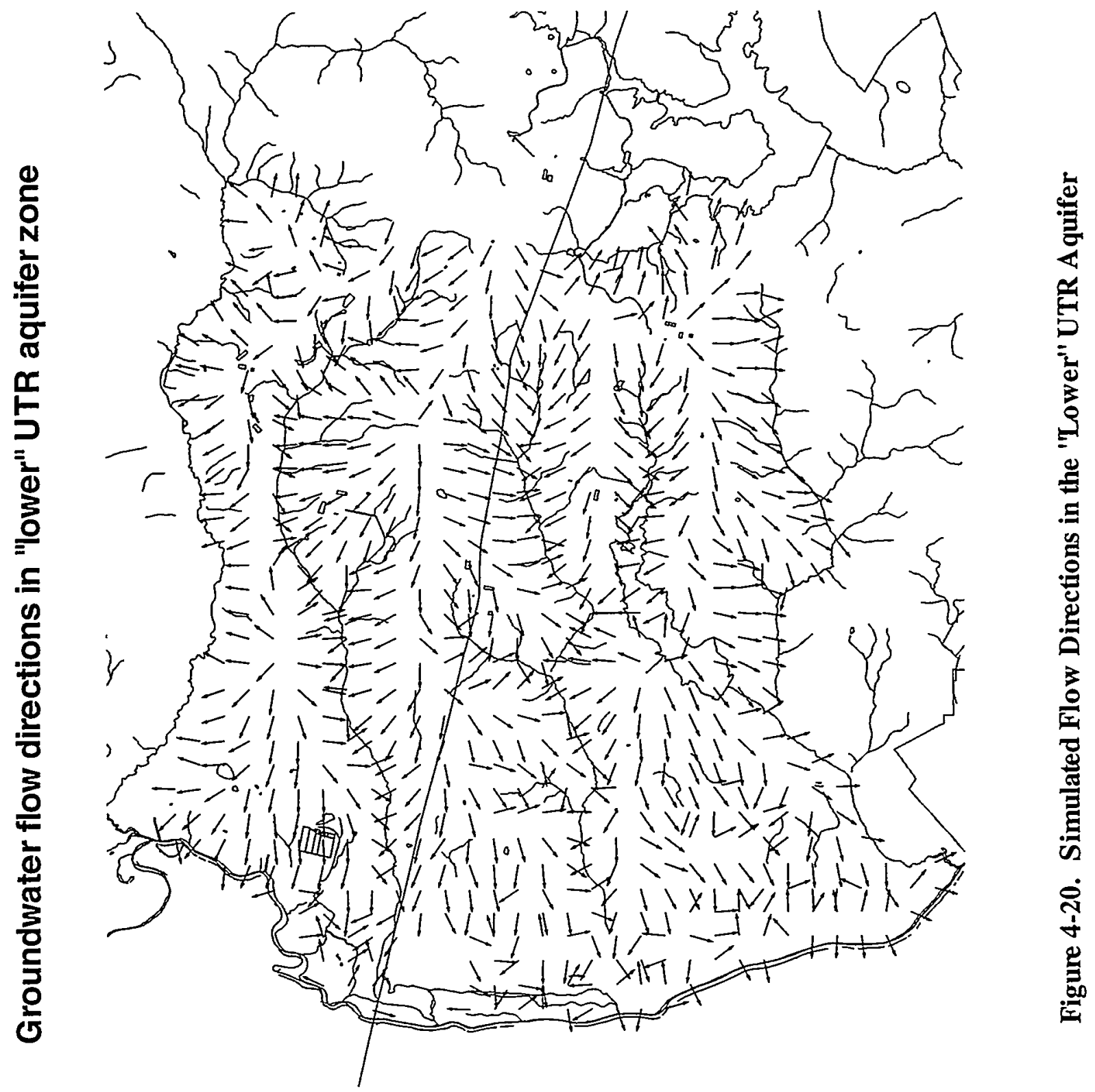




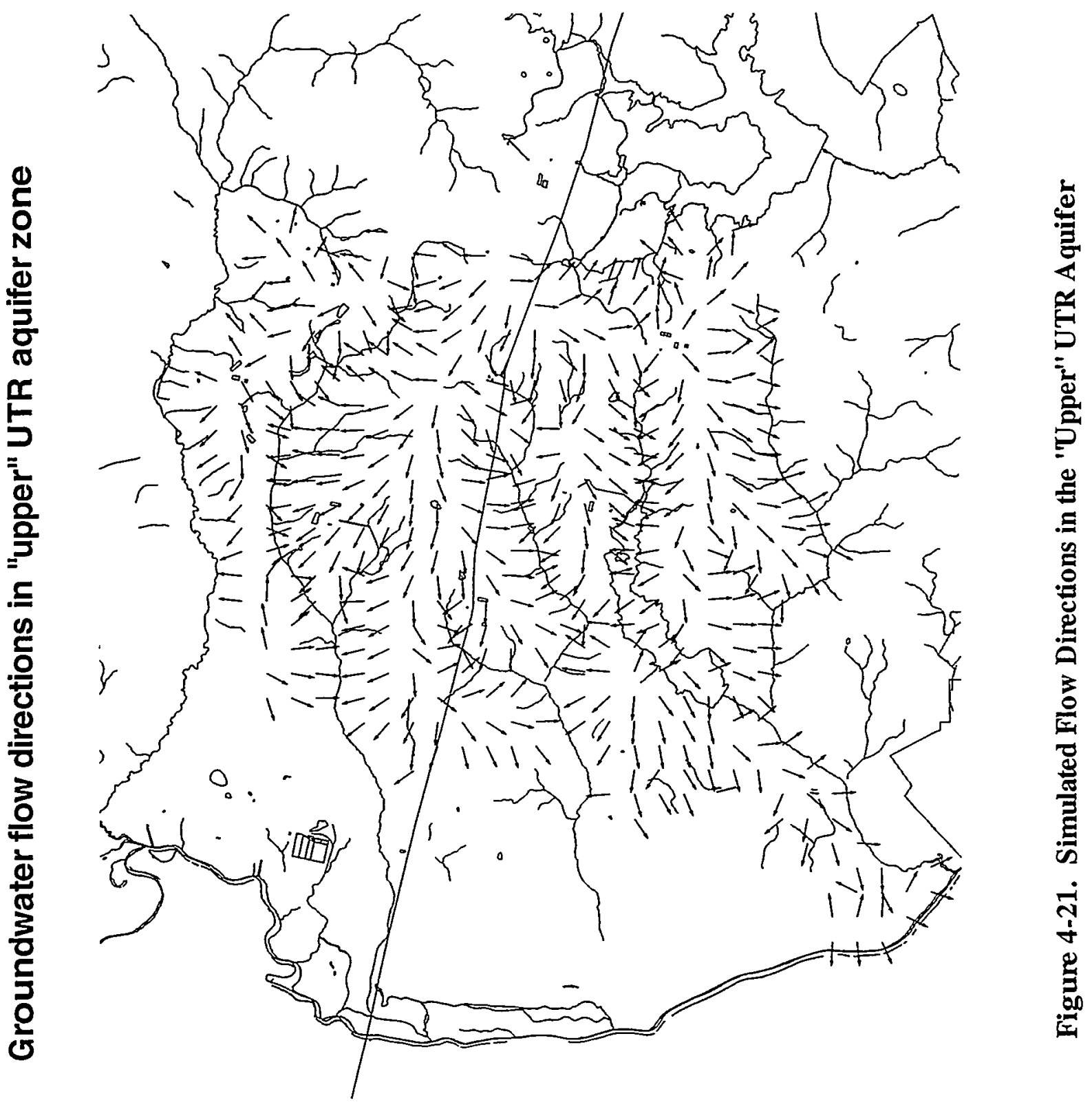




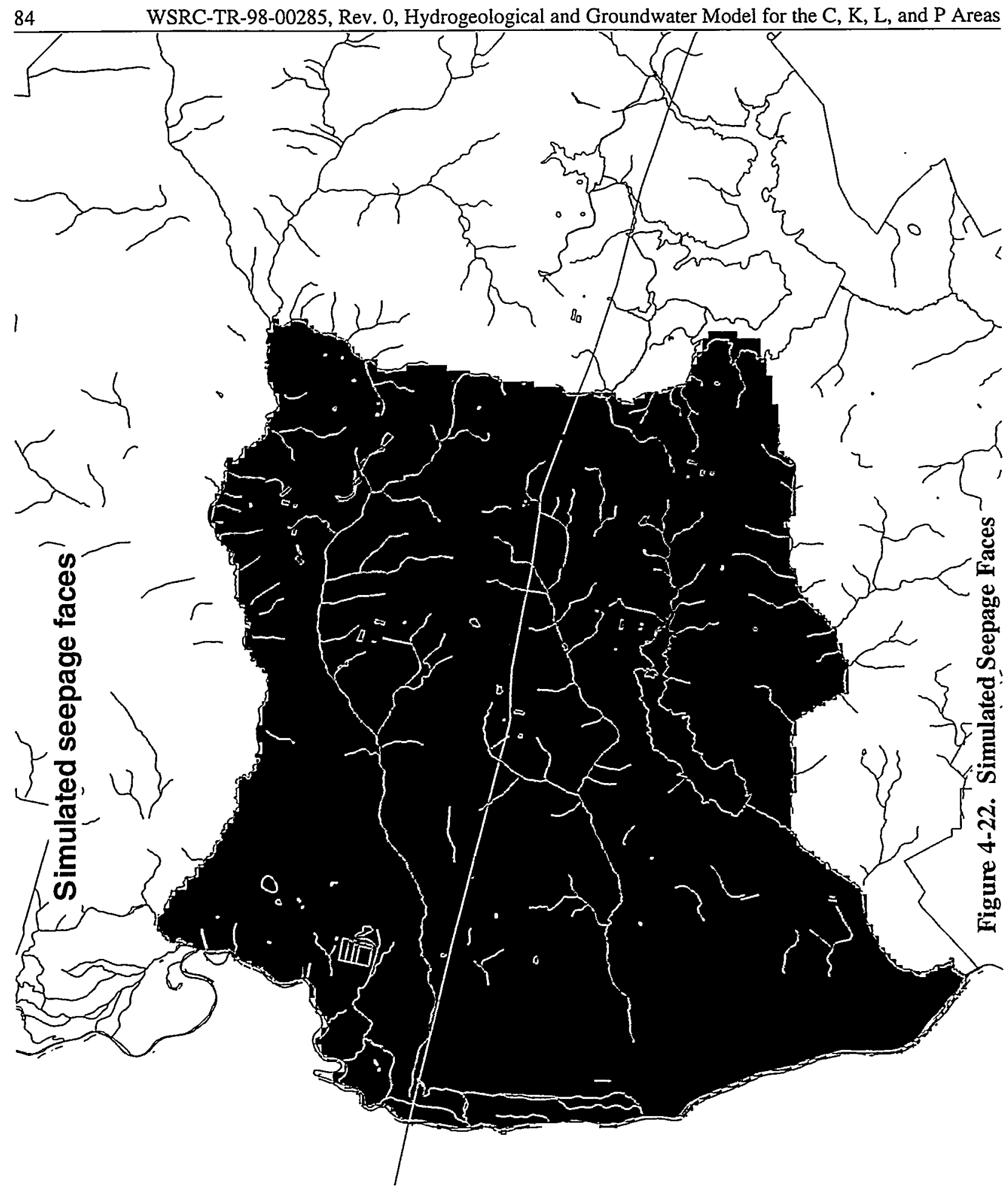




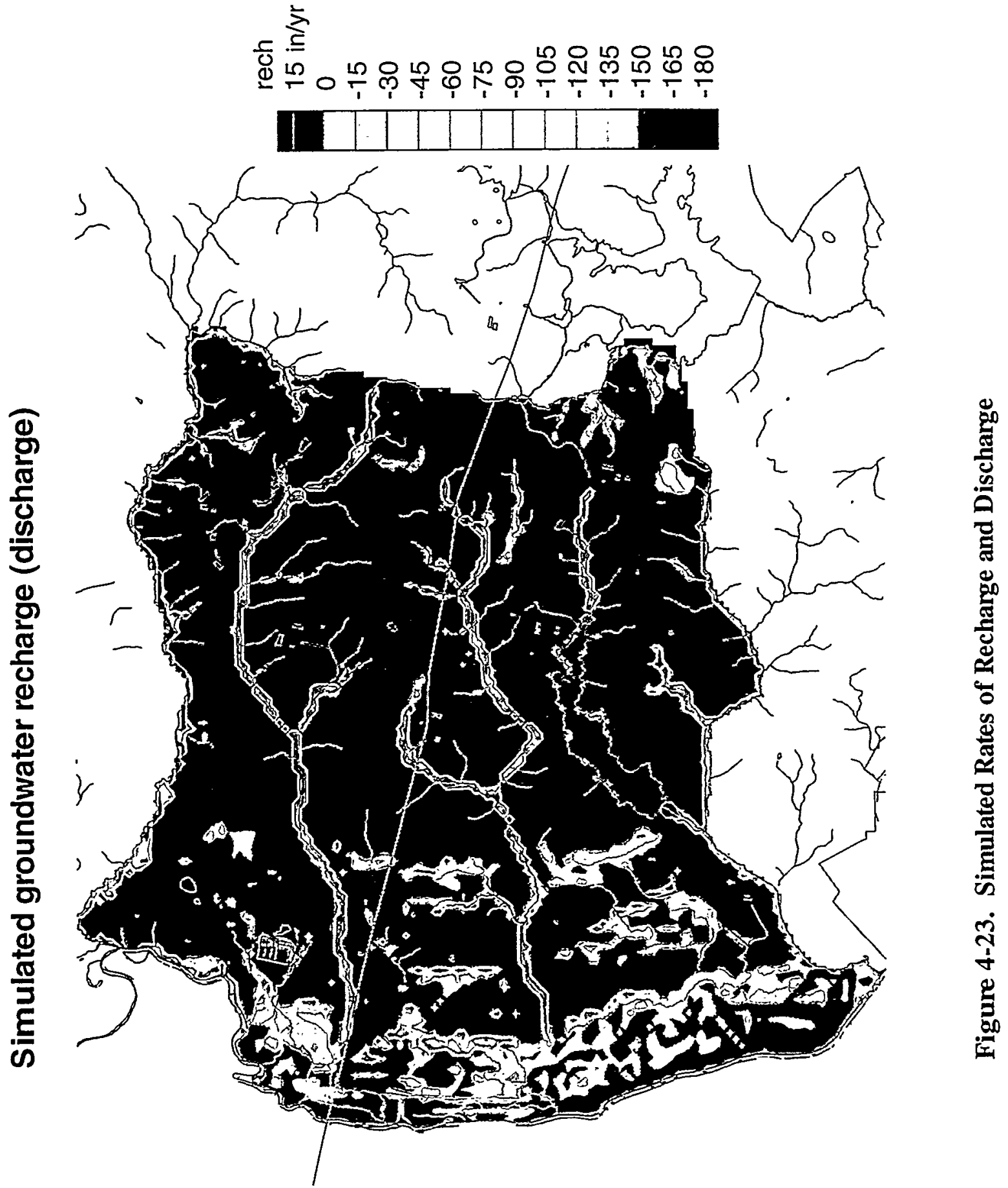




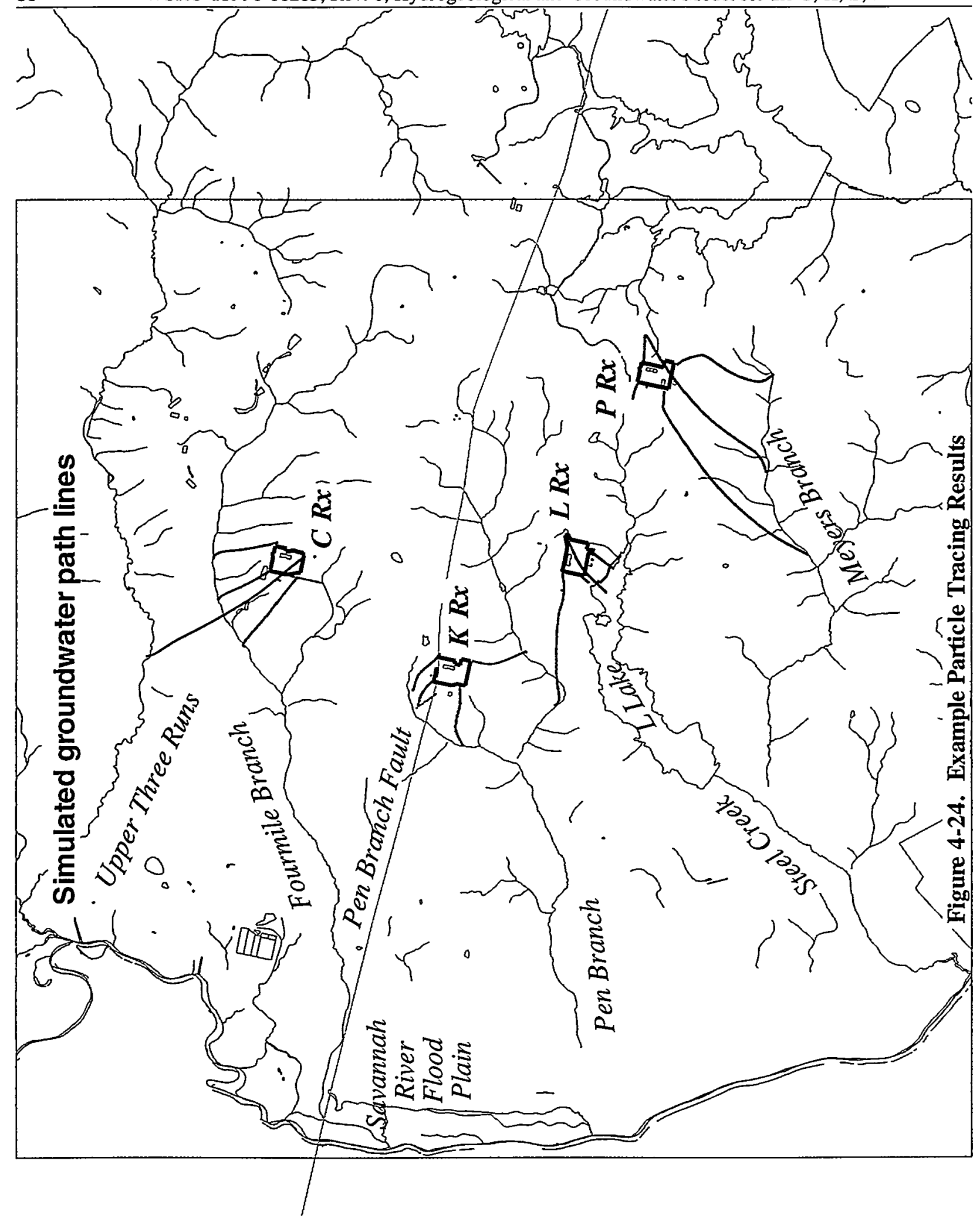




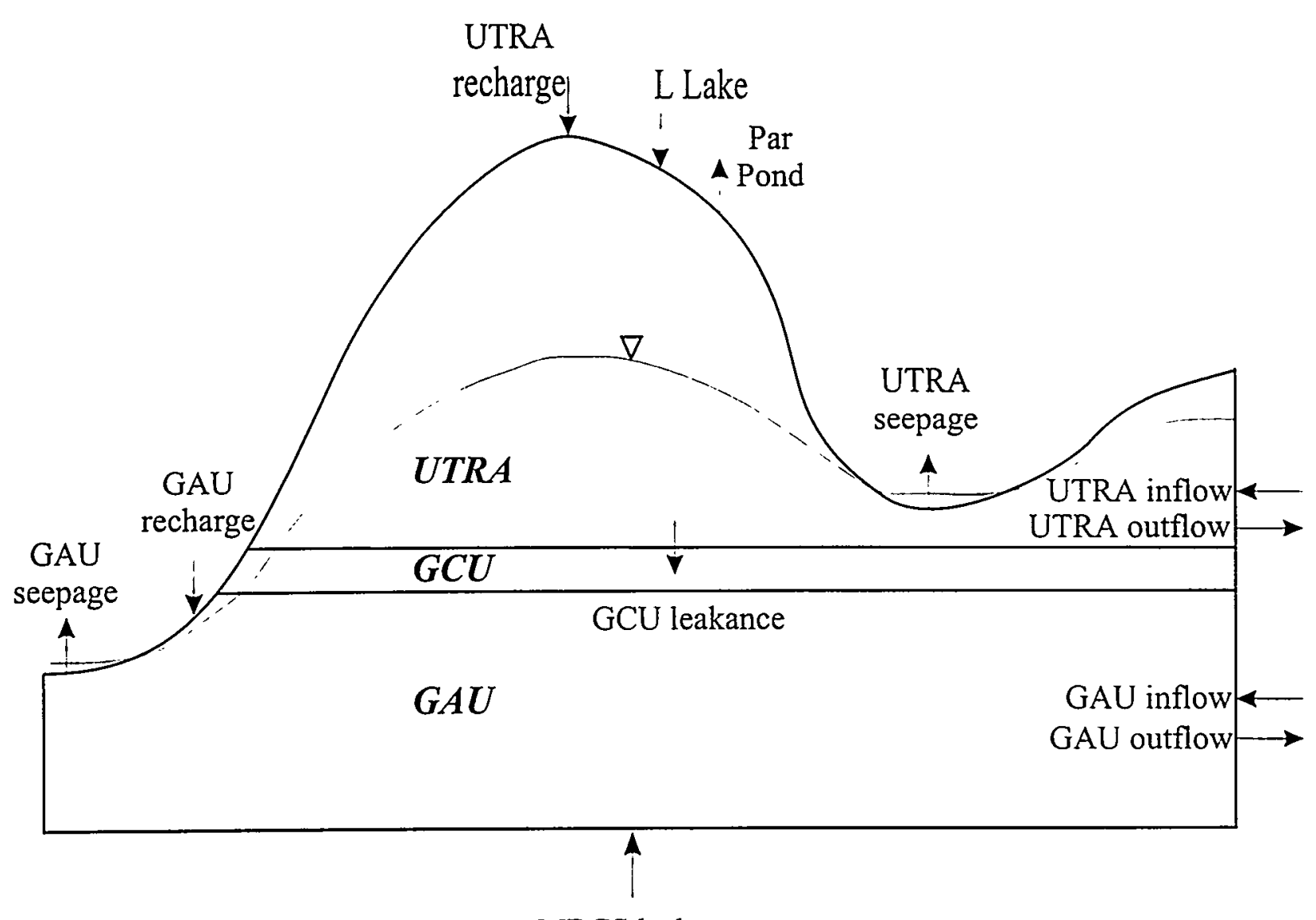

MBCS leakance

\begin{tabular}{lcrr}
\hline Flow component (cfs) & Entire model & UTR aquifer & Gordon aquifer \\
\hline Recharge & +79.9694 & +78.3983 & +1.5711 \\
Seepage & -80.7454 & -64.3827 & -16.3627 \\
In flows (head BCs) & +104.9055 & +0.5450 & +104.3605 \\
Out flows (head BCs) & -106.6514 & -2.2367 & -104.4148 \\
L Lake & +0.2734 & +0.2734 & N/A \\
Par Pond & -0.1225 & -0.1225 & N/A \\
Gordon c.u. leakage & $\mathrm{N} / \mathrm{A}$ & -12.4745 & +12.4745 \\
Meyers Br. c.s. leakage & +2.3717 & $\mathrm{~N} / \mathrm{A}$ & +2.3717 \\
Net total flow & +0.0007 & $+\mathbf{0 . 0 0 0 3}$ & $+\mathbf{0 . 0 0 0 3}$ \\
\hline
\end{tabular}


Table 4-1. Calibration Summary for Groundwater Flow Targets

\begin{tabular}{|c|c|c|c|c|}
\hline Flow target & $\begin{array}{l}\text { Prior } \\
\text { estimate }\end{array}$ & $\begin{array}{l}\text { Range or } \\
\text { Uncertainty }\end{array}$ & $\begin{array}{l}\text { Model value } \\
\text { (in/yr for recharge; } \\
\mathrm{ft} 3 / \mathrm{s} \text { otherwise) }\end{array}$ & Difference \\
\hline Surface recharge & $15 \mathrm{in} / \mathrm{yr}$ & $10-16 \mathrm{in} / \mathrm{yr}$ & $\begin{array}{l}12.5 \text { max. local } \\
\left(\begin{array}{c}9.7 \text { based on total } \\
\text { area })\end{array}\right.\end{array}$ & $\overline{-17 \%}$ \\
\hline $\begin{array}{l}\text { Meyers Branch } \\
\text { base flow } \\
\text { (headwaters to Road 9) }\end{array}$ & 3.2 & $\pm 20-25 \%$ & 2.9 & $-9 \%$ \\
\hline $\begin{array}{l}\text { Steel Creek base } \\
\text { flow } \\
\text { (above Road B to Road } \\
\text { A; includes L-Lake) }\end{array}$ & $\begin{array}{c}-2.2 \\
\text { (losing reach) }\end{array}$ & $\pm 20-25 \%$ & $\begin{array}{c}3.8 \\
\text { (drain BCs: }+4.1 \\
\text { gen. head BCs: }-0.3 \text { ) }\end{array}$ & $+6 \mathrm{ft}^{3} / \mathrm{s}$ \\
\hline $\begin{array}{l}\text { Pen Branch base } \\
\text { flow } \\
\text { (headwaters to Road } \\
\text { A13; } \\
\text { includes Indian Grave } \\
\text { Branch) }\end{array}$ & 13.3 & $\pm 15-20 \%$ & 14.7 & $+11 \%$ \\
\hline $\begin{array}{l}\text { Fourmile Branch } \\
\text { base flow } \\
\text { (headwaters to Road } \\
\text { A12) }\end{array}$ & 14.1 & $\pm 15-20 \%$ & 14.0 & $-1 \%$ \\
\hline $\begin{array}{l}\text { Upper Three Runs } \\
\text { base flow } \\
\text { (Road C to Road A) }\end{array}$ & 4.5 & $\pm 20-25 \%$ & 6.7 & $+49 \%$ \\
\hline L Lake & - & - & $\begin{array}{c}-0.3 \\
\text { (losing lake) }\end{array}$ & - \\
\hline $\begin{array}{l}\text { Par Pond } \\
\text { (portion within model) }\end{array}$ & - & - & 0.1 & - \\
\hline
\end{tabular}


Table 4-2. Calibration Summary for Hydraulic Head Targets

\begin{tabular}{|l|c|c|c|c|}
\hline $\begin{array}{c}\text { Measure } \\
\text { (ft) }\end{array}$ & Gordon aquifer & $\begin{array}{c}\text { "lower" UTR } \\
\text { aquifer }\end{array}$ & $\begin{array}{c}\text { "upper" UTR } \\
\text { aquifer }\end{array}$ & Overall \\
\hline RMS difference & 3.9 & 6.7 & 5.1 & 5.64 \\
\hline Avg. difference & -1.3 & 0.3 & 0.2 & - \\
\hline Median difference & -0.9 & 0.6 & 0.0 & - \\
\hline Avg. Idifferencel & 2.0 & 5.3 & 3.8 & - \\
\hline Max. difference & -18 & -34 & +16 & \\
\hline
\end{tabular}


Table 4-3. Calibration Summary for Hydraulic Conductivity

\begin{tabular}{|l|c|c|c|c|}
\hline Hydrostratigraphic Unit & $\begin{array}{c}\text { Nominal } \\
\mathrm{K}_{\mathbf{h}} \\
\text { (ft/day) }\end{array}$ & Range & $\begin{array}{c}\text { Nominal } \\
\mathbf{K}_{\mathbf{V}} \\
(\mathbf{f t} / \text { day) }\end{array}$ & Range \\
\hline Gordon aquifer & 35 & - & $\mathrm{K}_{\mathrm{h}} / 100$ & - \\
\hline Gordon confining unit & $\mathrm{K}_{\mathrm{V}} \times 100$ & - & $10^{-4}$ & - \\
\hline "lower" UTR aquifer zone & 5.6 & 5 to 1.6 & $\mathrm{~K}_{\mathrm{h}} / 100$ & $\mathrm{~K}_{\mathrm{h}} / 100$ \\
\hline $\begin{array}{l}\text { zone } \\
\text { "tan clay" UTR confining }\end{array}$ & $\mathrm{K}_{\mathrm{V}} \times 100$ & $\mathrm{~K}_{\mathrm{V}} \times 100$ & $4 \times 10^{-3}$ & $4 \times 10^{-2}$ to \\
$4 \times 10^{-4}$
\end{tabular}


Table 4-4. Summary of Uncertainty Cases

GCU Kv

\begin{tabular}{|c|c|c|c|}
\cline { 2 - 4 } Recharge & $5 \times 10^{-4} \mathrm{ft} /$ day & $10^{-4} \mathrm{ft} /$ day & $2 \times 10^{-5} \mathrm{ft} /$ day \\
\hline $15 \mathrm{in} / \mathrm{yr}$ & - & Case 1 & (Case 5) \\
\hline $12.5 \mathrm{in} / \mathrm{yr}$ & Case 3 & Nominal & Case 4 \\
\hline $10 \mathrm{in} / \mathrm{yr}$ & (Case 6) & Case 2 & - \\
\hline
\end{tabular}


Table 4-5. Calibration Summary for Uncertainty Cases

\begin{tabular}{|l|c|c|c|c|c|}
\hline Calibration measure & Nominal & Case 1 & Case 2 & Case 3 & Case 4 \\
\hline Overall RMS head residual (ft) & 5.6 & 5.8 & 5.5 & 9.5 & 5.7 \\
\hline Gordon aquifer RMS head residual (ft) & 3.9 & 3.3 & 3.5 & 3.6 & 3.6 \\
\hline "lower" UTRA RMS head residual (ft) & 6.7 & 6.9 & 6.5 & 12.5 & 6.9 \\
\hline "upper" UTRA RMS head residual (ft) & 5.1 & 5.3 & 4.9 & 7.9 & 5.0 \\
\hline Meyers Branch base flow residual (cfs) & -0.3 & 0.3 & -0.9 & -1.7 & 0.0 \\
\hline Steel Creek base flow residual (cfs) & 6.0 & 6.8 & 5.2 & 4.3 & 6.0 \\
\hline Pen Branch base flow residual (cfs) & 1.4 & 4.5 & -1.8 & -5.0 & 3.2 \\
\hline $\begin{array}{l}\text { Fourmile Branch base flow residual } \\
\text { (cfs) }\end{array}$ & -0.1 & 2.4 & -2.8 & -7.0 & 2.6 \\
\hline $\begin{array}{l}\text { Upper Three Runs base flow residual } \\
\text { (cfs) }\end{array}$ & 2.2 & 2.5 & 1.8 & 7.1 & 0.1 \\
\hline $\begin{array}{l}\text { Nominal "lower" UTR aquifer zone, } \\
\text { Kh (ft/day) }\end{array}$ & 5.6 & 6.7 & 4.5 & 0.84 & 7.6 \\
\hline $\begin{array}{l}\text { Nominal "tan clay" UTR confining } \\
\text { zone, Kv (ft/day) }\end{array}$ & $4 \times 10^{-3}$ & $4 \times 10^{-3}$ & $4 \times 10^{-3}$ & $4 \times 10^{-2}$ & $2 \times 10^{-3}$ \\
\hline $\begin{array}{l}\text { Nominal "upper" UTR aquifer zone, } \\
\text { Kh (ft/day) }\end{array}$ & 5.6 & 6.7 & 4.5 & 0.84 & 7.6 \\
\hline $\begin{array}{l}\text { Nominal Gordon aquifer unit, } \\
\text { Kh (ft/d) }\end{array}$ & 35 & 35 & 35 & 88 & 12 \\
\hline
\end{tabular}




\subsection{SUMMARY AND RECOMMENDATIONS}

Important attributes of the baseline CKLP model are:

- the present baseline model is current with available reactor characterization data through Spring 1998. All the characterization data has been incorporated into a project database that can be easily updated as additional field data is obtained.

- aquifer zones are sub-divided by several vertical mesh layers

- model preprocessing has been fully automated using the make software language

- both the vadose and saturated zones are simulated in the model

- groundwater flow beneath the model boundaries are simulated to the top of the Meyers Branch confining system

- the alluvial valley has been included in the model to realistically illustrate the extent to which the Savannah River has incised the hydrostratigraphic units. The Savannah River has cut down to the Gordon aquifer at the northern and southern ends of the valley but does not incise the Meyers Branch confining system within the model area.

- the model is based on the FACT code

Important implications of the CKLP model:

- the model meets the planning objectives of the General Groundwater Strategy for Reactor Area Projects (WSRC, 1997) by providing a common framework for analyzing groundwater flow, contaminant migration and remedial alternatives across ERD programs

- the CKLP groundwater flow model provides a good understanding of the groundwater flow regime for these reactor areas on a regional scale. The model is suited to assist in scoping characterization and remedial activities by providing a common base for the subsequent finer scale transport and remedial/feasibility models for each of these areas.

- the model has been constructed to incorporate new data as it is collected, providing quick and cost-effective updates. 
Recommendations for future refinements to the CKLP model are:

- additional head data are needed for the Upper Three Runs aquifer above and below the "tan clay" confining zone on a regional scale to provide data away from the reactor facilities

- pump tests in non-contaminated areas are needed for each reactor area in order to provide direct, field scale, conductivity measurements. In addition, previous conductivity measurements derived from slug tests and pump tests should be reviewed to determine data quality and validity of the measurements.

- baseflow measurements should be completed during the 1999 fiscal year.

- a field survey and walk-down of the NPDES outfalls is recommended in order to assess the elevation of these drainages and how deep they have incised the hydrostratigraphic units due to process water flows since the 1950s.

- evaluate high and low head residual areas for both UTR and Gordon aquifers by looking at both hydrostratigraphy and well screen intervals.

- utilization of mathematical optimization algorithms such as the new FACT/Data Fusion Modeling code to improve and automate model calibration. The software also provides better estimates of model uncertainty, which is desirable for regulatory applications.

- Additional documentation on data preprocessing algorithms and software. 


\subsection{REFERENCES}

Aadland, R. K., Gellici, J. A., and Thayer, P. A., 1995. Hydrogeologic Framework of WestCentral.South Carolina. Report 5, Water Resources Division. South Carolina Department of Natural Resources, Columbia, SC.

Aadland, R. K., Harris, M. K., Lewis, C. M., Gaughan, T. F., and Westbrook. T. M., 1991. Hydrostratigraphy of the General Separations Area, Savannah River Site (SRS), South Carolina. WSRC-RP-91-13, Westinghouse Savannah River Company, Aiken. SC 29808.

Amidon, M. B., 1996. Re: Geotechnical Report (U), memorandum to G. Flach dated May 13.

Beard, D. C., and Weyl, P. K., 1973. "Influence of Texture on Porosity and Permeability of Unconsolidated Sand", American Association of Petroleum Geologists Bulletin, V. 57, p. 349-369.

Cahill, J. M., 1982. Hydrology of the Low Level Radioactive Solid Waste Burial Site and vicinity near Barnwell, South Carolina, United States Geological Survey Open File Report 82-863.

Camp Dresser \& McKee, 1989. Numerical Simulation of Groundwater Flow and Contaminant Transport at the K, L, and P Areas of the Savannah River Site, Aiken, South Carolina, Final Report, prepared for Westinghouse Savannah River Company.

Cooney, T. W., Drewes, P. A., Jones, K. H., Gissendanner, J. W., and Church, B. W., 1998. Water Resources Data - South Carolina, Water year 1997, Volume 1, U. S. Geological Survey Water-Data Report SC-97-1.

De Marsily, G., 1986. Quantitative Hydrogeology, Groundwater Hydrology for Engineers, Academic Press, Inc., Harcourt Brace Jovanovich, Publishers.

Denehy, K., and McMahon, P., 1985. Hydrologic and Micrometeorological Data for an Unsaturated Zone Flow Study at a Low-Level Radioactive Waste Burial Site, Bannwell, South Carolina, U. S. Geological Survey Open File Report OF85-476.

Environmental Protection Department and Exploration Resources, Inc., 1996a. Environmental Protection Department's Well Inventory (U), ESH-EMS-960488. Westinghouse Savannah River Company, Aiken, SC 29808. 
Environmental Protection Department and Exploration Resources, Inc., 1996b. The Savannah River Site's Groundwater Monitoring Program; Second Quarter 1996 (U), ESH-EMS960057. Westinghouse Savannah River Company, Aiken, SC 29808.

Flach, G. P. and Harris, M. K., 1997. Integrated Hydrogeological Model of the General Separations Area (U), Volume 2: Groundwater Flow Model (U), WSRC-TR-96-0399, Rev. 0, Westinghouse Savannah River Company, Aiken, SC 29808.

Flach, G. P., 1998. Impact of F- and H-Area Pump-Treat-Reinject Remediation Systems on the Old Radioactive Waste Burial Ground (U), SRT-EST-98-154.

Freeze, R. A., and Cherry, J. A., 1979. Groundwater, Prentice-Hall, Inc.

GeoTrans, 1992. Groundwater flow model of the General Separations Area, Savannah River Site, prepared for Westinghouse Savannah River Company, Project no. 3017-003.

GeoTrans, 1993. Groundwater Model Calibration and Review of Remedial Alternatives at the F- and H-Area Seepage Basins, WSRC-TR-93-384, Westinghouse Savannah River Company, Aiken, SC 29808.

Gruber, P., 1981. A Hydrology Study of the Unsaturated Zone Adjacent to a RadioactiveWaste Disposal Site at the Savannah River Plant, Aiken, South Carolina, M.S. Thesis, Geology Department, University of Georgia, Athens, GA.

Gruber, P., 1983. "A Hydrology Study of the Unsaturated Zone Adjacent to a RadioactiveWaste Disposal Site at the Savannah River Plant, Aiken, South Carolina", Role of Unsaturated Zone in Radioactive and Hazardous Waste Disposal, J.W. Mercer, P.S.C. Rao, and I.W. Marine (editors), An Arbor Science Publishers, Ann Arbor, MI.

Hamm, L. L., Aleman, S. E., Flach, G. P, and Jones, W. F., 1997. Subsurface Flow and Contaminant Transport Documentation and User's Guide (U), WSRC-TR-95-0223, Savannah River Technology Center, Westinghouse Savannah River Company, Aiken, SC . 29808.

Harris, M. K., Aadland, R. K., and Westbrook, T. M., 1990. "Lithological and Hydrological Characteristics of the Tertiary Hydrostratigraphic Systems of the General Separations Area, Savannah River Site, South Carolina". Savannah River Region: Transition Between the Gulf and Atlantic Coastal Plains, Proceedings of the Second Bald Head Island Conference on Coastal Plains Geology, University of North Carolina at Wilmington, pp 68-73. 
Hiergesell, R. A., 1997. Personal communication, January 6, 1997.

Hiergesell, R. A., 1998a. Regional Water Table Coverage of the Savannah River Site. WSRC-TR-98-00045, Rev. 0, Westinghouse Savannah River Company. Aiken. SC 29808.

Hiergesell, R. A., 1998b. Summary of Stream Baseflow and Water Table Work Conducted in Support of the R-Reactor and K-Reactor Groundwater Modeling Efforts. Westinghouse Savannah River Company Inter-Office Memorandum, SRT-EST-98-110.

Hiergesell, R. A., 1998c. Transmittal of Stream Baseflow Measurement Data, Westinghouse Savannah River Company Inter-Office Memorandum, SRT-EST-98-197.

HSI GeoTrans, 1998. Groundwater Flow and Solute Transport Modeling Report; K-Area Buming/Rubble Pit and Rubble Pile, WSRC-TR-98-5052. Westinghouse Savannah River Company, Aiken, SC 29808.

Hubbard, J. E., and Emslie, R. E., 1984. Water Budget for the SRP Burial Ground Area, DPST-83-742.

Hubbard, J. E., 1986. An Update on the SRP Burial Ground Area Water Balance and Hydrology, DPST-85-958.

Huyakorn, P. S., Panday, S., and Birdie, T., 1991. Subsurface Analysis Finite Element Model for Flow and Transport in 3 Dimensions, Version 1.3, Documentation and User's Guide, prepared for Westinghouse Savannah River Company.

HydroGeoLogic, Inc., 1997. Groundwater Flow Model for the R-Reactor Area (U). WSRCOS-97-00006, Revision 0, HydroGeoLogic, Inc., Herndon, VA, 81 pp.

HydroGeoLogic, Inc., 1998. Groundwater Flow and Contaminant Transport for the RReactor Seepage Basins (U), HydroGeoLogic, Inc., Herndon, VA.

Leeth, D. C. and Nagle, D. D., 1996. "Shallow Subsurface Geology of Part of the Savannah River Alluvial Valley in the Upper Coastal Plain of Georgia and South Carolina", Southeastern Geology, v. 36, no. 1, pp. 1-14.

Looney, B. B., Grant, M. W., and King, C. M., 1987. Estimation of Geochemical Parameters for Assessing Subsurface Transport at the Savannah River Plant, DPST-85-904. 
O'Brien \& Gere Engineers, Inc., 1991. M Area Post-Test Characterization Geotechnical Testing, File: 4998.007 \#2.

Parizek, R. R., and Root, R. W., Jr., 1986. Development of a Ground-Water Velocity Model for the Radioactive Waste Management Facility, Savannah River Plant, South Carolina, DPST-86-658.

Siple, G. E., 1967. Geology and Ground Water of the Savannah River Plant and Vicinity: South Carolina, U.S. Geological Survey Water Supply Paper 1841.

Smits, A. D., Harris, M. K., Hawkins, K. L., and Flach, G. P., 1997. Integrated Hydrogeological Model of the General Separations Area (U), Volume I: Hydrogeologic Framework (U), WSRC-TR-96-0399, Westinghouse Savannah River Company, Aiken, SC, $118 \mathrm{pp}$.

Snipes, D. S., Fallaw, W. C., Price, V., Jr., and Cumbest, R. J., 1993. "The Pen Branch Fault: Documentation of Late Cretaceous-Tertiary Faulting in the Coastal Plain of South Carolina", Southeastern Geology, v. 33, no. 4, pp 195-218.

Stieve, A. and Stephenson, D., 1995. "Geophysical Evidence for Post Late Cretaceous Reactivation of Basement Structures in the Central Savannah River Area", Southeastem Geology, v. 35, no. 1, pp 1-20.

Walpole, R. E. and R. H. Meyers, 1978, Probability and statistics for engineers and scientists, $2^{\text {nd }}$ edition, MacMillan, New York.

WSRC, 1996. RCRA Facility Investigation/Remedial Investigation Report with Baseline Risk Assessment for the Chemicals, Metals, and Pesticides Pits (U), WSRC-RP-96-0012, Revision 1, Westinghouse Savannah River Company, Aiken, SC 29808.

WSRC, 1997. General Groundwater Strategy for Reactor Area Projects, WSRC-RP-97435, Revision 0, Westinghouse Savannah River Company, Environmental Restoration Division, Aiken, SC, 29808.

Yu, A. D., C. A. Langton and M. G. Serrato, 1993. Physical Properties Measurement Program (U), WSRC-RP-93-894, Westinghouse Savannah River Company, Aiken, SC 29808. 


\section{APPENDIX A. DATA COLLECTION AND HYDROGEOLOGIC MODEL METHODOLOGY}

\section{Hydrogeologic Data Collection}

Data utilized in this analysis include coordinates and elevations of SRS and off-site wells. geophysical logs, drill-core descriptions, and results from permeability. The study included collecting permeability data from the recent and historical literature. These data originate from the results of different types of tests. These include aquifer pumping tests, borehole permeability ("slug") tests, and laboratory tests performed on undisturbed samples.

\section{Project Database}

The project database used for the $\mathrm{C}, \mathrm{K}, \mathrm{L}$, and P groundwater model area (CKLP GWMA) is designed to support groundwater modeling conducted by the Environmental Sciences Section (ESS) of the Savannah River Technology Center (SRTC) such as that described in Flach, and Harris (1997). The scope of the groundwater modeling project database (GWMPD) for the CKLP GWMA includes the area bounded by Savannah River Site (SRS) local grid coordinates 10,000 to 85,000 North and 0 to 100,000 East.

The primary function of GWMPD is to record and report hydrogeologic parameters within the context of their spatial position and hydrostratigaphic assignment. The database is designed to accommodate geologic, geotechnical, geophysical, and stratigraphic data from any type of sampling location (site type). Current site types include soil borings, wells, and cone-penetrometer test (CPT) sites. Hydrogeologic data fall within three main categories: 1) field data collected during drilling and sampling; 2) Field analyses of borehole and aquifer permeability; and 3) laboratory analyses of core and undisturbed samples. The GWMPD also records "subjective" data such as stratigraphic analyses ("picks" for unit boundaries) in addition to the "objective" measurements described above.

The database is compiled in Paradox ${ }^{\circledR}$ software and incorporates a relational structure which defines unique data locations (sites) by their coordinates and elevations. The sites are used as the key field by which different types of data are related. The unique site identifiers allow multiple data types to be associated with a single data site. The database is constructed so that revisions made to the "subjective" data (hydrostratigraphic "picks") are documented. The database records and dates each revision to the picked boundaries, and automatically regenerates updated output files for re-loading into EarthVision ${ }^{\circledR}$. This aspect of the database 
facilitates data evaluation and revision. and provides a means by which to maintain a history of the "subjective" data set.

The GWMPD maintains a bibliographic record of all documents reviewed and summarized for data which are incorporated into the database. The database also records whether the documents serve as original sources for the data they contain. or summarize data extracted from previous reports. For example. a report that lists permeability values for undisturbed samples and includes copies of the laboratory reports in an appendix would be considered a "source" document. Similarly, a report that tabulates slug test results from several wells as average hydraulic conductivity values, and does not provide the test parameters or details of the individual analyses would be considered a "summary" document for those slug test results.

\section{Data Qualification}

Boundaries or "picks" for hydrostratigraphic units beneath the CKLP GWMA were established by the same method used in WSRC-RP-96-0399 for the General Separations Area (Smits and others, 1997). Because the CKLP GWMA includes the GSA modeling area. the picks were used to correlate hydrostratigraphic boundaries from within the GSA to cores in the remainder of the model area. The GWMPD uses the hydrostratigraphic nomenclature described in Aadland and others (1995). A rigorous Quality Review of the data was performed, comparing the core descriptions and geophysical logs with the list of unit boundaries. Geologists made refinements to these boundaries to ensure internal consistency between the unit boundaries and the lithology of the hydrostratigraphic units.

Hydrostratigraphic horizons include tops of the "tan clay" confining zone (TCCZ), "lower" aquifer zone (LAZ), Gordon confining unit (GCU), Gordon aquifer (GAU), and the Meyers Branch Confining System (MBCS).

\section{Hydrogeologic Model}

\section{Hydrostratigraphic Methods}

Hydrostratigraphic unit boundaries for the CKLP GWMA are based on the recent hydrostratigraphic anaysis of the GSA (Smits and others, 1997). Because the CKLP GWMA includes the GSA modeling area the hydrostratigraphic picks were used to correlate the hydrostratigraphic boundaries on the cores in the remainder of the model area. Boundaries are determined through evaluation of: 
Geophysical data. Gamma-ray logs in combination with resistivity logs are used to evaluate the potential confining properties of the strata. In general. low resistivity and high gamma-ray values indicate clay-rich sediment that impedes the flow of ground water.

Core description data. Core descriptions are used (in conjunction with the geophysical logs) to select boundaries between confining and transmissive units. Percentage of mud and estimated porosity are the primary criteria used. If core recovery is good. the foot-by-foot description is an excellent tool for determining the vertical extent of a confining or transmissive lithology.

The database was used to prepare a hydrogeologic model of the CKLP GWMA. The model was constructed with EarthVision ${ }^{\circledR}$ software. EarthVision ${ }^{\circledR}$ processes sets of spatial and property data by calculating minimum-tension grids to contour a "best fit" of the data. The grids can contour data in 3 dimensions $(x, y, z)$, such as the top of a geologic unit. as twodimensional grids, or contour data in 4-dimensions: $x, y, z$, and a "property." An example of a property might be the variation of the percentage of mud within a geologic unit. Only 3 dimension hydrogeologic modeling was performed for this study.

\section{Two-Dimensional Grid Calculation}

Data for hydrostratigraphic unit tops were exported from the Paradox ${ }^{\circledR}$ database into EarthVision $^{\circledR}$. After minor format changes, the data was processed by an algorithm, producing a two-dimensional grid of the unit top surface. The two-dimensional grids were calculated so as to incorporate effects of the Pen Branch Fault. The off-set is assumed to be a consistent, vertical displacement along the trace of the fault. The south side of the fault is displaced up relative to the north side.

The EarthVision ${ }^{\circledR}$ model utilizes digitized $x, y, z$ data for all U.S. Geological Survey topographic coverage of the GSA. The data was processed in the same manner as the data for the unit boundaries to produce a grid representing the topography of the study area. The high density of data points in this data set produced a two-dimensional grid of exceptional accuracy and detail. This grid was then used in subsequent grid calculation to determine the extent of the hydrostratigraphic units that crop out in the study area.

\section{Geologic Structure Builder}

\section{Altitude-Contour Maps}


Altitude-contour maps were constructed for each hydrostratigraphic unit and zone discussed in Section XXX using the two-dimensional grids calculated from the scattered data for the unit tops. The maps are plotted using the Contour and Basemap module of EarthVision ${ }^{\text {E }}$. Contour intervals are chosen by individual data sets so as to convey the information clearly and concisely, but virtually any level of detail is possible. An effort was made to keep the contour interval to within one-tenth of the range of the z-values. This serves to minimize the number of contour lines, yet generally maintains a level of detail suitable for interpretation of the map.

\section{Isopach Maps}

Two-dimensional grids of unit thickness (isopach grids) were calculated by first comparing the two-dimensional grids of the unit base and unit top with the two-dimensional grid of the topography. Isopach maps of vertical unit thickness were calculated from comparison of the two-dimensional grids of the unit base and unit top. A value was then written to the corresponding nodes of the resultant grid (the isopach grid) equal to the vertical distance between the base and upper surface of the unit.

The resultant two-dimensional isopach grids were contoured using EarthVision ${ }^{\circledR}$ in the same fashion as the structure-contour maps.

\section{REFERENCES}

Aadland, R. K., J. A. Gellici, and P. A. Thayer, 1995. Hydrogeologic Framework of WestCentral South Carolina, State of South Carolina Department of Natural Resources, Water Resources Division Report 5.

Flach, G. P., and M. K. Harris, 1997. Integrated Hydrogeological Model of the General Separations Area, Volume 2: Groundwater Flow Model (U), WSRC-TR-96-0399, Rev. 0, Westinghouse Savannah River Company, Savannah River Site, Aiken, SC. 29808.

Smits, A. D., M. K. Harris, K. L. Hawkins, and G. P. Flach. 1997. Integrated Hydrogeological Model of the General Separations Area, Volume 1: Hydrogeologic Framework (U), WSRC-TR-96-0399, Rev. 0, Westinghouse Savannah River Company. Savannah River Site, Aiken, SC, 29808. 
Appendix B-1: Locations of Sites within the Model Area

\begin{tabular}{|c|c|c|c|c|}
\hline Well ID & $\begin{array}{c}\text { SRS } \\
\text { Northing } \\
(\mathrm{ft})\end{array}$ & $\begin{array}{c}\text { SRS } \\
\text { Easting } \\
(\mathrm{ft})\end{array}$ & $\begin{array}{c}\text { Surface } \\
\text { Elevation } \\
(\mathrm{ft} \text { m.s.l. })\end{array}$ & Reference $^{\mathbf{l}}$ \\
\hline
\end{tabular}

\begin{tabular}{|c|c|c|c|c|}
\hline BGO-1D & 73737.9 & 58779.3 & 293 & WSRC. 1996d \\
\hline BGO-3A & 75561.7 & 58806.8 & 288.7 & WSRC. 1996d \\
\hline BGO-3D & 75351.3 & 58809.2 & 290.8 & WSRC. 1996d \\
\hline BGO-5C & 76476.9 & 58794.5 & 294.2 & WSRC. 1996d \\
\hline$\overline{B G O-6 A}$ & 76487.2 & 58316.8 & 283.8 & WSRC. 1996d \\
\hline BGO-6B & 76553.24 & 58346.46 & 284.5 & WSRC. 1996d \\
\hline BGO-8A & 76569 & 57618.3 & 281.3 & WSRC. 1996d \\
\hline BGO-9AA & 76975.69 & 57371.94 & 282.8 & WSRC. 1996d \\
\hline BGO-10A & 76805.18 & 57050.92 & 299.1 & WSRC. 1996d \\
\hline BGO-10AA & 76997.88 & 56990.54 & 298.8 & WSRC. 1996d \\
\hline $\mathrm{BGO}-12 \mathrm{~A}$ & 76804.63 & 56250.68 & 311.4 & WSRC. 1996d \\
\hline BGO-14A & 76377.54 & 55838.32 & 300.2 & WSRC. 1996d \\
\hline BGO-16A & 75756.95 & 56194.15 & 302.8 & WSRC. 1996d \\
\hline BGO-18A & 75599.89 & 56699.67 & 292.9 & WSRC. 1996d \\
\hline BGO-20AA & 74953.76 & 57114.81 & 280.88 & Rust. 1996 \\
\hline BGO-21D & 74688.53 & 57470.66 & .283 & WSRC. 1996d \\
\hline BGO-23D & 74238.09 & 58132.96 & 287 & WSRC. 1996d \\
\hline BGO-25A & 76158.5 & 55668.08 & 294.7 & \begin{tabular}{|l|} 
WSRC. 1996d \\
\end{tabular} \\
\hline $\mathrm{BGO}-26 \mathrm{~A}$ & 76144.6 & 55014.2 & 285.1 & WSRC. $1996 \mathrm{~d}$ \\
\hline BGO-27C & 75666.3 & 54671.4 & 273.9 & WSRC. 1996d \\
\hline BGO-29A & 75560 & 54103.5 & 262.1 & WSRC. 1996d \\
\hline BGO-31C & 74978 & 54816.2 & 271.1 & WSRC. 1996d \\
\hline BGO-33C & 74479.7 & 55681.4 & 277.4 & WSRC. 1996d \\
\hline BGO-35C & 73953.9 & 56545.7 & 271.4 & WSRC. 1996d \\
\hline BGO-37C & 73498.2 & 57279.2 & 284.3 & WSRC, 1996d \\
\hline BGO-39A & 73572.52 & 57821.93 & 293.7 & WSRC. 1996d \\
\hline BGO-41A & 76469.52 & 55403.69 & 298.3 & WSRC. 1996d \\
\hline $\mathrm{BGO}-42 \mathrm{C}$ & 76404.71 & 55522.27 & 295.9 & WSRC. 1996d \\
\hline BGO-43AA & 77066.01 & 56268.64 & 312.2 & WSRC. 1996d \\
\hline BGO-44AA & 76757.02 & 57880.51 & 283.3 & WSRC. 1996d \\
\hline BGO-45A & 75830.03 & 54550.14 & 276.9 & WSRC. 1996d \\
\hline BGO-46B & 75012.1 & 54444.65 & 263.4 & WSRC, 1996d \\
\hline BGO-47A & 74728.83 & 54914.04 & 264.8 & WSRC, 1996d \\
\hline BGO-48C & 74599.64 & 55124.38 & 274.7 & WSRC. 1996d \\
\hline BGO-49A & 73902.78 & 56205.08 & 269.1 & WSRC. 1996d \\
\hline BGO-50A & 75201.16 & 54179.77 & 253.5 & WSRC. 1996d \\
\hline BGO-51AA & 74113.1 & 57867 & 287.2 & WSRC. 1996d \\
\hline BGO-52AA & 74638 & 57178.1 & 281.6 & WSRC. 1996d \\
\hline BGO-53AA & 76065 & 55431.5 & 288.9 & WSRC. 1996d \\
\hline BGT-1 & 76700.6 & 59178.4 & 282.9 & WSRC, unknown \\
\hline BGT-2 & 76957.6 & 59607.2 & 276.4 & WSRC. unknown \\
\hline BGT-3 & 77197.6 & 60045.9 & 275.7 & Rust. 1996 \\
\hline BGT-4 & 77437.6 & 60484.5 & 259.2 & WSRC. unknown \\
\hline
\end{tabular}


$\underline{B-2}$

WSRC-TR-98-00285. Rev. 0. Hydrogeological and Groundwater Model for C. K. L. and P Areas

Appendix B-1: Locations of Sites within the Model Area (Continued)

\begin{tabular}{|c|c|c|c|c|}
\hline Well ID & $\begin{array}{c}\text { SRS } \\
\text { Northing } \\
(\mathrm{ft})\end{array}$ & $\begin{array}{c}\text { SRS } \\
\text { Easting } \\
(\mathrm{ft})\end{array}$ & $\begin{array}{c}\text { Surface } \\
\text { Elevation } \\
(\mathrm{ft} \text { m.s.l. })\end{array}$ & Reference $^{\text {l }}$ \\
\hline
\end{tabular}

\begin{tabular}{|c|c|c|c|c|}
\hline BGT-5 & 77677.6 & 60924.1 & 225.7 & Rust. 1996 \\
\hline$\overline{\text { BGT-6 }}$ & 77254.8 & 58746.7 & 282.2 & WSRC. unknown \\
\hline BGT-7 & 77717.8 & 58935.7 & 276.4 & WSRC. unknown \\
\hline BGT-8 & 78161.5 & 59118.6 & 249.3 & WSRC. unknown \\
\hline BGT-9 & 78642.3 & 59316.7 & 226 & Rust. 1996 \\
\hline BGT-10 & 79104.6 & 59507.2 & 215.2 & WSRC. unknown \\
\hline BGT-11 & 79566.9 & 59697.7 & 222.5 & Rust. 1996 \\
\hline BGT-12 & 77291.2 & 58045.9 & 284.2 & WSRC. unknown \\
\hline BGT-13 & 77488.9 & 58074 & 287.8 & WSRC, unknown \\
\hline BGT-14 & 77984 & 58143.4 & 280.7 & WSRC. unknown \\
\hline BGT-15 & 78479.2 & 58212.8 & 277.5 & WSRC. unknown \\
\hline BGT-16 & 78974.1 & 58283.5 & 250.7 & WSRC. unknown \\
\hline BGT-17 & 79469.7 & 58350 & 240.7 & WSRC. unknown \\
\hline BGT-18 & 79965.3 & 58416.5 & 216.5 & Rust. 1996 \\
\hline BGT-20 & 80956.4 & 58549.6 & 159.5 & Rust. 1996 \\
\hline BGT-21 & 77280.7 & 56952.5 & 294.2 & WSRC. unknown \\
\hline BGT-22 & 77860.3 & 56970.3 & 281 & Rust. 1996 \\
\hline BGT-23 & 78279.7 & 56997 & 270 & WSRC. unknown \\
\hline BGT-24 & 78779.2 & 57019.2 & 265.8 & WSRC. unknown \\
\hline BGT-25 & 79278.7 & 57041.4 & 264.8 & WSRC. unknown \\
\hline BGT-26 & 79778.2 & 57063.7 & 250.2 & WSRC. unknown \\
\hline BGT-27 & 80277.7 & 57085.9 & 256.9 & WSRC. unknown \\
\hline BGT-28 & 80777.2 & 57108.1 & 258.3 & Rust. 1996 \\
\hline BGT-29 & 81276.7 & 57130.4 & 243 & WSRC, unknown \\
\hline BGT-30 & 81726.3 & 57150.4 & 219 & WSRC. unknown \\
\hline BGT-31 & 77229 & 56189.8 & 308.76 & WSRC. unknown \\
\hline BGT-32 & 77791.4 & 56121.1 & 310.12 & WSRC, unknown \\
\hline BGT-33 & 78404.5 & 56037.2 & 290.42 & WSRC. unknown \\
\hline BGT-34 & 78803.9 & 56027.5 & 286.76 & WSRC. unknown \\
\hline BGT-35 & 79305.8 & 55929.9 & 267.73 & WSRC. unknown \\
\hline BGT-36 & 79801.9 & 55867.5 & 261.36 & WSRC. unknown \\
\hline BGT-37 & 80298 & 55805 & 251.6 & WSRC, unknown \\
\hline BGT-38 & 80870.5 & 55733 & 240.14 & WSRC. unknown \\
\hline BGT-39 & 81290.2 & 55680.3 & 241.88 & WSRC. unknown \\
\hline BGT-40 & 77297.2 & 55644.4 & 332.32 & WSRC. unknown \\
\hline BGT-41 & 77734.8 & 55490.1 & 328.37 & WSRC. unknown \\
\hline BGT-42 & 78240.7 & 55313.1 & 310.92 & WSRC. unknown \\
\hline BGT-43 & 79655.9 & 54816 & 277.08 & WSRC. unknown \\
\hline BGT-44 & 80127.7 & 54650.4 & 276.2 & WSRC. unknown \\
\hline BGT-45 & 80461.7 & 54533.1 & 285.28 & WSRC. unknown \\
\hline BGT-46 & 76714.3 & 55355 & 310 & WSRC. unknown \\
\hline BGT-47 & 77051.85 & 54986.57 & 317.32 & Rust, 1996 \\
\hline BGT-48 & 77135.7 & 54895.1 & 314.33 & WSRC. unknown \\
\hline
\end{tabular}


Appendix B-1: Locations of Sites within the Model Area (Continued)

\begin{tabular}{|c|c|c|c|c|}
\hline Well ID & $\begin{array}{c}\text { SRS } \\
\text { Northing } \\
(\mathrm{ft})\end{array}$ & $\begin{array}{c}\text { SRS } \\
\text { Easting } \\
(\mathrm{ft})\end{array}$ & $\begin{array}{c}\text { Surface } \\
\text { Elevation } \\
(\mathrm{ft} \text { m.s.l. })\end{array}$ & Reference $^{1}$ \\
\hline
\end{tabular}

\begin{tabular}{|c|c|c|c|c|}
\hline BGT-49 & 76203.9 & 54946.3 & 297.26 & WSRC. unknown \\
\hline BGT-50 & 76359.3 & 54756.2 & $296.27 \mid$ & WSRC. unknown \\
\hline BGT-51 & 75519.8 & 54505.7 & 272.64 & WSRC. unknown \\
\hline BGT-53 & 75837.68 & 53422.04 & 278.25 & Rust. 1996 \\
\hline BGT-54 & 75941.7 & 52889.1 & 279.96 & WSRC. unknown \\
\hline$\overline{\text { BGT-56 }}$ & 73521.2 & 56265.8 & 262.94 & WSRC. unknown \\
\hline BGT-57 & 73268.5 & 56104.2 & 259.35 & WSRC. unknown \\
\hline BGT-58 & 73406.9 & 57399.6 & 285.76 & WSRC. unknown \\
\hline BGT-59 & 72802.6 & 57123.2 & 281.88 & WSRC. unknown \\
\hline BGT-60 & 73120.6 & 58057.2 & 291.42 & WSRC. unknown \\
\hline BGT-61 & 72911.77 & 58490.09 & 284.3 & Rust. 1996 \\
\hline BGT-62 & 72854.4 & 58608 & 282.03 & WSRC, unknown \\
\hline BGT-63 & 73319.4 & 59146.3 & 293.67 & WSRC. unknown \\
\hline BGT-63A & 73646.4 & 58768.1 & 290.79 & WSRC. unknown \\
\hline BGT-64 & 73013.7 & 59500 & 283.25 & WSRC. unknown \\
\hline BGT-66 & 74476.6 & 60033.7 & 244.04 & WSRC. unknown \\
\hline BGT-67 & 74443.06 & 60426.74 & 242.03 & Rust. 1996 \\
\hline BGX-1A & 76831.89 & 58590.35 & 289.1 & WSRC. 1996d \\
\hline BGX-2B & 77203.4 & 58256.5 & 289.2 & WSRC. 1996d \\
\hline BGX-4A & 77879.2 & 57215.6 & 288.8 & WSRC. 1996d \\
\hline BGX-7D & 78349.3 & 58312.8 & 277.1 & WSRC. 1996d \\
\hline BGX-9D & 76936 & 59522.1 & 277.4 & WSRC. 1996d \\
\hline BGX-11D & 75300.7 & 59581.4 & 273.8 & WSRC. 1996d \\
\hline BRR-1D & 77365.2 & 50588.2 & 293.8 & WSRC. 1996d \\
\hline BRR-3D & 77398.3 & 50203.5 & 289.5 & WSRC. 1996d \\
\hline BRR-6B & 77054.6 & 51100 & 293.9 & WSRC. 1996d \\
\hline BRR-7B & 77575.4 & 50707.5 & 289.6 & WSRC. 1996d \\
\hline BRR-8B & 77634.7 & 50116.5 & 276.7 & WSRC. 1996d \\
\hline CCP-1A & 66659.2 & 46981.3 & 287.1 & WSRC, 1996d \\
\hline CFD-1 & 55486.64 & 54875.37 & 268.8 & WSRC. 1994 \\
\hline CFD-5 & 55769.51 & 54803.57 & 257.8 & WSRC, 1994 \\
\hline CFD-18 & 56297.09 & 54935.66 & 248.3 & WSRC. 1994 \\
\hline CMP-30B & 51729.8 & 53166.9 & 286.5 & WSRC. 1996d \\
\hline CMP-32B & 52220 & 54052.8 & 251.7 & WSRC. 1996d \\
\hline CPC-1 & 66855.77 & 47183.78 & 285.1 & WSRC. 1996d \\
\hline CRP-5DR & 68549.1 & 44515 & 274.6 & WSRC. 1996d \\
\hline CRP-9D & 69156.7 & 44243.2 & 268.4 & WSRC. 1996d \\
\hline CSD-4D & 63143.8 & 50058.9 & 306.5 & WSRC. 1996d \\
\hline FAC-1SB & 78138 & 55243 & 312.2 & WSRC. 1992b \\
\hline $\mathrm{FCH}-1$ & 79488.82 & 52843.11 & 316.8 & WSRC. 1993 \\
\hline FCH-2 & 78500 & 52599.59 & 288.7 & WSRC. 1993 \\
\hline FCH-3 & 78059.22 & 52087.22 & 307.2 & WSRC, 1993 \\
\hline FCH-4 & 77514.56 & 52021.03 & 297.5 & WSRC. 1993 \\
\hline
\end{tabular}


Appendix B-1: Locations of Sites within the Model Area (Continued)

\begin{tabular}{|c|c|c|c|c|}
\hline Well ID & $\begin{array}{c}\text { SRS } \\
\text { Northing } \\
(\mathrm{ft})\end{array}$ & $\begin{array}{c}\text { SRS } \\
\text { Easting } \\
(\mathrm{ft})\end{array}$ & $\begin{array}{c}\text { Surface } \\
\text { Elevation } \\
(\mathrm{ft} \text { m.s.l. })\end{array}$ & Reference $^{\mathbf{1}}$ \\
\hline
\end{tabular}

\begin{tabular}{|c|c|c|c|c|}
\hline FCH-5 & 76992.12 & 51667.65 & 284.2 & WSRC. 1993 \\
\hline $\mathrm{FCH}-6$ & 76410.33 & 51245.7 & 291.5 & WSRC. 1993 \\
\hline FIW-1MC & 76165.3 & 51354.4 & 293.3 & WSRC. 1996d \\
\hline FIW-2MA & 75930.8 & 51184.5 & 290.5 & WSRC. 1996d \\
\hline FNB-1A & 80154.5 & 54288.8 & 282.4 & WSRC. 1996d \\
\hline FNB-3A & 80557.2 & 54116.6 & 282.2 & WSRC. 1996d \\
\hline FSB-1TA & 75649.1 & 51658.3 & 275.4 & WSRC. 1996d \\
\hline FSB-PC & 74090.2 & 50140 & 230.8 & WSRC. 1996d \\
\hline FSB-PD & 74549.2 & 49849.81 & 252.6 & WSRC. 1996d \\
\hline FSB-76A & 76131.9 & 51391.6 & 291.5 & WSRC. 1996d \\
\hline FSB-78A & 74757.7 & 50172.8 & 270.5 & WSRC. 1996d \\
\hline FSB-79A & 73664.5 & 50149.6 & 216.1 & WSRC. 1996d \\
\hline$\overline{F S B}-87 \mathrm{~A}$ & 75601.7 & 50115.8 & 285.6 & WSRC. 1996d \\
\hline FSB-89C & 75553.2 & 51345.2 & 279.1 & WSRC. 1996d \\
\hline FSB-91C & 75213.3 & 50953.5 & 277 & WSRC. 1996d \\
\hline FSB-93C & 74897.3 & 50458.3 & 274 & WSRC. $1996 \mathrm{~d}$ \\
\hline FSB-95C & 74971.7 & 50016.7 & 281.8 & WSRC, 1996d \\
\hline FSB-96A & 74882.2 & 49778.7 & 277.7 & WSRC. 1996d \\
\hline FSB-97A & 75171.2 & 49965.7 & 283.8 & WSRC. 1996d \\
\hline FSB-98A & 75389.8 & 50121.6 & 280.7 & WSRC. 1996d \\
\hline FSB-99A & 75675.6 & 50314.8 & 285.3 & WSRC. 1996d \\
\hline FSB-100A & 75534.4 & 50958.4 & 283.8 & WSRC. 1996d \\
\hline FSB-101A & 75719 & 51191.3 & 282.9 & WSRC. 1996d \\
\hline FSB- $112 \mathrm{~A}$ & 74231.4 & 48809.1 & 227 & WSRC. 1996d \\
\hline FSB-113A & 74167.5 & 51068.1 & 221.3 & WSRC, 1996d \\
\hline FSB-114A & 75297.4 & 52046.6 & 250 & WSRC. 1996d \\
\hline FSB-115C & 72515.5 & 49736 & 205.8 & WSRC. 1996d \\
\hline FSB-116C & 72725.5 & 50645.9 & 200.5 & WSRC. 1996d \\
\hline FSB-120A & 75538.9 & 49175.7 & 278 & WSRC. 1996d \\
\hline FSB-121C & 75155.7 & 48413.1 & 254.4 & WSRC. 1996d \\
\hline FSB-122C & 73881.8 & 48195 & 216 & WSRC. 1996d \\
\hline FSB-123C & 74566.7 & 51750.5 & 236.3 & WSRC, 1996d \\
\hline GAPWR-TW-1 & 51036.5 & 1544.1 & 219 & Falls. 1998 \\
\hline HAA-1TA & 69892.2 & 62953.3 & 290.2 & WSRC. 1996d \\
\hline HAA-2AA & 70925.4 & 61285.1 & 291.4 & WSRC. 1996d \\
\hline HAA-3AA & 71488 & 60201.9 & 274.5 & WSRC. $1996 \mathrm{~d}$ \\
\hline HAA-4AA & 72223.2 & 61929.6 & 299.2 & WSRC. 1996d \\
\hline HAA-6AA & 71441 & 63860.2 & 279.8 & WSRC. 1996d \\
\hline $\mathrm{HC}-12 \mathrm{~A}$ & 73187 & 59504 & 287.3 & WSRC. 1996d \\
\hline HCA-4AA & 72513.7 & 62942.5 & 308.6 & WSRC. $1996 \mathrm{~d}$ \\
\hline $\mathrm{HCH}-1$ & 72796.38 & 60923.42 & 284 & WSRC. 1993 \\
\hline $\mathrm{HCH}-2$ & 72519.61 & 60091.79 & 270.9 & WSRC. 1993 \\
\hline $\mathrm{HCH}-3$ & 71998.82 & 59917.33 & 264 & WSRC. 1993 \\
\hline
\end{tabular}


Appendix B-1: Locations of Sites within the Model Area (Continued)

\begin{tabular}{|c|c|c|c|c|}
\hline Well ID & $\begin{array}{c}\text { SRS } \\
\text { Northing } \\
(\mathrm{ft})\end{array}$ & $\begin{array}{c}\text { SRS } \\
\text { Easting } \\
(\mathrm{ft})\end{array}$ & $\begin{array}{c}\text { Surface } \\
\text { Elevation } \\
(\mathrm{ft} \text { m.s.l. })\end{array}$ & Reference $^{\mathbf{1}}$ \\
\hline
\end{tabular}

\begin{tabular}{|c|c|c|c|c|}
\hline $\mathrm{HCH}-4$ & 72449.59 & 59139.93 & 269.9 & WSRC. 1993 \\
\hline $\mathrm{HCH}-5$ & 71810.36 & 59331.53 & 255 & WSRC. 1996d \\
\hline HIW-1BD & 72564.6 & 58342.2 & 275.8 & WSRC. 1996d \\
\hline HIW-1MC & 72500 & 58471.8 & 272.3 & WSRC. 1996d \\
\hline HIW-2A & 73249.7 & 56753 & 276.3 & WSRC. 1996d \\
\hline HIW-2MC & 73226.4 & 56698.4 & 269 & WSRC. 1996d \\
\hline HIW-4MC & 73160.1 & 56570.1 & 263.4 & WSRC. 1996d \\
\hline HIW-5MC & 73557.9 & 56498.9 & 266.1 & WSRC. 1996d \\
\hline HMD-1C & 78731.7 & 56973.3 & 262.7 & WSRC. 1996d \\
\hline HMD-2C & 79665.8 & 57269.7 & 259.3 & WSRC. 1996d \\
\hline HMD-3C & 79578.7 & 57745.2 & 257.2 & WSRC. 1996d \\
\hline HMD-4C & 79160.4 & 58188.5 & 248.5 & WSRC. 1996d \\
\hline HPC-1 & 70395.4 & 62493.6 & 293.5 & WSRC, 1996d \\
\hline HPT-1A & 74847.1 & 60587 & 232.9 & WSRC. 1996d \\
\hline HPT-2A & 75061.8 & 60200.5 & 257.8 & WSRC. 1996d \\
\hline HSB-PC & 72119.31 & 55650.03 & 227.8 & WSRC. 1996d \\
\hline HSB-TB & 72394 & 58696.1 & 267.1 & WSRC. 1996d \\
\hline HSB-65A & 72436.2 & 58436 & 270.7 & WSRC. 1996d \\
\hline HSB-68A & 71526.9 & 56892.1 & 247.4 & WSRC, 1996d \\
\hline HSB-69A & 71549.4 & 56465.1 & 234.1 & WSRC. 1996d \\
\hline HSB-83A & 71648.6 & 58606.1 & 234.9 & WSRC. 1996d \\
\hline HSB-84A & 71586.2 & 56359.1 & 226.7 & WSRC. $1996 \mathrm{~d}$ \\
\hline HSB-85A & 73791.9 & 58943.4 & 292.1 & WSRC. 1996d \\
\hline HSB-86A & 72520.2 & 55985.9 & 260 & WSRC. 1996d \\
\hline HSB-101C & 72001.9 & 58604.4 & 256.3 & WSRC. 1996d \\
\hline HSB-103C & 71593.9 & 58323.6 & 245.2 & WSRC. 1996d \\
\hline HSB-104C & 71376.8 & 58082.6 & 245.5 & WSRC. 1996d \\
\hline HSB-105C & 71447.3 & 57883.8 & 247.2 & WSRC, 1996d \\
\hline HSB-106C & 71720.9 & 57651.5 & 250.7 & WSRC. 1996d \\
\hline HSB-107C & 71698.5 & 57432 & 259.3 & WSRC, 1996d \\
\hline HSB-109C & 71684.8 & 56895.6 & 259.4 & WSRC. 1996d \\
\hline HSB-110C & 71779.3 & 56680.7 & 253.4 & WSRC. 1996d \\
\hline HSB-111C & 71919.4 & 56501.9 & 253.7 & WSRC. 1996d \\
\hline HSB-112C & 72156.4 & 56417.4 & 252.6 & WSRC. 1996d \\
\hline HSB-113C & 72312.3 & 56160.4 & 258.7 & WSRC, 1996d \\
\hline HSB-115C & 72653.2 & 56043.2 & 266.8 & WSRC. 1996d \\
\hline HSB-117A & 72733.6 & 55170.1 & 234.8 & WSRC. 1996d \\
\hline HSB-118A & 72696.4 & 55775.6 & 245 & WSRC. 1996d \\
\hline HSB-119A & 73082.5 & 56100.2 & 254.8 & WSRC. 1996d \\
\hline HSB-120A & 73395.1 & 56431.9 & 266 & WSRC. 1996d \\
\hline $\mathrm{HSB}-121 \mathrm{~A}$ & 72024.8 & 57389.6 & 272.3 & WSRC. 1996d \\
\hline $\mathrm{HSB}-122 \mathrm{~A}$ & 72195.9 & 57747.4 & 269.4 & WSRC, 1996d \\
\hline $\mathrm{HSB}-123 \mathrm{~A}$ & 72189.8 & 58124.8 & 263.6 & WSRC. 1996d \\
\hline
\end{tabular}


Appendix B-1: Locations of Sites within the Model Area (Continued)

\begin{tabular}{|c|c|c|c|c|}
\hline & $\begin{array}{c}\text { SRS } \\
\text { Worthing } \\
(\mathrm{ft})\end{array}$ & $\begin{array}{c}\text { SRS } \\
\text { Easting } \\
(\mathbf{f t})\end{array}$ & $\begin{array}{c}\text { Surface } \\
\text { Elevation } \\
(\mathbf{f t} \text { m.s.l. })\end{array}$ & Reference $^{1}$ \\
\hline
\end{tabular}

\begin{tabular}{|c|c|c|c|c|}
\hline HSB-124A & 72199.6 & 58514.6 & 263.9 & WSRC. 1996d \\
\hline HSB-132C & 71472.4 & 58787.7 & 238.3 & WSRC. 1996d \\
\hline HSB-139A & 71127.4 & 57365.4 & 231.5 & WSRC. 1996d \\
\hline HSB-140A & 70050.3 & 56535.4 & 234 & WSRC. 1996d \\
\hline HSB-141A & 71213.6 & 59168.7 & 252.6 & WSRC. 1996d \\
\hline HSB-142C & 73119 & 53505.3 & 201.6 & WSRC. 1996d \\
\hline HSB-143C & 73738.2 & 52773.2 & 220.1 & WSRC. 1996d \\
\hline HSB-144A & 71892.1 & 56200.5 & 233.6 & WSRC. 1996d \\
\hline HSB-145C & 71098.9 & 57769 & 233.7 & WSRC, 1996d \\
\hline HSB-146A & 70478.9 & 58454 & 249.5 & WSRC. 1996d \\
\hline HSB-148C & 70151.5 & 55344.2 & 248.9 & WSRC. 1996d \\
\hline HSB-151C & 72997.9 & 54014.9 & 211.6 & WSRC. 1996d \\
\hline HSB-152C & 72012 & 54346.7 & 212.1 & WSRC. 1996d \\
\hline HSL-6AA & 72692.6 & 60555.7 & 274.6 & \begin{tabular}{|l|} 
WSRC. $1996 \mathrm{~d}$ \\
\end{tabular} \\
\hline \begin{tabular}{|l} 
HSL-8AA \\
\end{tabular} & 72729.4 & 61113.8 & 286.7 & WSRC, 1996d \\
\hline IDB-2A & 77284.4 & 75391.1 & 302.4 & Harris. 1997 \\
\hline IDP-3A & 85104.3 & 3778.11 & 282.2 & WSRC. 1996d \\
\hline IDQ-3A & 80553.7 & 35854 & 203.2 & WSRC, 1996d \\
\hline \begin{tabular}{|l|} 
KAC-9D \\
\end{tabular} & 53197.8 & 42588.1 & 260.2 & Harris, 1997 \\
\hline LAC-5DL & 45365.4 & 51352 & 239.8 & WSRC. 1996d \\
\hline LAC-6DL & 45272.8 & 51188.1 & 239.8 & WSRC, 1996d \\
\hline LAC-7DL & 45097.1 & 51118.4 & 239.4 & WSRC. 1996d \\
\hline LAC-8DL & 45096.6 & 51300.9 & 234 & WSRC. 1996d \\
\hline LCO-5A & 44987 & 50866 & 230 & WSRC, 1996d \\
\hline LCO-5DL & 44974.5 & 50887.5 & 230.3 & WSRC, 1996d \\
\hline LCO-8DL & 45586.1 & 51380.6 & 243.4 & WSRC, 1996d \\
\hline LFW-10SB & 83162.5 & 46137.5 & 168.4 & WSRC. 1991e \\
\hline LWN-1SB & 68131.9 & 33690.8 & 282.5 & WSRC, 1996d \\
\hline LWN-2SB & 66548.6 & 34739.1 & 231 & WSRC. 1996d \\
\hline LWN-3SB & 66900.2 & 32092.1 & 245.7 & WSRC. 1996d \\
\hline \begin{tabular}{|l} 
LWR-2SB \\
\end{tabular} & 71766 & 45998.8 & 248.1 & WSRC. 1996d \\
\hline LWR-3SB & 71243.3 & 47068.9 & 249.1 & WSRC. 1996d \\
\hline LWR-4SB & 70051.6 & 46749.6 & 293.8 & WSRC. 1996d \\
\hline LWR-9SB & 71658.83 & 45406.62 & 238.2 & WSRC. 1996d \\
\hline M121A & 62170.7 & 56819.9 & 303.7 & WSRC. 1996d \\
\hline MWD-1A & 69592.8 & 75121.9 & 327.5 & WSRC, 1996d \\
\hline NPN-1A & 66632.1 & 70856.2 & 335.9 & WSRC. 1996d \\
\hline OFS-1SB & 74967.5 & 54032.6 & 261.6 & Amidon. 1995 \\
\hline OFS-2SB & 74671 & 53848 & 257.5 & Amidon. 1995 \\
\hline OFS-3SB & 74270 & 54579 & 258.1 & Amidon. 1995 \\
\hline OFS-4SB & 73874 & 55188 & 258.7 & Amidon, 1995 \\
\hline OFS-5SB & 73623 & 54298 & 228.7 & Amidon, 1995 \\
\hline $\mathrm{P}-13 \mathrm{TA}$ & 35600 & 60000 & 252.4 & WSRC. 1996d \\
\hline
\end{tabular}


WSRC-TR-98-00285, Rev. 0, Hydrogeological and Groundwater Model for C. K. L. and P Areas

B-7

Appendix B-1: Locations of Sites within the Model Area (Continued)

\begin{tabular}{|c|c|c|c|c|}
\hline Well ID & $\begin{array}{c}\text { SRS } \\
\text { Northing } \\
(\mathrm{ft})\end{array}$ & $\begin{array}{c}\text { SRS } \\
\text { Easting } \\
(\mathrm{ft})\end{array}$ & $\begin{array}{c}\text { Surface } \\
\text { Elevation } \\
(\mathrm{ft} \text { m.s.l. })\end{array}$ & Reference $^{\mathrm{l}}$ \\
\hline
\end{tabular}

\begin{tabular}{|l|r|r|r|l|}
\hline P-14TA & 72444.9 & 76439.6 & 294.4 & WSRC. 1996d \\
\hline P-18TA & 67578.5 & 47652.7 & 296.9 & WSRC. 1996d \\
\hline P-19TA & 55295.9 & 60034.6 & 297.4 & WSRC. 1996d \\
\hline P-20TA & 56094.1 & 76768.1 & 287.7 & WSRC. 1996d \\
\hline P-21TA & 24674.6 & 40739.2 & 207 & WSRC. 1996d \\
\hline P-22TA & 20593.4 & 73555.3 & 215.4 & WSRC. 1996d \\
\hline P-23TA & 48063.3 & 30931.3 & 181.5 & WSRC. 1996d \\
\hline P-24TA & 43096.2 & 66565.2 & 313.3 & WSRC. 1996d \\
\hline P-25TA & 52493.6 & 42261 & 265.1 & WSRC. 1996d \\
\hline P-26TA & 71958.6 & 18051.5 & 152.2 & WSRC. 1996d \\
\hline P-27TA & 70382 & 64022.9 & 274.1 & WSRC. 1996d \\
\hline P-28TA & 79284.3 & 55441.1 & 285.6 & WSRC. 1996d \\
\hline PBF-3 & 58766.62 & 60380.36 & 316.65 & Harris. 1997 \\
\hline PBF-4 & 58148.66 & 29985.13 & 208.1 & Harris. 1997 \\
\hline PBF-5 & 53591.29 & 30319.43 & 240.6 & Harris. 1997 \\
\hline PBF-6 & 55621.75 & 12814.48 & 92.5 & Harris. 1997 \\
\hline PBF-7 & 55420.69 & 59568.97 & 285.42 & Harris. 1997 \\
\hline PBF-8 & 55744.48 & 59812.89 & 292.01 & Harris. 1997 \\
\hline PPC-1 & 42727.22 & 66137.83 & 313.3 & Harris. 1997 \\
\hline RCP-1A & 56968.1 & 74238.3 & 294.8 & WSRC. 1996d \\
\hline RSF-1 & 58505.3 & 74869.4 & 300.8 & WSRC. 1996d \\
\hline RSF-2 & 57670.4 & 74628.6 & 300.3 & WSRC. 1996d \\
\hline RSF-3 & 57621.4 & 75206.7 & 304.8 & WSRC. 1996d \\
\hline SDS-21 & 78951 & 67087 & 251 & WSRC. 1993b \\
\hline SDS-22 & 76887 & 66304 & 283 & WSRC. 1993b \\
\hline SSW-1 & 71223.25 & 33206.83 & 311.3 & WSRC. 1989 \\
\hline SSW-2 & 72230.42 & 28236.98 & 167.3 & WSRC. 1996d \\
\hline SSW-3 & 70517.63 & 40532.31 & 178.7 & WSRC. 1989 \\
\hline T18N1A & 57015.7 & 45553.2 & 258.4 & WSRC. 1996d \\
\hline T18S1A & 46111.5 & 43897.6 & 233.5 & WSRC. 1996d \\
\hline T18W1A & 48773.1 & 40275.2 & 244.4 & WSRC. 1996d \\
\hline USGS-MP & 98367.1 & -8045.7 & 245 & Falls. 1998 \\
\hline VG-1 & 11543.5 & 17064.2 & 156.6 & Bechtel. 1982 \\
\hline VG-7 & 28828.3 & 5392.8 & 250.6 & Bechtel. 1982 \\
\hline VG-8 & 78039.9 & 65438.93 & 268.9 & WSRC. 1996d \\
\hline YSC-1A & 78311.53 & 66100.08 & 281.7 & WSRC. 1996d \\
\hline YSC-1C & 6590 & 65883.5 & 287.5 & WSRC. 1996d \\
\hline YSC-2A & 67134.9 & WSRC. 1996d \\
\hline YSC-3SB & & & \\
\hline
\end{tabular}

Notes: 
B-8

WSRC-TR-98-00285, Rev. 0. Hydrogeological and Groundwater Model for C. K. L. and P Areas Appendix B-1: Locations of Sites within the Model Area (Continued)

\begin{tabular}{|c|c|c|c|c|}
\hline Well ID & $\begin{array}{c}\text { SRS } \\
\text { Northing } \\
(\mathrm{ft})\end{array}$ & $\begin{array}{c}\text { SRS } \\
\text { Easting } \\
(\mathrm{ft})\end{array}$ & $\begin{array}{c}\text { Surface } \\
\text { Elevation } \\
(\mathrm{ft} \text { m.s.l. })\end{array}$ & Reference $^{1}$ \\
\hline
\end{tabular}

$\mathrm{ft}$ - feet

ft m.s.l. - feet above mean sea level

1 - Detailed description of references in Appendix D 
WSRC-TR-98-00285, Rev. 0. Hydrogeological and Groundwater Model for C. K. L. and P Areas

B-9

\section{Appendix B-2: Hydrostratigraphic Boundaries}

\begin{tabular}{|c|c|c|c|c|c|c|c|c|c|c|c|}
\hline & & \multicolumn{2}{|c|}{ TCCZ } & \multicolumn{2}{|c|}{ LAZ } & \multicolumn{2}{|c|}{ GCU } & \multicolumn{2}{|c|}{$\mathrm{GAI}^{\prime}$} & \multicolumn{2}{|c|}{ MBCS } \\
\hline Well ID & $\begin{array}{l}\text { Surface } \\
\text { Elevation } \\
\text { (ft m.s.l.) }\end{array}$ & $\begin{array}{c}\text { Elev. (ft } \\
\text { m.s.l.) }\end{array}$ & $\begin{array}{c}\text { Depth (ft } \\
\text { b.g.l.) }\end{array}$ & $\begin{array}{l}\text { Eler. (ft } \\
\text { m.s.l.) }\end{array}$ & \begin{tabular}{|c|} 
Depth (ft \\
b.g.l.)
\end{tabular} & $\begin{array}{c}\text { Elev. (ft } \\
\text { m.s.l.) }\end{array}$ & $\begin{array}{c}\text { Depth (ft } \\
\text { b.g.l.) }\end{array}$ & $\begin{array}{l}\text { Eler. (ft } \\
\text { m.s.l.) }\end{array}$ & \begin{tabular}{|c|} 
Depth (ft \\
b.g.l.)
\end{tabular} & $\begin{array}{c}\text { Eler. (ft } \\
\text { m.s.l.) }\end{array}$ & $\begin{array}{c}\text { Depth (fit } \\
\text { b.g.l.) }\end{array}$ \\
\hline
\end{tabular}

\begin{tabular}{|c|c|c|c|c|c|c|c|c|c|c|c|}
\hline BGO-3A & 288.7 & 198 & 911 & 189 & 100 & 131 & 158 & 122 & 167 & +1 & 248 \\
\hline BGO-5C & 294.2 & 218 & 76 & 201 & 93 & & & & & & \\
\hline BGO-6A & 283.8 & 210 & 74 & 195 & 89 & 121 & 163 & 120 & 164 & & \\
\hline BGO-6B & 284.5 & 203 & 82 & 192 & 93 & 137 & 148 & 123 & 162 & & \\
\hline BGO-8A & 281.3 & 213 & 68 & 199 & 82 & 130 & 151 & 120 & 161 & & \\
\hline BGO-9AA & 282.8 & 224 & 59 & 211 & 72 & 135 & 148 & 125 & 158 & & \\
\hline $\mathrm{BGO}-10 \mathrm{~A}$ & 299.1 & 209 & 90 & 207 & 92 & 131 & 168 & 124 & 175 & & \\
\hline BGO-10AA & 298.8 & 219 & 80 & 207 & 92 & 130 & 169 & 126 & 173 & & \\
\hline$B G 0-12 A$ & 311.4 & 199 & 112 & 186 & 125 & 137 & 174 & 132 & 179 & & \\
\hline BGO-14A & 300.2 & 220 & 80 & 212 & 88 & 133 & 167 & 127 & 173 & & \\
\hline$B G O-16 A$ & 302.8 & 196 & 107 & 183 & 120 & 131 & 172 & 126 & 177 & & \\
\hline$B G O-18 \mathrm{~A}$ & 292.9 & 194 & 99 & 199 & 94 & 131 & 162 & 126 & 167 & & \\
\hline BGO-20AA & 280.9 & 206 & 75 & 194 & 87 & 125 & 156 & 114 & 167 & +3 & 238 \\
\hline BGO-25A & 294.7 & 212 & 83 & 201 & 94 & 138 & 157 & 128 & 167 & & \\
\hline BGO-26A & 285.1 & 219 & 66 & 205 & 80 & 133 & 152 & 129 & 1.56 & & \\
\hline BGO-27C & 273.9 & 199 & 75 & 192 & 82 & & & & & & \\
\hline BGO-29A & 262.1 & 196 & \begin{tabular}{ll|}
66 \\
\end{tabular} & 185 & 77 & 124 & 138 & 113 & 149 & & \\
\hline $\mathrm{BGO}-31 \mathrm{C}$ & 271.1 & 198 & 73 & 188 & 83 & & & & & & \\
\hline BGO-33C & 277.4 & 200 & 77 & 191 & 86 & & & & & & \\
\hline BGO-35C & 271.4 & 204 & 67 & 197 & 74 & & & & & & \\
\hline BGO-37C & 284.3 & 199 & 85 & 191 & 93 & & & & & & \\
\hline BGO-39A & 293.7 & 204 & 90 & 202 & 92 & 113 & 181 & 102 & 192 & 29 & 265 \\
\hline$B G O-+1 A$ & 298.3 & 217 & 81 & 208 & 90 & 138 & 160 & 131 & 167 & & \\
\hline BGO- $+2 \mathrm{C}$ & 295.9 & 216 & 80 & 209 & 87 & & & & & & \\
\hline $\mathrm{BGO}-43 \mathrm{AA}$ & 312.2 & 195 & 117 & 187 & 125 & 135 & 177 & 127 & 185 & & \\
\hline BGO-44AA & 283.3 & 222 & 61 & 199 & 84 & 131 & 152 & 120 & 163 & & \\
\hline BGO- $+5 \mathrm{~A}$ & 276.9 & 207 & 70 & 201 & 76 & 134 & $1+3$ & 130 & $1+7$ & & \\
\hline BGO-46B & 263.4 & 199 & $6+$ & 193 & 70 & 128 & 135 & 126 & 137 & & \\
\hline BGO- $+7 \mathrm{~A}$ & 264.8 & 198 & 67 & 190 & 75 & 131 & 134 & 125 & $1+0$ & & \\
\hline BGO-48C & $27+.7$ & 198 & 77 & 192 & 83 & & & & & & \\
\hline BGO- $+9 \mathrm{~A}$ & 269.1 & 201 & 68 & 192 & 77 & 119 & 150 & 115 & 154 & & \\
\hline BGO-50A & 253.5 & 194 & 60 & 184 & 70 & 133 & 121 & 129 & 125 & & \\
\hline BGO-5IAA & 287.2 & 205 & 82 & 194 & 93 & 107 & 180 & 93 & $19+$ & 32 & 255 \\
\hline BGO-52AA & 281.6 & 207 & 75 & 197 & 85 & 125 & 157 & 116 & 166 & 18 & 264 \\
\hline $\mathrm{BGO}-53 \mathrm{AA}$ & 288.9 & 223 & 66 & 216 & 73 & 138 & 151 & 132 & 157 & 29 & 260 \\
\hline BGT-1 & 282.9 & 222 & 61 & 208 & 75 & & & & & & \\
\hline BGT-2 & 276.4 & 213 & 63 & 198 & 78 & & & & & & \\
\hline BGT-3 & 275.7 & 212 & 64 & 198 & 78 & $1+3$ & 133 & $1+1$ & 135 & 6.5 & 211 \\
\hline BGT-4 & 259.2 & 213 & 46 & 204 & 55 & 149 & 110 & & & & \\
\hline BGT-5 & 225.7 & 214 & 12 & 206 & 20 & 154 & 72 & 146 & 80 & 72 & 154 \\
\hline BGT-6 & 282.2 & 218 & 64 & & & & & & & & \\
\hline BGT-7 & 276.4 & 212 & 64 & 199 & 77 & & & & & & \\
\hline BGT-8 & 249.3 & 221 & 28 & 217 & 32 & 149 & 100 & & & & \\
\hline BGT-9 & 226.0 & 210 & 16 & 205 & 21 & 149 & 77 & $1+1$ & 85 & $6+$ & 162 \\
\hline BGT-10 & 215.2 & 201 & 14 & 194 & 21 & 156 & 59 & 147 & 68 & & \\
\hline BGT-II & 222.5 & ND & ND & 223 & 0 & 151 & 72 & 146 & 77 & 68 & 155 \\
\hline BGT-12 & 284.2 & 225 & 59 & 214 & 70 & & & & & & \\
\hline BGT-13 & 287.8 & 224 & $6+1$ & 216 & 72 & & & & & & \\
\hline BGT-1t & 280.7 & 215 & 66 & 209 & 72 & & & & & & \\
\hline \begin{tabular}{|l} 
BGT-15 \\
\end{tabular} & 277.5 & 209 & 69 & 201 & 77 & 150 & 128 & & & & \\
\hline BGT-16 & 250.7 & & & & & 151 & 100 & & & & \\
\hline
\end{tabular}


Appendix B-2: Hydrostratigraphic Boundaries (Continued)

\begin{tabular}{|c|c||c|c|c|c|c|c|c|c|c|c|}
\hline & \multicolumn{2}{|c|}{} & \multicolumn{2}{|c|}{ TCCZ } & \multicolumn{2}{|c|}{ LAZ } & \multicolumn{2}{|c|}{ GCU } & \multicolumn{2}{|c|}{ GAU } & \multicolumn{2}{c|}{ MBCS } \\
\hline Well ID & $\begin{array}{c}\text { Surface } \\
\text { Elevation } \\
\text { (ft m.s.l.) }\end{array}$ & $\begin{array}{c}\text { Elev. (ft } \\
\text { m.s.l.) }\end{array}$ & $\begin{array}{c}\text { Depth (ft } \\
\text { b.g.l.) }\end{array}$ & $\begin{array}{c}\text { Elev. (ft } \\
\text { m.s.l.) }\end{array}$ & $\begin{array}{c}\text { Depth (ft } \\
\text { b.g.l) }\end{array}$ & $\begin{array}{c}\text { Elev. (ft } \\
\text { m.s.l.) }\end{array}$ & $\begin{array}{c}\text { Depth (ft } \\
\text { b.g.l.) }\end{array}$ & $\begin{array}{c}\text { Elev. (ft } \\
\text { m.s.l.) }\end{array}$ & $\begin{array}{c}\text { Depth (ft } \\
\text { b.g.l.) }\end{array}$ & $\begin{array}{c}\text { Elev. (ft } \\
\text { m.s.l.) }\end{array}$ & $\begin{array}{c}\text { Depth (fit } \\
\text { b.g l.) }\end{array}$ \\
\end{tabular}

\begin{tabular}{|c|c|c|c|c|c|c|c|c|c|c|c|}
\hline BGT-17 & 240.7 & & & & & 150 & 91 & & & & \\
\hline BGT-18 & 216.5 & abs. & abs. & 217 & 0 & 162 & \begin{tabular}{|l|}
55 \\
\end{tabular} & $1+7$ & 70 & 55 & 162 \\
\hline BGT-20 & .159 .5 & abs. & abs. & abs. & $\mathrm{abs}$ & 151 & 9 & $1+0$ & 20 & 70 & 90 \\
\hline \begin{tabular}{|l|} 
BGT-2I \\
\end{tabular} & 294.2 & 223 & 71 & 216 & 78 & & & & & & \\
\hline BGT-22 & 281.0 & 231 & 50 & 216 & 65 & 126 & 155 & 114 & 167 & 53 & 228 \\
\hline BGT-23 & 270.0 & 216 & 54 & 210 & 60 & & & & & & \\
\hline BGT-24 & 265.8 & 227 & 39 & 220 & 46 & & & & & & \\
\hline BGT.25 & 264.8 & 229 & 36 & 224 & +1 & & & & & & \\
\hline \begin{tabular}{|l} 
BGT-27 \\
\end{tabular} & 256.9 & 217 & 40 & 207 & 50 & 152 & 105 & & & & \\
\hline BGT.28 & 258.3 & 216 & 42 & 194 & $6+1$ & 156 & 102 & 150 & 108 & 48 & 210 \\
\hline BGT-29 & 243.0 & 219 & 24 & 215 & 28 & & & & & & \\
\hline BGT-30 & 219.0 & & & & & 147 & 72 & 141 & 78 & & \\
\hline BGT-31 & 308.8 & 220 & 89 & 215 & 94 & & & & & & \\
\hline BGT-32 & 310.1 & 237 & 73 & 234 & 76 & & & & & & \\
\hline \begin{tabular}{|l|} 
BGT-33 \\
\end{tabular} & 290.4 & 239 & 51 & 223 & \begin{tabular}{l|l|}
67 & \\
\end{tabular} & & & & & & \\
\hline BGT-34 & 286.8 & 228 & 59 & 218 & \begin{tabular}{l|l|}
69 \\
\end{tabular} & & & & & & \\
\hline BGT-35 & 267.7 & 217 & 51 & 212 & 56 & & & & & & \\
\hline$\overline{\text { BGT-36 }}$ & 261.4 & 226 & 35 & 215 & 46 & 148 & 113 & & & & \\
\hline$\overline{\text { BGT }-37}$ & 251.6 & 222 & 30 & 215 & \begin{tabular}{|l|}
37 \\
\end{tabular} & 133 & 119 & & & & \\
\hline BGT-40 & 332.3 & 209 & 123 & 203 & 129 & & & & & & \\
\hline $\mid \overline{B G T-41}$ & 328.4 & 224 & 104 & 219 & 109 & 149 & 179 & $1+2$ & 186 & & \\
\hline BGT-42 & 310.9 & 224 & 87 & 219 & 92 & & & & & & \\
\hline BGT -43 & 277.1 & 205 & 72 & 201 & 76 & & & & & & \\
\hline BGT-4t & 276.2 & 214 & 62 & 209 & 67 & & & & & & \\
\hline$\overline{B G T-45}$ & 285.3 & 218 & 67 & 209 & 76 & 150 & 135 & & & & \\
\hline$\overline{B G T-46}$ & 310.0 & 213 & 97 & 205 & 105 & 134 & 176 & 125 & 185 & & \\
\hline$\overline{B G T-47}$ & 317.3 & 214 & 103 & 210 & 107 & 137 & 180 & 128 & 189 & & \\
\hline BGT-48 & 314.3 & 217 & 97 & 209 & 105 & & & & & & \\
\hline BGT -49 & 297.3 & 222 & 75 & 214 & 83 & 135 & 162 & 126 & 171 & & \\
\hline BGT-50 & 296.3 & 221 & 75 & 214 & 82 & 132 & $16+$ & 124 & 172 & & \\
\hline BGT-51 & 272.6 & 193 & 80 & 186 & 87 & & & & & & \\
\hline \begin{tabular}{|l|} 
BGT -53 \\
\end{tabular} & 278.3 & 200 & 78 & 191 & $87 \mid$ & 120 & 158 & 109 & 169 & 32 & $2+6$ \\
\hline BGT-54 & 280.0 & 205 & 75 & 196 & 84 & & & & & & \\
\hline \begin{tabular}{|l|} 
BGT-56 \\
\end{tabular} & 262.9 & 182 & 81 & 175 & 88 & & & & & & \\
\hline \begin{tabular}{|l|} 
BGT-57 \\
\end{tabular} & 259.4 & 179 & 80 & 169 & 90 & & & & & & \\
\hline BGT-58 & 285.8 & 192 & 94 & 190 & $\begin{array}{ll}96 \\
\end{array}$ & 112 & 174 & 103 & 183 & & \\
\hline BGT-59 & 281.9 & 182 & 100 & 173: & 109 & & & & & & \\
\hline BGT-60) & 291.4 & 186 & 105 & 176 & 115 & & & & & & \\
\hline $\mid \overline{B G T-61}$ & 284.3 & 184 & 100 & 178 & 106 & 108 & 176 & 101 & $183^{3}$ & & \\
\hline BGT-62 & 282.0 & 190 & 92 & 176 & 106 & & & & & & \\
\hline BGT-63 & 293.7 & 195 & 99 & 189 & 105 & & & & & & \\
\hline BGT-63A & 290.8 & 198 & 93 & 194 & 97 & & & & & & \\
\hline BGT-64 & 283.3 & 195 & 88 & 188 & 95 & 123 & 160 & & & & \\
\hline BGT-66 & $2+4.0$ & 195 & 49 & 188 & 56 & & & & & & \\
\hline BGT-67 & $2+2.0$ & 186 & 57 & $17+$ & 69 & 135 & 107 & 128 & 115 & 27 & 21.5 \\
\hline$B G X-1 A$ & 289.1 & 211 & 78 & 198 & 91 & 132 & 157 & 127 & 162 & & \\
\hline$B G X-2 B$ & 289.2 & 216 & 73 & 198 & 91 & 140 & 149 & 127 & 162 & & \\
\hline$B G X-4 A$ & 288.8 & 225 & 64 & 213 & 76 & 1.30 & 159 & $12+4$ & 165 & & \\
\hline$B G X-7 D$ & 277.1 & 225 & 52 & 220 & 57 & 157 & 120 & $1+4$ & 1.3 .3 & & \\
\hline$B G X-9 D$ & 277.4 & 207 & 70 & 202 & 75 & 1.39 & 138 & 131 & $1+6$ & & \\
\hline
\end{tabular}


WSRC-TR-98-00285, Rev. 0. Hydrogeological and Groundwater Model for C. K. L. and P Areas

Appendix B-2: Hydrostratigraphic Boundaries (Continued)

\begin{tabular}{|c|c|c|c|c|c|c|c|c|c|c|c|}
\hline & & \multicolumn{2}{|c|}{ TCCZ } & \multicolumn{2}{|c|}{ LAZ } & \multicolumn{2}{|c|}{ GCU } & \multicolumn{2}{|c|}{$\mathrm{GAL}^{-1}$} & \multicolumn{2}{|c|}{ MBCS } \\
\hline Well ID & $\begin{array}{l}\text { Surface } \\
\text { Elevation } \\
\text { (ft m.s.l.) }\end{array}$ & $\begin{array}{l}\text { Elev. (ft } \\
\text { m.s.l.) }\end{array}$ & \begin{tabular}{|c} 
Depth (ft \\
b.g.l.
\end{tabular} & $\begin{array}{l}\text { Elev: (ft } \\
\text { m.s.l.) }\end{array}$ & $\begin{array}{c}\text { Depth (ft } \\
\text { b.g.l.) }\end{array}$ & $\begin{array}{l}\text { Eler. (ft } \\
\text { m.s.l.) }\end{array}$ & $\begin{array}{c}\text { Depth (ft } \\
\text { b.g.l.l.) }\end{array}$ & $\begin{array}{l}\text { Elev: (ft } \\
\text { m.s.s.l.) }\end{array}$ & $\begin{array}{c}\text { Depth }(\mathrm{ft} \\
\text { b.g.l.) }\end{array}$ & $\begin{array}{l}\text { Eler. (ft } \\
\text { m.s.l.) }\end{array}$ & $\mid \begin{array}{c}\text { Depth (fit } \\
\text { b. } .1 .1 .)\end{array}$ \\
\hline
\end{tabular}

\begin{tabular}{|c|c|c|c|c|c|c|c|c|c|c|c|}
\hline$B G X-11 D$ & 273.8 & 193 & 81 & 177) & 97 & 126 & $1+8$ & 117 & 157 & & \\
\hline BRR-1D & 293.8 & 195 & 99 & & & & & & & & \\
\hline BRR-3D & 289.5 & 208 & 82 & 194 & 96 & & & & & & \\
\hline BRR-6B & 293.9 & 178 & 116 & 166 & 128 & 123 & 171 & 108 & 186 & & \\
\hline BRR-7B & 289.6 & 202 & 88 & 190 & 100 & 135 & 155 & 122 & 168 & & \\
\hline BRR-8B & 276.7 & 205 & 72 & 200 & 77 & 131 & 146 & 126 & 151 & & \\
\hline CCP-1A & 287.1 & 176 & 112 & 162 & 125] & & & & & & \\
\hline CFD-1 & 268.8 & 188 & 81 & 179 & 90 & 111 & 158 & 107 & 162 & -45 & 314 \\
\hline CFD-5 & 257.8 & 180 & 78 & 173 & 85 & 9.3 & 165 & 89 & 169 & 28 & 230 \\
\hline CFD-18 & 248.3 & 167 & 81 & 150 & 99 & 97 & 151 & 90 & 158 & -4 & 253 \\
\hline CMP-30B & 286.5 & 210 & 77 & 197 & 90 & 95 & 192 & 87 & 200 & -10 & 297 \\
\hline CMP-32B & 251.7 & 217 & 35 & 202 & 50 & 100 & 152 & 93 & 159 & & \\
\hline CPC-1 & 285.1 & 166 & 120 & 156 & 129 & 96 & 190 & 87 & 199 & -8 & 294 \\
\hline CRP-5DR & 274.6 & 183 & 92 & 169 & 106 & 106 & 169 & & & & \\
\hline CRP-9D & 268.4 & 163 & 105 & $1+3.4$ & 125 & 94 & 175 & 92 & 177 & & \\
\hline CSD-4D & 306.5 & 150 & 157] & 134 & 173 & & & & & & \\
\hline FAC-1SB & 312.2 & 224 & 88 & 217 & 95 & $1+9$ & 163 & & & & \\
\hline $\mathrm{FCH}-\mathrm{I}$ & 316.8 & 214 & 103 & 202 & 115 & $1+2$ & 175 & 126 & 191 & 67 & 250 \\
\hline FCH-2 & 288.7 & 213 & 76 & 197| & 92 & $1+2$ & $1+7$ & 130 & 159 & 58 & 231 \\
\hline $\mathrm{FCH}-3$ & 307.2 & 207 & 100 & 196 & 111) & $1+0$ & 167 & 131 & 176 & 59 & $2+8$ \\
\hline $\mathrm{FCH}-4$ & 297.5 & 197 & 101 & 187 & 111 & 128 & 170 & 121 & 177 & +2 & 256 \\
\hline $\mathrm{FCH}-5$ & 284.2 & 196 & 88 & 191 & 93 & 129 & 155 & 128 & 156 & 36 & $2+8$ \\
\hline $\mathrm{FCH}-6$ & 291.5 & 189 & 103 & 182 & 110 & 124 & 168 & 121 & 171 & 2.5 & 267 \\
\hline FIW-IMC & 29.3.3. & 190 & 103 & 18.5 & 108 & 121 & 172 & & & & \\
\hline FIW-2MA & 290.5 & 189 & 102 & 180 & 111 & 121 & 170 & 117 & 174 & & \\
\hline FNB-IA & 282.4 & 208 & $7+$ & 202 & 80 & 151 & 131 & 138 & 145 & & \\
\hline FNB-3A & 282.2 & 211 & 71) & 208 & 75 & $1+6$ & 136 & 140 & $1+2$ & & \\
\hline FSB-PC & 230.8 & 161 & 70 & 157 & $7+4$ & & & & & & \\
\hline FSB-ITA & 275.4 & 191 & 84 & 187 & 88 & 117 & 158 & 115 & 160 & 24 & 251 \\
\hline FSB-76A & 291.5 & abs. & abs. & abs. & abs. & 121 & 171 & 117 & 175 & & \\
\hline FSB-78A & 270.5 & 163 & 108 & $1+7$ & 124 & 105 & 166 & 100 & 171 & & \\
\hline FSB-79A & 216.1 & 173 & +3 & 164 & 52 & 103 & 113 & 100 & 116 & 18 & 198 \\
\hline FSB-87A & 285.6 & 176 & 110 & 173 & 113 & 115 & 171 & 109 & 177 & & \\
\hline FSB-89C & 279.1 & 186 & 9.3 & 180 & 99 & & & & & & \\
\hline FSB-91C & 277.0 & 168 & 109 & 161 & 116 & & & & & & \\
\hline FSB-93C & 274.0 & 166 & 108 & 151 & 123 & & & & & & \\
\hline FSB-95C & 281.8 & 174 & 108 & 158 & 124 & & & & & & \\
\hline FSB-96A & 277.7 & 167 & 111 & 154 & 124 & 109 & 169 & 101 & 177 & & \\
\hline FSB-97A & 283.8 & 163. & 121 & 152 & 132 & 111 & 173. & 107 & 177 & & \\
\hline FSB-98A & 280.7 & 172 & 109 & 160 & 121 & 109 & 172 & 107 & 174 & & \\
\hline FSB-99A & 285.3 & 178 & 107 & 173 & 112 & 115 & 170 & 112 & 173 & & \\
\hline FSB-100A & 283.8 & 185 & 99 & 183 & 101 & 118 & 166 & 114 & 170 & & \\
\hline FSB-101A & 282.9 & 191 & 92 & 183 & 100 & 119 & 164 & 116 & 167 & & \\
\hline FSB-112A & 227.0 & 164 & 63 & $1+4$ & 8.3 & 103 & 124 & 98 & 129 & & \\
\hline FSB-113A & 221.3 & 178 & 43 & 171 & 50 & 109 & 112 & 104 & 117 & 22 & 199) \\
\hline FSB-11+A & 250.0 & 178 & 72 & 173 & 77 & 114 & 136 & 110 & $1+0$ & & \\
\hline FSB- $115 \mathrm{C}$ & 205.8 & 181 & 25 & 16.5 & +1 & 101 & 105 & 86 & 120 & 6 & 200 \\
\hline FSB-116C & 200.5 & 176 & 25 & 171 & 30 & & & & & & \\
\hline FSB-120A & 278.0 & 181 & 97. & 165 & 113 & 112 & 166 & 110 & 168 & & \\
\hline FSB-12IC & $25+.4$ & 173 & 81 & 162 & 92 & & & & & & \\
\hline
\end{tabular}


Appendix B-2: Hydrostratigraphic Boundaries (Continued)

\begin{tabular}{|c|c|c|c|c|c|c|c|c|c|c|c|}
\hline & & \multicolumn{2}{|c|}{ TCCZ } & \multicolumn{2}{|c|}{$\mathrm{LAZ}$} & \multicolumn{2}{|c|}{$\mathrm{GCE}$} & \multicolumn{2}{|c|}{ GAU } & \multicolumn{2}{|c|}{ MBCS } \\
\hline Well ID & $\begin{array}{c}\text { Surface } \\
\text { Elevation } \\
\text { (ft m.s.l.) }\end{array}$ & $\begin{array}{c}\text { Elev. (ft } \\
\text { m.s.l.) }\end{array}$ & $\begin{array}{c}\text { Depth (ft } \\
\text { b.g.l.) }\end{array}$ & $\begin{array}{c}\text { Elev. (ft } \\
\text { m.s.l.) }\end{array}$ & $\begin{array}{c}\text { Depth (ft } \\
\text { b.g.l.) }\end{array}$ & $\begin{array}{l}\text { Elev. (ft } \\
\text { m.s.l.) }\end{array}$ & $\begin{array}{l}\text { Depth (ft } \\
\text { b.g.l. }\end{array}$ & $\begin{array}{c}\text { Elev: (ft } \\
\text { m.s.l.) }\end{array}$ & $\begin{array}{c}\text { Depth (ft } \\
\text { b.g.l.) }\end{array}$ & $\begin{array}{l}\text { Eler: (ft } \\
\text { m.s.l.) }\end{array}$ & $\begin{array}{c}\text { Depth (ft } \\
\text { b.gll) }\end{array}$ \\
\hline
\end{tabular}

\begin{tabular}{|c|c|c|c|c|c|c|c|c|c|c|c|}
\hline FSB-122C & 216.0 & 164 & 52 & $1+8$ & 68 & 104 & 112 & & & & \\
\hline FSB-123C & 236.3 & 183 & 53 & 172 & 64 & & & & & & \\
\hline GAPWR-TW-1 & 219.0 & 151 & 68 & $1+3$ & 76 & 87 & 132 & 55 & 164 & -31 & 250 \\
\hline HAA-ITA & 290.2 & 208 & 83 & 204 & 86 & 117 & 173 & 110 & 181 & & \\
\hline HAA-2AA & 291.4 & 190 & 102 & 186 & 106 & 125 & 167 & 119 & 173 & 30 & 262 \\
\hline HAA-3AA & 274.5 & 191 & 84 & 179 & 96 & 128 & $1+7$ & 123 & 152 & 10 & 265 \\
\hline HAA-4AA & 299.2 & 202 & 97 & 194 & 106 & 125 & 175 & 119 & 181 & & \\
\hline HAA-6AA & 279.8 & 210 & 70 & 183 & 97 & 125 & 155 & 120 & 160 & 23 & 257 \\
\hline $\mathrm{HC}-12 \mathrm{~A}$ & 287.3 & 195 & 92 & 190 & 97 & & & & & & \\
\hline $\mathrm{HCA}-+\mathrm{AA}$ & 308.6 & 234 & 75 & 230 & 79 & 124 & 185 & 117 & 192 & & \\
\hline $\mathrm{HCH}-\mathrm{I}$ & 284.0 & 202 & 82 & 187 & 97 & 135 & $1+9$ & 126 & 158 & 18 & 266 \\
\hline $\mathrm{HCH}-2$ & 270.9 & 196 & 75 & 180 & 91 & 131 & 140 & 123 & $1+8$ & 0 & 271 \\
\hline $\mathrm{HCH}-3$ & 264.0 & 197 & 67 & 179 & 85 & 130 & 134 & 123 & 141 & & \\
\hline $\mathrm{HCH}-4$ & 269.9 & 193 & 77 & 183 & 87 & 123 & 147 & $11+$ & 156 & & \\
\hline $\mathrm{HCH}-5$ & 255.0 & 192 & 63 & 180 & 75 & 123 & 132 & 119 & 136 & -10 & 26.5 \\
\hline HIW-IBD & 275.8 & 205 & 71 & & & & & & & & \\
\hline HIW-IMC & 272.3 & 187 & 86 & 180 & 93 & & & & & & \\
\hline HIW-2A & 276.3 & 202 & 75 & 195 & 81 & 116 & 160 & 110 & 166 & & \\
\hline HIW-2MC & 269.0 & 199 & 70 & 194 & 76 & & & & & & \\
\hline HIW-4MC & 263.4 & 197 & 66 & 190 & 73 & 112 & 151 & & & & \\
\hline HIW-5MC & 266.1 & 184 & 82 & 178 & 88 & & & & & & \\
\hline HMD. IC & 262.7 & 229 & 34 & 226 & 37 & 139 & 124 & 127 & 136 & & \\
\hline HMD-2C & 259.3 & 222 & 37 & 216 & +3 & $1+3$ & 116 & 138 & 121 & & \\
\hline HMD-3C & 257.2 & 223 & 34 & 218 & 39 & 154 & 103 & $1+4$ & 108 & & \\
\hline HMD + C & 248.5 & 224 & 25 & 220 & 29 & 153 & 96 & $1+1$ & 108 & & \\
\hline $\mathrm{HPC}-\mathrm{I}$ & 293.5 & 195 & 99 & 188 & 106 & 116 & 178 & 110 & 184 & 28 & 266 \\
\hline HPT-IA & 232.9 & ND & ND & ND & ND & 119 & 114 & 115 & 118 & 53 & 180 \\
\hline HPT-2A & 257.8 & ND & ND & ND & $\mathrm{ND}$ & 121 & 137 & 118 & 140 & 57 & 201 \\
\hline HSB-PC & 227.8 & 188 & 40 & 178 & 50 & & & & & & \\
\hline HSB-TB & 267.1 & 207 & 60 & 199 & 68 & 110 & 157 & 106 & 161 & 9 & 258 \\
\hline HSB-65A & 270.7 & 204 & 67 & 199 & 72 & 119 & 152 & 113 & 158 & & \\
\hline HSB-68A & 247.4 & 198 & 49 & 193 & 54 & 116 & 131 & 110 & 137 & & \\
\hline HSB-69A & 234.1 & 187 & 47 & 181 & 53 & 115 & 119 & 112 & 122 & & \\
\hline HSB-83A & 234.9 & 195 & 40 & 188 & +7 & 114 & 121 & 104 & 131 & 12 & 223 \\
\hline HSB-84A & 226.7 & 205 & 22 & 181 & 46 & 119 & 108 & 111 & 116 & & \\
\hline HSB-85A & 292.1 & 204 & 88 & 200 & 92 & 126 & 166 & 119 & 173 & & \\
\hline HSB-86A & 260.0 & 185 & 75 & 178 & 82 & 112 & 148 & 109 & 151 & & \\
\hline HSB-101C & 256.3 & 195 & 61 & 189 & 67 & & & & & & \\
\hline HSB-103C & $2+5.2$ & 195 & 50 & 181 & 64 & & & & & & \\
\hline HSB-104C & 245.5 & 194 & 52 & 185 & 61 & & & & & & \\
\hline HSB-105C & 247.2 & 190 & 57 & 183 & 64 & & & & & & \\
\hline HSB-106C & 250.7 & 192 & 59 & 184 & 67 & & & & & & \\
\hline HSB-107C & 259.3 & 199 & 60 & 191 & 68 & & & & & & \\
\hline HSB-109C & 259.4 & 203 & 56 & 189 & 70 & & & & & & \\
\hline HSB-110C & 253.4 & 192 & 61 & 188 & 65 & & & & & & \\
\hline $\mathrm{HSB}-11 \mathrm{IC}$ & 253.7 & 188 & 66 & 172 & 82 & & & & & & \\
\hline HSB-112C & 252.6 & 191 & 62 & 186 & 67 & & & & & & \\
\hline HSB-11.3C & 258.7 & 188 & 71 & 174 & 85 & & & & & & \\
\hline HSB- $115 \mathrm{C}$ & 266.8 & 209 & 58 & 197 & 70 & & & & & & \\
\hline HSB-117A & 234.8 & 216 & 19 & 192 & +3 & 123 & 112 & 117 & 118 & & \\
\hline
\end{tabular}


Appendix B-2: Hydrostratigraphic Boundaries (Continued)

\begin{tabular}{|c|c|c|c|c|c|c|c|c|c|c|c|}
\hline & & \multicolumn{2}{|c|}{ TCCZ } & \multicolumn{2}{|c|}{ LAZ } & \multicolumn{2}{|c|}{ GCU } & \multicolumn{2}{|c|}{$\mathrm{GAC}^{\circ}$} & \multicolumn{2}{|c|}{ MBCS } \\
\hline Well ID & $\begin{array}{l}\text { Surface } \\
\text { Elevation } \\
\text { (ft m.s.l.) }\end{array}$ & \begin{tabular}{|c} 
Elev. (ft \\
m.s.l.)
\end{tabular} & $\begin{array}{c}\text { Depth (ft } \\
\text { b.g.l.) }\end{array}$ & $\begin{array}{c}\text { Elev. (ft } \\
\text { m.s.l.) }\end{array}$ & $\begin{array}{c}\text { Depth (ft } \\
\text { b.g.l.) }\end{array}$ & $\begin{array}{c}\text { Elev. (ft } \\
\text { m.s.l.) }\end{array}$ & $\begin{array}{c}\text { Depth (ft } \\
\text { b.g.l.) }\end{array}$ & $\begin{array}{c}\text { Elev. (ft } \\
\text { m.s.l.) }\end{array}$ & $\begin{array}{c}\text { Depth (ft } \\
\text { b.g.l.) }\end{array}$ & $\begin{array}{c}\text { Eler. (ft } \\
\text { m.s.l.) }\end{array}$ & $\begin{array}{c}\text { Depth (ft } \\
\text { b.g I) }\end{array}$ \\
\hline
\end{tabular}

\begin{tabular}{|c|c|c|c|c|c|c|c|c|c|c|c|}
\hline HSB-118A & 245.0 & 183 & 62 & 173 & 72 & 119 & 126 & $11+$ & 131 & & \\
\hline HSB-119A & 254.8 & 213 & +2 & 195 & 60 & 115 & 140 & 111 & 14 & & \\
\hline HSB-120A & 266.0 & 203 & 63 & 196 & 70 & 112 & 154 & 110 & 156 & & \\
\hline HSB-121A & 272.3 & 197 & 75 & $18+$ & 88 & 113 & 159 & 109 & 163 & & \\
\hline HSB-122A & 269.4 & 188 & 81 & 177 & 92 & 110 & 159 & 108 & 161 & & \\
\hline HSB-123A & 263.6 & 196 & 68 & 186 & 78 & 114 & 150 & 108 & 156 & & \\
\hline HSB-12+A & 263.9 & abs. & abs. & abs. & abs. & 118 & 146 & & & & \\
\hline HSB-132C & 238.3 & 163 & 75 & 158 & 80 & & & & & & \\
\hline HSB-139A & 231.5 & 190 & 42 & 179 & 53 & 119 & 113 & 115 & 117 & & \\
\hline HSB-140A & 234.0 & 194 & 40 & 181 & 53 & 111 & 123 & 105 & 129 & & \\
\hline $\mathrm{HSB}-141 \mathrm{~A}$ & 252.6 & 181 & 72 & 167 & 86 & 119 & 134 & 113 & 140 & & \\
\hline HSB- $1+2 C$ & 201.6 & abs. & abs. & & & & & & & & \\
\hline HSB-143C & 220.1 & 198 & 22 & 179 & $4 !$ & & & & & & \\
\hline HSB-1+HA & 233.6 & 186 & 48 & 179 & 55 & 109 & 125 & 104 & 130 & & \\
\hline HSB- $1+5 \mathrm{C}$ & 233.7 & 184 & 50 & 175 & 59 & & & & & & \\
\hline HSB-I $46 \mathrm{~A}$ & 249.5 & 174 & 76 & 163 & 87 & 119 & 131 & 112 & 138 & & \\
\hline HSB-148C & 248.9 & 187 & 62 & 171 & 78 & & & & & & \\
\hline HSB-151C & 211.6 & 193 & 19 & 183 & 29 & & & & & & \\
\hline HSB-152C & 212.1 & 198 & 14 & 186 & 26 & & & & & & \\
\hline HSL-6AA & 274.6 & 17.4 & 101 & 169 & 106 & 126 & 149 & 121 & 154 & 9 & 266 \\
\hline HSL-8AA & 286.7 & 193 & 94 & 186 & 101 & 137 & 150 & 129 & 158 & & \\
\hline IDB-2A & 302.4 & 245 & 57 & 228 & 74 & 142 & 160 & 138 & 164 & -13 & 316 \\
\hline IDP-3A & 282.2 & 190 & 92 & 182 & 100 & 161 & 121 & $1+0$ & $1+2$ & 73 & 209 \\
\hline IDQ-3A & 203.2 & abs. & abs. & 203 & 0 & 132 & $7 !$ & 124 & 79 & 55 & 148 \\
\hline KAC-9D & 260.2 & 170 & 91 & 1.59 & 102 & 95 & 165 & 89 & 171 & & \\
\hline LAC-5DL & 239.8 & & & & & & & & & & \\
\hline LAC-6DL & 239.8 & & & & & & & & & & \\
\hline LAC-7DL & 239.4 & & & & & & & & & & \\
\hline LAC-8DL & 234.0 & 207 & 27 & 196 & 38 & & & & & & \\
\hline $\mathrm{LCO}-5 \mathrm{~A}$ & 230.0 & 150 & 80 & $1+1$ & 89 & 78 & 152 & 66 & 164 & & \\
\hline LCO-5DL & 230.3 & & & & & & & & & & \\
\hline LCO-8DL & 243.4 & & & & & & & & & & \\
\hline LFW-10SB & 168.4 & abs. & abs. & abs. & abs. & abs. & abs. & 168 & 0 & +4 & 124 \\
\hline LWN-ISB & 282.5 & 162 & 121 & 151 & 132 & 132 & 151 & 119 & 164 & & \\
\hline LWN-2SB & 231.0 & 168 & 63 & 151 & 80 & 90 & $1+1$ & 82 & $1+9$ & 11 & 220 \\
\hline LWN-3SB & 24.5 .7 & 165 & 81 & 156 & 90 & 96 & 150 & 89 & 157 & 12 & 2.34 \\
\hline LWR-2SB & 248.1 & 177 & 71 & 167 & 81 & 146 & 102 & 131 & 117 & 17 & 2.31 \\
\hline \begin{tabular}{|l} 
LWR-3SB \\
\end{tabular} & 249.1 & 178 & 72 & 162 & 88 & 95 & 154 & 86 & 16.3 & 12 & 238 \\
\hline LWR-4SB & 293.8 & 178 & 116 & 165 & 129 & 104 & 190 & 96 & 198 & 7 & 287 \\
\hline LWR-9SB & 238.2 & 179 & 59 & 161 & 77 & 110 & 128 & 108 & 130 & & \\
\hline$M \mid 2 I A$ & 303.7 & 155 & 149 & 1.39 & 165 & 89 & 215 & $7+$ & 230 & -5 & 309 \\
\hline MWD-!A & 327.5 & 218 & 110 & 211 & 117 & 13.3 & 195 & 1.30 & 198 & 22 & 306 \\
\hline NPN-IA & 335.9 & 235 & 101 & 224 & 112 & 110 & 226 & 105 & 231 & 2 & 334 \\
\hline OFS-1SB & 261.6 & 196 & 66 & 186 & 76 & 129 & 133 & 126 & 136 & & \\
\hline OFS-2SB & 257.5 & 198 & 60 & 188 & 70 & 125 & 133 & 121 & 1.37 & & \\
\hline \begin{tabular}{|l} 
OFS-3SB \\
\end{tabular} & 258.1 & 196 & 62 & 185 & 73 & 125 & 133 & 120 & 138 & & \\
\hline OFS- + SB & 258.7 & 196 & 63 & 192 & 67 & 127 & 132 & 122 & 1.37 & & \\
\hline OFS-5SB & 228.7 & 189 & +0 & 178 & 51 & 122 & 107 & 117 & 112 & & \\
\hline P-13TA & 252.4 & 108 & $1+4$ & 86 & 167 & 32 & 220 & 10 & 243 & -103 & 35.5 \\
\hline P-I ITA & $29+4.4$ & 213 & 81 & 203 & 92 & 139 & 15.5 & 131 & 16.3 & 26 & 269 \\
\hline
\end{tabular}


Appendix B-2: Hydrostratigraphic Boundaries (Continued)

\begin{tabular}{|c|c|c|c|c|c|c|c|c|c|c|c|}
\hline & & \multicolumn{2}{|c|}{$\overline{T C C Z}$} & \multicolumn{2}{|c|}{ LAZ } & \multicolumn{2}{|c|}{$\overline{\mathrm{GCU}}$} & \multicolumn{2}{|c|}{ GAU } & \multicolumn{2}{|c|}{ MBCS } \\
\hline Well ID & $\begin{array}{l}\text { Surface } \\
\text { Elevation } \\
\text { (ft m.s.l.) }\end{array}$ & $\begin{array}{c}\text { Elev. (ft } \\
\text { m.s.l.) }\end{array}$ & $\begin{array}{c}\text { Depth (ft } \\
\text { b.g.l.) }\end{array}$ & $\begin{array}{c}\text { Elev. (ft } \\
\text { m.s.l.) }\end{array}$ & $\begin{array}{c}\text { Depth (ft } \\
\text { b.g.l.) }\end{array}$ & $\begin{array}{l}\text { Elev. (ft } \\
\text { m.s.l.) }\end{array}$ & $\begin{array}{c}\text { Depth (fft } \\
\text { b.g.l.) }\end{array}$ & $\begin{array}{c}\text { Elev. (ft } \\
\text { m.s.l.) }\end{array}$ & $\begin{array}{c}\text { Depth (ft } \\
\text { b.g.l.) }\end{array}$ & $\begin{array}{l}\text { Eler. (ft } \\
\text { m.s.l.) }\end{array}$ & $\begin{array}{c}\text { Depth (ft } \\
\text { b.g.l.) }\end{array}$ \\
\hline
\end{tabular}

\begin{tabular}{|c|c|c|c|c|c|c|c|c|c|c|c|}
\hline P-18TA & 296.9 & 175 & 122 & \begin{tabular}{l|l|}
167 & \\
\end{tabular} & 130 & 91 & 206 & \begin{tabular}{l|l|}
86 \\
\end{tabular} & 211 & -17 & 314 \\
\hline P-19TA & 297.4 & 195 & 103 & 174 & 123 & 120 & 178 & 114 & 184 & -.56 & 353 \\
\hline P-20TA & 287.7 & 161 & 127 & 152 & $\begin{array}{l}136 \\
\end{array}$ & 84 & 204 & 75 & 213 & -10 & 298 \\
\hline P-21TA & 207.0 & 99 & 108 & 93 & 114 & 48 & 160 & -24 & 231 & -115 & 322 \\
\hline P.22TA & 215.4 & 158 & 57 & $1+7$ & 69 & \begin{tabular}{l|l|}
37 \\
\end{tabular} & 178 & -19 & 234 & -91 & 306 \\
\hline P-23TA & 181.5 & $1+0$ & +2 & 129 & 53 & 89 & 93 & \begin{tabular}{l|l|}
58 & \\
\end{tabular} & 124 & -4 & 186 \\
\hline $\mathrm{P}-2+\mathrm{TA}$ & 313.3 & 193 & 121 & 181 & 132 & 115 & 198 & 99 & 214 & -40 & 354 \\
\hline P-25TA & 265.1 & $1+5$ & 120 & 136 & 129 & 100 & 165 & 95 & 171 & 1.3 & 253 \\
\hline P-26TA & 152.2 & & & 152 & 0 & 71 & 81 & 65 & 87 & 14 & 138 \\
\hline P-27TA & 274.1 & 180 & \begin{tabular}{l|l}
94 \\
\end{tabular} & 169 & 105 & 129 & 14.5 & 127 & 147 & 49 & 225 \\
\hline$P-28 T A$ & 285.6 & 215 & 71 & 211 & 75 & $1+1$ & $1+5$ & 133 & 153 & 64 & 222 \\
\hline PBF-3 & 316.7 & 138 & 179 & 137 & 180 & 79 & 238 & 50 & 267 & -23 & 340 \\
\hline PBF-t & 208.1 & 153 & 55 & 129 & 79 & \begin{tabular}{l|l|}
66 & \\
\end{tabular} & $1+2$ & +1 & 167 & -32 & 240 \\
\hline PBF-5 & 240.6 & 153 & 88 & $1+3$ & 98 & \begin{tabular}{l|l|}
103 \\
\end{tabular} & 138 & 78 & 163 & \begin{tabular}{l|l}
6 \\
\end{tabular} & 23.5 \\
\hline PBF-6 & 92.5 & abs. & abs. & abs. & abs. & abs. & abs. & 93 & 0 & -2 & 95 \\
\hline PBF-7 & 285.4 & 184 & 101 & 174 & 111 & 118 & 168 & $11+$ & 172 & -55 & $3+0$ \\
\hline PBF-8 & 292.0 & 196 & 96 & 173 & 119 & 114 & 178 & 110 & 182 & -44 & 336 \\
\hline PPC-1 & 313.3 & 187 & 126 & 168 & $1+5$ & 120 & 193 & 106 & 208 & -56 & 370 \\
\hline RCP.IA & 294.8 & 152 & 143 & 140 & 155 & 83 & 212 & 78 & 217 & & \\
\hline RSF-1 & 300.8 & 153 & 148 & $1+4$ & 157 & & & & & & \\
\hline RSF.? & 300.3 & 172 & 128 & 163 & \begin{tabular}{ll|}
137 \\
\end{tabular} & & & & & & \\
\hline RSF-3 & $30+.8$ & 140 & 165 & 129 & 176 & & & & & & \\
\hline SDS-21 & 251.0 & 205 & 47 & 199 & 53 & 163 & \begin{tabular}{l|l|}
89 \\
\end{tabular} & $1+8$ & 104 & & \\
\hline SDS-22 & 283.0 & 191 & 93 & 188 & 96 & $1+9$ & 134 & 138 & 145 & & \\
\hline SSW-1 & 311.3 & 195 & 116 & 175 & 136 & 126 & 185 & 123 & 188 & 12 & 300 \\
\hline SSW-? & 167.3 & abs. & abs. & 167 & 0 & 109 & 59 & 96 & 72 & -10 & 177 \\
\hline SSW-3 & 178.7 & 139 & 40 & 134 & 45 & 89 & 90 & 84 & 95 & & \\
\hline TI8NIA & 258.4 & 135 & 123 & 121 & 138 & 82 & 177 & 74 & 185 & -12 & 270 \\
\hline TI8S1A & 233.5 & 137 & 97 & 124 & 110 & 96 & 138 & $7 !$ & 163 & -+1 & 238 \\
\hline $\mathrm{T} 18 \mathrm{~W} 1 \mathrm{~A}$ & 244.4 & 164 & 81 & 139 & 106 & 94 & 150 & 84 & 160 & -26 & 270 \\
\hline USGS-MP & 245.0 & 178 & 67 & 172 & 73 & 133 & 112 & 113 & 132 & 80 & 165 \\
\hline VG-1 & 156.6 & 60 & 97 & 47 & 110 & -1 & 158 & -80 & 237 & -198 & 355 \\
\hline$\widehat{V G-7}$ & 250.6 & 105 & 146 & 90 & 161 & 39 & 212 & -32 & 283 & -123 & 374 \\
\hline \begin{tabular}{|l|} 
VG-8 \\
\end{tabular} & 103.7 & 24 & 80 & 6 & 98 & -38 & $1+2$ & -117 & 221 & -239 & $3+3$ \\
\hline YSC-IA & 268.9 & 210 & 59 & 199 & 70 & 159 & 110 & 154 & 115 & 69 & 200 \\
\hline YSC-IC & 272.5 & 215 & 58 & 213 & 60 & 164 & 109 & 157 & 116 & & \\
\hline YSC-2A & 281.7 & 220 & 62 & 215 & 67 & 162 & 120 & 151 & 131 & & \\
\hline YSC-3SB & 277.0 & 211 & 66 & 205 & 72 & $1+9$ & 128 & $1+0$ & 137 & & \\
\hline \begin{tabular}{|l|} 
YSC- $+A$ \\
\end{tabular} & 287.5 & 223 & 65 & 214 & 74 & 160 & 128 & 145 & $1+3$ & 87 & 201 \\
\hline YSC-5A & 273.0 & 221 & 52 & 209 & 64 & 136 & 137 & 128 & $1+5$ & & \\
\hline
\end{tabular}

Notes:

TCCZ - Tan Clay Confining Zone

LAZ - Lower Aquifer Zone

GCU - Gordon Confining Unit

GAU - Gordon Aquifer Unit

MBCS - Meyers Branch Confining System

ft m.s.l. - feet above mean sea level

ft b.g.l. - feet below ground level

Blank field indicales unit not penetrated

ND - Unit boundary not delineated

abs. - Unit absent 
WSRC-TR-98-00285, Rev. 0, Hydrogeological and Groundwater Model for C. K. L. and P Areas

C-1

Appendix C-1. Permeability Values Recorded from Pumping Tests (Continued)

\begin{tabular}{|c|c|c|c|c|l|l|}
\hline $\begin{array}{c}\text { Pumped } \\
\text { Well }\end{array}$ & $\begin{array}{c}\text { Test } \\
\text { Observation } \\
\text { Well }\end{array}$ & $\begin{array}{c}\text { Test } \\
\text { Top } \\
\text { (ft b.g.l.) }\end{array}$ & $\begin{array}{c}\text { Interval } \\
\text { Bottom } \\
\text { (ft b.g.l.) }\end{array}$ & $\begin{array}{c}\text { Permeability } \\
\text { (ft/day) }\end{array}$ & Analysis Method & Reference $^{1}$ \\
\hline
\end{tabular}

\begin{tabular}{|c|c|c|c|c|c|c|}
\hline FSB-PC & FSB-25PC & 75.1 & 125.0 & 0.80 & $\begin{array}{l}\text { Aqetsolv (Hantush } \\
\text { leaky) }\end{array}$ & WSRC. 1995b \\
\hline FSB-PC & FSB-50PC & 75.1 & 125.0 & 1.40 & $\begin{array}{l}\text { Aqetsolv (Hantush } \\
\text { leaky) }\end{array}$ & WSRC. $1995 \mathrm{~b}$ \\
\hline FSB-PC & FSB-79C & 75.1 & 125.0 & 3.00 & $\begin{array}{l}\text { Aqetsolv (Hantush } \\
\text { leaky) }\end{array}$ & WSRC. 1995b \\
\hline FSB-PC & FSB-100PC & 75.1 & 125.0 & 2.10 & $\begin{array}{l}\text { Aqetsolv (Hantush } \\
\text { leaky) }\end{array}$ & WSRC. $1995 \mathrm{~b}$ \\
\hline FSB-PC & FSB-103C & 75.1 & 125.0 & 3.60 & $\begin{array}{l}\text { Aqetsolv (Hantush } \\
\text { leaky) }\end{array}$ & WSRC. 1995b \\
\hline FSB-PC & FSB-106C & 75.1 & 125.0 & 3.40 & \begin{tabular}{|l|}
$\begin{array}{l}\text { Aqetsolv (Hantush } \\
\text { leaky) }\end{array}$ \\
\end{tabular} & WSRC. 1995b \\
\hline FSB-PC & FSB-110C & 75.1 & 125.0 & 1.20 & \begin{tabular}{|l|}
$\begin{array}{l}\text { Aqetsolv (Hantush } \\
\text { leaky) }\end{array}$ \\
\end{tabular} & WSRC. $1995 \mathrm{~b}$ \\
\hline FSB-PC & FSB-150PC & 75.1 & 125.0 & 1.30 & $\begin{array}{l}\text { Aqetsolv (Hantush } \\
\text { leaky) }\end{array}$ & WSRC. 19956 \\
\hline FSB-PD & FSB-25PD & 37.3 & 81.0 & 46.40 & \begin{tabular}{|l|} 
Aqetsolv (Neuman \\
method)
\end{tabular} & WSRC. $1995 \mathrm{~b}$ \\
\hline FSB-PD & FSB-50PD & 37.3 & 81.0 & 62.50 & $\begin{array}{l}\text { Aqetsolv (Neuman } \\
\text { method) }\end{array}$ & WSRC. 1995b \\
\hline FSB-PD & FSB-100PD & 37.3 & 81.0 & 48.30 & $\begin{array}{l}\text { Aqetsolv (Neuman } \\
\text { method) }\end{array}$ & WSRC, $1995 \mathrm{~b}$ \\
\hline FSB-PD & FSB-150PD & 37.3 & 81.0 & 49.20 & $\begin{array}{l}\text { Aqetsolv (Neuman } \\
\text { method) }\end{array}$ & WSRC. 1995b \\
\hline FSB-76A & FSB-76A & 244.1 & 254.6 & 1.29 & $\begin{array}{l}\text { Jacob Semi- } \\
\text { Logarithmic }\end{array}$ & $\begin{array}{l}\text { Woodward-Clyde. } \\
\text { 1985a }\end{array}$ \\
\hline$\overline{F S B-78 A}$ & FSB-78A & 233.0 & 243.4 & 0.82 & \begin{tabular}{|l|} 
Jacob Semi- \\
Logarithmic
\end{tabular} & $\begin{array}{l}\text { Woodward-Clyde. } \\
\text { 1985a }\end{array}$ \\
\hline FSB-79A & FSB-79A & 181.6 & 192.0 & 142.90 & $\begin{array}{l}\text { Jacob Semi- } \\
\text { Logarithmic } \\
\end{array}$ & $\begin{array}{l}\text { Woodward-Clyde. } \\
\text { 1985a }\end{array}$ \\
\hline FSB-87A & FSB-87A & 242.0 & 252.5 & 51.02 & $\begin{array}{l}\text { Jacob Semi- } \\
\text { Logarithmic } \\
\end{array}$ & $\begin{array}{l}\text { Woodward-Clyde. } \\
1985 \text { a }\end{array}$ \\
\hline HPT-IA & DRB-6WW & 127.0 & 178.0 & $1.47 \mathrm{E}-04$ & Hantush-Jacob & $\mathrm{CH} 2 \mathrm{M}$ Hill. 1989 \\
\hline HPT-IA & $\mathrm{HC}-10 \mathrm{~A}$ & 127.0 & 178.0 & $1.26 \mathrm{E}-03$ & Hantush-Jacob & $\mathrm{CH} 2 \mathrm{M}$ Hill. 1989 \\
\hline HPT-1A & HPT-2A & 127.0 & 178.0 & $2.86 \mathrm{E}-04$ & Hantush-Jacob & CH2M Hill. 1989 \\
\hline HSB-PC & HSB-25PC & 57.0 & 110.6 & 0.90 & Hantush-Jacob & WSRC. 1995b \\
\hline HSB-PC & HSB-50PC & 57.0 & 110.6 & 1.30 & Hantush-Jacob & WSRC. 1995b \\
\hline HSB-PC & HSB-100PC & 57.0 & 110.6 & 1.30 & Hantush-Jacob & WSRC. $1995 \mathrm{~b}$ \\
\hline HSB-PC & HSB-136C & 57.0 & 110.6 & 1.60 & Hantush-Jacob & WSRC. $1995 \mathrm{~b}$ \\
\hline HSB-PC & HSB-137C & 57.0 & 110.6 & 1.10 & Hantush-Jacob & WSRC, 1995b \\
\hline HSB-PC & HSB-150PC & 57.0 & 110.6 & 1.20 & Hantush-Jacob & WSRC. 1995b \\
\hline HSB-65A & HSB-65A & 197.5 & 208.2 & 1.74 & $\begin{array}{l}\text { Jacob Semi- } \\
\text { Logarithmic }\end{array}$ & $\begin{array}{l}\text { Woodward-Clyde. } \\
\text { 1985b }\end{array}$ \\
\hline HSB-68A & HSB-68A & 189.4 & 199.9 & 1.13 & $\begin{array}{l}\text { Jacob Semi- } \\
\text { Logarithmic }\end{array}$ & $\begin{array}{l}\text { Woodward-Clyde. } \\
1985 \mathrm{~b}\end{array}$ \\
\hline HSB-83A & HSB-83A & 158.9 & 169.7 & 10.48 & $\begin{array}{l}\text { Jacob Semi- } \\
\text { Logarithmic } \\
\end{array}$ & $\begin{array}{l}\text { Woodward-Clyde. } \\
1985 \mathrm{~b}\end{array}$ \\
\hline HSB-84A & HSB-68A & 150.8 & 162.0 & 33.80 & \multicolumn{2}{|c|}{ Aqtesolv (Non-Leaky Theis) } \\
\hline HSB-84A & HSB-69A & 150.8 & 162.0 & 17.29 & \multicolumn{2}{|c|}{ Aqtesolv (Non-Leaky Theis) } \\
\hline
\end{tabular}


Appendix C-1. Permeability Values Recorded from Pumping Tests (Continued)

\begin{tabular}{|c|c|c|c|c|c|c|}
\hline $\begin{array}{l}\text { Pumped } \\
\text { Well }\end{array}$ & $\begin{array}{c}\text { Observation } \\
\text { Well }\end{array}$ & $\begin{array}{c}\text { Test } \\
\text { Interval } \\
\text { Top } \\
\text { (ft b.g.l.) }\end{array}$ & $\begin{array}{c}\text { Test } \\
\text { Interval } \\
\text { Bottom } \\
\text { (ft b.g.l.) }\end{array}$ & $\begin{array}{c}\text { Permeability } \\
\text { (ft/day) }\end{array}$ & Analysis Method & Reference ${ }^{\prime}$ \\
\hline
\end{tabular}

\begin{tabular}{|c|c|c|c|c|c|c|}
\hline HSB-84A & HSB-83A & 150.8 & 162.0 & 39.72 & \multicolumn{2}{|c|}{ Aqtesolv (Non-Leaky Theis) } \\
\hline HSB-84A & HSB-86A & 150.8 & 162.0 & 34.25 & \multicolumn{2}{|c|}{ Aqtesolv (Non-Leaky Theis) } \\
\hline HSB-84A & HSB-118A & 150.8 & 162.0 & 39.12 & \multicolumn{2}{|c|}{ Aqtesolv (Non-Leaky Theis) } \\
\hline HSB-84A & HSB-139A & 150.8 & 162.0 & 27.88 & \multicolumn{2}{|c|}{ Aqtesolv (Non-Leaky Theis) } \\
\hline HSB-85A & HSB-85A & 221.0 & 231.0 & 8.72 & \multicolumn{2}{|c|}{ Aqtesolv (Non-Leaky Theis) } \\
\hline HSB-86A & HSB-86A & 186.1 & 196.9 & 5.46 & \multicolumn{2}{|c|}{ Aqtesolv (Non-Leaky Theis) } \\
\hline HSB-10IC & HSB-101C & 80.0 & 90.0 & 1.68 & $\begin{array}{l}\text { Hantush and Jacob } \\
\text { (1955) Leaky Artesian } \\
\text { Solution }\end{array}$ & Evans. 1991 \\
\hline YSC-1A & YSC-1A & 132.0 & 192.1 & 62.00 & Cooper-Jacob & WEGS. 1990 \\
\hline YSC-1A & YSC-1A & 132.0 & 192.1 & 37.00 & Recovery & WEGS. 1990 \\
\hline YSC-1A & YSC-1A & 132.0 & 192.1 & 22.00 & Theis & WEGS. 1990 \\
\hline YSC-1A & YSC-1A & 132.0 & 192.1 & 52.00 & WHIP(Recovery) & WEGS. 1990 \\
\hline YSC-1A & YSC-1A & 132.0 & 192.1 & 57.00 & WHIP(Theis) & WEGS. 1990 \\
\hline YSC-1A & YSC-4A & 132.0 & 192.1 & 40.00 & Theis Non-Eq. & WEGS. 1990 \\
\hline$\longdiv { Y S C - 1 A }$ & YSC-4A & 132.0 & 192.1 & 43.00 & WHIP(Theis) & WEGS. 1990 \\
\hline YSC-1A & YSC-4A & 132.0 & 192.1 & 47.00 & WHIP(Recovery) & WEGS. 1990 \\
\hline YSC-1A & YSC-4A & 132.0 & 192.1 & 52.00 & Recovery & WEGS. 1990 \\
\hline
\end{tabular}

Notes:

ft b.g.l. - feet below ground level

fu/day - feet per day

1 - Detailed description of references in Appendix D 
WSRC-TR-98-00285. Rev. 0. Hydrogeological and Groundwater Model for C. K. L. and P Areas C- 3

Appendix C-2. Permeability Values Recorded from Slug Tests

\begin{tabular}{|c|c|c|c|c|c|c|}
\hline We & $\begin{array}{c}\text { Screen } \\
\text { Top } \\
\text { (ft b.g.l.) }\end{array}$ & $\begin{array}{c}\text { Screen } \\
\text { Bottom } \\
\text { (ft b.g.l.) }\end{array}$ & $\begin{array}{c}\text { Permeability } \\
\text { (ft/day) }\end{array}$ & Solution Method & Test Type & Reference \\
\hline
\end{tabular}

\begin{tabular}{|c|c|c|c|c|c|c|}
\hline BGO-1D & 48 & 68 & 0.31 & Bouwer-Rice 1976 & Falling Head & \begin{tabular}{|l} 
S\&ME. \\
1988 \\
\end{tabular} \\
\hline $\mathrm{BGO}-3 \mathrm{~A}$ & 175 & 185 & 3.25142 & Bouwer-Rice & Rising Head & \begin{tabular}{|l} 
Amidon \\
1995 \\
\end{tabular} \\
\hline $\mathrm{BGO}-3 \mathrm{~A}$ & 175 & 185 & 5.191 & Bouwer-Rice & Falling Head & \begin{tabular}{|l} 
Amidon \\
1995 \\
\end{tabular} \\
\hline BGO-3D & 51.7 & 71.8 & 0.14 & Bouwer-Rice 1976 & Falling Head & \begin{tabular}{|l} 
S\&ME. \\
1988 \\
\end{tabular} \\
\hline BGO-5C & 101 & 111 & 0.13 & Hvorslev & Falling Head & \begin{tabular}{|l|} 
S\&ME, \\
1988 \\
\end{tabular} \\
\hline BGO-6A & 166.3 & 176.3 & 0.77 & Hvorslev & Falling Head & $\begin{array}{l}\text { S\&ME. } \\
1988\end{array}$ \\
\hline $\mathrm{BGO}-8 \mathrm{~A}$ & 166 & 176 & 0.21 & Hvorslev & Falling Head & \begin{tabular}{|l} 
S\&ME. \\
1988
\end{tabular} \\
\hline BGO-10A & 178 & 188 & 0.16 & Hvorslev & Falling Head & \begin{tabular}{|l} 
S\&ME. \\
1988
\end{tabular} \\
\hline $\begin{array}{l}\text { BGO- } \\
10 \mathrm{AA}\end{array}$ & 208 & 218 & 0.43 & Bouwer-Rice 1976 & Falling Head & $\begin{array}{l}\text { WSRC. } \\
1992 \mathrm{a}\end{array}$ \\
\hline$\overline{B G O}-12 \mathrm{~A}$ & 195 & 205 & 0.005 & Hvorslev & Falling Head & $\begin{array}{l}\text { S\&ME. } \\
1988\end{array}$ \\
\hline BGO-14A & 180.6 & 190.6 & 0.04 & Hvorslev & Falling Head & $\begin{array}{l}\text { S\&ME. } \\
1988\end{array}$ \\
\hline $\mathrm{BGO}-16 \mathrm{~A}$ & 190.3 & 200.3 & 0.15 & Hvorslev & Falling Head & \begin{tabular}{|l} 
S\&ME. \\
1988 \\
\end{tabular} \\
\hline $\mathrm{BGO}-18 \mathrm{~A}$ & 183.4 & 193.4 & 11.98 & Hvorslev & Falling Head & $\begin{array}{l}\text { S\&ME. } \\
1988\end{array}$ \\
\hline BGO-2ID & 45.3 & 65.3 & 0.79 & Bouwer-Rice 1976 & Falling Head & $\begin{array}{l}\text { S\&ME. } \\
1988\end{array}$ \\
\hline BGO-23D & 45 & 65 & 1.11 & Bouwer-Rice 1976 & Falling Head & $\begin{array}{l}\text { S\&ME. } \\
1988\end{array}$ \\
\hline BGO-25A & 180.6 & 190.6 & 0.5 & Hvorslev & Falling Head & $\begin{array}{l}\text { S\&ME. } \\
1988\end{array}$ \\
\hline $\mathrm{BGO}-41 \mathrm{~A}$ & 185 & 195 & 0.13 & Bouwer-Rice 1976 & Falling Head & $\begin{array}{l}\text { WSRC. } \\
1992 \mathrm{a}\end{array}$ \\
\hline BGO-42C & 100 & 110 & 0.45 & Bouwer-Rice 1976 & Falling Head & $\begin{array}{l}\text { WSRC. } \\
\text { 1992a }\end{array}$ \\
\hline $\begin{array}{l}\text { BGO- } \\
43 \mathrm{AA}\end{array}$ & 240 & 250 & 0.86 & Bouwer-Rice 1976 & Falling Head & $\begin{array}{l}\text { WSRC. } \\
1992 \mathrm{a}\end{array}$ \\
\hline $\begin{array}{l}\text { BGO- } \\
44 \mathrm{AA}\end{array}$ & 212 & 222.1 & 4.36 & Bouwer-Rice 1976 & Falling Head & $\begin{array}{l}\text { WSRC. } \\
1992 \mathrm{a} \\
\end{array}$ \\
\hline $\mathrm{BGO}-45 \mathrm{~A}$ & 150 & 160 & 2.45 & Bouwer-Rice 1976 & Falling Head & $\begin{array}{l}\text { WSRC. } \\
1992 a\end{array}$ \\
\hline BGO-46B & 113 & 123 & 2.33 & Bouwer-Rice 1976 & Falling Head & $\begin{array}{l}\text { WSRC. } \\
1992 \mathrm{a}\end{array}$ \\
\hline $\mathrm{BGO}-47 \mathrm{~A}$ & 168 & 178 & 3.07 & Bouwer-Rice 1976 & Falling Head & $\begin{array}{l}\text { WSRC. } \\
1992 \mathrm{a} \\
\end{array}$ \\
\hline BGO-48C & 88 & 98 & 2.15 & Bouwer-Rice 1976 & Falling Head & $\begin{array}{l}\text { WSRC. } \\
1992 a\end{array}$ \\
\hline BGO-49A & 184 & 194 & 0.49 & Bouwer-Rice 1976 & Falling Head & $\begin{array}{l}\text { WSRC, } \\
1992 \mathrm{a} \\
\end{array}$ \\
\hline BGO-50A & 153 & 163 & 0.4 & Bouwer-Rice 1976 & Falling Head & WSRC. \\
\hline
\end{tabular}


Appendix C-2. Permeability Values Recorded from Slug Tests (Continued)

\begin{tabular}{|c|c|c|c|c|c|c|}
\hline We & $\begin{array}{c}\text { Screen } \\
\text { Top } \\
\text { (ft b.g.l.) }\end{array}$ & $\begin{array}{c}\text { Screen } \\
\text { Bottom } \\
\text { (ft b.g.l.) }\end{array}$ & $\begin{array}{c}\text { Permeability } \\
\text { (ft/day) }\end{array}$ & Solution Method & Test Type & Reference ${ }^{3}$ \\
\hline
\end{tabular}

\begin{tabular}{|c|c|c|c|c|c|c|}
\hline & & & & & & $1992 a$ \\
\hline $\begin{array}{l}\text { BGO- } \\
51 \mathrm{AA}\end{array}$ & 248 & 263.6 & 0.7762 & Bouw'er-Rice 1976 & Rising Head & $\begin{array}{l}\text { Amidon. } \\
1995\end{array}$ \\
\hline $\begin{array}{l}\text { BGO- } \\
\text { 51AA }\end{array}$ & 248 & 263.6 & 1.188 & Bouwer-Rice 1976 & Falling Head & $\begin{array}{l}\text { Amidon. } \\
1995\end{array}$ \\
\hline $\begin{array}{l}\text { BGO- } \\
52 \mathrm{AA}\end{array}$ & 235 & 247.8 & 0.8996 & Bouwer-Rice 1976 & Rising Head & $\begin{array}{l}\text { Amidon. } \\
1995\end{array}$ \\
\hline $\begin{array}{l}\text { BGO- } \\
52 \mathrm{AA}\end{array}$ & 235 & 247.8 & 8.15 & Bouwer-Rice 1976 & Falling Head & \begin{tabular}{|l} 
Amidon. \\
1995
\end{tabular} \\
\hline $\begin{array}{l}\text { BGO- } \\
53 \mathrm{AA}\end{array}$ & 240 & 250 & 1.11744 & Bouwer-Rice 1976 & Falling Head & Rust. 1996 \\
\hline$B G X-1 A$ & 165 & 175.02 & 0.01 & Bouwer-Rice 1976 & Falling Head & \begin{tabular}{|l} 
WSRC. \\
1991a
\end{tabular} \\
\hline BGX-2B & 142 & 151.95 & 0.21 & Bouwer-Rice 1976 & Falling Head & $\begin{array}{l}\text { WSRC. } \\
1991 \mathrm{a}\end{array}$ \\
\hline$B G X-4 A$ & 172 & 182 & 1.83 & Bouwer-Rice 1976 & Falling Head & $\begin{array}{l}\text { WSRC. } \\
1991 \mathrm{a}\end{array}$ \\
\hline BGX-7D & 63 & 83.03 & 20.38 & Bouwer-Rice 1976 & Rising Head & $\begin{array}{l}\text { WSRC. } \\
1991 \mathrm{a}\end{array}$ \\
\hline BGX-9D & 45 & 65.01 & 0.36 & Bouwer-Rice 1976 & Rising Head & $\begin{array}{l}\text { WSRC. } \\
\text { 1991a }\end{array}$ \\
\hline CMP-30B & 172.2 & 195.5 & 1.1 & Bouwer Rice & Rising Head & $\begin{array}{l}\text { WSRC. } \\
1996 c\end{array}$ \\
\hline CMP-30B & 172.2 & 195.5 & 1.4 & Bouwer Rice & Falling Head & $\begin{array}{l}\text { WSRC. } \\
1996 \mathrm{c}\end{array}$ \\
\hline FSB-89C & 113 & 123 & 0.524 & Hvorslev & Falling Head & $\begin{array}{l}\text { WSRC, } \\
\text { 1991d }\end{array}$ \\
\hline FSB-91C & 117.9 & 127.9 & 0.141 & Hvorslev & Falling Head & $\begin{array}{l}\text { WSRC. } \\
1991 \mathrm{~d}\end{array}$ \\
\hline FSB-93C & 122 & 132 & 5.27 & Hvorslev & Falling Head & $\begin{array}{l}\text { WSRC. } \\
\text { 1991d }\end{array}$ \\
\hline FSB-97A & 188 & 198 & 0.852 & Hvorslev & Falling Head & $\begin{array}{l}\text { WSRC. } \\
\text { 1991d }\end{array}$ \\
\hline FSB-101A & 180 & 190 & 33.2 & Hvorslev & Falling Head & Sirrine. 1987 \\
\hline FSB-112A & 136 & 146 & 1.7 & Bouwer-Rice 1976 & Rising Head & \begin{tabular}{|l} 
WEGS. \\
1991
\end{tabular} \\
\hline FSB-113A & 130 & 140 & 0.62 & Bouwer-Rice 1976 & Rising Head & \begin{tabular}{|l} 
WEGS. \\
1991
\end{tabular} \\
\hline FSB-114A & 145 & 155 & 0.44 & Bouwer-Rice 1976 & Rising Head & $\begin{array}{l}\text { WEGS. } \\
1991\end{array}$ \\
\hline FSB-115C & 32 & 42 & 0.36 & Bouwer-Rice 1976 & Rising Head & \begin{tabular}{|l} 
WEGS. \\
1991
\end{tabular} \\
\hline FSB-116C & 30 & 40 & 0.69 & Bouwer-Rice 1976 & Rising Head & $\begin{array}{l}\text { WEGS, } \\
1991\end{array}$ \\
\hline FSB-120A & 169 & 179 & 0.65 & Bouwer-Rice 1976 & Rising Head & $\begin{array}{l}\text { WEGS. } \\
1991\end{array}$ \\
\hline FSB-121C & 96 & 106 & 11 & Bouwer-Rice 1976 & Rising Head & $\begin{array}{l}\text { WEGS. } \\
1991\end{array}$ \\
\hline FSB-122C & 46 & 56 & 2.6 & Bouwer-Rice 1976 & Rising Hcad & \begin{tabular}{|l} 
WEGS, \\
1991
\end{tabular} \\
\hline FSB-123C & 71 & 81 & 6.7 & Bouwer-Rice 1976 & Rising Head & WEGS, \\
\hline
\end{tabular}


WSRC-TR-98-00285. Rev. 0, Hydrogeological and Groundwater Model for C. K. L. and P Areas

Appendix C-2. Permeability Values Recorded from Slug Tests (Continued)

\begin{tabular}{|c|c|c|c|c|c|c|}
\hline Well & $\begin{array}{c}\text { Screen } \\
\text { Top } \\
\text { (ft b.g.l.) }\end{array}$ & $\begin{array}{c}\text { Screen } \\
\text { Bottom } \\
\text { (ft b.g.l.) }\end{array}$ & $\begin{array}{c}\text { Permeability } \\
\text { (ft/day) }\end{array}$ & Solution Method & Test Type & Reference $^{1}$ \\
\hline
\end{tabular}

\begin{tabular}{|c|c|c|c|c|c|c|}
\hline & & & & & & 1991 \\
\hline HAA-1TA & 310 & 320 & 0.548 & Bouwer-Rice 1976 & Rising Head & $\begin{array}{l}\text { WSRC. } \\
1995 \mathrm{a}\end{array}$ \\
\hline HAA-ITA & 310 & 320 & 0.786 & Bouwer-Rice 1976 & Falling Head & \begin{tabular}{|l|} 
WSRC. \\
$1995 \mathrm{a}$ \\
\end{tabular} \\
\hline HAA-2AA & 252 & 262 & 19.858 & Bouwer-Rice 1976 & Rising Head & $\begin{array}{l}\text { WSRC. } \\
1995 \mathrm{a} \\
\end{array}$ \\
\hline HAA-2AA & 252 & 262 & 30.6552 & Bouwer-Rice 1976 & Falling Head & $\begin{array}{l}\text { WSRC. } \\
1995 \mathrm{a} \\
\end{array}$ \\
\hline HAA-3AA & 258 & 268 & 0.3229 & Bouwer-Rice 1976 & Rising Head & $\begin{array}{l}\text { WSRC. } \\
1995 \mathrm{a}\end{array}$ \\
\hline HAA-3AA & 258 & 268 & 0.504 & Bouwer-Rice 1976 & Falling Head & \begin{tabular}{|l} 
WSRC. \\
$1995 \mathrm{a}$ \\
\end{tabular} \\
\hline HAA-6AA & 244 & 254 & 0.224 & Bouwer-Rice 1976 & Rising Head & \begin{tabular}{|l|} 
WSRC. \\
$1995 \mathrm{a}$
\end{tabular} \\
\hline HAA-6AA & 244 & 254 & 0.2587 & Bouwer-Rice 1976 & Falling Head & $\begin{array}{l}\text { WSRC. } \\
1995 \mathrm{a}\end{array}$ \\
\hline HCA-4AA & 265 & 275 & 13.1717 & Bouwer-Rice 1976 & Rising Head & $\begin{array}{l}\text { WSRC. } \\
1995 \mathrm{a} \\
\end{array}$ \\
\hline $\mathrm{HCA}-4 \mathrm{AA}$ & 265 & 275 & 13.78 & Bouwer-Rice 1976 & Falling Head & \begin{tabular}{|l|} 
WSRC. \\
$1995 \mathrm{a}$ \\
\end{tabular} \\
\hline HSB-69A & 141 & 151 & 8.79 & Hvorslev & Rising Head & $\begin{array}{l}\text { WSRC. } \\
199 \text { lc } \\
\end{array}$ \\
\hline HSB-101C & 80 & 90 & 4 & Hvorslev & Falling Head & $\begin{array}{l}\text { WSRC, } \\
199 \mathrm{lc}\end{array}$ \\
\hline HSB-103C & 76 & 86 & 3.1 & Hvorslev & Falling Head & $\begin{array}{l}\text { WSRC. } \\
\text { 199lc }\end{array}$ \\
\hline HSB-105C & 85 & 95 & 4.3 & Hvorslev & Falling Head & $\begin{array}{l}\text { WSRC, } \\
1991 \mathrm{c} \\
\end{array}$ \\
\hline HSB-106C & 82 & 92 & 24.4 & Hvorslev & Falling Head & \begin{tabular}{|l|} 
WSRC, \\
$1991 \mathrm{c}$ \\
\end{tabular} \\
\hline HSB-109C & 81 & 91 & 0.952 & Hvorslev & Falling Head & Sirrine. 1988 \\
\hline HSB-110C & 72 & 82 & 0.709 & Hvorslev & Falling Head & Sirrine, 1988 \\
\hline HSB-111C & 103 & 113 & 1.7 & Hvorslev & Falling Head & $\begin{array}{l}\text { WSRC. } \\
1991 \mathrm{c} \\
\end{array}$ \\
\hline HSB-112C & 102 & 112 & 4.2 & Hvorslev & Falling Head & $\begin{array}{l}\text { WSRC. } \\
1991 \mathrm{lc} \\
\end{array}$ \\
\hline HSB-113C & 97 & 107 & 0.992 & Hvorslev & Falling Head & Sirrine. 1988 \\
\hline HSB-117A & 140 & 150 & 0.16 & Hvorslev & Falling Head & $\begin{array}{l}\text { WSRC. } \\
1991 \mathrm{lc} \\
\end{array}$ \\
\hline HSB-I18A & 144 & 154 & 12 & Hvorslev & Falling Head & $\begin{array}{l}\text { WSRC. } \\
1991 \mathrm{c} \\
\end{array}$ \\
\hline $\mathrm{HSB}-122 \mathrm{~A}$ & 85.8 & 94.8 & 6.8 & Hvorslev & Falling Head & Sirrine. 1988 \\
\hline HSB-132C & 60.2 & 69.2 & 0.22 & Hvorslev & \begin{tabular}{|l} 
Rising Head \\
\end{tabular} & Sirrine. 1988 \\
\hline HSB-132C & 60.2 & 69.2 & 0.28 & Hvorslev & \begin{tabular}{|l} 
Falling Head \\
\end{tabular} & Sirrine. 1988 \\
\hline HSB-139A & 134.4 & 143.4 & 3.82 & Hvorslev & Falling Head & Sirrinc. 1988 \\
\hline HSB-140A & 143 & 153 & 12 & Bouwer-Rice 1976 & Rising Head & $\begin{array}{l}\text { WEGS. } \\
1991 \\
\end{array}$ \\
\hline HSB-141A & 162 & 172 & 1.9 & Bouwer-Rice 1976 & Rising Head & \begin{tabular}{|l|} 
WEGS. \\
1991 \\
\end{tabular} \\
\hline
\end{tabular}


Appendix C-2. Permeability Values Recorded from Slug Tests (Continued)

\begin{tabular}{|c|c|c|c|c|c|c|}
\hline$\cdot$ & $\begin{array}{c}\text { Screen } \\
\text { Top } \\
\text { (ft b.g.l.) }\end{array}$ & $\begin{array}{c}\text { Screen } \\
\text { Bottom } \\
\text { (ft b.g.l.) }\end{array}$ & $\begin{array}{c}\text { Permeability } \\
\text { (ft/day) }\end{array}$ & Solution Method & Test Type & Reference $^{1}$ \\
\hline
\end{tabular}

\begin{tabular}{|l|r|r|r|r|l|l|}
\hline HSB-142C & 30 & 40 & 0.6 & Bouwer-Rice 1976 & Rising Head & $\begin{array}{l}\text { WEGS. } \\
1991\end{array}$ \\
\hline HSB-143C & 41 & 51 & 2.4 & Bouwer-Rice 1976 & Rising Head & $\begin{array}{l}\text { WEGS. } \\
1991\end{array}$ \\
\hline HSB-144A & 145 & 155 & 0.22 & Bouwer-Rice 1976 & Rising Head & $\begin{array}{l}\text { WEGS. } \\
1991\end{array}$ \\
\hline HSB-145C & 59 & 69 & 0.38 & Bouwer-Rice 1976 & Rising Head & $\begin{array}{l}\text { WEGS. } \\
1991\end{array}$ \\
\hline HSB-146A & 154 & 164 & 9.4 & Bouwer-Rice 1976 & Rising Head & $\begin{array}{l}\text { WEGS. } \\
1991\end{array}$ \\
\hline HSB-148C & 80 & 90 & 1.8 & Bouwer-Rice 1976 & Rising Head & $\begin{array}{l}\text { WEGS. } \\
1991\end{array}$ \\
\hline HSB-151C & 31 & 41 & 0.8 & Bouwer-Rice 1976 & Rising Head & $\begin{array}{l}\text { WEGS. } \\
1991\end{array}$ \\
\hline HSB-152C & 29 & 59 & 0.8 & Bouwer-Rice 1976 & Rising Head & $\begin{array}{l}\text { WEGS. } \\
1991\end{array}$ \\
\hline HSL-6AA & 246 & 266 & 4.2 & Bouwer-Rice 1976 & Falling Head & $\begin{array}{l}\text { WSRC. } \\
1995 \mathrm{a}\end{array}$ \\
\hline HSL-6AA & 246 & 266 & 6.7602 & Bouwer-Rice 1976 & Rising Head & $\begin{array}{l}\text { WSRC. } \\
1995 \mathrm{a}\end{array}$ \\
\hline LAC-5DL & 53.6 & 63.6 & 0.61 & Bouwer-Rice 1976 & Rising Head & $\begin{array}{l}\text { WSRC. } \\
\text { 1996a }\end{array}$ \\
\hline LAC-6DL & 52 & 62 & 1.33 & Bouwer-Rice 1976 & Rising Head & $\begin{array}{l}\text { WSRC. } \\
1996 \mathrm{a}\end{array}$ \\
\hline LAC-7DL & 52 & 62 & 0.27 & Bouwer-Rice 1976 & Rising Head & $\begin{array}{l}\text { WSRC. } \\
1996 \mathrm{a}\end{array}$ \\
\hline LAC-8DL & 43.6 & 53.6 & 0.74 & Bouwer-Rice 1976 & Rising Head & $\begin{array}{l}\text { WSRC. } \\
1996 \mathrm{a}\end{array}$ \\
\hline LCO-5A & 190 & 200 & 0.1 & Bouwer-Rice 1976 & Rising Head & $\begin{array}{l}\text { WSRC. } \\
1996 \mathrm{a}\end{array}$ \\
\hline LCO-5DL & 45.4 & 55.4 & 4.62 & Bouwer-Rice 1976 & Rising Head & $\begin{array}{l}\text { WSRC. } \\
1996 \mathrm{a}\end{array}$ \\
\hline LCO-8DL & 55 & 65 & 12.17 & Bouwer-Rice 1976 & Rising Head & $\begin{array}{l}\text { WSRC. } \\
1996 \mathrm{a}\end{array}$ \\
\hline YSC-1C & 65 & 75 & 2.4 & Bouwer-Rice & Rising Head & $\begin{array}{l}\text { WEGS. } \\
1990\end{array}$ \\
\hline
\end{tabular}

\section{Notes:}

ft b.g.l. - feet below ground level

ft/day - feet per day

1 - Detailed description of references in Appendix D 
WSRC-TR-98-00285. Rev. 0. Hydrogeological and Groundwater Model for C. K. L. and P Areas

Appendix C-3. Permeability Values Recorded from Laboratory Tests

\begin{tabular}{|c|c|c|c|c|c|}
\hline & $\begin{array}{c}\text { Interval } \\
\text { Top } \\
\text { (ft b.g.l.) }\end{array}$ & $\begin{array}{c}\text { Interval } \\
\text { Bottom } \\
\text { (ft b.g.l.) }\end{array}$ & $\begin{array}{c}\text { Permeability- } \\
\text { vertical } \\
\text { (ft/day) }\end{array}$ & $\begin{array}{c}\text { Permeability- } \\
\text { horizontal } \\
\text { (ft/day) }\end{array}$ & Reference $^{\text {(fD }}$ \\
\hline
\end{tabular}

\begin{tabular}{|c|c|c|c|c|c|}
\hline$\widehat{B G O-3 A}$ & 162 & 164 & $1.14 \mathrm{E}-05$ & $2.10 \mathrm{E}-05$ & Amidon. 1995 \\
\hline BGO-3A & 266.1 & 267 & $1.40 \mathrm{E}-04$ & $2.30 \mathrm{E}-04$ & Amidon. 1995 \\
\hline BGO-9AA & 62 & 63.5 & $5.68 \mathrm{E}-05$ & $2.07 \mathrm{E}-04$ & WSRC. 1992 \\
\hline BGO-9AA & 137.4 & 137.7 & $1.38 \mathrm{E}-01$ & $1.00 \mathrm{E}-01$ & Core Laboratories. 1995 \\
\hline BGO-9AA & 142 & 142.3 & $2.27 \mathrm{E}-02$ & $2.69 \mathrm{E}-02$ & Core Laboratories. 1995 \\
\hline BGO-9AA & 158.7 & 158.8 & 3.49E-01 & $2.08 \mathrm{E}-02$ & Core Laboratories. 1995 \\
\hline BGO-9AA & 222 & 223.5 & 7.67E-05 & $1.76 \mathrm{E}-03$ & WSRC. 1992a \\
\hline $\mathrm{BGO}-10 \mathrm{~A}$ & 220 & 221.5 & $3.12 \mathrm{E}-06$ & $5.96 \mathrm{E}-05$ & WSRC. 1992a \\
\hline$\overline{\mathrm{BGO}-20 \mathrm{AA}}$ & 268 & 270 & $4.26 \mathrm{E}-06$ & $1.22 \mathrm{E}-02$ & RUST. 1996 \\
\hline BGO-39A & 280.5 & 282.5 & $1.36 \mathrm{E}-03$ & $6.53 \mathrm{E}-03$ & RUST. 1996 \\
\hline $\mathrm{BGO}-41 \mathrm{~A}$ & 88 & 90 & $9.66 \mathrm{E}-02$ & $8.52 \mathrm{E}-04$ & WSRC. 1992a \\
\hline BGO-41A & 164 & 166 & $2.84 \mathrm{E}-05$ & $3.69 \mathrm{E}-04$ & WSRC. 1992a \\
\hline BGO-43AA & 185 & 187 & $8.80 \mathrm{E}-06$ & $2.44 \mathrm{E}-05$ & WSRC. 1992a \\
\hline BGO-44AA & 226 & 227.5 & $3.41 \mathrm{E}-02$ & $2.36 \mathrm{E}-01$ & WSRC. 1992a \\
\hline BGO-45A & 75 & 76.8 & $5.40 \mathrm{E}-05$ & $7.10 \mathrm{E}-05$ & WSRC. 1992a \\
\hline BGO-45A & 144 & 145 & $2.04 \mathrm{E}-04$ & $1.28 \mathrm{E}-04$ & WSRC. 1992a \\
\hline BGO-47A & 145.5 & 147 & $3.41 \mathrm{E}-03$ & $5.68 \mathrm{E}-03$ & WSRC. 1992a \\
\hline BGO-49A & 75 & 77 & $3.70 \mathrm{E}-08$ & $5.20 \mathrm{E}-05$ & WSRC. 1992a \\
\hline BGO-51AA & 298 & 299.75 & $2.27 \mathrm{E}-05$ & $1.11 \mathrm{E}-05$ & Amidon. 1995 \\
\hline BGO-53AA & 265 & 267 & $2.27 \mathrm{E}-05$ & $2.84 \mathrm{E}-05$ & RUST. 1996 \\
\hline BGT-9 & 72 & 74 & $8.24 \mathrm{E}-04$ & $1.70 \mathrm{E}-03$ & RUST. 1996 \\
\hline \begin{tabular}{|l|} 
BGT-9 \\
\end{tabular} & 80 & 82 & $8.24 \mathrm{E}-04$ & $3.12 \mathrm{E}-03$ & RUST. 1996 \\
\hline BGT-11 & 70 & 71 & $3.12 \mathrm{E}-04$ & $9.90 \mathrm{E}-04$ & RUST. 1996 \\
\hline BGT-11 & 179.8 & 179.8 & $1.16 \mathrm{E}-04$ & $1.22 \mathrm{E}-04$ & RUST. 1996 \\
\hline BGT-18 & 175 & 177 & $5.96 \mathrm{E}-05$ & $1.56 \mathrm{E}-04$ & RUST. 1996 \\
\hline BGT-18 & 192 & 194 & 1.99E-03 & $4.54 \mathrm{E}-03$ & RUST. 1996 \\
\hline BGT-22 & 55 & 57 & $5.68 \mathrm{E}-06$ & $3.12 \mathrm{E}-05$ & RUST. 1996 \\
\hline \begin{tabular}{|l|} 
BGT-22 \\
\end{tabular} & 165 & 167 & $8.52 \mathrm{E}-04$ & $1.85 \mathrm{E}-02$ & RUST, 1996 \\
\hline BGT-22 & 275 & 276 & $3.41 \mathrm{E}-05$ & & RUST. 1996 \\
\hline BGT-28 & 207.3 & 208.7 & $7.10 \mathrm{E}-05$ & $7.10 \mathrm{E}-04$ & RUST. 1996 \\
\hline$\overline{\text { BGT-47 }}$ & 108 & 109 & $2.84 \mathrm{E}-03$ & & RUST, 1996 \\
\hline BGT-47 & 178 & 179 & $5.68 \mathrm{E}-03$ & $1.68 \mathrm{E}-02$ & RUST, 1996 \\
\hline BGT-53 & 88 & 90 & $5.11 \mathrm{E}-05$ & $1.70 \mathrm{E}-05$ & RUST, 1996 \\
\hline BGT-53 & 314 & 315.6 & $1.42 \mathrm{E}-05$ & $1.33 \mathrm{E}-05$ & RUST. 1996 \\
\hline BGT-61 & 102 & 104 & $1.42 \mathrm{E}-05$ & $4.26 \mathrm{E}-05$ & RUST, 1996 \\
\hline BGT-61 & 178 & 179.1 & $7.67 \mathrm{E}-06$ & $8.52 \mathrm{E}-06$ & RUST. 1996 \\
\hline BGT-67 & 57 & 59 & $6.82 \mathrm{E}-02$ & $3.41 \mathrm{E}-03$ & RUST. 1996 \\
\hline BGT-67 & 112 & 113 & 7.67E-05 & $1.16 \mathrm{E}-05$ & RUST. 1996 \\
\hline BGX-1A & 80 & 82 & $3.41 \mathrm{E}-06$ & $2.53 \mathrm{E}-05$ & WSRC. 1991a \\
\hline$B G X-2 B$ & 75 & 77 & $4.26 \mathrm{E}-06$ & $1.99 \mathrm{E}-05$ & WSRC. 1991a \\
\hline $\mathrm{BGX}-2 \mathrm{~B}$ & 156 & 156.8 & $1.85 \mathrm{E}-05$ & $3.98 \mathrm{E}-05$ & WSRC. 199la \\
\hline BGX-4A & 65 & 67 & $8.24 \mathrm{E}-06$ & $1.70 \mathrm{E}-05$ & WSRC. 199la \\
\hline BGX-7D & 123 & 124.5 & $6.53 \mathrm{E}-05$ & & WSRC. 1992a \\
\hline
\end{tabular}


Appendix C-3. Permeability Values Recorded from Laboratory Tests (Continued)

\begin{tabular}{|c|c|c|c|c|c|}
\hline Well ID & $\begin{array}{c}\text { Interval } \\
\text { Top } \\
\text { (ft b.g.l.) }\end{array}$ & $\begin{array}{c}\text { Interval } \\
\text { Bottom } \\
\text { (ft b.g.l.) }\end{array}$ & $\begin{array}{c}\text { Permeability- } \\
\text { vertical } \\
\text { (ft/day) }\end{array}$ & $\begin{array}{c}\text { Permeability- } \\
\text { horizontal } \\
\text { (ft/day) }\end{array}$ & Reference ${ }^{l}$ \\
\hline
\end{tabular}

\begin{tabular}{|c|c|c|c|c|c|}
\hline BGX-9D & 70 & 70.8 & $9.66 \mathrm{E}-05$ & $3.41 \mathrm{E}-04$ & WSRC. 1991a \\
\hline BGX-9D & 102.5 & 104.5 & $1.25 \mathrm{E}-04$ & $4.54 \mathrm{E}-04$ & WSRC. 1992a \\
\hline$B G X-11 D$ & 94 & 96 & $1.14 \mathrm{E}-03$ & & WSRC. 1992a \\
\hline$B G X-11 D$ & 154 & 156 & $1.87 \mathrm{E}-05$ & $9.09 \mathrm{E}-05$ & WSRC. 1992a \\
\hline CPC-1 & 137.3 & 137.6 & $3.42 \mathrm{E}+00$ & $1.48 \mathrm{E}+00$ & Core Laboratories. 1995 \\
\hline FAC-ISB & 170 & 172 & $3.12 \mathrm{E}-05$ & $2.64 \mathrm{E}-04$ & WSRC. 1992b \\
\hline FCH-1 & 54.8 & 56.3 & $3.69 \mathrm{E}-02$ & $1.09 \mathrm{E}-01$ & WSRC. 1993 \\
\hline $\mathrm{FCH}-1$ & 104.8 & 107.8 & $2.06 \mathrm{E}-05$ & & WSRC. 1993 \\
\hline FCH-1 & 145.8 & 146.8 & $8.78 \mathrm{E}-04$ & $1.17 \mathrm{E}-03$ & WSRC, 1993 \\
\hline FCH-1 & 169.8 & 170.8 & $1.02 \mathrm{E}-03$ & & WSRC. 1993 \\
\hline $\mathrm{FCH}-1$ & 208.8 & 211.8 & $2.07 \mathrm{E}-05$ & $2.06 \mathrm{E}-05$ & WSRC. 1993 \\
\hline $\mathrm{FCH}-1$ & 260.3 & 261.8 & $7.29 \mathrm{E}-02$ & & WSRC, 1993 \\
\hline $\mathrm{FCH}-2$ & 57.9 & 59.4 & $9.46 \mathrm{E}-05$ & $2.25 \mathrm{E}-04$ & WSRC. 1993 \\
\hline FCH-2 & 80.1 & 83.1 & $2.26 \mathrm{E}-05$ & & WSRC, 1993 \\
\hline $\mathrm{FCH}-2$ & 135.7 & 138.7 & $1.94 \mathrm{E}-05$ & $2.55 \mathrm{E}-05$ & WSRC. 1993 \\
\hline $\mathrm{FCH}-2$ & 150.1 & 153.1 & $2.24 \mathrm{E}-05$ & & WSRC. 1993 \\
\hline FCH-2 & 205.7 & 208.7 & $2.38 \mathrm{E}-05$ & $2.16 \mathrm{E}-05$ & WSRC, 1993 \\
\hline $\mathrm{FCH}-2$ & 229.4 & 230.9 & $1.60 \mathrm{E}-04$ & & WSRC. 1993 \\
\hline $\mathrm{FCH}-3$ & 40.8 & 41.9 & $1.46 \mathrm{E}-04$ & $2.90 \mathrm{E}-04$ & WSRC, 1993 \\
\hline $\mathrm{FCH}-3$ & 104.8 & 107.8 & $6.64 \mathrm{E}-05$ & & WSRC. 1993 \\
\hline FCH-3 & 130.9 & 132.2 & $1.52 \mathrm{E}-03$ & $1.60 \mathrm{E}-03$ & WSRC. 1993 \\
\hline FCH-3 & 174.8 & 176 & $1.55 \mathrm{E}-03$ & & WSRC. 1993 \\
\hline FCH-3 & 199.2 & 202.2 & $6.36 \mathrm{E}-05$ & $6.90 \mathrm{E}-05$ & WSRC. 1993 \\
\hline $\mathrm{FCH}-3$ & 265.1 & 266.2 & $2.05 \mathrm{E}-04$ & & WSRC, 1993 \\
\hline $\mathrm{FCH}-4$ & 33.1 & 34.7 & $9.20 \mathrm{E}-05$ & $2.24 \mathrm{E}-04$ & WSRC. 1993 \\
\hline $\mathrm{FCH}-4$ & 103.9 & 106.9 & $2.98 \mathrm{E}-05$ & & WSRC, 1993 \\
\hline $\mathrm{FCH}-4$ & 120 & 122.5 & $1.62 \mathrm{E}-05$ & $2.11 \mathrm{E}-05$ & WSRC, 1993 \\
\hline $\mathrm{FCH}-4$ & 174.9 & 177.4 & $1.86 \mathrm{E}-05$ & & WSRC. 1993 \\
\hline $\mathrm{FCH}-4$ & 190.5 & 193.5 & $2.67 \mathrm{E}-05$ & $3.27 \mathrm{E}-05$ & WSRC, 1993 \\
\hline $\mathrm{FCH}-4$ & 262.7 & 264.3 & $1.58 \mathrm{E}-04$ & & WSRC. 1993 \\
\hline $\mathrm{FCH}-5$ & 90 & 93 & $3.01 \mathrm{E}-05$ & & WSRC, 1993 \\
\hline $\mathrm{FCH}-5$ & 122.2 & 124.2 & $1.10 \mathrm{E}+00$ & $1.52 \mathrm{E}+00$ & WSRC, 1993 \\
\hline $\mathrm{FCH}-5$ & 160 & 162 & $1.31 \mathrm{E}+00$ & & WSRC. 1993 \\
\hline $\mathrm{FCH}-5$ & 191.2 & 194.2 & $2.76 \mathrm{E}-05$ & $3.24 \mathrm{E}-05$ & WSRC. 1993 \\
\hline $\mathrm{FCH}-5$ & 259 & 259.5 & $1.15 \mathrm{E}-04$ & & WSRC. 1993 \\
\hline $\mathrm{FCH}-6$ & 105.7 & 108.2 & $1.86 \mathrm{E}-04$ & & WSRC. 1993 \\
\hline FCH-6 & 170.7 & 171.7 & $1.11 \mathrm{E}-03$ & & WSRC. 1993 \\
\hline $\mathrm{FCH}-6$ & 268.2 & 269.7 & $9.40 \mathrm{E}-04$ & & WSRC. 1993 \\
\hline FIW-IMC & 104 & 106 & $4.30 \mathrm{E}-05$ & $1.50 \mathrm{E}-03$ & AT\&E. 1992 \\
\hline FIW-2MA & 103.5 & 105.5 & $3.70 \mathrm{E}-05$ & $2.30 \mathrm{E}-02$ & AT\&E. 1992 \\
\hline FIW-2MA & 171.2 & 172 & $2.10 \mathrm{E}-05$ & $4.30 \mathrm{E}-05$ & AT\&E, 1992 \\
\hline FSB-89C & 97 & 97.7 & $8.83 \mathrm{E}-05$ & & AT\&E, 1987 \\
\hline FSB-9IC & 110 & 110.7 & $5.40 \mathrm{E}-05$ & & AT\&E. 1987 \\
\hline
\end{tabular}


WSRC-TR-98-00285. Rev. 0. Hydrogeological and Groundwater Model for C. K. L. and P Areas

C-9

Appendix C-3. Permeability Values Recorded from Laboratory Tests (Continued)

\begin{tabular}{|c|c|c|c|c|c|}
\hline Well ID & $\begin{array}{c}\text { Interval } \\
\text { Top } \\
\text { (ft b.g.l.) }\end{array}$ & $\begin{array}{c}\text { Interval } \\
\text { Bottom } \\
\text { (ft b.g.l.) }\end{array}$ & $\begin{array}{c}\text { Permeability- } \\
\text { vertical } \\
\text { (ft/day) }\end{array}$ & $\begin{array}{c}\text { Permeability- } \\
\text { horizontal } \\
\text { (ft/day) }\end{array}$ & Reference $^{{ }^{\prime}}$ \\
\hline
\end{tabular}

\begin{tabular}{|c|c|c|c|c|c|}
\hline FSB-96A & 117 & 119.5 & & $8.43 \mathrm{E}-04$ & RUST. 1994 \\
\hline FSB-96A & 172 & 173 & & $1.05 \mathrm{E}-05$ & RUST. 1994 \\
\hline FSB-97A & 126.33 & 127.08 & 1.15E-04 & & AT\&E. 1987 \\
\hline FSB-97A & 127.5 & 128.25 & $1.87 \mathrm{E}-05$ & & AT\&E. 1987 \\
\hline FSB-101A & 166.5 & 167 & $3.81 \mathrm{E}-06$ & & AT\&E. 1987 \\
\hline FSB-114A & 138.5 & 140 & & $5.96 \mathrm{E}-05$ & WEGS. 1991 \\
\hline FSB-120A & 168 & 168.4 & & $8.50 \mathrm{E}-03$ & WEGS. 1991 \\
\hline FSB-122C & 70 & 72 & $9.00 \mathrm{E}-04$ & & WEGS. 1991 \\
\hline $\mathrm{HCH}-1$ & 55 & 58 & $2.28 \mathrm{E}-01$ & $2.58 \mathrm{E}-01$ & WSRC. 1993 \\
\hline $\mathrm{HCH}-1$ & 155 & 156.5 & 4.32E-02 & $1.01 \mathrm{E}-01$ & WSRC. 1993 \\
\hline $\mathrm{HCH}-1$ & 270 & 273 & $4.54 \mathrm{E}-05$ & $5.42 \mathrm{E}-05$ & WSRC. 1993 \\
\hline $\mathrm{HCH}-2$ & 65 & 68 & $1.37 \mathrm{E}-01$ & $1.79 \mathrm{E}-01$ & WSRC. 1993 \\
\hline $\mathrm{HCH}-2$ & 145 & 148 & $1.47 \mathrm{E}-04$ & $1.76 \mathrm{E}-04$ & WSRC. 1993 \\
\hline $\mathrm{HCH}-2$ & 276.3 & 278 & $3.12 \mathrm{E}-04$ & $4.63 \mathrm{E}-04$ & WSRC. 1993 \\
\hline $\mathrm{HCH}-3$ & 85 & 88 & $1.54 \mathrm{E}-03$ & $2.09 \mathrm{E}-03$ & WSRC. 1993 \\
\hline $\mathrm{HCH}-3$ & 140 & 141.5 & $1.10 \mathrm{E}-03$ & $1.16 \mathrm{E}-03$ & WSRC. 1993 \\
\hline $\mathrm{HCH}-3$ & 255 & 258 & $4.80 \mathrm{E}-03$ & $1.10 \mathrm{E}-02$ & WSRC. 1993 \\
\hline $\mathrm{HCH}-4$ & 80 & 83 & $7.10 \mathrm{E}-05$ & $8.80 \mathrm{E}-05$ & WSRC. 1993 \\
\hline $\mathrm{HCH}-4$ & 230 & 231.6 & $2.52 \mathrm{E}-04$ & $3.46 \mathrm{E}-04$ & WSRC. 1993 \\
\hline $\mathrm{HCH}-5$ & 140 & 142.5 & $1.23 \mathrm{E}-01$ & $1.58 \mathrm{E}-01$ & WSRC. 1993 \\
\hline $\mathrm{HCH}-5$ & 271.6 & 273.4 & $2.75 \mathrm{E}-04$ & $3.24 \mathrm{E}-04$ & WSRC. 1993 \\
\hline HIW-1MC & 79 & 81 & $5.40 \mathrm{E}-04$ & $1.40 \mathrm{E}-02$ & AT\&E. 1992 \\
\hline HIW-2A & 78 & 80 & $1.02 \mathrm{E}-05$ & $1.14 \mathrm{E}-03$ & RUST, 1994 \\
\hline HIW-2A & 165 & 165.4 & $2.84 \mathrm{E}-04$ & $3.41 \mathrm{E}-04$ & RUST. 1994 \\
\hline HMD-1C & 132 & 134 & $1.33 \mathrm{E}-06$ & $5.96 \mathrm{E}-06$ & WSRC. 199lb \\
\hline HMD-2C & 117 & 118.6 & $1.14 \mathrm{E}-06$ & $5.40 \mathrm{E}-06$ & WSRC. 199lb \\
\hline HMD-3C & 107.3 & 108.6 & $1.90 \mathrm{E}-03$ & $3.41 \mathrm{E}-03$ & WSRC. 199lb \\
\hline HMD-4C & 29 & 31 & $9.09 \mathrm{E}-03$ & $7.67 \mathrm{E}-02$ & WSRC. 1991b \\
\hline HSB-TB & 112 & 112.6 & $5.30 \mathrm{E}-01$ & $1.97 \mathrm{E}-01$ & Core Laboratories. 1995 \\
\hline HSB-TB & 127 & 127.3 & $1.40 \mathrm{E}-01$ & $5.29 \mathrm{E}-01$ & Core Laboratories. 1995 \\
\hline HSB-TB & 151 & 151.3 & $4.00 \mathrm{E}-02$ & $1.00 \mathrm{E}-01$ & Core Laboratories. 1995 \\
\hline HSB-TB & 154.4 & 154.6 & & $1.73 \mathrm{E}+00$ & Core Laboratories. 1995 \\
\hline HSB-69A & 120 & 120.8 & $1.52 \mathrm{E}-04$ & & AT\&E. 1988 \\
\hline HSB-107C & 60.9 & 62 & $1.75 \mathrm{E}-04$ & & WSRC. 1990 \\
\hline HSB-117A & 111.67 & 112.34 & $1.81 \mathrm{E}-03$ & & AT\&E. 1988 \\
\hline HSB-118A & 128 & 129 & $1.57 \mathrm{E}-05$ & & WSRC. $1991 \mathrm{c}$ \\
\hline $\mathrm{HSB}-119 \mathrm{~A}$ & 141.1 & 141.5 & 9.34E-04 & & WSRC. 1991c \\
\hline HSB-120A & 155 & 155.5 & 2.72E-03 & & WSRC. 1991c \\
\hline HSB-121A & 164 & 165 & $7.51 \mathrm{E}-05$ & & WSRC. $1991 \mathrm{c}$ \\
\hline HSB-122A & 65 & 65.5 & $7.40 \mathrm{E}-04$ & & WSRC. 199lc \\
\hline HSB-122A & 161 & 161.5 & $1.79 \mathrm{E}-05$ & & WSRC. $1991 \mathrm{l}$ \\
\hline HSB-123A & 150.5 & 151.5 & $6.69 \mathrm{E}-04$ & & WSRC. 1991c \\
\hline HSB-139A & 115 & 115.6 & $2.20 \mathrm{E}-04$ & & AT\&E. 1988 \\
\hline
\end{tabular}


C-10 WSRC-TR-98-00285. Rev. 0. Hydrogeological and Groundwater Model for C. K. L. and P Areas

Appendix C-3. Permeability Values Recorded from Laboratory Tests (Continued)

\begin{tabular}{|c|c|c|c|c|c|}
\hline Well ID & $\begin{array}{c}\text { Interval } \\
\text { Top } \\
\text { (ft b.g.l.) }\end{array}$ & $\begin{array}{c}\text { Interval } \\
\text { Bottom } \\
\text { (ft b.g.l.) }\end{array}$ & $\begin{array}{c}\text { Permeability- } \\
\text { vertical } \\
\text { (ft/day) }\end{array}$ & $\begin{array}{c}\text { Permeability- } \\
\text { horizontal } \\
\text { (ft/day) }\end{array}$ & Reference $^{l}$ \\
\hline
\end{tabular}

\begin{tabular}{|c|c|c|c|c|c|}
\hline HSB-140A & 124 & 126 & 1.64E-04 & & WEGS. 1991 \\
\hline HSB-146A & 131 & 132 & $3.40 \mathrm{E}-04$ & & WEGS. 1991 \\
\hline HSB-148C & 66 & 68 & $1.09 \mathrm{E}-03$ & & WEGS. 1991 \\
\hline IDP-3A & 261.25 & 262.75 & $3.41 \mathrm{E}-02$ & & Law Engineering. 1988 \\
\hline IDQ-3A & 49 & 51 & $2.04 \mathrm{E}-04$ & & Law Engineering. 1988 \\
\hline IDQ-3A & 75 & 77 & $7.83 \mathrm{E}-03$ & & Law Engineering. 1988 \\
\hline IDQ-3A & 172 & 174 & $4.83 \mathrm{E}-05$ & & Law Engineering. 1988 \\
\hline LCO-5A & 18.1 & 19.9 & $9.94 \mathrm{E}-04$ & $3.41 \mathrm{E}-03$ & WSRC. 1996a \\
\hline MWD-1A & 115.5 & 116 & $7.04 \mathrm{E}-05$ & $2.69 \mathrm{E}-04$ & AT\&E. 1988 \\
\hline OFS-1SB & 67 & 68.65 & $3.41 \mathrm{E}-05$ & & Amidon. 1995 \\
\hline OFS-2SB & 108 & 108.3 & & $3.60 \mathrm{E}-02$ & Core Laboratories. 1995 \\
\hline OFS-2SB & 114 & 114.2 & $7.60 \mathrm{E}-02$ & $1.32 \mathrm{E}-03$ & Core Laboratories. 1995 \\
\hline OFS-3SB & 63 & 65 & 6.82E-05 & $1.70 \mathrm{E}-01$ & Amidon. 1995 \\
\hline OFS-3SB & 135 & 137 & $4.80 \mathrm{E}-06$ & $8.00 \mathrm{E}-06$ & Amidon. 1995 \\
\hline OFS-4SB & 25.2 & 25.5 & & $6.04 \mathrm{E}+00$ & \begin{tabular}{|l} 
Core Laboratories. 1995 \\
\end{tabular} \\
\hline OFS-4SB & 45 & 47 & $6.25 \mathrm{E}-04$ & $5.40 \mathrm{E}-03$ & Amidon. 1995 \\
\hline OFS-4SB & 47.5 & 47.8 & & $7.50 \mathrm{E}-01$ & Core Laboratories, 1995 \\
\hline OFS-4SB & 56 & 56.3 & $2.77 \mathrm{E}+01$ & $5.80 \mathrm{E}+00$ & Core Laboratories. 1995 \\
\hline OFS-4SB & 78 & 78.4 & & $2.17 \mathrm{E}-01$ & Core Laboratories, 1995 \\
\hline OFS-4SB & 85.6 & 86 & $1.60 \mathrm{E}-03$ & & Core Laboratories. 1995 \\
\hline OFS-4SB & 98.4 & 98.75 & $5.37 \mathrm{E}-03$ & $1.80 \mathrm{E}-01$ & Core Laboratories, 1995 \\
\hline OFS-4SB & 109 & 109.35 & $1.89 \mathrm{E}-01$ & & Core Laboratories. 1995 \\
\hline OFS-4SB & 114.5 & 115 & $1.93 \mathrm{E}-03$ & & Core Laboratories. 1995 \\
\hline OFS-4SB & 126.4 & 126.7 & & $2.49 \mathrm{E}+00$ & Core Laboratories. 1995 \\
\hline OFS-4SB & 135 & 136.5 & $1.14 \mathrm{E}-05$ & $6.53 \mathrm{E}-05$ & Amidon, 1995 \\
\hline OFS-4SB & 143 & 143.3 & & $7.72 \mathrm{E}+00$ & Core Laboratories. 1995 \\
\hline OFS-4SB & 167 & 167.3 & & $2.41 \mathrm{E}+01$ & Core Laboratories. 1995 \\
\hline OFS-4SB & 175.7 & 176 & & $3.18 \mathrm{E}+01$ & \begin{tabular}{|l} 
Core Laboratories. 1995 \\
\end{tabular} \\
\hline OFS-5SB & 27 & 28.9 & $1.42 \mathrm{E}+00$ & $1.42 \mathrm{E}+00$ & Amidon. 1995 \\
\hline OFS-5SB & 56.5 & 56.8 & & $1.11 \mathrm{E}+01$ & Core Laboratories. 1995 \\
\hline OFS-5SB & 108 & 108.3 & $4.27 \mathrm{E}-01$ & $1.22 \mathrm{E}-01$ & Core Laboratories, 1995 \\
\hline OFS-5SB & 108.6 & 109.6 & $4.50 \mathrm{E}-06$ & $1.79 \mathrm{E}-05$ & Amidon, 1995 \\
\hline OFS-5SB & 129.5 & 129.8 & $3.62 \mathrm{E}+01$ & $2.92 \mathrm{E}+01$ & Core Laboratories. 1995 \\
\hline OFS-5SB & 158.2 & 159.2 & & $3.26 \mathrm{E}+01$ & \begin{tabular}{|l|} 
Core Laboratories. 1995 \\
\end{tabular} \\
\hline P-18TA & 180 & 182 & $7.60 \mathrm{E}-05$ & $5.60 \mathrm{E}-05$ & Bledsoe, 1987 \\
\hline $\mathrm{P}-18 \mathrm{TA}$ & 261 & 263 & $3.90 \mathrm{E}-02$ & $8.80 \mathrm{E}-02$ & Bledsoe, 1987 \\
\hline P-18TA & 410 & 412 & 9.00E-05 & $1.00 \mathrm{E}-04$ & Bledsoe. 1987 \\
\hline P-I8TA & 643 & 645 & $6.80 \mathrm{E}-05$ & & Bledsoe. 1987 \\
\hline P-19TA & 190 & 192.9 & $3.40 \mathrm{E}-05$ & $7.90 \mathrm{E}-03$ & Bledsoe. 1987 \\
\hline P-19TA & 282 & 283 & $9.60 \mathrm{E}-03$ & $9.90 \mathrm{E}-02$ & Bledsoe. 1987 \\
\hline P-19TA & 355 & 358 & $3.90 \mathrm{E}-05$ & $5.90 \mathrm{E}-05$ & Bledsoe. 1987 \\
\hline P-19TA & 495 & 497 & $8.50 \mathrm{E}-05$ & $6.50 \mathrm{E}-03$ & Bledsoe, 1987 \\
\hline P-19TA & 548 & 550 & $1.90 \mathrm{E}-02$ & $7.90 \mathrm{E}-03$ & Bledsoe. 1987 \\
\hline
\end{tabular}


WSRC-TR-98-00285, Rev. 0. Hydrogeological and Groundwater Model for C. K. L. and P Areas C-11

Appendix C-3. Permeability Values Recorded from Laboratory Tests (Continued)

\begin{tabular}{|c|c|c|c|c|c|}
\hline Well ID & $\begin{array}{c}\text { Interval } \\
\text { Top } \\
\text { (ft h g })\end{array}$ & $\begin{array}{c}\text { Interval } \\
\text { Bottom } \\
\text { (ft b. g.l.) }\end{array}$ & $\begin{array}{c}\text { Permeability- } \\
\text { vertical } \\
\text { (ft/dav) }\end{array}$ & $\begin{array}{c}\text { Permeability- } \\
\text { horizontal } \\
\text { (ft/day) }\end{array}$ & Reference $^{l}$ \\
\hline
\end{tabular}

\begin{tabular}{|l|r|r|r|r|l|}
\hline P-21TA & 160 & 162 & $1.90 \mathrm{E}-03$ & $1.70 \mathrm{E}-02$ & PSI. 1986 \\
\hline P-21TA & 325 & 327 & $3.40 \mathrm{E}-01$ & $1.50 \mathrm{E}+00$ & PSI. 1986 \\
\hline P-21TA & 380 & 382 & $5.40 \mathrm{E}-02$ & $6.80 \mathrm{E}-01$ & PSI. 1986 \\
\hline P-21TA & 495 & 497 & $6.30 \mathrm{E}-04$ & $7.70 \mathrm{E}-04$ & PSI. 1986 \\
\hline P-21TA & 522 & 524 & $1.80 \mathrm{E}-05$ & $2.80 \mathrm{E}-05$ & PSI. 1986 \\
\hline P-21TA & 560 & 562 & $9.40 \mathrm{E}-05$ & $8.50 \mathrm{E}-05$ & PSI. 1986 \\
\hline P-22TA & 61 & 63 & $4.80 \mathrm{E}-04$ & $9.70 \mathrm{E}-04$ & PSI. 1986 \\
\hline P-22TA & 140 & 142 & $3.70 \mathrm{E}-04$ & $1.90 \mathrm{E}-04$ & PSI. 1986 \\
\hline P-22TA & 331 & 333 & $1.40 \mathrm{E}-04$ & $1.20 \mathrm{E}-04$ & Bledsoe. 1987 \\
\hline P-22TA & 390 & 392 & $1.02 \mathrm{E}-03$ & & PSI. 1986 \\
\hline P-22TA & 612 & 614 & $1.20 \mathrm{E}-04$ & $2.80 \mathrm{E}-04$ & PSI. 1986 \\
\hline P-23TA & 97 & 99 & $3.60 \mathrm{E}-04$ & & Bledsoe. 1987 \\
\hline P-23TA & 185 & 187 & $9.60 \mathrm{E}-05$ & $1.10 \mathrm{E}-04$ & Bledsoe. 1987 \\
\hline P-23TA & 224 & 226 & $4.20 \mathrm{E}-05$ & $3.60 \mathrm{E}-05$ & Bledsoe. 1987 \\
\hline P-23TA & 301 & 303 & $3.40 \mathrm{E}-05$ & $1.10 \mathrm{E}-01$ & Bledsoe. 1987 \\
\hline P-23TA & 361 & 363 & $9.60 \mathrm{E}-04$ & & Bledsoe. 1987 \\
\hline P-23TA & 401 & 403 & $1.10 \mathrm{E}-04$ & $2.40 \mathrm{E}-04$ & Bledsoe. 1987 \\
\hline YSC-1A & 65 & 67 & $7.38 \mathrm{E}-05$ & $8.24 \mathrm{E}-05$ & WEGS. 1990 \\
\hline YSC-1A & 113.1 & 113.7 & $1.48 \mathrm{E}-04$ & $4.54 \mathrm{E}-05$ & WEGS. 1990 \\
\hline YSC-1C & 59 & 60.9 & $1.25 \mathrm{E}-05$ & $5.96 \mathrm{E}-04$ & WEGS. 1990 \\
\hline YSC-1C & 113 & 114.5 & $2.58 \mathrm{E}-04$ & $3.98 \mathrm{E}-05$ & WEGS. 1990 \\
\hline YSC-2A & 121.8 & 122.6 & $2.61 \mathrm{E}-06$ & $0.00 \mathrm{E}+00$ & WEGS. 1990 \\
\hline YSC-3SB & 69 & 71 & $1.28 \mathrm{E}-05$ & $1.45 \mathrm{E}-05$ & WEGS, 1990 \\
\hline YSC-3SB & 127 & 128 & $4.54 \mathrm{E}-06$ & $5.11 \mathrm{E}-05$ & WEGS. 1990 \\
\hline YSC-4A & 71.3 & 72 & $1.73 \mathrm{E}-03$ & $8.80 \mathrm{E}-05$ & WEGS, 1990 \\
\hline YSC-4A & 130.3 & 130.8 & $1.82 \mathrm{E}-03$ & $0.00 \mathrm{E}+00$ & WEGS. 1990 \\
\hline YSC-4A & 140 & 141.1 & $2.67 \mathrm{E}-06$ & $0.00 \mathrm{E}+00$ & WEGS, 1990 \\
\hline YSC-5A & 54 & 55 & $1.62 \mathrm{E}-05$ & $4.26 \mathrm{E}-05$ & WEGS. 1990 \\
\hline YSC-5A & 108.3 & 108.6 & $1.16 \mathrm{E}-04$ & $5.34 \mathrm{E}-02$ & Core Laboratories. 1995 \\
\hline YSC-5A & 110.3 & 110.6 & $1.43 \mathrm{E}-01$ & $1.88 \mathrm{E}-01$ & Core Laboratories. 1995 \\
\hline YSC-5A & 136 & 137 & $1.39 \mathrm{E}-03$ & $1.59 \mathrm{E}-05$ & WEGS. 1990 \\
\hline
\end{tabular}

Notes:

ft b.g.l. - feet below ground level

ft/day - feet per day

1 - Detailed description of references in Appendix D 


\section{Appendix D. References}

Albenesius, P. W., Amidon, M. A.. and Gaughan. T. F., 1990. HSB 84A Pumping Test. WSRC-TR-90-0313, Westinghouse Savannah River Company. Aiken, SC 29808.

Amidon, M. A., 1995, Burial Ground Complex Field Investigation Preliminan Data Report \#l, WSRC-RP-94-1286, Westinghouse Savannah River Company, Aiken. SC 29808.

AT\&E, 1987, Laboratory Permeability Test Results "F" Area Seepage Basins Job No. 7781. Report No. 1721, Atlanta Testing and Engineering, Duluth, GA.

AT\&E, 1988, Report of Laboratory Testing, Savannah River Plant, Job No. 7778-C, Report No. 3473, Atlanta Testing and Engineering, Duluth, GA.

AT\&E, 1992, F\&H-Area Seepage Basins Injection Wells/G2049, Soil Laboratory Testing, Job Number 11360, Report Number 63535, Atlanta Testing and Engineering. Duluth. GA.

Bechtel, 1982, Vogtle Electric Generating Plant, Studies of Postulated Millett Fault. Bechtel.

Bledsoe, H.W., 1987, Savannah River Plant Baseline Hydrogeologic Investigation - Phase II, DPST-86-674, E.I. DuPont de Nemours and Company, Savannah River Laboratory. Aiken, SC.

CH2M Hill, 1989, Congaree Aquifer Test Savannah River Site. CH2M Hill. Reston. VA.

Core Laboratories. 1995, Core Analysis Report, Savannah River Site. Core Laboratories. Carrollton, TX.

Evans, E. K. and Parizek, R. R., 1991, Characterization of Hydraulic Conductivity. Heterogeneity in Tertiary Sediments within the General Separations Area. Pennsylvania State University, Department of Geosciences.

Falls, W. F., 1998, Well Locations and Hydrostratigraphic Picks from USGS Water Resources Investigation Report 97-4245, U. S. Geological Survey, Columbia. SC.

Harris, M. K., 1997, Locations of SRS Borings, Electronic file received from M. K. Harris. Westinghouse Savannah River Company, Aiken, SC 29808.

Law Engineering, 1988, Results of Soil Testing, Purchase Order Number: AX0798832. Law Engineering, Atlanta, GA.

PSI, 1986, Monitor Wells Hydrogeologic Study, Phase II, Savannah River Plant, Aiken, South Carolina, Service Subcontract AX-0681729, Professional Service Industries. Inc., Oak Brook, IL. 


\section{Appendix D. References (Continued)}

Rust, 1994, Central Shops Burning/Rubble Pit 63I-6G Soil Sampling Report (U). WSRCRP-94-0382, Rust Environment and Infrastructure Inc.. Aiken. SC.

Rust, 1996, Burial Ground Complex Field Investigation Preliminary Data Report \#2. WSRC-RP-96-060, Rust Environment and Infrastructure Inc., Aiken. SC.

S\&ME, 1988, Borehole Permeability Analyses Burial Ground Perimeter Wells. Soil and Materials Engineering, Inc., Columbia, SC 29203.

Sirrine, 1987, F-Area Compliance Monitoring Program Field Permeabiliț Tests. Sirrine Environmental Consultants, Greenville, SC.

Sirrine, 1988, Field Permeability Tests, H-Area Seepage Basins, Sirrine Environmental Consultants, Greenville, SC.

WEGS, 1990, Hydrogeologic Characterization of the Proposed Waste Solidification and Disposal Facility Site, Y-Area, Westinghouse Environmental and Geotechnical Services. Inc., Columbia, SC 29203.

WEGS, 1991, Summary of Well Installations and Aquifer Test Results F and H Seepage Basins Assessment $(U)$, Westinghouse Environmental and Geotechnical Services, Inc., Columbia, SC 29203.

Woodward-Clyde Consultants, 1985a, F-Area Seepage Basins Site Assessment Report Part 1: Groundwater, Woodward-Clyde Consultants, Plymouth Meeting, Pennsylvania.

Woodward-Clyde Consultants, 1985b, H-Area Seepage Basins Site Assessment Report Part I: Groundwater, Woodward-Clyde Consultants, Plymouth Meeting, Pennsylvania.

WSRC, 1989, Deep Corehole Project, Basic Data Report, Westinghouse Savannah River Company, Aiken, SC 29808.

WSRC, 1990, Application for a Hazardous Waste Part B Post Closure Care Permit Volume $V$, Book 2, Westinghouse Savannah River Company. Aiken, SC 29808.

WSRC, 1991a, Burial Ground Expansion(U) Hydrogeologic Characterization. WSRC-RP91-0866, Westinghouse Savannah River Company. Aiken, SC 29808.

WSRC, 1991b, Hydrogeologic Characterization Hazardous Waste/Mixed Waste Disposal Facility, WSRC-RP-91-0423, Westinghouse Savannah River Company, Aiken. SC 29808. 


\section{Appendix D. References (Continued)}

WSRC, 1991c, RCRA/CERCLA Integration Document for the H-Area Seepage Basins Groundwater Unit, WSRC-RP-91-1019. Westinghouse Savannah River Company. Aiken. SC 29808.

WSRC, 1991d, RCRA/CERCLA Integration Document for the F-Area Seepage Basins Groundwater Unit, WSRC-RP-91-1018. Westinghouse Savannah River Company. Aiken. SC 29808.

WSRC, 1991e, Sanitan Landfill Hydrogeologic Characterization. WSRC-TR-91-0565. Westinghouse Savannah River Company, Aiken, SC 29808.

WSRC, 1992a, Mixed Waste Management Facility and Old Burial Groundwater Monitoring Assessment Well Installations, WSRC-RP-92-0195, Westinghouse Savannah River Company, Aiken, SC 29808.

WSRC, 1992b, Hydrogeology of the F-Area and K-Area Acid Caustic Basins. WSRC-RP91504, Westinghouse Savannah River Company, Aiken, SC 29808.

WSRC, 1993, F- and H-Areas Inactive Process Sewer Lines Groundwater Assessment (U). WSRC-RP-93-0532, Westinghouse Savannah River Company, Aiken, SC 29808.

WSRC, 1993b, F-and H-Area Tank Farms Preliminary Characterization Part A: Phase 1 Report, WSRC-TR-93-197, Westinghouse Savannah River Company, Aiken. SC 29808.

WSRC, 1994, Confirmatory Drilling Project Final Report (U), WSRC-RP-94-0136. Westinghouse Savannah River Company. Aiken, SC 29808.

WSRC, 1995a, H-Area Tank 16 Monitoring Well Installation Field Report. WSRC-RP-950296, Westinghouse Savannah River Company, Aiken, SC 29808.

WSRC, 1995b, Summan Report for Aquifer Extraction (Pumping) Test Anclyses Aquifer IIB, F\&H Area Seepage Basins, Westinghouse Savannah River Company, Aiken. SC 29808.

WSRC, 1996a, RFI/RI Report L-Area Oil and Chemical Basin and L-Area Acid/Caustic Basin, WSRC-RP-95-0305, Westinghouse Savannah River Company, Aiken, SC 29808.

WSRC, 1996b, L- P-and R-Areas Bingham Pump Outage Pits Addendum to the Work Plan for K-Area Bingham Pump Outage Pit, WSRC-RP-96-0173, Westinghouse Savannah River Company, Aiken, SC 29808.

WSRC, 1996c, Field Activities Report, Chemicals, Metals, and Pesticides Pits, Monitoring Well Installation (U), WSRC-RP-96-00121, Westinghouse Savannah River Company, Aiken, SC 29808. 
WSRC, 1996d, Environmental Protection Department's Well Inventory (U). ESH-EMS960488, Westinghouse Savannah River Company, Aiken. SC 29808.

WSRC, unknown, Hydrostratigraphic Picks for BGT Cores. Data received from M. Amidon, WSRC, Westinghouse Savannah River Company, Aiken. SC 29808. 


\section{Appendix E-1. Stream Base Flow Estimates Based on USGS Gauging Station Data}

Groundwater flow in upper aquifers at the Savannah River Site is recharge driven. with streams intercepting flow from higher elevations. Nearly all recharge within the CKLP reactor region discharges to streams within or bounding the same area. usually the nearest stream. For this type of groundwater flow system. recharge and discharge estimates. coupled with head measurements and confining unit leakance estimates, define the overall horizontal conductivities of upper aquifers required to calibrate a numerical flow model. Because conductivity data at the model scale are typically non-existent. stream base flow estimates are important model calibration targets. In this appendix, simple hydrograph separation techniques are used to estimate the long-term average rate of groundwater discharge to certain stream reaches within the CKLP reactor area.

The U. S. Geological Survey has monitored stream flows at numerous locations across the Savannah River Site for decades. The data are published annually for the preceding water year (Cooney and others, 1998, for example), and made available electronically from the United States NWIS-W data retrieval web site (http://h2o-nwisw.er.usgs.gov/nwis-w/US/). Figure E-1 illustrates the location and identification number of each USGS gauging station. Industrial discharges from SRS operations are monitored near outfalls by the USGS. separate from NPDES outfall monitoring conducted by SRS. Figures E-2, E-3 and E-4 show the relationship between USGS and NPDES gauging stations for the General Separations Area/C-Area, K-Area, and L- and P-Areas, respectively.

Given the locations of the USGS gauging stations, regional scale base flows are most easily estimated for the stream reaches and wetland areas enclosed by the polygons depicted in Figure E-5. For example, base flow between the headwaters of Meyers Branch and Road 9 is more conveniently estimated than base flow over the entire reach, because there is not a gauging station on Meyers Branch just above its confluence with Steel Creek. Similarly, base flow will be estimated for portions of Upper Three Runs and Steel Creek. On the other hand, gauging stations are located where Pen Branch and Fourmile Branch enter the Savannah River Swamp, so base flow for the entire drainage can be conveniently estimated.

Figure E-6 is an example hydrograph produced from USGS data for the two gauging stations located on Meyers Branch for water years 1993 through 1996. Station 021973561 is located at Road 9 and station 02197354 monitors the P007 outfall. Discharges to P007 are small relative to the total flow at Road 9. Not surprisingly, the downstream data exhibits a seasonal variation with elevated average flows occurring from late fall through early spring. Over 
shorter periods, individual rainfall events are readily observed as a step increase in daily flow followed by an exponential decline. Presumably these peaks are due to direct precipitation. surface runoff and subsurface stormflow. and not reflective of base flow.

Because downstream USGS gauging stations measure total stream flow, the base flow component must be separated from other contributors to a hydrograph of total flow. These include the direct precipitation, surface runoff and subsurface stormflow components mentioned above, as well as process water discharges to outfalls. Shirmohammadi and others (1984) observed that "daily values of precipitation and streamflow are not sufficient for detailed hydrograph analysis using traditional hydrograph separation techniques" and developed an approximate method for partitioning daily total streamflow data. such as that available from the USGS for SRS streams. Hydrograph separation for this project is accomplished with a simplified version of the approach of Shirmohammadi and others (1984). The following steps are applied to the time series of daily total stream flow:

1) Compute the average, $F_{a v g}$, of the downstream flow, $F$

2) Subtract outfall flows from the downstream flow leaving "natural" flow components. $F_{\text {natural }}$. For Steel Creek and Upper Three Runs, flow entering the polygonal area of interest from upstream is also subtracted.

3) Remove the remaining direct precipitation. surface runoff and subsurface stormflow components by creating a "clipped" time series, Fbase flow, according to

$F_{\text {base flow }}=\min \left[F_{\text {natural }}, 1.05 \times \max \left(F_{\text {natural, }}\right.\right.$ previous,$\left.\left.F_{\text {avg }}\right)\right]$

4) Smooth the base flow component. Fbase flow, over 4 water years. 1993 to 1996. for easier visualization using a running digital filter:

$\mathrm{F}_{\text {smooth }}=\left(\mathrm{F}_{\text {base flow }, \mathrm{i}-1}+\mathrm{F}_{\text {base flow }, \mathrm{i}}+\mathrm{F}_{\text {base flow }, \mathrm{i}+1}\right) / 3$

5) Average the smoothed base flow component, $F_{\text {smooth }}$, over the 4 water years from 1993 to 1996, producing $F_{\text {smthavg. }}$.

The third step is based on the assumption that the base flow component responds slowly to rainfall events, and therefore cannot increase very rapidly from one day to the next $5 \%$ or less). No restriction on the rate of decrease is imposed. The fourth step does not affect the average computed in the fifth step. 
The maximum rate of base flow increase. specified in step 3. was selected according to the recommendations of Linsley and others (1982. chapter 7). As a rule of thumb. the duration of direct runoff following the end of a rainfall is approximately $\mathrm{A}^{0.2}$ days, where $\mathrm{A}$ is the drainage area in square miles (Linsley and others, 1982. equation 7-4). Pen Branch has a drainage area of 21 square miles resulting in runoff terminating after about 2 days. The drainage area of Fourmile Branch is 22 square miles yielding essentially the same duration. Taking these streams as representative, base flow should typically depart from total flow at the start of a rainfall event and rejoin the total flow after 2 days plus the duration of the rain. The total time of departure would be roughly 2 to 3 days. However, inspection of several individual rainfall events in comparison to the qualitative guidelines of Linsley and others (1982, Figure 7-5) suggests that runoff often lasts longer, sometimes up to roughly 6 days following a heavy rain. The maximum rate of base flow increase was set to 1.05 to yield a 2 to 6 day duration. Figure E- 6 shows a sample segment of total and estimated base flow for Meyers Branch.

Applying the above procedure to the appropriate data for each drainage basin yields the results illustrated in Figures E-7 through E-12. In these figures. the upper plots (a) show the reference downstream flow and any outfall or upstream flows. Additional detail on the more significant outfall flow rates is provided by Figures E-13 through E-20. Note that generally outfall and upstream flows form a large component of the downstream flow. The curves (b) at the bottom of Figures E-6 through E-11 show the "base flow". "smooth" and "smthavg" components as defined in steps 3) to 5) above.

Table E-1 summarizes the bottom line results. The appropriate base flow target for CKLP model calibration is gotten by multiplying the base flow estimate for the stream reach by the fraction of the reach contained within the model domain. For Upper Three Runs between Road C and Road A, which lies on the CKLP model boundary, a reasonable assumption is that each side contributes equally. The main branch of Meyers Branch forms a boundary of the model, but a major tributary just south of Dunbarton Road is totally outside the model domain. Overall, perhaps $1 / 3$ of this reach lies within the model. Far more uncertain is the fraction of base flow to the larger Upper Three Runs reach that should be attributed to groundwater from within the model: 1/4 is suggested in Table E-1. The Steel Creek estimate is negative and indicates a losing reach, presumably reflecting artificial flows to L-Lake to maintain the current lake level.

The stated accuracy of the various raw USGS gauging station data is typically "good" $(<10 \%$ error $95 \%$ of the time), "fair" ( $<15 \%$ error $95 \%$ of the time) or "poor" (less than "fair" 
accuracy) (Cooney and others, 1998, p. 16). Uncertainty in the long-term average flows ultimately used in this analysis are much smaller than uncertainty in a daily flow. Larger contributors to overall uncertainty are biases in the hydrograph separation procedure. and the estimated fraction of the analyzed reach that lies within the model domain. The uncertainty of the results summarized in Table E-1 can be estimated by considering different values for the assumed maximum rate of base flow increase. As shown by Table E-2. the base flow estimates appear to have an uncertainty around plus or minus $10 \%$ due to uncertainty in the chosen rate. Biases in hydrograph separation technique might add another 5 to $10 \%$. For example, base flow continues to decrease during flood conditions before ascending. The hydrograph separation technique used here allows baseflow to increase immediately. and might produce slightly high estimates. Some of the model calibration targets contain added uncertainty in the amount that should be partitioned to the model domain. Overall. the baseflow targets may have an uncertainty of 15 to $25 \%$.

\section{References}

Cooney, T. W., P. A. Drewes, K. H. Jones. J. W. Gissendanner and B. W. Church. 1998, Water resources data - South Carolina, Water year 1997, Volume 1, U. S. Geological Survey Water-Data Report SC-97-1.

Linsley, R. K. Jr., M. A. Kohler and J. L. H. Paulhus, 1982, Hydrology for engineers. $3^{\text {rd }}$ edition, McGraw-Hill, New York.

Shirmohammadi, A., W. G. Knisel and J. M. Sheridan, 1984, An approximate method for partitioning daily streamflow data, Journal of Hydrology, v74. p. 335-354. 


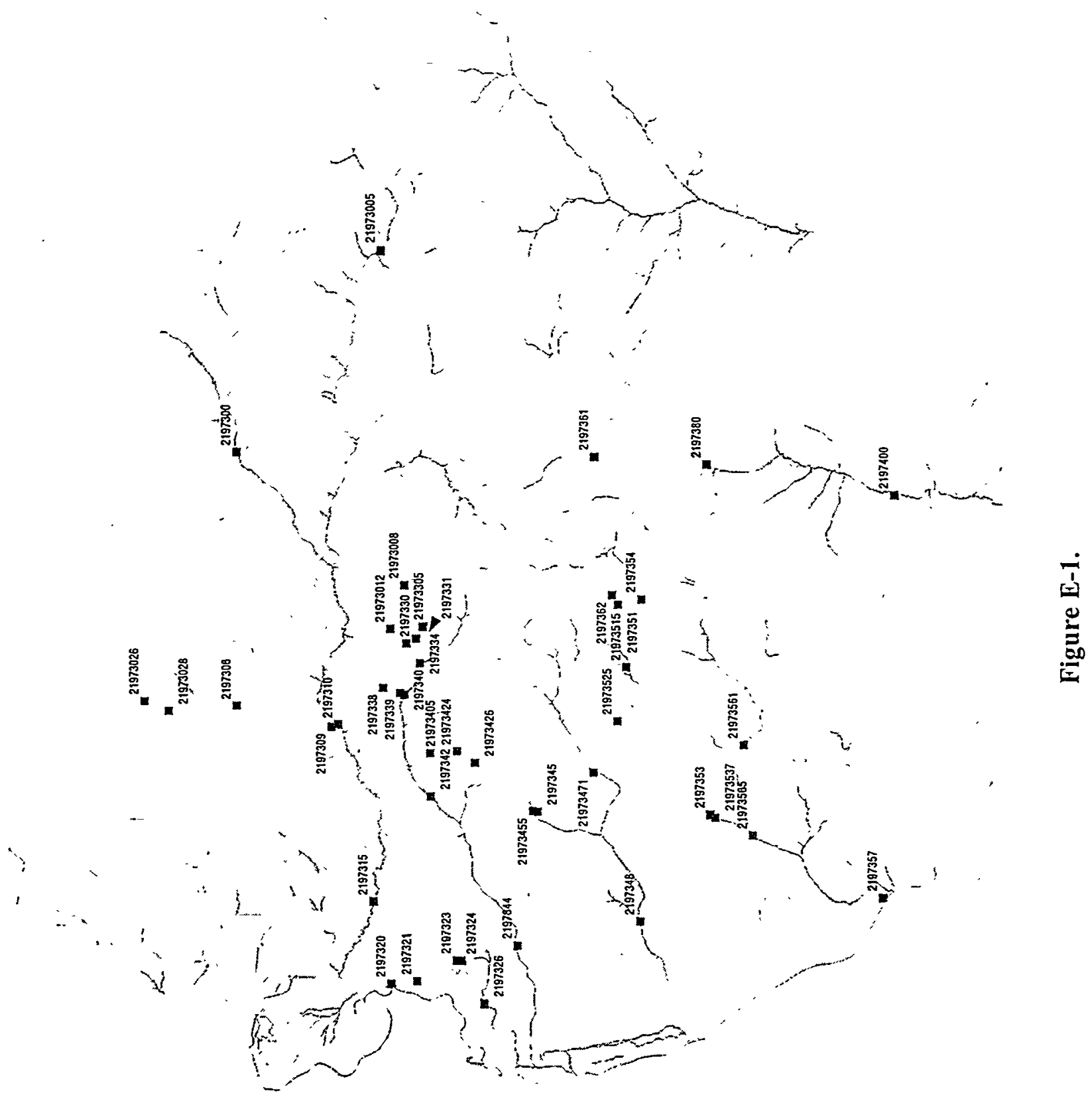




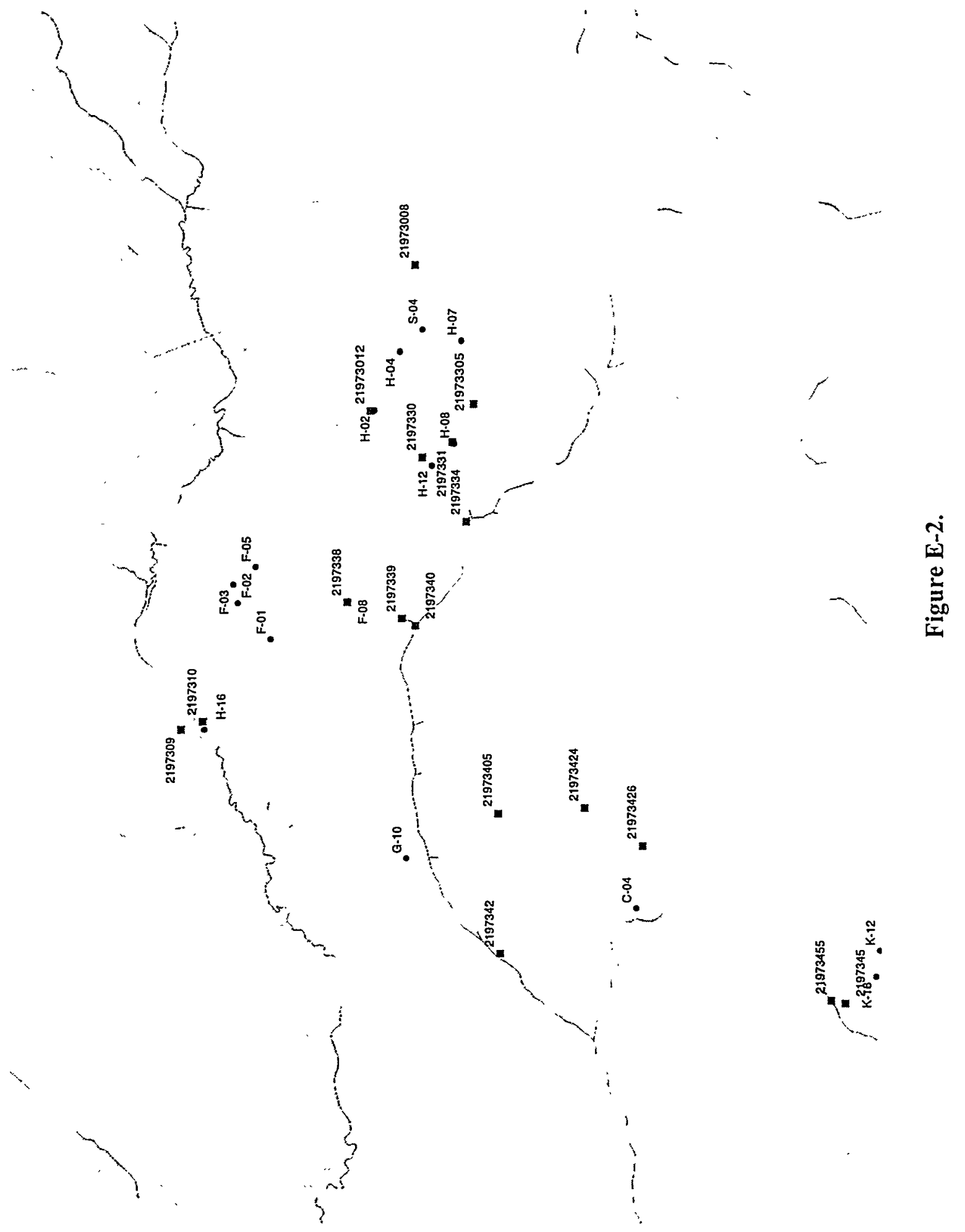




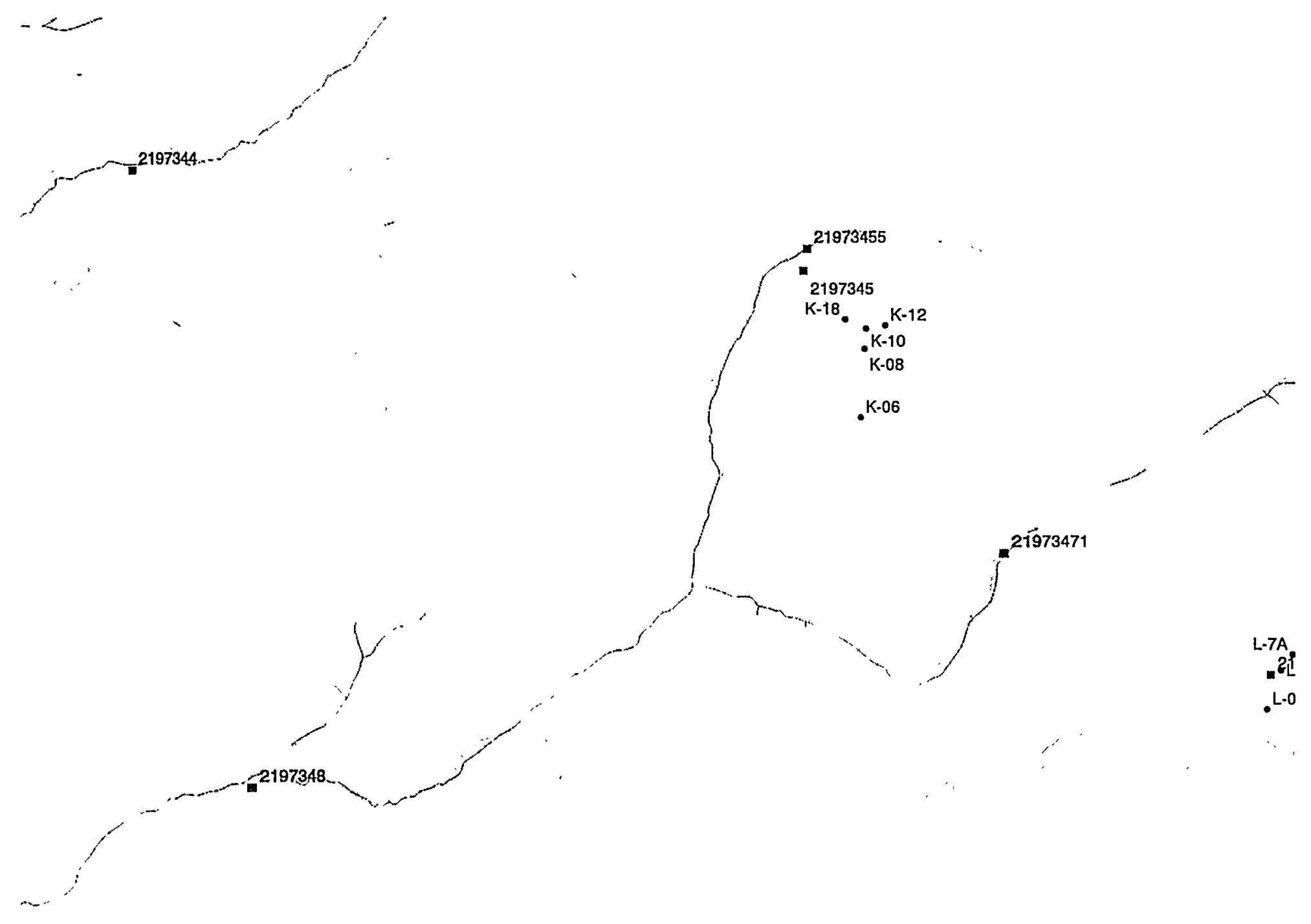

Figure E-3. 


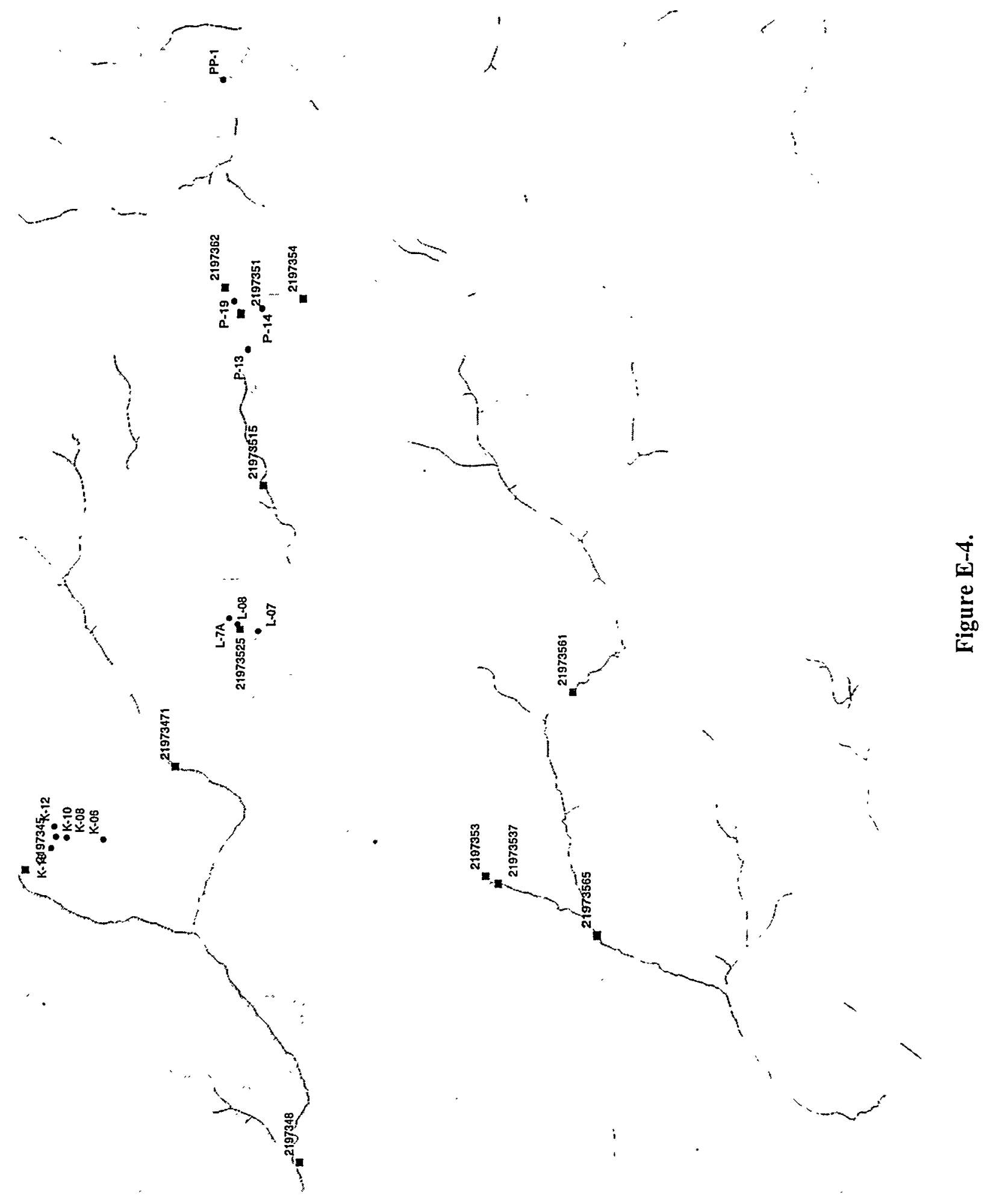




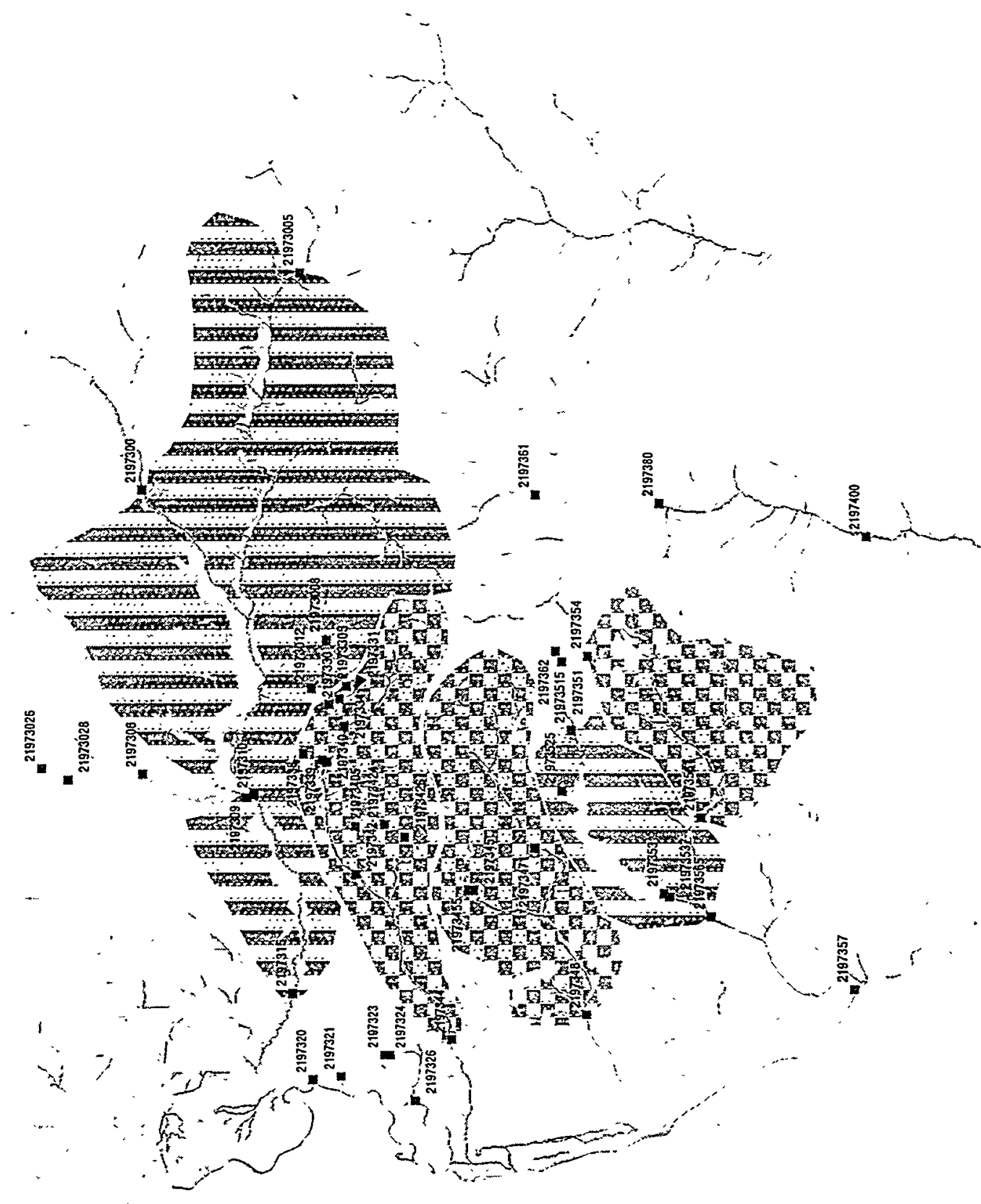




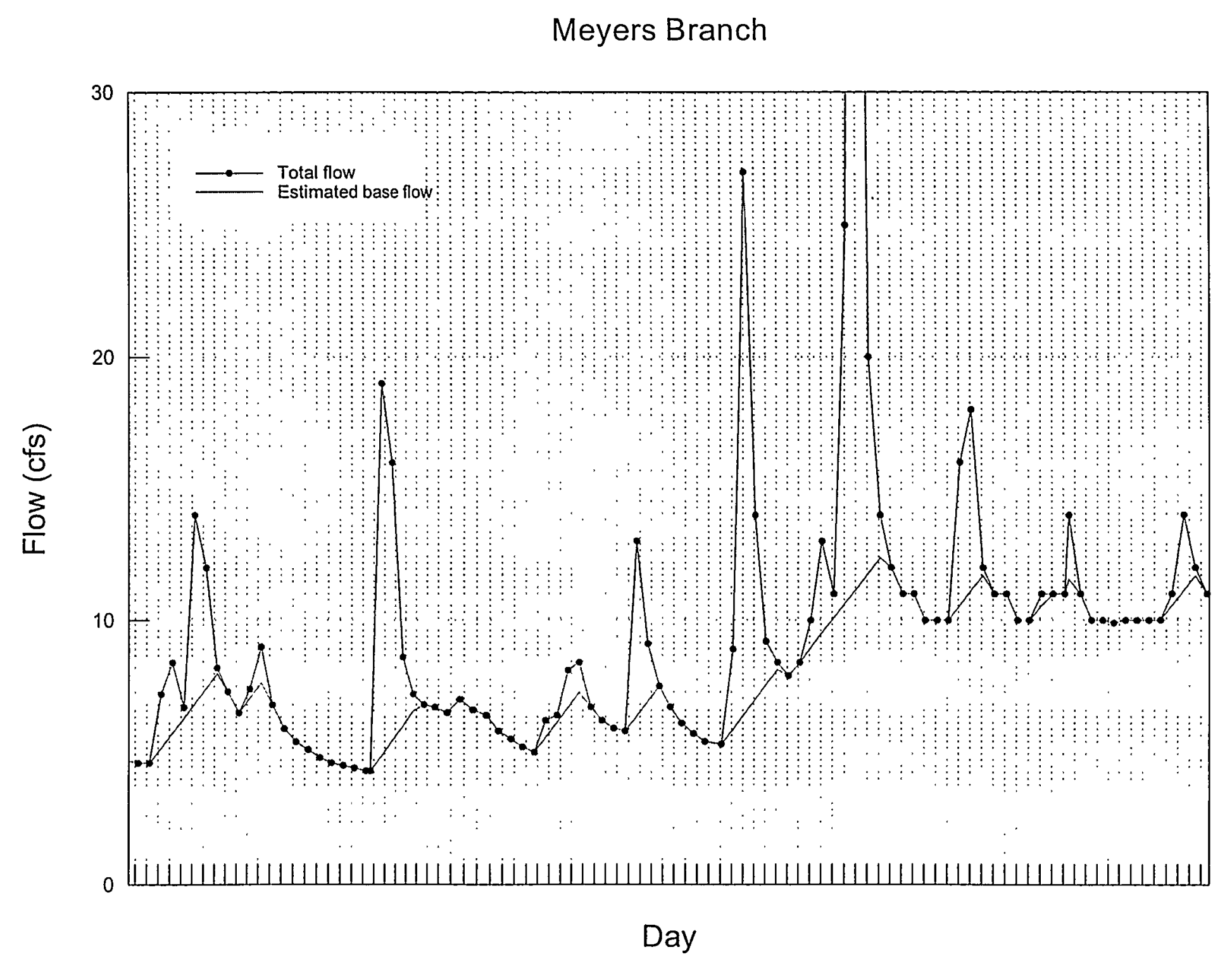

Figure E-6. 


\section{Meyers Branch}

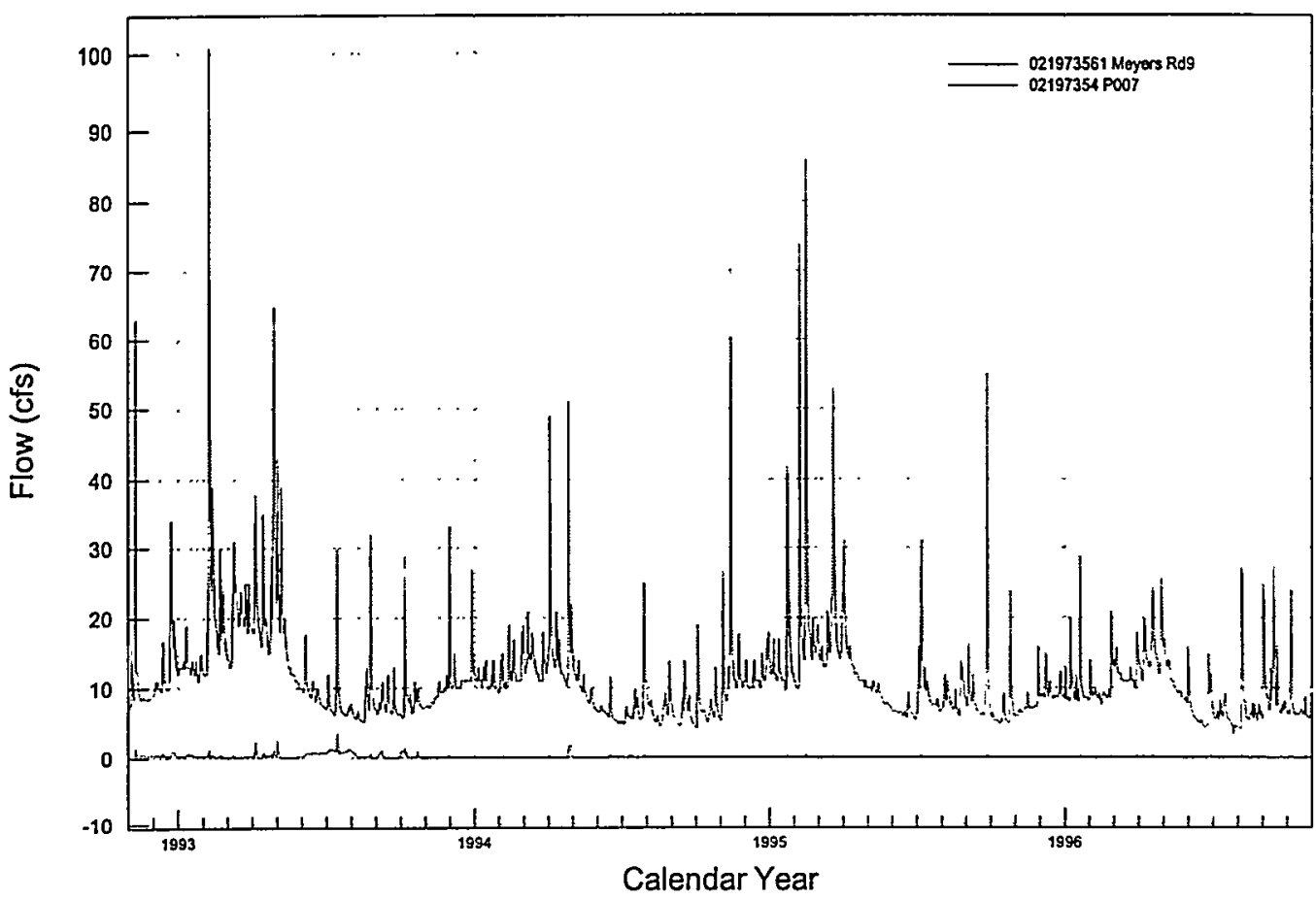

Meyers Branch

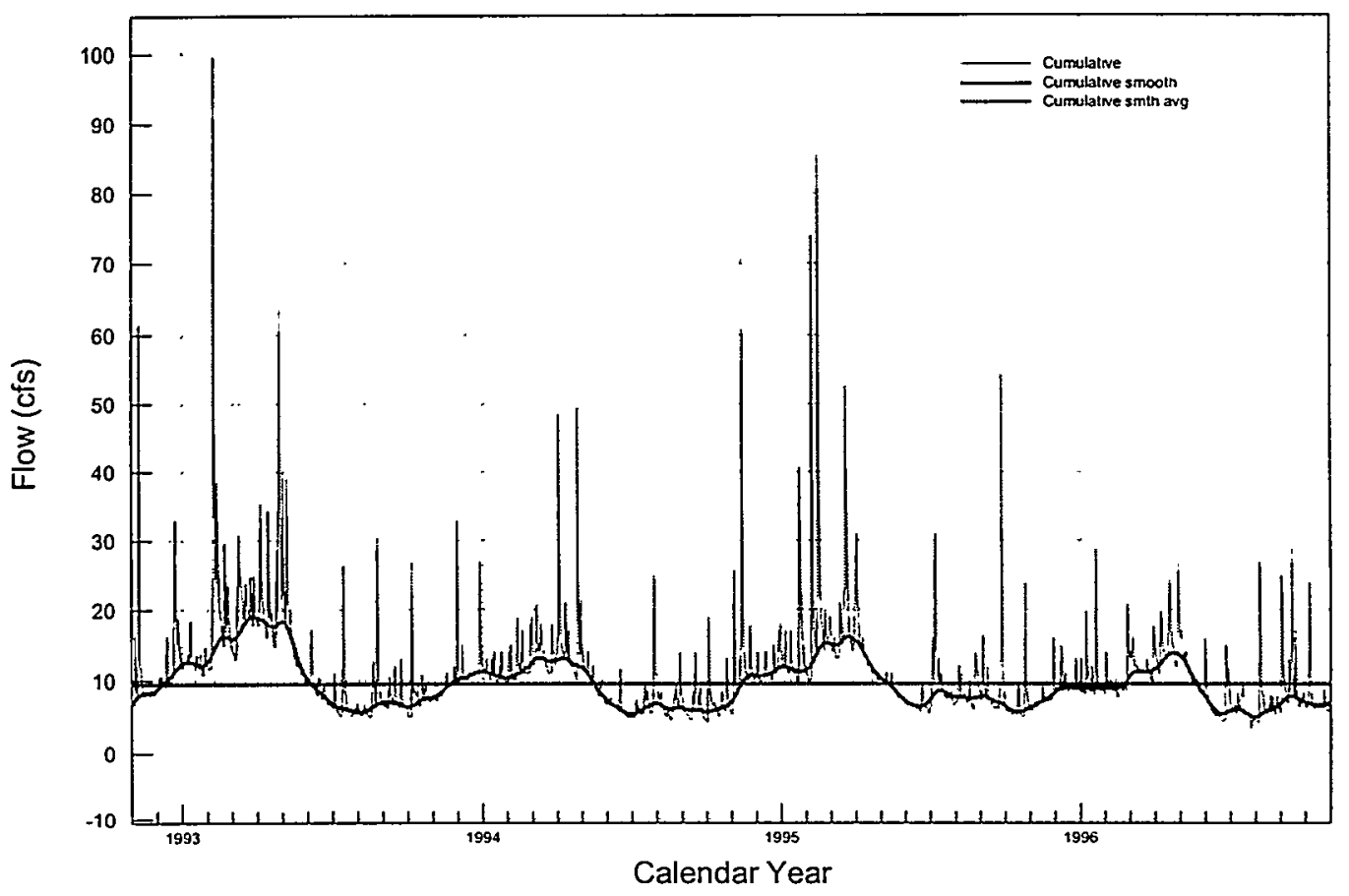

Figure E-7. 


\section{Steel Creek}

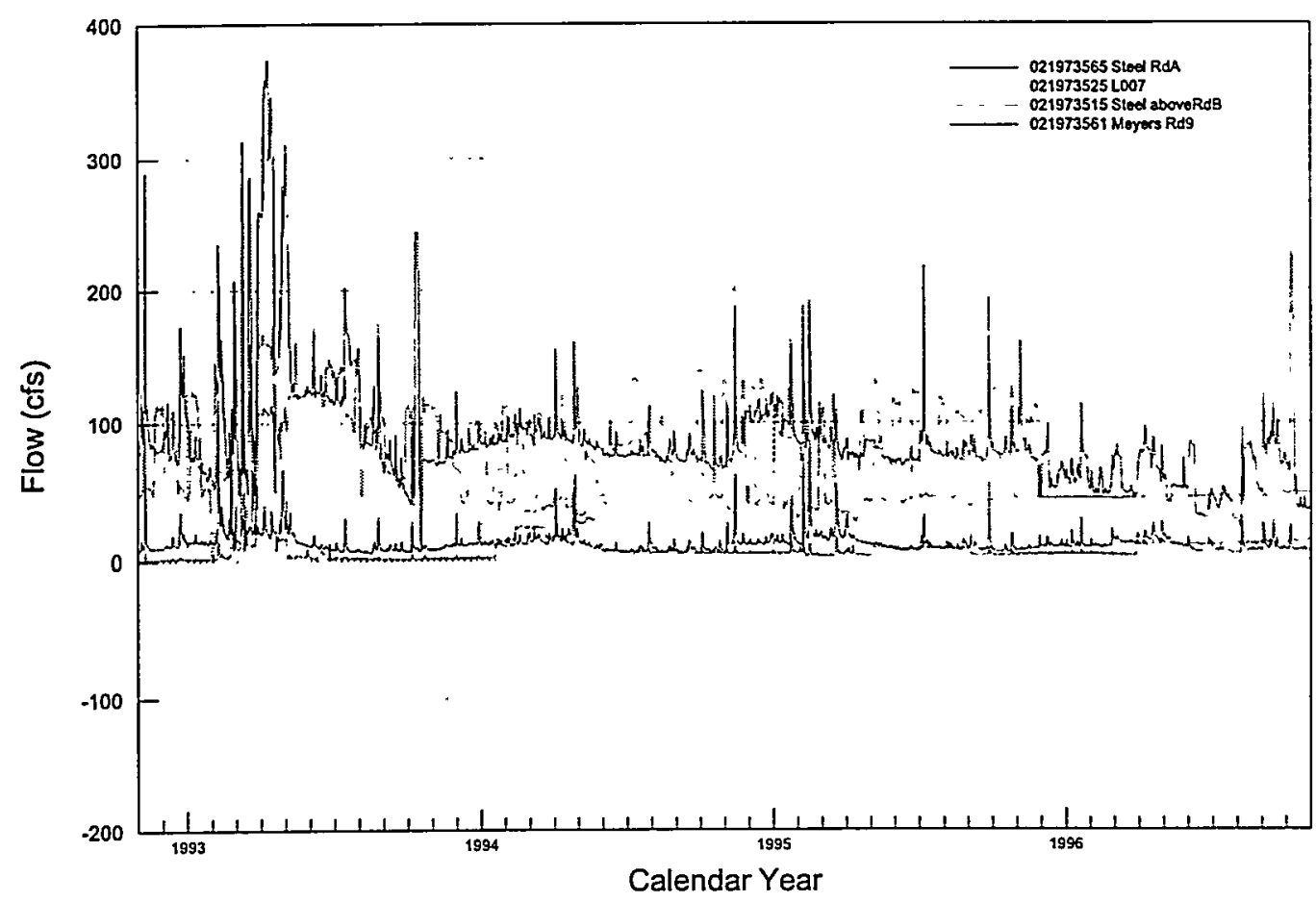

Steel Creek

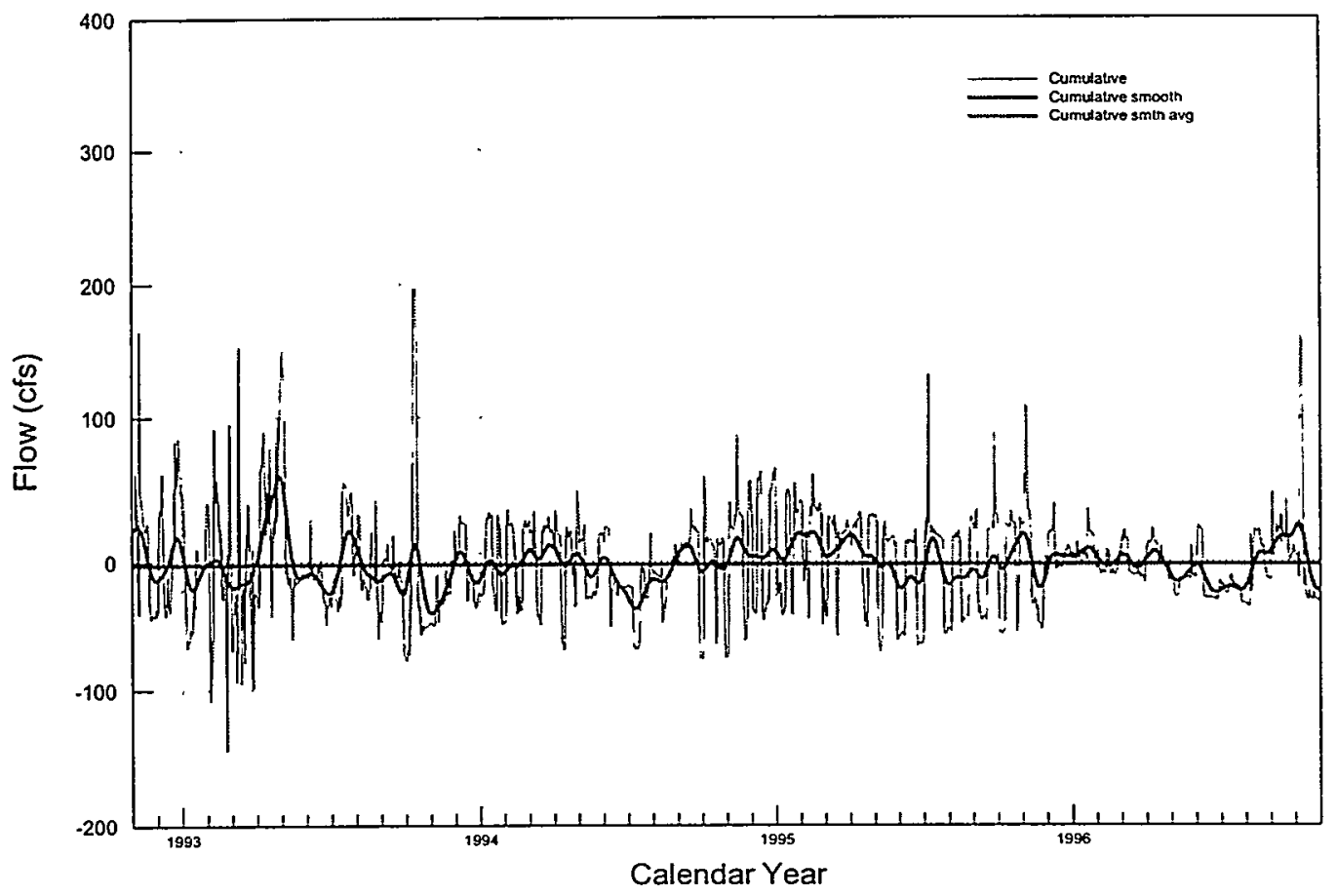

Figure E-8. 

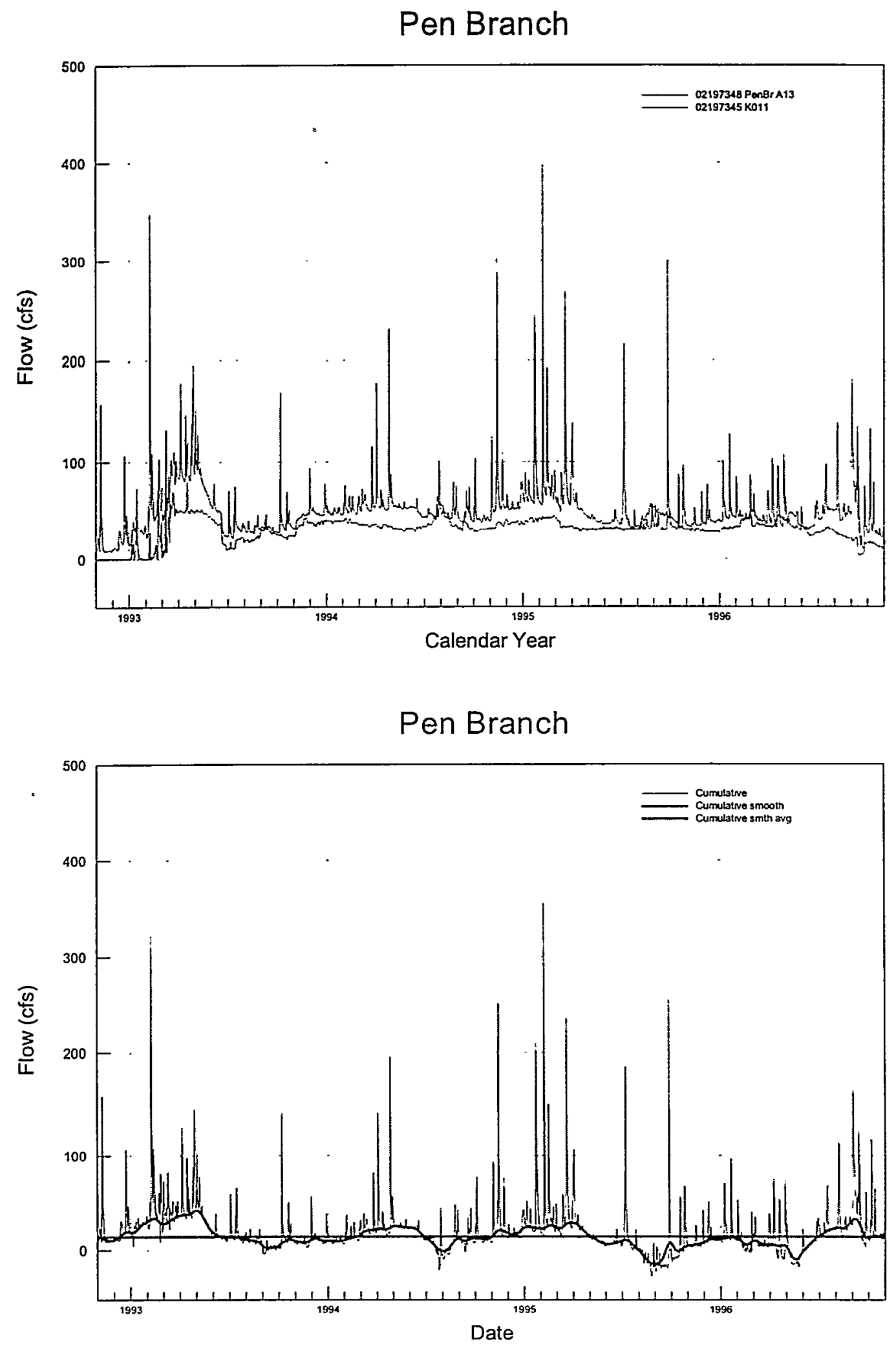

Figure E-9. 


\section{Fourmile Branch}

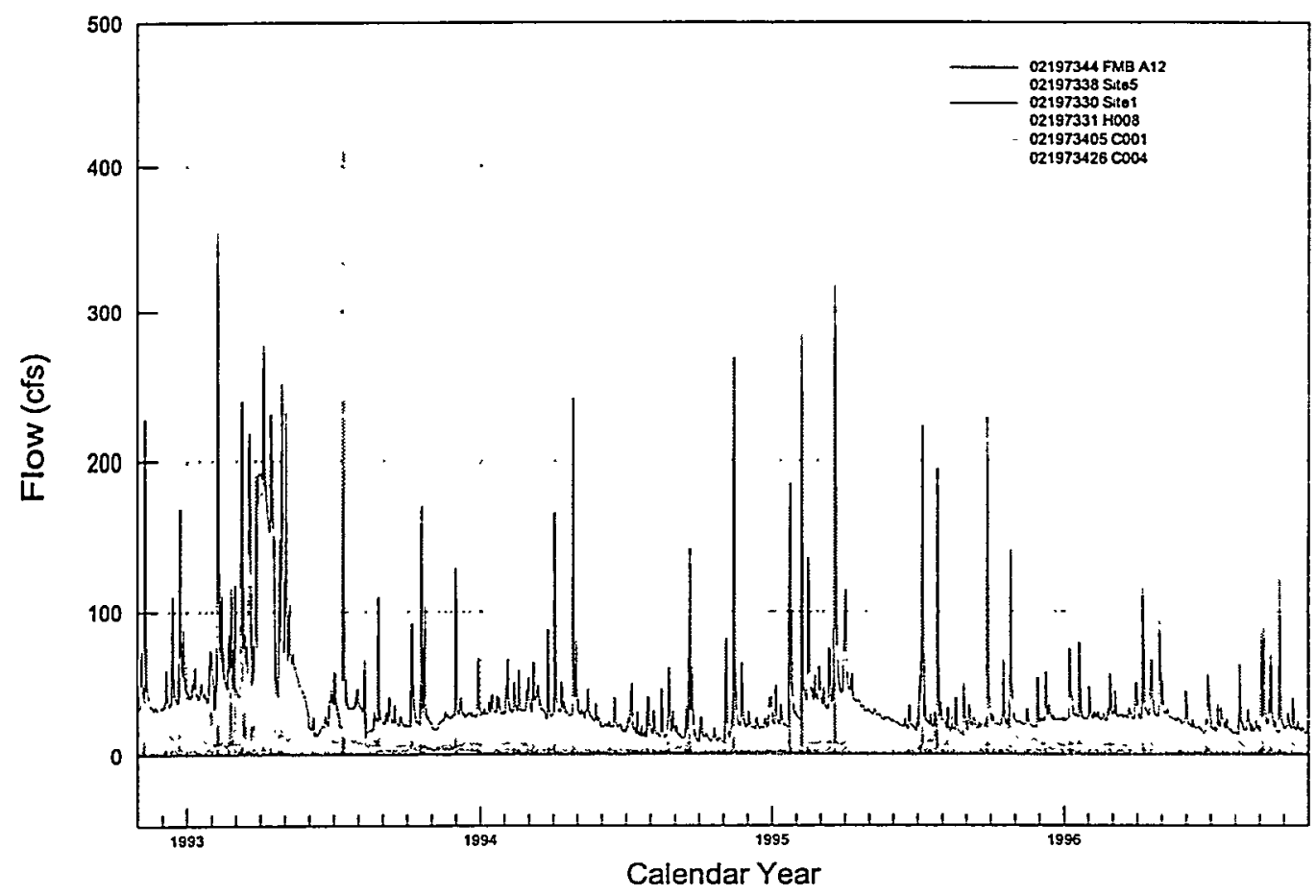

Fourmile Branch

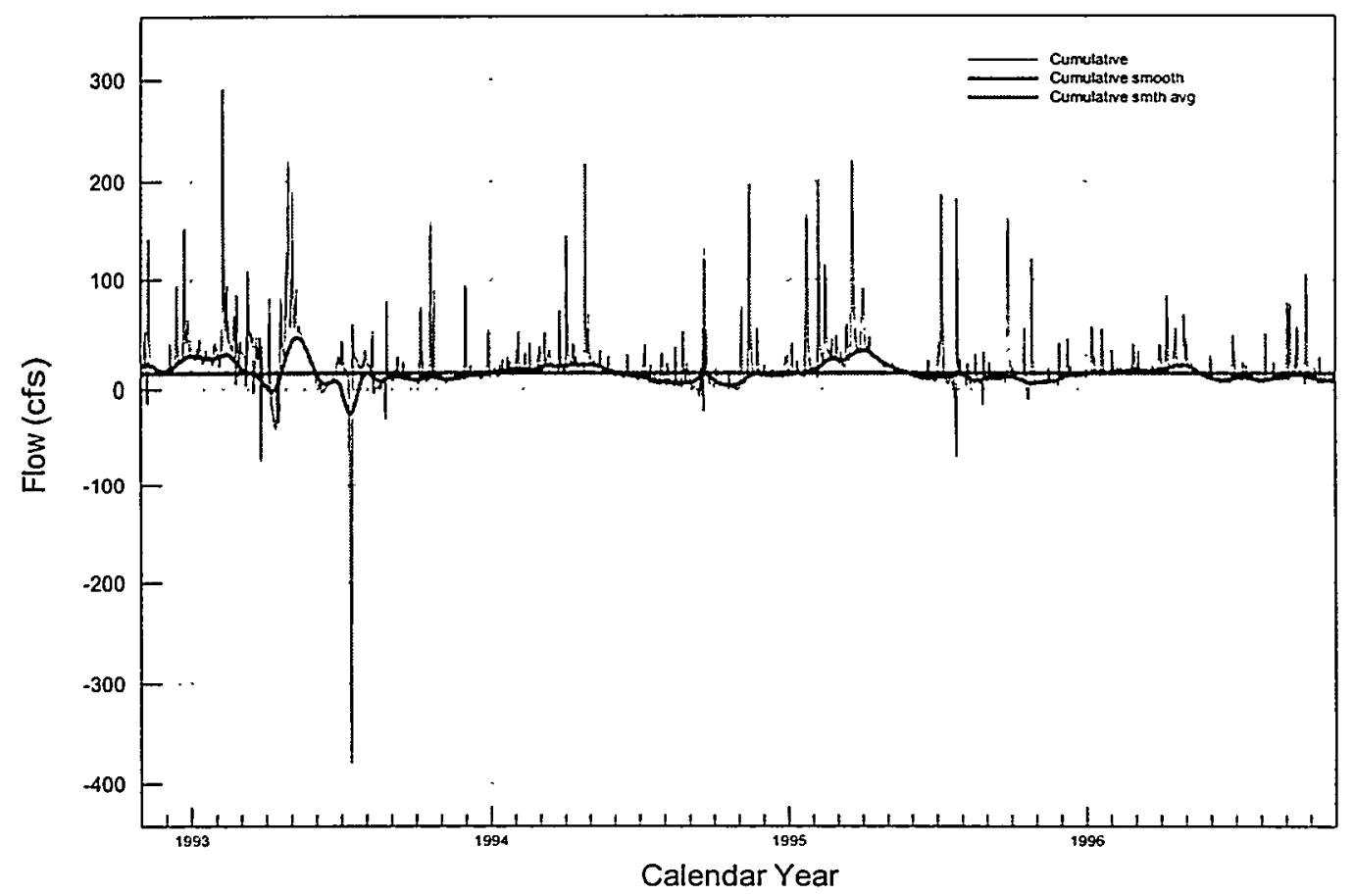

Figure E-10. 


\section{Upper Three Runs}

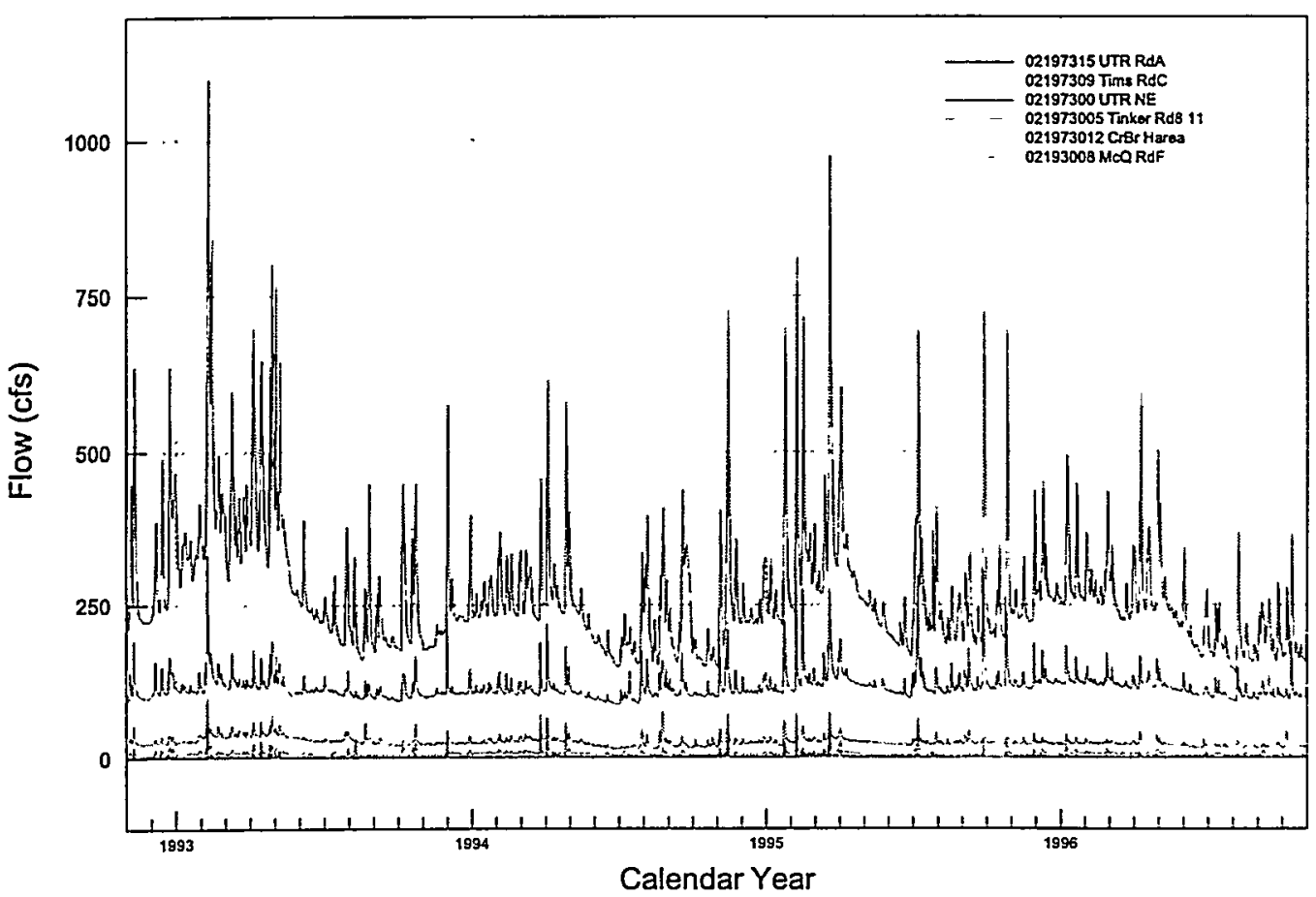

\section{Upper Three Runs}

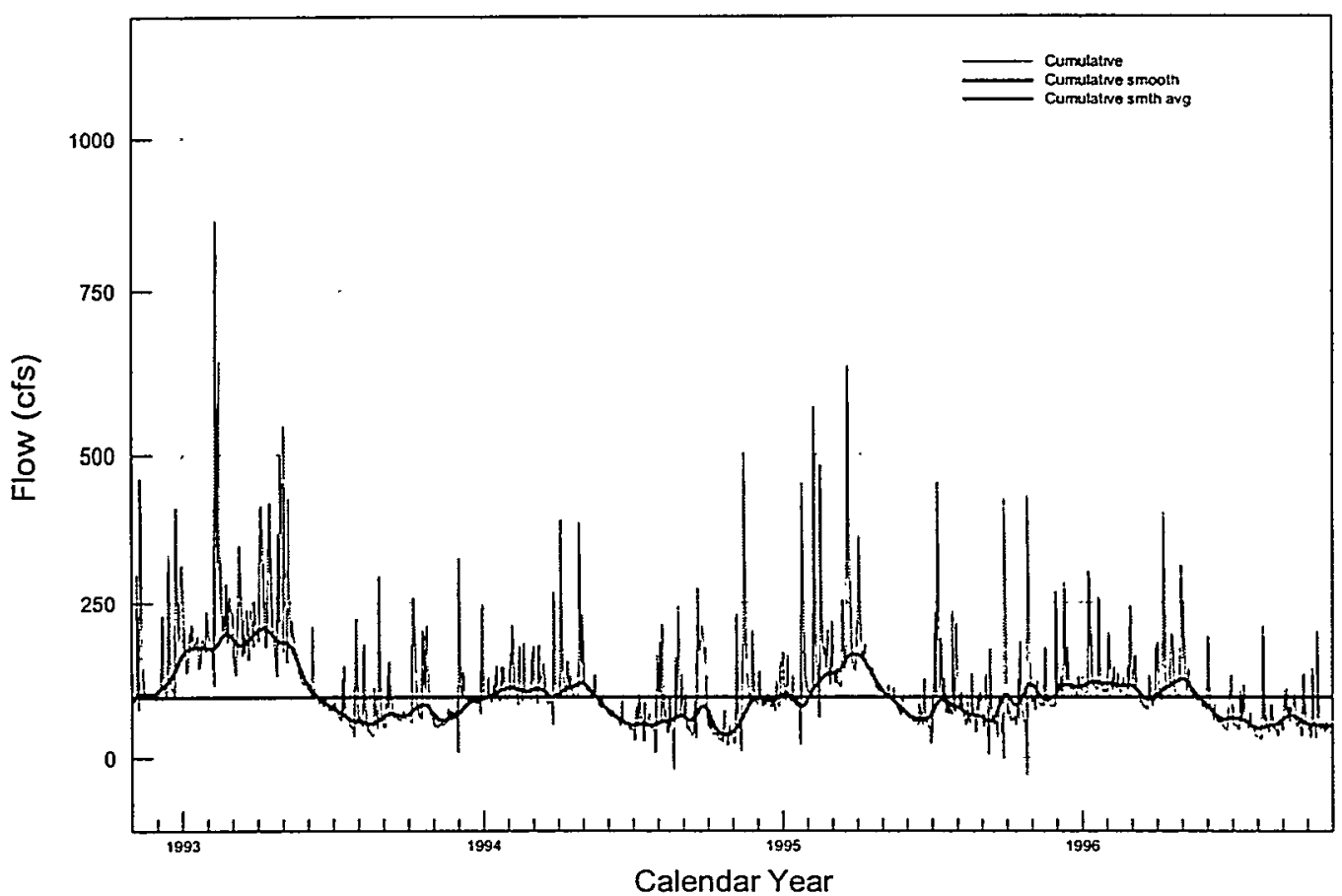

Figure E-11. 


\section{Upper Three Runs}

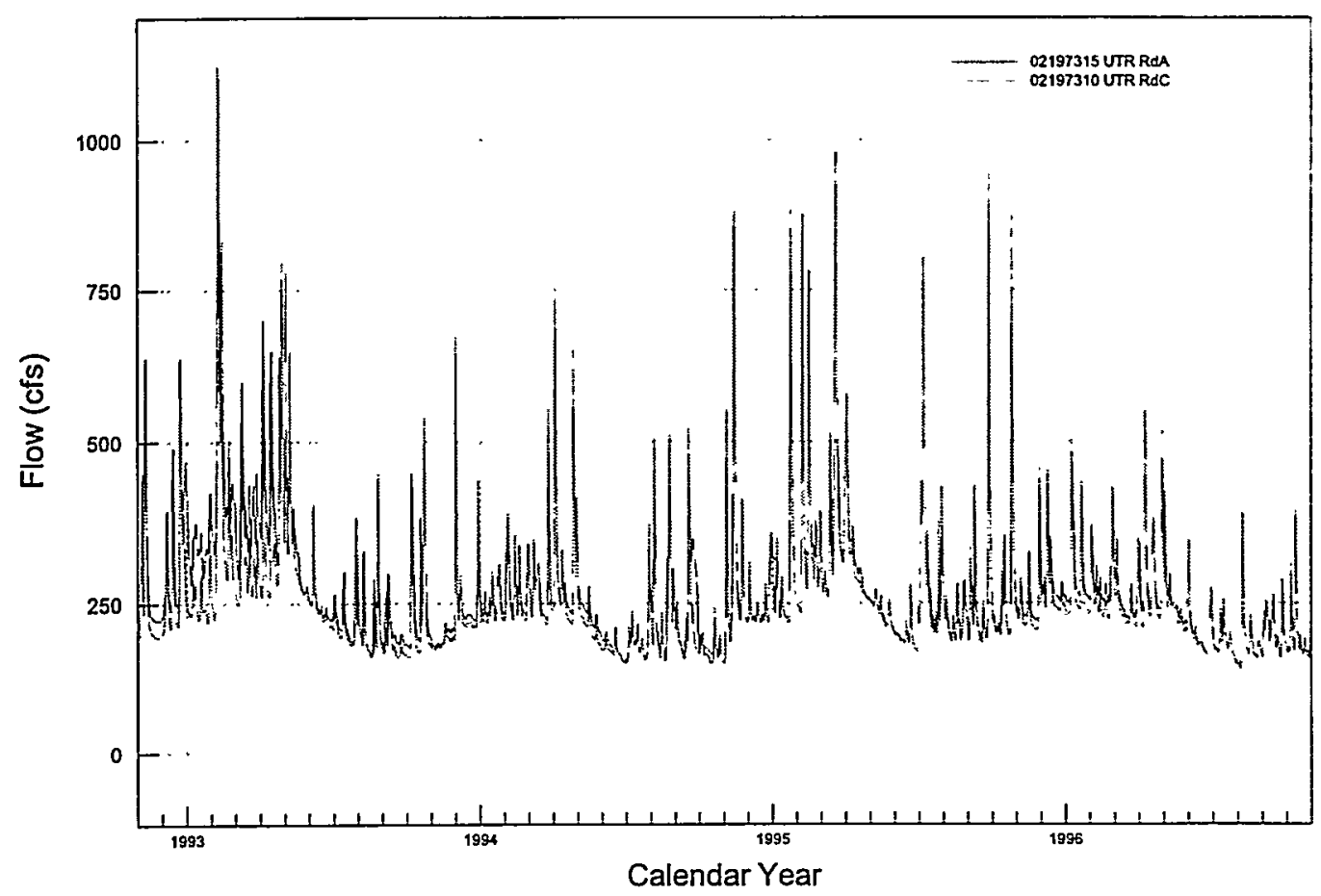

Upper Three Runs

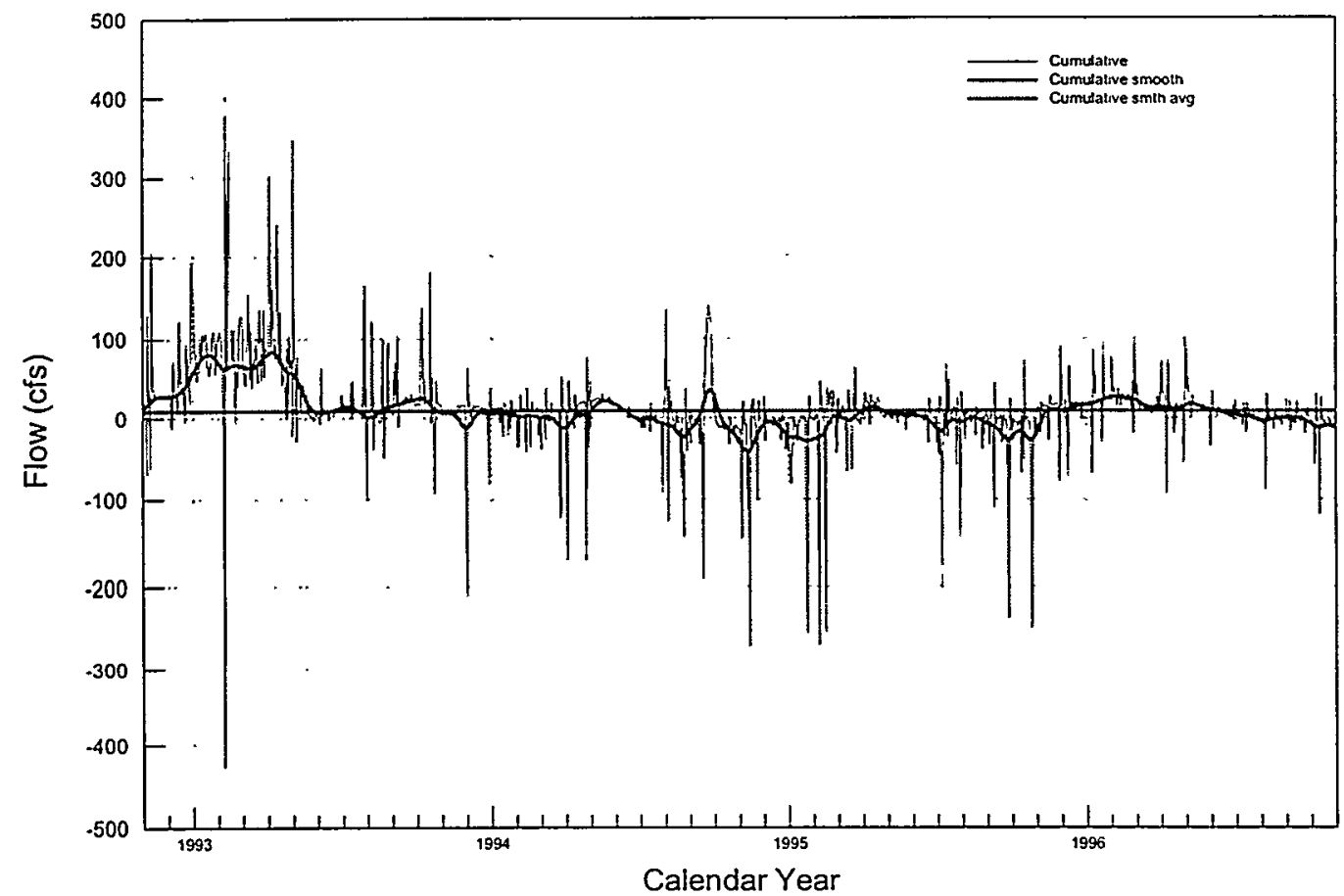

Figure E-12. 


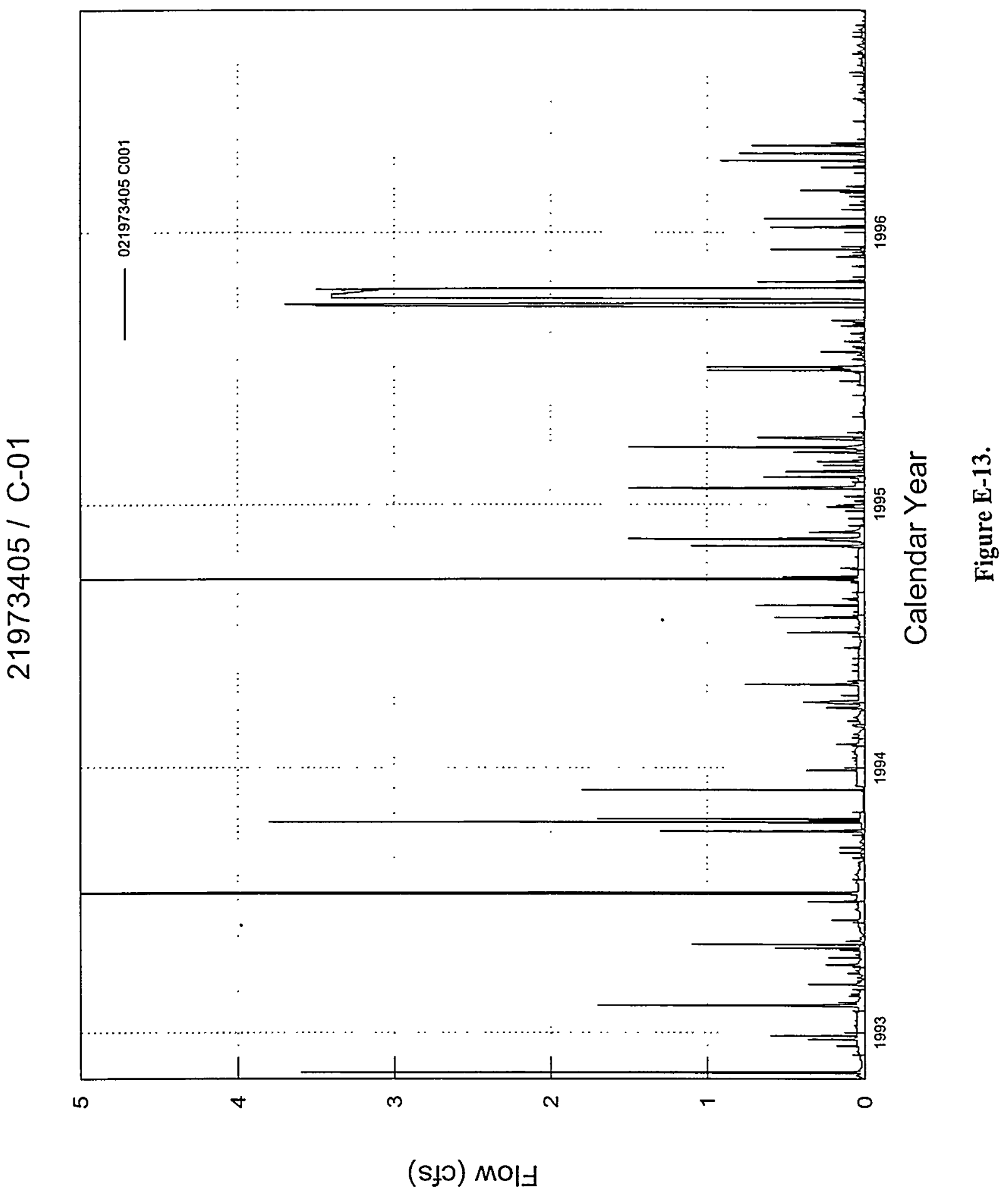




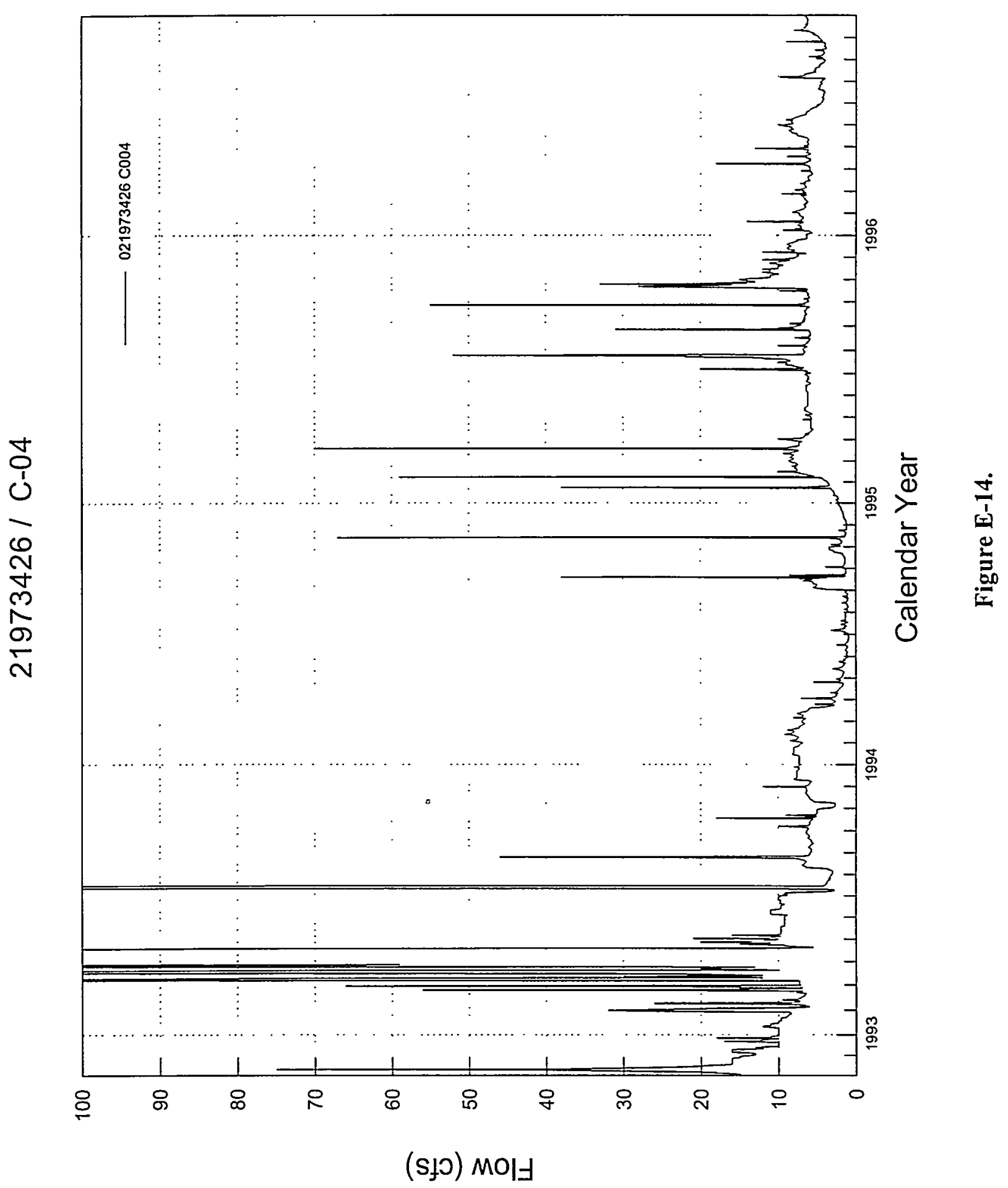




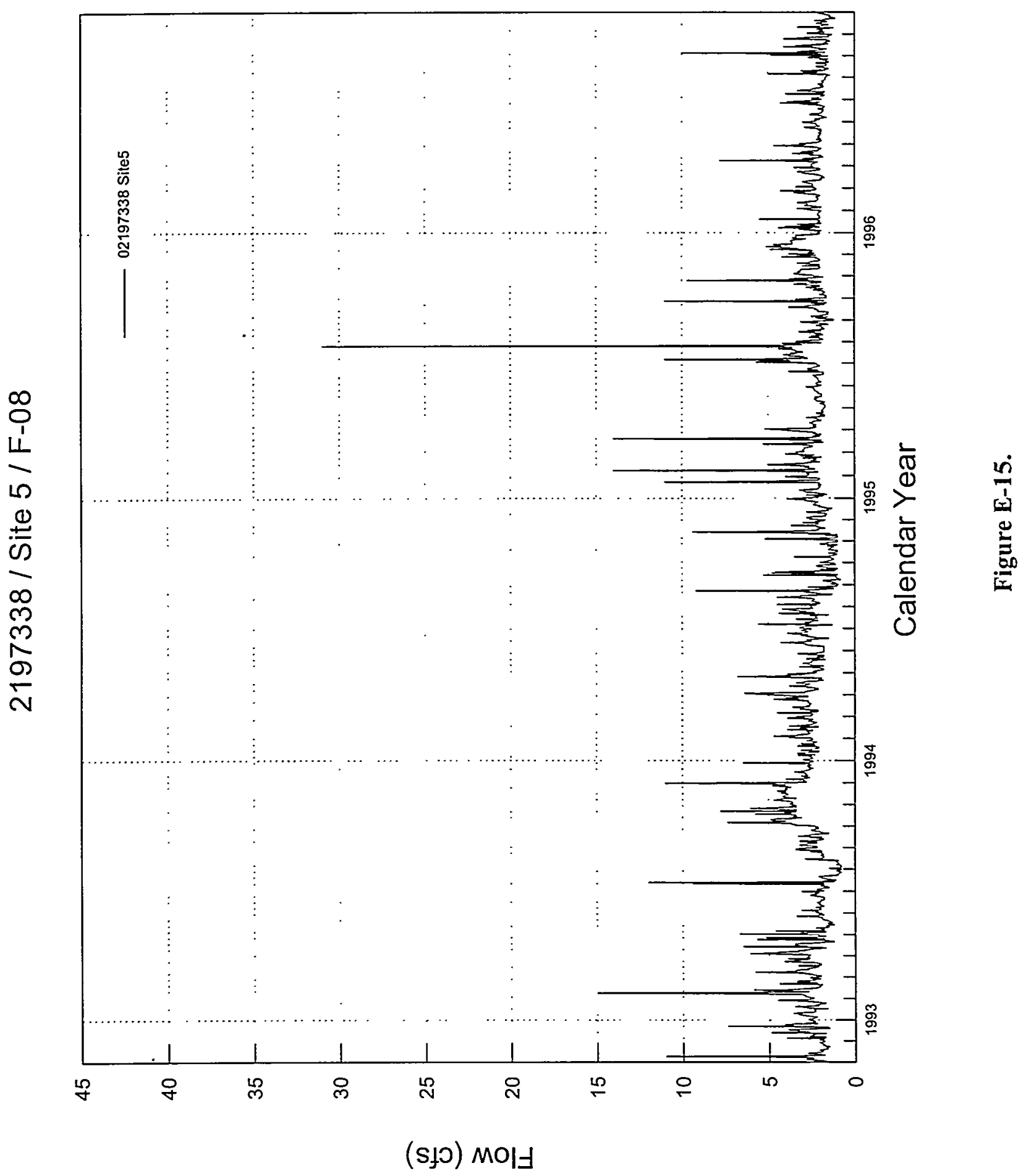




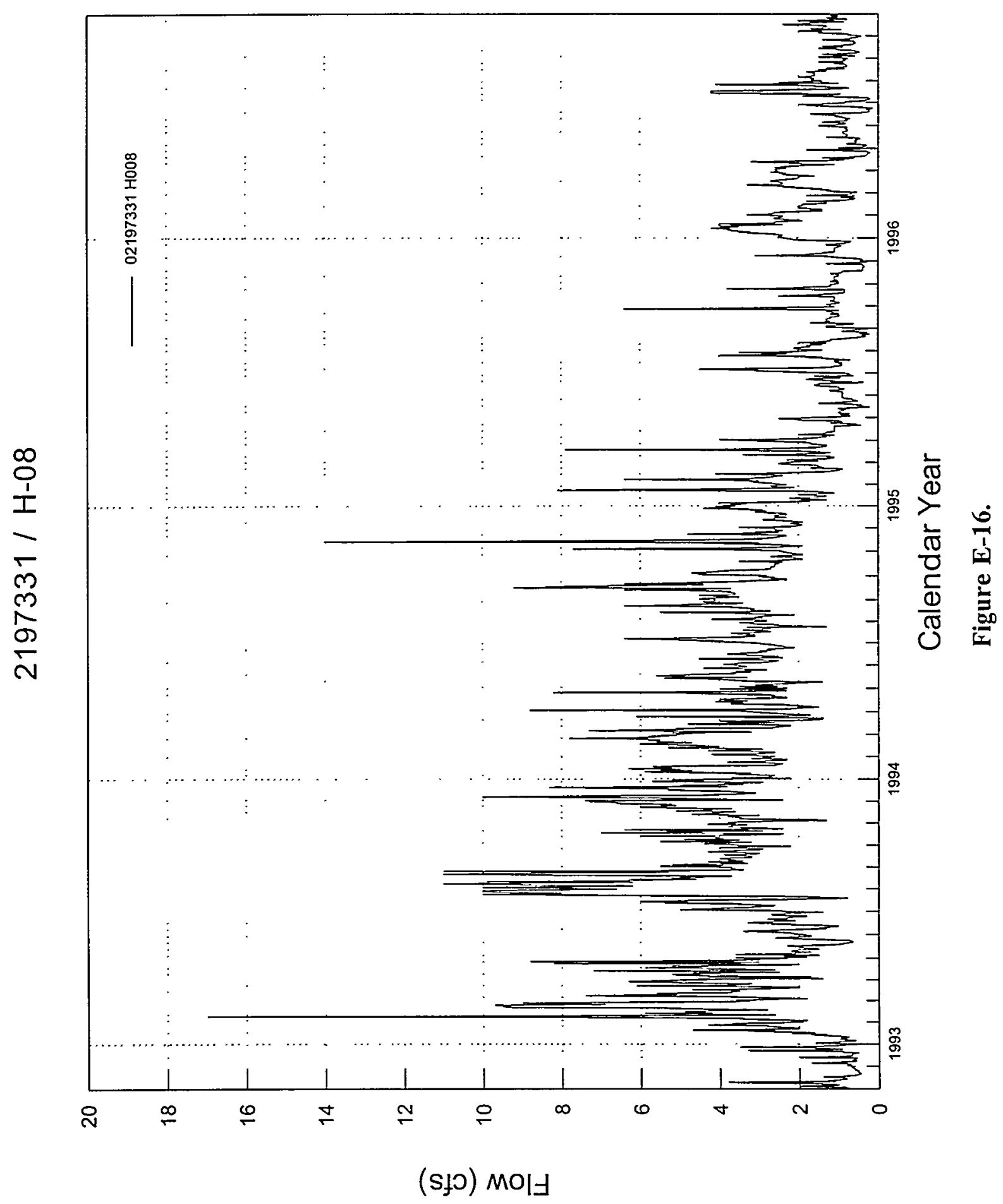




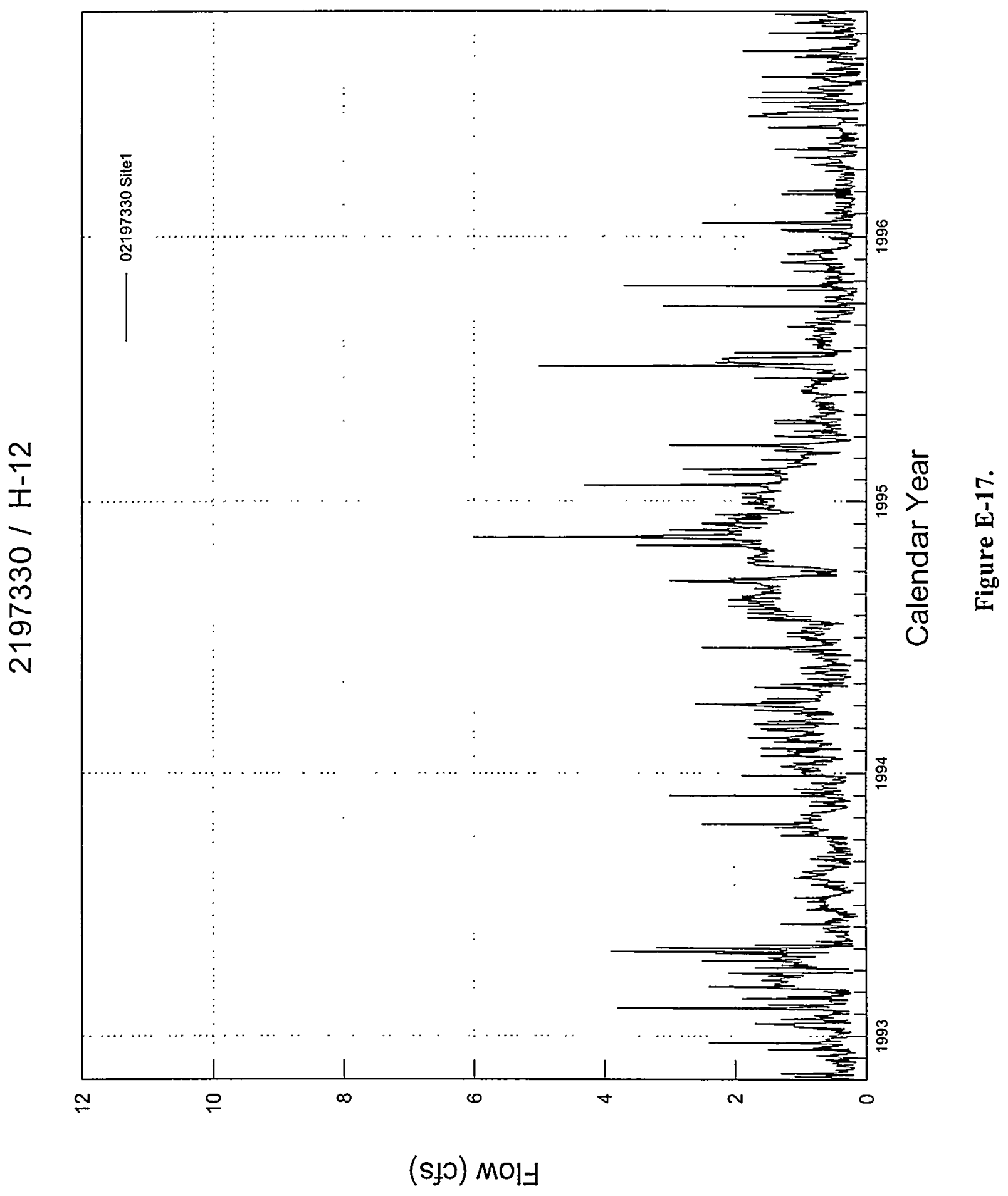

Figure E-17. 


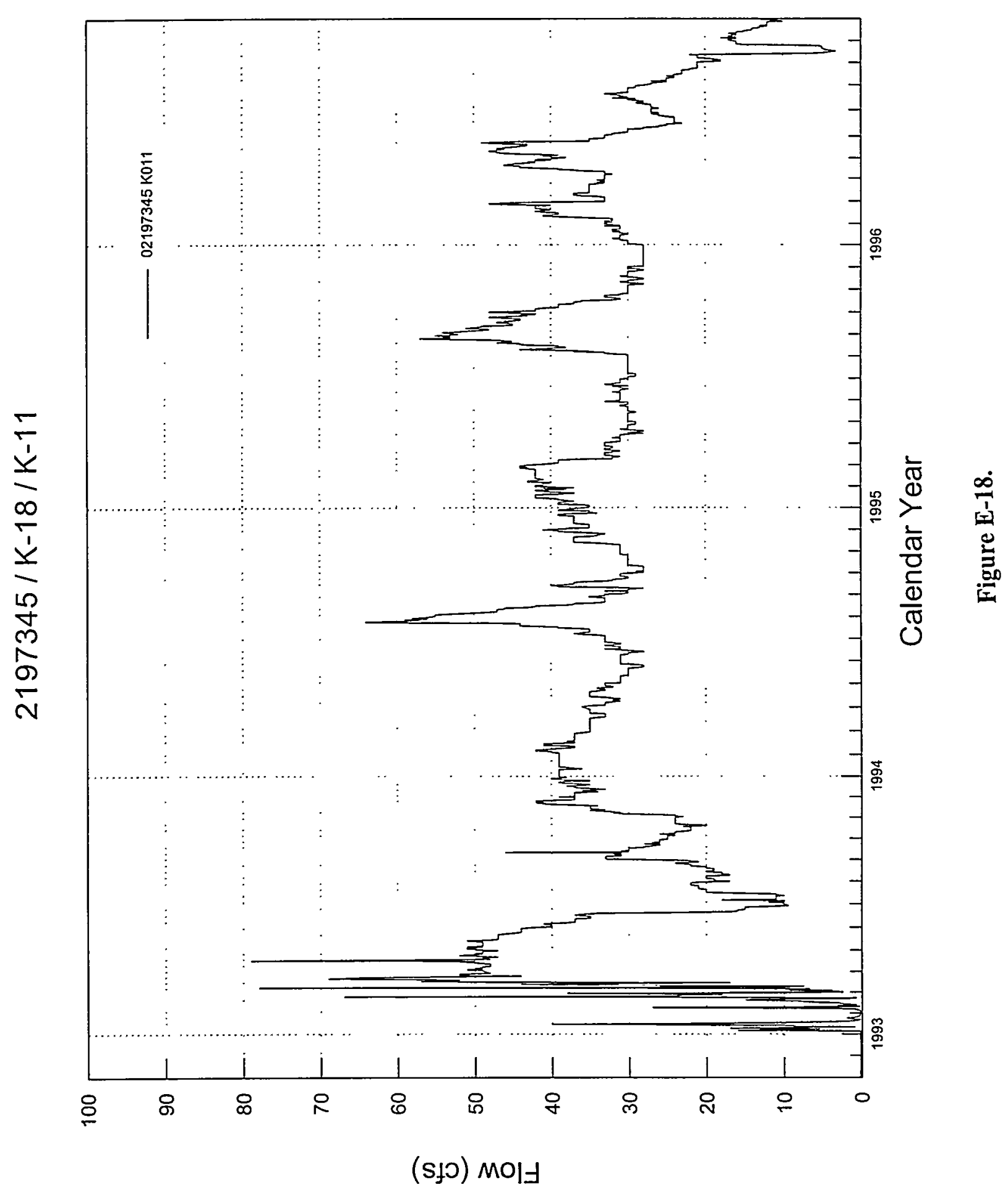




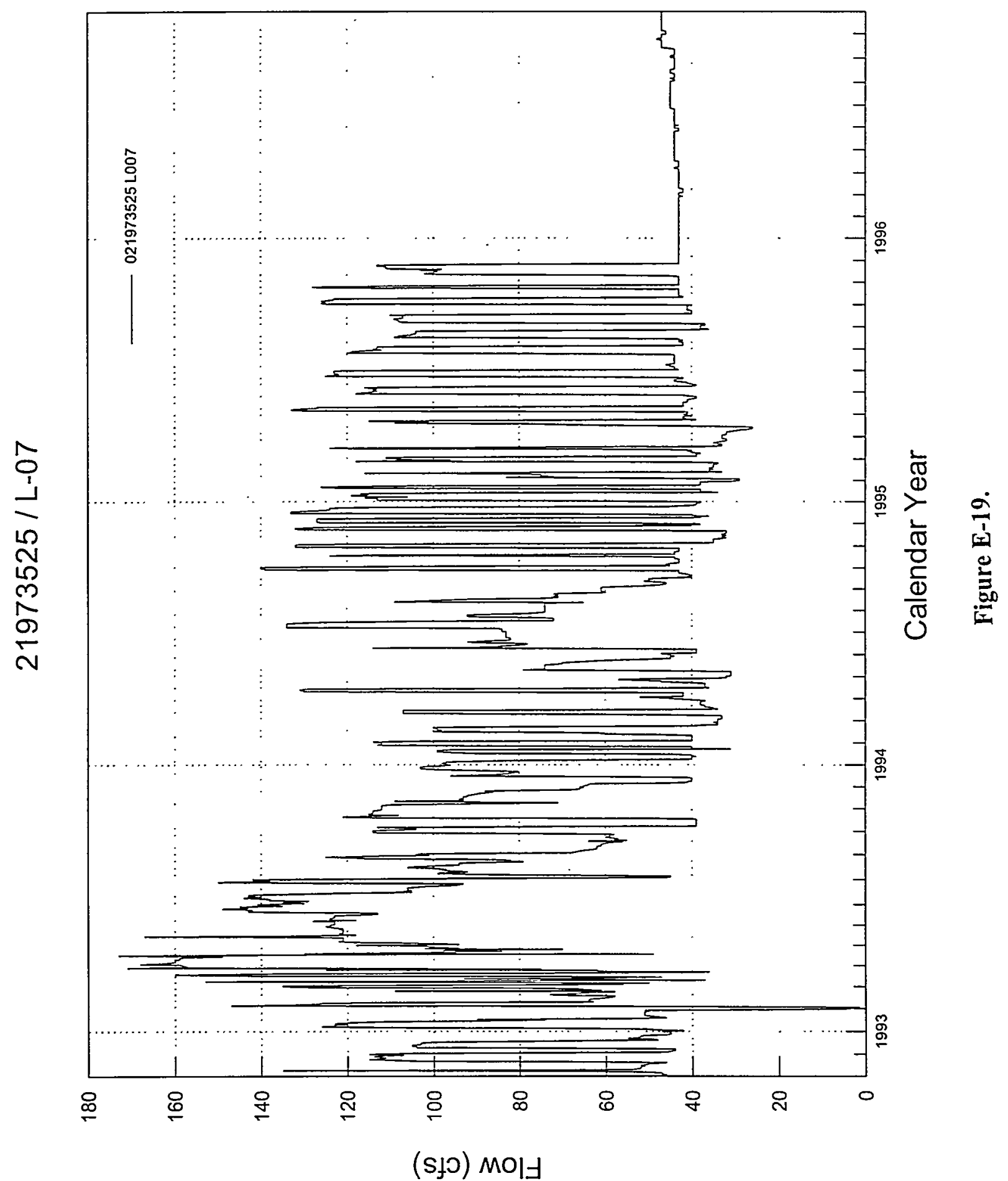


2197362 / P-19

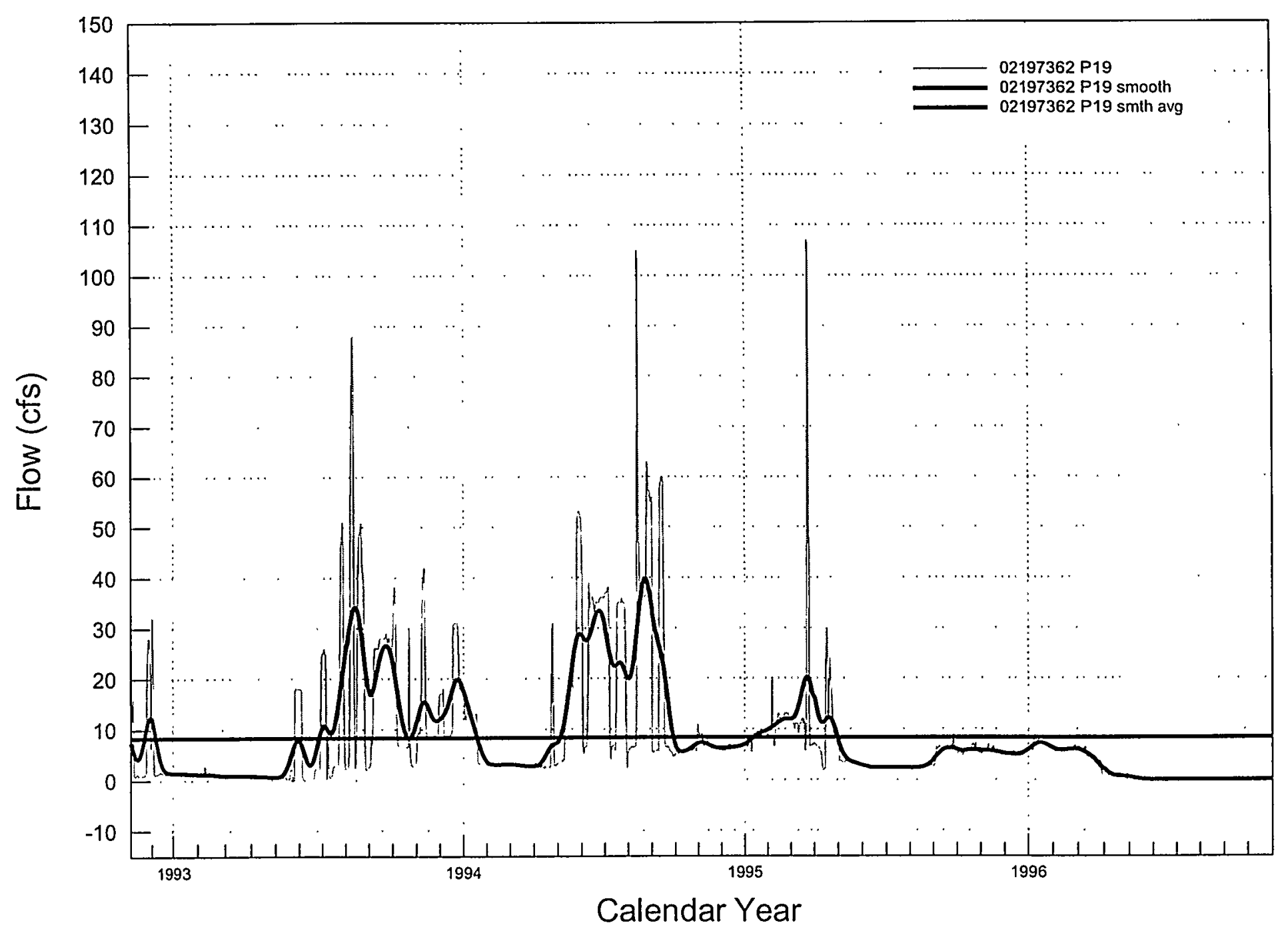

Figure E-20. 
Table E-1. Base flow estimates based on hydrograph separation of USGS gauging station data.

\begin{tabular}{|c|c|c|c|}
\hline Stream reach & $\begin{array}{l}\text { Estimated } \\
\text { base flow } \\
\text { (cfs) }\end{array}$ & $\begin{array}{c}\text { Fraction of } \\
\text { reach } \\
\text { within } \\
\text { CKLP } \\
\text { model }\end{array}$ & $\begin{array}{c}\text { Base flow } \\
\text { target } \\
\text { (cfs) }\end{array}$ \\
\hline $\begin{array}{l}\text { Meyers Branch } \\
\text { (headwaters to Road 9) }\end{array}$ & 9.5 & $1 / 3 ?$ & $3.2 ?$ \\
\hline $\begin{array}{l}\text { Steel Creek } \\
\text { (above Road B to Road A; } \\
\text { includes L-Lake) }\end{array}$ & -2.2 & 1 & -2.2 \\
\hline $\begin{array}{l}\text { Pen Branch } \\
\text { (headwaters to Road A13; } \\
\text { includes Indian Grave Branch) }\end{array}$ & 13.3 & 1 & 13.3 \\
\hline $\begin{array}{l}\text { Fourmile Branch } \\
\text { (headwaters to Road A12) }\end{array}$ & 14.1 & 1 & 14.1 \\
\hline $\begin{array}{l}\text { Upper Three Runs } \\
\text { (Tims Branch at Road C/UTR near } \\
\text { site boundary/Tinker Creek at } \\
\text { Road 8-11 to UTR at Road A) }\end{array}$ & 97 & $1 / 4 ? ?$ & $24 ? ?$ \\
\hline $\begin{array}{l}\text { Upper Three Runs } \\
\text { (Road C to Road A) }\end{array}$ & 8.9 & $1 / 2$ & 4.5 \\
\hline
\end{tabular}


Table E-2. Sensitivity of base flow estimates to the assumed maximum rate of daily base flow increase.

\begin{tabular}{|c|c|c|c|}
\hline Stream reach & $\begin{array}{l}\text { Estimated } \\
\text { base flow } \\
\quad \text { for } \\
r=1.025 \\
\text { (cfs) }\end{array}$ & $\begin{array}{l}\text { Estimated } \\
\text { base flow } \\
\quad \text { for } \\
r=1.05 \\
\text { (cfs) }\end{array}$ & $\begin{array}{l}\text { Estimated } \\
\text { base flow } \\
\quad \text { for } \\
r=1.10 \\
\text { (cfs) }\end{array}$ \\
\hline $\begin{array}{l}\text { Meyers Branch } \\
\text { (headwaters to Road 9) }\end{array}$ & $\begin{array}{c}9.2 \\
(-3 \%)\end{array}$ & 9.5 & $\begin{array}{c}9.8 \\
(+3 \%)\end{array}$ \\
\hline $\begin{array}{l}\text { Steel Creek } \\
\text { (above Road B to Road A; } \\
\text { includes L-Lake) }\end{array}$ & $\begin{array}{l}-2.2 \\
(0 \%)\end{array}$ & -2.2 & $\begin{array}{l}-2.2 \\
(0 \%)\end{array}$ \\
\hline $\begin{array}{l}\text { Pen Branch } \\
\text { (headwaters to Road A13; } \\
\text { includes Indian Grave Branch) }\end{array}$ & $\begin{array}{c}12.3 \\
(-8 \%)\end{array}$ & 13.3 & $\begin{array}{c}14.3 \\
(+8 \%)\end{array}$ \\
\hline $\begin{array}{l}\text { Fourmile Branch } \\
\text { (headwaters to Road A12) }\end{array}$ & $\begin{array}{l}13.0 \\
(-8 \%)\end{array}$ & 14.1 & $\begin{array}{c}15.1 \\
(+7 \%)\end{array}$ \\
\hline $\begin{array}{l}\text { Upper Three Runs } \\
\text { (Tims Branch at Road C/UTR near } \\
\text { site boundary/Tinker Creek at } \\
\text { Road 8-11 to UTR at Road A) }\end{array}$ & $\begin{array}{c}91 \\
(-6 \%)\end{array}$ & 97 & $\begin{array}{c}104 \\
(+7 \%)\end{array}$ \\
\hline $\begin{array}{l}\text { Upper Three Runs } \\
\text { (Road C to Road A) }\end{array}$ & $\begin{array}{c}7.7 \\
(-13 \%)\end{array}$ & 8.9 & $\begin{array}{c}10.1 \\
(+13 \%)\end{array}$ \\
\hline
\end{tabular}


Appendix E-2. Summary of Stream Baseflow and Water Table Work Conducted in Support of the R-Reactor and K-Reactor Groundwater Modeling Efforts, SRT-EST-98110, Westinghouse Savannah River Company Inter-Office Memorandum from R. A. Hiergesell to R. Falise, January 12, 1997, Westinghouse Savannah River Company, Aiken ,SC, 13 pp. 


\section{This page intentionally left blank}


WESTINGHOUSE SAVANNAH RIVER COMPANY

SRT-EST-98-110 INTER-OFFICE MEMORANDUM

January 12. 1997

TO:

Ron Falise, 730-2B

FROM:

R.A. Hiergesell, $773-42 \mathrm{~A}$

SUBJECT: Summary of stream baseflow and water table work conducted in support of the R-Reactor and K-Reactor groundwater modeling efforts.

The purpose of this memorandum is to summarize the work that has been done to characterize stream baseflow and the water table configuration in the vicinity of the R-Area and K-Area Reactors. This information provides important measurements which must be used in the groundwater flow model calibration process an the models will be calibrated such that these measurements are adhered to as closely as possible.

\section{Baseflow measurements}

Stream baseflow measurements have been obtained along reaches of Mill Creek, Indian Grave Branch and the upper part of Pen Branch, above the confluence with Indian Grave Branch. At least parts of these drainage basins fall within the model domains for the R-Area and K-Area reactor ground water flow models.

Measurements were obtained at times when streamflow was thought to reflect baseflow conditions. The baseflow component of streamflow is that component derived directly from discharge of the underlying aquifer. At times between significant precipitation events the measured streamflow reflects that portion of streamflow that originates in the aquifer. Following a significant precipitation event we have been waiting 6-8 days for streamflow to recede back to baseflow conditions.

To obtain in-stream flow measurements two types of instruments are used, a cutthroat flume for stream reaches with flow rates less than 0.2 to 0.4 cubic feet/second (cfs) while an instream flow velocity indicator is utilized to acquire stream flow rates greater than approximately $0.4 \mathrm{cfs}$. The general strategy is to start at the headwaters of a stream and obtain measurements at different stations while working in the downstream direction. If possible, measurements were obtained at the confluence of significant tributary branches of the main stream so that the relative contribution of different tributaries could be quantified. All measurements were obtained within a short a period of time as possible, generally over a period of 1 to 2 days.

For each of the stream basins maps illustrating the ground water basin boundary, the trace of the stream and the position of measurement stations are attached to this memorandum. Also illustrated on each map is the configuration of the water table. Actual labels of water table contours are not illustrated on these maps, however. In addition to these maps, the measurements that were obtained to calculate flow rate at each station are included. 


\section{Water table map development}

Work has also been conducted to refine the water table configuration maps within the ground water flow model domain areas. This work has involved obtaining water level measurements from selected wells and careful examination of flowing reaches of the headwater segments of streams. Information obtained in this way has been utilized to refine previously existing maps of the water table configuration in the vicinity of the R-Area and the K-Area Reactor. A refined map was utilized as a calibration target for the R-Area ground water model and another refined map will be utilized during calibration when the K-Area mode is developed.

Additonal work remains to be done on both of these work components. Additional baseflow measurements will be obtained as the absence of precipitation allows, and a regional water table map for all of the reactor areas is being developed. 


\section{Mill Creek Baseflow Measurements}

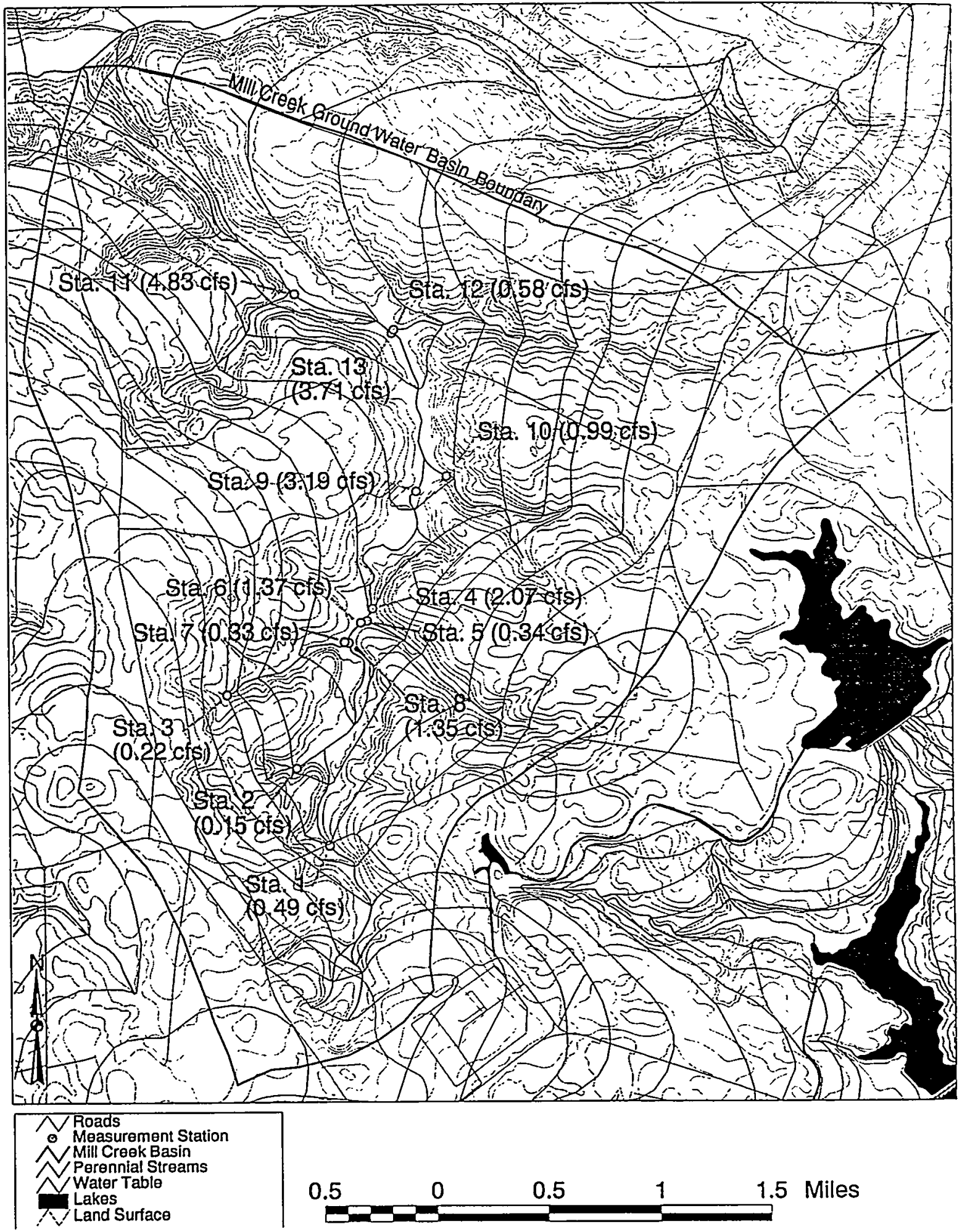




\section{MILL CREEK BASEFLOW}

Station 1 Mill Creek where Woodward Rd. crosses, upstream side of road.

(12/4/97) Approximate UTM Coordinates: 445115E, 3682835N

Flume Measurement: 8 " throat, fluid height $=0.5 \mathrm{ft} ., Q=1.06 \mathrm{cfs}$ or $475 \mathrm{gmp}$

Flowmeter Measurement

$\begin{array}{cccccccc}\text { Flowmeter Measurement } & & & \text { flow vel. } & \text { flow vel. } \\ \text { Segment } & \text { Tape } & \text { width (ft) } & \text { depth }(\mathrm{cm}) & \text { depth (ft) } & \text { (ft/sec) } & \text { (ft/sec) } & \text { Q (cfs) } \\ 1 & 0.5 & 1 & 9 & 0.30 & 0.01 & 0.06 & 0.018 \\ 2 & 1.5 & 1 & 12 & 0.39 & 0.03 & 0.08 & 0.031 \\ 3 & 2.5 & 1 & 16 & 0.52 & 0.18 & 0.23 & 0.121 \\ 4 & 3.5 & 1 & 18 & 0.59 & 0.40 & 0.45 & 0.266 \\ 5 & 4.5 & 1 & 11 & 0.36 & 0.11 & 0.16 & 0.058 \\ & & & & & & \text { Tot. flow }= & 0.49\end{array}$

Station 2 Along Monroe-Owens Rd. First tributary north of main channel of Mill Creek.

(12/4/97) Approximate UTM Coordinates: 444846E, 3683390N

Flume Measurement: 8 " throat, fluid height $=0.19 \mathrm{ft} ., Q=0.152 \mathrm{cfs}$ or $69 \mathrm{gmp}$

Station 3 Along Monroe-Owens Rd. Second tributary north of main channel of Mill Creek.

(12/4/97) Approximate UTM Coordinates: 444344E, 3683928N

Flume Measurement: $8^{\mathrm{n}}$ throat, fluid height $=0.23 \mathrm{ft} ., \mathrm{Q}=0.22 \mathrm{cfs}$ or $101 \mathrm{gmp}$

Station 4 Main branch of Mill Creek, downstream of first major tributary entering from south.

(12/4/97) Approximate UTM Coordinates: 445355E, 3684472N

\begin{tabular}{|c|c|c|c|c|c|c|c|}
\hline & \\
\hline Flowmeter & Measuremen & & & & flow vel. & flow vel. & \\
\hline Segment & Tape & width (ft.) & $\operatorname{depth}(\mathrm{cm})$ & depth (ft) & (ft/sec) & $(\mathrm{ft} / \mathrm{sec})$ & $Q$ (cfs) \\
\hline 1 & 0.5 & 1 & 14 & 0.46 & 0.16 & 0.21 & 0.096 \\
\hline 2 & 1.5 & 1 & 15 & 0.49 & 0.35 & 0.40 & 0.197 \\
\hline 3 & 2.5 & 1 & 14 & 0.46 & 0.26 & 0.31 & 0.142 \\
\hline 4 & 3.5 & 1 & 24 & 0.79 & 0.34 & 0.39 & 0.307 \\
\hline 5 & 4.5 & 1 & 22 & 0.72 & 0.24 & 0.29 & 0.209 \\
\hline 6 & 5.5 & 1 & 25 & 0.82 & 0.36 & 0.41 & 0.336 \\
\hline 7 & 6.5 & 1 & 30 & 0.98 & 0.40 & 0.45 & 0.443 \\
\hline 8 & 7.5 & 1 & 26 & 0.85 & 0.22 & 0.27 & 0.230 \\
\hline 9 & 8.5 & 1 & 25 & 0.82 & 0.07 & 0.12 & 0.098 \\
\hline 10 & 9.25 & 0.5 & 20 & 0.66 & -0.02 & 0.03 & 0.010 \\
\hline & & & & & & Tot. flow= & 2.07 \\
\hline
\end{tabular}

Station 5 Tributary to Mill Creek, entering from south, just upstream of confluence with Mill Ck.

(12/4/97) Approximate UTM Coordinates: 445348E, 3684437N

Flowmeter Measurement

\begin{tabular}{|c|c|c|c|c|c|c|c|}
\hline Flowmeter & Measureme & & & & $\begin{array}{l}\text { flow vel. } \\
\text { (ft/sec) }\end{array}$ & $\begin{array}{l}\text { flow vel. } \\
\text { (ft/sec) }\end{array}$ & $Q$ (cfs) \\
\hline $\begin{array}{c}\text { Segment } \\
1\end{array}$ & $\begin{array}{l}\text { Tape } \\
0.5\end{array}$ & $\begin{array}{c}\text { width (ft.) } \\
1\end{array}$ & $\begin{array}{c}\text { depth }(\mathrm{cm}) \\
4\end{array}$ & $\begin{array}{c}\text { depth (ft) } \\
0.13\end{array}$ & $\begin{array}{c}(\mathrm{ft} / \mathrm{sec}) \\
0.06\end{array}$ & $\begin{array}{c}(\mathrm{ft} / \mathrm{sec}) \\
0.11\end{array}$ & $\begin{array}{l}0.014 \\
0.015)\end{array}$ \\
\hline 2 & 1.5 & 1 & 10 & 0.33 & 0.15 & 0.20 & 0.066 \\
\hline 3 & 2.5 & 1 & 17 & 0.56 & 0.37 & 0.42 & 0.234 \\
\hline 4 & 3.5 & 1 & 8 & 0.26 & 0.04 & $\begin{array}{c}0.09 \\
\text { Tot. flow= }\end{array}$ & $\begin{array}{c}0.024 \\
0.34\end{array}$ \\
\hline
\end{tabular}


Station 6 Main branch of Mill Creek, upstream of first major tributary entering from south.

(12/4/97) Approximate UTM Coordinates: 445318E, 3684317N

\begin{tabular}{cccccccc} 
Flowmeter Measurement & & & & \multicolumn{3}{c}{$\begin{array}{c}\text { corrected } \\
\text { flow vel. }\end{array}$} \\
Segment & Tape & width (ft.) & depth (cm) & depth (ft) & (ftsec) & (f/sec) & Q (cfs) \\
1 & 0.5 & 1 & 9 & 0.30 & 0.38 & 0.43 & 0.127 \\
2 & 1.5 & 1 & 20 & 0.66 & 0.10 & 0.15 & 0.098 \\
3 & 2.5 & 1 & 20 & 0.66 & 0.51 & 0.56 & 0.367 \\
4 & 3.5 & 1 & 20 & 0.66 & 0.79 & 0.84 & 0.551 \\
5 & 4.5 & 1 & 15 & 0.49 & 0.05 & 0.10 & 0.049 \\
6 & 5.5 & 1 & 17 & 0.56 & 0.04 & 0.09 & 0.050 \\
7 & 6.5 & 1 & 10 & 0.33 & 0.35 & 0.40 & 0.131 \\
& & & & & & Tot. flow= & 1.37
\end{tabular}

Station 7 Northemmost trib. to Mill $\mathrm{Ck}$ that crosses powerline road, just above entry into Mill $\mathrm{Ck}$.

(12/4/97) Approximate UTM Coordinates: 445200E, 3684304N

$\begin{array}{cccccccc}\text { Flowmeter Measurement } & & & & \text { flow vel. } & \begin{array}{c}\text { corrected } \\ \text { flow vel. }\end{array} \\ \text { Segment } & \text { Tape } & \text { width }(\mathrm{ft} .) & \text { depth }(\mathrm{cm}) & \text { depth }(\mathrm{ft}) & (\mathrm{ft} / \mathrm{sec}) & \text { (ft/sec) } & \mathrm{Q} \text { (cfs) } \\ 1 & 0.5 & 1 & 24 & 0.79 & 0.37 & 0.42 & 0.331 \\ & & & & & & \text { Tot. flow= } & 0.33\end{array}$

Station 8 Main branch of Mill Creek, upstream of confluence with northernmost powerline tirbutary

(12/4/97) Approximate UTM Coordinates: 445216E, 3684298N

Flowmeter Measurement

Segment Tape width (ft.) depth (cm) depth (ft)

$\begin{array}{cc}\text { th }(\mathrm{cm}) & \text { depth }(\mathrm{ft}) \\ 12 & 0.39 \\ 13 & 0.43 \\ 13 & 0.43 \\ 14 & 0.46 \\ 18 & 0.59 \\ 20 & 0.66 \\ 20 & 0.66\end{array}$

$\begin{array}{ccc}\text { flow vel. } & \begin{array}{c}\text { corrected } \\ \text { flow vel. }\end{array} \\ \text { (ft/sec) } & \text { (ft/sec) } & \text { Q (cfs) } \\ 0.04 & 0.09 & 0.035 \\ 0.26 & 0.31 & 0.132 \\ 0.38 & 0.43 & 0.183 \\ 0.44 & 0.49 & 0.225 \\ 0.48 & 0.53 & 0.313 \\ 0.35 & 0.40 & 0.262 \\ 0.25 & 0.30 & 0.197 \\ & \text { Tot. flow }= & 1.35\end{array}$


Station 9 Main branch of Mill Creek, upstream of confluence with 2'nd major trib. from south

(12/4/97) Approximate UTM Coordinates: 445744E. 3685452N

Flowmeter Measurement

$\begin{array}{ccc}\text { flow vel. } & \begin{array}{c}\text { corrected } \\ \text { flow vel. }\end{array} \\ \text { (ft/sec) } & \text { (ft/sec) } & \text { Q (cfs) } \\ 0.02 & 0.07 & 0.051 \\ 0.06 & 0.11 & 0.108 \\ 0.04 & 0.09 & 0.118 \\ 0.12 & 0.17 & 0.279 \\ 0.16 & 0.21 & 0.331 \\ 0.20 & 0.25 & 0.394 \\ 0.22 & 0.27 & 0.399 \\ 0.20 & 0.25 & 0.353 \\ 0.13 & 0.18 & 0.283 \\ 0.11 & 0.16 & 0.252 \\ 0.07 & 0.12 & 0.220 \\ 0.10 & 0.15 & 0.266 \\ 0.04 & 0.09 & 0.136 \\ & \text { Tot. flow= } & 3.19\end{array}$

Station 102 'nd major tributary to Mill Ck. from south. just upstream from confluence. (12/4/97) Approximate UTM Coordinates: 445899E, 3685493N

$\begin{array}{ccccc}\text { Flowmeter Measurement } & & & \\ \text { Segment } & \text { Tape } & \text { width (ft.) } & \text { depth (cm) } & \text { depth (ft) } \\ 1 & 0.5 & 1 & 6 & 0.20 \\ 2 & 1.5 & 1 & 6 & 0.20 \\ 3 & 2.5 & 1 & 5 & 0.16 \\ 4 & 3.5 & 1 & 6 & 0.20 \\ 5 & 4.5 & 1 & 7 & 0.23 \\ 6 & 5.5 & 1 & 7 & 0.23 \\ 7 & 6.5 & 1 & 8 & 0.26 \\ 8 & 7.5 & 1 & 8 & 0.26\end{array}$

$\begin{array}{ccc}\begin{array}{c}\text { corrected } \\ \text { flow vel. }\end{array} & \begin{array}{c}\text { cow vel. } \\ \text { flowsec) } \\ \text { (ft/sec) }\end{array} & \mathrm{Q} \text { (cfs) } \\ 0.24 & 0.29 & 0.057 \\ 0.58 & 0.63 & 0.124 \\ 0.61 & 0.66 & 0.108 \\ 0.78 & 0.83 & 0.163 \\ 0.64 & 0.69 & 0.158 \\ 0.65 & 0.70 & 0.161 \\ 0.55 & 0.60 & 0.157 \\ 0.17 & 0.22 & 0.058\end{array}$

Station 11 Main branch of Mill Creek, at USGS station site where "buried cable road" crosses.

(12/8/97) Approximate UTM Coordinates: $44821 \mathrm{E}, 3686806 \mathrm{~N}$

$\begin{array}{ccccc}\text { Flowmeter Measurement } & & & \\ \text { Segment } & \text { Tape } & \text { width (ft.) } & \text { depth (cm) } & \text { depth (ft) } \\ 1 & 0.5 & 1 & 19 & 0.62 \\ 2 & 1.5 & 1 & 22 & 0.72 \\ 3 & 2.5 & 1 & 22 & 0.72 \\ 4 & 3.5 & 1 & 22 & 0.72 \\ 5 & 4.5 & 1 & 22 & 0.72 \\ 6 & 5.5 & 1 & 22 & 0.72 \\ 7 & 6.5 & 1 & 22 & 0.72 \\ 8 & 7.5 & 1 & 24 & 0.79 \\ 9 & 8.5 & 1 & 24 & 0.79 \\ 10 & 9.5 & 1 & 25 & 0.82 \\ 11 & 10.5 & 1 & 22 & 0.72 \\ 12 & 11.5 & 1 & 19 & 0.62\end{array}$

$\begin{array}{ccc}\begin{array}{c}\text { flow vel. } \\ \text { (ft/sec) }\end{array} & \begin{array}{c}\text { corrected } \\ \text { flow vel. } \\ \text { (ft/sec) }\end{array} & \text { Q (cfs) } \\ 0.04 & 0.09 & 0.056 \\ 0.43 & 0.48 & 0.346 \\ 0.54 & 0.59 & 0.426 \\ 0.58 & 0.63 & 0.455 \\ 0.63 & 0.68 & 0.491 \\ 0.70 & 0.75 & 0.541 \\ 0.67 & 0.72 & 0.520 \\ 0.65 & 0.70 & 0.551 \\ 0.58 & 0.63 & 0.496 \\ 0.41 & 0.46 & 0.377 \\ 0.34 & 0.39 & 0.282 \\ 0.41 & 0.46 & 0.287 \\ & \text { Tot. flow= } & 4.83\end{array}$


Station 121 'st major tributary from east as you proceed upstream from Tinker Ck. Measured

(12/8/97) very close to confluence with Mill Creek.

Approximate UTM Coordinates: $445559 \mathrm{E}, 3686545 \mathrm{~N}$

Flowmeter Measurement

Segment Tape width (ft.) depth (cm) depth (ft)

$\begin{array}{ccc}\text { flow vel. } & \begin{array}{c}\text { corrected } \\ \text { flow vel. }\end{array} \\ \text { (ft/sec) } & \text { (ft/sec) } & \mathrm{Q} \text { (cfs) } \\ 0.23 & 0.28 & 0.083 \\ 0.50 & 0.55 & 0.217 \\ 0.53 & 0.58 & 0.228 \\ 0.16 & 0.21 & 0.055 \\ & \text { Tot. flow= } & 0.58\end{array}$

Station 13 Main branch of Mill Creek, just upstream of confluence with 1'st major tributary to enter (12/8/97) Mill Creek from east, as you proceed upstream from Tinker Creek.

Approximate UTM Coordinates: 445534E, 3686510N

Flowmeter Measurement

Segment Tape width (ft.) depth (cm) depth (ft)

corrected

\begin{tabular}{|c|c|c|c|c|c|c|c|}
\hline ment & Tape & width (ft.) & depth $(\mathrm{cm})$ & depth (ff) & (ft/sec) & ( $\mathrm{f} / \mathrm{sec})$ & $Q$ (cfs) \\
\hline 1 & 0.5 & 1 & 8 & 0.26 & 0.25 & 0.30 & 0.079 \\
\hline 2 & 1.5 & 1 & 16 & 0.52 & 0.34 & 0.39 & 0.205 \\
\hline 3 & 2.5 & 1 & 19 & 0.62 & 0.67 & 0.72 & 0.449 \\
\hline 4 & 3.5 & 1 & 22 & 0.72 & 0.79 & 0.84 & 0.606 \\
\hline 5 & 4.5 & 1 & 21 & 0.69 & 0.85 & $\cdot 0.90$ & 0.620 \\
\hline 6 & 5.5 & 1 & 19 & 0.62 & 0.71 & 0.76 & 0.474 \\
\hline 7 & 6.5 & 1 & 20 & 0.66 & 0.71 & 0.76 & 0.499 \\
\hline 8 & 7.5 & 1 & 20 & 0.66 & 0.65 & 0.70 & 0.459 \\
\hline 9 & 8.5 & 1 & 12 & 0.39 & 0.56 & 0.61 & 0.240 \\
\hline 10 & 9.5 & 1 & 8 & 0.26 & 0.27 & 0.32 & $\begin{array}{c}0.084 \\
371\end{array}$ \\
\hline
\end{tabular}




\section{Upper Pen Branch Ground Water Basin}
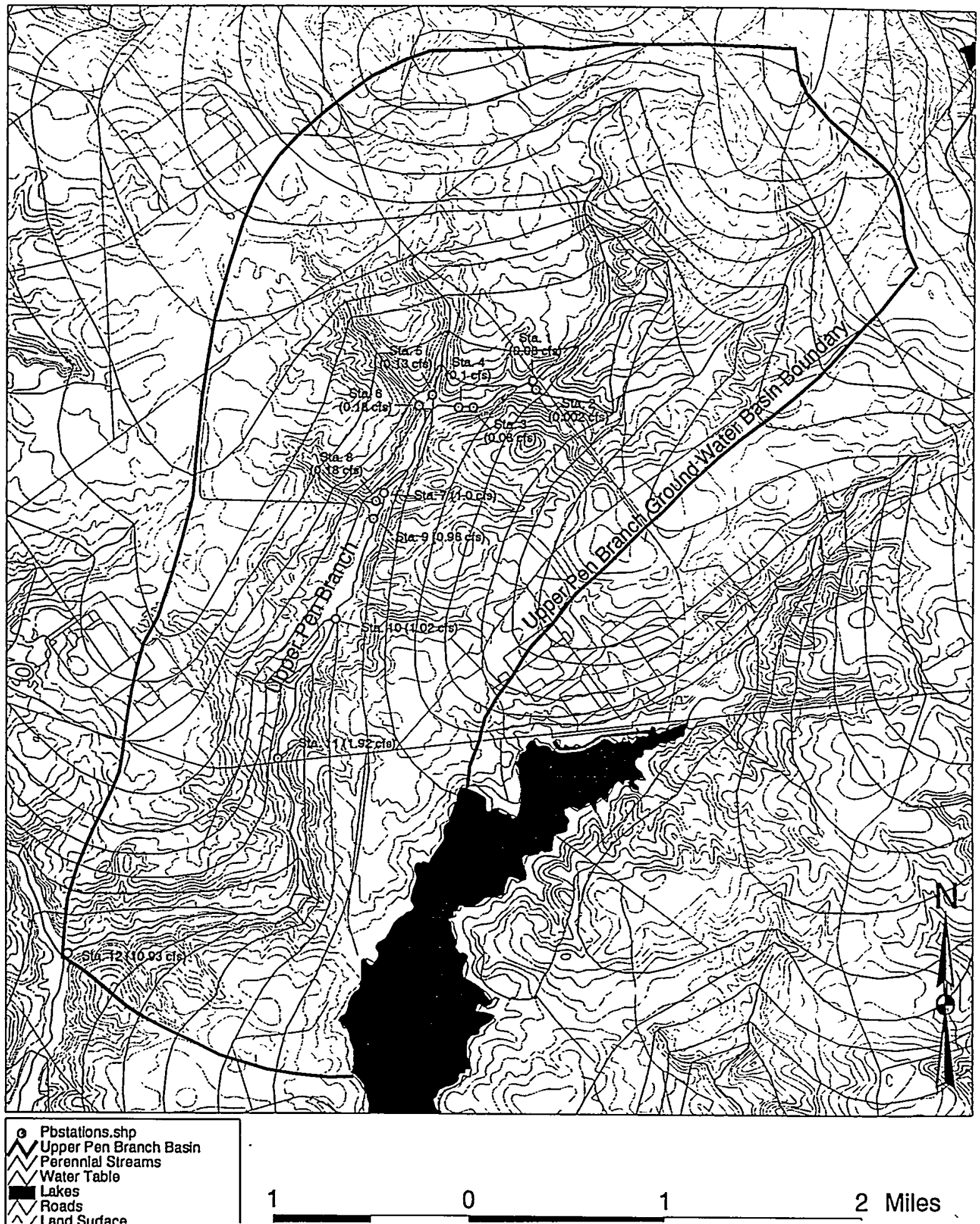

1

0 


\section{PEN BRANCH BASEFLOW}

: Station 1 Just downstream from Road C. Approx UTM Coord. 441732E, 3676976N

(10/14/97) Near confluence of easternmost two headwater tributaries

Flume Measurement 4 " throat width, fluid height $=0.2$ ', $Q=0.082 \mathrm{cfs}$ or $37.3 \mathrm{gpm}$

Station 2 Just downstream from Road C. Approx UTM Coord. 441740E, 3676937N

(10/14/97) Near confluence of easternmost two headwater tributaries

Flume Measurement, $4^{\prime \prime}$ throat width, fluid height $=0.03$ ', $Q=0.0019 \mathrm{cfs}$ or $0.84 \mathrm{gpm}$

Station 3 Just downstream from powerline road, approximately $150 \mathrm{ft}$.

(10/14/97) Approx UTM coordinates 441114E, 3676771N

Flume Measurement; 4 " throat width, height $=0.192, Q=0.078 \mathrm{cfs}$ or $35 \mathrm{gpm}$

Station 4 Just downstream from powerline road, approximately $200 \mathrm{ft}$.

(10/14/97) Approx UTM coordinates 441044E, 36767791N

Flume Measurement; 4" throat width, height=0.22, Q=0.101cfs or $45.1 \mathrm{gpm}$

Station 5 On central headwater tributary of Pen Branch, just upstream of confluence with

$(10 / 14 / 97)$ the headwater branch containing the eastern two headwater tributaries. Approx UTM coordinates 440930E, 36768281N

Flume Measurement; $4 "$ throat width, height $=0.25, Q=0.13 \mathrm{cfs}$ or $58.3 \mathrm{gpm}$

Station 6 On westernmost headwater tributary of Pen Branch, just upstream from confluence

(10/14/97) with the main branch (containing the three eastermost headwater tributaries.) Approx UTM coordinates $440850 E$, $36767511 \mathrm{~N}$

Flume Measurement; 4 " throat width, height $=0.29, Q=0.175 \mathrm{cfs}$ or $78.4 \mathrm{gpm}$

Station 7 On main segment Pen Branch, approx 780 ft downstream from Sta. 6

(10/15/97) Approx UTM coordinates 440523E, 36760281N

Flume Measurement; $4^{\prime \prime}$ throat width, height $=0.38, Q=0.3 \mathrm{cfs}$ or $135 \mathrm{gpm}$

: Flowmeter Measurement

$\begin{array}{rrrrcr}\text { Segment } & \text { depth(cm) } & \text { depth(ft) } & \text { width(ft) } & \text { velocity(ft/sec) } & \text { Q (cfs) } \\ 1 & 8 & 0.26 & 1 & 0.96 & 0.25 \\ 2 & 10 & 0.33 & 1 & 0.96 & 0.31 \\ 3 & 9 & 0.30 & 1 & 0.69 & 0.20 \\ 4 & 9 & 0.30 & 1 & 0.79 & 0.23 \\ & & & & & \end{array}$

Station 8 On lateral tributary to main branch of Pen Branch, close to sta. 7.

(10/15/97) Approx UTM coordinates 440487E, 36759941N .

Flume Measurement; 4 " throat width, height=0.29, $Q=0.175 \mathrm{cfs}$ or $78.4 \mathrm{gpm}$ 
Station 9 On main fork of Pen Branch, close to stations 7 and 8 , downstream of their confluence (10/15/97) Approx UTM coordinates 440479E, 36758991N

Flowmeter Measurement

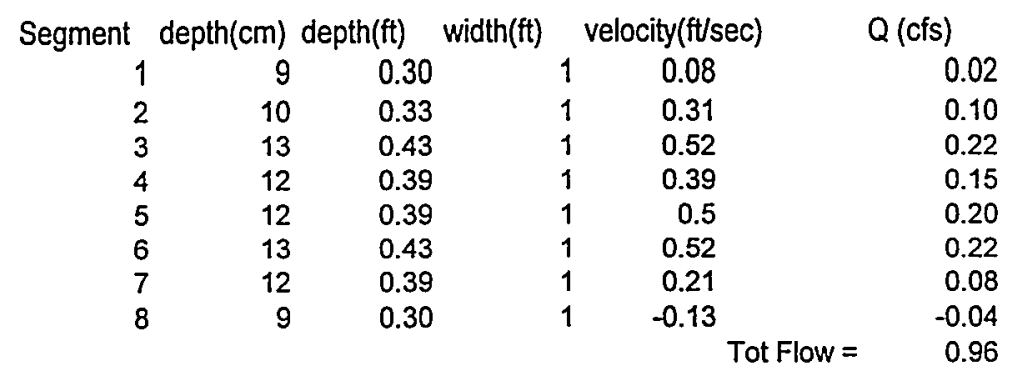

Station 10 On Pen Branch at Road 6.2, approximately $100 \mathrm{ft}$ downstream from bridge.

(10/15/97) Approx UTM coordinates 440122E, 3674981N

Flowmeter Measurement

Tape msmt Segment depth(cm) depth(ft) width(ft) velocity(ft/sec) Q (cfs)

\begin{tabular}{|c|c|c|c|c|c|c|}
\hline 1.5 & 1 & 8 & 0.26 & 1 & 0.22 & 0.06 \\
\hline 2.5 & 2 & 10 & 0.33 & 1 & 0.2 & 0.07 \\
\hline 3.5 & 3 & 9 & 0.30 & 1 & 0.49 & 0.14 \\
\hline 4.5 & 4 & 10 & 0.33 & 1 & 0.55 & 0.18 \\
\hline 5.5 & 5 & 8 & 0.26 & 1 & 0.63 & 0.17 \\
\hline 6.5 & 6 & 10 & 0.33 & 1 & 0.52 & 0.17 \\
\hline 7.5 & 7 & 7 & 0.23 & 1 & 0.41 & 0.09 \\
\hline 8.5 & 8 & 7 & 0.23 & 1 & 0.32 & 0.07 \\
\hline 9.5 & 9 & 8 & 0.26 & 1 & 0.21 & 0.06 \\
\hline \multirow[t]{2}{*}{10.5} & 10 & 6 & 0.20 & 1 & 0.06 & 0.01 \\
\hline & & & & & & 1.02 \\
\hline
\end{tabular}

Station 11 On Pen Branch at B Road, approximately $75 \mathrm{ft}$ upstream from bridge.

(10/15/97) Approx UTM coordinates 439666E, 3673894N

Flowmeter Measurement

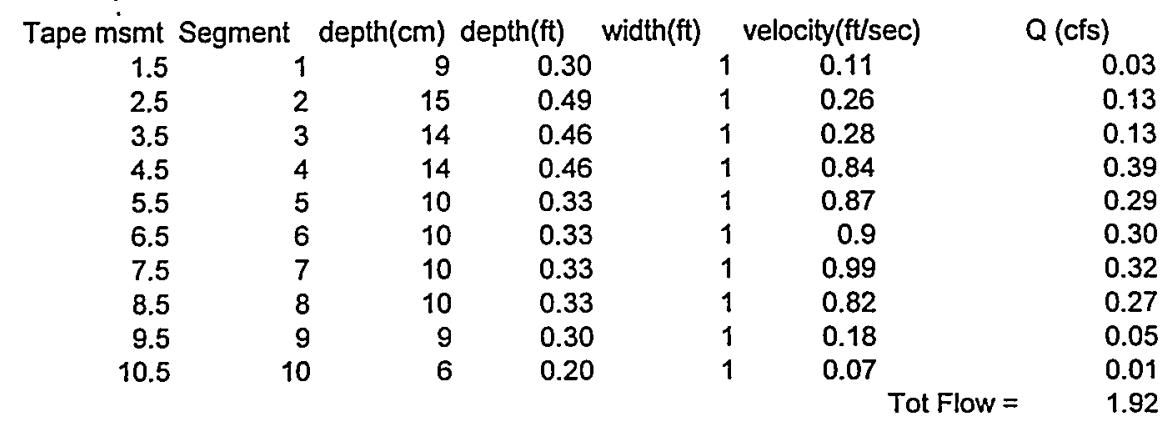


Station 12 On Pen Branch just upstream from confluence with Indinian Grave Branch 12/18/97 Approx UTM coordinates 437922E, 3672243N

\begin{tabular}{crrrrrrr} 
Segment & Tape & depth(cm) depth(ft) & width(ft) & $\begin{array}{c}\text { velocity } \\
\text { (ft/sec) }\end{array}$ & \multicolumn{2}{c}{ com. velocity } \\
(ft/sec) & Q (cfs) \\
1 & 0.5 & 24 & 0.79 & 1 & -0.05 & 0 & 0.00 \\
2 & 1.5 & 26 & 0.85 & 1 & 0.22 & 0.27 & 0.23 \\
3 & 2.5 & 39 & 1.28 & 1 & 0.9 & 0.95 & 1.22 \\
4 & 3.5 & 35 & 1.15 & 1 & 0.8 & 0.85 & 0.98 \\
5 & 4.5 & 33 & 1.08 & 1 & 0.91 & 0.96 & 1.04 \\
6 & 5.5 & 29 & 0.95 & 1 & 0.88 & 0.93 & 0.88 \\
7 & 6.5 & 27 & 0.89 & 1 & 0.94 & 0.99 & 0.88 \\
8 & 7.5 & 26 & 0.85 & 1 & 0.98 & 1.03 & 0.88 \\
9 & 8.5 & 27 & 0.89 & 1 & 0.87 & 0.92 & 0.82 \\
10 & 9.5 & 26 & 0.85 & 1 & 0.97 & 1.02 & 0.87 \\
11 & 10.5 & 26 & 0.85 & 1 & 0.79 & 0.84 & 0.72 \\
12 & 11.5 & 24 & 0.79 & 1 & 0.59 & 0.64 & 0.50 \\
13 & 12.5 & 25 & 0.82 & 1 & 0.48 & 0.53 & 0.43 \\
14 & 13.5 & 30 & 0.98 & 1 & 0.62 & 0.67 & 0.66 \\
15 & 14.5 & 26 & 0.85 & 1 & 0.66 & 0.71 & 0.61 \\
16 & 15.5 & 16 & 0.52 & 1 & 0.38 & 0.43 & 0.23 \\
& & & & & & Tot Flow & 10.93
\end{tabular}




\section{Indian Grave Branch Baseflow}

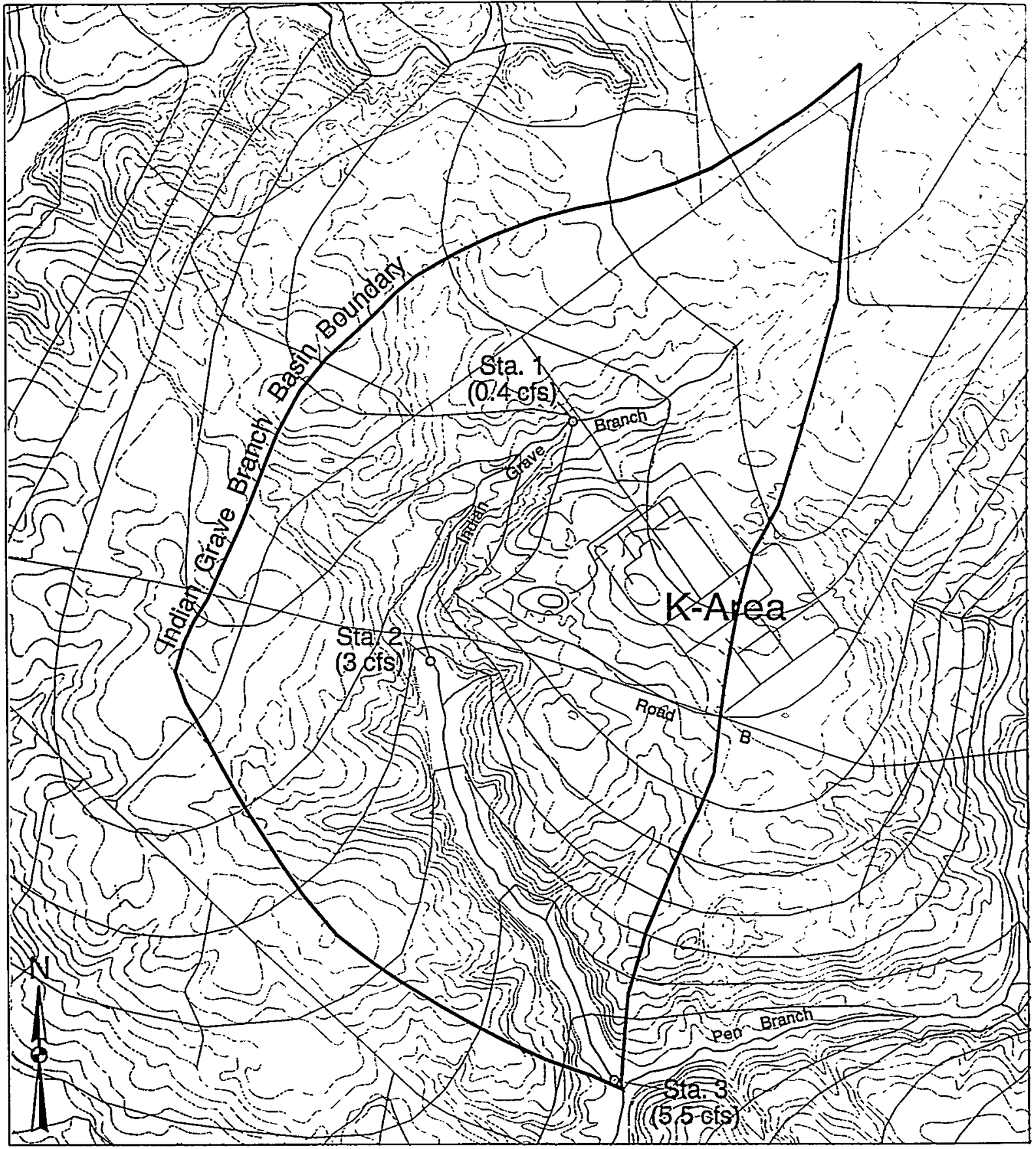

\begin{tabular}{|c|}
\hline 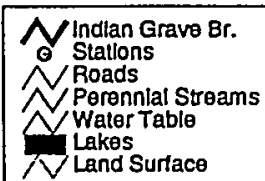 \\
\hline
\end{tabular}


INDIAN GRAVE BRANCH BASEFLOW

Station 1 Indian Grave Branch, approximately $100 \mathrm{ft}$. downstream from road 6.4

(12/18/97) Approximate UTM Coordinates:437677E, $3675456 \mathrm{~N}$

Flowmeter Measurement Segment Tape

$\begin{array}{ccc}\text { width (ft.) } & \text { depth }(\mathrm{cm}) & \text { depth }(\mathrm{ft}) \\ 1 & 6 & 0.20 \\ 1 & 12 & 0.39 \\ 1 & 12 & 0.39 \\ 1 & 12 & 0.39\end{array}$

$\begin{array}{ccc}\text { flow vel. } & \begin{array}{c}\text { corrected } \\ \text { flow vel. }\end{array} \\ \text { (ft/sec) } & \text { (ft/sec) } & \text { Q (cfs) } \\ -0.03 & 0.02 & 0.004 \\ -0.04 & 0.01 & 0.004 \\ 0.45 & 0.50 & 0.197 \\ 0.40 & 0.45 & 0.177 \\ & \text { Tot. flow }= & 0.38\end{array}$

Station 2 Indian Grave Branch about 150 yards downstream from Road B (12/18/97) Approximate UTM Coordinates: 436979E, 3674290N

Flowmeter Measurement Segment Tape width

depth $(f t)$
0.23
0.46
0.56
0.66
0.72
0.85
0.98
0.79
0.79
0.69
0.52
0.33
flow vel.
(ft/sec)

corrected flow vel. (ft/sec) Q (cfs) $\begin{array}{lll}0.02 & 0.07 & 0.016\end{array}$ $\begin{array}{lll}0.27 & 0.32 & 0.147\end{array}$ $\begin{array}{lll}0.56 & 0.61 & 0.340\end{array}$ $\begin{array}{lll}0.48 & 0.53 \quad 0.348\end{array}$ $\begin{array}{lll}0.47 & 0.52 & 0.375\end{array}$ $\begin{array}{lll}0.36 & 0.41 \quad 0.350\end{array}$ $\begin{array}{lll}0.56 & 0.61 & 0.600\end{array}$ $\begin{array}{lll}0.38 & 0.43 & 0.339\end{array}$ $\begin{array}{ccc}-0.23 & 0.28 & 0.220 \\ 0.38 & 0.23 & 0.158\end{array}$ $\begin{array}{lll}0.18 & 0.23 & 0.158\end{array}$ $\begin{array}{lll}0.07 & 0.12 & 0.063\end{array}$ $\begin{array}{lll}0.02 & 0.07 & 0.023\end{array}$ Tot. flow $=$ 2.98

Station 3 Indian Grave Branch just above confluence with Pen Branch (12/18/97) Approximate UTM Coordinates: 437845E, 3672268N

Flowmeter Measurement Segment Tape

$\begin{array}{cc}1 & 0.5 \\ 2 & 1.5 \\ 3 & 2.5 \\ 4 & 3.5 \\ 5 & 4.5 \\ 6 & 5.5 \\ 7 & 6.5 \\ 8 & 7.5 \\ 9 & 8.5 \\ 10 & 9.5\end{array}$
width (ft.) depth (cm) depth (ft)

1
1
1
1
1
1
1
1
1
1

flow vel.
(ftsec)
0.20
0.64
1.13
1.33
1.39
1.51
1.63
1.02
0.87
0.37

corrected

flow vel.

(ft/sec)

0.25

0.69

1.18

1.38

1.44

1.56

1.68

1.07

0.92

0.42

Tot. flow=
$Q$ (cfs)

0.049

0.204

0.465

0.724

0.756

1.024

1.102

0.597

0.423

0.165 


\section{This page intentionally left blank}




\section{APPENDIX F. HYDRAULIC HEAD TARGET AND RESIDUAL DATA}

\section{Hydraulic Head Targets}

Table F-1 summarizes the hydraulic head data available for model calibration. When multiple measurements are available for a given well. the mean water level is shown. Otherwise, the single reading is given. The sample standard deviation of the mean. sample standard deviation of the population. and number of readings follow the target head. where applicable. The "category" column refers to the aquifer zone: 1=Gordon aquifer. 2="lower" UTRA, 3="upper" UTRA, and 4=mixed or other. The average head target has a "2 sigma" uncertainty of $\pm 0.76 \mathrm{ft}$, not counting one time readings which inflate the overall average uncertainty.

Table F-1. Hydraulic Head Targets for Model Calibration

\begin{tabular}{|c|c|c|c|c|c|c|c|c|c|}
\hline Well ID & $\begin{array}{l}\text { SRS Easting } \\
\text { (ft) }\end{array}$ & $\begin{array}{l}\text { SRS Northing } \\
\text { (ft) }\end{array}$ & $\begin{array}{l}\text { Screen } \\
\text { Bottom } \\
\text { (ft msl) }\end{array}$ & $\begin{array}{c}\text { Screen } \\
\text { Top } \\
\text { (ft msl) }\end{array}$ & $\begin{array}{c}\text { Mean } \\
\text { Head } \\
\text { (ft msl) }\end{array}$ & $\begin{array}{l}\text { Sample } \\
\text { Sid. Dev. } \\
\text { of Mean }\end{array}$ & $\begin{array}{l}\text { Sample } \\
\text { Std. Det. }\end{array}$ & $\begin{array}{l}\text { No. of } \\
\text { Neas }\end{array}$ & Cat \\
\hline BG 26 & 58809.70 & 73958.40 & 210.7 & 230.7 & 239.35 & 0.85 & 1.20 & 2 & 3 \\
\hline BG 27 & 58810.00 & 74356.70 & 234.4 & 254.4 & 240.95 & 0.85 & 1.20 & 2 & 3 \\
\hline BG 28 & 58810.20 & 74752.00 & 239.7 & 259.7 & 247.10 & 0.60 & 0.85 & 2 & 3 \\
\hline$B G 29$ & 58809.90 & 75151.60 & 231.6 & 251.6 & 245.00 & 0.60 & 0.85 & 2 & 3 \\
\hline BG 30 & 58809.10 & 75550.10 & 231.7 & 251.7 & 237.55 & 0.05 & 0.07 & 2 & 3 \\
\hline BG 31 & 58803.70 & 75949.90 & 223.3 & 243.3 & 233.70 & 0.50 & 0.71 & 2 & 3 \\
\hline BG 32 & 58803.50 & 76349.90 & 226.9 & 246.9 & 233.40 & 0.30 & 0.42 & 2 & 3 \\
\hline BG 33 & 58526.00 & 76479.90 & 221.2 & 241.2 & 232.90 & 0.30 & 0.42 & 2 & 3 \\
\hline BG 34 & 58107.40 & 76493.60 & 217.4 & 237.4 & 232.85 & 0.45 & 0.64 & 2 & 3 \\
\hline BG 35 & 57726.40 & 76495.30 & 228.0 & 248.0 & 232.90 & 0.20 & 0.28 & 2 & 3 \\
\hline BG 36 & 57620.30 & 76747.60 & 223.3 & 243.3 & 232.50 & 0.60 & 0.85 & 2 & 3 \\
\hline BG 37 & 57251.00 & 76804.90 & 227.8 & 247.8 & 232.85 & 0.55 & 0.78 & 2 & 3 \\
\hline BG 38 & 56851.10 & 76805.00 & 225.9 & 245.9 & 232.30 & 0.40 & 0.57 & 2 & 3 \\
\hline BG 39 & 56451.30 & 76804.90 & 226.0 & 246.0 & 231.70 & 0.50 & 0.71 & 2 & 3 \\
\hline$B G 40$ & 56051.00 & 76805.10 & 221.9 & 241.9 & 231.40 & 0.50 & 0.71 & 2 & 3 \\
\hline BG 41 & 55868.80 & 76576.30 & 221.0 & 241.0 & 230.75 & 0.25 & 0.35 & 2 & 3 \\
\hline BG 42 & 55869.50 & 76178.80 & 217.1 & 237.1 & 230.70 & 0.60 & 0.85 & 2 & 3 \\
\hline BG 43 & 56039.40 & 75852.50 & 222.9 & 242.9 & 230.50 & 0.40 & 0.57 & 2 & 3 \\
\hline BG 51 & 58599.30 & 73864.30 & 221.2 & 241.2 & 240.70 & -1.00 & -1.00 & 1 & 3 \\
\hline BG 52 & 55524.30 & 75910.40 & 223.8 & 243.8 & 229.10 & 0.25 & 1.25 & 25 & 3 \\
\hline BG 53 & 55073.90 & 76157.30 & 214.7 & 234.7 & 228.04 & 0.31 & 0.94 & 9 & 3 \\
\hline BG 54 & 54830.30 & 75837.90 & 215.2 & 235.2 & 228.42 & 0.29 & 1.51 & 27 & 3 \\
\hline BG 55 & 54590.50 & 75525.30 & 214.9 & 234.9 & 226.30 & 0.61 & 3.19 & 27 & 3 \\
\hline BG 56 & 54481.90 & 75206.50 & 210.9 & 230.9 & 225.05 & 0.27 & 0.76 & 8 & 3 \\
\hline BG 57 & 54820.00 & 75000.40 & 214.6 & 234.6 & 225.27 & 0.15 & 0.45 & 9 & 3 \\
\hline BG 58 & 55162.30 & 74790.90 & 218.2 & 238.2 & 226.78 & 0.27 & 0.81 & 9 & 3 \\
\hline BG 59 & 55508.30 & 74593.40 & 217.7 & 237.7 & 229.63 & 0.39 & 1.90 & 24 & 3 \\
\hline BG 60 & 55850.30 & 74386.30 & 215.5 & 235.5 & 230.55 & 0.37 & 1.81 & 24 & 3 \\
\hline BG 61 & 56360.80 & 74075.40 & 225.0 & 245.0 & 232.51 & 0.44 & 2.16 & 24 & 3 \\
\hline$B G 62$ & 56530.90 & 73971.60 & 222.5 & 242.5 & 233.22 & 0.44 & 1.40 & 10 & 3 \\
\hline BG 63 & 56870.50 & 73754.50 & 224.2 & 244.2 & 235.24 & 0.43 & 1.35 & 10 & 3 \\
\hline BG 64 & 57212.40 & 73547.20 & 227.3 & 247.3 & 238.13 & 0.38 & 1.21 & 10 & 3 \\
\hline BG 65 & 57552.70 & 73340.60 & 230.9 & 250.9 & 235.74 & 0.42 & 1.31 & 10 & 3 \\
\hline$B G 66$ & 57805.00 & 73585.00 & 231.0 & 251.0 & 235.20 & 0.60 & 1.81 & 9 & 3 \\
\hline BG 67 & 57902.60 & 73954.10 & 224.7 & 244.7 & 236.33 & 0.56 & 2.88 & 26 & 3 \\
\hline BG 68 & 58251.50 & 76553.60 & 216.5 & 242.9 & 232.22 & -1.00 & -1.00 & 1 & 3 \\
\hline $\mathrm{BG} 69$ & 58226.20 & 76553.80 & 222.2 & 242.2 & 232.48 & -1.00 & -1.00 & 1 & 3 \\
\hline BG 80 & 57962.60 & 76596.50 & 226.2 & 248.6 & 232.73 & -1.00 & -1.00 & 1 & 3 \\
\hline BG 81 & 57983.00 & 76621.90 & 222.9 & 246.9 & 227.35 & -1.00 & -1.00 & 1 & 3 \\
\hline BG 84 & 57955.40 & 76695.90 & 227.2 & 247.2 & 232.58 & -1.00 & -1.00 & 1 & 3 \\
\hline
\end{tabular}


Table F-1. Hydraulic Head Targets for Model Calibration (Continued)

\begin{tabular}{|c|c|c|c|c|c|c|c|c|}
\hline BG 85 & 57928.90 & 76719.00 & 228.0 & 248.0 & 232.55 & -1.00 & -1.00 & 1 \\
\hline BG 86 & 57979.40 & 76721.40 & 228.0 & 248.0 & 232.48 & -1.00 & -1.00 & 1 \\
\hline BG 87 & 57951.90 & 76748.90 & 226.2 & 245.8 & 232.30 & -1.00 & -1.00 & 1 \\
\hline BG 91 & 56649.40 & 78031.30 & 205.4 & 235.4 & 218.57 & 0.47 & 1.95 & 17 \\
\hline BG 92 & 56828.00 & 79019.60 & 197.2 & 227.2 & 208.80 & 0.76 & 3.11 & 17 \\
\hline BG 93 & 57160.80 & 79930.80 & 180.5 & 210.5 & 198.85 & 1.09 & 4.50 & 17 \\
\hline BG 94 & 57494.00 & 80867.20 & 152.8 & 182.8 & 191.12 & 0.28 & 1.20 & 18 \\
\hline BG 95 & 58407.00 & 80059.90 & 152.5 & 182.5 & 192.79 & 0.27 & 1.14 & 18 \\
\hline BG 96 & 58297.80 & 79396.30 & 177.2 & 207.2 & 197.66 & 0.70 & 2.87 & 17 \\
\hline BG 98 & 57398.70 & 77597.90 & 212.5 & 242.5 & 224.46 & -1.00 & -1.00 & 1 \\
\hline BG 99 & 58404.10 & 76904.60 & 215.9 & 245.9 & 232.53 & -1.00 & -1.00 & 1 \\
\hline$B G 100$ & 58899.10 & 77815.60 & 203.3 & 233.3 & 224.80 & -1.00 & -1.00 & 1 \\
\hline BG 103 & 59752.10 & 77883.60 & 169.5 & 199.5 & 199.79 & 0.34 & 1.32 & 15 \\
\hline BG 104 & 59888.00 & 77038.80 & 215.8 & 245.8 & 224.79 & -1.00 & -1.00 & 1 \\
\hline BG 107 & 60120.10 & 74803.60 & 208.3 & 228.3 & 235.28 & 0.35 & 1.47 & 18 \\
\hline BG 108 & 59827.90 & 74383.00 & 217.3 & 247.3 & 238.77 & 0.31 & 1.33 & 18 \\
\hline BG 109 & 59626.10 & 73926.20 & 228.4 & 258.4 & 240.12 & 0.35 & 1.44 & 17 \\
\hline$B G 110$ & 59277.20 & 73354.70 & 224.3 & 254.3 & 241.23 & 0.51 & 2.09 & 17 \\
\hline BG 113 & 59386.00 & 77410.20 & 196.4 & 216.4 & 217.10 & -1.00 & -1.00 & 1 \\
\hline BG 115 & 57884.50 & 77207.20 & 198.9 & 218.9 & 215.80 & -1.00 & -1.00 & 1 \\
\hline BG 119 & 57004.90 & 77743.70 & 209.2 & 229.2 & 215.37 & -1.00 & -1.00 & 1 \\
\hline BG 122 & 56789.70 & 78581.10 & 189.9 & 209.9 & 211.22 & 0.37 & 1.51 & 17 \\
\hline BG 124 & 57095.00 & 77254.00 & 214.8 & 234.8 & 231.82 & -1.00 & -1.00 & 1 \\
\hline$B G O 1 D$ & 58779.30 & 73737.90 & 225.0 & 245.0 & 237.92 & 0.37 & 2.78 & 56 \\
\hline$B G O 2 D$ & 58809.70 & 74552.90 & 218.9 & 238.9 & 238.00 & 0.19 & 1.34 & 51 \\
\hline$B G O 3 A$ & 58806.80 & 75561.70 & 103.7 & 113.7 & 162.93 & 0.14 & 0.55 & 15 \\
\hline BGO 3C & 58806.40 & 75550.40 & 178.7 & 188.7 & 225.54 & 0.25 & 1.02 & 17 \\
\hline$B G O 3 D$ & 58809.20 & 75351.30 & 227.6 & 247.6 & 235.46 & 0.20 & 1.13 & 33 \\
\hline$B G 03 D R$ & 58820.00 & 75512.30 & 217.5 & 237.6 & 231.77 & 0.16 & 0.61 & 15 \\
\hline$B G O 4 D$ & 58803.70 & 76150.10 & 220.6 & 240.6 & 231.82 & 0.31 & 1.44 & 21 \\
\hline $\mathrm{BGO} 5 \mathrm{C}$ & 58794.50 & 76476.90 & 183.2 & 193.2 & 216.22 & 0.41 & 2.75 & 46 \\
\hline BGO 5D & 58784.80 & 76477.50 & 219.3 & 239.3 & 230.40 & 0.36 & 2.50 & 48 \\
\hline$B G O 6 A$ & 58316.80 & 76487.20 & 107.5 & 117.5 & 159.25 & 0.09 & 0.61 & 50 \\
\hline $\mathrm{BGO} 6 \mathrm{~B}$ & 58346.50 & 76553.20 & 139.7 & 149.7 & 218.79 & 0.16 & 0.94 & 34 \\
\hline BGO $6 \mathrm{C}$ & 58307.00 & 76487.10 & 158.0 & 168.0 & 219.97 & 0.16 & 1.14 & 52 \\
\hline BGO $6 D$ & 58297.10 & 76487.30 & 217.2 & 237.2 & 231.37 & 0.11 & 0.78 & 53 \\
\hline BGO $7 D$ & 57917.20 & 76494.50 & 220.2 & 240.2 & 232.69 & 0.33 & 2.30 & 48 \\
\hline$B G O B A$ & 57618.30 & 76569.00 & 105.3 & 115.3 & 160.96 & 0.77 & 2.43 & 10 \\
\hline BGO $8 A R$ & 57617.50 & 76598.80 & 94.6 & 104.6 & 160.82 & 0.22 & 1.39 & 40 \\
\hline$B G 08 C$ & 57618.70 & 76579.20 & 174.3 & 184.3 & 224.34 & 0.32 & 2.24 & 48 \\
\hline$B G O 8 D$ & 57617.80 & 76588.80 & 220.6 & 240.6 & 232.73 & 0.48 & 3.37 & 49 \\
\hline$B G O 9 A A$ & 57371.90 & 76975.70 & 73.8 & 83.8 & 157.89 & 0.10 & 0.53 & 31 \\
\hline BGO 9D & 57478.90 & 76811.60 & 209.2 & 229.2 & 230.04 & 0.52 & 3.75 & 52 \\
\hline BGO $10 \mathrm{~A}$ & 57050.90 & 76805.20 & 111.1 & 121.1 & 170.57 & 1.50 & 6.17 & 17 \\
\hline $\mathrm{BGO} 10 \mathrm{AA}$ & 56990.50 & 76997.90 & 80.8 & 90.8 & 157.44 & 0.68 & 3.62 & 28 \\
\hline BGO 10AR & 57063.80 & 76806.00 & 96.5 & 106.5 & 158.45 & 0.10 & 0.60 & 35 \\
\hline$B G 010 B$ & 56978.80 & 76982.10 & 139.0 & 149.0 & 219.55 & 0.25 & 1.33 & 28 \\
\hline $\mathrm{BGO} 10 \mathrm{C}$ & 57041.10 & 76805.20 & 157.3 & 167.3 & 220.23 & 0.15 & 1.11 & 54 \\
\hline BGO $10 D$ & 57030.60 & 76805.10 & 230.5 & 250.5 & 231.80 & 0.24 & 0.72 & 9 \\
\hline BGO 10DR & 57073.70 & 76804.80 & 218.3 & 238.3 & 231.49 & 0.29 & 1.70 & 35 \\
\hline$B G O 11 D$ & 56651.30 & 76805.10 & 216.3 & 236.3 & 230.71 & 0.39 & 2.43 & 38 \\
\hline BGO 11DR & 56650.40 & 76849.30 & 213.1 & 233.0 & 230.11 & 0.23 & 0.90 & 15 \\
\hline BGO $12 A R$ & 56259.90 & 76803.80 & 99.3 & 109.3 & 157.79 & 0.11 & 0.51 & 22 \\
\hline BGO $12 A X$ & 56258.00 & 76834.80 & 99.5 & 109.5 & 157.21 & 0.19 & 0.73 & 15 \\
\hline$B G O 12 C$ & 56241.10 & 76805.20 & 153.6 & 163.6 & 220.05 & 0.24 & 0.77 & 10 \\
\hline BGO $12 C R$ & 56215.20 & 76806.00 & 144.0 & 154.0 & 221.87 & 0.22 & 1.04 & 22 \\
\hline BGO $12 C X$ & 56230.40 & 76834.50 & 141.2 & 151.2 & 229.96 & 0.23 & 0.93 & 16 \\
\hline BGO $12 D$ & 56231.10 & 76805.20 & 217.8 & 237.8 & 231.31 & 0.21 & 1.30 & 38 \\
\hline BGO 12DR & 56214.70 & 76834.60 & 212.7 & 232.8 & 219.57 & 0.25 & 0.96 & 15 \\
\hline
\end{tabular}


Table F-1. Hydraulic Head Targets for Model Calibration (Continued)

\begin{tabular}{|c|c|c|c|c|c|c|c|c|}
\hline$B G 013 D$ & 55840.00 & 76805.30 & 228.5 & 248.5 & 231.03 & 0.90 & 2.39 & 7 \\
\hline BGO 13DR & 55840.40 & 76824.70 & 210.3 & 220.3 & 230.73 & 0.23 & 1.42 & 39 \\
\hline BGO 14A & 55838.30 & 76377.50 & 109.6 & 119.6 & 157.95 & 0.16 & 0.59 & 14 \\
\hline BGO 14AR & 55788.90 & 76351.80 & 96.8 & 106.8 & 159.35 & 0.20 & 1.18 & 36 \\
\hline $\mathrm{BGO} 14 \mathrm{C}$ & 55839.00 & 76367.70 & 192.1 & 202.1 & 221.36 & 0.95 & 3.55 & 14 \\
\hline BGO 14CR & 55789.00 & 76337.80 & 190.1 & 200.1 & 223.55 & 0.22 & 1.40 & 39 \\
\hline $\mathrm{BGO} 14 \mathrm{DR}$ & 55789.40 & 76322.10 & 218.1 & 238.1 & 230.43 & 0.27 & 1.63 & 37 \\
\hline BGO 15D & 55859.10 & 75973.50 & 218.7 & 238.7 & 229.74 & 0.20 & 1.45 & 51 \\
\hline BGO 16A & 56194.20 & 75757.00 & 102.5 & 112.5 & 160.96 & 0.22 & 1.06 & 22 \\
\hline BGO 16AR & 56217.10 & 75743.20 & 103.7 & 113.7 & 160.91 & 0.09 & 0.50 & 30 \\
\hline BGO $16 B$ & 56183.80 & 75767.50 & 136.0 & 146.0 & 218.14 & 0.22 & 1.25 & 33 \\
\hline BGO 16D & 56202.10 & 75751.40 & 217.3 & 237.3 & 230.81 & 0.16 & 1.16 & 52 \\
\hline BGO $17 D$ & 56399.40 & 75599.60 & 204.0 & 224.0 & 230.77 & 0.27 & 0.82 & 9 \\
\hline BGO 17DR & 56407.20 & 75604.00 & 216.9 & 236.9 & 231.96 & 0.37 & 2.08 & 32 \\
\hline BGO 18A & 56699.70 & 75599.90 & 99.5 & 109.5 & 161.04 & 0.11 & 0.76 & 52 \\
\hline$B G 018 D$ & 56711.20 & 75600.00 & 219.6 & 239.6 & 231.88 & 0.17 & 1.16 & 49 \\
\hline BGO 19D & 56997.30 & 75350.00 & 196.8 & 216.8 & 234.16 & 0.25 & 1.29 & 26 \\
\hline BGO 19DR & 56800.70 & 75520.00 & 196.7 & 216.7 & 231.26 & 0.22 & 0.87 & 15 \\
\hline $\mathrm{BGO} 20 \mathrm{~A}$ & 57100.40 & 74966.40 & 86.3 & 96.3 & 163.56 & 0.55 & 2.14 & 15 \\
\hline $\mathrm{BGO} 20 \mathrm{AA}$ & 57089.50 & 74949.80 & 18.3 & 28.3 & 161.48 & 0.13 & 0.51 & 16 \\
\hline BGO 20B & 57119.80 & 74951.50 & 131.0 & 141.0 & 226.92 & 0.24 & 1.02 & 18 \\
\hline $\mathrm{BGO} 20 \mathrm{C}$ & 57106.00 & 74937.60 & 174.0 & 184.0 & 228.16 & 0.27 & 1.08 & 16 \\
\hline$B G O 20 D$ & 57113.80 & 74962.20 & 216.3 & 236.3 & 233.91 & 0.21 & 1.48 & 49 \\
\hline BGO 21D & 57470.70 & 74688.50 & 217.7 & 237.7 & 234.83 & 0.24 & 1.77 & 55 \\
\hline $\mathrm{BGO} 22 \mathrm{D}$ & 57817.30 & 74482.20 & 194.2 & 214.2 & 232.60 & 0.20 & 0.94 & 21 \\
\hline BGO 22DR & 57831.50 & 74471.50 & 219.2 & 239.2 & 236.04 & 0.99 & 4.30 & 19 \\
\hline$B G O 22 D X$ & 57770.74 & 74560.48 & 217.9 & 237.9 & 233.90 & 0.23 & 0.73 & 10 \\
\hline $\mathrm{BGO} 23 \mathrm{D}$ & 58133.00 & 74238.10 & 222.0 & 242.0 & 235.84 & 0.15 & 1.07 & 52 \\
\hline$B G O 24 D$ & 58438.80 & 74012.40 & 221.0 & 241.0 & 236.79 & 0.15 & 1.05 & 52 \\
\hline$B G O 25 A$ & 55668.10 & 76158.50 & 104.1 & 114.1 & 160.63 & 0.17 & 1.16 & 49 \\
\hline $\mathrm{BGO} 26 \mathrm{~A}$ & 55014.20 & 76144.60 & 81.0 & 91.0 & 160.92 & 0.81 & 4.67 & 33 \\
\hline $\mathrm{BGO} 26 \mathrm{D}$ & 55015.20 & 76128.00 & 213.4 & 233.5 & 227.69 & 0.22 & 1.47 & 46 \\
\hline $\mathrm{BGO} 27 \mathrm{C}$ & 54671.40 & 75666.30 & 154.9 & 163.9 & 220.61 & 0.23 & 1.48 & 41 \\
\hline BGO 27D & 54680.20 & 75677.30 & 209.3 & 229.3 & 227.41 & 0.21 & 1.47 & 47 \\
\hline $\mathrm{BGO} 28 \mathrm{D}$ & 54457.90 & 75348.30 & 210.1 & 230.1 & 226.10 & 0.22 & 1.47 & 46 \\
\hline $\mathrm{BGO} 29 \mathrm{~A}$ & 54103.50 & 75560.00 & 102.5 & 112.5 & 159.55 & 0.15 & 0.96 & 43 \\
\hline $\mathrm{BGO} 29 \mathrm{C}$ & 54099.10 & 75577.80 & 176.8 & 186.8 & 222.83 & 0.24 & 1.36 & 33 \\
\hline BGO 29D & 54099.40 & 75592.50 & 208.5 & 228.5 & 226.12 & 0.25 & 1.46 & 35 \\
\hline $\mathrm{BGO} 30 \mathrm{C}$ & 54512.30 & 75181.00 & 178.4 & 188.4 & 219.02 & 0.20 & 1.35 & 45 \\
\hline$B G 030 D$ & 54499.20 & 75187.70 & 207.8 & 227.8 & 225.48 & 0.22 & 1.48 & 46 \\
\hline $\mathrm{BGO} 31 \mathrm{C}$ & 54816.20 & 74978.00 & 176.4 & 186.4 & 225.33 & 0.23 & 1.49 & 44 \\
\hline $\mathrm{BGO} 31 \mathrm{D}$ & 54841.70 & 74985.30 & 211.1 & 231.1 & 226.43 & 0.23 & 1.54 & 46 \\
\hline$B G O 32 D$ & 55250.20 & 74727.00 & 214.5 & 234.5 & 227.47 & 0.22 & 1.47 & 46 \\
\hline $\mathrm{BGO} 33 \mathrm{C}$ & 55681.40 & 74479.70 & 177.8 & 187.8 & 224.93 & 0.20 & 1.36 & 45 \\
\hline $\mathrm{BGO} 33 \mathrm{D}$ & 55695.40 & 74468.70 & 213.1 & 233.1 & 229.91 & 0.34 & 2.34 & 46 \\
\hline $\mathrm{BGO} 34 \mathrm{D}$ & 56082.60 & 74228.80 & 212.7 & 232.7 & 232.68 & 0.26 & 1.72 & 45 \\
\hline $\mathrm{BGO} 35 \mathrm{C}$ & 56545.70 & 73953.90 & 161.9 & 171.9 & 228.57 & 0.23 & 1.50 & 42 \\
\hline $\mathrm{BGO} 35 \mathrm{D}$ & 56556.50 & 73946.00 & 219.4 & 239.4 & 234.51 & 0.38 & 2.49 & 43 \\
\hline $\mathrm{BGO} 36 \mathrm{D}$ & 56888.10 & 73743.80 & 223.3 & 243.3 & 236.60 & 0.35 & 2.40 & 46 \\
\hline $\mathrm{BGO} 37 \mathrm{C}$ & 57279.20 & 73498.20 & 168.8 & 178.8 & 229.91 & 0.23 & 1.24 & 29 \\
\hline BGO 37D & 57292.90 & 73490.80 & 226.1 & 246.1 & 237.87 & 0.30 & 2.03 & 45 \\
\hline$B G 038 D$ & 57557.50 & 73329.30 & 222.3 & 242.3 & 235.20 & 0.25 & 1.65 & 45 \\
\hline$B G 039 A$ & 57821.90 & 73573.20 & 84.8 & 94.8 & 167.49 & 0.13 & 0.47 & 13 \\
\hline $\mathrm{BGO} 39 \mathrm{C}$ & 57816.10 & 73563.30 & 174.9 & 184.9 & 229.34 & 1.25 & 4.66 & 14 \\
\hline $\mathrm{BGO} 39 \mathrm{D}$ & 57831.00 & 73583.50 & 224.7 & 244.7 & 234.58 & 0.50 & 3.33 & 44 \\
\hline$B G O 40 D$ & 54638.60 & 76125.80 & 216.6 & 226.5 & 222.20 & 0.26 & 1.55 & 35 \\
\hline $\mathrm{BGO} 41 \mathrm{~A}$ & 55403.70 & 76469.50 & 103.3 & 113.3 & 158.32 & 0.12 & 0.61 & 27 \\
\hline $\mathrm{BGO} 42 \mathrm{C}$ & 55522.30 & 76404.70 & 185.9 & 195.9 & 223.18 & 0.25 & 1.44 & 32 \\
\hline
\end{tabular}


Table F-1. Hydraulic Head Targets for Model Calibration (Continued)

\begin{tabular}{|c|c|c|c|c|c|c|c|c|}
\hline$B G O 43 A$ & 56253.40 & 77061.40 & 105.9 & 115.9 & 158.76 & 0.34 & 1.72 & 26 \\
\hline $\mathrm{BGO} 43 \mathrm{AA}$ & 56268.60 & 77066.00 & 62.2 & 72.2 & 156.65 & 0.18 & 0.98 & 31 \\
\hline $\mathrm{BGO} 43 \mathrm{CR}$ & 56237.20 & 77035.20 & 178.4 & 188.4 & 225.21 & 0.29 & 1.57 & 29 \\
\hline BGO 43D & 56238.80 & 77056.70 & 198.2 & 208.2 & 231.27 & 0.25 & 1.41 & 32 \\
\hline BGO 44A & 57851.20 & 76755.20 & 98.0 & 108.0 & 158.40 & 0.08 & 0.45 & 32 \\
\hline BGO 44AA & 57880.50 & 76757.00 & 61.2 & 71.3 & 158.68 & 0.08 & 0.44 & 30 \\
\hline $\mathrm{BGO} 44 \mathrm{~B}$ & 57865.80 & 76756.00 & 148.1 & 158.1 & 221.28 & 0.31 & 1.79 & 33 \\
\hline $\mathrm{BGO} 44 \mathrm{C}$ & 57894.90 & 76757.80 & 190.6 & 200.6 & 220.82 & 0.18 & 1.01 & 33 \\
\hline BGO 44D & 57910.00 & 76759.50 & 223.4 & 233.4 & 232.53 & 0.17 & 0.95 & 31 \\
\hline $\mathrm{BGO} 45 \mathrm{~A}$ & 54550.10 & 75830.00 & 116.9 & 126.9 & 160.72 & 0.09 & 0.50 & 34 \\
\hline $\mathrm{BGO} 45 \mathrm{~B}$ & 54563.60 & 75840.30 & 137.0 & 147.0 & 218.73 & 0.43 & 2.53 & 34 \\
\hline $\mathrm{BGO} 45 \mathrm{C}$ & 54577.40 & 75835.00 & 190.5 & 200.5 & 222.62 & 0.39 & 2.29 & 34 \\
\hline $\mathrm{BGO} 45 \mathrm{D}$ & 54585.60 & 75854.30 & 209.6 & 229.6 & 227.70 & 0.25 & 1.43 & 34 \\
\hline $\mathrm{BGO} 46 \mathrm{~B}$ & 54444.70 & 75012.10 & 140.4 & 150.4 & 217.94 & 0.20 & 1.14 & 31 \\
\hline $\mathrm{BGO} 46 \mathrm{C}$ & 54433.90 & 75022.20 & 178.0 & 188.0 & 219.37 & 0.30 & 1.72 & 34 \\
\hline BGO 46D & 54420.00 & 75033.80 & 202.1 & 212.1 & 224.96 & 0.32 & 1.82 & 33 \\
\hline $\mathrm{BGO} 47 \mathrm{~A}$ & 54914.00 & 74728.80 & 86.8 & 96.8 & 162.32 & 0.08 & 0.47 & 32 \\
\hline $\mathrm{BGO} 47 \mathrm{C}$ & 54933.40 & 74752.00 & 178.6 & 188.6 & 222.67 & 0.22 & 1.25 & 32 \\
\hline BGO 47D & 54922.90 & 74739.70 & 203.4 & 213.4 & 226.27 & 0.24 & 1.36 & 32 \\
\hline $\mathrm{BGO} 48 \mathrm{C}$ & 55124.40 & 74599.60 & 176.7 & 186.7 & 223.33 & 0.22 & 1.27 & 33 \\
\hline $\mathrm{BGO} 48 \mathrm{D}$ & 55121.00 & 74586.40 & 202.0 & 212.0 & 226.52 & 0.24 & 1.38 & 33 \\
\hline $\mathrm{BGO} 49 \mathrm{~A}$ & 56205.10 & 73902.80 & 75.1 & 85.1 & 167.18 & 1.49 & 4.94 & 11 \\
\hline $\mathrm{BGO} 49 \mathrm{C}$ & 56202.20 & 73917.20 & 166.0 & 176.0 & 227.74 & 0.29 & 1.65 & 33 \\
\hline BGO 49D & 56198.80 & 73931.50 & 218.5 & 238.5 & 234.48 & 0.28 & 1.51 & 29 \\
\hline BGO 50A & 54179.80 & 75201.20 & 90.5 & 100.5 & 160.09 & 0.09 & 0.56 & 36 \\
\hline BGO $50 \mathrm{C}$ & 54197.00 & 75190.40 & 162.5 & 172.5 & 218.08 & 0.40 & 2.24 & 32 \\
\hline BGO 50D & 54209.10 & 75181.30 & 208.0 & 228.0 & 225.02 & 0.25 & 1.41 & 33 \\
\hline BGO $51 A$ & 57841.80 & 74133.00 & 75.1 & 85.1 & 165.89 & 0.26 & 1.00 & 15 \\
\hline BGO 51AA & 57867.00 & 74113.10 & 29.2 & 39.2 & 168.18 & 0.13 & 0.48 & 14 \\
\hline BGO 51B & 57848.30 & 74127.70 & 116.9 & 126.9 & 229.39 & 0.35 & 1.36 & 15 \\
\hline BGO 51C & 57854.40 & 74123.10 & 175.1 & 185.1 & 230.27 & 0.30 & 1.16 & 15 \\
\hline BGO 51D & 57860.60 & 74118.00 & 220.1 & 240.1 & 235.17 & 0.29 & 1.11 & 15 \\
\hline BGO 52A & 57184.00 & 74632.60 & 81.7 & 91.7 & 163.71 & 0.12 & 0.46 & 15 \\
\hline BGO 52AA & 57178.10 & 74638.00 & 36.6 & 46.6 & 162.94 & 0.11 & 0.44 & 15 \\
\hline $\mathrm{BGO} 52 \mathrm{~B}$ & 57189.80 & 74627.30 & 126.7 & 136.7 & 227.45 & 0.26 & 1.02 & 15 \\
\hline BGO 52B & 57189.80 & 74627.30 & 126.7 & 136.7 & 227.45 & 0.26 & 1.02 & 15 \\
\hline BGO 52C & 57195.50 & 74622.00 & 178.7 & 188.7 & 228.68 & 0.27 & 1.03 & 15 \\
\hline BGO 52D & 57201.40 & 74617.30 & 219.4 & 239.4 & 233.60 & 0.28 & 1.10 & 15 \\
\hline BGO 53A & 55423.90 & 76070.80 & 78.7 & 88.7 & 158.95 & 0.12 & 0.46 & 15 \\
\hline BGO 53AA & 55431.50 & 76065.00 & 38.9 & 48.9 & 155.61 & 0.11 & 0.42 & 15 \\
\hline BGO 53B & 55416.20 & 76076.60 & 143.5 & 153.5 & 221.27 & 0.55 & 2.15 & 15 \\
\hline BGO 53C & 55408.30 & 76082.50 & 183.2 & 193.2 & 222.01 & 0.27 & 1.00 & 14 \\
\hline BGO 53D & 55425.50 & 76056.00 & 225.3 & 245.3 & 229.13 & 0.26 & 0.98 & 14 \\
\hline$B G X 1 A$ & 58590.40 & 76831.90 & 114.1 & 124.1 & 158.77 & 0.69 & 3.77 & 30 \\
\hline$B G X 1 C$ & 58599.80 & 76820.00 & 176.0 & 186.0 & 215.82 & 0.19 & 1.09 & 34 \\
\hline$B G X 1 D$ & 58608.60 & 76809.50 & 214.7 & 234.7 & 229.54 & 0.12 & 0.73 & 35 \\
\hline$B G \times 2 B$ & 58256.50 & 77203.40 & 137.2 & 147.2 & 212.74 & 0.20 & 1.19 & 34 \\
\hline$B G \times 2 D$ & 58265.60 & 77192.40 & 181.1 & 191.1 & 215.22 & 0.27 & 1.59 & 36 \\
\hline$B G \times 3 D$ & 57780.10 & 77577.00 & 201.6 & 221.6 & 214.62 & 0.39 & 2.32 & 35 \\
\hline$B G \times 4 A$ & 57215.60 & 77879.20 & 106.8 & 116.8 & 155.11 & 0.08 & 0.45 & 34 \\
\hline$B G \times 4 C$ & 57202.20 & 77886.20 & 170.7 & 180.7 & 214.48 & 0.27 & 1.55 & 33 \\
\hline$B G \times 4 D$ & 57186.20 & 77893.90 & 203.8 & 223.8 & 215.70 & 0.27 & 1.55 & 34 \\
\hline$B G X 5 D$ & 57308.60 & 78402.00 & 195.0 & 215.0 & 209.00 & 0.28 & 1.65 & 34 \\
\hline$B G \times 6 D$ & 57524.90 & 78740.10 & 191.0 & 211.0 & 205.73 & 0.28 & 1.67 & 35 \\
\hline$B G \times 7 D$ & 58312.80 & 78349.30 & 194.1 & 214.1 & 205.54 & 0.27 & 1.44 & 29 \\
\hline $\mathrm{BGX} 8 \mathrm{DR}$ & 58942.50 & 77589.60 & 183.1 & 203.1 & 205.39 & 0.21 & 1.15 & 31 \\
\hline$B G \times 9 D$ & 59522.10 & 76936.00 & 212.4 & 232.4 & 226.47 & 0.39 & 2.31 & 35 \\
\hline$B G \times 10 D$ & 59765.50 & 76183.30 & 216.2 & 236.2 & 225.41 & 0.33 & 1.90 & 34 \\
\hline $\mathrm{BGX} 11 \mathrm{D}$ & 59581.40 & 75300.70 & 216.7 & 236.7 & 235.34 & 0.22 & 1.22 & 31 \\
\hline
\end{tabular}


Table F-1. Hydraulic Head Targets for Model Calibration (Continued)

\begin{tabular}{|c|c|c|c|c|c|c|c|c|}
\hline $\mathrm{BG} \times 12 \mathrm{C}$ & 59675.30 & 74427.90 & 174.1 & 184.1 & 234.17 & 0.51 & 2.94 & 33 \\
\hline$B G X 12 D$ & 59674.30 & 74410.90 & 223.7 & 243.7 & 238.78 & 0.30 & 1.80 & 35 \\
\hline BRD 1 & 29277.70 & 55860.50 & 148.9 & 178.9 & 167.10 & 0.30 & 1.69 & 32 \\
\hline BRD 2 & 29357.10 & 56093.30 & 148.5 & 178.5 & 169.27 & 0.60 & 3.37 & 32 \\
\hline BRD 3 & 29538.90 & 55918.70 & 158.5 & 188.5 & 169.95 & 0.14 & 0.44 & 10 \\
\hline BRD 4 & 29219.20 & 56060.40 & 129.1 & 159.1 & 165.91 & 0.36 & 1.96 & 30 \\
\hline BRD 5D & 29252.60 & 55955.70 & 148.4 & 168.4 & 166.75 & 0.37 & 1.84 & 25 \\
\hline BRR 1D & 50588.20 & 77365.20 & 200.4 & 220.4 & 217.15 & 0.46 & 2.11 & 21 \\
\hline BRR 2D & 50306.30 & 77431.40 & 196.1 & 216.1 & 215.49 & 0.47 & 2.20 & 22 \\
\hline BRR 3D & 50203.50 & 77398.30 & 197.1 & 217.1 & 215.18 & 0.43 & 2.06 & 23 \\
\hline BRR 4D & 50104.50 & 77360.50 & 198.7 & 218.7 & 215.10 & 0.45 & 2.06 & 21 \\
\hline BRR 5D & 50009.00 & 77266.70 & 202.1 & 222.1 & 214.85 & 0.43 & 1.91 & 20 \\
\hline BRR $6 C$ & 51094.70 & 77062.90 & 156.0 & 166.0 & 211.63 & 0.26 & 0.57 & 5 \\
\hline BRR 7BR & 50707.50 & 77575.40 & 141.6 & 151.6 & 204.87 & 0.03 & 0.05 & 2 \\
\hline BRR 7C & 50698.10 & 77572.90 & 175.9 & 185.9 & 209.81 & 0.34 & 0.75 & 5 \\
\hline BRR 7D & 50688.30 & 77570.70 & 201.9 & 221.9 & 217.88 & 0.30 & 0.67 & 5 \\
\hline BRR 8B & 50116.50 & 77634.70 & 138.7 & 148.7 & 204.34 & 0.38 & 0.85 & 5 \\
\hline BRR $8 C$ & 50125.60 & 77632.00 & 182.7 & 192.7 & 208.50 & 0.38 & 0.84 & 5 \\
\hline BRR 8DR & 50142.30 & 77627.30 & 204.0 & 219.0 & 214.34 & 0.19 & 0.33 & 3 \\
\hline CBR 1D & 52822.10 & 60419.50 & 230.9 & 250.9 & 253.45 & 0.56 & 2.55 & 21 \\
\hline CBR 2D & 52694.00 & 60368.90 & 233.8 & 253.8 & 252.91 & 0.53 & 2.49 & 22 \\
\hline CBR 3D & 52627.20 & 60388.50 & 234.1 & 254.1 & 253.02 & 0.53 & 2.51 & 22 \\
\hline CCB 1 & 46990.10 & 65438.50 & 198.4 & 228.4 & 226.06 & 0.72 & 3.37 & 22 \\
\hline $\mathrm{CCB} 2$ & 46893.60 & 65306.10 & 198.6 & 228.6 & 222.53 & 0.74 & 4.24 & 33 \\
\hline CCB 3 & 47006.60 & 65187.50 & 205.6 & 235.6 & 225.15 & 0.66 & 3.60 & 30 \\
\hline CCB 4 & 47181.60 & 65310.20 & 211.2 & 241.2 & 226.12 & 0.70 & 3.96 & 32 \\
\hline CDB 1 & 45685.50 & 67514.60 & 195.7 & 216.6 & 213.86 & 0.55 & 3.23 & 35 \\
\hline $\mathrm{CDB} 2$ & 45617.70 & 67415.30 & 195.1 & 216.1 & 214.92 & 0.59 & 3.43 & 34 \\
\hline CMP $8 A$ & 54270.20 & 52671.20 & 13.7 & 23.5 & 182.94 & 0.30 & 1.62 & 29 \\
\hline CMP 8B & 54280.20 & 52674.60 & 156.6 & 166.6 & 198.46 & 0.14 & 0.76 & 32 \\
\hline CMP 9B & 53842.30 & 51691.60 & 149.0 & 159.0 & 194.72 & 0.13 & 0.68 & 28 \\
\hline CMP 10 & 54006.50 & 51390.40 & 188.8 & 218.8 & 220.11 & 0.42 & 2.06 & 24 \\
\hline CMP 10B & 54005.90 & 51380.70 & 137.4 & 147.4 & 195.01 & 0.13 & 0.74 & 31 \\
\hline CMP 10C & 53994.30 & 51402.70 & 179.6 & 189.6 & 198.92 & 0.26 & 0.51 & 4 \\
\hline CMP 11 & 53640.60 & 51481.30 & 185.2 & 215.2 & 212.03 & 0.45 & 2.36 & 27 \\
\hline CMP 11B & 53661.90 & 51456.60 & 139.7 & 149.7 & 195.01 & 0.16 & 0.85 & 29 \\
\hline CMP 110 & 53647.00 & 51467.90 & 209.5 & 229.9 & 221.20 & 1.04 & 2.32 & 5 \\
\hline CMP 12A & 53524.60 & 51949.20 & 22.1 & 32.1 & 181.59 & 0.36 & 1.92 & 29 \\
\hline CMP 12B & 53517.70 & 51943.30 & 148.0 & 158.0 & 194.64 & 0.14 & 0.76 & 31 \\
\hline CMP 13B & 53937.80 & 51855.50 & 134.2 & 144.2 & 194.67 & 0.14 & 0.75 & 31 \\
\hline CMP 14B & 52587.30 & 52376.40 & 130.0 & 140.0 & 194.55 & 0.12 & 0.68 & 31 \\
\hline CMP 14C & 52579.60 & 52371.70 & 185.1 & 215.1 & 212.44 & 0.63 & 3.29 & 27 \\
\hline CMP 14D & 52589.50 & 52363.50 & 204.1 & 224.5 & 216.16 & 0.91 & 2.04 & 5 \\
\hline CMP 15A & 52896.80 & 51357.20 & 14.2 & 24.2 & 180.60 & 0.31 & 1.67 & 29 \\
\hline CMP 15B & 52904.70 & 51349.50 & 145.1 & 155.1 & 202.85 & 0.38 & 2.20 & 33 \\
\hline CMP 15C & 52907.80 & 51361.40 & 220.6 & 250.6 & 239.61 & 0.69 & 2.93 & 18 \\
\hline CMP 16B & 53849.90 & 51576.70 & 141.7 & 151.7 & 194.77 & 0.14 & 0.75 & 31 \\
\hline CMP $16 \mathrm{C}$ & 53856.00 & 51569.50 & 215.6 & 235.6 & 223.48 & 0.47 & 0.94 & 4 \\
\hline CMP $30 \mathrm{~B}$ & 53166.90 & 51729.80 & 97.4 & 107.5 & 194.72 & 0.17 & 0.30 & 3 \\
\hline CMP $30 \mathrm{C}$ & 53208.20 & 51718.40 & 179.5 & 189.5 & 210.85 & 0.20 & 0.40 & 4 \\
\hline CMP 30D & 53202.90 & 51709.70 & 211.6 & 231.6 & 221.12 & 1.07 & 2.62 & 6 \\
\hline CMP $31 \mathrm{~B}$ & 53259.80 & 52319.10 & 110.0 & 120.0 & 194.41 & 0.13 & 0.26 & 4 \\
\hline CMP $32 B$ & 54052.80 & 52220.00 & 97.7 & 107.7 & 195.54 & 0.15 & 0.37 & 6 \\
\hline CMP $32 C$ & 54061.10 & 52214.60 & 185.2 & 195.2 & 195.93 & 0.17 & 0.34 & 4 \\
\hline CMP 32D & 54069.20 & 52209.20 & 218.6 & 228.6 & 220.90 & 0.08 & 0.17 & 5 \\
\hline CRP 1 & 44372.20 & 68617.70 & 187.8 & 217.8 & 207.91 & 0.42 & 2.28 & 30 \\
\hline CRP 2 & 44336.40 & 69043.00 & 171.8 & 201.8 & 207.12 & 0.35 & 2.02 & 33 \\
\hline CRP 3 & 44001.00 & 68665.50 & 184.0 & 214.0 & 207.80 & 0.52 & 1.64 & 10 \\
\hline
\end{tabular}


Table F-1. Hydraulic Head Targets for Model Calibration (Continued)

\begin{tabular}{|c|c|c|c|c|c|c|c|c|}
\hline CRP $3 \mathrm{C}$ & 44023.80 & 68701.60 & 121.1 & 131.1 & 196.71 & 0.22 & 0.57 & 7 \\
\hline CRP 3D & 44012.90 & 68693.60 & 194.3 & 214.3 & 207.39 & 0.32 & 1.06 & 11 \\
\hline CRP 4 & 44101.20 & 68447.40 & 180.7 & 210.7 & 207.89 & 0.49 & 2.71 & 31 \\
\hline CRP 5C & 44527.70 & 68535.60 & 110.1 & 120.1 & 198.20 & 0.27 & 0.77 & 8 \\
\hline CRP 5D & 44515.00 & 68549.10 & 194.6 & 214.6 & 211.58 & 0.48 & 1.65 & 12 \\
\hline CRP 6DR & 44017.50 & 68311.50 & 194.2 & 214.2 & 210.50 & -1.00 & -1.00 & 1 \\
\hline CRP 7D & 44081.80 & 69196.70 & 188.0 & 208.0 & 206.46 & 0.53 & 1.75 & 11 \\
\hline CRP 8D & 43681.70 & 68650.40 & 191.0 & 211.0 & 207.63 & 0.79 & 1.93 & 6 \\
\hline CRP 9D & 44243.20 & 69156.70 & 191.4 & 211.4 & 207.13 & 0.46 & 1.21 & 7 \\
\hline CRP 10D & 43742.70 & 68999.80 & 189.5 & 209.5 & 204.96 & 0.89 & 1.98 & 5 \\
\hline CAP 11D & 44164.40 & 68713.50 & 193.7 & 203.6 & 206.91 & 0.86 & 1.93 & 5 \\
\hline $\operatorname{CSA} 1$ & 50197.00 & 61808.40 & 232.0 & 262.0 & 243.30 & 0.65 & 3.40 & 27 \\
\hline CSA 2 & 50218.60 & 61761.80 & 218.2 & 248.2 & 243.73 & 0.72 & 3.83 & 28 \\
\hline $\operatorname{CSA} 3$ & 50173.20 & 61720.20 & 218.6 & 248.6 & 242.97 & 0.65 & 3.41 & 28 \\
\hline $\operatorname{CSA} 4$ & 50132.70 & 61781.90 & 218.4 & 248.4 & 242.67 & 0.65 & 3.46 & 28 \\
\hline $\operatorname{CSB} 1 \mathrm{~A}$ & 44974.00 & 67593.00 & 194.9 & 224.9 & 213.18 & 0.47 & 2.39 & 26 \\
\hline $\operatorname{CSB} 2 A$ & 44802.60 & 67310.20 & 192.6 & 222.6 & 210.49 & 0.61 & 3.11 & 26 \\
\hline $\operatorname{CSB} 3 A$ & 44648.30 & 67385.60 & 193.0 & 223.0 & 210.42 & 0.53 & 3.04 & 33 \\
\hline $\operatorname{CSB} 4 A$ & 44618.50 & 67561.80 & 188.0 & 218.0 & 210.60 & 0.51 & 3.07 & 36 \\
\hline CSB $5 A$ & 44618.90 & 67751.60 & 185.9 & 215.9 & 210.66 & 0.50 & 2.97 & 36 \\
\hline $\operatorname{CSB} 6 \mathrm{~A}$ & 44863.80 & 67812.40 & 189.8 & 219.8 & 211.13 & 0.54 & 3.02 & 31 \\
\hline CSD 1D & 50170.50 & 63255.80 & 238.4 & 273.4 & 244.91 & 0.56 & 2.68 & 23 \\
\hline CSD 2D & 50144.00 & 63126.20 & 233.8 & 258.8 & 248.86 & 0.30 & 1.04 & 12 \\
\hline $\operatorname{CSD} 4 D$ & 50058.90 & 63143.80 & 213.5 & 263.5 & 243.99 & 0.64 & 2.94 & 21 \\
\hline CSD 8D & 49903.10 & 63195.00 & 226.8 & 256.8 & 243.13 & 0.57 & 2.68 & 22 \\
\hline CSD 9D & 49838.80 & 63080.90 & 226.2 & 256.2 & 243.22 & 0.62 & 2.82 & 21 \\
\hline CSD 100 & 49806.50 & 63094.10 & 224.5 & 254.5 & 243.12 & 0.62 & 2.82 & 21 \\
\hline CSD $11 D$ & 49763.90 & 63956.30 & 220.9 & 250.9 & 242.95 & 0.65 & 3.00 & 21 \\
\hline CSD 12D & 49937.30 & 63004.70 & 224.5 & 254.5 & 243.59 & 0.63 & 2.87 & 21 \\
\hline CSD 13D & 49665.50 & 62897.80 & 202.4 & 252.4 & 242.42 & 0.63 & 2.96 & 22 \\
\hline CSF 10 & 49431.30 & 62368.60 & 228.2 & 248.2 & 243.36 & 0.17 & 0.29 & 3 \\
\hline CSF 2D & 50880.70 & 61053.30 & 235.2 & 255.2 & 250.98 & 0.34 & 0.48 & 2 \\
\hline CSO 1 & 52484.20 & 61071.10 & 232.0 & 262.0 & 251.03 & 0.67 & 3.71 & 31 \\
\hline $\mathrm{CSO} 2$ & 52559.00 & 61114.30 & 209.7 & 239.7 & 252.22 & 0.61 & 3.05 & 25 \\
\hline $\operatorname{CSR} 1$ & 52804.30 & 64413.10 & 237.2 & 267.2 & 256.06 & 0.71 & 3.67 & 27 \\
\hline $\operatorname{CSR} 3$ & 53229.90 & 65234.80 & 238.1 & 268.1 & 254.36 & 0.74 & 3.83 & 27 \\
\hline $\operatorname{CSR} 4$ & 53214.40 & 64412.80 & 237.6 & 267.6 & 256.11 & 0.74 & 3.78 & 26 \\
\hline DBP 1 & 18661.80 & 66691.40 & 93.2 & 123.2 & 119.77 & 0.42 & 2.39 & 32 \\
\hline DBP 2 & 18407.30 & 66478.20 & 84.3 & 114.3 & 117.38 & 0.28 & 1.64 & 34 \\
\hline DBP 3 & 18427.50 & 66775.50 & 86.4 & 116.4 & 120.98 & 0.38 & 2.25 & 35 \\
\hline DBP 4 & 18342.10 & 66679.60 & 84.2 & 114.2 & 118.93 & 0.34 & 1.93 & 32 \\
\hline DBP 5 & 18605.20 & 66485.60 & 96.1 & 116.1 & 117.60 & 0.56 & 2.03 & 13 \\
\hline $\mathrm{DCB} 1 \mathrm{~A}$ & 19856.30 & 64028.50 & 90.1 & 120.1 & 115.24 & 0.15 & 0.76 & 26 \\
\hline DCB $2 A$ & 20895.20 & 63436.10 & 97.4 & 127.4 & 124.79 & 0.24 & 1.31 & 29 \\
\hline DCB $3 A$ & 20899.90 & 62674.90 & 96.2 & 126.2 & 120.60 & 0.21 & 1.11 & 28 \\
\hline DCB 4A & 20493.80 & 62678.80 & 92.5 & 122.5 & 119.15 & 0.15 & 0.86 & 31 \\
\hline DCB 5A & 20139.80 & 63126.10 & 85.9 & 115.9 & 118.85 & 0.15 & 0.80 & 30 \\
\hline DCB 6 & 19979.30 & 64167.90 & 109.5 & 129.5 & 116.77 & 0.16 & 0.90 & 30 \\
\hline DCB 7 & 20036.30 & 64001.40 & 108.9 & 128.9 & 117.98 & 0.16 & 0.87 & 30 \\
\hline DCB 8 & 21014.10 & 63473.90 & 110.3 & 130.3 & 126.49 & 0.27 & 1.48 & 30 \\
\hline DCB 9 & 19807.40 & 64190.60 & 97.3 & 117.3 & 114.78 & 0.16 & 0.85 & 28 \\
\hline DCB 10 & 19852.30 & 63803.10 & 99.8 & 119.8 & 116.60 & 0.36 & 1.99 & 30 \\
\hline DCB 11 & 19248.60 & 64638.30 & 106.8 & 126.8 & 122.00 & 0.30 & 1.59 & 29 \\
\hline DCB 12 & 18529.80 & 65150.00 & 92.0 & 112.0 & 109.74 & 0.14 & 0.75 & 29 \\
\hline DCB 13 & 19235.40 & 63842.50 & 102.0 & 122.1 & 116.91 & 0.92 & 4.59 & 25 \\
\hline DCB 14 & 19392.40 & 64909.80 & 94.6 & 114.6 & 109.79 & 0.23 & 0.60 & 7 \\
\hline DCB 15 & 17635.90 & 64607.40 & 99.8 & 119.9 & 111.55 & 0.48 & 2.29 & 23 \\
\hline DCB 16 & 17611.20 & 63956.00 & 100.1 & 120.1 & 111.94 & 0.25 & 1.32 & 27 \\
\hline DCB 17A & 19841.80 & 64583.20 & 109.4 & 119.4 & 116.60 & 0.18 & 0.30 & 3 \\
\hline
\end{tabular}


Table F-1. Hydraulic Head Targets for Model Calibration (Continued)

\begin{tabular}{|c|c|c|c|c|c|c|c|c|}
\hline DCB $17 \mathrm{~B}$ & 19844.70 & 64588.80 & 99.2 & 101.7 & 116.92 & 0.17 & 0.29 & 3 \\
\hline DCB $17 \mathrm{C}$ & 19846.50 & 64593.70 & 87.4 & 89.9 & 116.07 & 0.17 & 0.29 & 3 \\
\hline DCB 18A & 19881.30 & 64051.80 & 110.1 & 120.1 & 116.17 & 0.44 & 0.88 & 4 \\
\hline DCB 18B & 19874.50 & 64046.10 & 100.5 & 103.0 & 113.32 & 0.44 & 0.77 & 3 \\
\hline DCB $18 \mathrm{C}$ & 19869.40 & 64041.40 & 87.7 & 90.2 & 112.73 & 0.38 & 0.66 & 3 \\
\hline DCB $19 A$ & 19890.30 & 64022.10 & 111.9 & 121.9 & 119.95 & 0.90 & 1.56 & 3 \\
\hline DCB $19 B$ & 19885.30 & 64016.50 & 101.9 & 104.4 & 117.38 & 0.41 & 0.71 & 3 \\
\hline DCB $19 C$ & 19879.70 & 64010.90 & 89.1 & 91.6 & 116.52 & 0.38 & 0.66 & 3 \\
\hline DCB 20A & 20106.50 & 63931.00 & 110.9 & 120.9 & 117.17 & 0.17 & 0.29 & 3 \\
\hline DCB 20B & 20102.60 & 63935.30 & 100.3 & 102.8 & 116.50 & 0.10 & 0.17 & 3 \\
\hline DCB $20 \mathrm{C}$ & 20098.10 & 63940.40 & 89.4 & 91.9 & 116.39 & 0.19 & 0.33 & 3 \\
\hline DCB 20D & 20087.90 & 63953.30 & 46.2 & 48.7 & 114.00 & 0.10 & 0.17 & 3 \\
\hline DCB $21 A$ & 19854.70 & 63914.80 & 110.1 & 120.1 & 116.93 & 0.41 & 0.70 & 3 \\
\hline DCB 21B & 19851.50 & 63920.00 & 102.2 & 104.7 & 113.41 & 0.25 & 0.44 & 3 \\
\hline DCB 21C & 19849.20 & 63925.30 & 88.3 & 90.8 & 112.93 & 0.28 & 0.49 & 3 \\
\hline DCB 22A & 19794.20 & 63907.60 & 109.8 & 119.8 & 112.77 & 0.14 & 0.29 & 4 \\
\hline DCB 22B & 19790.70 & 63913.10 & 100.9 & 103.4 & 112.75 & 0.23 & 0.39 & 3 \\
\hline DCB $22 C$ & 19788.70 & 63919.10 & 88.1 & 90.6 & 112.95 & 0.46 & 0.81 & 3 \\
\hline DCB 23A & 19608.30 & 63870.40 & 105.7 & 115.7 & 111.79 & 0.14 & 0.31 & 5 \\
\hline DCB 23B & 19607.00 & 63876.30 & 94.1 & 96.6 & 108.75 & 0.10 & 0.18 & 3 \\
\hline DCB $23 \mathrm{C}$ & 19605.70 & 63882.50 & 86.6 & 89.1 & 109.02 & 0.18 & 0.31 & 3 \\
\hline DCB 23D & 19602.20 & 63900.00 & 49.1 & 51.6 & 111.19 & 0.13 & 0.23 & 3 \\
\hline DCB $24 A$ & 19983.10 & 63321.60 & 109.2 & 119.2 & 115.47 & 0.14 & 0.24 & 3 \\
\hline DCB 24B & 19972.40 & 63318.20 & 100.6 & 103.1 & 115.21 & 0.01 & 0.01 & 2 \\
\hline DCB $24 \mathrm{C}$ & 19966.40 & 63315.70 & 87.6 & 90.1 & 116.27 & 0.14 & 0.25 & 3 \\
\hline DOB 1 & 23567.80 & 68438.10 & 114.7 & 144.7 & 143.16 & 0.41 & 2.74 & 45 \\
\hline DOB 2 & 23340.80 & 68568.00 & 115.3 & 145.3 & 143.18 & 0.44 & 2.96 & 45 \\
\hline DOB 3 & 23633.30 & 68693.50 & 115.9 & 145.9 & 143.15 & 0.55 & 3.18 & 34 \\
\hline DOB 4 & 23815.60 & 68514.40 & 109.2 & 139.2 & 142.37 & 0.53 & 3.06 & 34 \\
\hline DOB 7 & 23485.70 & 68315.80 & 125.7 & 145.7 & 143.10 & 0.49 & 1.85 & 14 \\
\hline DOB 8 & 23710.40 & 68429.20 & 128.3 & 148.3 & 143.65 & 0.48 & 1.81 & 14 \\
\hline DOB 9 & 23690.70 & 68811.60 & 128.5 & 148.5 & 144.10 & 0.42 & 0.73 & 3 \\
\hline DOB 10 & 23291.40 & 68490.90 & 128.3 & 148.3 & 143.24 & 0.45 & 1.67 & 14 \\
\hline DOB 11 & 23400.80 & 68445.20 & 126.7 & 131.7 & 140.92 & 0.32 & 0.56 & 3 \\
\hline DOB 12 & 23398.78 & 68450.08 & 133.1 & 138.1 & 140.48 & 0.38 & 1.50 & 16 \\
\hline DOB 14 & 23527.50 & 68335.00 & 132.6 & 137.6 & 139.68 & 0.33 & 0.58 & 3 \\
\hline DOB 15 & 23189.90 & 68139.60 & 110.9 & 116.0 & 141.92 & 0.20 & 0.34 & 3 \\
\hline DOB 16 & 23190.80 & 68133.90 & 103.5 & 108.6 & 141.39 & 0.19 & 0.32 & 3 \\
\hline DOL 1 & 23586.10 & 68794.40 & 109.2 & 119.2 & 144.27 & 0.40 & 0.69 & 3 \\
\hline$F \quad 10$ & 50444.30 & 75155.30 & 266.5 & 276.5 & 270.35 & 1.25 & 1.77 & 2 \\
\hline$F 18 \mathrm{~A}$ & 50108.00 & 74170.20 & 194.4 & 204.4 & 203.79 & 1.24 & 3.71 & 9 \\
\hline FAB 1 & 54915.50 & 77798.80 & 215.4 & 235.4 & 228.30 & 0.23 & 0.79 & 12 \\
\hline FAB 2 & 55137.50 & 77470.10 & 216.5 & 236.5 & 229.05 & 0.21 & 0.76 & 13 \\
\hline FAB 3 & 55030.80 & 77151.20 & 211.8 & 231.8 & 228.78 & 0.21 & 0.70 & 11 \\
\hline FAB 4 & 54759.70 & 77584.60 & 214.2 & 234.2 & 228.49 & 0.22 & 0.70 & 10 \\
\hline FAC 3 & 55322.70 & 78018.30 & 224.8 & 254.8 & 229.11 & 0.28 & 1.58 & 31 \\
\hline FAC 4 & 55472.90 & 78223.80 & 207.8 & 237.8 & 228.52 & 0.26 & 1.45 & 31 \\
\hline FAC 5 & 55241.30 & 77960.30 & 214.0 & 234.0 & 224.91 & 0.60 & 3.18 & 28 \\
\hline FAC $5 P$ & 55314.80 & 78175.70 & 225.7 & 235.7 & 229.98 & 0.38 & 0.76 & 4 \\
\hline FAC 6 & 55335.50 & 78129.00 & 216.2 & 236.2 & 220.71 & 0.83 & 4.17 & 25 \\
\hline FAC 7 & 55356.20 & 78123.40 & 215.7 & 235.7 & 223.18 & 1.03 & 5.57 & 29 \\
\hline FAC 8 & 55366.00 & 78090.90 & 216.0 & 236.0 & 227.17 & 0.73 & 3.91 & 29 \\
\hline FAC $9 C$ & 55339.30 & 78030.50 & 197.4 & 207.4 & 217.42 & 0.28 & 0.57 & 4 \\
\hline FAC $10 \mathrm{C}$ & 55298.40 & 78119.70 & 200.2 & 210.2 & 217.42 & 0.28 & 0.63 & 5 \\
\hline FAC $11 C$ & 55231.90 & 78100.30 & 201.4 & 211.4 & 217.49 & 0.28 & 0.63 & 5 \\
\hline FAC $12 C$ & 55226.40 & 78047.20 & 198.0 & 208.0 & 217.55 & 0.28 & 0.63 & 5 \\
\hline FAL 2 & 53757.40 & 78231.90 & 206.6 & 238.0 & 217.13 & 0.30 & 1.74 & 33 \\
\hline FBP $1 \mathrm{~A}$ & 51080.70 & 78893.00 & 161.8 & 191.8 & 206.67 & 0.38 & 2.14 & 32 \\
\hline
\end{tabular}


Table F-1. Hydraulic Head Targets for Model Calibration (Continued)

\begin{tabular}{|c|c|c|c|c|c|c|c|c|c|}
\hline FBP $2 A$ & 50534.10 & 79711.40 & 137.1 & 167.1 & 191.59 & 0.48 & 2.71 & 32 & 2 \\
\hline FBP $3 A$ & 50913.40 & 79838.90 & 141.0 & 171.0 & 194.16 & 0.47 & 2.79 & 35 & 2 \\
\hline FBP 4 & 51368.20 & 79320.00 & 165.2 & 195.2 & 212.35 & 0.34 & 1.93 & 32 & 2 \\
\hline FBP 5D & 51073.90 & 79193.80 & 192.6 & 212.6 & 205.23 & 0.41 & 1.53 & 14 & 4 \\
\hline FBP $6 D$ & 50547.10 & 79672.90 & 178.3 & 198.3 & 194.77 & 0.55 & 2.20 & 16 & 2 \\
\hline FBP $7 D$ & 50878.90 & 79805.70 & 183.2 & 203.2 & 194.09 & 0.28 & 0.68 & 6 & 2 \\
\hline FBP 8D & 51386.40 & 79291.80 & 172.8 & 192.8 & 207.08 & 0.49 & 1.82 & 14 & 2 \\
\hline FBP 9D & 51074.00 & 79565.10 & 177.9 & 197.9 & 200.29 & 0.71 & 2.54 & 13 & 2 \\
\hline FBP 11D & 50767.90 & 79099.30 & 192.0 & 212.1 & 203.03 & 0.15 & 0.41 & 7 & 4 \\
\hline FBP $12 D$ & 51165.70 & 78932.30 & 182.1 & 202.1 & 208.42 & 0.45 & 1.58 & 12 & 2 \\
\hline FBP 13D & 50694.10 & 79748.90 & 172.7 & 192.7 & 194.94 & 0.91 & 3.51 & 15 & 2 \\
\hline $\mathrm{FC} \quad 1 \mathrm{~A}$ & 53115.10 & 79664.50 & 96.7 & 101.7 & 143.51 & -1.00 & -1.00 & 1 & 1 \\
\hline $\mathrm{FC} \quad 1 \mathrm{~B}$ & 53115.00 & 79672.40 & 151.8 & 156.8 & 210.78 & -1.00 & -1.00 & 1 & 2 \\
\hline $\mathrm{FC} 1 \mathrm{C}$ & 53115.10 & 79680.10 & 183.9 & 188.9 & 214.00 & -1.00 & -1.00 & 1 & 2 \\
\hline $\mathrm{FC} \quad 10$ & 53114.50 & 79688.30 & 217.2 & 222.2 & 223.63 & -1.00 & -1.00 & 1 & 3 \\
\hline FC $3 A$ & 57620.00 & 78726.60 & 21.5 & 26.5 & 175.47 & -1.00 & -1.00 & 1 & 4 \\
\hline FC $3 B$ & 57629.90 & 78727.70 & 61.2 & 66.2 & 150.63 & -1.00 & -1.00 & 1 & 1 \\
\hline FC $3 C$ & 57639.00 & 78728.00 & 121.0 & 126.0 & 151.80 & -1.00 & -1.00 & 1 & 1 \\
\hline$F C \quad 3 D$ & 57647.90 & 78728.40 & 165.9 & 170.9 & 206.43 & -1.00 & -1.00 & 1 & 2 \\
\hline FC $3 E$ & 57655.50 & 78728.80 & 185.7 & 190.7 & 205.33 & -1.00 & -1.00 & 1 & 2 \\
\hline FC $3 F$ & 57663.20 & 78729.10 & 205.1 & 210.1 & 206.25 & -1.00 & -1.00 & 1 & 2 \\
\hline FC $4 \mathrm{~A}$ & 53896.50 & 82242.50 & -28.0 & -23.0 & 173.31 & -1.00 & -1.00 & 1 & 4 \\
\hline FC $4 B$ & 53901.30 & 82249.00 & 76.1 & 81.1 & 140.96 & -1.00 & -1.00 & 1 & 1 \\
\hline FC $4 C$ & 53905.90 & 82255.40 & 116.3 & 121.3 & 137.64 & -1.00 & -1.00 & 1 & 1 \\
\hline FC $4 D$ & 53910.70 & 82262.20 & 146.4 & 151.4 & 151.03 & -1.00 & -1.00 & 1 & 4 \\
\hline $\mathrm{FC} \quad 4 \mathrm{E}$ & 53915.30 & 82268.90 & 176.4 & 181.4 & 185.19 & -1.00 & -1.00 & 1 & 2 \\
\hline FCA $1 \mathrm{~N}$ & 53675.90 & 79037.30 & 296.8 & 298.3 & 299.27 & 0.23 & 0.74 & 10 & 3 \\
\hline FCA $2 C$ & 53712.20 & 78296.00 & 295.3 & 299.3 & 297.99 & 0.09 & 0.42 & 20 & 3 \\
\hline FCA 2D & 53715.20 & 78295.80 & 219.0 & 239.0 & 225.03 & 0.35 & 2.28 & 42 & 3 \\
\hline FCA 9D & 53733.10 & 78600.50 & 221.9 & 241.9 & 225.27 & 0.23 & 1.26 & 31 & 3 \\
\hline FCA 9DR & 53734.50 & 78608.80 & 207.7 & 227.7 & 224.00 & 0.41 & 1.52 & 14 & 3 \\
\hline FCA $10 A$ & 53571.90 & 78640.40 & 221.0 & 241.0 & 225.27 & 0.22 & 1.40 & 42 & 3 \\
\hline FCA $10 \mathrm{C}$ & 53717.70 & 78642.50 & 295.9 & 298.4 & 302.96 & 0.83 & 1.67 & 4 & 3 \\
\hline FCA 10D & 53732.00 & 78640.00 & 219.5 & 239.5 & 226.38 & 0.27 & 1.25 & 22 & 3 \\
\hline FCA $16 A$ & 53568.80 & 78899.50 & 215.1 & 235.1 & 225.18 & 0.20 & 1.28 & 42 & 3 \\
\hline FCA 16B & 53571.00 & 78898.00 & 295.3 & 299.3 & 298.00 & 0.41 & 1.73 & 18 & 3 \\
\hline FCA 16D & 53719.50 & 78898.50 & 221.1 & 241.1 & 224.96 & 0.26 & 1.37 & 28 & 3 \\
\hline FCA $16 \mathrm{~T}$ & 53579.00 & 78898.00 & 291.3 & 292.8 & 297.63 & -1.00 & -1.00 & 1 & 3 \\
\hline FCA 19D & 53719.10 & 78271.90 & 209.7 & 229.7 & 217.22 & 0.34 & 1.85 & 29 & 3 \\
\hline FCB 1 & 54871.80 & 76835.40 & 205.6 & 235.6 & 230.23 & 0.24 & 0.34 & 2 & 3 \\
\hline FCB 2 & 55046.70 & 76679.70 & 205.2 & 235.2 & 229.12 & 0.61 & 3.37 & 31 & 4 \\
\hline FCB 3 & 54874.40 & 76427.80 & 195.3 & 225.3 & 223.94 & 0.31 & 1.72 & 30 & 2 \\
\hline FCB 4 & 54605.90 & 76780.40 & 204.5 & 234.5 & 228.18 & 0.60 & 3.42 & 32 & 3 \\
\hline FCB 5 & 54773.00 & 76492.60 & 217.1 & 237.1 & 228.82 & 0.33 & 1.76 & 29 & 3 \\
\hline FCB 6 & 54733.40 & 76582.10 & 215.1 & 235.1 & 229.08 & 0.27 & 1.40 & 26 & 3 \\
\hline FCB 7 & 54957.10 & 76913.90 & 218.3 & 238.3 & 231.03 & -1.00 & -1.00 & 1 & 3 \\
\hline FET 10 & 53299.90 & 76165.60 & 206.9 & 226.9 & 223.54 & 0.27 & 1.43 & 27 & 3 \\
\hline FET 2D & 52981.20 & 76045.80 & 209.5 & 229.5 & 222.25 & 0.29 & 1.52 & 27 & 3 \\
\hline FET 3D & 53025.70 & 75961.00 & 203.0 & 223.0 & 222.39 & 0.29 & 1.51 & 27 & 3 \\
\hline FET 4D & 53149,00 & 75959.30 & 205.1 & 225.1 & 222.67 & 0.28 & 1.49 & 28 & 3 \\
\hline FIW 1D & 51420.00 & 76114.90 & 198.9 & 218.9 & 214.73 & -1.00 & -1.00 & 1 & 3 \\
\hline FIW IID & 51362.50 & 76171.60 & 194.0 & 214.0 & 216.62 & 1.12 & 1.59 & 2 & 3 \\
\hline FIW $21 \mathrm{C}$ & 51202.60 & 75924.50 & 125.3 & 175.2 & 210.81 & 0.70 & 1.40 & 4 & 2 \\
\hline FIW 2MA & 51184.50 & 75930.80 & 100.5 & 110.5 & 151.50 & 0.39 & 0.79 & 4 & 1 \\
\hline FIW $2 M D$ & 51202.40 & 75934.90 & 190.9 & 220.8 & 215.21 & 0.65 & 1.30 & 4 & 3 \\
\hline FNB 1 & 54271.60 & 80151.50 & 177.2 & 207.2 & 210.94 & 0.40 & 2.22 & 30 & 2 \\
\hline FNB $1 \mathrm{~A}$ & 54288.80 & 80154.50 & 107.9 & 117.9 & 144.29 & 0.10 & 0.25 & 7 & I \\
\hline FNB 2 & 54362.10 & 80442.30 & 180.8 & 210.8 & 207.10 & 0.42 & 2.33 & 31 & 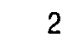 \\
\hline FNB $2 A$ & 54355.80 & 80454.70 & 111.1 & 121.1 & 143.59 & 0.15 & 0.40 & 7 & \\
\hline
\end{tabular}


Table F-1. Hydraulic Head Targets for Model Calibration (Continued)

\begin{tabular}{|c|c|c|c|c|c|c|c|c|}
\hline FNB 3 & 54105.80 & 80553.10 & 182.1 & 212.1 & 209.27 & 0.43 & 2.37 & 31 \\
\hline FNB $3 A$ & 54116.60 & 80557.20 & 109.2 & 119.2 & 143.14 & 0.22 & 0.59 & 7 \\
\hline FNB 4 & 53843.50 & 80409.80 & 179.6 & 209.6 & 213.61 & 0.48 & 2.70 & 31 \\
\hline FNB 5 & 54295.20 & 80556.10 & 193.5 & 203.5 & 206.66 & 0.40 & 1.12 & 8 \\
\hline FNB 6 & 54096.28 & 80822.49 & 200.6 & 210.6 & 208.73 & 0.21 & 0.43 & 4 \\
\hline FNB 7 & 54398.46 & 80649.18 & 192.4 & 202.4 & 203.95 & 0.22 & 0.44 & 4 \\
\hline FNB 8 & 54550.33 & 80521.45 & 195.4 & 205.4 & 202.85 & 0.15 & 0.33 & 5 \\
\hline FOB $1 D$ & 50026.60 & 73812.76 & 175.4 & 195.4 & 203.43 & 0.95 & 1.90 & 4 \\
\hline FOB 2D & 49527.75 & 73973.78 & 175.5 & 195.5 & 204.68 & 1.14 & 2.29 & 4 \\
\hline FOB 3D & 49082.37 & 74138.79 & 183.4 & 203.4 & 204.97 & 1.21 & 2.42 & 4 \\
\hline FOB $4 D$ & 49338.12 & 74430.27 & 174.0 & 194.1 & 205.97 & 1.06 & 2.13 & 4 \\
\hline FOB $5 C$ & 49730.31 & 74607.04 & 129.3 & 149.3 & 202.89 & 1.04 & 2.08 & 4 \\
\hline FOB $7 C$ & 50235.60 & 76074.12 & 148.9 & 168.9 & 208.05 & 0.55 & 1.10 & 4 \\
\hline FOB 7D & 50244.28 & 76085.38 & 193.9 & 213.9 & 211.69 & 0.51 & 1.03 & 4 \\
\hline FOB 8D & 49940.18 & 75772.14 & 191.4 & 211.4 & 210.59 & 0.62 & 1.24 & 4 \\
\hline FOB $9 C$ & 50797.38 & 75773.51 & 155.5 & 175.5 & 210.24 & 0.60 & 1.19 & 4 \\
\hline FOB 9D & 50782.52 & 75774.99 & 192.6 & 212.6 & 213.10 & 0.63 & 1.27 & 4 \\
\hline FOB $11 C$ & 51920.55 & 75613.91 & 156.2 & 176.2 & 212.44 & 0.78 & 1.56 & 4 \\
\hline FOB $11 D$ & 51909.29 & 75602.78 & 199.0 & 219.0 & 216.11 & 0.93 & 1.87 & 4 \\
\hline FOB $12 \mathrm{D}$ & 49785.91 & 75596.56 & 179.3 & 199.3 & 209.84 & 0.67 & 1.34 & 4 \\
\hline FRB 4 & 53653.31 & 76076.19 & 214.6 & 229.6 & 222.98 & 0.12 & 0.25 & 4 \\
\hline FSB OPD & 49849.80 & 74549.20 & 171.6 & 215.3 & 207.37 & 0.34 & 0.76 & 5 \\
\hline FSB 50PD & 49874.60 & 74600.90 & 174.7 & 219.8 & 207.07 & 1.12 & 2.25 & 4 \\
\hline FSB 76 & 51388.80 & 76141.60 & 197.0 & 227.0 & 217.84 & 0.31 & 2.27 & 54 \\
\hline FSB 76A & 51391.60 & 76131.90 & 36.9 & 47.4 & 155.12 & 0.13 & 0.97 & 58 \\
\hline FSB 76B & 51394.00 & 76122.40 & 99.2 & 109.7 & 151.64 & 0.09 & 0.67 & 57 \\
\hline FSB 76C & 51396.40 & 76112.40 & 154.8 & 165.3 & 212.78 & 0.18 & 1.48 & 68 \\
\hline FSB 77 & 50713.10 & 75129.40 & 186.4 & 216.4 & 212.04 & 0.20 & 1.55 & 62 \\
\hline FSB 78 & 50164.70 & 74764.00 & 187.7 & 217.7 & 208.55 & 0.27 & 2.23 & 69 \\
\hline FSB 78A & 50172.80 & 74757.70 & 27.0 & 37.5 & 156.10 & 0.10 & 0.78 & 60 \\
\hline FSB 78B & 50178.80 & 74765.90 & 82.4 & 92.8 & 154.52 & 0.10 & 0.77 & 58 \\
\hline FSB $78 \mathrm{C}$ & 50170.20 & 74772.50 & 141.6 & 151.4 & 207.77 & 0.16 & 1.31 & 66 \\
\hline FSB 79 & 50139.70 & 73663.10 & 174.1 & 204.1 & 201.93 & 0.24 & 2.00 & 67 \\
\hline FSB 79A & 50149.60 & 73664.50 & 24.0 & 34.4 & 158.05 & 0.20 & 1.56 & 59 \\
\hline FSB 79B & 50159.20 & 73666.10 & 80.7 & 91.2 & 158.12 & 0.12 & 0.89 & 59 \\
\hline FSB $79 C$ & 50171.30 & 73668.00 & 149.8 & 159.6 & 196.78 & 0.14 & 1.14 & 66 \\
\hline FSB 87A & 50115.80 & 75601.70 & 33.1 & 43.6 & 153.84 & 0.10 & 0.75 & 58 \\
\hline FSB $87 B$ & 50104.90 & 75597.00 & 90.0 & 100.5 & 150.64 & 0.09 & 0.66 & 59 \\
\hline FSB 87C & 50093.40 & 75591.90 & 148.8 & 159.3 & 208.44 & 0.23 & 1.83 & 61 \\
\hline FSB 870 & 50081.10 & 75586.30 & 187.4 & 216.8 & 213.81 & 0.22 & 0.84 & 15 \\
\hline FSB $88 \mathrm{C}$ & 51518.00 & 75619.40 & 158.4 & 168.4 & 212.29 & 0.21 & 1.59 & 58 \\
\hline FSB 88D & 51527.00 & 75621.80 & 202.1 & 222.1 & 215.85 & 0.21 & 1.58 & 59 \\
\hline FSB $89 C$ & 51345.20 & 75553.20 & 156.1 & 166.1 & 211.69 & 0.19 & 1.40 & 56 \\
\hline FSB 89D & 51335.80 & 75548.30 & 201.9 & 221.9 & 215.23 & 0.22 & 1.61 & 56 \\
\hline FSB 90C & 51148.60 & 75382.90 & 158.1 & 168.1 & 210.81 & 0.23 & 1.73 & 59 \\
\hline FSB 90D & 51140.70 & 75376.90 & 205.1 & 225.1 & 215.00 & 0.69 & 4.03 & 34 \\
\hline FSB 91C & 50953.50 & 75213.30 & 149.1 & 159.1 & 210.54 & 0.17 & 1.34 & 62 \\
\hline FSB 91D & 50946.60 & 75207.60 & 200.9 & 220.9 & 213.37 & 0.21 & 1.58 & 57 \\
\hline FSB 92C & 50564.00 & 75053.20 & 147.6 & 157.6 & 208.67 & 0.66 & 3.71 & 32 \\
\hline FSB 92D & 50557.60 & 75045.80 & 201.7 & 221.7 & 211.69 & 0.19 & 1.45 & 56 \\
\hline FSB 93C & 50458.30 & 74897.30 & 142.0 & 152.0 & 208.65 & 0.17 & 1.32 & 64 \\
\hline FSB 93D & 50452.40 & 74888.50 & 197.9 & 217.9 & 210.51 & 0.21 & 1.69 & 62 \\
\hline FSB $94 C$ & 50180.00 & 74869.00 & 139.8 & 149.8 & 207.66 & 0.30 & 2.36 & 62 \\
\hline FSB 94DR & 50162.90 & 74869.10 & 183.3 & 203.4 & 209.92 & 0.22 & 1.43 & 43 \\
\hline FSB 95C & 50016.70 & 74971.70 & 145.8 & 155.8 & 205.64 & 0.30 & 1.05 & 12 \\
\hline FSB 95CR & 49987.80 & 75001.90 & 151.9 & 161.9 & 207.72 & 0.19 & 1.25 & 44 \\
\hline FSB 95D & 50008.90 & 74977.50 & 207.8 & 227.8 & 208.76 & 0.39 & 1.09 & 8 \\
\hline FSB 95DR & 49996.00 & 74991.70 & 187.0 & 207.0 & 210.16 & 0.22 & 1.44 & 44 \\
\hline
\end{tabular}


Table F-1. Hydraulic Head Targets for Model Calibration (Continued)

\begin{tabular}{|c|c|c|c|c|c|c|c|c|}
\hline FSB $96 A$ & 49778.70 & 74882.20 & 85.7 & 95.7 & 152.05 & 0.11 & 0.37 & 12 \\
\hline FSB 96AR & 49746.60 & 74914.90 & 79.0 & 89.0 & 153.36 & 0.08 & 0.52 & 43 \\
\hline FSB 97A & 49965.70 & 75171.20 & 85.8 & 95.8 & 152.23 & 0.09 & 0.69 & 58 \\
\hline FSB 97C & 49970.60 & 75179.60 & 143.8 & 153.8 & 208.01 & 0.18 & 1.43 & 62 \\
\hline FSB 97D & 49975.50 & 75188.90 & 196.9 & 216.9 & 210.49 & 0.18 & 1.48 & 65 \\
\hline FSB 98A & 50121.60 & 75389.80 & 84.7 & 94.7 & 150.61 & 0.14 & 0.51 & 14 \\
\hline FSB 98AR & 50105.80 & 75362.00 & 82.1 & 92.1 & 151.79 & 0.06 & 0.37 & 39 \\
\hline FSB 98C & 50116.50 & 75381.20 & 148.4 & 158.4 & 208.97 & 0.23 & 1.68 & 55 \\
\hline FSB 980 & 50111.60 & 75371.90 & 200.3 & 220.3 & 211.99 & 0.20 & 1.57 & 60 \\
\hline FSB 99A & 50314.80 & 75675.60 & 92.9 & 102.9 & 150.65 & 0.08 & 0.64 & 57 \\
\hline FSB $99 \mathrm{C}$ & 50320.60 & 75683.70 & 157.2 & 167.2 & 209.43 & 0.19 & 1.43 & 57 \\
\hline FSB 99D & 50326.90 & 75691.70 & 198.1 & 218.1 & 211.89 & 0.21 & 1.71 & 64 \\
\hline FSB100A & 50958.40 & 75534.40 & 95.8 & 105.8 & 151.49 & 0.09 & 0.68 & 57 \\
\hline FSB101A & 51191.30 & 75719.00 & 92.9 & 102.9 & 151.71 & 0.10 & 0.79 & 57 \\
\hline FSB102C & 50834.80 & 73582.90 & 145.9 & 155.9 & 195.31 & 0.06 & 0.48 & 57 \\
\hline FSB103C & 49651.30 & 74210.00 & 147.1 & 157.1 & 202.53 & 0.14 & 1.17 & 67 \\
\hline FSB104C & 49248.60 & 73872.60 & 150.7 & 160.7 & 200.94 & 0.17 & 1.26 & 57 \\
\hline FSB104D & 49255.40 & 73865.20 & 190.4 & 210.4 & 204.41 & 0.20 & 1.49 & 57 \\
\hline FSB105C & 49828.00 & 75234.20 & 141.5 & 151.5 & 207.70 & 0.36 & 2.95 & 66 \\
\hline FSB105D & 49833.30 & 75244.30 & 203.7 & 223.7 & 208.26 & 0.31 & 1.02 & 11 \\
\hline FSB105DR & 49841.00 & 75258.10 & 188.5 & 208.6 & 210.56 & 0.23 & 1.51 & 43 \\
\hline FSB106C & 50651.30 & 74190.10 & 156.0 & 166.0 & 201.25 & 0.11 & 0.89 & 62 \\
\hline FSB106D & 50636.80 & 74193.00 & 202.9 & 222.9 & 207.31 & 0.36 & 1.83 & 26 \\
\hline FSB107C & 51158.10 & 75184.00 & 150.8 & 160.8 & 209.90 & 0.40 & 3.00 & 57 \\
\hline FSB107D & 51149.80 & 75177.20 & 200.9 & 220.9 & 213.49 & 0.19 & 1.49 & 61 \\
\hline FSB108D & 51142.30 & 76260.70 & 203.8 & 223.8 & 217.47 & 0.23 & 2.05 & 80 \\
\hline FSB109D & 50488.60 & 75855.90 & 205.8 & 225.8 & 213.14 & 0.25 & 1.93 & 60 \\
\hline FSB110C & 50150.60 & 74190.70 & 137.2 & 147.2 & 201.19 & 0.23 & 1.80 & 63 \\
\hline FSB110D & 50141.60 & 74193.30 & 191.1 & 211.1 & 205.45 & 0.17 & 1.31 & 63 \\
\hline FSB111C & 51526.30 & 75383.30 & 159.0 & 169.0 & 211.82 & 0.21 & 1.58 & 57 \\
\hline FSB111D & 51515.90 & 75382.90 & 201.7 & 221.7 & 215.18 & 0.27 & 2.04 & 56 \\
\hline FSB112A & 48809.10 & 74231.40 & 81.0 & 91.0 & 153.49 & 0.07 & 0.45 & 45 \\
\hline FSB112C & 48794.80 & 74227.50 & 129.1 & 139.1 & 201.88 & 0.19 & 1.30 & 46 \\
\hline FSB112D & 48780.00 & 74223.70 & 188.9 & 208.9 & 205.91 & 0.20 & 1.36 & 45 \\
\hline FSB113A & 51068.10 & 74167.50 & 81.0 & 91.3 & 158.69 & 0.44 & 3.02 & 47 \\
\hline FSB113C & 51084.20 & 74160.70 & 154.0 & 164.0 & 202.46 & 0.21 & 1.47 & 47 \\
\hline FSB113D & 51098.40 & 74154.80 & 189.6 & 209.6 & 207.29 & 0.20 & 1.31 & 44 \\
\hline FSB114A & 52046.60 & 75297.40 & 95.2 & 105.0 & 155.64 & 0.07 & 0.46 & 44 \\
\hline FSB114C & 52033.80 & 75288.50 & 158.0 & 168.0 & 213.33 & 0.18 & 1.21 & 47 \\
\hline FSB114D & 52018.60 & 75278.60 & 197.7 & 217.8 & 216.88 & 0.21 & 1.39 & 44 \\
\hline FSB115C & 49736.00 & 72515.50 & 163.8 & 173.8 & 184.41 & 0.12 & 0.84 & 49 \\
\hline FSB115D & 49728.30 & 72504.30 & 182.5 & 192.5 & 191.34 & 0.18 & 1.25 & 48 \\
\hline FSB116C & 50645.90 & 72725.50 & 160.5 & 170.5 & 189.72 & 0.09 & 0.62 & 44 \\
\hline FSB116D & 50629.70 & 72727.40 & 186.4 & 196.4 & 191.79 & 0.19 & 1.36 & 51 \\
\hline FSB117D & 50486.80 & 74070.40 & 189.7 & 209.7 & 205.05 & 0.16 & 1.06 & 42 \\
\hline FSB118D & 51276.30 & 74697.90 & 191.3 & 211.3 & 211.35 & 0.24 & 1.60 & 44 \\
\hline FSB119D & 50600.60 & 74599.70 & 193.1 & 213.1 & 208.05 & 0.18 & 1.31 & 52 \\
\hline FSB120A & 49175.70 & 75538.90 & 99.0 & 109.0 & 151.31 & 0.94 & 6.21 & 44 \\
\hline FSB120C & 49171.10 & 75549.80 & 150.7 & 160.7 & 206.01 & 0.19 & 1.29 & 44 \\
\hline FSB120D & 49163.70 & 75568.70 & 196.5 & 216.5 & 209.21 & 0.26 & 1.81 & 50 \\
\hline FSB121C & 48413.10 & 75155.70 & 148.4 & 158.4 & 204.07 & 0.19 & 1.29 & 45 \\
\hline FSB121DR & 48429.70 & 75151.90 & 191.3 & 211.3 & 206.86 & 0.22 & 1.35 & 39 \\
\hline FSB122C & 48195.00 & 73881.80 & 160.0 & 170.0 & 199.71 & 0.18 & 1.19 & 44 \\
\hline FSB122D & 48201.70 & 73865.50 & 186.6 & 206.6 & 203.47 & 0.23 & 1.54 & 45 \\
\hline FSB123C & 51750.50 & 74566.70 & 155.3 & 165.3 & 210.18 & 0.22 & 1.50 & 45 \\
\hline FSB123D & 51734.80 & 74562.70 & 194.1 & 214.1 & 212.06 & 0.19 & 1.30 & 45 \\
\hline FSB150PC & 49990.10 & 74090.00 & 107.6 & 160.1 & 198.18 & 0.77 & 1.54 & 4 \\
\hline FSB150PD & 49717.90 & 74615.80 & 176.2 & 221.3 & 206.97 & 1.07 & 2.14 & 4 \\
\hline FSL 10 & 52992.50 & 79063.10 & 208.5 & 228.6 & 224.48 & 0.19 & 1.18 & 39 \\
\hline
\end{tabular}


Table F-1. Hydraulic Head Targets for Model Calibration (Continued)

\begin{tabular}{|c|c|c|c|c|c|c|c|c|}
\hline FSL 20 & 52790.60 & 78636.50 & 208.7 & 228.8 & 224.82 & 0.20 & 1.34 & 44 \\
\hline FSL 3D & 52465.20 & 77765.20 & 205.9 & 226.0 & 222.49 & 0.31 & 2.02 & 42 \\
\hline FSL 4D & 52230.40 & 77452.40 & 204.0 & 224.1 & 217.14 & 0.22 & 1.33 & 38 \\
\hline FSL 5D & 51903.30 & 77047.70 & 203.5 & 223.7 & 220.43 & 0.24 & 1.46 & 37 \\
\hline FSL 6D & 51727.90 & 76733.10 & 202.1 & 222.1 & 219.79 & 0.22 & 1.35 & 37 \\
\hline FSL 7D & 51485.60 & 76327.80 & 199.5 & 219.6 & 217.91 & 0.33 & 2.05 & 38 \\
\hline FSL 8D & 51513.50 & 76054.70 & 202.7 & 222.8 & 217.19 & 0.23 & 1.37 & 35 \\
\hline FSL $9 D$ & 51543.90 & 75768.40 & 201.4 & 221.5 & 216.18 & 0.61 & 3.62 & 35 \\
\hline FSS 10 & 53897.60 & 75257.60 & 209.9 & 229.9 & 223.45 & 0.24 & 1.59 & 44 \\
\hline FSS 2D & 53918.90 & 75103.50 & 204.4 & 224.4 & 222.67 & 0.26 & 1.74 & 44 \\
\hline FSS 3D & 53548.00 & 74960.50 & 205.8 & 225.8 & 220.42 & 0.25 & 1.69 & 44 \\
\hline FSS 4D & 52876.10 & 75537.80 & 202.6 & 222.6 & 218.67 & 0.29 & 1.90 & 44 \\
\hline FST 1D & 49102.00 & 81242.60 & 119.5 & 129.5 & 125.75 & 0.42 & 1.11 & 7 \\
\hline FTF 2 & 53275.10 & 77336.00 & 219.4 & 239.4 & 224.87 & 0.37 & 1.48 & 16 \\
\hline FTF 3 & 53244.80 & 77235.30 & 218.2 & 221.2 & 223.36 & 0.62 & 3.09 & 25 \\
\hline FTF 4 & 53268.20 & 77132.90 & 216.6 & 236.6 & 223.97 & 0.36 & 1.82 & 26 \\
\hline FTF 5 & 53168.30 & 77035.60 & 215.3 & 235.3 & 224.01 & 0.58 & 2.76 & 23 \\
\hline FTF 6 & 53062.00 & 77151.40 & 216.9 & 236.9 & 223.93 & 0.48 & 2.14 & 20 \\
\hline FTF 7 & 53089.70 & 77235.90 & 222.1 & 226.1 & 223.57 & 0.39 & 2.11 & 29 \\
\hline FTF 8 & 53059.90 & 77336.20 & 219.6 & 239.6 & 227.10 & 1.28 & 3.63 & 8 \\
\hline FTF 9 & 52769.50 & 77482.80 & 216.4 & 236.4 & 223.65 & 0.34 & 1.41 & 17 \\
\hline FTF 10 & 52905.00 & 77336.00 & 215.1 & 235.1 & 224.17 & 0.24 & 0.81 & 11 \\
\hline FTF 11 & 52748.80 & 77180.70 & 215.8 & 235.8 & 224.80 & 0.56 & 1.84 & 11 \\
\hline FTF 12 & 52648.50 & 77321.40 & 215.0 & 235.0 & 226.67 & 0.31 & 1.63 & 27 \\
\hline FTF 13 & 53098.40 & 76637.80 & 216.1 & 236.1 & 225.25 & 0.61 & 2.72 & 20 \\
\hline FTF 15 & 53230.00 & 76732.00 & 197.5 & 227.5 & 225.11 & 0.64 & 3.44 & 29 \\
\hline FTF 16 & 52879.80 & 76758.60 & 203.8 & 233.8 & 223.17 & 0.53 & 2.87 & 29 \\
\hline FTF 17 & 52884.00 & 76872.00 & 200.6 & 230.6 & 222.85 & 0.38 & 2.06 & 30 \\
\hline FTF 18 & 52879.20 & 76955.80 & 202.3 & 232.3 & 223.14 & 0.57 & 3.04 & 28 \\
\hline FTF 19 & 52670.40 & 77139.10 & 198.3 & 228.3 & 222.25 & 0.39 & 2.12 & 29 \\
\hline FTF 20 & 52500.00 & 77015.00 & 198.3 & 228.3 & 221.65 & 0.33 & 1.80 & 30 \\
\hline FTF 21 & 52498.60 & 76866.70 & 198.7 & 228.7 & 222.94 & 0.27 & 1.49 & 30 \\
\hline FTF 22 & 52494.70 & 76751.30 & 212.6 & 242.6 & 221.64 & 0.37 & 2.04 & 30 \\
\hline FTF 23 & 52660.30 & 76611.80 & 201.2 & 231.2 & 222.06 & 0.40 & 2.13 & 29 \\
\hline FTF 24A & 52780.80 & 77256.60 & 212.7 & 232.7 & 222.35 & 0.58 & 3.06 & 28 \\
\hline FTF 25A & 52868.70 & 77308.40 & 212.8 & 232.8 & 223.06 & 0.36 & 1.95 & 29 \\
\hline FTF 26 & 52875.40 & 77250.00 & 206.3 & 226.3 & 223.07 & 0.36 & 1.93 & 28 \\
\hline FTF 27 & 52823.50 & 77227.20 & 213.5 & 243.5 & 223.24 & 0.44 & 2.33 & 28 \\
\hline H 6 & 58335.40 & 72009.10 & 225.2 & 235.2 & 231.04 & 0.86 & 1.91 & 5 \\
\hline H 7 & 58336.10 & 71949.20 & 224.9 & 234.9 & 228.96 & 0.48 & 1.07 & 5 \\
\hline H 8 & 58233.90 & 71615.40 & 218.4 & 228.4 & 227.01 & 0.18 & 0.48 & 7 \\
\hline H 9 & 58275.30 & 71572.60 & 207.4 & 217.4 & 226.76 & 0.33 & 0.74 & 5 \\
\hline $\begin{array}{ll}H & 10\end{array}$ & 57822.80 & 71607.20 & 222.5 & 232.5 & 227.27 & 0.39 & 1.04 & 7 \\
\hline H 11 & 57779.40 & 71565.90 & 212.0 & 222.0 & 227.70 & 0.41 & 0.92 & 5 \\
\hline H $18 \mathrm{~A}$ & 57337.70 & 71339.60 & 217.5 & 227.5 & 224.12 & 0.26 & 1.11 & 18 \\
\hline H 19 & 57041.70 & 71434.20 & 219.6 & 221.1 & 223.76 & 0.34 & 0.77 & 5 \\
\hline HAA 1 A & 62967.90 & 69879.10 & 94.9 & 104.9 & 181.12 & 0.20 & 0.57 & 8 \\
\hline HAA IAA & 62960.40 & 69885.70 & 13.6 & 23.6 & 180.99 & 0.29 & 0.81 & 8 \\
\hline HAA $1 B$ & 62976.00 & 69872.20 & 119.3 & 129.3 & 251.41 & 0.57 & 1.60 & 8 \\
\hline HAA 1C & 62983.00 & 69866.20 & 147.4 & 157.4 & 252.00 & 0.58 & 1.63 & 8 \\
\hline HAA 10 & 62991.00 & 69859.10 & 261.8 & 281.8 & 276.42 & 0.54 & 1.53 & 8 \\
\hline HAA $1 T A$ & 62953.30 & 69892.20 & -29.8 & -19.8 & 180.69 & 0.45 & 1.27 & 8 \\
\hline HAA 2 A & 61276.00 & 70930.40 & 107.3 & 117.3 & 177.01 & 0.19 & 0.49 & 7 \\
\hline HAA 2 AA & 61285.10 & 70925.40 & 29.4 & 39.4 & 177.65 & 0.23 & 0.64 & 8 \\
\hline HAA 2B & 61267.50 & 70935.40 & 127.2 & 137.2 & 253.24 & 0.42 & 1.26 & 9 \\
\hline HAA $2 \mathrm{C}$ & 61258.90 & 70940.40 & 171.9 & 181.9 & 254.82 & 0.35 & 1.04 & 9 \\
\hline HAA 2D & 61250.60 & 70945.40 & 260.3 & 280.4 & 276.53 & 0.28 & 0.89 & 10 \\
\hline HAA $3 A$ & 60190.40 & 71470.90 & 96.8 & 106.8 & 175.78 & 0.19 & 0.57 & 9 \\
\hline
\end{tabular}


Table F-1. Hydraulic Head Targets for Model Calibration (Continued)

\begin{tabular}{|c|c|c|c|c|c|c|c|c|}
\hline HAA $3 A A$ & 60201.90 & 71488.00 & 6.5 & 16.5 & 175.03 & 0.19 & 0.58 & 9 \\
\hline HAA 3B & 60178.40 & 71453.20 & 125.9 & 135.9 & 240.66 & 0.43 & 1.34 & 10 \\
\hline HAA 3C & 60167.40 & 71436.90 & 163.3 & 173.3 & 243.95 & 0.49 & 1.48 & 9 \\
\hline HAA 3D & 60154.30 & 71418.40 & 246.7 & 266.7 & 265.35 & 0.96 & 4.07 & 18 \\
\hline HAA 4A & 61920.00 & 72223.00 & 105.4 & 115.3 & 174.73 & 0.20 & 0.55 & 8 \\
\hline HAA $4 A A$ & 61929.60 & 72223.20 & 32.2 & 42.2 & 174.95 & 0.22 & 0.62 & 8 \\
\hline HAA 4B & 61909.90 & 72222.90 & 124.5 & 135.0 & 250.16 & 0.32 & 0.92 & 8 \\
\hline HAA 4C & 61899.90 & 72223.10 & 158.3 & 168.3 & 251.39 & 0.34 & 0.84 & 6 \\
\hline HAA 4D & 61890.00 & 72223.30 & 255.7 & 275.7 & 269.87 & 0.37 & 1.04 & 8 \\
\hline HAA $6 \mathrm{~A}$ & 63870.00 & 71440.90 & 95.6 & 105.6 & 178.92 & 0.19 & 0.57 & 9 \\
\hline HAA $6 A A$ & 63860.20 & 71441.00 & 25.8 & 35.8 & 178.60 & 0.18 & 0.54 & 9 \\
\hline HAA 6B & 63879.80 & 71440.40 & 131.3 & 141.4 & 235.67 & 0.27 & 0.82 & 9 \\
\hline HAA $6 \mathrm{C}$ & 63889.90 & 71440.60 & 161.1 & 171.1 & 235.86 & 0.28 & 0.84 & 9 \\
\hline HAA 6D & 63900.20 & 71440.30 & 247.1 & 267.2 & 265.14 & 0.37 & 1.18 & 10 \\
\hline HAC 1 & 61415.20 & 72171.00 & 258.8 & 278.8 & 269.40 & 0.31 & 1.64 & 28 \\
\hline HAC 2 & 61366.90 & 72220.20 & 258.8 & 278.8 & 268.99 & 0.34 & 1.79 & 28 \\
\hline HAC 3 & 61313.60 & 72183.40 & 255.0 & 275.0 & 269.11 & 0.29 & 1.56 & 29 \\
\hline HAC 4 & 61372.00 & 72120.30 & 254.1 & 274.1 & 269.63 & 0.31 & 1.66 & 28 \\
\hline HAP 1 & 63398.80 & 71209.80 & 256.3 & 276.3 & 270.84 & 0.31 & 1.48 & 23 \\
\hline HAP 2 & 63519.80 & 71122.90 & 243.8 & 263.8 & 270.32 & 0.24 & 1.27 & 28 \\
\hline $\mathrm{HC} \quad 1 \mathrm{~A}$ & 61867.00 & 71755.00 & 89.5 & 94.5 & 175.80 & 0.00 & 0.00 & 2 \\
\hline$H C \quad 1 D$ & 61867.00 & 71746.00 & 206.5 & 211.5 & 268.20 & -1.00 & -1.00 & 1 \\
\hline HC $1 E$ & 61864.00 & 71746.00 & 251.5 & 256.5 & 275.00 & 0.50 & 0.71 & 2 \\
\hline $\mathrm{HC} \quad 2 \mathrm{~A}$ & 61866.00 & 71794.00 & 72.2 & 77.2 & 175.80 & 0.50 & 0.71 & 2 \\
\hline $\mathrm{HC} \quad 2 \mathrm{~B}$ & 61876.00 & 71785.00 & 85.7 & 90.7 & 175.00 & 1.00 & 1.41 & 2 \\
\hline $\mathrm{HC} 2 \mathrm{C}$ & 61872.00 & 71784.00 & 135.7 & 140.7 & 253.70 & 0.50 & 0.71 & 2 \\
\hline $\mathrm{HC} 2 \mathrm{D}$ & 61866.00 & 71784.00 & 178.2 & 183.2 & 255.80 & 0.50 & 0.71 & 2 \\
\hline $\mathrm{HC} \quad 2 \mathrm{E}$ & 61861.00 & 71784.00 & 205.7 & 210.7 & 269.50 & 1.00 & 1.41 & 2 \\
\hline $\mathrm{HC} \quad 2 \mathrm{~F}$ & 61861.00 & 71780.00 & 250.7 & 255.7 & 274.30 & 0.00 & 0.00 & 2 \\
\hline $\mathrm{HC} \quad 4 \mathrm{~A}$ & 63409.00 & 71606.00 & 150.0 & 155.0 & 244.70 & 0.00 & 0.00 & 2 \\
\hline $\mathrm{HC} \quad 6 \mathrm{~A}$ & 62060.00 & 72150.00 & 156.2 & 161.2 & 252.20 & 0.50 & 0.71 & 2 \\
\hline $\mathrm{HC} \quad 6 \mathrm{~B}$ & 62070.00 & 72150.00 & 210.2 & 215.2 & 268.90 & 1.00 & 1.41 & 2 \\
\hline $\mathrm{HC} 8 \mathrm{~A}$ & 60058.50 & 77481.80 & 13.3 & 16.3 & 175.63 & -1.00 & -1.00 & 1 \\
\hline $\mathrm{HC} 8 \mathrm{~B}$ & 60058.40 & 77487.50 & 132.5 & 137.5 & 155.47 & -1.00 & -1.00 & 1 \\
\hline $\mathrm{HC} 8 \mathrm{C}$ & 60065.10 & 77484.40 & 187.3 & 192.3 & 197.49 & -1.00 & -1.00 & 1 \\
\hline $\mathrm{HC} 10 \mathrm{~A}$ & 61593.40 & 75806.70 & 114.0 & 117.0 & 163.34 & -1.00 & -1.00 & 1 \\
\hline $\mathrm{HC} 10 \mathrm{~B}$ & 61600.10 & 75801.30 & 164.8 & 169.8 & 208.91 & 1.11 & 1.92 & 3 \\
\hline $\mathrm{HC} 11 \mathrm{C}$ & 62131.40 & 74496.40 & 190.8 & 195.8 & 236.60 & 1.00 & 1.41 & 2 \\
\hline $\mathrm{HC} 12 \mathrm{~B}$ & 59488.40 & 73186.90 & 177.3 & 182.3 & 240.75 & 1.43 & 2.48 & 3 \\
\hline HCA 1 & 63109.00 & 72521.70 & 253.7 & 273.7 & 269.37 & 0.26 & 1.52 & 34 \\
\hline HCA 2 & 62943.30 & 72265.90 & 242.0 & 273.4 & 270.22 & 0.28 & 1.57 & 32 \\
\hline HCA 3 & 63108.70 & 72651.70 & 253.8 & 273.8 & 269.16 & 0.24 & 1.42 & 34 \\
\hline HCA 4 & 62942.90 & 72523.70 & 241.9 & 273.3 & 269.30 & 0.25 & 1.57 & 40 \\
\hline HCA $4 A$ & 62929.90 & 72515.50 & 103.7 & 113.7 & 175.57 & 0.17 & 0.52 & 10 \\
\hline HCA $4 A A$ & 62942.50 & 72513.70 & 33.6 & 43.6 & 175.22 & 0.17 & 0.53 & 10 \\
\hline HCA 4B & 62942.30 & 72532.90 & 126.6 & 136.6 & 245.93 & 0.25 & 0.80 & 10 \\
\hline $\mathrm{HCA} 4 \mathrm{C}$ & 62931.80 & 72532.80 & 153.8 & 163.8 & 246.64 & 0.26 & 0.83 & 10 \\
\hline HCB 1 & 63921.50 & 71426.80 & 222.6 & 252.6 & 263.59 & 0.26 & 1.45 & 30 \\
\hline HCB 2 & 63797.90 & 71289.70 & 239.9 & 269.9 & 268.15 & 0.23 & 1.27 & 32 \\
\hline HCB 3 & 63919.90 & 71098.80 & 233.6 & 263.6 & 266.55 & 0.18 & 0.97 & 30 \\
\hline HCB 4 & 64054.50 & 71244.20 & 235.9 & 265.9 & 264.49 & 0.25 & 1.35 & 30 \\
\hline HET 1D & 60546.00 & 71948.30 & 240.3 & 260.3 & 267.71 & 0.38 & 2.02 & 29 \\
\hline HET $2 D$ & 60094.40 & 72006.00 & 239.7 & 259.7 & 258.53 & 0.36 & 2.00 & 31 \\
\hline HET 3D & 60110.50 & 72093.90 & 239.9 & 259.9 & 258.88 & 0.33 & 1.92 & 33 \\
\hline HET 4D & 60166.50 & 72178.10 & 239.5 & 259.6 & 259.25 & 0.32 & 1.77 & 31 \\
\hline HHP 1D & 60533.88 & 71026.79 & 260.4 & 270.4 & 271.15 & 0.00 & 0.00 & 2 \\
\hline HHP 2D & 60803.08 & 70886.58 & 263.2 & 273.2 & 273.85 & 0.00 & 0.00 & 2 \\
\hline HIW IID & 58480.00 & 72506.90 & 213.0 & 228.0 & 231.88 & 0.58 & 0.81 & 2 \\
\hline HIW 1MD & 58486.00 & 72546.30 & 214.9 & 239.7 & 232.38 & 0.33 & 0.58 & 3 \\
\hline
\end{tabular}


Table F-1. Hydraulic Head Targets for Model Calibration (Continued)

\begin{tabular}{|c|c|c|c|c|c|c|c|c|}
\hline HIW 1PD & 58395.30 & 72543.30 & 215.5 & 240.5 & 231.91 & 0.30 & 0.52 & 3 \\
\hline HIW $2 A$ & 56753.00 & 73249.70 & 78.3 & 88.3 & 167.23 & 0.24 & 0.60 & 6 \\
\hline HIW 2D & 56750.20 & 73269.20 & 210.9 & 230.8 & 229.66 & 0.69 & 2.06 & 9 \\
\hline HIW $2 M C$ & 56698.40 & 73226.40 & 154.0 & 184.0 & 226.69 & 0.60 & 1.20 & 4 \\
\hline HIW $2 M C$ & 56698.40 & 73226.40 & 124.1 & 139.0 & 226.69 & 0.60 & 1.20 & 4 \\
\hline HIW $4 M C$ & 56570.10 & 73160.10 & 150.4 & 180.4 & 219.68 & -1.00 & -1.00 & 1 \\
\hline HIW 4MC & 56570.10 & 73160.10 & 120.8 & 135.7 & 219.68 & -1.00 & -1.00 & 1 \\
\hline HIW 5MC & 56498.90 & 73557.90 & 154.2 & 184.1 & 227.80 & 1.04 & 2.32 & 5 \\
\hline HIW 5MC & 56498.90 & 73557.90 & 124.4 & 139.2 & 227.80 & 1.04 & 2.32 & 5 \\
\hline HMD 1D & 56973.30 & 78731.70 & 199.7 & 219.7 & 209.46 & 0.29 & 1.71 & 35 \\
\hline HMD 2D & 57269.70 & 79665.80 & 190.8 & 210.8 & 200.74 & 0.29 & 1.72 & 36 \\
\hline HMD 3D & 57745.20 & 79578.70 & 187.7 & 207.7 & 200.07 & 0.29 & 1.70 & 35 \\
\hline HMD 4D & 58188.50 & 79160.40 & 188.9 & 208.9 & 199.62 & 0.47 & 2.76 & 35 \\
\hline HOB 1D & 56917.49 & 72993.46 & 204.2 & 224.2 & 230.51 & 1.43 & 2.85 & 4 \\
\hline HOB 2D & 57273.89 & 72811.95 & 200.4 & 220.4 & 228.91 & 1.19 & 2.37 & 4 \\
\hline HOB 3D & 58034.78 & 72326.22 & 207.7 & 227.7 & 229.11 & 1.48 & 2.96 & 4 \\
\hline HOB 4D & 58370.03 & 72223.65 & 210.4 & 230.4 & 229.91 & 0.30 & 0.52 & 3 \\
\hline HOB $6 \mathrm{D}$ & 57421.25 & 70577.88 & 186.9 & 196.9 & 207.14 & 0.83 & 1.65 & 4 \\
\hline HOB 7D & 56289.34 & 71879.82 & 197.4 & 217.4 & 220.84 & 1.02 & 2.04 & 4 \\
\hline HR3 11 & 60146.50 & 71402.80 & 200.4 & 230.0 & 259.66 & 0.35 & 1.96 & 32 \\
\hline HR3 13 & 60065.50 & 71649.40 & 205.1 & 234.8 & 258.78 & 0.49 & 2.79 & 32 \\
\hline HR8 11 & 59559.80 & 71945.70 & 207.9 & 237.6 & 246.21 & 0.25 & 1.43 & 34 \\
\hline HR8 12 & 59330.10 & 71780.10 & 206.3 & 235.9 & 239.79 & 0.22 & 1.24 & 33 \\
\hline HR8 13 & 59300.20 & 71559.60 & 201.7 & 231.4 & 237.79 & 0.17 & 0.98 & 32 \\
\hline HR8 14 & 59612.10 & 71431.40 & 202.3 & 231.9 & 243.91 & 0.09 & 0.33 & 13 \\
\hline HSB 50PC & 55690.30 & 72161.10 & 119.5 & 169.6 & 218.00 & 1.23 & 2.47 & 4 \\
\hline HSB 65 & 58432.00 & 72425.60 & 212.4 & 242.4 & 232.49 & 0.34 & 2.51 & 56 \\
\hline HSB $65 A$ & 58436.00 & 72436.20 & 62.5 & 73.2 & 171.33 & 0.15 & 1.13 & 55 \\
\hline HSB 65B & 58439.40 & 72445.60 & 123.3 & 133.3 & 224.31 & 0.13 & 0.95 & 56 \\
\hline HSB 65C & 58447.10 & 72439.60 & 207.8 & 218.6 & 232.49 & 0.24 & 1.77 & 56 \\
\hline HSB 66 & 56928.30 & 72429.20 & 198.1 & 228.1 & 224.69 & 0.38 & 3.08 & 67 \\
\hline HSB 67 & 58424.30 & 71505.00 & 200.7 & 230.7 & 223.34 & 0.31 & 2.50 & 64 \\
\hline HSB 68 & 56901.00 & 71528.00 & 213.3 & 243.3 & 221.58 & 0.18 & 1.21 & 43 \\
\hline HSB $68 \mathrm{~A}$ & 56892.10 & 71526.90 & 47.5 & 58.0 & 171.75 & 0.13 & 1.00 & 57 \\
\hline HSB 68B & 56882.10 & 71525.50 & 123.5 & 134.5 & 216.59 & 0.29 & 2.23 & 59 \\
\hline HSB 68C & 56872.70 & 71524.10 & 168.4 & 179.5 & 217.60 & 0.21 & 1.63 & 58 \\
\hline HSB 69 & 56475.10 & 71546.90 & 199.0 & 229.0 & 219.43 & 0.11 & 0.86 & 62 \\
\hline HSB 69A & 56465.10 & 71549.40 & 83.1 & 93.1 & 171.68 & 0.39 & 2.82 & 53 \\
\hline HSB 70 & 55758.90 & 72606.90 & 205.7 & 235.7 & 223.89 & 0.43 & 3.15 & 54 \\
\hline HSB 70C & 55757.10 & 72597.30 & 164.9 & 174.9 & 223.17 & 0.24 & 1.82 & 56 \\
\hline HSB 71 & 55279.20 & 72875.90 & 204.8 & 234.8 & 223.99 & 0.46 & 3.41 & 54 \\
\hline HSB 71C & 55281.50 & 72866.60 & 171.9 & 181.9 & 222.61 & 0.28 & 2.07 & 55 \\
\hline HSB 83A & 58606.10 & 71648.60 & 65.2 & 76.0 & 172.85 & 0.31 & 2.53 & 69 \\
\hline HSB 83B & 58594.90 & 71639.60 & 121.2 & 132.1 & 222.82 & 0.16 & 1.21 & 59 \\
\hline HSB 83C & 58614.80 & 71636.90 & 160.2 & 171.2 & 224.65 & 0.13 & 1.01 & 57 \\
\hline HSB 83D & 58601.70 & 71628.10 & 198.7 & 228.7 & 224.84 & 0.15 & 1.18 & 59 \\
\hline HSB 84A & 56359.10 & 71586.20 & 64.7 & 75.9 & 171.79 & 0.13 & 0.94 & 56 \\
\hline HSB 84B & 56352.40 & 71603.30 & 121.8 & 132.9 & 210.75 & 0.10 & 0.80 & 58 \\
\hline HSB 84C & 56360.10 & 71597.10 & 170.9 & 181.8 & 213.48 & 0.26 & 2.02 & 59 \\
\hline HSB 84D & 56349.90 & 71583.90 & 199.5 & 219.5 & 218.91 & 0.11 & 0.85 & 55 \\
\hline HSB 85A & 58943.40 & 73791.90 & 61.1 & 71.1 & 168.75 & 0.10 & 0.80 & 69 \\
\hline HSB 85B & 58953.30 & 73789.30 & 133.2 & 143.2 & 233.66 & 0.22 & 1.80 & 70 \\
\hline HSB 85C & 58947.40 & 73802.30 & 214.2 & 224.2 & 238.69 & 0.23 & 1.80 & 60 \\
\hline HSB $86 A$ & 55985.90 & 72520.20 & 63.1 & 73.9 & 168.59 & 0.12 & 0.88 & 58 \\
\hline HSB 868 & 55976.90 & 72519.00 & 113.8 & 124.0 & 221.55 & 0.17 & 1.31 & 59 \\
\hline HSB 86C & 55984.60 & 72529.70 & 189.4 & 199.4 & 223.55 & 0.23 & 1.71 & 58 \\
\hline HSB 86D & 55996.50 & 72522.10 & 206.6 & 236.6 & 223.52 & 0.23 & 1.73 & 57 \\
\hline HSB100C & 58806.50 & 72077.20 & 153.0 & 163.0 & 226.55 & 0.16 & 1.21 & 59 \\
\hline
\end{tabular}


Table F-1. Hydraulic Head Targets for Model Calibration (Continued)

\begin{tabular}{|c|c|c|c|c|c|c|c|c|}
\hline HSB100D & 58796.90 & 72073.80 & 216.9 & 236.9 & 233.49 & 0.21 & 1.65 & 64 \\
\hline HSB10OPC & 55720.00 & 72058.30 & 117.6 & 167.7 & 217.15 & 1.19 & 2.38 & 4 \\
\hline HSB100PD & 56379.50 & 71445.30 & 195.0 & 214.9 & 217.41 & 0.64 & 1.28 & 4 \\
\hline HSB101C & 58604.40 & 72001.90 & 166.3 & 176.3 & 225.47 & 0.15 & 1.10 & 57 \\
\hline HSB101D & 58594.80 & 71997.50 & 216.1 & 236.1 & 230.80 & 0.18 & 1.44 & 62 \\
\hline HSB102C & 58399.70 & 71960.10 & 166.7 & 176.7 & 224.62 & 0.15 & 1.10 & 56 \\
\hline HSB102D & 58393.40 & 71952.40 & 216.3 & 236.3 & 228.24 & 0.21 & 1.53 & 54 \\
\hline HSB103C & 58323.60 & 71593.90 & 159.2 & 169.2 & 223.31 & 0.16 & 1.24 & 58 \\
\hline HSB103D & 58315.60 & 71588.10 & 213.7 & 233.7 & 225.59 & 0.17 & 1.27 & 59 \\
\hline HSB104C & 58082.60 & 71376.80 & 163.5 & 173.5 & 220.59 & 0.13 & 1.02 & 58 \\
\hline HSB104D & 58075.80 & 71370.20 & 210.6 & 230.6 & 224.91 & 0.20 & 1.51 & 58 \\
\hline HSB105C & 57883.80 & 71447.30 & 152.2 & 162.2 & 219.57 & 0.12 & 0.94 & 57 \\
\hline HSB105D & 57877.40 & 71454.80 & 211.8 & 231.8 & 225.29 & 0.16 & 1.29 & 62 \\
\hline HSB106C & 57651.50 & 71720.90 & 158.7 & 168.7 & 221.73 & 0.13 & 0.99 & 57 \\
\hline HSB106D & 57644.80 & 71727.80 & 210.7 & 230.7 & 225.88 & 0.17 & 1.29 & 55 \\
\hline HSB107C & 57432.00 & 71698.50 & 159.3 & 169.3 & 219.29 & 0.12 & 0.89 & 57 \\
\hline HSB107D & 57412.20 & 71696.60 & 215.1 & 235.1 & 224.69 & 0.16 & 1.19 & 58 \\
\hline HSB108C & 57155.50 & 71688.70 & 186.0 & 196.0 & 218.54 & 0.18 & 1.34 & 58 \\
\hline HSB108D & 57145.60 & 71688.00 & 212.0 & 232.0 & 223.46 & 0.16 & 1.14 & 49 \\
\hline HSB109C & 56895.60 & 71684.80 & 168.4 & 178.4 & 218.75 & 0.12 & 0.95 & 59 \\
\hline HSB109D & 56885.50 & 71685.60 & 213.0 & 233.0 & 222.85 & 0.16 & 1.12 & 47 \\
\hline HSB110C & 56680.70 & 71779.30 & 171.4 & 181.4 & 219.07 & 0.12 & 0.92 & 58 \\
\hline HSB110D & 56672.10 & 71785.20 & 211.4 & 231.4 & 222.09 & 0.17 & 1.26 & 57 \\
\hline HSB111C & 56501.90 & 71919.40 & 140.7 & 150.7 & 220.27 & 0.13 & 1.01 & 58 \\
\hline HSB111D & 56494.50 & 71926.20 & 185.7 & 195.7 & 222.03 & 0.15 & 1.13 & 57 \\
\hline HSB111E & 56487.20 & 71932.80 & 211.7 & 231.7 & 222.02 & 0.17 & 1.27 & 56 \\
\hline HSB112C & 56417.40 & 72156.40 & 140.6 & 150.6 & 221.59 & 0.16 & 1.22 & 55 \\
\hline HSB112D & 56408.10 & 72161.60 & 188.3 & 198.3 & 222.75 & 0.19 & 1.43 & 57 \\
\hline HSB112E & 56399.50 & 72166.60 & 211.7 & 231.7 & 222.54 & 0.18 & 1.41 & 64 \\
\hline HSB113C & 56160.40 & 72312.30 & 154.7 & 164.7 & 221.87 & 0.16 & 1.22 & 56 \\
\hline HSB113C & 56160.40 & 72312.30 & 151.7 & 161.7 & 221.87 & 0.16 & 1.22 & 56 \\
\hline HSB113D & 56164.30 & 72302.70 & 216.2 & 236.2 & 222.52 & 0.20 & 1.58 & 60 \\
\hline HSB114C & 56107.00 & 72464.60 & 185.6 & 195.6 & 223.38 & 0.21 & 1.59 & 56 \\
\hline HSB114D & 56104.60 & 72474.20 & 212.8 & 232.8 & 223.29 & 0.23 & 1.73 & 56 \\
\hline HSB115C & 56043.20 & 72653.20 & 182.8 & 192.8 & 224.36 & 0.34 & 2.60 & 57 \\
\hline HSB115D & 56039.80 & 72662.30 & 213.9 & 233.9 & 223.93 & 0.24 & 1.98 & 67 \\
\hline HSB116C & 55989.10 & 72888.10 & 180.5 & 190.5 & 225.04 & 0.22 & 1.60 & 55 \\
\hline HSB116D & 55988.20 & 72898.10 & 214.5 & 234.5 & 226.21 & 0.50 & 3.80 & 57 \\
\hline HSB117A & 55170.10 & 72733.60 & 84.8 & 94.8 & 166.67 & 0.10 & 0.74 & 55 \\
\hline HSB117C & 55162.90 & 72740.70 & 165.1 & 175.1 & 221.61 & 0.29 & 2.10 & 54 \\
\hline HSB1170 & 55155.60 & 72747.60 & 200.3 & 220.3 & 223.87 & 0.35 & 2.75 & 62 \\
\hline HSB118A & 55775.60 & 72696.40 & 91.0 & 101.0 & 167.58 & 0.12 & 0.92 & 56 \\
\hline HSB119A & 56100.20 & 73082.50 & 93.3 & 103.3 & 166.93 & 0.11 & 0.85 & 58 \\
\hline HSB120A & 56431.90 & 73395.10 & 91.0 & 101.0 & 166.22 & 0.11 & 0.82 & 55 \\
\hline HSB121A & 57389.60 & 72024.80 & 88.3 & 98.3 & 171.56 & 0.12 & 0.91 & 56 \\
\hline HSB122A & 57747.40 & 72195.90 & 85.4 & 95.4 & 171.34 & 0.12 & 0.88 & 56 \\
\hline HSB123A & 58124.80 & 72189.80 & 93.6 & 103.6 & 171.67 & 0.34 & 2.68 & 61 \\
\hline HSB124AR & 58531.70 & 72202.70 & 94.6 & 104.6 & 172.00 & 0.14 & 0.87 & 39 \\
\hline HSB125C & 58592.80 & 71503.60 & 145.6 & 155.6 & 223.34 & 0.16 & 1.17 & 56 \\
\hline HSB125D & 58584.10 & 71498.20 & 199.4 & 219.4 & 221.34 & 0.15 & 1.14 & 57 \\
\hline HSB126C & 57178.20 & 70627.70 & 176.3 & 181.3 & 203.91 & 0.07 & 0.51 & 53 \\
\hline HSB126D & 57169.60 & 70633.40 & 190.5 & 200.5 & 205.15 & 0.07 & 0.56 & 58 \\
\hline HSB127C & 56792.10 & 71210.10 & 148.4 & 158.4 & 210.33 & 0.08 & 0.58 & 57 \\
\hline HSB127D & 56788.00 & 71218.90 & 197.8 & 217.8 & 218.19 & 0.09 & 0.69 & 56 \\
\hline HSB129C & 55110.00 & 71830.40 & 147.8 & 157.8 & 205.75 & 0.19 & 1.39 & 56 \\
\hline HSB129D & 55103.40 & 71837.10 & 185.2 & 205.2 & 208.53 & 0.13 & 0.94 & 56 \\
\hline HSB130C & 54643.60 & 70762.40 & 159.9 & 169.9 & 199.92 & 0.07 & 0.54 & 59 \\
\hline HSB130D & 54651.70 & 70757.20 & 182.1 & 202.1 & 200.17 & 0.10 & 0.74 & 59 \\
\hline HSB131C & 56894.90 & 70374.70 & 148.5 & 158.5 & 203.87 & 0.08 & 0.57 & 56 \\
\hline
\end{tabular}


Table F-1. Hydraulic Head Targets for Model Calibration (Continued)

\begin{tabular}{|c|c|c|c|c|c|c|c|c|}
\hline HSB131D & 56891.10 & 70365.00 & 195.7 & 205.7 & 205.15 & 0.12 & 0.88 & 58 \\
\hline HSB132C & 58787.70 & 71472.40 & 168.6 & 178.6 & 221.62 & 0.12 & 0.88 & 56 \\
\hline HSB132D & 58799.30 & 71469.50 & 206.5 & 226.5 & 221.32 & 0.18 & 1.31 & 55 \\
\hline HSB133C & 59110.30 & 71949.50 & 173.3 & 183.3 & 230.55 & 0.18 & 1.39 & 57 \\
\hline HSB133D & 59102.30 & 71943.50 & 208.5 & 228.5 & 235.09 & 0.22 & 1.65 & 57 \\
\hline HSB134C & 58289.90 & 71210.30 & 149.1 & 159.1 & 220.87 & 0.13 & 0.98 & 58 \\
\hline HSB134D & 58296.50 & 71217.30 & 205.8 & 225.8 & 222.33 & 0.24 & 1.83 & 59 \\
\hline HSB135C & 56560.80 & 71390.20 & 147.3 & 157.3 & 206.71 & 0.07 & 0.54 & 55 \\
\hline HSB135D & 56552.80 & 71396.70 & 199.9 & 219.9 & 218.31 & 0.11 & 0.80 & 55 \\
\hline HSB136C & 55949.60 & 71900.30 & 160.5 & 170.5 & 217.46 & 0.14 & 1.09 & 57 \\
\hline HSB136D & 55941.70 & 71906.00 & 200.2 & 220.2 & 220.81 & 0.17 & 1.24 & 56 \\
\hline HSB137C & 55700.20 & 72269.90 & 163.8 & 173.8 & 220.25 & 0.19 & 1.43 & 58 \\
\hline HSB137D & 55696.10 & 72278.90 & 205.3 & 225.3 & 222.19 & 0.21 & 1.55 & 56 \\
\hline HSB138D & 55260.70 & 73160.20 & 208.1 & 228.1 & 223.65 & 0.33 & 2.49 & 57 \\
\hline HSB139A & 57365.40 & 71127.40 & 87.6 & 97.6 & 173.56 & 0.13 & 0.99 & 55 \\
\hline HSB139C & 57374.50 & 71129.80 & 148.5 & 158.5 & 214.48 & 0.10 & 0.77 & 57 \\
\hline HSB139D & 57384.40 & 71133.20 & 206.7 & 226.7 & 222.60 & 0.24 & 1.80 & 58 \\
\hline HSB140A & 56535.40 & 70050.30 & 81.0 & 91.0 & 175.70 & 0.09 & 0.57 & 43 \\
\hline HSB140C & 56551.80 & 70049.20 & 161.6 & 171.6 & 204.23 & 0.68 & 2.78 & 17 \\
\hline HSB140D & 56560.60 & 70036.00 & 194.1 & 214.1 & 213.61 & 0.42 & 2.79 & 44 \\
\hline HSB141A & 59168.70 & 71213.60 & 80.6 & 90.6 & 174.97 & 0.19 & 1.33 & 48 \\
\hline HSB141C & 59170.20 & 71196.70 & 154.7 & 164.7 & 228.85 & 0.34 & 1.55 & 21 \\
\hline HSB141CR & 59167.20 & 71226.70 & 152.1 & 162.1 & 229.52 & 0.87 & 3.81 & 19 \\
\hline HSB141D & 59170.90 & 71184.40 & 217.8 & 237.8 & 241.18 & 0.70 & 4.84 & 48 \\
\hline HSB142C & 53505.30 & 73119.00 & 161.6 & 171.6 & 198.26 & 0.34 & 2.28 & 45 \\
\hline HSB142D & 53493.10 & 73113.00 & 189.7 & 199.7 & 198.03 & 0.36 & 2.45 & 46 \\
\hline HSB143C & 52773.20 & 73738.20 & 169.1 & 179.1 & 209.27 & 0.17 & 1.10 & 44 \\
\hline HSB143D & 52774.50 & 73754.00 & 196.9 & 216.9 & 213.14 & 0.20 & 1.33 & 45 \\
\hline HSB144A & 56200.50 & 71892.10 & 78.6 & 88.6 & 170.91 & 0.07 & 0.47 & 45 \\
\hline HSB145C & 57769.00 & 71098.90 & 164.7 & 174.7 & 213.44 & 0.27 & 1.80 & 46 \\
\hline HSB145D & 57753.90 & 71088.00 & 184.2 & 194.2 & 220.54 & 0.24 & 1.62 & 46 \\
\hline HSB146A & 58454.00 & 70478.90 & 85.5 & 95.5 & 175.93 & 0.08 & 0.53 & 44 \\
\hline HSB146C & 58473.10 & 70471.60 & 152.3 & 162.3 & 209.92 & 0.19 & 1.25 & 45 \\
\hline HSB146D & 58493.00 & 70469.70 & 204.0 & 224.1 & 222.42 & 0.51 & 3.45 & 46 \\
\hline HSB147D & 55804.40 & 73827.90 & 215.2 & 235.2 & 231.32 & 0.36 & 2.40 & 45 \\
\hline HSB148C & 55344.20 & 70151.50 & 158.9 & 168.9 & 201.72 & 0.09 & 0.67 & 50 \\
\hline HSB148D & 55355.70 & 70160.90 & 198.1 & 218.1 & 213.31 & 0.23 & 1.66 & 51 \\
\hline HSB149D & 57286.30 & 71338.80 & 207.0 & 227.0 & 222.44 & 0.50 & 3.33 & 45 \\
\hline HSB150D & 58692.80 & 71692.60 & 206.9 & 226.9 & 226.94 & 0.41 & 2.82 & 48 \\
\hline HSB150PC & 55543.90 & 72236.40 & 119.5 & 169.6 & 218.15 & 1.40 & 2.79 & 4 \\
\hline HSB151C & 54014.90 & 72997.90 & 170.6 & 180.6 & 207.91 & 0.18 & 1.22 & 46 \\
\hline HSB151D & 54026.40 & 72997.80 & 197.6 & 207.6 & 207.27 & 0.22 & 1.43 & 44 \\
\hline HSB152C & 54346.70 & 72012.00 & 173.1 & 183.1 & 199.03 & 0.07 & 0.48 & 45 \\
\hline HSB152D & 54362.10 & 72011.70 & 197.0 & 207.0 & 205.63 & 0.38 & 1.39 & 13 \\
\hline HSL 1D & 58925.00 & 72179.60 & 219.8 & 239.8 & 235.28 & 0.38 & 2.30 & 36 \\
\hline HSL 2D & 59423.50 & 72190.80 & 225.2 & 245.3 & 241.92 & 0.30 & 1.82 & 36 \\
\hline HSL 3D & 59770.60 & 72251.50 & 233.7 & 253.8 & 250.33 & 0.40 & 2.52 & 39 \\
\hline HSL 4D & 60171.90 & 72453.70 & 245.0 & 265.1 & 261.88 & 0.32 & 2.03 & 39 \\
\hline HSL 5D & 60339.40 & 72562.20 & 247.8 & 267.7 & 266.03 & 0.53 & 3.12 & 35 \\
\hline HSL 50 & 60339.40 & 72562.20 & 242.6 & 247.7 & 266.03 & 0.53 & 3.12 & 35 \\
\hline HSL $6 A$ & 60549.50 & 72684.50 & 104.7 & 114.7 & 168.23 & 0.15 & 0.51 & 12 \\
\hline HSL 6AA & 60555.70 & 72692.60 & 18.6 & 28.6 & 168.95 & 0.14 & 0.52 & 13 \\
\hline HSL 6B & 60543.60 & 72676.30 & 127.9 & 137.9 & 244.32 & 0.33 & 1.15 & 12 \\
\hline HSL $6 \mathrm{C}$ & 60537.60 & 72667.50 & 157.6 & 167.6 & 245.19 & 0.32 & 1.14 & 13 \\
\hline HSL $6 D$ & 60531.10 & 72659.70 & 243.9 & 264.0 & 260.01 & 0.38 & 2.40 & 41 \\
\hline HSL $6 D$ & 60531.10 & 72659.70 & 239.4 & 243.9 & 260.01 & 0.38 & 2.40 & 41 \\
\hline HSL 7D & 60723.00 & 72674.40 & 242.3 & 262.4 & 259.75 & 0.33 & 2.03 & 39 \\
\hline HSL $8 \mathrm{~A}$ & 61113.90 & 72721.00 & 108.8 & 118.8 & 172.61 & 0.15 & 0.54 & 13 \\
\hline
\end{tabular}


Table F-1. Hydraulic Head Targets for Model Calibration (Continued)

\begin{tabular}{|c|c|c|c|c|c|c|c|c|}
\hline HSL $8 A A$ & 61113.80 & 72729.40 & 28.7 & 38.7 & 175.50 & 0.76 & 2.73 & 13 \\
\hline HSL 8B & 61115.00 & 72710.20 & 138.7 & 148.7 & 248.98 & 0.32 & 1.15 & 13 \\
\hline HSL 8C & 611115.90 & 72700.50 & 171.7 & 181.7 & 250.16 & 0.26 & 1.01 & 15 \\
\hline HSL 80 & 61117.10 & 72688.10 & 248.4 & 268.4 & 260.66 & 0.24 & 1.62 & 44 \\
\hline HSS 10 & 64675.60 & 67610.30 & 236.5 & 256.5 & 268.77 & 0.66 & 3.42 & 27 \\
\hline HSS 2D & 64785.90 & 67355.90 & 234.5 & 254.5 & 267.87 & 0.66 & 3.42 & 27 \\
\hline HSS 3D & 64709.50 & 68257.50 & 262.6 & 282.6 & 281.85 & 0.72 & 3.73 & 27 \\
\hline HTF 1 & 62067.00 & 71745.00 & 236.9 & 256.9 & 272.74 & 0.30 & 1.67 & 31 \\
\hline HTF 2 & 62175.00 & 71610.00 & 237.0 & 257.0 & 274.27 & 0.29 & 1.59 & 31 \\
\hline HTF 4 & 61942.00 & 71630.00 & 235.2 & 255.2 & 274.27 & 0.27 & 1.50 & 30 \\
\hline HTF 5 & 62110.00 & 71390.00 & 264.3 & 284.3 & 277.24 & 0.61 & 2.85 & 22 \\
\hline HTF 6 & 62228.00 & 71259.00 & 263.6 & 283.6 & 276.06 & 0.60 & 2.76 & 21 \\
\hline HTF 7 & 62112.00 & 71130.00 & 263.5 & 283.5 & 275.95 & 0.35 & 1.80 & 26 \\
\hline HTF 8 & 61965.00 & 71270.00 & 263.6 & 283.6 & 273.68 & 0.61 & 2.73 & 20 \\
\hline HTF 9 & 61698.00 & 71652.00 & 245.8 & 265.8 & 273.46 & 0.25 & 1.43 & 32 \\
\hline HTF 10 & 61838.00 & 71520.00 & 245.2 & 265.2 & 273.16 & 0.27 & 1.46 & 29 \\
\hline HTF 11 & 61722.00 & 71398.00 & 238.9 & 258.9 & 273.88 & 0.33 & 1.83 & 30 \\
\hline HTF 12 & 61593.00 & 71520.00 & 242.9 & 262.9 & 273.41 & 0.36 & 2.12 & 34 \\
\hline HTF 13 & 61586.00 & 71856.00 & 262.6 & 282.6 & 274.15 & 0.32 & 1.70 & 28 \\
\hline HTF 14 & 61462.00 & 71858.00 & 261.9 & 281.9 & 273.44 & 0.50 & 2.30 & 21 \\
\hline HTF 15 & 61353.00 & 71700.00 & 260.7 & 280.7 & 273.36 & 0.24 & 1.34 & 32 \\
\hline HTF 16 & 61950.00 & 72150.00 & 248.3 & 268.3 & 269.67 & 0.41 & 2.00 & 24 \\
\hline HTF 17 & 61188.00 & 72600.00 & 238.4 & 258.4 & 262.39 & 0.57 & 3.17 & 31 \\
\hline HTF 18 & 61223.30 & 71771.80 & 251.7 & 271.7 & 271.60 & 0.27 & 1.56 & 33 \\
\hline HTF 19 & 61079.20 & 71902.50 & 245.7 & 265.7 & 268.96 & 0.26 & 1.47 & 33 \\
\hline HTF 20 & 61086.40 & 72073.30 & 251.9 & 271.9 & 267.77 & 0.37 & 2.12 & 33 \\
\hline HTF 21 & 61261.00 & 71998.20 & 242.6 & 262.6 & 269.38 & 0.28 & 1.58 & 31 \\
\hline HTF 22 & 62553.60 & 71363.40 & 251.4 & 271.4 & 275.41 & 0.33 & 1.82 & 31 \\
\hline HTF 23 & 62670.30 & 71363.10 & 256.8 & 276.8 & 274.48 & 0.39 & 2.21 & 32 \\
\hline HTF 24 & 62775.60 & 71362.60 & 257.8 & 277.8 & 274.05 & 0.32 & 1.75 & 30 \\
\hline HTF 25 & 62902.00 & 71224.30 & 252.5 & 272.5 & 274.57 & 0.54 & 2.98 & 31 \\
\hline HTF 26 & 62815.70 & 71090.70 & 255.5 & 275.5 & 275.35 & 0.50 & 2.76 & 31 \\
\hline HTF 27 & 62660.30 & 71057.90 & 259.1 & 279.1 & 276.72 & 0.71 & 4.03 & 32 \\
\hline HTF 28 & 62515.70 & 71080.10 & 251.9 & 271.9 & 275.84 & 0.26 & 1.38 & 29 \\
\hline HTF 29 & 62414.90 & 71229.90 & 259.9 & 289.9 & 275.57 & 0.28 & 1.54 & 30 \\
\hline HTF 31 & 62662.50 & 70747.00 & 246.7 & 266.7 & 275.64 & 0.28 & 1.44 & 27 \\
\hline HTF 32 & 62807.90 & 70880.60 & 251.1 & 271.1 & 274.71 & 0.27 & 1.48 & 31 \\
\hline HTF 34 & 61978.50 & 71144.10 & 251.7 & 271.7 & 275.63 & 0.30 & 1.33 & 20 \\
\hline HWP 1D & 59852.50 & 72158.08 & 239.9 & 249.9 & 245.25 & 0.20 & 0.29 & 2 \\
\hline HWP 2D & 59918.86 & 72368.22 & 253.0 & 263.0 & 262.46 & 0.12 & 0.16 & 2 \\
\hline HWS $1 A$ & 50234.80 & 64885.10 & 225.2 & 255.2 & 244.81 & 0.38 & 1.95 & 27 \\
\hline HWS 2 & 50346.40 & 64786.30 & 215.3 & 245.3 & 245.40 & 0.41 & 2.10 & 27 \\
\hline HXB 1 & 52557.80 & 60549.70 & 214.2 & 244.2 & 251.40 & 0.56 & 2.85 & 26 \\
\hline $\mathrm{HXB} 2$ & 52892.80 & 60866.50 & 212.1 & 242.1 & 252.55 & 0.62 & 3.12 & 25 \\
\hline HXB 3 & 52707.30 & 60631.20 & 212.2 & 242.2 & 251.89 & 0.61 & 3.04 & 25 \\
\hline $\mathrm{HXB} \quad 40$ & 52617.30 & 60685.70 & 234.9 & 254.9 & 253.62 & 0.46 & 2.22 & 23 \\
\hline HXB 5D & 52510.40 & 60587.70 & 234.2 & 254.2 & 252.73 & 0.46 & 2.19 & 23 \\
\hline IDP $3 A$ & 37781.10 & 85104.30 & -86.7 & -81.3 & 167.02 & 0.24 & 1.02 & 18 \\
\hline IDP $3 B$ & 37785.30 & 85119.50 & 95.7 & 100.7 & 157.13 & 0.52 & 2.13 & 17 \\
\hline IDP $3 C$ & 37790.10 & 85133.70 & 164.1 & 169.1 & 201.89 & 0.92 & 3.70 & 16 \\
\hline IDP 30 & 37794.30 & 85148.40 & 208.8 & 228.8 & 209.08 & -1.00 & .1 .00 & 1 \\
\hline IDP 4 & 38615.40 & 82812.60 & 189.5 & 199.6 & 193.17 & 0.52 & 1.96 & 14 \\
\hline IDP 5 & 38284.50 & 83521.50 & 186.4 & 206.6 & 198.18 & 0.80 & 3.40 & 18 \\
\hline IDP 6 & 38248.50 & 84113.90 & 184.5 & 209.1 & 201.31 & 0.79 & 3.36 & 18 \\
\hline IDP 7 & 38713.90 & 84460.10 & 188.6 & 208.6 & 201.08 & 0.83 & 3.53 & 18 \\
\hline IDP 8 & 39174.30 & 84740.40 & 185.4 & 204.5 & 198.90 & 1.12 & 4.74 & 18 \\
\hline IDQ $3 A$ & 35854.00 & 80553.70 & -189.8 & -184.3 & 165.87 & 0.26 & 1.12 & 18 \\
\hline IDQ 3B & 35858.80 & 80578.40 & 108.4 & 113.4 & 139.94 & 1.40 & 6.09 & 19 \\
\hline IDQ 3C & 35863.50 & 80601.70 & 136.6 & 141.6 & 164.21 & 0.88 & 3.62 & 17 \\
\hline
\end{tabular}


Table F-1. Hydraulic Head Targets for Model Calibration (Continued)

\begin{tabular}{|c|c|c|c|c|c|c|c|c|}
\hline IDQ 4 & 36726.20 & 83125.10 & 185.6 & 205.6 & 198.18 & 0.77 & 3.25 & 18 \\
\hline IDQ 5 & 36851.80 & 82763.60 & 187.4 & 207.5 & 196.99 & 0.50 & 1.75 & 12 \\
\hline IDQ 6 & 37299.30 & 82414.40 & 181.9 & 202.1 & 193.62 & 0.71 & 3.08 & 19 \\
\hline IDQ 7 & 37836.30 & 82107.40 & 174.6 & 194.8 & 187.94 & 0.60 & 2.15 & 13 \\
\hline IDQ 8 & 34688.10 & 83602.80 & 180.4 & 200.4 & 189.25 & 0.35 & 1.05 & 9 \\
\hline IDQ 9 & 34053.40 & 82729.60 & 173.9 & 193.9 & 181.84 & 0.46 & 1.21 & 7 \\
\hline IDQ 10 & 33610.10 & 82135.80 & 165.7 & 185.7 & 174.03 & 0.45 & 1.63 & 13 \\
\hline IDQ 12 & 37116.50 & 81913.70 & 164.9 & 184.9 & 187.82 & 0.59 & 2.04 & 12 \\
\hline K 301AP & 40034.00 & 54284.00 & 193.3 & 197.7 & 208.77 & -1.00 & -1.00 & 1 \\
\hline K 301P & 39842.00 & 54320.00 & 194.4 & 201.0 & 204.90 & 0.32 & 1.94 & 36 \\
\hline KAB 1 & 39919.70 & 53055.60 & 194.0 & 224.0 & 205.94 & 0.60 & 3.10 & 27 \\
\hline KAB 2 & 40277.90 & 52410.80 & 198.6 & 228.6 & 209.89 & 0.87 & 4.61 & 28 \\
\hline KAB 3 & 39918.40 & 51807.70 & 193.0 & 223.0 & 204.06 & 0.68 & 3.42 & 25 \\
\hline KAB 4 & 39457.00 & 52807.10 & 187.0 & 217.0 & 203.15 & 0.69 & 3.53 & 26 \\
\hline KAC 1 & 42614.80 & 53167.00 & 199.0 & 229.0 & 219.27 & 0.50 & 2.81 & 32 \\
\hline KAC 2 & 42677.20 & 53255.50 & 195.4 & 225.4 & 221.51 & 0.56 & 3.12 & 31 \\
\hline KAC 3 & 42723.90 & 53201.80 & 195.8 & 225.8 & 221.96 & 0.47 & 2.68 & 32 \\
\hline KAC 4 & 42676.40 & 53053.50 & 178.0 & 208.0 & 218.07 & 0.47 & 2.65 & 32 \\
\hline KAC 5 & 42716.30 & 53161.70 & 204.3 & 224.3 & 222.40 & 0.44 & 2.39 & 29 \\
\hline KAC 6 & 42693.50 & 53139.90 & 204.6 & 224.6 & 222.34 & 0.46 & 2.45 & 28 \\
\hline KAC 7 & 42574.50 & 53252.90 & 203.0 & 223.0 & 219.45 & 0.42 & 2.29 & 30 \\
\hline KAC 8 & 42641.90 & 53136.00 & 192.3 & 212.3 & 221.18 & 0.52 & 2.02 & 15 \\
\hline KAC 9 & 42588.10 & 53197.80 & 195.7 & 215.7 & 220.84 & 0.49 & 1.89 & 15 \\
\hline $\mathrm{KBP} 2 \mathrm{D}$ & 40230.71 & 52063.71 & 184.3 & 194.3 & 203.35 & 0.05 & 0.06 & 2 \\
\hline KCB 1 & 39523.10 & 53453.00 & 183.6 & 213.6 & 204.62 & 0.49 & 2.79 & 32 \\
\hline KCB 2 & 39337.20 & 53634.40 & 187.7 & 217.7 & 202.81 & 0.71 & 3.98 & 31 \\
\hline KCB 3 & 39139.20 & 53440.50 & 184.1 & 214.1 & 202.20 & 0.43 & 2.48 & 33 \\
\hline KCB 4 & 39315.60 & 53256.10 & 188.9 & 218.9 & 205.48 & 0.75 & 2.70 & 13 \\
\hline KCB 5 & 39090.70 & 53353.70 & 189.3 & 209.3 & 200.43 & 0.58 & 1.54 & 7 \\
\hline KCB 6 & 39108.00 & 53559.20 & 188.7 & 208.7 & 200.97 & 0.71 & 1.73 & 6 \\
\hline KCB 7 & 39812.30 & 53435.60 & 196.5 & 216.5 & 205.33 & 0.60 & 1.68 & 8 \\
\hline KDB 1 & 40425.90 & 54050.50 & 184.8 & 205.8 & 208.11 & 0.23 & 1.72 & 55 \\
\hline KDB 2 & 40241.40 & 53907.30 & 182.5 & 203.5 & 206.73 & 0.25 & 1.85 & 55 \\
\hline KDB 3 & 40393.70 & 53794.60 & 184.2 & 205.4 & 207.52 & 0.23 & 1.79 & 59 \\
\hline KDB 4 & 40150.30 & 53787.40 & 189.2 & 209.2 & 206.50 & 0.23 & 0.99 & 18 \\
\hline KDB 5 & 40033.10 & 54052.20 & 188.5 & 208.5 & 204.89 & 0.29 & 1.64 & 31 \\
\hline KDT $1 D$ & 40380.00 & 54154.10 & 193.7 & 213.7 & 208.10 & 0.37 & 1.63 & 19 \\
\hline KRB 8 & 40302.10 & 54893.60 & 195.8 & 215.8 & 208.55 & 0.20 & 0.65 & 11 \\
\hline KRB 13 & 39986.60 & 55344.20 & 197.8 & 217.8 & 205.47 & 0.22 & 0.53 & 6 \\
\hline KRB 16D & 40390.30 & 54888.00 & 191.5 & 211.5 & 209.22 & 0.24 & 1.03 & 19 \\
\hline KRB 17D & 39991.90 & 55446.40 & 186.8 & 206.8 & 205.94 & 0.26 & 1.11 & 19 \\
\hline KRB 18D & 40084.90 & 55563.70 & 185.8 & 205.8 & 204.54 & 0.22 & 0.95 & 19 \\
\hline KRB 19D & 40207.40 & 55620.90 & 186.8 & 206.8 & 203.82 & 0.21 & 0.92 & 19 \\
\hline KRP 1 & 42471.20 & 54544.00 & 207.0 & 237.0 & 218.37 & 0.45 & 2.56 & 33 \\
\hline KRP 2 & 42681.60 & 54503.60 & 199.2 & 229.2 & 219.13 & 0.40 & 2.18 & 30 \\
\hline KRP 3 & 42814.30 & 54248.70 & 207.5 & 237.5 & 219.14 & 0.48 & 2.57 & 29 \\
\hline KRP 4 & 42590.30 & 54362.90 & 188.7 & 218.7 & 218.32 & 0.36 & 2.04 & 32 \\
\hline KRP 5 & 42181.80 & 54606.60 & 200.8 & 210.8 & 216.03 & 0.21 & 0.41 & 4 \\
\hline KRP 6 & 42226.90 & 54206.70 & 203.1 & 213.1 & 217.44 & 0.07 & 0.19 & 7 \\
\hline KRP 7 & 41871.70 & 54390.30 & 203.1 & 213.2 & 215.38 & 0.07 & 0.18 & 6 \\
\hline KRP 8 & 42280.42 & 54470.74 & 200.1 & 210.1 & 217.15 & -1.00 & -1.00 & 1 \\
\hline KRP $g$ & 42400.03 & 54360.10 & 200.8 & 210.8 & 218.40 & -1.00 & -1.00 & 1 \\
\hline KSB 1 & 39806.80 & 54044.40 & 175.6 & 205.6 & 204.05 & 0.29 & 2.12 & 52 \\
\hline KSB 2 & 39703.40 & 53927.60 & 173.8 & 203.8 & 203.81 & 0.30 & 2.21 & 55 \\
\hline KSB 3 & 39625.30 & 54040.20 & 169.7 & 199.7 & 203.05 & 0.30 & 2.22 & 54 \\
\hline KSB 4A & 39756.70 & 54140.40 & 169.6 & 199.6 & 203.16 & 0.51 & 3.68 & 51 \\
\hline KSB 5C & 39969.90 & 54165.60 & 172.9 & 182.9 & 204.88 & 0.06 & 0.10 & 3 \\
\hline KSB 5D & 39970.50 & 54156.50 & 194.5 & 214.5 & 204.54 & 0.37 & 0.98 & 7 \\
\hline
\end{tabular}


Table F-1. Hydraulic Head Targets for Model Calibration (Continued)

\begin{tabular}{|c|c|c|c|c|c|c|c|c|}
\hline KSM 1D & 40328.20 & 54188.00 & 193.7 & 213.7 & 208.14 & 0.22 & 1.18 & 28 \\
\hline KSS $1 D$ & 40219.10 & 47758.90 & 157.4 & 177.5 & 174.31 & 0.44 & 2.33 & 28 \\
\hline KSS 2D & 40437.00 & 46803.80 & 144.6 & 164.7 & 164.65 & 0.43 & 2.28 & 28 \\
\hline KSS 3D & 40748.00 & 46644.30 & 139.3 & 159.3 & 163.82 & 0.56 & 2.96 & 28 \\
\hline LAC 1 & 51318.80 & 45238.80 & 191.1 & 221.1 & 216.48 & 0.54 & 2.96 & 30 \\
\hline LAC 2 & 51270.20 & 45330.40 & 193.4 & 223.4 & 216.09 & 0.65 & 3.68 & 32 \\
\hline LAC 3 & 51186.80 & 45201.90 & 190.7 & 220.7 & 216.55 & 0.51 & 2.90 & 32 \\
\hline LAC 4 & 51270.40 & 45213.10 & 185.3 & 215.3 & 216.07 & 0.53 & 2.86 & 29 \\
\hline LAC 5DL & 51352.00 & 45365.40 & 176.2 & 186.2 & 219.74 & 0.89 & 2.18 & 6 \\
\hline LAC 5DU & 51348.60 & 45345.90 & 207.9 & 227.8 & 219.48 & 0.79 & 2.10 & 7 \\
\hline LAC 6DL & 51188.10 & 45272.80 & 175.9 & 185.9 & 217.89 & 0.90 & 2.21 & 6 \\
\hline LAC $6 D U$ & 51185.80 & 45252.50 & 201.7 & 221.7 & 218.97 & 0.93 & 2.27 & 6 \\
\hline LAC 7DL & 51118.40 & 45097.10 & 177.4 & 187.4 & 215.11 & 0.93 & 2.29 & 6 \\
\hline LAC 7DU & 51120.10 & 45114.70 & 204.9 & 224.8 & 218.06 & 0.97 & 2.38 & 6 \\
\hline LAC 8DL & 51300.90 & 45096.60 & 180.4 & 190.4 & 217.45 & 0.87 & 2.12 & 6 \\
\hline LAC 8DU & 51301.80 & 45116.00 & 199.8 & 219.8 & 218.07 & 0.93 & 2.29 & 6 \\
\hline LAW 1C & 50603.60 & 44562.40 & -34.0 & -29.0 & 176.21 & 0.29 & 0.64 & 5 \\
\hline LAW 10 & 50595.60 & 44562.00 & 6.6 & 11.6 & 176.50 & 0.17 & 0.55 & 10 \\
\hline LAW 1E & 50579.00 & 44561.20 & 90.1 & 95.1 & 205.04 & 0.59 & 1.33 & 5 \\
\hline LAW IF & 50567.10 & 44562.10 & 165.9 & 185.9 & 203.89 & 0.96 & 2.87 & 9 \\
\hline LAW 2B & 49635.50 & 45641.00 & -9.8 & -4.8 & 176.23 & 0.17 & 0.52 & 10 \\
\hline LAW $2 \mathrm{C}$ & 49638.70 & 45610.90 & 171.2 & 191.2 & 209.21 & 0.43 & 2.41 & 32 \\
\hline LAW 3B & 52269.50 & 45600.70 & -1.0 & 4.0 & 178.20 & 0.17 & 0.55 & 10 \\
\hline LAW 3C & 52272.90 & 45616.10 & 194.9 & 214.9 & 235.20 & 0.58 & 2.01 & 12 \\
\hline LBP 10 & 53508.08 & 48716.40 & 246.3 & 256.3 & 257.11 & 0.06 & 0.13 & 4 \\
\hline LBP $2 D$ & 53476.51 & 48924.92 & 241.9 & 251.9 & 256.15 & 0.16 & 0.22 & 2 \\
\hline LBP 3D & 53007.66 & 48912.68 & 242.8 & 252.8 & 256.60 & 0.10 & 0.17 & 3 \\
\hline LCO 1 & 50957.70 & 45198.20 & 195.8 & 225.8 & 214.76 & 0.60 & 3.35 & 31 \\
\hline LCO 2 & 51043.40 & 45317.80 & 196.6 & 226.6 & 215.14 & 0.58 & 3.30 & 32 \\
\hline $\operatorname{LCO} 3$ & 51113.20 & 45203.00 & 196.3 & 226.3 & 229.09 & 0.51 & 2.81 & 30 \\
\hline $\operatorname{LCO} 4$ & 51036.10 & 45087.40 & 192.3 & 222.3 & 212.57 & 0.61 & 3.52 & 33 \\
\hline LCO $5 A$ & 50866.00 & 44987.00 & 30.0 & 40.0 & 177.24 & 0.28 & 0.68 & 6 \\
\hline LCO 5C & 50881.80 & 44988.50 & 110.5 & 120.5 & 210.99 & 0.60 & 1.48 & 6 \\
\hline LCO 5DL & 50887.50 & 44974.50 & 174.9 & 184.9 & 212.95 & 0.86 & 2.10 & 6 \\
\hline LCO 6DL & 50921.20 & 45069.30 & 178.0 & 188.0 & 213.67 & 0.83 & 2.02 & 6 \\
\hline LCO 7DL & 51055.90 & 44946.90 & 170.2 & 180.2 & 213.31 & 0.83 & 2.03 & 6 \\
\hline LCO 8DL & 51380.60 & 45586.10 & 178.4 & 188.4 & 220.55 & 0.83 & 2.04 & 6 \\
\hline LCO 8DU & 51361.70 & 45586.10 & 211.1 & 226.1 & 220.60 & 0.84 & 2.05 & 6 \\
\hline LDB 1 & 50590.50 & 45886.50 & 185.0 & 215.0 & 216.92 & 0.40 & 2.87 & 51 \\
\hline LDB 2 & 50784.60 & 46007.40 & 184.5 & 214.5 & 218.97 & 0.38 & 2.76 & 53 \\
\hline LDB 3 & 50525.80 & 46068.90 & 199.3 & 219.3 & 218.46 & 0.42 & 2.35 & 31 \\
\hline LDB 4 & 50339.50 & 45809.00 & 200.7 & 220.7 & 216.50 & 0.46 & . 2.50 & 30 \\
\hline LFW 6 & 45241.20 & 84537.80 & 141.1 & 160.4 & 154.07 & 0.34 & 1.93 & 32 \\
\hline LFW $6 \mathrm{R}$ & 45194.00 & 84413.90 & 134.5 & 154.5 & 153.64 & 0.41 & 1.16 & 8 \\
\hline LFW 7 & 45318.90 & 84310.30 & 140.5 & 159.8 & 152.01 & 0.23 & 1.20 & 27 \\
\hline LFW 8 & 45415.30 & 84032.60 & 139.9 & 159.2 & 150.03 & 0.21 & 1.22 & 34 \\
\hline LFW 8R & 45414.60 & 83949.00 & 135.1 & 155.1 & 149.78 & 0.32 & 0.90 & 8 \\
\hline LFW 10A & 45935.60 & 84369.60 & 129.2 & 159.2 & 151.27 & 0.41 & 2.55 & 39 \\
\hline LFW 16 & 45852.60 & 84748.90 & 131.2 & 161.2 & 155.54 & 0.29 & 1.63 & 31 \\
\hline LFW 17 & 45607.30 & 84602.80 & 128.5 & 158.5 & 153.88 & 0.49 & 2.74 & 32 \\
\hline LFW 18 & 45459.40 & 84577.30 & 130.1 & 160.1 & 153.05 & 0.58 & 3.56 & 37 \\
\hline LFW 19 & 45135.40 & 84817.20 & 130.0 & 160.0 & 156.16 & 0.29 & 1.67 & 33 \\
\hline LFW 20 & 45582.90 & 85262.60 & 135.0 & 165.0 & 158.98 & 0.33 & 1.85 & 32 \\
\hline LFW 21 & 46149.40 & 84178.30 & 128.9 & 158.9 & 148.75 & 0.59 & 3.65 & 38 \\
\hline LFW 22 & 46325.20 & 84223.60 & 122.4 & 152.4 & 151.34 & 0.30 & 1.75 & 34 \\
\hline LFW 23 & 46456.10 & 84251.30 & 125.1 & 155.1 & 151.34 & 0.67 & 3.86 & 33 \\
\hline LFW 23R & 46512.90 & 84206.10 & 118.4 & 138.4 & 149.12 & 1.14 & 3.03 & 7 \\
\hline LFW 24 & 46520.80 & 84544.20 & 124.5 & 154.5 & 154.38 & 0.36 & 2.04 & 33 \\
\hline LFW 25 & 46425.70 & 84967.20 & 123.2 & 153.2 & 156.78 & 0.35 & 2.03 & 33 \\
\hline
\end{tabular}


Table F-1. Hydraulic Head Targets for Model Calibration (Continued)

\begin{tabular}{|c|c|c|c|c|c|c|c|c|}
\hline LFW 26 & 45633.80 & 85654.60 & 143.2 & 164.2 & 161.19 & 0.33 & 1.88 & 32 \\
\hline LFW 27 & 45596.10 & 85839.10 & 142.9 & 163.9 & 162.11 & 0.33 & 1.91 & 33 \\
\hline LFW 28 & 45555.30 & 86079.60 & 141.1 & 162.1 & 163.48 & 0.31 & 1.95 & 39 \\
\hline LFW 29 & 45503.30 & 86372.70 & 143.9 & 164.9 & 164.72 & 0.36 & 2.07 & 33 \\
\hline LFW 30 & 45170.90 & 86318.40 & 141.7 & 162.7 & 164.80 & 0.35 & 2.09 & 35 \\
\hline LFW 31 & 44869.00 & 86262.20 & 145.0 & 166.0 & 164.64 & 0.40 & 2.62 & 42 \\
\hline LFW 32 & 44935.90 & 85836.80 & 144.3 & 165.3 & 162.31 & 0.28 & 1.77 & 40 \\
\hline LFW $32 \mathrm{C}$ & 44923.00 & 85837.80 & 98.6 & 113.6 & 160.85 & -1.00 & -1.00 & 1 \\
\hline LFW 33 & 44973.00 & 85633.80 & 144.4 & 165.4 & 161.01 & 0.31 & 1.84 & 35 \\
\hline LFW 34 & 45016.90 & 85409.50 & 143.7 & 164.7 & 159.85 & 0.28 & 1.73 & 37 \\
\hline LFW 35 & 45378.80 & 85237.40 & 143.4 & 164.4 & 158.79 & 0.31 & 1.76 & 33 \\
\hline LFW 36 & 45582.30 & 83535.50 & 130.3 & 151.3 & 145.93 & 0.20 & 1.19 & 35 \\
\hline LFW $36 R$ & 45519.10 & 83537.30 & 122.0 & 142.0 & 146.13 & 0.30 & 0.91 & 9 \\
\hline LFW 37 & 45667.70 & 83113.20 & 129.8 & 150.8 & 142.84 & 0.17 & 0.98 & 35 \\
\hline LFW 38 & 46018.50 & 83172.30 & 130.5 & 151.5 & 143.44 & 0.33 & 1.81 & 30 \\
\hline LFW 39 & 46218.50 & 83213.10 & 131.2 & 152.2 & 143.63 & 0.33 & 1.83 & 30 \\
\hline LFW 40 & 46395.10 & 83248.80 & 131.2 & 152.2 & 143.54 & 0.32 & 1.68 & 28 \\
\hline LFW 41 & 46626.90 & 83304.90 & 130.3 & 151.3 & 145.21 & 0.44 & 2.57 & 34 \\
\hline LFW 42 & 46532.90 & 83776.20 & 130.2 & 151.2 & 147.51 & 0.49 & 2.67 & 30 \\
\hline LFW 43B & 45240.50 & 86459.20 & 90.4 & 100.4 & 165.85 & 0.21 & 1.15 & 30 \\
\hline LFW $43 \mathrm{C}$ & 45234.90 & 86480.60 & 128.5 & 138.5 & 166.02 & 0.20 & 1.09 & 30 \\
\hline LFW 43D & 45244.50 & 86443.20 & 150.9 & 170.9 & 166.57 & 0.27 & 1.47 & 30 \\
\hline LFW 44D & 45022.60 & 84524.40 & 139.5 & 159.3 & 155.33 & 0.15 & 0.67 & 19 \\
\hline LFW 45D & 45142.00 & 84217.80 & 134.7 & 154.7 & 152.58 & 0.16 & 0.83 & 28 \\
\hline LFW 46D & 45162.80 & 84054.00 & 137.3 & 157.1 & 151.48 & 0.14 & 0.62 & 19 \\
\hline LFW 46D & 45162.80 & 84054.00 & 109.5 & 119.6 & 151.48 & 0.14 & 0.62 & 19 \\
\hline LFW $47 \mathrm{C}$ & 45161.60 & 83823.30 & 105.7 & 115.8 & 148.91 & 0.11 & 0.46 & 19 \\
\hline LFW 47D & 45150.80 & 83838.60 & 134.9 & 154.7 & 149.43 & 0.11 & 0.61 & 29 \\
\hline LFW 48C & 45413.30 & 83856.40 & 108.2 & 118.2 & 148.96 & 0.15 & 0.66 & 20 \\
\hline LFW 48D & 45426.70 & 83856.90 & 134.9 & 155.0 & 149.42 & 0.13 & 0.61 & 21 \\
\hline LFW 55C & 45205.90 & 83613.20 & 94.1 & 104.1 & 146.97 & 0.09 & 0.40 & 19 \\
\hline LFW 55D & 45189.30 & 83601.30 & 121.2 & 141.4 & 147.10 & 0.09 & 0.41 & 19 \\
\hline LFW 56D & 45306.60 & 83398.00 & 131.3 & 151.4 & 145.50 & 0.09 & 0.48 & 29 \\
\hline LFW 57B & 45440.60 & 83196.70 & 68.4 & 78.4 & 143.76 & 0.09 & 0.40 & 21 \\
\hline LFW 57C & 45411.10 & 83200.10 & 107.8 & 117.9 & 143.94 & 0.08 & 0.38 & 21 \\
\hline LFW 57D & 45417.40 & 83190.20 & 130.6 & 150.4 & 143.96 & 0.08 & 0.39 & 21 \\
\hline LFW 58D & 45700.20 & 82940.60 & 127.5 & 147.6 & 141.99 & 0.10 & 0.55 & 28 \\
\hline LFW 59B & 46047.40 & 83027.10 & 66.0 & 76.0 & 142.81 & 0.12 & 0.53 & 21 \\
\hline LFW 59C & 46052.00 & 83011.00 & 100.3 & 110.3 & 142.62 & 0.16 & 0.62 & 16 \\
\hline LFW 59D & 46056.10 & 83000.10 & 129.3 & 149.3 & 142.68 & 0.44 & 2.31 & 28 \\
\hline LFW $60 \mathrm{~B}$ & 45710.20 & 82517.50 & 67.7 & 77.7 & 137.86 & 0.07 & 0.21 & 10 \\
\hline LFW $60 \mathrm{C}$ & 45711.90 & 82529.60 & 98.3 & 108.3 & 138.31 & 0.35 & 1.56 & 20 \\
\hline LFW 60D & 45722.30 & 82531.50 & 123.8 & 143.8 & 138.22 & 0.08 & 0.45 & 32 \\
\hline LFW 61C & 46489.60 & 83084.40 & 111.0 & 121.1 & 142.09 & 0.17 & 0.80 & 21 \\
\hline LFW 610 & 46471.10 & 83089.10 & 130.3 & 150.4 & 144.12 & 0.29 & 1.44 & 24 \\
\hline LFW 628 & 45915.50 & 83001.20 & 62.8 & 72.8 & 142.30 & 0.10 & 0.44 & 21 \\
\hline LFW $62 C$ & 45906.70 & 83012.70 & 108.4 & 118.4 & 142.74 & 0.14 & 0.61 & 19 \\
\hline LFW 62D & 45922.90 & 82991.60 & 127.6 & 147.6 & 143.42 & 0.22 & 1.05 & 22 \\
\hline LFW 63B & 45550.70 & 82740.80 & 66.1 & 76.1 & 140.17 & 0.08 & 0.35 & 20 \\
\hline LFW $63 C$ & 45559.20 & 82746.10 & 96.2 & 106.2 & 140.19 & 0.09 & 0.41 & 19 \\
\hline LFW $63 D$ & 45569.10 & 82751.80 & 126.4 & 146.4 & 140.56 & 0.15 & 0.67 & 20 \\
\hline LFW 64B & 45268.80 & 82736.40 & 51.9 & 61.9 & 140.04 & 0.07 & 0.24 & 11 \\
\hline LFW $64 \mathrm{C}$ & 45271.30 & 82744.80 & 83.0 & 93.0 & 140.33 & 0.20 & 0.90 & 20 \\
\hline LFW 64D & 45280.70 & 82737.80 & 115.2 & 135.2 & 140.34 & 0.06 & 0.29 & 21 \\
\hline LFW $65 B$ & 46061.80 & 82589.20 & 53.5 & 63.5 & 137.91 & 0.07 & 0.31 & 18 \\
\hline LFW $65 \mathrm{C}$ & 46064.40 & 82592.90 & 86.1 & 96.1 & 137.90 & 0.10 & 0.44 & 19 \\
\hline LFW 65D & 46071.80 & 82598.40 & 111.5 & 131.5 & 138.38 & 0.20 & 0.91 & 21 \\
\hline LFW 66B & 46195.90 & 82838.30 & 70.3 & 80.3 & 140.70 & 0.15 & 0.37 & 6 \\
\hline
\end{tabular}


Table F-1. Hydraulic Head Targets for Model Calibration (Continued)

\begin{tabular}{|c|c|c|c|c|c|c|c|c|}
\hline LFW 66C & 46186.00 & 82836.50 & 100.0 & 110.0 & 140.72 & 0.43 & 1.22 & 8 \\
\hline LFW 66D & 46173.70 & 82835.10 & 121.8 & 141.8 & 141.90 & 0.26 & 1.01 & 15 \\
\hline LFW $67 \mathrm{~B}$ & 46517.10 & 82847.10 & 55.6 & 65.6 & 139.07 & 0.12 & 0.51 & 19 \\
\hline LFW 67C & 46527.50 & 82844.20 & 86.1 & 96.1 & 138.71 & 0.20 & 0.79 & 15 \\
\hline LFW 67D & 46529.90 & 82855.00 & 120.6 & 140.6 & 141.98 & 0.36 & 1.60 & 20 \\
\hline LFW 68B & 46885.30 & 83023.30 & 56.7 & 66.7 & 140.21 & 0.15 & 0.47 & 10 \\
\hline LFW 68C & 46876.20 & 83027.50 & 88.3 & 98.3 & 139.61 & 0.22 & 0.71 & 10 \\
\hline LFW 68D & 46868.00 & 83031.60 & 124.6 & 144.6 & 142.64 & 0.38 & 1.70 & 20 \\
\hline LFW 69B & 45492.00 & 82451.20 & 52.0 & 57.0 & 137.56 & 0.06 & 0.18 & 10 \\
\hline LFW $69 \mathrm{C}$ & 45494.50 & 82458.60 & 79.1 & 89.1 & 137.75 & 0.07 & 0.31 & 19 \\
\hline LFW 69D & 45501.00 & 82452.00 & 119.0 & 139.0 & 137.84 & 0.07 & 0.34 & 20 \\
\hline LFW 70B & 45825.50 & 82300.50 & 61.5 & 66.5 & 136.20 & 0.07 & 0.22 & 10 \\
\hline LFW 70C & 45833.40 & 82309.00 & 78.8 & 88.8 & 136.23 & 0.06 & 0.20 & 10 \\
\hline LFW 70D & 45839.80 & 82316.30 & 118.3 & 138.3 & 135.67 & 0.12 & 0.37 & 10 \\
\hline LFW 71B & 46340.40 & 82616.70 & 57.0 & 67.0 & 137.74 & 0.11 & 0.47 & 20 \\
\hline LFW 71C & 46329.80 & 82615.80 & 80.4 & 90.4 & 137.90 & 0.09 & 0.40 & 20 \\
\hline LFW 71D & 46319.80 & 82615.10 & 115.5 & 135.5 & 137.38 & 0.15 & 0.68 & 19 \\
\hline LFW 72B & 46944.30 & 82872.10 & 50.9 & 60.9 & 138.08 & 0.16 & 0.54 & 11 \\
\hline LFW 72C & 46937.10 & 82875.80 & 87.8 & 97.8 & 137.63 & 0.24 & 0.76 & 10 \\
\hline LFW $72 D$ & 46943.00 & 82881.50 & 120.0 & 140.0 & 138.74 & 0.27 & 0.87 & 10 \\
\hline LFW 74C & 45097.80 & 85813.80 & 101.0 & 116.0 & 163.04 & 0.27 & 0.73 & 7 \\
\hline LFW 74D & 45098.00 & 85828.10 & 152.7 & 167.7 & 162.91 & 0.21 & 0.70 & 11 \\
\hline LFW 75C & 45357.00 & 85856.80 & 100.6 & 115.6 & 162.61 & 0.31 & 0.93 & 9 \\
\hline LFW 75D & 45355.60 & 85868.00 & 151.0 & 166.0 & 162.92 & 0.34 & 1.01 & 9 \\
\hline LRP 1 & 49128.70 & 48548.60 & 185.8 & 215.8 & 209.13 & 0.57 & 3.08 & 29 \\
\hline LRP 2 & 49214.40 & 48352.90 & 184.7 & 214.7 & 209.61 & 0.94 & 5.04 & 29 \\
\hline LRP 3 & 49057.70 & 48333.60 & 191.4 & 221.4 & 209.45 & 0.55 & 3.06 & 31 \\
\hline LRP 4 & 48964.70 & 48440.20 & 173.3 & 203.3 & 208.59 & 0.54 & 3.02 & 31 \\
\hline LSB 1 & 50700.90 & 45153.10 & 192.7 & 222.7 & 211.61 & 0.48 & 2.91 & 37 \\
\hline LSB 2 & 50824.50 & 45224.00 & 195.0 & 225.0 & 212.39 & 0.51 & 3.02 & 35 \\
\hline LSB 3 & 50729.70 & 45388.70 & 196.6 & 226.6 & 217.16 & 0.51 & 3.15 & 38 \\
\hline LSB 4 & 50513.00 & 45321.60 & 191.5 & 221.5 & 216.84 & 0.74 & 4.53 & 38 \\
\hline MGA 36 & 57891.50 & 73904.00 & 234.2 & 254.2 & 237.38 & 0.33 & 0.80 & 6 \\
\hline MGC 9 & 55610.70 & 75372.10 & 217.3 & 237.3 & 229.44 & 0.30 & 1.51 & 25 \\
\hline MGC 11 & 55770.70 & 75252.30 & 219.2 & 239.2 & 230.70 & 0.58 & 1.00 & 3 \\
\hline MGC 19 & 56408.70 & 74770.10 & 230.6 & 234.6 & 232.01 & 0.38 & 1.92 & 25 \\
\hline MGC 32 & 57448.80 & 73982.10 & 232.0 & 252.0 & 244.87 & 0.30 & 1.42 & 23 \\
\hline MGC 36 & 57776.00 & 73738.90 & 234.4 & 254.4 & 235.82 & 0.34 & 1.67 & 24 \\
\hline MGE 9 & 55489.40 & 75215.10 & 218.1 & 238.1 & 228.78 & 0.23 & 0.97 & 17 \\
\hline MGE 21 & 56446.20 & 74487.80 & 227.9 & 247.9 & 234.00 & 0.47 & 1.64 & 12 \\
\hline MGE 30 & 57175.40 & 73935.80 & 229.3 & 249.3 & 235.74 & 0.66 & 3.11 & 22 \\
\hline MGE 34 & 57495.10 & 73695.00 & 237.2 & 257.2 & 238.08 & 0.48 & 1.43 & 9 \\
\hline MGG 15 & 55851.50 & 74699.00 & 223.3 & 243.3 & 232.50 & 1.11 & 2.93 & 7 \\
\hline MGG 19 & 56174.30 & 74456.00 & 226.0 & 246.0 & 232.35 & 0.70 & 2.44 & 12 \\
\hline MGG 23 & 56491.80 & 74214.00 & 227.1 & 247.1 & 235.00 & 0.38 & 1.32 & 12 \\
\hline MGG 28 & 56895.40 & 73905.00 & 230.3 & 250.3 & 235.31 & 0.34 & 1.03 & 9 \\
\hline MGG 36 & 57541.70 & 73413.00 & 232.5 & 252.5 & 237.48 & 0.42 & 1.75 & 17 \\
\hline NBG 1 & 53879.30 & 79300.40 & 200.9 & 232.3 & 224.47 & 0.18 & 1.06 & 35 \\
\hline NBG 2 & 53958.40 & 79099.80 & 203.6 & 233.6 & 224.96 & 0.18 & 1.06 & 34 \\
\hline NBG 3 & 54068.10 & 78939.60 & 202.1 & 233.5 & 217.54 & 0.36 & 2.08 & 33 \\
\hline NBG 4 & 54329.20 & 78942.10 & 196.1 & 227.5 & 217.05 & 0.31 & 1.80 & 34 \\
\hline NBG 5 & 54515.60 & 78943.40 & 194.9 & 226.4 & 217.77 & 0.35 & 2.06 & 34 \\
\hline NPM 1 & 56851.60 & 62153.40 & 257.1 & 277.1 & 287.08 & 0.67 & 1.77 & 7 \\
\hline NPM 2 & 58252.00 & 63056.80 & 244.2 & 264.2 & 271.63 & 0.72 & 2.27 & 10 \\
\hline NPM 3 & 55417.60 & 62109.20 & 247.2 & 267.2 & 274.40 & 0.59 & 1.86 & 10 \\
\hline NPM 4 & 57215.00 & 60883.20 & 256.7 & 276.7 & 284.24 & 0.68 & 2.05 & 9 \\
\hline NPM 19A & 57551.80 & 62970.70 & 248.2 & 268.2 & 270.59 & 0.71 & 2.24 & 10 \\
\hline NPM 19B & 57558.30 & 62981.80 & 217.7 & 227.7 & 268.72 & 0.70 & 2.22 & 10 \\
\hline NPM 19C & 57575.40 & 62977.10 & 193.5 & 203.5 & 267.70 & 0.68 & 2.25 & 11 \\
\hline
\end{tabular}


Table F-1. Hydraulic Head Targets for Model Calibration (Continued)

\begin{tabular}{|c|c|c|c|c|c|c|c|c|}
\hline NPM 19D & 57567.90 & 62960.90 & 97.5 & 107.5 & 243.14 & 0.45 & 1.42 & 10 \\
\hline NPM 19E & 57582.60 & 62991.70 & 33.9 & 43.9 & 188.42 & 1.01 & 3.20 & 10 \\
\hline NPM $34 A$ & 56301.20 & 60774.50 & 279.8 & 289.8 & 290.62 & 0.67 & 2.11 & 10 \\
\hline NPM $34 B$ & 56315.10 & 60768.90 & 225.6 & 235.6 & 271.02 & 0.51 & 1.62 & 10 \\
\hline NPM $34 C$ & 56329.10 & 60764.20 & 181.8 & 191.8 & 267.58 & 0.51 & 1.60 & 10 \\
\hline NPM 340 & 56354.90 & 60752.00 & 86.4 & 96.4 & 253.73 & 0.50 & 1.59 & 10 \\
\hline NPM $34 E$ & 56342.80 & 60758.80 & 33.1 & 43.1 & 187.04 & 0.18 & 0.58 & 10 \\
\hline PAC 1 & 66753.40 & 43543.30 & 253.9 & 283.9 & 284.74 & 0.22 & 1.27 & 32 \\
\hline PAC 2 & 66980.90 & 43527.70 & 247.9 & 277.9 & 271.02 & 0.29 & 1.64 & 31 \\
\hline PAC 3 & 66861.40 & 43585.60 & 252.9 & 282.9 & 271.35 & 0.38 & 2.15 & 32 \\
\hline PAC 4 & 66863.20 & 43495.40 & 250.6 & 280.6 & 284.42 & 0.17 & 0.92 & 31 \\
\hline PAC 5 & 66907.10 & 43561.70 & 255.1 & 275.1 & 275.05 & 0.48 & 2.56 & 29 \\
\hline PAC 6 & 66894.70 & 43580.10 & 255.2 & 275.2 & 274.58 & 0.38 & 2.02 & 28 \\
\hline PBP 10 & 65727.60 & 45611.30 & 269.1 & 279.1 & 280.30 & 0.00 & 0.00 & 2 \\
\hline PBP 2D & 65359.88 & 45481.46 & 262.8 & 272.8 & 278.37 & 1.02 & 1.45 & 2 \\
\hline PBP 3D & 65510.20 & 45603.52 & 268.9 & 278.9 & 279.85 & 0.05 & 0.07 & 2 \\
\hline PCB 1A & 65070.60 & 41988.20 & 263.5 & 293.5 & 280.73 & 0.52 & 2.75 & 28 \\
\hline PCB 2A & 64891.40 & 41821.40 & 257.8 & 287.8 & 279.51 & 0.51 & 2.70 & 28 \\
\hline PCB $3 A$ & 64706.30 & 42036.00 & 262.7 & 292.7 & 281.56 & 0.51 & 2.86 & 31 \\
\hline PCB 4A & 64901.40 & 42171.00 & 262.9 & 292.9 & 279.70 & 0.48 & 2.61 & 29 \\
\hline PDB 2 & 64743.10 & 43513.10 & 247.7 & 268.7 & 277.85 & 0.39 & 2.36 & 36 \\
\hline PDB 3 & 64938.20 & 43542.20 & 248.1 & 269.1 & 278.07 & 0.39 & 2.32 & 35 \\
\hline PDB 4 & 64623.80 & 43455.10 & 266.2 & 286.2 & 278.92 & 0.44 & 1.44 & 11 \\
\hline PDB 5 & 64584.40 & 44106.60 & 264.2 & 284.2 & 277.70 & 0.39 & 1.28 & 11 \\
\hline PRP 1A & 63032.70 & 45349.80 & 232.9 & 262.9 & 249.09 & 0.42 & 2.31 & 30 \\
\hline PRP 2 & 63229.00 & 45389.50 & 234.1 & 264.1 & 255.53 & 0.88 & 4.84 & 30 \\
\hline PRP 3 & 63165.50 & 45200.70 & 228.6 & 258.6 & 255.38 & 0.67 & 3.59 & 29 \\
\hline PRP 4 & 63345.90 & 45268.90 & 232.9 & 262.9 & 257.61 & 0.47 & 2.61 & 31 \\
\hline PSB 1A & 64141.40 & 43619.30 & 257.4 & 287.4 & 276.46 & 0.42 & 2.65 & 39 \\
\hline PSB 2A & 63916.50 & 43612.40 & 257.2 & 287.2 & 276.32 & 0.44 & 2.77 & 39 \\
\hline PSB $3 A$ & 63590.40 & 43599.80 & 256.5 & 286.5 & 275.15 & 0.46 & 2.89 & 39 \\
\hline PSB 4A & 63347.00 & 43534.20 & 255.5 & 285.5 & 274.28 & 0.51 & 3.20 & 39 \\
\hline PSB $5 A$ & 63606.50 & 43440.50 & 262.3 & 292.3 & 275.68 & 0.48 & 3.05 & 40 \\
\hline PSB $6 A$ & 63975.70 & 43436.00 & 262.1 & 292.1 & 277.17 & 0.45 & 2.80 & 38 \\
\hline PSB 7A & 64301.00 & 43553.30 & 259.0 & 289.0 & 276.94 & 0.41 & 2.53 & 39 \\
\hline PSS $1 D$ & 75773.30 & 37298.40 & 182.1 & 202.1 & 198.17 & 0.71 & 3.76 & 28 \\
\hline PSS 2D & 75910.10 & 36037.90 & 177.1 & 197.1 & 195.23 & 0.69 & 3.59 & 27 \\
\hline PSS 3D & 76138.70 & 35974.10 & 178.5 & 198.5 & 197.97 & 0.90 & 3.12 & 12 \\
\hline PW 83N & 52202.00 & 61394.00 & 4.0 & 9.0 & 168.43 & -1.00 & -1.00 & 1 \\
\hline RAC 1 & 74570.70 & 55107.30 & 247.3 & 277.3 & 273.93 & 0.38 & 1.95 & 27 \\
\hline RAC 2 & 74555.50 & 55026.30 & 243.4 & 273.4 & 272.62 & 0.26 & 1.31 & 26 \\
\hline RAC 3 & 74667.50 & 55015.30 & 242.3 & 272.3 & 272.37 & 0.30 & 1.56 & 27 \\
\hline RAC 4 & 74588.80 & 54984.00 & 238.2 & 268.2 & 271.64 & 0.33 & 1.71 & 27 \\
\hline RBW $1 C L$ & 74227.40 & 62038.50 & 105.5 & 115.5 & 255.93 & 0.37 & 0.64 & 3 \\
\hline RBW $1 C U$ & 74214.00 & 62047.40 & 156.1 & 166.1 & 255.80 & 0.40 & 0.69 & 3 \\
\hline RBW 1D & 74237.50 & 62031.60 & 243.0 & 263.1 & 259.01 & 0.45 & 0.78 & 3 \\
\hline RBW $2 C L$ & 71795.10 & 58712.00 & 96.4 & 106.4 & 269.44 & 0.53 & 0.91 & 3 \\
\hline RBW $2 \mathrm{CU}$ & 71785.90 & 58715.40 & 145.1 & 155.1 & 269.85 & 0.57 & 0.99 & 3 \\
\hline RBW $2 D$ & 71776.70 & 58719.90 & 284.9 & 304.9 & 297.55 & 0.72 & 1.25 & 3 \\
\hline RCP 1A & 74238.30 & 56968.10 & 46.8 & 56.8 & 194.20 & 0.23 & 0.69 & 9 \\
\hline RCP 1D & 74223.50 & 56967.90 & 261.3 & 281.3 & 281.78 & 0.64 & 2.20 & 12 \\
\hline RDB $1 D$ & 74844.50 & 57097.30 & 265.5 & 285.5 & 286.08 & 0.26 & 1.29 & 25 \\
\hline RDB 2D & 74782.20 & 56879.80 & 265.7 & 285.7 & 285.22 & 0.22 & 1.09 & 24 \\
\hline RDB 3D & 74899.00 & 56881.90 & 265.8 & 285.8 & 283.06 & 0.32 & 1.59 & 25 \\
\hline $\mathrm{RPC} 1 \mathrm{CL}$ & 74261.86 & 57923.24 & 103.3 & 113.3 & 256.90 & 0.17 & 0.30 & 3 \\
\hline RPC 1D & 74215.65 & 57931.26 & 264.5 & 284.5 & 276.77 & 0.16 & 0.28 & 3 \\
\hline RPC 7DL & 74726.38 & 58812.32 & 209.9 & 219.9 & 274.90 & 0.67 & 0.95 & 2 \\
\hline RPC 7DU & 74720.18 & 58803.87 & 240.8 & 277.8 & 275.68 & 0.57 & 0.81 & 2 \\
\hline
\end{tabular}


Table F-1. Hydraulic Head Targets for Model Calibration (Continued)

\begin{tabular}{|c|c|c|c|c|c|c|c|c|}
\hline RPC 8DL & 74671.66 & 58276.90 & 204.1 & 214.1 & 278.92 & 0.92 & 1.29 & 2 \\
\hline RPC 8DU & 74664.76 & 58279.13 & 273.0 & 288.0 & 290.58 & 1.11 & 1.56 & 2 \\
\hline RPC 9DL & 74507.87 & 57908.37 & 216.4 & 226.4 & 279.10 & 0.70 & 0.99 & 2 \\
\hline RPC 9DU & 74507.71 & 57898.35 & 268.3 & 283.3 & 280.96 & 0.54 & 0.76 & 2 \\
\hline RPC 10DL & 74551.49 & 57380.20 & 200.5 & 210.5 & 280.56 & 0.87 & 1.22 & 2 \\
\hline RPC 10DU & 74540.11 & 57380.29 & 272.5 & 287.4 & 290.42 & 0.10 & 0.14 & 2 \\
\hline RPC 11DL & 75240.08 & 57380.02 & 180.2 & 190.2 & 278.49 & 0.54 & 0.76 & 2 \\
\hline RPC 11DU & 75250.01 & 57380.43 & 271.2 & 286.2 & 289.45 & 0.00 & 0.01 & 2 \\
\hline RRP 1 & 75634.60 & 54563.50 & 242.4 & 272.4 & 265.67 & 0.64 & 3.35 & 27 \\
\hline RRP 2 & 75829.80 & 54468.30 & 242.5 & 272.5 & 264.47 & 0.66 & 3.37 & 26 \\
\hline RRP 3 & 75853.00 & 54303.00 & 238.1 & 268.1 & 264.51 & 0.72 & 3.84 & 28 \\
\hline RRP 4 & 75723.30 & 54294.50 & 238.3 & 268.3 & 263.90 & 0.67 & 3.48 & 27 \\
\hline RSB 7 & 75044.30 & 57692.80 & 272.7 & 292.6 & 285.76 & 0.81 & 4.28 & 28 \\
\hline RSB 8 & 75178.20 & 57612.90 & 274.3 & 294.3 & 287.79 & 0.88 & 4.21 & 23 \\
\hline RSC 2 & 74378.60 & 58543.00 & 261.9 & 281.9 & 278.28 & 0.73 & 3.42 & 22 \\
\hline RSC 3 & 74699.70 & 58724.70 & 258.6 & 278.6 & 276.60 & 0.93 & 4.35 & 22 \\
\hline $\mathrm{RSC} 9$ & 74565.30 & 59241.20 & 251.6 & 271.6 & 271.79 & 0.79 & 3.63 & 21 \\
\hline RSD 1 & 75035.10 & 57440.80 & 267.9 & 287.7 & 286.45 & 0.60 & 3.32 & 31 \\
\hline RSD 3 & 74702.30 & 57451.60 & 269.3 & 289.1 & 286.76 & 0.74 & 4.10 & 31 \\
\hline RSD 4 & 75154.60 & 57441.40 & 270.6 & 290.6 & 288.43 & 0.53 & 2.75 & 27 \\
\hline RSD 5 & 75207.00 & 57439.90 & 269.6 & 289.6 & 287.07 & 0.56 & 2.89 & 27 \\
\hline RSD 6 & 75256.60 & 57441.30 & 270.1 & 290.1 & 286.97 & 0.48 & 2.49 & 27 \\
\hline RSD 7 & 75178.40 & 57394.30 & 267.3 & 287.3 & 285.13 & 0.46 & 2.46 & 28 \\
\hline RSD 8 & 75229.60 & 57394.00 & 267.3 & 287.3 & 285.43 & 0.45 & 2.33 & 27 \\
\hline RSD 9 & 75185.90 & 57245.60 & 251.7 & 271.7 & 283.71 & 0.35 & 1.75 & 25 \\
\hline RSE $1 A$ & 74712.70 & 57734.50 & 274.8 & 294.8 & 288.53 & 0.77 & 4.49 & 34 \\
\hline RSE $1 \mathrm{~B}$ & 74698.10 & 57731.40 & 275.7 & 295.7 & 288.84 & 0.99 & 5.32 & 29 \\
\hline RSE $1 \mathrm{C}$ & 74684.10 & 57730.80 & 268.5 & 288.5 & 288.72 & 1.11 & 5.88 & 28 \\
\hline RSE 2 & 74743.50 & 57594.90 & 269.7 & 289.5 & 286.39 & 1.08 & 5.60 & 27 \\
\hline RSE $3 A$ & 74931.20 & 57445.80 & 268.2 & 288.0 & 285.20 & 0.75 & 4.03 & 29 \\
\hline RSE 4A & 75101.10 & 57528.40 & 260.6 & 270.6 & 286.51 & 0.65 & 3.44 & 28 \\
\hline RSE 7 & 74783.70 & 58481.50 & 266.5 & 286.3 & 280.80 & 0.86 & 4.79 & 31 \\
\hline RSE 8 & 74869.40 & 58538.80 & 271.2 & 291.0 & 284.00 & 1.32 & 6.99 & 28 \\
\hline RSE 9 & 74971.10 & 58463.30 & 266.7 & 286.7 & 279.23 & 0.77 & 4.15 & 29 \\
\hline RSE 10 & 74848.30 & 58420.70 & 270.7 & 290.5 & 281.52 & 1.16 & 5.93 & 26 \\
\hline RSE 11 & 74787.70 & 58357.60 & 262.1 & 272.1 & 282.54 & 1.36 & 6.94 & 26 \\
\hline RSE 12 & 74842.30 & 58318.20 & 259.1 & 269.1 & 276.09 & 0.40 & 1.31 & 11 \\
\hline RSE 18 & 74839.50 & 58247.20 & 268.1 & 288.1 & 279.50 & 0.76 & 3.87 & 26 \\
\hline RSE 19 & 74791.20 & 58318.40 & 262.5 & 282.5 & 280.66 & 1.15 & 5.88 & 26 \\
\hline RSE 24 & 74638.90 & 57370.40 & 237.6 & 257.6 & 279.63 & 0.57 & 3.00 & 28 \\
\hline RSE 25 & 74544.50 & 55824.50 & 237.5 & 257.5 & 275.41 & 0.47 & 2.56 & 29 \\
\hline RSF 1 & 74869.40 & 58505.30 & 228.8 & 238.8 & 277.64 & 0.68 & 3.66 & 29 \\
\hline RSF 2 & 74628.60 & 57670.40 & 224.8 & 235.3 & 278.38 & 0.60 & 3.25 & 29 \\
\hline RSF 3 & 75206.70 & 57621.40 & 229.8 & 239.8 & 279.63 & 0.64 & 3.39 & 28 \\
\hline RSP 10 & 74426.80 & 56879.40 & 274.7 & 289.7 & 289.71 & 1.19 & 1.68 & 2 \\
\hline RSP 2D & 75568.60 & 55947.10 & 260.3 & 280.3 & 278.40 & -1.00 & -1.00 & 1 \\
\hline SBG 1 & 63749.10 & 74619.40 & 190.7 & 220.7 & 237.86 & 0.30 & 1.53 & 26 \\
\hline SBG 2 & 64939.60 & 74570.20 & 205.9 & 235.9 & 237.79 & 0.33 & 1.76 & 28 \\
\hline SBG 3 & 65265.60 & 73699.90 & 206.6 & 236.6 & 237.52 & 0.37 & 1.99 & 29 \\
\hline SBG 4 & 65010.20 & 72399.80 & 185.6 & 215.6 & 240.93 & 0.27 & 1.37 & 26 \\
\hline SBG 5 & 64499.00 & 72208.30 & 199.4 & 219.4 & 249.31 & 0.30 & 1.52 & 25 \\
\hline SBG 6 & 63860.00 & 73599.30 & 208.1 & 238.1 & 244.49 & 0.33 & 1.73 & 28 \\
\hline SCA 2 & 64697.10 & 73850.60 & 215.9 & 245.9 & 242.16 & 0.36 & 1.58 & 19 \\
\hline SCA 3 & 64571.20 & 73959.30 & 220.3 & 240.3 & 241.30 & 0.33 & 1.06 & 10 \\
\hline SCA $3 A$ & 64571.20 & 73965.00 & 267.1 & 277.1 & 271.08 & 0.48 & 1.94 & 16 \\
\hline SCA 4 & 64563.50 & 73856.50 & 220.4 & 240.4 & 241.53 & 0.37 & 1.48 & 16 \\
\hline SCA $4 A$ & 64567.20 & 73855.20 & 265.3 & 275.3 & 268.78 & 0.42 & 1.47 & 12 \\
\hline SCA 5 & 64630.80 & 74092.90 & 223.7 & 243.7 & 241.33 & 0.25 & 1.02 & 17 \\
\hline SCA 6 & 64637.50 & 73706.20 & 221.3 & 241.1 & 241.98 & 0.26 & 1.03 & 16 \\
\hline
\end{tabular}


Table F-1. Hydraulic Head Targets for Model Calibration (Continued)

\begin{tabular}{|c|c|c|c|c|c|c|c|c|}
\hline SLP 1 & 64449.10 & 72958.40 & 228.0 & 248.0 & 245.10 & 0.34 & 1.82 & 28 \\
\hline SLP 2 & 64529.70 & 72863.40 & 217.7 & 237.7 & 244.72 & 0.30 & 1.58 & 28 \\
\hline TBG 1 & 17134.70 & 71429.50 & 89.1 & 109.1 & 100.58 & 0.20 & 1.38 & 46 \\
\hline TBG 3 & 17177.70 & 71324.10 & 88.9 & 108.9 & 103.11 & 0.27 & 1.70 & 40 \\
\hline TBG 4 & 17177.70 & 71267.10 & 89.3 & 109.3 & 103.07 & 0.27 & 1.62 & 35 \\
\hline TBG 5 & 17354.50 & 71226.50 & 92.4 & 112.4 & 102.65 & 0.35 & 2.02 & 34 \\
\hline TBG 5A & 17348.80 & 71206.80 & 70.0 & 80.0 & 103.90 & 0.28 & 1.67 & 36 \\
\hline TBG 5B & 17354.80 & 71216.80 & 46.2 & 56.2 & 113.25 & 0.45 & 2.79 & 38 \\
\hline TBG 6 & 17290.50 & 71482.30 & 89.1 & 109.1 & 102.65 & 0.25 & 1.50 & 37 \\
\hline TBG 7 & 17548.10 & 71298.50 & 84.7 & 104.7 & 105.45 & 0.33 & 2.09 & 40 \\
\hline TIR 1L & 16169.25 & 71019.05 & 65.7 & 67.7 & 93.17 & 0.31 & 0.97 & 10 \\
\hline TIR 1M & 16170.12 & 71024.12 & 84.6 & 86.6 & 93.87 & 0.79 & 2.36 & 9 \\
\hline TIR $1 U$ & 16170.93 & 71028.98 & 90.0 & 92.0 & 93.23 & 0.25 & 0.75 & 9 \\
\hline TIR 2 & 16096.27 & 71068.64 & 84.2 & 86.2 & 92.41 & 0.27 & 0.82 & 9 \\
\hline TIR 3B & 16522.86 & 71099.07 & 83.5 & 85.5 & 95.75 & 0.34 & 1.09 & 10 \\
\hline TNX 1D & 16699.60 & 71613.50 & 79.6 & 99.6 & 99.45 & 0.15 & 0.92 & 38 \\
\hline TNX 2D & 16788.20 & 71452.00 & 82.8 & 102.8 & 99.29 & 0.16 & 0.99 & 38 \\
\hline TNX 3D & 17043.10 & 71236.70 & 84.9 & 104.9 & 99.78 & 0.19 & 1.24 & 43 \\
\hline TNX 4D & 17223.00 & 71002.70 & 85.5 & 105.5 & 103.13 & 0.31 & 2.01 & 43 \\
\hline TNX 5D & 17363.70 & 70995.30 & 88.5 & 108.5 & 104.96 & 0.32 & 1.98 & 38 \\
\hline TNX 6D & 17428.70 & 70717.60 & 89.8 & 109.8 & 105.32 & 0.34 & 2.08 & 38 \\
\hline TNX 7D & 17080.60 & 71738.10 & 83.6 & 103.6 & 101.19 & 0.16 & 1.06 & 43 \\
\hline TNX 8D & 16168.30 & 70591.90 & 74.0 & 94.0 & 94.04 & 0.17 & 1.05 & 38 \\
\hline TNX 9D & 16145.80 & 70791.40 & 75.4 & 95.4 & 93.82 & 0.15 & 1.02 & 45 \\
\hline TNX 10D & 16166.70 & 70999.30 & 77.0 & 97.0 & 94.12 & 0.18 & 1.07 & 37 \\
\hline TNX 11D & 16165.50 & 71199.30 & 73.2 & 93.2 & 94.12 & 0.16 & 1.02 & 39 \\
\hline TNX 12D & 16176.30 & 71598.30 & 73.1 & 93.1 & 94.99 & 0.12 & 0.72 & 38 \\
\hline TNX 13D & 15938.80 & 70842.00 & 87.9 & 89.9 & 92.03 & 0.25 & 0.55 & 5 \\
\hline TNX 14D & 15971.10 & 70931.80 & 85.8 & 87.8 & 92.12 & 0.08 & 0.16 & 4 \\
\hline TNX 15D & 16002.10 & 71021.10 & 85.9 & 87.9 & 91.73 & 0.55 & 1.65 & 9 \\
\hline TNX 16D & 16012.20 & 71111.30 & 86.1 & 88.1 & 91.45 & 0.44 & 1.39 & 10 \\
\hline TNX 17D & 16047.40 & 71583.80 & 89.7 & 91.7 & 93.31 & 0.17 & 0.39 & 5 \\
\hline TNX 18D & 15898.00 & 70748.20 & 84.9 & 86.9 & 91.70 & 0.15 & 0.31 & 4 \\
\hline TNX 19D & 15848.40 & 70626.70 & 84.9 & 86.9 & 91.46 & 0.54 & 1.21 & 5 \\
\hline TNX 20D & 15826.10 & 70579.00 & 86.2 & 88.2 & 91.52 & 0.59 & 1.32 & 5 \\
\hline TNX 21D & 15833.50 & 70446.80 & 86.9 & 88.9 & 91.82 & 0.54 & 1.22 & 5 \\
\hline TNX 22D & 15757.70 & 70184.70 & 85.8 & 87.8 & 90.16 & 0.40 & 0.89 & 5 \\
\hline TNX 23D & 16927.00 & 71414.50 & 84.8 & 104.8 & 99.34 & 0.57 & 1.39 & 6 \\
\hline TNX 24D & 17534.60 & 71536.90 & 99.8 & 114.8 & 108.99 & 0.20 & 0.55 & 8 \\
\hline TNX 26D & 16251.00 & 70424.40 & 87.8 & 90.1 & 94.24 & 0.38 & 1.21 & 10 \\
\hline TNX 270 & 16609.14 & 71180.09 & 81.3 & 101.3 & 96.39 & 0.40 & 1.20 & 9 \\
\hline TRW 1 & 16947.00 & 71162.80 & 81.4 & 106.4 & 93.43 & 1.21 & 4.02 & 11 \\
\hline TRW 2 & 16803.80 & 71259.60 & 77.2 & 112.2 & 93.96 & 1.22 & 3.45 & 8 \\
\hline XSB 1 & 16901.00 & 71133.10 & 92.0 & 112.0 & 102.82 & 0.47 & 0.66 & 2 \\
\hline XSB $1 \mathrm{~A}$ & 16883.00 & 71105.40 & 43.6 & 53.6 & 98.70 & 0.21 & 1.23 & 36 \\
\hline XSB 1B & 16872.90 & 71105.00 & 64.6 & 74.6 & 102.71 & 0.35 & 2.10 & 37 \\
\hline XSB 10 & 16893.50 & 71104.80 & 87.9 & 107.9 & 99.00 & 0.27 & 1.77 & 42 \\
\hline XSB 2D & 16823.10 & 71086.00 & 84.0 & 104.0 & 98.54 & 0.18 & 1.22 & 45 \\
\hline XSB $3 A$ & 16901.30 & 70915.30 & 87.4 & 103.2 & 99.80 & 0.19 & 1.20 & 39 \\
\hline XSB 4 & 16851.10 & 71024.50 & 94.3 & 114.3 & 98.27 & 0.36 & 0.63 & 3 \\
\hline XSB 4D & 16826.20 & 70997.90 & 83.9 & 103.9 & 98.61 & 0.20 & 1.27 & 42 \\
\hline YSB $1 \mathrm{~A}$ & 17808.80 & 71162.20 & 98.4 & 128.4 & 118.28 & 0.77 & 5.05 & 43 \\
\hline YSB 2A & 17850.20 & 71010.00 & 97.7 & 127.7 & 119.20 & 0.74 & 4.85 & 43 \\
\hline YSB $3 A$ & 17755.20 & 70859.00 & 96.7 & 126.7 & 119.40 & 0.40 & 2.65 & 44 \\
\hline YSB 4A & 17739.80 & 71020.70 & 97.6 & 127.6 & 118.08 & 0.71 & 4.64 & 43 \\
\hline YSC $1 \mathrm{~A}$ & 65438.90 & 78039.90 & 76.8 & 136.9 & 163.03 & 0.57 & 1.28 & 5 \\
\hline YSC $1 \mathrm{C}$ & 65855.50 & 78186.20 & 197.5 & 207.5 & 217.37 & 0.75 & 2.98 & 16 \\
\hline YSC 10 & 65859.10 & 78170.70 & 216.8 & 236.8 & 221.34 & 0.26 & 0.37 & 2 \\
\hline
\end{tabular}


Table F-1. Hydraulic Head Targets for Model Calibration (Continued)

\begin{tabular}{|c|c|c|c|c|c|c|c|c|}
\hline YSC $2 A$ & 66100.10 & 78311.50 & 134.7 & 144.7 & 162.89 & 0.20 & 0.79 & 16 \\
\hline YSC 2D & 66130.70 & 78320.40 & 197.9 & 218.0 & 216.15 & 0.55 & 2.35 & 18 \\
\hline YSC $4 C$ & 65901.90 & 77059.70 & 195.9 & 205.9 & 227.53 & 0.62 & 2.47 & 16 \\
\hline YSC $5 \mathrm{~A}$ & 67134.90 & 74295.90 & 116.0 & 121.0 & 180.77 & 1.13 & 4.52 & 16 \\
\hline$Z 2$ & 53181.60 & 74785.30 & 214.0 & 214.5 & 218.74 & 0.38 & 1.27 & 11 \\
\hline Z 3 & 51328.30 & 75086.20 & 206.6 & 207.1 & 212.57 & 0.71 & 2.02 & 8 \\
\hline 28 & 51584.90 & 76640.50 & 213.6 & 214.1 & 218.90 & 0.60 & 2.08 & 12 \\
\hline Z 9 & 50570.50 & 77732.00 & 207.5 & 227.5 & 214.89 & 0.42 & 2.08 & 25 \\
\hline 212 & 61400.90 & 71198.90 & 251.3 & 251.8 & 274.33 & 0.22 & 0.53 & 6 \\
\hline 213 & 62203.60 & 70785.80 & 256.6 & 257.1 & 275.24 & 0.80 & 2.65 & 11 \\
\hline 215 & 63419.20 & 72802.10 & 253.8 & 254.3 & 263.72 & 0.26 & 0.63 & 6 \\
\hline Z 17 & 43797.80 & 72260.90 & 148.2 & 148.7 & 169.17 & 0.31 & 1.03 & 11 \\
\hline Z 18 & 43774.10 & 73077.20 & 159.9 & 160.4 & 184.23 & 0.63 & 2.09 & 11 \\
\hline 220 & 43722.40 & 74080.70 & 173.4 & 193.4 & 184.74 & 0.36 & 0.80 & 5 \\
\hline$Z 20 B$ & 43721.00 & 74085.00 & 175.6 & 195.6 & 190.67 & 1.09 & 3.09 & 8 \\
\hline ZBG 1 & 65584.10 & 76584.20 & 220.0 & 240.1 & 234.05 & 0.50 & 3.04 & 37 \\
\hline ZBG $1 A$ & 65598.80 & 76588.50 & 276.0 & 281.0 & 279.89 & 1.22 & 4.22 & 12 \\
\hline ZBG 2 & 67472.90 & 76170.50 & 210.9 & 230.9 & 221.73 & 0.39 & 2.42 & 38 \\
\hline ZDT 1 & 65114.80 & 71644.40 & 227.0 & 247.0 & 239.89 & 0.16 & 0.92 & 32 \\
\hline ZDT 2 & 65059.90 & 71696.50 & 225.1 & 245.1 & 241.42 & 0.18 & 1.01 & 32 \\
\hline ZW 2 & 54388.70 & 80701.50 & 194.8 & 204.8 & 207.07 & 0.57 & 2.34 & 17 \\
\hline $\mathrm{ZW} 3$ & 57078.20 & 80746.50 & 194.6 & 205.1 & 200.66 & 0.46 & 1.89 & 17 \\
\hline ZW 4 & 56556.90 & 77667.40 & 229.2 & 239.7 & 232.21 & 0.51 & 2.10 & 17 \\
\hline ZW 5 & 54708.60 & 75767.40 & 221.0 & 231.0 & 227.26 & 0.27 & 1.25 & 21 \\
\hline$Z W 6$ & 52030.80 & 76166.00 & 216.7 & 227.2 & 220.19 & 0.85 & 3.30 & 15 \\
\hline ZW 7 & 60300.70 & 72399.50 & 254.5 & 264.8 & 265.83 & 0.39 & 1.55 & 16 \\
\hline$Z W 8$ & 63801.50 & 70800.80 & 254.1 & 264.1 & 270.85 & 0.21 & 0.91 & 18 \\
\hline$Z W \quad 9$ & 61400.30 & 73198.40 & 242.4 & 252.4 & 251.97 & 0.45 & 1.93 & 18 \\
\hline ZW 10 & 63401.00 & 73212.40 & 242.2 & 252.2 & 249.72 & 0.86 & 4.13 & 23 \\
\hline CMP 10C & 53994.30 & 51402.70 & 179.6 & 189.6 & 198.53 & -1.00 & -1.00 & 1 \\
\hline CMP 10D & 53994.30 & 51392.50 & 209.6 & 229.6 & 229.84 & -1.00 & -1.00 & 1 \\
\hline CMP 11D & 53647.00 & 51467.90 & 209.5 & 229.9 & 223.34 & -1.00 & -1.00 & 1 \\
\hline CMP 14D & 52589.50 & 52363.50 & 204.1 & 224.5 & 217.43 & -1.00 & -1.00 & 1 \\
\hline CMP 15C & 52907.80 & 51361.40 & 220.6 & 250.6 & 244.53 & -1.00 & -1.00 & 1 \\
\hline CMP 30B & 53166.90 & 51729.80 & 97.4 & 107.5 & 195.00 & -1.00 & -1.00 & 1 \\
\hline CMP $30 \mathrm{C}$ & 53208.20 & 51718.40 & 179.5 & 189.5 & 210.55 & .1 .00 & -1.00 & 1 \\
\hline CMP $30 D$ & 53202.90 & 51709.70 & 211.6 & 231.6 & 227.97 & -1.00 & -1.00 & 1 \\
\hline CMP $31 \mathrm{C}$ & 53255.70 & 52389.70 & 197.9 & 207.9 & 210.78 & -1.00 & -1.00 & 1 \\
\hline CMP 32B & 54052.80 & 52220.00 & 97.7 & 107.7 & 195.31 & .1 .00 & .1 .00 & 1 \\
\hline CMP $32 C$ & 54061.10 & 52214.60 & 185.2 & 195.2 & 195.44 & -1.00 & -1.00 & 1 \\
\hline CMP 32D & 54069.20 & 52209.20 & 218.6 & 228.6 & 220.77 & -1.00 & -1.00 & 1 \\
\hline NPM 2 & 58252.00 & 63056.80 & 244.2 & 264.2 & 267.00 & -1.00 & -1.00 & 1 \\
\hline NPM 3 & 55417.60 & 62109.20 & 247.2 & 267.2 & 267.60 & -1.00 & -1.00 & 1 \\
\hline NPM 4 & 57215.00 & 60883.20 & 256.7 & 276.7 & 272.70 & -1.00 & -1.00 & 1 \\
\hline NPN 1 & 70879.60 & 66661.40 & 257.3 & 277.4 & 277.50 & -1.00 & -1.00 & 1 \\
\hline NPN 2 & 72541.50 & 67394.10 & 257.9 & 278.0 & 273.50 & -1.00 & -1.00 & 1 \\
\hline NPN 3 & 70029.20 & 67989.80 & 260.0 & 280.1 & 276.70 & -1.00 & -1.00 & 1 \\
\hline NPN 4 & 71021.80 & 65357.20 & 265.4 & 285.5 & 278.50 & -1.00 & -1.00 & 1 \\
\hline NTN 1 & 45562.30 & 56993.70 & 212.4 & 232.4 & 233.70 & -1.00 & -1.00 & 1 \\
\hline NTN 2 & 46735.10 & 57935.50 & 207.2 & 227.2 & 235.20 & -1.00 & -1.00 & 1 \\
\hline NTS 1 & 43893.90 & 46082.00 & 164.3 & 184.4 & 180.40 & -1.00 & -1.00 & 1 \\
\hline NTS 2 & 45825.20 & 46262.60 & 174.7 & 194.8 & 192.30 & -1.00 & -1.00 & 1 \\
\hline NTW 1 & 40257.70 & 48776.50 & 168.9 & 188.8 & 183.60 & -1.00 & -1.00 & 1 \\
\hline NTW 2 & 39353.20 & 49309.30 & 171.5 & 191.5 & 183.90 & -1.00 & -1.00 & 1 \\
\hline NTW 3 & 41208.70 & 50040.00 & 176.7 & 196.6 & 191.80 & -1.00 & -1.00 & 1 \\
\hline NTW 4 & 41678.20 & 48636.30 & 166.0 & 185.8 & 180.40 & -1.00 & -1.00 & 1 \\
\hline P $13 A$ & 60000.00 & 35600.00 & -67.3 & -57.4 & 173.07 & 0.17 & 1.24 & 56 \\
\hline$P \quad 138$ & 60000.00 & 35600.00 & -7.2 & 3.0 & 175.65 & 0.22 & 1.64 & 56 \\
\hline$P \quad 15 A$ & 51376.30 & 46755.30 & -97.0 & -87.0 & 176.77 & 0.23 & 1.63 & 51 \\
\hline
\end{tabular}


Table F-1. Hydraulic Head Targets for Model Calibration (Continued)

\begin{tabular}{|c|c|c|c|c|c|c|c|c|}
\hline$P \quad 18 \mathrm{~A}$ & 47688.10 & 67592.80 & 12.0 & 22.0 & 168.48 & 0.16 & 1.27 & 6 \\
\hline P $18 B$ & 47680.90 & 67578.90 & 67.0 & 77.0 & 169.01 & 0.16 & 1.30 & 6 \\
\hline$P \quad 19 A$ & 60031.30 & 55347.10 & -36.7 & -26.7 & 186.83 & -1.00 & 1.60 & -1 \\
\hline$P 21 B$ & 40757.60 & 24641.80 & -82.2 & -72.2 & 134.01 & 0.16 & 1.29 & 6 \\
\hline$P 23 A$ & 30914.50 & 48114.90 & .38 .8 & -28.8 & 146.11 & 0.17 & 1.44 & 6 \\
\hline$P 23 B$ & 30925.30 & 48101.20 & 41.5 & 46.5 & 137.85 & 0.19 & 1.58 & 6 \\
\hline$P 24 A$ & 66569.70 & 43142.20 & -1.9 & 8.9 & 191.47 & -1.00 & 1.00 & -1 \\
\hline$P 25 B$ & 42241.90 & 52521.40 & 80.6 & 90.6 & 178.24 & 0.65 & 5.17 & 6 \\
\hline$P 26 A$ & 18055.90 & 72010.40 & 22.0 & 32.0 & 117.48 & 0.33 & 2.73 & 6 \\
\hline P $27 \mathrm{~B}$ & 64000.30 & 70405.90 & 74.8 & 94.8 & 179.76 & 0.15 & 1.18 & 6 \\
\hline
\end{tabular}




\section{Hydraulic Head Residuals}

The complete contents of the FACT code observation well file are listed in Table F-2. FACT does not compute a hydraulic head for wells outside of the saturated zone and model domain (model area). Wells outside the model area are denoted by a simulated head of " 0.0 " in Table F-2. The associated (large negative) residual is meaningless, and ignored in the calculation of summary statistics.

Table F-2. Summary of Group Statistical Parameters

Group Statistics for Steady-state Analysis Only overall rms hydraulic head difference:

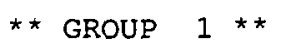

\begin{tabular}{|c|c|c|}
\hline 50 & $3 \mathrm{~A}$ & 62 \\
\hline BGO & $6 \mathrm{~A}$ & 57379.75 \\
\hline " BGO & $8 \mathrm{~A} "$ & 56713.52 \\
\hline " BGO & 8AR" & 56718.93 \\
\hline " BGO & 9AA" & 56557.06 \\
\hline " BGO & 10AA" & 56188.61 \\
\hline " BGO & 10AR" & 56220.41 \\
\hline " BGO & 12AR" & 55433.62 \\
\hline "BGO & $12 \mathrm{AX} "$ & 55438.21 \\
\hline " BGO & $14 \mathrm{~A} "$ & 54932.60 \\
\hline "BGO & I 4AR" & 54878.94 \\
\hline " BGO & $16 \mathrm{~A} "$ & 55151.72 \\
\hline " BGO & 16AR" & 55171.25 \\
\hline " BGO & $18 \mathrm{~A} "$ & 55613.51 \\
\hline " BGO & $20 A "$ & 55873.74 \\
\hline " BGO & $25 \mathrm{~A} "$ & 54720.59 \\
\hline " BGO & $26 \mathrm{~A} "$ & 54078.09 \\
\hline " BGO & $29 A^{\prime \prime}$ & 53065.74 \\
\hline " BGO & $39 A "$ & 56289.81 \\
\hline "BGO & $41 \mathrm{~A} "$ & 54526.63 \\
\hline "BGO & $43 A^{\prime \prime}$ & 55480.82 \\
\hline " BGO & 43AA" & 55496.65 \\
\hline " BGO & $44 \mathrm{~A} "$ & 56980.04 \\
\hline " BGO & 44AA" & 57009.08 \\
\hline " BGO & $47 A "$ & 53685.72 \\
\hline " BGO & $49 A "$ & 54776.87 \\
\hline " BGO & $50 \mathrm{~A} "$ & 53065.78 \\
\hline " BGO & $51 A^{\prime \prime}$ & 56425.66 \\
\hline "BGO & $52 \mathrm{~A} "$ & 55886.11 \\
\hline "BGO & $52 \mathrm{AA}^{\prime \prime}$ & 55881.46 \\
\hline "BGO & $53 A "$ & 54463.49 \\
\hline " BGO & 53AA." & 54469.72 \\
\hline "BGX & $1 \mathrm{~A} "$ & 57719.04 \\
\hline$B G X$ & $4 A "$ & 56592.03 \\
\hline CMP & $8 \mathrm{~A} "$ & 48469.95 \\
\hline CMP & $12 \mathrm{~A} "$ & 47590.53 \\
\hline " CMP & 15A" & 46853.37 \\
\hline
\end{tabular}

55791.31 56798.46 57023.70

57053.02 57472.74 57573.76

57370.81 57535.80 57566.51 57206.47 57191.60 56525.53 56507.27 56266.77 55563.80 57027.64 57150.00 56767.52 54051.04 57386.82 57789.12 57790.46 57157.41 57153.08 55785.97 54709.58 56400.69 54594.46 55219.91 55226.42 56992.63 56985.38 57078.74 58389.00 34344.23 33793.03 33344.49

$\begin{array}{rrr}103.7 & 113.7 & 162.9 \\ 107.5 & 117.5 & 159.2 \\ 105.3 & 115.3 & 161.0 \\ 94.6 & 104.6 & 160.8 \\ 73.8 & 83.8 & 157.9 \\ 80.8 & 90.8 & 157.4 \\ 96.5 & 106.5 & 158.4 \\ 99.3 & 109.3 & 157.8 \\ 99.5 & 109.5 & 157.2 \\ 109.6 & 119.6 & 158.0 \\ 96.8 & 106.8 & 159.3 \\ 102.5 & 112.5 & 161.0 \\ 103.7 & 113.7 & 160.9 \\ 99.5 & 109.5 & 161.0 \\ 86.3 & 96.3 & 163.6 \\ 104.1 & 114.1 & 160.6 \\ 81.0 & 91.0 & 160.9 \\ 102.5 & 112.5 & 159.5 \\ 84.8 & 94.8 & 167.5 \\ 103.3 & 113.3 & 158.3 \\ 105.9 & 115.9 & 158.8 \\ 62.2 & 72.2 & 156.7 \\ 98.0 & 108.0 & 158.4 \\ 61.2 & 71.3 & 158.7 \\ 86.8 & 96.8 & 162.3 \\ 75.1 & 85.1 & 167.2 \\ 90.5 & 100.5 & 160.1 \\ 75.1 & 85.1 & 165.9 \\ 81.7 & 91.7 & 163.7 \\ 36.6 & 46.6 & 162.9 \\ 78.7 & 88.7 & 158.9 \\ 38.9 & 48.9 & 155.6 \\ 114.1 & 124.1 & 158.8 \\ 106.8 & 116.8 & 155.1 \\ 13.7 & 23.5 & 182.9 \\ 22.1 & 32.1 & 181.6 \\ 14.2 & 24.2 & 180.6 \\ & & \end{array}$

5.64

3.389

$-1.271$

2.009

$-18.142$

$\begin{array}{llr}162.9 & 162.7 & -0.2 \\ 159.2 & 159.2 & 0.0 \\ 161.0 & 158.4 & -2.6 \\ 160.8 & 158.3 & -2.5 \\ 157.9 & 156.9 & -1.0 \\ 157.4 & 156.6 & -0.8 \\ 158.4 & 157.2 & -1.2 \\ 157.8 & 156.7 & -1.1 \\ 157.2 & 156.6 & -0.6 \\ 158.0 & 157.6 & -0.4 \\ 159.3 & 157.6 & -1.7 \\ 161.0 & 159.6 & -1.4 \\ 160.9 & 159.6 & -1.3 \\ 161.0 & 160.5 & -0.5 \\ 163.6 & 162.7 & -0.9 \\ 160.6 & 158.0 & -2.6 \\ 160.9 & 157.3 & -3.6 \\ 159.5 & 157.6 & -1.9 \\ 167.5 & 167.3 & -0.2 \\ 158.3 & 156.9 & -1.4 \\ 158.8 & 155.9 & -2.9 \\ 156.7 & 155.9 & -0.8 \\ 158.4 & 157.9 & -0.5 \\ 158.7 & 157.9 & -0.8 \\ 162.3 & 160.6 & -1.7 \\ 167.2 & 164.2 & -3.0 \\ 160.1 & 158.5 & -1.6 \\ 165.9 & 165.9 & 0.0 \\ 163.7 & 163.7 & 0.0 \\ 162.9 & 163.6 & 0.7 \\ 158.9 & 158.0 & -0.9 \\ 155.6 & 157.9 & 2.3 \\ 158.8 & 158.2 & -0.6 \\ 155.1 & 153.5 & -1.6 \\ 182.9 & 184.7 & 1.8 \\ 181.6 & 183.6 & 2.0 \\ 180.6 & 182.5 & 1.9\end{array}$


Table F-2. Summary of Group Statistical Parameters (Continued)

\begin{tabular}{|c|c|c|c|c|c|c|c|c|}
\hline "DCB & $20 \mathrm{D}$ & 17380.30 & 52486.69 & 46.2 & 48.7 & 114.0 & 109.5 & -4.5 \\
\hline " DCB & $23 D$ & 16894.13 & 52535.54 & 49.1 & 51.6 & 111.2 & 108.3 & -2.9 \\
\hline "FC & $1 \mathrm{~A}$ & 52952.32 & 60987.82 & 96.7 & 101.7 & 143.5 & 144.6 & 1.1 \\
\hline "FC & $3 B$ & 57173.69 & 59132.82 & 61.2 & 66.2 & 150.6 & 150.3 & -0.3 \\
\hline "FC & $3 c$ & 57182.65 & 59131.22 & 121.0 & 126.0 & 151.8 & 150.4 & -1.4 \\
\hline "FC & $4 B$ & 54258.68 & 63352.39 & 76.1 & 81.1 & 141.0 & 137.7 & -3.3 \\
\hline "FC & $4 \mathrm{C}$ & 54264.51 & 63357.69 & 116.3 & 121.3 & 137.6 & 138.2 & 0.5 \\
\hline "FIW & 2MA & 50287.63 & 57737.11 & 100.5 & 110.5 & 151.5 & 151.3 & -0.2 \\
\hline "FNB & $1 \mathrm{~A}$ & 54202.25 & 61223.09 & 107.9 & 117.9 & 144.3 & 144.5 & 0.2 \\
\hline "FNB & $2 \mathrm{~A}$ & 54330.20 & 61502.80 & 111.1 & 121.1 & 143.6 & 143.7 & 0.1 \\
\hline "FNB & $3 \mathrm{~A}$ & 54117.53 & 61652.79 & 109.2 & 119.2 & 143.1 & 143.2 & 0.1 \\
\hline "FSB & $76 \mathrm{~A}$ & 50532.01 & 57890.76 & 36.9 & 47.4 & 155.1 & 151.1 & -4.0 \\
\hline "FSB & $76 \mathrm{~B}$ & 50532.38 & 57880.96 & 99.2 & 109.7 & 151.6 & 151.2 & -0.4 \\
\hline "FSB & $78 \mathrm{~A}$ & 49054.13 & 56799.99 & 27.0 & 37.5 & 156.1 & 152.1 & -4.0 \\
\hline "FSB & $78 B$ & 49061.71 & 56806.76 & 82.4 & 92.8 & 154.5 & 152.1 & -2.4 \\
\hline "FSB & $79 \mathrm{~A}$ & 48804.15 & 55735.50 & 24.0 & 34.4 & 158.0 & 154.9 & -3.1 \\
\hline "FSB & $79 B$ & 48813.87 & 55735.07 & 80.7 & 91.2 & 158.1 & 155.0 & -3.1 \\
\hline "FSB & $87 \mathrm{~A}$ & 49173.86 & 57637.40 & 33.1 & 43.6 & 153.8 & 149.7 & -4.1 \\
\hline "FSB & $87 B$ & 49162.22 & 57635.06 & 90.0 & 100.5 & 150.6 & 149.7 & -0.9 \\
\hline "FSB & $96 \mathrm{~A}$ & 48694.53 & 57003.71 & 85.7 & 95.7 & 152.1 & 150.9 & -1.2 \\
\hline "FSB & 96AR' & 48669.93 & 57042.37 & 79.0 & 89.0 & 153.4 & 150.7 & -2.7 \\
\hline "FSB & $97 \mathrm{~A}$ & 48937.53 & 57247.51 & 85.8 & 95.8 & 152.2 & 150.5 & -1.7 \\
\hline "FSB & $98 \mathrm{~A}$ & 49135.47 & 57428.92 & 84.7 & 94.7 & 150.6 & 150.3 & -0.3 \\
\hline "FSB & 98AR' & 49114.24 & 57405.01 & 82.1 & 92.1 & 151.8 & 150.4 & -1.4 \\
\hline "FSB & $99 \mathrm{~A}$ & 49383.87 & 57668.31 & 92.9 & 102.9 & 150.7 & 150.0 & -0.7 \\
\hline "FSB1 & $100 \mathrm{~A}$ & 49984.05 & 57396.38 & 95.8 & 105.8 & 151.5 & 151.8 & 0.3 \\
\hline "FSB1 & $101 \mathrm{~A}$ & 50250.24 & 57528.52 & 92.9 & 102.9 & 151.7 & 151.8 & 0.1 \\
\hline "FSB1 & $112 \mathrm{~A}$ & 47610.81 & 56568.72 & 81.0 & 91.0 & 153.5 & 150.5 & -3.0 \\
\hline "FSB1 & $113 \mathrm{~A}$ & 49807.16 & 56036.54 & 81.0 & 91.3 & 158.7 & 155.5 & -3.2 \\
\hline "FSB1 & $114 \mathrm{~A}$ & 50999.20 & 56938.31 & 95.2 & 105.0 & 155.6 & 154.6 & -1.0 \\
\hline "FSB1 & $120 \mathrm{~A}$ & 48241.24 & 57771.43 & 99.0 & 109.0 & 151.3 & 147.6 & -3.7 \\
\hline "HAA & $1 \mathrm{~A}$ & 60555.31 & 49367.75 & 94.9 & 104.9 & 181.1 & 180.4 & -0.7 \\
\hline "HAA & $2 \mathrm{~A}$ & 59118.96 & 50747.84 & 107.3 & 117.3 & 177.0 & 176.7 & -0.3 \\
\hline "HAA & $3 \mathrm{~A}$ & 58169.46 & 51502.24 & 96.8 & 106.8 & 175.8 & 174.6 & -1.2 \\
\hline "HAA & $4 \mathrm{~A}$ & 60017.63 & 51878.30 & 105.4 & 115.3 & 174.7 & 175.1 & 0.4 \\
\hline "HAA & $4 A A$ & 60027.07 & 51876.50 & 32.2 & 42.2 & 174.9 & 175.0 & 0.1 \\
\hline "HA.A. & $6 \mathrm{~A}$ & 61762.41 & 50707.86 & 95.6 & 105.6 & 178.9 & 178.4 & -0.5 \\
\hline "HAA & $6 A A$ & 61752.85 & 50710.00 & 28.5 & 35.8 & 178.6 & 178.3 & -0.3 \\
\hline "HC & $1 \mathrm{~A}$ & 59868.49 & 51431.54 & 89.5 & 94.5 & 175.8 & 175.8 & 0.0 \\
\hline " $\mathrm{HC}$ & $2 \mathrm{~A}$ & 59875.62 & 51469.90 & 72.2 & 77.2 & 175.8 & 175.7 & -0.1 \\
\hline "HC & $2 \mathrm{~B}$ & 59883.53 & 51459.02 & 85.7 & 90.7 & 175.0 & 175.8 & 0.8 \\
\hline "HC & $8 \mathrm{~B}$ & 59291.27 & 57414.80 & 132.5 & 137.5 & 155.5 & 156.5 & 1.0 \\
\hline " $\mathrm{HC}$ & $10 \mathrm{~A}$ & 60443.26 & 55451.59 & 114.0 & 117.0 & 163.3 & 164.7 & 1.4 \\
\hline "HCA & $4 \mathrm{~A}$ & 61066.28 & 51954.44 & 103.7 & 113.7 & 175.6 & 175.5 & -0.1 \\
\hline "HCA & $4 A A$ & 61078.23 & 51950.06 & 33.6 & 43.6 & 175.2 & 175.4 & 0.2 \\
\hline "HIW & $2 \mathrm{~A}$ & 55177.01 & 53956.84 & 78.3 & 88.3 & 167.2 & 166.5 & -0.7 \\
\hline "HSB & $65 \mathrm{~A}$ & 56654.09 & 52811.20 & 62.5 & 73.2 & 171.3 & 170.9 & -0.4 \\
\hline "HSB & $68 \mathrm{~A}$ & 54954.88 & 52242.77 & 47.5 & 58.0 & 171.8 & 170.4 & -1.4 \\
\hline "HSB & $69 \mathrm{~A}$ & 54541.89 & 52353.55 & 83.1 & 93.1 & 171.7 & 169.8 & -1.9 \\
\hline "HSB & $83 \mathrm{~A}$ & 56656.73 & 52005.45 & 65.2 & 76.0 & 172.9 & 172.6 & -0.3 \\
\hline "HSB & $84 \mathrm{~A}$ & 54445.85 & 52411.59 & 64.7 & 75.9 & 171.8 & 169.6 & -2.2 \\
\hline "HSB & $85 \mathrm{~A}$ & 57432.27 & 54031.78 & 61.1 & 71.1 & 168.8 & 168.5 & -0.3 \\
\hline "HSB & $86 \mathrm{~A}$ & 54275.00 & 53402.77 & 63.1 & 73.9 & 168.6 & 167.0 & -1.6 \\
\hline "HSB1 & $117 \mathrm{~A}$ & 53521.40 & 53781.12 & 84.8 & 94.8 & 166.7 & 165.5 & -1.2 \\
\hline "HSB1 & $119 \mathrm{~A}$ & 54503.71 & 53929.02 & 93.3 & 103.3 & 166.9 & 166.0 & -0.9 \\
\hline "HSB1 & $120 \mathrm{~A}$ & 54893.16 & 54165.82 & 91.0 & 101.0 & 166.2 & 165.7 & -0.5 \\
\hline "HSB1 & $122 \mathrm{~A}$ & 55930.58 & 52719.32 & 85.4 & 95.4 & 171.3 & 170.4 & -0.9 \\
\hline "HSB1 & $140 \mathrm{~A}$ & 54298.97 & 50872.60 & 81.0 & 91.0 & 175.7 & 172.8 & -2.9 \\
\hline "HSBI & $141 \mathrm{~A}$ & 57116.59 & 51462.98 & 80.6 & 90.6 & 175.0 & 174.0 & -1.0 \\
\hline "HSB1 & $144 \mathrm{~A}$ & 54354.32 & 52743.78 & 78.6 & 88.6 & 170.9 & 168.7 & -2.2 \\
\hline
\end{tabular}


Table F-2. Summary of Group Statistical Parameters (Continued)

\begin{tabular}{|c|c|c|c|c|c|c|c|c|c|}
\hline \multicolumn{2}{|c|}{ "HSB146A } & $"$ & 56264.76 & \multirow{2}{*}{$\begin{array}{l}50892.93 \\
52614.66\end{array}$} & \multirow{2}{*}{$\begin{array}{r}85.5 \\
104.7\end{array}$} & \multirow{2}{*}{$\begin{array}{r}95.5 \\
114.7\end{array}$} & \multirow{2}{*}{$\begin{array}{l}175.9 \\
168.2\end{array}$} & 174.4 & -1.5 \\
\hline "HSL & $6 A$ & $"$ & 58773.03 & & & & & 172.9 & 4.7 \\
\hline "HSL & 6AA & & 58780.78 & 52621.29 & 18.6 & 28.6 & 168.9 & 172.8 & 3.9 \\
\hline "HSL & $8 A$ & $"$ & 59332.69 & 52533.01 & 108.8 & 118.8 & 172.6 & 173.3 & 0.7 \\
\hline "HSL & $8 A A^{\prime}$ & & 59334.34 & 52541.25 & 28.7 & 38.7 & 175.5 & 173.2 & -2.3 \\
\hline "LAW & $1 D$ & $"$ & 43189.65 & 27176.23 & 6.6 & 11.6 & 176.5 & 174.7 & -1.8 \\
\hline " LAW & $2 B$ & $"$ & 42474.87 & 28431.27 & -9.8 & -4.8 & 176.2 & 174.0 & -2.2 \\
\hline "LAW & $3 \mathrm{~B}$ & $"$ & 45042.93 & 27844.21 & -1.0 & 4.0 & 178.2 & 178.4 & 0.2 \\
\hline "LCO & $5 \mathrm{~A}$ & $"$ & 43542.51 & 27535.73 & 30.0 & 40.0 & 177.2 & 175.6 & $-1 \cdot 6$ \\
\hline "NPM & $19 E$ & $"$ & 53855.72 & 43750.52 & 33.9 & 43.9 & 188.4 & 183.6 & $-4 \cdot 8$ \\
\hline "NPM & $34 \mathrm{E}$ & $"$ & 52178.77 & 41824.18 & 33.1 & 43.1 & 187.0 & 184.5 & -2.5 \\
\hline " $\mathrm{PW}$ & $83 N^{\prime}$ & $"$ & 48260.52 & 43306.42 & 4.0 & 9.0 & 168.4 & 179.6 & 11.2 \\
\hline "TBG & $5 B$ & $"$ & 16217.09 & 60159.71 & 46.2 & 56.2 & 113.2 & 97.7 & -15.5 \\
\hline "XSB & $1 \mathrm{~A}$ & $"$ & 15732.44 & 60148.84 & 43.6 & 53.6 & 98.7 & 96.2 & -2.5 \\
\hline "YSC & 1A. & $"$ & 64669.04 & 56836.46 & 76.8 & 136.9 & 163.0 & 160.0 & -3.0 \\
\hline "YSC & $2 \mathrm{~A}$ & $"$ & 65372.26 & 56964.66 & 134.7 & 144.7 & 162.9 & 159.8 & -3.1 \\
\hline "YSC & $5 A^{\prime}$ & $"$ & 65549.56 & 52821.66 & 116.0 & 121.0 & 180.8 & 173.8 & -7.0 \\
\hline " & $13 \mathrm{~A}$ & $"$ & 50525.24 & 16454.79 & -67.3 & -57.4 & 173.1 & 176.1 & 3.0 \\
\hline " p & $13 B$ & $"$ & 50525.24 & 16454.79 & -7.2 & 3.0 & 175.7 & 176.1 & 0.4 \\
\hline$P$ & $18 \mathrm{~A}$ & $"$ & 45134.06 & 50308.26 & 12.0 & 22.0 & 168.5 & 165.1 & -3.4 \\
\hline "P & $18 \mathrm{~B}$ & $"$ & 45124.13 & 50296.16 & 67.0 & 77.0 & 169.0 & 165.2 & -3.8 \\
\hline "P & $19 \mathrm{~A}$ & $"$ & 54661.51 & 35763.86 & -36.7 & -26.7 & 186.8 & 191.1 & 4.3 \\
\hline "P & $23 B$ & $"$ & 24685.04 & 34727.78 & 41.5 & 46.5 & 137.8 & 138.6 & 0.8 \\
\hline "P & $24 \mathrm{~A}$ & $"$ & 58519.49 & 22466.26 & -1.9 & 8.9 & 191.5 & 192.4 & 0.9 \\
\hline "P & $25 B$ & $"$ & 36673.35 & 36698.53 & 80.6 & 90.6 & 178.2 & 163.5 & -14.7 \\
\hline "P & $26 \mathrm{~A}$ & $"$ & 17067.87 & 60790.20 & 22.0 & 32.0 & 117.5 & 99.4 & -18.1 \\
\hline "P & $27 B$ & $"$ & 61674.68 & 49668.39 & 74.8 & 94.8 & 179.8 & 180.4 & 0.6 \\
\hline \multirow[t]{4}{*}{ * G } & \multirow[t]{4}{*}{ ROUP } & 2 & * rms of & (FACT-data) & \multirow{4}{*}{\multicolumn{2}{|c|}{$\begin{array}{l}\text { differences: } \\
\text { differences: } \\
\text { differences: } \\
\text { differences: }\end{array}$}} & \multicolumn{2}{|l|}{6.703} & \\
\hline & & & avg of & (FACT-data) & & & \multicolumn{2}{|l|}{0.309} & \\
\hline & & & avg of & |FACT-data| & & & 5.291 & & \\
\hline & & & $\max$ of & $\{F A C T-d a t a\}$ & & & -33.655 & & \\
\hline "BG & 92 & $"$ & 56450.00 & 59585.06 & 197.2 & 227.2 & 208.8 & 211.8 & 3.0 \\
\hline " BG & 93 & $"$ & 56964.98 & 60407.16 & 180.5 & 210.5 & 198.8 & 193.3 & -5.5 \\
\hline "BG & 94 & $"$ & 57485.58 & 61253.82 & 152.8 & 182.8 & 191.1 & 157.4 & -33.7 \\
\hline "BG & 95 & $"$ & 58210.78 & 60274.34 & 152.5 & 182.5 & 192.8 & 164.0 & -28.8 \\
\hline "BG & 96 & $"$ & 57966.00 & 59647.94 & 177.2 & 207.2 & 197.7 & 191.8 & -5.9 \\
\hline "BG 1 & 103 & $"$ & 59074.01 & 57865.93 & 169.5 & 199.5 & 199.8 & 199.6 & -0.2 \\
\hline "BG 1 & 122 & $"$ & 56321.37 & 59164.11 & 189.9 & 209.9 & 211.2 & 216.3 & 5.1 \\
\hline " BGO & $3 c$ & $"$ & 57663.88 & 55780.34 & 178.7 & 188.7 & 225.5 & 226.5 & 1.0 \\
\hline " BGO & $5 \mathrm{C}$ & $"$ & 57844.87 & 56689.07 & 183.2 & 193.2 & 216.2 & 221.6 & 5.4 \\
\hline "BGO & $6 \mathrm{~B}$ & $"$ & 57422.52 & 56856.84 & 139.7 & 149.7 & 218.8 & 221.6 & 2.8 \\
\hline " BGO & $6 C$ & $"$ & 57370.14 & 56800.40 & 158.0 & 168.0 & 220.0 & 222.5 & 2.5 \\
\hline " BGO & $8 \mathrm{C}$ & $"$ & 56716.03 & 57033.59 & 174.3 & 184.3 & 224.3 & 224.3 & 0.0 \\
\hline " BGO & $10 \mathrm{~B}$ & $"$ & 56173.88 & 57560.73 & 139.0 & 149.0 & 219.6 & 223.2 & 3.6 \\
\hline " BGO & $10 \mathrm{C}$ & $"$ & 56198.04 & 57374.75 & 157.3 & 167.3 & 220.2 & 224.0 & 3.8 \\
\hline " BGO & $12 \mathrm{C}$ & $"$ & 55415.52 & 57541.08 & 153.6 & 163.6 & 220.1 & 225.0 & 4.9 \\
\hline " BGO & $12 \mathrm{CR}$ & $"$ & 55390.36 & 57547.24 & 144.0 & 154.0 & 221.9 & 224.7 & 2.8 \\
\hline " BGO & $12 \mathrm{CX}$ & 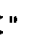 & 55411.15 & 57571.96 & 141.2 & 151.2 & 230.0 & 224.6 & -5.4 \\
\hline " BGO & $13 \mathrm{DR}$ & $"$ & 55027.63 & 57643.46 & 210.3 & 220.3 & 230.7 & 227.8 & -2.9 \\
\hline " BGO & $14 \mathrm{C}$ & $"$ & 54931.25 & 57196.74 & 192.1 & 202.1 & 221.4 & 226.5 & 5.1 \\
\hline " BGO & $14 \mathrm{CR}$ & 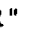 & 54876.13 & 57177.89 & 190.1 & 200.1 & 223.5 & 226.4 & 2.9 \\
\hline "BGO & $16 \mathrm{~B}$ & $"$ & 55143.73 & 56537.96 & 136.0 & 146.0 & 218.1 & 224.9 & 6.8 \\
\hline " BGO & $20 \mathrm{~B}$ & $"$ & 55889.62 & 55545.19 & 131.0 & 141.0 & 226.9 & 226.5 & -0.4 \\
\hline " BGO & $20 \mathrm{C}$ & $"$ & 55873.23 & 55534.46 & 174.0 & 184.0 & 228.2 & 227.3 & -0.9 \\
\hline "BGO & $27 c$ & $"$ & 53643.34 & 56753.42 & 154.9 & 163.9 & 220.6 & 222.9 & 2.3 \\
\hline " BGO & $29 C$ & $"$ & 53065.14 & 56785.84 & 176.8 & 186.8 & 222.8 & 222.1 & -0.7 \\
\hline " BGO & $30 \mathrm{C}$ & $"$ & 53386.81 & 56311.81 & 178.4 & 188.4 & 219.0 & 221.4 & 2.4 \\
\hline " BGO & $31 \mathrm{C}$ & $"$ & 53641.87 & 56050.06 & 176.4 & 186.4 & 225.3 & 221.3 & -4.0 \\
\hline
\end{tabular}


Table F-2. Summary of Group Statistical Parameters (Continued)

\begin{tabular}{|c|c|c|c|c|c|c|c|c|c|}
\hline " BGO & $33 c$ & $"$ & 54384.56 & 55382.76 & 177.8 & 187.8 & 224.9 & 222.6 & -2.3 \\
\hline " BGO & $35 \mathrm{C}$ & $"$ & 55120.65 & 54688.75 & 161.9 & 171.9 & 228.6 & 224.3 & -4.3 \\
\hline " BGO & $37 \mathrm{C}$ & $"$ & 55743.38 & 54090.51 & 168.8 & 178.8 & 229.9 & 226.6 & -3.3 \\
\hline " BGO & $39 c$ & $"$ & 56282.08 & 54042.56 & 174.9 & 184.9 & 229.3 & 229.0 & -0.3 \\
\hline " BGO & $42 C$ & $"$ & 54629.16 & 57298.77 & 185.9 & 195.9 & 223.2 & 226.2 & 3.0 \\
\hline " BGO & $43 \mathrm{CR}$ & ?" & 55459.53 & 57766.86 & 178.4 & 188.4 & 225.2 & 225.3 & 0.1 \\
\hline " BGO & $43 D$ & $"$ & 55465.56 & 57787.56 & 198.2 & 208.2 & 231.3 & 226.0 & -5.3 \\
\hline " BGO & $44 B$ & $"$ & 56994.49 & 57155.16 & 148.1 & 158.1 & 221.3 & 222.4 & 1.1 \\
\hline " BGO & $44 \mathrm{C}$ & $"$ & 57023.33 & 57150.87 & 190.6 & 200.6 & 220.8 & 223.6 & 2.8 \\
\hline " BGO & $45 B$ & $"$ & 53574.07 & 56946.03 & 137.0 & 147.0 & 218.7 & 222.9 & 4.2 \\
\hline " BGO & $45 \mathrm{C}$ & $"$ & 53586.46 & 56937.98 & 190.5 & 200.5 & 222.6 & 224.4 & 1.8 \\
\hline "BGO & $46 \mathrm{~B}$ & $"$ & 53285.57 & 56160.65 & 140.4 & 150.4 & 217.9 & 219.3 & 1.4 \\
\hline "BGO & $46 C$ & $"$ & 53277.11 & 56172.78 & 178.0 & 188.0 & 219.4 & 220.4 & 1.0 \\
\hline "BGO & $47 C$ & $"$ & 53709.52 & 55804.63 & 178.6 & 188.6 & 222.7 & 220.8 & -1.9 \\
\hline " BGO & $48 \mathrm{C}$ & $"$ & 53864.66 & 55615.85 & 176.7 & 186.7 & 223.3 & 220.8 & -2.5 \\
\hline " BGO & $49 C$ & $"$ & 54777.03 & 54724.27 & 166.0 & 176.0 & 227.7 & 222.9 & -4.8 \\
\hline " BGO & $50 \mathrm{C}$ & $"$ & 53080.36 & 56386.55 & 162.5 & 172.5 & 218.1 & 220.0 & 1.9 \\
\hline "BGO & $51 B$ & $"$ & 56430.92 & 54587.93 & 116.9 & 126.9 & 229.4 & 228.1 & -1.3 \\
\hline " BGO & $51 \mathrm{C}$ & $"$ & 56435.93 & 54582.16 & 175.1 & 185.1 & 230.3 & 229.5 & -0.8 \\
\hline " BGO & $52 B$ & $"$ & 55890.68 & 55213.52 & 126.7 & 136.7 & 227.4 & 226.6 & -0.8 \\
\hline "BGO & $52 \mathrm{~B}$ & $"$ & 55890.68 & 55213.52 & 126.7 & 136.7 & 227.4 & 226.6 & -0.8 \\
\hline " BGO & $52 \mathrm{C}$ & $"$ & 55895.16 & 55207.15 & 178.7 & 188.7 & 228.7 & 227.7 & -1.0 \\
\hline " BGO & $53 \mathrm{~B}$ & $"$ & 54457.17 & 57000.00 & 143.5 & 153.5 & 221.3 & 224.6 & 3.3 \\
\hline " BGO & $53 \mathrm{C}$ & $"$ & 54450.67 & 57007.32 & 183.2 & 193.2 & 222.0 & 225.7 & 3.7 \\
\hline "BGX & $1 \mathrm{C}$ & $"$ & 57725.76 & 57065.15 & 176.0 & 186.0 & 215.8 & 220.0 & 4.2 \\
\hline "BGX & $2 \mathrm{~B}$ & $"$ & 57469.67 & 57511.55 & 137.2 & 147.2 & 212.7 & 218.1 & 5.4 \\
\hline "BGX & $2 \mathrm{D}$ & $"$ & 57476.29 & 57498.90 & 181.1 & 191.1 & 215.2 & 219.5 & 4.3 \\
\hline " BGX & $4 C$ & $"$ & 56580.37 & 58398.63 & 170.7 & 180.7 & 214.5 & 219.1 & 4.6 \\
\hline "BGX & $4 D$ & $"$ & 56566.33 & 58409.49 & 203.8 & 223.8 & 215.7 & 222.2 & 6.5 \\
\hline " BGX & $5 D$ & $"$ & 56791.69 & 58881.04 & 195.0 & 215.0 & 209.0 & 216.0 & 7.0 \\
\hline "BGX & $6 \mathrm{D}$ & $"$ & 57073.56 & 59166.78 & 191.0 & 211.0 & 205.7 & 211.2 & 5.5 \\
\hline "BGX & $7 D$ & $"$ & 57762.99 & 58620.70 & 194.1 & 214.1 & 205.5 & 210.2 & 4.7 \\
\hline " BGX & 8DR & & 58220.98 & 57746.68 & 183.1 & 203.1 & 205.4 & 211.8 & 6.4 \\
\hline " BGX. & $12 \mathrm{C}$ & $"$ & 58280.41 & 54501.71 & 174.1 & 184.1 & 234.2 & 229.9 & -4.3 \\
\hline " BRR & $6 \mathrm{C}$ & $"$ & 50435.16 & 58863.14 & 156.0 & 166.0 & 211.6 & 211.4 & -0.2 \\
\hline " BRR & $7 \mathrm{BR}$ & & 50162.98 & 59444.94 & 141.6 & 151.6 & 204.9 & 206.2 & 1.3 \\
\hline " BRR & $7 \mathrm{C}$ & $"$ & 50153.27 & 59444.45 & 175.9 & 185.9 & 209.8 & 207.6 & -2.2 \\
\hline " BRR & $8 B$ & $"$ & 49597.22 & 59625.82 & 138.7 & 148.7 & 204.3 & 200.5 & -3.8 \\
\hline " CMP & $8 B$ & $"$ & 48480.44 & 34345.48 & 156.6 & 166.6 & 198.5 & 205.2 & 6.7 \\
\hline "CMP & $9 B$ & $"$ & 47847.73 & 33475.01 & 149.0 & 159.0 & 194.7 & 210.3 & 15.6 \\
\hline " CMP & $10 B$ & $"$ & 47943.12 & 33136.89 & 137.4 & 147.4 & 195.0 & 212.4 & 17.4 \\
\hline "CMP & $10 \mathrm{C}$ & $"$ & 47936.35 & 33160.82 & 179.6 & 189.6 & 198.9 & 212.7 & 13.8 \\
\hline " CMP & $11 B$ & $"$ & 47622.42 & 33282.65 & 139.7 & 149.7 & 195.0 & 210.8 & 15.8 \\
\hline " CMP & $12 \mathrm{~B}$ & $"$ & 47582.56 & 33788.69 & 148.0 & 158.0 & 194.6 & 207.8 & 13.2 \\
\hline "CMP & $13 \mathrm{~B}$ & $"$ & 47975.22 & 33615.47 & 134.2 & 144.2 & 194.7 & 209.5 & 14.8 \\
\hline " CMP & $14 \mathrm{~B}$ & $"$ & 46762.54 & 34405.77 & 130.0 & 140.0 & 194.6 & 200.6 & 6.0 \\
\hline "CMP & $15 B$ & $"$ & 46859.50 & 33335.32 & 145.1 & 155.1 & 202.9 & 208.3 & 5.4 \\
\hline "CMP & $16 \mathrm{~B}$ & $"$ & 47831.28 & 33361.04 & 141.7 & 151.7 & 194.8 & 210.8 & 16.0 \\
\hline "CMP & $30 \mathrm{~B}$ & $"$ & 47195.03 & 33652.79 & 97.4 & 107.5 & 194.7 & 207.0 & 12.3 \\
\hline "CMP & $30 \mathrm{C}$ & $"$ & 47233.06 & 33633.06 & 179.5 & 189.5 & 210.8 & 208.2 & -2.6 \\
\hline " CMP & $31 B$ & $"$ & 47408.43 & 34209.90 & 110.0 & 120.0 & 194.4 & 204.3 & 9.9 \\
\hline " CMP & $32 \mathrm{~B}$ & $"$ & 48163.49 & 33948.09 & 97.7 & 107.7 & 195.5 & 207.0 & 11.5 \\
\hline " CMP & $32 c$ & $"$ & 48170.49 & 33941.09 & 185.2 & 195.2 & 195.9 & 208.6 & 12.7 \\
\hline "CRP & $3 c$ & $"$ & 41780.37 & 52154.68 & 121.1 & 131.1 & 196.7 & 203.0 & 6.3 \\
\hline "CRP & $5 \mathrm{C}$ & $"$ & 42238.74 & 51887.54 & 110.1 & 120.1 & 198.2 & 207.7 & 9.5 \\
\hline "DBP & 1 & $"$ & 16554.65 & 55461.46 & 93.2 & 121.4 & 119.8 & 120.9 & 1.1 \\
\hline " DBP & 2 & $"$ & 16261.38 & 55305.83 & 84.3 & 114.3 & 117.4 & 118.3 & 0.9 \\
\hline " DBP & 3 & $"$ & 16342.95 & 55592.44 & 86.4 & 116.4 & 121.0 & 119.4 & -1.6 \\
\hline "DBP & 4 & $"$ & 16239.48 & 55516.39 & 84.2 & 114.2 & 118.9 & 118.5 & -0.4 \\
\hline "DBP & 5 & $"$ & 16456.49 & 55271.93 & 96.1 & 116.1 & 117.6 & 119.9 & 2.3 \\
\hline
\end{tabular}


Table F-2. Summary of Group Statistical Parameters (Continued)

\begin{tabular}{|c|c|c|c|c|c|c|c|c|c|}
\hline " DCB & $1 \mathrm{~A}$ & " & 17169.39 & 52608.40 & 90.1 & 120.1 & 115.2 & 122.8 & 7.6 \\
\hline " DCB & $2 \mathrm{~A}$ & " & 18062.42 & 51812.95 & 97.4 & 127.4 & 124.8 & 129.5 & 4.7 \\
\hline " $D C B$ & $3 A$ & " & 17908.76 & 51067.40 & 96.2 & 126.2 & 120.6 & 127.9 & 7.3 \\
\hline " DCB & $4 \mathrm{~A}$ & " & 17512.34 & 51155.65 & 92.5 & 122.5 & 119.1 & 125.5 & 6.4 \\
\hline " $D C B$ & $5 A$ & $"$ & 17259.08 & 51666.78 & 85.9 & 115.9 & 118.8 & 123.8 & 5.0 \\
\hline " DCB & 6 & $"$ & 17318.69 & 52719.18 & 109.5 & 128.2 & 116.8 & 124.1 & 7.3 \\
\hline " DCB & 7 & $"$ & 17339.83 & 52544.47 & 108.9 & 128.9 & 118.0 & 124.4 & 6.4 \\
\hline "DCB & 8 & " & 18186.59 & 51825.20 & 110.3 & 130.3 & 126.5 & 130.3 & 3.8 \\
\hline " DCB & 9 & $"$ & 17155.27 & 52777.13 & 97.3 & 117.3 & 114.8 & 122.5 & 7.7 \\
\hline "DCB & 10 & $"$ & 17118.62 & 52388.76 & 99.8 & 119.8 & 116.6 & 122.6 & 6.0 \\
\hline "DCB & 11 & $"$ & 16701.76 & 53331.22 & 106.8 & 117.0 & 122.0 & 117.1 & $-4 \cdot 9$ \\
\hline " DCB & 12 & $"$ & 16105.05 & 53981.19 & 92.0 & 112.0 & 109.7 & 115.5 & 5.8 \\
\hline " DCB & 13 & " & 16523.39 & 52555.56 & 102.0 & 117.6 & 116.9 & 117.5 & 0.6 \\
\hline " DCB & 14 & $"$ & 16898.86 & 53566.89 & 94.6 & 114.6 & 109.8 & 119.0 & 9.2 \\
\hline " DCB & 15 & $"$ & 15117.88 & 53636.30 & 99.8 & 114.5 & 111.5 & 110.1 & -1.4 \\
\hline " DCB & 16 & $"$ & 14958.28 & 53004.27 & 100.1 & 114.7 & 111.9 & 110.3 & -1.6 \\
\hline " DCB & $17 \mathrm{~A}$ & " & 17270.54 & 53154.00 & 109.4 & 119.4 & 116.6 & 123.1 & 6.5 \\
\hline " DCB & $17 \mathrm{~B}$ & $"$ & 17274.54 & 53158.87 & 99.2 & 101.7 & 116.9 & 123.2 & 6.3 \\
\hline " DCB & $17 \mathrm{C}$ & " & 17277.32 & 53163.29 & 87.4 & 89.9 & 116.1 & 123.2 & 7.1 \\
\hline "DCB & $18 \mathrm{~A}$ & $"$ & 17198.69 & 52626.00 & 110.1 & 120.1 & 116.2 & 123.1 & 6.9 \\
\hline " DCB & $18 \mathrm{~B}$ & $"$ & 17190.86 & 52621.83 & 100.5 & 103.0 & 113.3 & 123.0 & 9.7 \\
\hline " DCB & $18 \mathrm{C}$ & $"$ & 17184.89 & 52618.30 & 87.7 & 90.2 & 112.7 & 122.9 & 10.2 \\
\hline " DCB & $19 \mathrm{~A}$ & $"$ & 17201.32 & 52595.07 & 111.9 & 121.9 & 120.0 & 123.2 & 3.2 \\
\hline " DCB & $19 \mathrm{~B}$ & " & 17195.27 & 52590.63 & 101.9 & 104.4 & 117.4 & 123.1 & 5.7 \\
\hline " DCB & $19 \mathrm{C}$ & $"$ & 17188.62 & 52586.32 & 89.1 & 91.6 & 116.5 & 122.9 & 6.4 \\
\hline " DCB & $20 \mathrm{~A}$ & $"$ & 17393.86 & 52461.01 & 110.9 & 120.9 & 117.2 & 124.9 & 7.7 \\
\hline " DCB & $20 B$ & $"$ & 17390.93 & 52466.03 & 100.3 & 102.8 & 116.5 & 124.8 & 8.3 \\
\hline " DCB & $20 \mathrm{C}$ & $"$ & 17387.59 & 52471.95 & 89.4 & 91.9 & 116.4 & 124.7 & 8.3 \\
\hline " DCB & $21 \mathrm{~A}$ & $"$ & 17144.19 & 52497.52 & 110.1 & 120.1 & 116.9 & 122.8 & 5.9 \\
\hline "DCB & $21 B$ & $"$ & 17142.14 & 52503.27 & 102.2 & 104.7 & 113.4 & 122.7 & 9.3 \\
\hline " DCB & $21 C$ & $"$ & 17140.99 & 52508.93 & 88.3 & 90.8 & 112.9 & 122.6 & 9.7 \\
\hline "DCB & $22 \mathrm{~A}$ & $"$ & 17083.51 & 52503.06 & 109.8 & 119.8 & 112.8 & 122.3 & 9.5 \\
\hline " DCB & $22 B$ & $"$ & 17081.23 & 52509.16 & 100.9 & 103.4 & 112.8 & 122.2 & 9.4 \\
\hline " DCB & $22 \mathrm{C}$ & $"$ & 17080.53 & 52515.45 & 88.1 & 90.6 & 112.9 & 122.1 & 9.2 \\
\hline " DCB & $23 \mathrm{~A}$ & " & 16893.94 & 52505.32 & 105.7 & 115.7 & 111.8 & 120.7 & 8.9 \\
\hline " DCB & $23 B$ & " & 16893.90 & 52511.36 & 94.1 & 96.6 & 108.8 & 120.6 & 11.8 \\
\hline "DCB & $23 c$ & $"$ & 16893.92 & 52517.70 & 86.6 & 89.1 & 109.0 & 120.6 & 11.6 \\
\hline "DCB & $24 \mathrm{~A}$ & $"$ & 17146.45 & 51890.59 & 109.2 & 119.2 & 115.5 & 123.1 & 7.6 \\
\hline "DCB & $24 B$ & $"$ & 17135.28 & 51889.49 & 100.6 & 103.1 & 115.2 & 122.9 & 7.7 \\
\hline "DCB & $24 \mathrm{C}$ & $"$ & 17128.89 & 51888.29 & 87.6 & 90.1 & 116.3 & 122.7 & 6.4 \\
\hline "DOB & 1 & $"$ & 21716.60 & 56149.98 & 114.7 & 144.7 & 143.2 & 147.4 & 4.2 \\
\hline "DOB & 2 & $"$ & 21521.56 & 56324.23 & 115.3 & 145.3 & 143.2 & 146.1 & 2.9 \\
\hline " DOB & 3 & $"$ & 21833.77 & 56386.18 & 115.9 & 145.9 & 143.2 & 147.5 & 4.3 \\
\hline "DOB & 4 & $"$ & 21974.85 & 56173.09 & 109.2 & 139.2 & 142.4 & 148.6 & 6.2 \\
\hline " DOB & 7 & $"$ & 21610.86 & 56047.42 & 125.7 & 145.7 & 143.1 & 147.0 & 3.9 \\
\hline " DOB & 8 & $"$ & 21854.23 & 56111.62 & 128.3 & 148.3 & 143.7 & 148.4 & 4.7 \\
\hline "DOB & 9 & $"$ & 21914.47 & 56489.76 & 128.5 & 148.5 & 144.1 & 147.6 & 3.5 \\
\hline "DOB & 10 & $"$ & 21457.21 & 56259.09 & 128.3 & 148.2 & 143.2 & 146.0 & 2.8 \\
\hline "DOB & 11 & $"$ & 21554.72 & 56191.64 & 126.7 & 131.7 & 140.9 & 146.4 & 5.5 \\
\hline "DOB & 12 & $"$ & 21553.76 & 56196.84 & 133.1 & 138.1 & 140.5 & 146.5 & 6.0 \\
\hline "DOB & 14 & $"$ & 21655.74 & 56057.51 & 132.6 & 137.6 & 139.7 & 147.2 & 7.5 \\
\hline "DOB & 15 & $"$ & 21284.89 & 55936.57 & 110.9 & 116.0 & 141.9 & 145.5 & 3.6 \\
\hline "DOB & 16 & $"$ & 21284.59 & 55930.81 & 103.5 & 108.6 & 141.4 & 145.5 & 4.1 \\
\hline " DOL & 1 & " & 21808.58 & 56494.69 & 109.2 & 119.2 & 144.3 & 146.9 & 2.6 \\
\hline "FAC & $9 \mathrm{C}$ & $"$ & 54788.19 & 58927.09 & 197.4 & 207.4 & 217.4 & 224.4 & 7.0 \\
\hline "FAC & $10 \mathrm{C}$ & $"$ & 54766.72 & 59022.85 & 200.2 & 210.2 & 217.4 & 224.2 & 6.8 \\
\hline "FAC & $11 \mathrm{C}$ & $"$ & 54697.64 & 59017.70 & 201.4 & 211.4 & 217.5 & 224.5 & 7.0 \\
\hline "FAC & $12 \mathrm{C}$ & $"$ & 54681.22 & 58966.90 & 198.0 & 208.0 & 217.5 & 224.5 & 7.0 \\
\hline "FBP & $1 \mathrm{~A}$. & $"$ & $50801: 97$ & 60656.16 & 161.8 & 191.8 & 206.7 & 200.1 & -6.6 \\
\hline "FBP & $2 \mathrm{~A}$ & " & 50437.47 & 61570.32 & 137.1 & 167.1 & 191.6 & 173.8 & -17.8 \\
\hline
\end{tabular}


Table F-2. Summary of Group Statistical Parameters (Continued)

\begin{tabular}{|c|c|c|c|c|c|c|c|c|c|}
\hline "FBP & $3 \mathrm{~A}$ & $"$ & 50834.99 & 61616.17 & 141.0 & 171.0 & 194.2 & 182.3 & -11.9 \\
\hline "FBP & 4 & $"$ & 51171.97 & 61014.05 & 165.2 & 195.2 & 212.3 & 199.1 & -13.2 \\
\hline "FBP & $6 \mathrm{D}$ & " & 50442.18 & 61529.96 & 178.3 & 198.3 & 194.8 & 179.8 & -15.0 \\
\hline "FBP & $7 \mathrm{D}$ & $"$ & 50794.34 & 61590.87 & 183.2 & 203.2 & 194.1 & 184.4 & -9.7 \\
\hline "FBP & $8 D$ & $"$ & 51183.90 & 60982.69 & 172.8 & 192.8 & 207.1 & 199.7 & -7.4 \\
\hline "FBP & $9 D$ & $"$ & 50935.15 & 61314.97 & 177.9 & 197.9 & 200.3 & 192.0 & -8.3 \\
\hline "FBP & $12 \mathrm{D}$ & $"$ & 50893.28 & 60676.93 & 182.1 & 202.1 & 208.4 & 202.8 & -5.6 \\
\hline "FBP & $13 \mathrm{D}$ & $"$ & 50601.77 & 61573.73 & 172.7 & 192.7 & 194.9 & 181.3 & -13.6 \\
\hline "FC & $1 B$ & $"$ & 52953.86 & 60995.57 & 151.8 & 156.8 & 210.8 & 209.9 & -0.9 \\
\hline "FC & $1 C$ & $"$ & 52955.56 & 61003.08 & 183.9 & 188.9 & 214.0 & 210.9 & -3.1 \\
\hline "FC & $3 \mathrm{D}$ & $"$ & 57191.44 & 59129.76 & 165.9 & 170.9 & 206.4 & 208.9 & 2.5 \\
\hline "FC & $3 E$ & " & 57198.96 & 59128.57 & 185.7 & 190.7 & 205.3 & 209.7 & 4.4 \\
\hline "FC & $3 F$ & $"$ & 57206.55 & 59127.26 & 205.1 & 210.1 & 206.2 & 210.7 & 4.5 \\
\hline "FC & $4 E$ & $"$ & 54276.52 & 63368.94 & 176.4 & 168.5 & 185.2 & 0.0 & -185.2 \\
\hline "FCB & 3 & $"$ & 54000.00 & 57456.08 & 195.3 & 225.3 & 223.9 & 228.3 & 4.4 \\
\hline " EIW & $2 I C$ & & 50304.02 & 57727.18 & 125.3 & 175.2 & 210.8 & 210.7 & -0.1 \\
\hline " FNB & 1 & $"$ & 54184.80 & 61223.73 & 177.2 & 207.2 & 210.9 & 208.0 & -2.9 \\
\hline " FNB & 2 & $"$ & 54333.78 & 61489.36 & 180.8 & 210.8 & 207.1 & 204.8 & -2.3 \\
\hline "FNB & 3 & $"$ & 54106.12 & 61651.03 & 182.1 & 212.1 & 209.3 & 203.0 & -6.3 \\
\hline "FNB & 4 & " & 53819.76 & 61565.40 & 179.6 & 209.6 & 213.6 & 205.2 & -8.4 \\
\hline "FNB & 5 & $"$ & 54292.00 & 61614.58 & 193.5 & 203.5 & 206.7 & 202.4 & -4.3 \\
\hline "FNB & 7 & $"$ & 54412.36 & 61684.16 & 192.4 & 202.4 & 203.9 & 200.6 & -3.3 \\
\hline "FNB & 8 & $"$ & 54534.35 & 61527.65 & 195.4 & 205.4 & 202.8 & 203.0 & 0.2 \\
\hline "FOB & $5 \mathrm{C}$ & $"$ & 48589.99 & 56744.62 & 129.3 & 149.3 & 202.9 & 196.2 & -6.7 \\
\hline "FOB & $7 C$ & $"$ & 49389.26 & 58074.58 & 148.9 & 168.9 & 208.0 & 206.1 & -1.9 \\
\hline "FOB & $9 \mathrm{C}$ & $"$ & 49876.26 & 57663.74 & 155.5 & 175.5 & 210.2 & 208.7 & -1.5 \\
\hline "FOB & $11 \mathrm{C}$ & $"$ & 50941.71 & 57274.11 & 156.2 & 176.2 & 212.4 & 213.4 & 1.0 \\
\hline "FSB & $76 \mathrm{C}$ & $"$ & 50532.65 & 57870.68 & 154.8 & 165.3 & 212.8 & 212.6 & -0.2 \\
\hline "FSB & $78 \mathrm{C}$ & $"$ & 49054.67 & 56815.01 & 141.6 & 151.4 & 207.8 & 199.4 & -8.4 \\
\hline "FSB & $79 \mathrm{C}$ & $"$ & 48826.10 & 55734.41 & 149.8 & 159.6 & 196.8 & 189.4 & -7.4 \\
\hline "FSB & $87 \mathrm{C}$ & $"$ & 49149.91 & 57632.47 & 148.8 & 159.3 & 208.4 & 203.9 & -4.5 \\
\hline "FSB & $88 \mathrm{C}$ & $"$ & 50549.09 & 57363.18 & 158.4 & 168.4 & 212.3 & 211.5 & -0.8 \\
\hline "FSB & $89 C$ & $"$ & 50366.31 & 57334.35 & 156.1 & 166.1 & 211.7 & 210.2 & -1.5 \\
\hline "FSB & $90 \mathrm{C}$ & $"$ & 50138.59 & 57208.65 & 158.1 & 168.1 & 210.8 & 208.5 & -2.3 \\
\hline "FSB & $91 \mathrm{C}$ & $"$ & 49912.50 & 57083.32 & 149.1 & 159.1 & 210.5 & 206.3 & -4.2 \\
\hline "FSB & $92 \mathrm{C}$ & $"$ & 49498.22 & 57007.70 & 147.6 & 157.6 & 208.7 & 203.5 & -5.2 \\
\hline "FSB & $93 \mathrm{C}$ & $"$ & 49362.42 & 56877.18 & 142.0 & 152.0 & 208.6 & 201.6 & -7.0 \\
\hline "FSB & $94 \mathrm{C}$ & $"$ & 49084.32 & 56907.36 & 139.8 & 149.8 & 207.7 & 200.2 & -7.5 \\
\hline "FSB & $95 \mathrm{C}$ & $"$ & 48945.94 & 57041.77 & 145.8 & 155.8 & 205.6 & 200.4 & -5.2 \\
\hline "FSB & $95 \mathrm{CR}$ & & 48923.95 & 57077.32 & 151.9 & 161.9 & 207.7 & 200.7 & -7.0 \\
\hline "FSB & $97 \mathrm{C}$ & $"$ & 48944.07 & 57254.71 & 143.8 & 153.8 & 208.0 & 201.2 & -6.8 \\
\hline "FSB & $98 \mathrm{C}$ & $"$ & 49128.70 & 57421.57 & 148.4 & 158.4 & 209.0 & 203.2 & -5.8 \\
\hline "FSB & $99 \mathrm{C}$ & $"$ & 49391.23 & 57675.02 & 157.2 & 167.2 & 209.4 & 205.7 & -3.7 \\
\hline "FSB1 & $.02 \mathrm{C}$ & $"$ & 49457.41 & 55513.22 & 145.9 & 155.9 & 195.3 & 189.1 & -6.2 \\
\hline "FSB1 & $03 \mathrm{C}$ & $"$ & 48430.15 & 56372.68 & 147.1 & 157.1 & 202.5 & 193.0 & -9.5 \\
\hline "FSB1 & $.04 \mathrm{C}$ & $"$ & 47966.11 & 56126.38 & 150.7 & 160.7 & 200.9 & 188.6 & -12.3 \\
\hline "FSB1 & $.05 \mathrm{C}$ & $"$ & 48815.94 & 57337.76 & 141.5 & 151.5 & 207.7 & 200.8 & -6.9 \\
\hline "FSB1 & $.06 \mathrm{C}$ & $"$ & 49404.17 & 56145.31 & 156.0 & 166.0 & 201.2 & 196.4 & -4.8 \\
\hline "FSB1 & $.07 \mathrm{C}$ & $"$ & 50106.53 & 57012.12 & 150.8 & 160.8 & 209.9 & 207.1 & -2.8 \\
\hline "FSBI & $10 \mathrm{C}$ & $"$ & 48914.53 & 56249.99 & 137.2 & 147.2 & 201.2 & 194.3 & -6.9 \\
\hline "FSBI & $11 \mathrm{C}$ & $"$ & 50508.12 & 57130.51 & 159.0 & 169.0 & 211.8 & 210.3 & -1.5 \\
\hline "FSB1 & $12 \mathrm{C}$ & $"$ & 47596.01 & 56567.88 & 129.1 & 139.1 & 201.9 & 189.7 & -12.2 \\
\hline "FSBI & $13 \mathrm{C}$ & $"$ & 49821.49 & 56026.54 & 154.0 & 164.0 & 202.5 & 197.4 & -5.1 \\
\hline "FSB1 & $14 \mathrm{C}$ & $"$ & 50984.82 & 56932.27 & 158.0 & 168.0 & 213.3 & 211.9 & -1.4 \\
\hline "FSB1 & $16 \mathrm{C}$ & $"$ & 49094.38 & 54713.83 & 160.5 & 170.5 & 189.7 & 187.1 & -2.6 \\
\hline "FSB1 & $20 \mathrm{C}$ & $"$ & 48239.01 & 57783.04 & 150.7 & 160.7 & 206.0 & 198.8 & -7.2 \\
\hline "FSB1 & $21 C$ & $"$ & 47415.63 & 57555.15 & 148.4 & 158.4 & 204.1 & 193.7 & -10.4 \\
\hline "FSB1 & $23 c$ & $"$ & 50557.64 & 56285.14 & 155.3 & 165.3 & 210.2 & 204.3 & -5.9 \\
\hline "FSB1 & $.50 \mathrm{PC}$ & & 48736.60 & 56184.86 & 107.6 & 160.1 & 198.2 & 192.7 & -5.5 \\
\hline "HA.A & $1 \mathrm{~B}$ & $"$ & 60561.80 & 49359.31 & 119.3 & 129.3 & 251.4 & 247.6 & -3.8 \\
\hline
\end{tabular}


Table F-2. Summary of Group Statistical Parameters (Continued)

\begin{tabular}{|c|c|c|c|c|c|c|c|c|c|}
\hline "HAA & $1 C$ & $"$ & 60567.40 & 49351.99 & 147.4 & 157.4 & 252.0 & 249.5 & -2.5 \\
\hline "HAA & $2 \mathrm{~B}$ & $"$ & 59111.69 & 50754.50 & 127.2 & 137.2 & 253.2 & 240.7 & -12.5 \\
\hline "HAA & $2 \mathrm{C}$ & $"$ & 59104.31 & 50761.18 & 171.9 & 181.9 & 254.8 & 244.3 & -10.5 \\
\hline "HAA & $3 B$ & $"$ & 58154.04 & 51487.42 & 125.9 & 135.9 & 240.7 & 231.4 & -9.3 \\
\hline "HAA & $3 C$ & $"$ & 58139.89 & 51473.76 & 163.3 & 173.3 & 244.0 & 234.8 & -9.2 \\
\hline "HAA. & $4 \mathrm{C}$ & $"$ & 59997.99 & 51882.57 & 158.3 & 168.3 & 251.4 & 242.0 & -9.4 \\
\hline "HAA & $6 B$ & $"$ & 61771.90 & 50705.33 & 131.3 & 141.4 & 235.7 & 243.2 & 7.5 \\
\hline "HAA & $6 C$ & $"$ & 61781.82 & 50703.43 & 161.1 & 171.1 & 235.9 & 244.2 & 8.3 \\
\hline "HC & $2 C$ & $"$ & 59879.41 & 51458.87 & 135.7 & 140.7 & 253.7 & 241.1 & -12.6 \\
\hline "HC & $2 \mathrm{D}$ & $"$ & 59873.54 & 51460.12 & 178.2 & 183.2 & 255.8 & 243.8 & -12.0 \\
\hline " $\mathrm{HC}$ & $4 \mathrm{~A}$ & $"$ & 61345.81 & 50965.20 & 150.0 & 155.0 & 244.7 & 243.7 & -1.0 \\
\hline " $\mathrm{HC}$ & $6 \mathrm{~A}$ & $"$ & 60139.40 & 51777.79 & 156.2 & 161.2 & 252.2 & 242.3 & -9.9 \\
\hline "HC & $8 \mathrm{C}$ & $"$ & 59297.17 & 57410.38 & 187.3 & 192.3 & 197.5 & 202.2 & 4.7 \\
\hline " $\mathrm{HC}$ & $10 \mathrm{~B}$ & $"$ & 60448.69 & 55444.91 & 164.8 & 169.8 & 208.9 & 209.1 & 0.2 \\
\hline " $\mathrm{HC}$ & $12 \mathrm{~B}$ & " & 57839.58 & 53326.69 & 177.3 & 182.3 & 240.8 & 233.8 & -7.0 \\
\hline " $\mathrm{HCA}$ & $4 \mathrm{~B}$ & $"$ & 61082.03 & 51968.88 & 126.6 & 136.6 & 245.9 & 234.8 & -11.1 \\
\hline "HCA & $4 \mathrm{C}$ & $"$ & 61071.73 & 51970.96 & 153.8 & 163.8 & 246.6 & 243.1 & -3.5 \\
\hline "HIW & $2 \mathrm{MC}$ & & 55118.76 & 53945.40 & 154.0 & 184.0 & 226.7 & 223.1 & -3.6 \\
\hline "HIW & $2 \mathrm{MC}$ & & 55118.76 & 53945.40 & 124.1 & 139.0 & 226.7 & 222.2 & -4.5 \\
\hline "HIW & $4 M C$ & & 54979.48 & 53907.23 & 150.4 & 180.4 & 219.7 & 222.1 & 2.4 \\
\hline "HIW & $4 M C$ & & 54979.48 & 53907.23 & 120.8 & 135.7 & 219.7 & 221.2 & 1.5 \\
\hline "HIW & $5 M C$ & & 54992.54 & 54311.14 & 154.2 & 184.1 & 227.8 & 223.3 & -4.5 \\
\hline "HIW & $5 M C$ & & 54992.54 & 54311.14 & 124.4 & 139.2 & 227.8 & 222.4 & -5.4 \\
\hline " HMD & $1 D$ & " & 56532.27 & 59273.24 & 199.7 & 219.7 & 209.5 & 214.6 & 5.1 \\
\hline "HMD & $2 \mathrm{D}$ & $"$ & 57016.40 & 60125.31 & 190.8 & 210.8 & 200.7 & 198.5 & -2.2 \\
\hline "HMD & $3 \mathrm{D}$ & $"$ & 57463.40 & 59941.25 & 187.7 & 207.7 & 200.1 & 196.5 & -3.6 \\
\hline " HMD & $4 D$ & $"$ & 57810.04 & 59439.92 & 188.9 & 208.9 & 199.6 & 198.8 & -0.8 \\
\hline "HSB & $50 \mathrm{PC}$ & 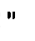 & 53911.20 & 53112.98 & 119.5 & 169.6 & 218.0 & 209.7 & -8.3 \\
\hline "HSB & $65 B$ & $"$ & 56659.37 & 52819.69 & 123.3 & 133.3 & 224.3 & 226.7 & 2.4 \\
\hline "HSB & $68 B$ & $"$ & 54944.81 & 52243.48 & 123.5 & 134.5 & 216.6 & 212.4 & -4.2 \\
\hline "HSB & $68 \mathrm{C}$ & $"$ & 54935.32 & 52244.06 & 168.4 & 179.5 & 217.6 & 212.5 & -5.1 \\
\hline "HSB & $70 \mathrm{C}$ & $"$ & 54067.23 & 53525.76 & 164.9 & 174.9 & 223.2 & 214.1 & -9.1 \\
\hline "HSB & $71 \mathrm{C}$ & $"$ & 53658.01 & 53888.06 & 171.9 & 181.9 & 222.6 & 212.5 & -10.1 \\
\hline "HSB & $83 B$ & $"$ & 56643.90 & 51998.97 & 121.2 & 132.1 & 222.8 & 223.0 & 0.2 \\
\hline "HSB & $83 C$ & $"$ & 56662.80 & 51992.19 & 160.2 & 171.2 & 224.6 & 223.9 & -0.7 \\
\hline "HSB & $84 \mathrm{~B}$ & $"$ & 54442.86 & 52429.71 & 121.8 & 132.9 & 210.8 & 209.8 & -1.0 \\
\hline "HSB & $84 \mathrm{C}$ & $"$ & 54449.10 & 52422.04 & 170.9 & 181.8 & 213.5 & 210.1 & -3.4 \\
\hline "HSB & $85 B$ & $"$ & 57441.42 & 54027.18 & 133.2 & 143.2 & 233.7 & 230.7 & -3.0 \\
\hline "HSB & $86 \mathrm{~B}$ & $"$ & 54265.95 & 53403.47 & 113.8 & 124.0 & 221.6 & 213.9 & -7.7 \\
\hline "HSB1 & $100 \mathrm{C}$ & $"$ & 56941.86 & 52383.02 & 153.0 & 163.0 & 226.5 & 227.6 & 1.1 \\
\hline "HSBI & $100 \mathrm{PC}$ & $: "$ & 53918.88 & 53006.25 & 117.6 & 167.7 & 217.2 & 209.1 & -8.1 \\
\hline "HSB1 & $101 \mathrm{C}$ & $"$ & 56728.52 & 52351.38 & 166.3 & 176.3 & 225.5 & 226.6 & 1.1 \\
\hline "HSB1 & $102 C$ & $"$ & 56519.60 & 52353.05 & 166.7 & 176.7 & 224.6 & 225.2 & 0.6 \\
\hline "HSB1 & $103 C$ & $"$ & 56369.03 & 52010.68 & 159.2 & 169.2 & 223.3 & 221.8 & -1.5 \\
\hline "HSB1 & $104 \mathrm{C}$ & $"$ & 56088.16 & 51848.43 & 163.5 & 173.5 & 220.6 & 218.5 & -2.1 \\
\hline "HSB1 & $105 \mathrm{C}$ & $"$ & 55908.36 & 51958.72 & 152.2 & 162.2 & 219.6 & 217.9 & -1.7 \\
\hline " HSB1 & $106 \mathrm{C}$ & $"$ & 55738.02 & 52274.64 & 158.7 & 168.7 & 221.7 & 219.1 & -2.6 \\
\hline "HSB1 & $107 \mathrm{C}$ & $"$ & 55518.66 & 52298.37 & 159.3 & 169.3 & 219.3 & 217.7 & -1.6 \\
\hline "HSB1 & $108 C$ & $"$ & 55246.16 & 52346.27 & 186.0 & 196.0 & 218.5 & 216.9 & -1.6 \\
\hline "HSB1 & $109 C$ & $"$ & 54991.13 & 52396.49 & 168.4 & 178.4 & 218.8 & 214.5 & -4.3 \\
\hline "HSB1 & $110 \mathrm{C}$ & $"$ & 54800.57 & 52533.61 & 171.4 & 181.4 & 219.1 & 214.2 & -4.9 \\
\hline "HSB1 & $111 \mathrm{C}$ & $"$ & 54654.81 & 52707.82 & 140.7 & 150.7 & 220.3 & 213.4 & -6.9 \\
\hline "HSB1 & $112 \mathrm{C}$ & $"$ & 54621.43 & 52957.21 & 140.6 & 150.6 & 221.6 & 214.8 & -6.8 \\
\hline "HSB1 & $113 \mathrm{C}$ & $"$ & 54402.46 & 53163.13 & 154.7 & 164.7 & 221.9 & 214.6 & -7.3 \\
\hline "HSB1 & $113 C$ & $"$ & 54402.46 & 53163.13 & 151.7 & 161.7 & 221.9 & 214.5 & -7.4 \\
\hline "HSB1 & $114 \mathrm{C}$ & $"$ & 54381.89 & 53323.21 & 185.6 & 195.6 & 223.4 & 216.7 & -6.7 \\
\hline "HSB1 & $115 \mathrm{C}$ & $"$ & 54358.70 & 53520.95 & 182.8 & 192.8 & 224.4 & 217.2 & -7.2 \\
\hline "HSB1 & $116 \mathrm{C}$ & $"$ & 54354.62 & 53761.97 & 180.5 & 190.5 & 225.0 & 218.1 & -6.9 \\
\hline "HSB1 & $117 \mathrm{C}$ & $"$ & 53515.83 & 53789.56 & 165.1 & 175.1 & 221.6 & 210.5 & -11.1 \\
\hline "HSB1 & $125 \mathrm{C}$ & $"$ & 56613.57 & 51866.38 & 145.6 & 155.6 & 223.3 & 222.4 & -0.9 \\
\hline
\end{tabular}


Table F-2. Summary of Group Statistical Parameters (Continued)

\begin{tabular}{|c|c|c|c|c|c|c|c|c|c|}
\hline \multicolumn{2}{|c|}{ "HSB126C } & " & 55047.77 & 51303.73 & 176.3 & 181.3 & 203.9 & 205.7 & 1.8 \\
\hline \multicolumn{2}{|c|}{ "HSB127C } & $"$ & 54791.20 & 51953.68 & 148.4 & 158.4 & 210.3 & 209.1 & -1.2 \\
\hline \multicolumn{2}{|c|}{ "HSB129C } & $"$ & 53274.82 & 52910.16 & 147.8 & 157.8 & 205.8 & 202.8 & -3.0 \\
\hline \multicolumn{2}{|c|}{ "HSB130C } & $"$ & 52596.56 & 51962.46 & 159.9 & 169.9 & 199.9 & 203.0 & 3.1 \\
\hline \multicolumn{2}{|c|}{ "HSB131C } & $"$ & 54718.06 & 51115.16 & 148.5 & 158.5 & 203.9 & 206.1 & 2.2 \\
\hline \multicolumn{2}{|c|}{ "HSB132C } & $"$ & 56797.72 & 51795.34 & 168.6 & 178.6 & 221.6 & 223.9 & 2.3 \\
\hline \multicolumn{2}{|c|}{ "HSB133C } & $"$ & 57212.47 & 52194.94 & 173.3 & 183.3 & 230.6 & 229.6 & $-1 \cdot 0$ \\
\hline \multicolumn{2}{|c|}{ "HSB134C } & $"$ & 56256.31 & 51642.47 & 149.1 & 159.1 & 220.9 & 218.1 & -2.8 \\
\hline \multicolumn{2}{|c|}{ "HSB135C } & $"$ & 54602.40 & 52177.94 & 147.3 & 157.3 & 206.7 & 209.3 & 2.6 \\
\hline \multicolumn{2}{|c|}{ "HSB136C } & $"$ & 54110.61 & 52803.97 & 160.5 & 170.5 & 217.5 & 209.7 & -7.8 \\
\hline \multicolumn{2}{|c|}{ "HSB137C } & $"$ & 53943.50 & 53217.34 & 163.8 & 173.8 & 220.2 & 211.1 & -9.1 \\
\hline \multicolumn{2}{|c|}{ "HSB139C } & $"$ & 55344.17 & 51754.05 & 148.5 & 158.5 & 214.5 & 212.0 & -2.5 \\
\hline \multicolumn{2}{|c|}{ "HSB140C } & $"$ & 54314.78 & 50868.11 & 161.6 & 171.6 & 204.2 & 206.6 & 2.4 \\
\hline \multicolumn{3}{|c|}{ "HSB141C" } & 57114.54 & 51446.14 & 154.7 & 164.7 & 228.8 & 224.9 & -3.9 \\
\hline "HSBI & $141 \mathrm{CR}$ & & 57117.85 & 51476.11 & 152.1 & 162.1 & 229.5 & 224.9 & -4.6 \\
\hline "HSB] & $.42 \mathrm{C}$ & $"$ & 51973.10 & 54504.23 & 161.6 & 171.6 & 198.3 & 195.0 & -3.3 \\
\hline "HSB] & $43 C$ & $"$ & 51385.74 & 55262.11 & 169.1 & 179.1 & 209.3 & 198.8 & -10.5 \\
\hline "HSB1 & $45 \mathrm{C}$ & $"$ & 55723.63 & 51641.80 & 164.7 & 174.7 & 213.4 & 213.5 & 0.1 \\
\hline "HSB1 & $46 \mathrm{C}$ & $"$ & 56281.92 & 50881.82 & 152.3 & 162.3 & 209.9 & 214.6 & 4.7 \\
\hline "HSB1 & $48 \mathrm{C}$ & $"$ & 53154.84 & 51219.25 & 158.9 & 168.9 & 201.7 & 207.8 & 6.1 \\
\hline "HSB1 & $50 \mathrm{PC}$ & & 53783.65 & 53217.07 & 119.5 & 169.6 & 218.1 & 209.2 & -8.9 \\
\hline "HSB1 & $51 \mathrm{C}$ & $"$ & 52446.39 & 54279.83 & 170.6 & 180.6 & 207.9 & 199.8 & -8.1 \\
\hline "HSB] & $52 \mathrm{C}$ & $"$ & 52565.96 & 53246.49 & 173.1 & 183.1 & 199.0 & 196.6 & -2.4 \\
\hline "HSL & $6 C$ & $"$ & 58757.86 & 52600.50 & 157.6 & 167.6 & 245.2 & 237.3 & -7.9 \\
\hline "HSL & $8 B$ & $"$ & 59331.52 & 52522.22 & 138.7 & 148.7 & 249.0 & 238.5 & -10.5 \\
\hline "HSL & $8 \mathrm{C}$ & $"$ & 59330.38 & 52512.54 & 171.7 & 181.7 & 250.2 & 239.8 & -10.4 \\
\hline " LAW & $1 E$ & $"$ & 43173.25 & 27178.90 & 90.1 & 95.1 & 205.0 & 205.3 & 0.3 \\
\hline "LCO & $5 c$ & $"$ & 43558.27 & 27533.91 & 110.5 & 120.5 & 211.0 & 209.7 & $-1 \cdot 3$ \\
\hline "NPM & $19 D$ & $"$ & 53834.94 & 43723.45 & 97.5 & 107.5 & 243.1 & 250.7 & 7.6 \\
\hline "NPM & $34 D$ & $"$ & 52189.19 & 41815.02 & 86.4 & 96.4 & 253.7 & 250.9 & -2.8 \\
\hline " TBG & 1 & $"$ & 16046.02 & 60413.52 & 89.1 & 109.1 & 100.6 & 106.7 & 6.1 \\
\hline "TBG & 3 & $"$ & 16066.17 & 60301.49 & 88.9 & 108.9 & 103.1 & 107.8 & 4.7 \\
\hline "TBG & 4 & $"$ & 16054.32 & 60245.73 & 89.3 & 109.3 & 103.1 & 108.1 & 5.0 \\
\hline "TBG & 5 & $"$ & 16218.81 & 60169.26 & 92.4 & 112.4 & 102.6 & 110.4 & 7.8 \\
\hline "TBG & $5 A$ & $"$ & 16209.14 & 60151.18 & 70.0 & 80.0 & 103.9 & 110.1 & 6.2 \\
\hline "TBG & 6 & $"$ & 16209.40 & 60432.78 & 89.1 & 109.1 & 102.7 & 108.5 & 5.8 \\
\hline "TBG & 7 & $"$ & 16423.15 & 60199.44 & 84.7 & 104.7 & 105.5 & 112.3 & 6.8 \\
\hline "TIR & $1 \mathrm{M}$ & $"$ & 15018.24 & 60217.55 & 84.6 & 86.6 & 93.9 & 95.7 & 1.8 \\
\hline "TIR & 10 & $"$ & 15020.04 & 60222.14 & 90.0 & 92.0 & 93.2 & 95.7 & 2.5 \\
\hline "TIR & 2 & $"$ & 14955.26 & 60276.45 & 84.2 & 86.2 & 92.4 & 95.0 & 2.6 \\
\hline "TIR & $3 \mathrm{~B}$ & $"$ & 15378.85 & 60217.52 & 83.5 & 85.5 & 95.8 & 100.0 & 4.2 \\
\hline "TNX & ID & $"$ & 15658.69 & 60683.97 & 79.6 & 99.6 & 99.4 & 101.1 & 1.7 \\
\hline " TNX & $2 D$ & $"$ & 15711.77 & 60507.57 & 82.8 & 102.8 & 99.3 & 102.4 & 3.1 \\
\hline "TNX & $3 D$ & $"$ & 15916.34 & 60243.98 & 84.9 & 104.9 & 99.8 & 106.4 & 6.6 \\
\hline "TNX & $4 \mathrm{D}$ & $"$ & 16043.66 & 59977.69 & 85.5 & 105.5 & 103.1 & 109.9 & 6.8 \\
\hline "TNX & $5 D$ & $"$ & 16179.74 & 59941.20 & 88.5 & 108.5 & 105.0 & 111.4 & 6.4 \\
\hline "TNX & $6 \mathrm{D}$ & $"$ & 16185.59 & 59656.06 & 89.8 & 109.8 & 105.3 & 112.7 & 7.4 \\
\hline "TNX & $7 \mathrm{D}$ & $"$ & 16057.27 & 60726.63 & 83.6 & 103.6 & 101.2 & 104.8 & 3.6 \\
\hline "TNX & $8 D$ & $"$ & 14926.59 & 59795.15 & 74.0 & 94.0 & 94.0 & 95.5 & 1.5 \\
\hline "TNX & $9 \mathrm{D}$ & $"$ & 14946.06 & 59994.97 & 75.4 & 95.1 & 93.8 & 95.3 & 1.5 \\
\hline " TNX & $10 \mathrm{D}$ & $"$ & 15009.73 & 60193.98 & 77.0 & 95.9 & 94.1 & 95.7 & 1.6 \\
\hline “TNX & $11 D$ & $"$ & 15050.14 & 60389.86 & 73.2 & 93.2 & 94.1 & 95.8 & 1.7 \\
\hline " TNX & $12 \mathrm{D}$ & $"$ & 15143.66 & 60777.90 & 73.1 & 93.1 & 95.0 & 94.8 & -0.2 \\
\hline "TNX & $13 \mathrm{D}$ & $"$ & 14754.11 & 60087.50 & 87.9 & 89.9 & 92.0 & 93.4 & 1.4 \\
\hline "TNX. & $14 \mathrm{D}$ & $"$ & 14804.37 & 60168.63 & 85.8 & 87.8 & 92.1 & 93.8 & 1.7 \\
\hline "TNX & $15 D$ & $"$ & 14853.26 & 60249.53 & 85.9 & 87.9 & 91.7 & 94.2 & 2.5 \\
\hline " TNX & $16 \mathrm{D}$ & $"$ & 14881.89 & 60335.66 & 86.1 & 88.1 & 91.5 & 94.3 & 2.8 \\
\hline "TNX & $17 D$ & $"$ & 15014.56 & 60790.52 & 89.7 & 91.7 & 93.3 & 92.6 & -0.7 \\
\hline "TNX. & $18 \mathrm{D}$ & $"$ & 14694.70 & 60004.24 & 84.9 & 86.9 & 91.7 & 93.1 & 1.4 \\
\hline "TNX & 190 & $"$ & 14620.92 & 59895.70 & 84.9 & 86.9 & 91.5 & 92.6 & 1.1 \\
\hline
\end{tabular}


Table F-2. Summary of Group Statistical Parameters (Continued)

\begin{tabular}{|c|c|c|c|c|c|c|c|c|c|}
\hline "TNX & $20 \mathrm{D}$ & $"$ & 14589.19 & 59853.68 & 86.2 & 88.2 & 91.5 & 92.4 & 0.9 \\
\hline "TNX & $21 D$ & $"$ & 14568.94 & 59722.83 & 86.9 & 88.9 & 91.8 & 92.3 & 0.5 \\
\hline "TNX & $22 D$ & $"$ & 14440.30 & 59482.22 & 85.8 & 87.8 & 90.2 & 91.5 & 1.3 \\
\hline "TNX & $23 D$ & $"$ & 15839.74 & 60442.04 & 84.8 & 104.8 & 99.3 & 104.2 & 4.9 \\
\hline "TNX & $24 D$ & $"$ & 16459.51 & 60435.43 & 99.8 & 114.8 & 109.0 & 111.6 & 2.6 \\
\hline "TNX & $26 D$ & $"$ & 14972.66 & 59614.12 & 87.8 & 90.1 & 94.2 & 96.3 & 2.1 \\
\hline "TNX & $27 D$ & $"$ & 15480.09 & 60278.84 & 81.3 & 101.3 & 96.4 & 101.1 & 4.7 \\
\hline " TRW & 1 & $"$ & 15806.97 & 60191.68 & 81.4 & 106.4 & 93.4 & 105.5 & 12.1 \\
\hline "TRW & 2 & $"$ & 15687.03 & 60316.14 & 77.2 & 112.2 & 94.0 & 103.2 & 9.2 \\
\hline "XSB & 1 & $"$ & 15755.80 & 60172.19 & 92.0 & 112.0 & 102.8 & 105.0 & 2.2 \\
\hline "XsB & $1 B$ & $"$ & 15722.48 & 60150.55 & 64.6 & 74.6 & 102.7 & 102.8 & 0.1 \\
\hline "XSB & $1 D$ & $"$ & 15742.58 & 60146.07 & 87.9 & 107.9 & 99.0 & 105.0 & 6.0 \\
\hline "XSB & $2 D$ & $"$ & 15669.81 & 60142.32 & 84.0 & 104.0 & 98.5 & 104.1 & 5.6 \\
\hline "XSB & $3 \mathrm{~A}$ & $"$ & 15710.81 & 59959.09 & 87.4 & 103.2 & 99.8 & 105.7 & 5.9 \\
\hline "XSB & 4 & $"$ & 15684.42 & 60076.34 & 94.3 & 114.3 & 98.3 & 104.7 & 6.4 \\
\hline "XSB & $4 D$ & $"$ & 15654.53 & 60055.50 & 83.9 & 103.9 & 98.6 & 104.4 & 5.8 \\
\hline "YSB & $1 \mathrm{~A}$ & $"$ & 16649.82 & 60011.91 & 98.4 & 128.4 & 118.3 & 115.6 & -2.7 \\
\hline "YSB & $2 \mathrm{~A}$ & $"$ & 16658.67 & 59854.43 & 97.7 & 127.7 & 119.2 & 116.4 & -2.8 \\
\hline "YSB & $3 \mathrm{~A}$ & $"$ & 16534.35 & 59726.48 & 96.7 & 126.7 & 119.4 & 115.8 & -3.6 \\
\hline "YSB & $4 \mathrm{~A}$ & $"$ & 16552.90 & 59887.85 & 97.6 & 127.6 & 118.1 & 115.3 & -2.8 \\
\hline "YSC & $1 \mathrm{C}$ & $"$ & 65106.95 & 56892.95 & 197.5 & 207.5 & 217.4 & 213.6 & -3.8 \\
\hline "YSC & $4 C$ & $"$ & 64918.13 & 55781.42 & 195.9 & 205.9 & 227.5 & 223.8 & -3.7 \\
\hline "Z & 17 & $"$ & 42299.33 & 55683.19 & 148.2 & 148.7 & 169.2 & 168.3 & -0.9 \\
\hline$" \mathrm{ZW}$ & 2 & $"$ & 54413.69 & 61737.37 & 194.8 & 204.8 & 207.1 & 199.9 & -7.2 \\
\hline "CMP & $10 \mathrm{C}$ & $"$ & 47936.35 & 33160.82 & 179.6 & 189.6 & 198.5 & 212.7 & 14.2 \\
\hline "CMP & $30 \mathrm{~B}$ & $"$ & 47195.03 & 33652.79 & 97.4 & 107.5 & 195.0 & 207.0 & 12.0 \\
\hline "CMP & $30 \mathrm{C}$ & $"$ & 47233.06 & 33633.06 & 179.5 & 189.5 & 210.6 & 208.2 & -2.4 \\
\hline "CMP & $32 B$ & $"$ & 48163.49 & 33948.09 & 97.7 & 107.7 & 195.3 & 207.0 & 11.7 \\
\hline "CMP & $32 \mathrm{C}$ & $"$ & 48170.49 & 33941.09 & 185.2 & 195.2 & 195.4 & 208.6 & 13.2 \\
\hline \multicolumn{2}{|c|}{ ** GROUP } & 3 & $\begin{array}{l}\text { rms of } \\
\text { avg of } \\
\text { avg of } \\
\text { max of }\end{array}$ & $\begin{array}{l}\text { (FACT-data) } \\
\text { (FACT-data) } \\
\text { |FACT-data| } \\
\text { \{FACT-data }\end{array}$ & \multicolumn{2}{|c|}{$\begin{array}{l}\text { differences: } \\
\text { differences: } \\
\text { differences: } \\
\text { differences: }\end{array}$} & \multicolumn{2}{|c|}{$\begin{array}{r}5.061 \\
0.155 \\
3.830 \\
16.291\end{array}$} & \\
\hline "BG & 26 & $"$ & 57336.11 & 54222.44 & 210.7 & 230.7 & 239.3 & 238.7 & -0.6 \\
\hline "BG & 27 & $"$ & 57419.22 & 54611.98 & 234.4 & 254.4 & 240.9 & 238.5 & -2.4 \\
\hline "BG & 28 & $"$ & 57501.60 & 54998.60 & 239.7 & 259.7 & 247.1 & 0.0 & -247.1 \\
\hline "BG & 29 & $"$ & 57584.39 & 55389.53 & 231.6 & 251.6 & 245.0 & 234.8 & -10.2 \\
\hline "BG & 30 & $"$ & 57666.46 & 55779.48 & 231.7 & 251.7 & 237.5 & 233.9 & -3.6 \\
\hline "BG & 31 & $"$ & 57744.30 & 56171.67 & 223.3 & 243.3 & 233.7 & 232.6 & -1.1 \\
\hline "BG & 32 & $"$ & 57827.27 & 56562.97 & 226.9 & 246.9 & 233.4 & 231.3 & -2.1 \\
\hline "BG & 33 & $"$ & 57582.86 & 56747.83 & 221.2 & 241.2 & 232.9 & 231.4 & -1.5 \\
\hline "BG & 34 & $"$ & 57176.26 & 56848.26 & 217.4 & 237.4 & 232.8 & 231.7 & -1.1 \\
\hline "BG & 35 & " & 56803.94 & 56929.14 & 228.0 & 248.0 & 232.9 & 231.7 & -1.2 \\
\hline "BG & 36 & $"$ & 56752.61 & 57197.98 & 223.3 & 243.3 & 232.5 & 231.7 & -0.8 \\
\hline "BG & 37 & $"$ & 56403.29 & 57330.81 & 227.8 & 247.8 & 232.9 & 232.2 & -0.7 \\
\hline "BG & 38 & $"$ & 56012.15 & 57414.05 & 225.9 & 245.9 & 232.3 & 232.8 & 0.5 \\
\hline "BG & 39 & $"$ & 55621.07 & 57497.08 & 226.0 & 246.0 & 231.7 & 233.4 & 1.7 \\
\hline "BG & 40 & $"$ & 55229.56 & 57580.50 & 221.9 & 241.9 & 231.4 & 233.1 & 1.7 \\
\hline "BG & 41 & $"$ & 55003.77 & 57394.58 & 221.0 & 241.0 & 230.8 & 232.4 & 1.6 \\
\hline "BG & 42 & $"$ & 54921.81 & 57005.62 & 217.1 & 237.1 & 230.7 & 230.2 & -0.5 \\
\hline "BG & 43 & $"$ & 55020.15 & 56651.13 & 222.9 & 242.9 & 230.5 & 230.6 & 0.1 \\
\hline "BG & 51 & $"$ & 57110.74 & 54174.14 & 221.2 & 241.2 & 240.7 & 238.6 & -2.1 \\
\hline "BG & 52 & $"$ & 54528.35 & 56814.86 & 223.8 & 243.8 & 229.1 & 230.1 & 1.0 \\
\hline "BG & 53 & $"$ & 54139.12 & 57150.01 & 214.7 & 234.7 & 228.0 & 230.0 & 2.0 \\
\hline "BG & 54 & $"$ & 53834.44 & 56888.23 & 215.2 & 235.2 & 228.4 & 228.5 & 0.1 \\
\hline "BG & 55 & $"$ & 53534.89 & 56632.32 & 214.9 & 234.9 & 226.3 & 227.2 & 0.9 \\
\hline " BG & 56 & $"$ & 53362.38 & 56343.07 & 210.9 & 230.9 & 225.0 & 225.9 & 0.9 \\
\hline "BG & 57 & $"$ & 53650.24 & 56071.18 & 214.6 & 234.6 & 225.3 & 225.7 & 0.4 \\
\hline
\end{tabular}


Table F-2. Summary of Group Statistical Parameters (Continued)

\begin{tabular}{|c|c|c|c|c|c|c|c|c|}
\hline "BG & 58 & 53941.50 & 55795.09 & 218.2 & 238.2 & 226.8 & 225.7 & -1.1 \\
\hline "BG & 59 & 54238.88 & 55529.97 & 217.7 & 237.7 & 229.6 & 226.4 & -3.2 \\
\hline "BG & 60 & 54530.35 & 55256.29 & 215.5 & 235.5 & 230.6 & 227.1 & -3.5 \\
\hline "BG & 61 & 54965.05 & 54846.04 & 225.0 & 245.0 & 232.5 & 228.5 & -4.0 \\
\hline "BG & 62 & 55109.85 & 54709.14 & 222.5 & 242.5 & 233.2 & 229.1 & -4.1 \\
\hline "BG & 63 & 55396.89 & 54426.18 & 224.2 & 244.2 & 235.2 & 230.0 & -5.2 \\
\hline "BG & 64 & 55688.22 & 54152.33 & 227.3 & 247.3 & 238.1 & 231.3 & -6.8 \\
\hline "BG & 65 & 55978.13 & 53879.49 & 230.9 & 250.9 & 235.7 & 232.5 & -3.2 \\
\hline "BG & 66 & 56275.73 & 54066.09 & 231.0 & 251.0 & 235.2 & 234.5 & -0.7 \\
\hline "BG & 67 & 56447.94 & 54406.83 & 224.7 & 244.7 & 236.3 & 235.5 & -0.8 \\
\hline "BG & 68 & 57329.68 & 56876.99 & 216.5 & 242.9 & 232.2 & 231.4 & -0.8 \\
\hline "BG & 69 & 57304.98 & 56882.44 & 222.2 & 242.2 & 232.5 & 231.6 & -0.9 \\
\hline "BG & 80 & 57056.01 & 56979.02 & 226.2 & 248.6 & 232.7 & 232.0 & -0.7 \\
\hline "BG & 81 & 57081.25 & 57000.00 & 222.9 & 246.9 & 227.3 & 231.9 & 4.6 \\
\hline "BG & 84 & 57069.64 & 57077.74 & 227.2 & 247.2 & 232.6 & 231.9 & -0.7 \\
\hline "BG & 85 & 57048.52 & 57105.85 & 228.0 & 248.0 & 232.6 & 231.9 & -0.7 \\
\hline "BG & 86 & 57098.42 & 57097.69 & 228.0 & 248.0 & 232.5 & 231.8 & -0.7 \\
\hline "BG & 87 & 57077.23 & 57130.31 & 226.2 & 245.8 & 232.3 & 231.8 & -0.5 \\
\hline "BG & 98 & 56712.64 & 58075.77 & 212.5 & 242.5 & 224.5 & 227.9 & 3.4 \\
\hline "BG & 99 & 57551.92 & 57188.59 & 215.9 & 245.9 & 232.5 & 230.0 & -2.5 \\
\hline "BG & 100 & 58225.51 & 57976.77 & 203.3 & 233.3 & 224.8 & 216.3 & -8.5 \\
\hline "BG & 104 & 59031.30 & 57011.34 & 215.8 & 245.8 & 224.8 & 220.4 & -4.4 \\
\hline "BG & 107 & 58793.60 & 54776.73 & 208.3 & 228.3 & 235.3 & 233.0 & -2.3 \\
\hline "BG & 108 & 58420.34 & 54426.07 & 217.3 & 247.3 & 238.8 & 238.8 & 0.0 \\
\hline "BG & 109 & 58127.98 & 54021.21 & 228.4 & 258.4 & 240.1 & 241.9 & 1.8 \\
\hline "BG & 110 & 57667.88 & 53534.74 & 224.3 & 254.3 & 241.2 & 242.6 & 1.4 \\
\hline " BGO & $1 D$ & 57260.53 & 54013.08 & 225.0 & 245.0 & 237.9 & 239.7 & 1.8 \\
\hline " BGO & $2 \mathrm{D}$ & 57459.71 & 54803.95 & 218.9 & 238.9 & 238.0 & 237.3 & -0.7 \\
\hline "BGO & $3 \mathrm{D}$ & 57625.22 & 55585.01 & 227.6 & 247.6 & 235.5 & 234.1 & -1.4 \\
\hline "BGO & 3DR' & 57669.26 & 55740.24 & 217.5 & 237.6 & 231.8 & 233.6 & 1.8 \\
\hline " BGO & $4 D$ & 57785.92 & 56367.50 & 220.6 & 240.6 & 231.8 & 231.8 & 0.0 \\
\hline "BGO & $5 D$ & 57835.51 & 56691.67 & 219.3 & 239.3 & 230.4 & 230.6 & 0.2 \\
\hline "BGO & $6 D$ & 57360.50 & 56802.66 & 217.2 & 237.2 & 231.4 & 231.6 & 0.2 \\
\hline "BGO & $7 D$ & 56990.40 & 56888.68 & 220.2 & 240.2 & 232.7 & 231.9 & -0.8 \\
\hline " BGO & $8 D$ & 56717.15 & 57043.17 & 220.6 & 240.6 & 232.7 & 231.4 & -1.3 \\
\hline "BGO & $9 D$ & 56627.61 & 57289.98 & 209.2 & 229.2 & 230.0 & 230.4 & 0.4 \\
\hline "BGO & $10 D$ & 56187.75 & 57376.83 & 230.5 & 250.5 & 231.8 & 232.6 & 0.8 \\
\hline " BGO & 10DR & 56229.85 & 57367.58 & 218.3 & 238.3 & 231.5 & 232.0 & 0.5 \\
\hline "BGO & $11 D$ & 55816.74 & 57455.69 & 216.3 & 236.3 & 230.7 & 231.9 & 1.2 \\
\hline "BGO & $12 D$ & 55405.74 & 57543.15 & 217.8 & 237.8 & 231.3 & 232.3 & 1.0 \\
\hline " BGO & $13 D$ & 55023.21 & 57624.57 & 228.5 & 248.5 & 231.0 & 233.6 & 2.6 \\
\hline " BGO & $14 \mathrm{DR}$ & 54873.25 & 57162.45 & 218.1 & 238.1 & 230.4 & 231.0 & 0.6 \\
\hline " BGO & $15 D$ & 54868.95 & 56806.97 & 218.7 & 238.7 & 229.7 & 230.3 & 0.6 \\
\hline "BGO & $16 D$ & 55158.28 & 56518.41 & 217.3 & 237.3 & 230.8 & 230.5 & -0.3 \\
\hline " BGO & 17DR & 55328.25 & 56331.59 & 216.9 & 236.9 & 232.0 & 230.5 & -1.5 \\
\hline "BGO & $18 D$ & 55624.78 & 56264.47 & 219.6 & 239.6 & 231.9 & 231.2 & -0.7 \\
\hline " BGO & $20 D$ & 55885.97 & 55556.90 & 216.3 & 236.3 & 233.9 & 232.9 & -1.0 \\
\hline "BGO & $21 D$ & 56178.17 & 55214.98 & 217.7 & 237.7 & 234.8 & 234.1 & -0.7 \\
\hline " BGO & $22 \mathrm{D}$ & 56474.30 & 54941.13 & 194.2 & 214.2 & 232.6 & 233.3 & 0.7 \\
\hline " BGO & $22 \mathrm{DR}$ & 56485.97 & 54927.71 & 219.2 & 239.2 & 236.0 & 235.4 & -0.6 \\
\hline "BGO & $022 \mathrm{DX}$ & 56445.03 & 55027.38 & 217.9 & 237.9 & 233.9 & 235.1 & 1.2 \\
\hline "BGO & $023 D$ & 56732.35 & 54636.72 & 222.0 & 242.0 & 235.8 & 236.3 & 0.5 \\
\hline "BGO & $O 24 D$ & 56984.54 & 54352.38 & 221.0 & 241.0 & 236.8 & 237.9 & 1.1 \\
\hline " BGO & $26 \mathrm{D}$ & 54075.62 & 57133.55 & 213.4 & 233.5 & 227.7 & 229.6 & 1.9 \\
\hline " BGO & $027 D$ & 53654.23 & 56762.35 & 209.3 & 229.3 & 227.4 & 227.7 & 0.3 \\
\hline "BGO & $028 D$ & 53368.39 & 56486.76 & 210.1 & 230.1 & 226.1 & 226.3 & 0.2 \\
\hline "BGO & $029 D$ & 53068.49 & 56800.16 & 208.5 & 228.5 & 226.1 & 227.9 & 1.8 \\
\hline " BGO & $030 D$ & 53375.39 & 56321.08 & 207.8 & 227.8 & 225.5 & 225.8 & 0.3 \\
\hline "BGO & $031 D$ & 53668.33 & 56051.90 & 211.1 & 231.1 & 226.4 & 225.6 & -0.8 \\
\hline "BGO & $032 D$ & 54014.20 & 55714.31 & 214.5 & 234.5 & 227.5 & 225.9 & -1.6 \\
\hline
\end{tabular}


Table F-2. Summary of Group Statistical Parameters (Continued)

\begin{tabular}{|c|c|c|c|c|c|c|c|c|}
\hline $\mathrm{BGO}$ & $3 \mathrm{D}$ & 54395.96 & 55369.09 & 213.1 & 233.1 & 229.9 & 226.6 & -3.3 \\
\hline & $34 \mathrm{D}$ & 54724.82 & 55053.93 & 212.7 & 232.7 & 232.7 & 227.7 & -5.0 \\
\hline "BGO & $35 \mathrm{D}$ & 55129.57 & 54678.78 & 219.4 & 239.4 & 234.5 & 229.1 & -5.4 \\
\hline "BGO & $36 \mathrm{D}$ & 55411.89 & 54412.06 & 223.3 & 243.3 & 236.6 & 230.1 & -6.5 \\
\hline "BGO & $37 D$ & 55755.24 & 54080.42 & 226.1 & 246.1 & 237.9 & 231.5 & -6.4 \\
\hline "BGO & $38 \mathrm{D}$ & 55980.48 & 53867.44 & 222.3 & 242.3 & 235.2 & 232.3 & -2.9 \\
\hline "BGO & $39 D$ & 56300.85 & 54059.22 & 224.7 & 244.7 & 234.6 & 234.5 & -0.1 \\
\hline "BGO & $40 \mathrm{D}$ & 53706.79 & 57209.70 & 216.6 & 226.5 & 222.2 & 230.3 & 8.1 \\
\hline "BGO & $44 \mathrm{D}$ & 57038.45 & 57149.39 & 223.4 & 233.4 & 232.5 & 231.8 & -0.7 \\
\hline " BGO & $45 D$ & 53598.50 & 56955.15 & 209.6 & 229.6 & 227.7 & 228.8 & 1.1 \\
\hline "BGO & $49 \mathrm{D}$ & 54776.67 & 54738.97 & 218.5 & 238.5 & 234.5 & 228.1 & -6.4 \\
\hline "BGO & $50 \mathrm{D}$ & 53090.30 & 56375.14 & 208.0 & 228.0 & 225.0 & 225.8 & 0.8 \\
\hline "BGO & $51 \mathrm{D}$ & 56440.93 & 54575.88 & 220.1 & 240.1 & 235.2 & 235.3 & 0.1 \\
\hline "BGO & $52 D$ & 55899.95 & 55201.33 & 219.4 & 239.4 & 233.6 & 233.0 & -0.6 \\
\hline "BGO & $53 D$ & 54461.98 & 56977.82 & 225.3 & 245.3 & 229.1 & 231.0 & 1.9 \\
\hline "BGX & $1 D$ & 57732.18 & 57053.05 & 214.7 & 234.7 & 229.5 & 229.6 & 0.1 \\
\hline "BGX & $9 \mathrm{D}$ & 58652.02 & 56986.86 & 212.4 & 232.4 & 226.5 & 224.0 & -2.5 \\
\hline "BGX & $10 \mathrm{D}$ & 58733.61 & 56200.00 & 216.2 & 236.2 & 225.4 & 227.1 & 1.7 \\
\hline "BGX & $11 \mathrm{D}$ & 58370.03 & 55374.96 & 216.7 & 236.7 & 235.3 & 233.3 & -2.0 \\
\hline "BGX & $12 D$ & 58275.90 & 54485.29 & 223.7 & 243.7 & 238.8 & 238.8 & 0.0 \\
\hline "BRD & 1 & 24686.69 & 42660.07 & 148.9 & 178.9 & 167.1 & 177.3 & 10.2 \\
\hline "BRD & 2 & 24812.76 & 42871.28 & 148.5 & 178.5 & 169.3 & 178.1 & 8.8 \\
\hline "BRD & 3 & 24954.28 & 42662.69 & 158.5 & 188.5 & 169.9 & 180.1 & 10.2 \\
\hline " BRD & $5 \mathrm{D}$ & 24681.93 & 42758.41 & 148.4 & 168.4 & 166.8 & 176.9 & 10.1 \\
\hline "BRR & ID & 50002.58 & 59264.14 & 200.4 & 220.4 & 217.1 & 214.2 & -2.9 \\
\hline " BRR. & $2 \mathrm{D}$ & 49740.61 & 59387.51 & 196.1 & 216.1 & 215.5 & 211.7 & -3.8 \\
\hline "BRR & $3 \mathrm{D}$ & 49633.17 & 59376.50 & 197.1 & 217.1 & 215.2 & 211.1 & -4.1 \\
\hline "BRR & $4 \mathrm{D}$ & 49528.48 & 59360.11 & 198.7 & 218.7 & 215.1 & 210.5 & -4.6 \\
\hline "BRR & $5 D$ & 49415.56 & 59288.22 & 202.1 & 222.1 & 214.9 & 210.2 & -4.7 \\
\hline "BRR & $7 D$ & 50143.22 & 59444.34 & 201.9 & 221.9 & 217.9 & 214.5 & -3.4 \\
\hline "BRR & 8DR & 49620.92 & 59613.22 & 204.0 & 219.0 & 214.3 & 209.7 & -4.6 \\
\hline "CBR & $1 \mathrm{D}$ & 48664.46 & 42224.29 & 230.9 & 250.9 & 253.5 & 262.5 & 9.0 \\
\hline "CBR & $2 \mathrm{D}$ & 48528.64 & 42201.43 & 233.8 & 253.8 & 252.9 & 262.1 & 9.2 \\
\hline "CBR & $3 \mathrm{D}$ & 48467.37 & 42234.49 & 234.1 & 254.1 & 253.0 & 261.9 & 8.9 \\
\hline " $\mathrm{CCB}$ & 1 & 44003.41 & 48346.16 & 198.4 & 228.4 & 226.1 & 238.8 & 12.7 \\
\hline " $\mathrm{CCB}$ & 2 & 43881.49 & 48236.71 & 198.6 & 228.6 & 222.5 & 238.8 & 16.3 \\
\hline " $\mathrm{CCB}$ & 3 & 43967.36 & 48097.21 & 205.6 & 235.6 & 225.1 & 239.8 & 14.7 \\
\hline "CCB & 4 & 44164.05 & 48180.84 & 211.2 & 241.2 & 226.1 & 240.3 & 14.2 \\
\hline "CDB & 1 & 43158.97 & 50648.13 & 195.7 & 216.6 & 213.9 & 223.6 & 9.7 \\
\hline "CDB & 2 & 43072.00 & 50565.10 & 195.1 & 216.1 & 214.9 & 223.7 & 8.8 \\
\hline "CMP & $11 D$ & 47610.19 & 33296.80 & 209.5 & 229.9 & 221.2 & 234.4 & 13.2 \\
\hline "CMP & $14 \mathrm{D}$ & 46762.01 & 34392.70 & 204.1 & 224.5 & 216.2 & 211.6 & -4.6 \\
\hline "CMP & $15 \mathrm{C}$ & 46865.00 & 33346.32 & 220.6 & 250.6 & 239.6 & 234.5 & -5.1 \\
\hline "CMP & $16 \mathrm{C}$ & 47835.75 & 33352.73 & 215.6 & 235.6 & 223.5 & 233.7 & 10.2 \\
\hline "CMP & 30D & 47226.07 & 33625.65 & 211.6 & 231.6 & 221.1 & 228.8 & 7.7 \\
\hline "CMP & $32 \mathrm{D}$ & 48177.29 & 33934.12 & 218.6 & 228.6 & 220.9 & 0.0 & -220.9 \\
\hline "CRP & 1 & 42103.71 & 52000.00 & 187.8 & 217.8 & 207.9 & 207.9 & 0.0 \\
\hline "CRP & 2 & 42157.12 & 52423.62 & 171.8 & 201.8 & 207.1 & 204.3 & -2.8 \\
\hline "CRP & 3 & 41750.56 & 52124.11 & 184.0 & 214.0 & 207.8 & 204.7 & -3.1 \\
\hline "CRP & $3 \mathrm{D}$ & 41768.04 & 52149.12 & 194.3 & 214.3 & 207.4 & 204.7 & -2.7 \\
\hline "CRP & 4 & 41803.23 & 51889.94 & 180.7 & 210.7 & 207.9 & 206.9 & -1.0 \\
\hline "CRP & $5 \mathrm{D}$ & 42229.13 & 51903.38 & 194.6 & 214.6 & 211.6 & 209.5 & -2.1 \\
\hline "CRP & $6 \mathrm{DR}$ & 41693.10 & 51774.41 & 194.2 & 214.2 & 210.5 & 207.3 & -3.2 \\
\hline "CRP & $7 \mathrm{D}$ & 41940.04 & 52626.90 & 188.0 & 208.0 & 206.5 & 201.4 & -5.1 \\
\hline "CRP & $8 \mathrm{D}$ & 41435.10 & 52175.72 & 191.0 & 211.0 & 207.6 & 202.3 & -5.3 \\
\hline "CRP & $9 \mathrm{D}$ & 42089.59 & 52554.22 & 191.4 & 211.4 & 207.1 & 203.0 & -4.1 \\
\hline "CRP & $10 D$ & 41567.41 & 52504.81 & 189.5 & 209.5 & 205.0 & 200.3 & -4.7 \\
\hline "CRP & $11 D$ & 41920.37 & 52137.09 & 193.7 & 203.6 & 206.9 & 205.7 & -1.2 \\
\hline "CSA. & 1 & 46385.49 & 44128.63 & 232.0 & 262.0 & 243.3 & 255.9 & 12.6 \\
\hline "CSA & 2 & 46396.93 & 44078.56 & 218.2 & 248.2 & 243.7 & 255.7 & 12.0 \\
\hline
\end{tabular}


Table F-2. Summary of Group Statistical Parameters (Continued)

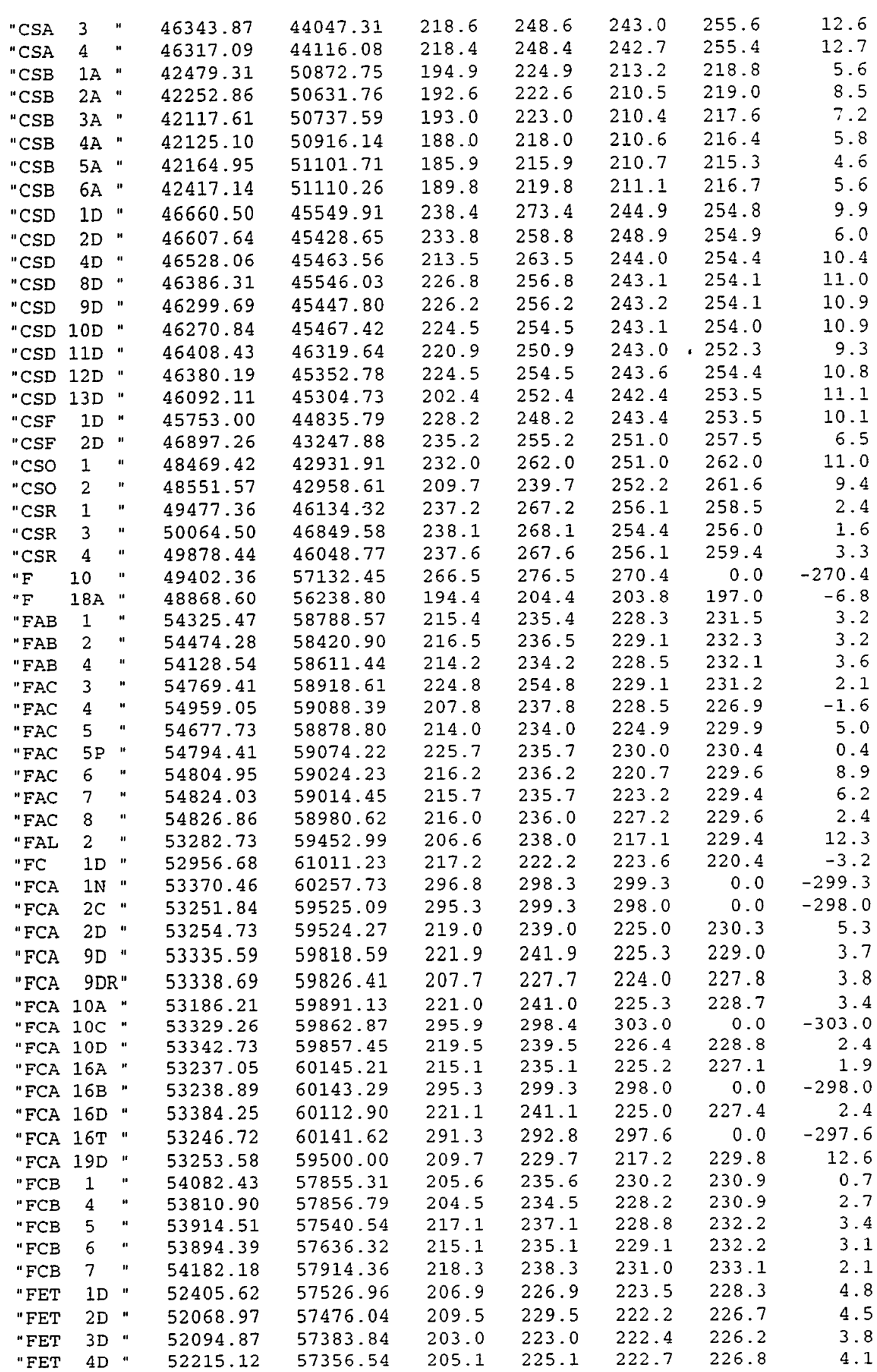


Table F-2. Summary of Group Statistical Parameters (Continued)

\begin{tabular}{|c|c|c|c|c|c|c|c|c|c|}
\hline "FIW & 1D" & $"$ & 50556.26 & 57868.22 & 198.9 & 218.9 & 214.7 & 218.6 & 3.5 \\
\hline "EIW & 1ID" & & 50511.80 & 57935.64 & 194.0 & 214.0 & 216.6 & 218.3 & 1 \\
\hline "FIW & $2 \mathrm{MD} "$ & & 50305.99 & 57737.40 & 190.9 & 220.8 & 215.2 & 216.6 & \\
\hline "FOB & 1D" & $"$ & 48714.66 & 55906.09 & 175.4 & 195.4 & 203.4 & 190.7 & -12 \\
\hline FOB & $2 \mathrm{D} "$ & $"$ & 48260.19 & 56167.31 & 175.5 & 195.5 & 204.7 & 192.2 & -12 \\
\hline$F O B$ & $3 D "$ & $"$ & 47858.85 & 56421.32 & 183.4 & 203.4 & 205.0 & 194.9 & -10 \\
\hline "FOB & $4 D "$ & $"$ & 48169.62 & 56653.25 & 174.0 & 194.1 & 206.0 & 198.9 & 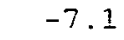 \\
\hline "FOB & $7 \mathrm{D}$ & $"$ & 49400.09 & 58083.79 & 193.9 & 213.9 & 211.7 & 212.4 & \\
\hline FOB & $8 \mathrm{D}$ & $"$ & 49037.51 & 57840.62 & 191.4 & 211.4 & 210.6 & 209.9 & \\
\hline$F O B$ & $9 D "$ & $"$ & 49862.03 & 57668.28 & 192.6 & 212.6 & 213.1 & 214.0 & \\
\hline "FOB & $11 D "$ & $"$ & 50928.38 & 57265.56 & 199.0 & 219.0 & 216.1 & 218.9 & \\
\hline "FOB & $12 \mathrm{D}$ & $"$ & 48850.11 & 57700.96 & 179.3 & 199.3 & 209.8 & 208.0 & \\
\hline "FRB & 4 & $"$ & 52732.71 & 57366.03 & 214.6 & 229.6 & 223.0 & 229.3 & \\
\hline "FSB & OPD" & & 48694.84 & 56663.20 & 171.6 & 215.3 & 207.4 & 201.7 & \\
\hline "FSB & 50PD" & & 48729.85 & 56708.61 & 174.7 & 219.8 & 207.1 & 202.4 & \\
\hline "FSB & 76 & " & 50531.29 & 57900.83 & 197.0 & 227.0 & 217.8 & 218.5 & \\
\hline "FSB & 77 & $"$ & 49659.91 & 57051.23 & 186.4 & 216.4 & 212.0 & 210.2 & -1 \\
\hline "FSB & 78 & $"$ & 49047.52 & 56807.83 & 187.7 & 217.7 & 208.5 & 205.3 & -3 \\
\hline "FSB & 79 & " & 48794.18 & 55736.19 & 174.1 & 204.1 & 201.9 & 189.5 & -12 \\
\hline "FSB & $87 \mathrm{D}$ & $"$ & 49136.71 & 57629.55 & 187.4 & 216.8 & 213.8 & 209.9 & \\
\hline "FSB & $88 \mathrm{D}$ & $"$ & 50558.40 & 57363.65 & 202.1 & 222.1 & 215.8 & 217.1 & \\
\hline "FSB & 89D" & $"$ & 50356.09 & 57331.51 & 201.9 & 221.9 & 215.2 & 215.8 & \\
\hline "FSB & $90 \mathrm{D}$ & " & 50129.62 & 57204.42 & 205.1 & 225.1 & 215.0 & 214.0 & -1 \\
\hline "FSB & $910 "$ & $"$ & 49904.56 & 57079.18 & 200.9 & 220.9 & 213.4 & 212.1 & \\
\hline "FSB & $92 \mathrm{D}$ & $"$ & 49490.42 & 57001.79 & 201.7 & 221.7 & 211.7 & 209.5 & -2 \\
\hline "FSB & $93 \mathrm{D}$ & $"$ & 49354.82 & 56869.80 & 197.9 & 217.9 & 210.5 & 207.7 & \\
\hline "FSB & $94 \mathrm{DR} "$ & & 49067.61 & 56911.01 & 183.3 & 203.4 & 209.9 & 206.0 & -3 \\
\hline "FSB & 95D" & " & 48939.51 & 57049.06 & 207.8 & 227.8 & 208.8 & 0.0 & 208 \\
\hline "FSB & 95DR" & & 48929.85 & 57065.63 & 187.0 & 207.0 & 210.2 & 206.5 & -3 \\
\hline "FSB & $97 \mathrm{D}$ & $"$ & 48950.80 & 57262.79 & 196.9 & 216.9 & 210.5 & 207.7 & -2 \\
\hline "FSB & $98 \mathrm{D}$ & $"$ & 49121.97 & 57413.49 & 200.3 & 220.3 & 212.0 & 209.4 & -2 \\
\hline "FSB & 990 & $"$ & 49399.05 & 57681.54 & 198.1 & 218.1 & 211.9 & 211.7 & -0 \\
\hline "FSB1 & $04 \mathrm{D}$ & $"$ & 47971.22 & 56117.73 & 190.4 & 210.4 & 204.4 & 0.0 & -204 \\
\hline "FSB1 & $05 \mathrm{D}$ & $"$ & 48823.22 & 57346.54 & 203.7 & 223.7 & 208.3 & 207.7 & -0 \\
\hline "FSB1 & 05DR" & & 48833.62 & 57358.44 & 188.5 & 208.6 & 210.6 & 207.4 & -3 \\
\hline "FSB1 & $.06 \mathrm{D}$ & $"$ & 49390.58 & 56151.16 & 202.9 & 222.9 & 207.3 & 0.0 & -207 \\
\hline "FSB1 & $07 \mathrm{D}$ & $"$ & 50097.00 & 57007.19 & 200.9 & 220.9 & 213.5 & 212.8 & -0 \\
\hline "FSB1 & .08D & $"$ & 50314.94 & 58068.57 & 203.8 & 223.8 & 217.5 & 217.8 & \\
\hline "FSB1 & 09D" & $"$ & 49591.36 & 57808.53 & 205.8 & 225.8 & 213.1 & 213.3 & \\
\hline "FSB1 & 10D" & $"$ & 48906.27 & 56254.41 & 191.1 & 211.1 & 205.4 & 197.5 & -7 \\
\hline "FSB1 & 110 & $"$ & 50497.87 & 57132.28 & 201.7 & 221.7 & 215.2 & 215.7 & \\
\hline " FSB1 & $12 \mathrm{D}$ & $"$ & 47580.74 & $56567: 24$ & 188.9 & 208.9 & 205.9 & 195.8 & -10 \\
\hline "FSB1 & $13 \mathrm{D}$ & $"$ & 49834.16 & 56017.82 & 189.6 & 209.6 & 207.3 & 201.6 & -5 \\
\hline "FSB1 & $14 \mathrm{D}$ & $"$ & 50967.90 & 56925.74 & 197.7 & 217.8 & 216.9 & 217.4 & \\
\hline "FSB1 & 150 & $"$ & 48150.84 & 54688.25 & 182.5 & 191.3 & 191.3 & 185.3 & -6 \\
\hline "FSB1 & $16 \mathrm{D}$ & $"$ & 49078.92 & 54719.06 & 186.4 & 195.1 & 191.8 & 0.0 & -191 \\
\hline "FSBI & $17 \mathrm{D}$ & $"$ & 49218.37 & 56062.42 & 189.7 & 209.7 & 205.1 & 196.8 & -8 \\
\hline "FSBI & $18 \mathrm{D}$ & " & 50121.08 & 56512.06 & 191.3 & 211.3 & 211.4 & 209.2 & -2 \\
\hline "FSB1 & 190 & $"$ & 49439.73 & 56556.50 & 193.1 & 213.1 & 208.1 & 205.6 & -2 \\
\hline "FSB1 & $20 \mathrm{D}$ & $"$ & 48235.70 & 57803.07 & 196.5 & 216.5 & 209.2 & 205.6 & -3 \\
\hline "FSB1 & $21 \mathrm{DR}$ & & 47431.08 & 57547.99 & 191.3 & 211.3 & 206.9 & 201.1 & -5 \\
\hline "FSB1 & $22 \mathrm{D}$ & $"$ & 46940.61 & 56337.10 & 186.6 & 206.6 & 203.5 & 189.2 & -14 \\
\hline "FSB1 & $23 \mathrm{D}$ & $"$ & 50541.46 & 56284.49 & 194.1 & 214.1 & 212.1 & 209.0 & -3 \\
\hline "FSB1 & $50 \mathrm{PD}$ & & 48579.67 & 56755.77 & 176.2 & 221.3 & 207.0 & 202.0 & -5 \\
\hline "FSL & 10 & $"$ & 52707.36 & 60425.06 & 208.5 & 228.6 & 224.5 & 224.1 & -0 \\
\hline "FSL & $2 D$ & $"$ & 52421.17 & 60049.76 & 208.7 & 228.8 & 224.8 & 226.0 & 1 \\
\hline "FSL & $3 D "$ & $"$ & 51921.73 & 59265.15 & 205.9 & 226.0 & 222.5 & 226.7 & \\
\hline "FSL & $4 \mathrm{D}$ & $"$ & 51627.03 & 59008.00 & 204.0 & 224.1 & 217.1 & 225.6 & \\
\hline "ESL & $5 D^{\prime \prime}$ & $"$ & 51222.93 & 58680.16 & 203.5 & 223.7 & 220.4 & 223.4 & \\
\hline FSL & $6 D$ & " & 50985.96 & 58408.90 & 202.1 & 222.1 & 219.8 & 222.0 & \\
\hline
\end{tabular}


Table F-2. Summary of Group Statistical Parameters (Continued)

\begin{tabular}{|c|c|c|c|c|c|c|c|c|}
\hline $\mathrm{L}$ & $7 \mathrm{D}$ & 50664.69 & 58062.83 & 199.5 & 219.6 & 217.9 & 219.7 & 1.8 \\
\hline "FSL & $8 \mathrm{D}$ & 50635.20 & 57789.90 & 202.7 & 222.8 & 217.2 & 219.0 & 1.8 \\
\hline "FSL & $9 D$ & 50605.41 & 57503.53 & 201.4 & 221.5 & 216.2 & 218.0 & 1.8 \\
\hline "FSS & $1 D$ & 52801.47 & 56514.53 & 209.9 & 229.9 & 223.5 & 225.8 & 2.3 \\
\hline "FSS & $2 \mathrm{D}$ & 52790.27 & 56359.37 & 204.4 & 224.4 & 222.7 & 224.7 & 2.0 \\
\hline "FSS & $3 \mathrm{D}$ & 52397.74 & 56296.61 & 205.8 & 225.8 & 220.4 & 222.5 & 2.1 \\
\hline "FSS & $4 \mathrm{D}$ & 51860.55 & 57000.99 & 202.6 & 222.6 & 218.7 & 223.5 & 4.8 \\
\hline "FTF & 2 & 52624.70 & 58676.94 & 219.4 & 239.4 & 224.9 & 230.7 & 5.8 \\
\hline "FTF & 3 & 52574.12 & 58584.74 & 218.2 & 221.2 & 223.4 & 230.3 & 6.9 \\
\hline "FTF & 4 & 52575.72 & 58479.71 & 216.6 & 236.6 & 224.0 & 230.6 & 6.6 \\
\hline "FTF & 5 & 52457.78 & 58405.31 & 215.3 & 235.3 & 224.0 & 230.1 & 6.1 \\
\hline "FTF & 6 & 52377.87 & 58540.68 & 216.9 & 236.9 & 223.9 & 229.8 & 5.9 \\
\hline "FTF & 7 & 52422.54 & 58617.58 & 222.1 & 226.1 & 223.6 & 230.0 & 6.4 \\
\hline "FTF & 8 & 52414.24 & 58721.88 & 219.6 & 239.6 & 227.1 & 230.0 & 2.9 \\
\hline "FTF & 9 & 52160.67 & 58925.65 & 216.4 & 236.4 & 223.6 & 228.7 & 5.1 \\
\hline " FTE & 10 & 52262.69 & 58753.89 & 215.1 & 235.1 & 224.2 & 229.2 & 5.0 \\
\hline " FTE & 11 & 52077.61 & 58634.46 & 215.8 & 235.8 & 224.8 & 228.5 & 3.7 \\
\hline "FTE & 12 & 52008.76 & 58792.94 & 215.0 & 235.0 & 226.7 & 228.1 & 1.4 \\
\hline " FTF & 13 & 52306.70 & 58030.74 & 216.1 & 236.1 & 225.2 & 229.2 & 4.0 \\
\hline " ETF & 15 & 52455.01 & 58095.52 & 197.5 & 227.5 & 225.1 & 229.0 & 3.9 \\
\hline " FTF & 16 & 52117.99 & 58194.35 & 203.8 & 233.8 & 223.2 & 228.2 & 5.0 \\
\hline " FTF & 17 & 52145.67 & 58304.40 & 200.6 & 230.6 & 222.9 & 228.3 & 5.4 \\
\hline "FTF & 18 & 52158.40 & 58387.36 & 202.3 & 232.3 & 223.1 & 228.5 & 5.4 \\
\hline "FTF & 19 & 51992.27 & 58610.07 & 198.3 & 228.3 & 222.2 & 227.6 & 5.4 \\
\hline "FTF & 20 & 51799.80 & 58524.11 & 198.3 & 228.3 & 221.7 & 226.7 & 5.0 \\
\hline " FTF & 21 & 51767.59 & 58379.34 & 198.7 & 228.7 & 222.9 & 226.4 & 3.5 \\
\hline "FTF & 22 & 51739.79 & 58267.27 & 212.6 & 242.6 & 221.6 & 226.6 & 5.0 \\
\hline "FTF & 23 & 51872.76 & 58096.39 & 201.2 & 231.2 & 222.1 & 226.8 & 4.7 \\
\hline "FTF & $24 \mathrm{~A}$ & 52124.69 & 58702.05 & 212.7 & 232.7 & 222.4 & 228.6 & 6.2 \\
\hline "FTF & $25 \mathrm{~A}$ & 52221.44 & 58734.44 & 212.8 & 232.8 & 223.1 & 229.0 & 5.9 \\
\hline "FTF & 26 & 52215.85 & 58675.92 & 206.3 & 226.3 & 223.1 & 228.7 & 5.6 \\
\hline "FTF & 27 & 52160.35 & 58664.41 & 213.5 & 243.5 & 223.2 & 228.8 & 5.6 \\
\hline$" \mathrm{H}$ & 6 & 56466.89 & 52414.35 & 225.2 & 235.2 & 231.0 & 231.3 & 0.3 \\
\hline$" \mathrm{H}$ & 7 & 56455.12 & 52355.62 & 224.9 & 234.9 & 229.0 & 230.3 & 1.3 \\
\hline$" \mathrm{H}$ & 8 & 56285.76 & 52050.36 & 218.4 & 228.4 & 227.0 & 224.4 & -2.6 \\
\hline$" \mathrm{H}$ & 9 & 56317.35 & 52000.00 & 207.4 & 217.4 & 226.8 & 223.9 & -2.9 \\
\hline$" \mathrm{H}$ & 10 & 55881.94 & 52127.81 & 222.5 & 232.5 & 227.3 & 223.7 & -3.6 \\
\hline "H & 11 & 55830.90 & 52096.44 & 212.0 & 222.0 & 227.7 & 222.7 & -5.0 \\
\hline "H & $18 \mathrm{~A}$ & 55351.80 & 51966.92 & 217.5 & 227.5 & 224.1 & 0.0 & -224.1 \\
\hline "H & 19 & 55081.94 & 52120.99 & 219.6 & 221.1 & 223.8 & 0.0 & -223.8 \\
\hline "HA.A & 1D & 60573.75 & 49343.38 & 51.8 & 281.8 & 276.4 & 285.1 & 8.7 \\
\hline "HAA & $2 \mathrm{D}$ & 7.23 & 50767.79 & 260.3 & 280.4 & 276.5 & 278.2 & 1.7 \\
\hline "HAA & $3 D$ & 58123.23 & 8.39 & 6.7 & 6.7 & 265.4 & 263.3 & -2.1 \\
\hline "HAA & $4 \mathrm{D}$ & 59988.35 & 51884.83 & 255.7 & 275.7 & 269.9 & 264.7 & -5.2 \\
\hline "HA. & $6 \mathrm{D}$ & 61791.83 & 50700.99 & 247.1 & 267.2 & 265.1 & 261.6 & -3.5 \\
\hline " $\mathrm{HAC}$ & 1 & 59513.05 & 51932.39 & 258.8 & 278.8 & 269.4 & 265.8 & -3.6 \\
\hline "HAC & 2 & 59476.04 & 51990.55 & 258.8 & 278.8 & 269.0 & 265.0 & -4.0 \\
\hline " HAC & 3 & 59416.25 & 51965.64 & 255.0 & 275.0 & 269.1 & 265.3 & -3.8 \\
\hline "HAC & 4 & 59460.26 & 51891.78 & 254.1 & 274.1 & 269.6 & 266.3 & -3.3 \\
\hline "HAP & 1 & 61253.46 & 50579.78 & 256.3 & 276.3 & 270.8 & 269.6 & -1.2 \\
\hline "HAP & 2 & 61353.75 & 50469.62 & 243.8 & 263.8 & 270.3 & 267.6 & -2.7 \\
\hline " $\mathrm{HC}$ & 1D & 59866.62 & 51422.74 & 206.5 & 211.5 & 268.2 & 266.1 & -2.1 \\
\hline " $\mathrm{HC}$ & $1 \mathrm{E}$ & 59863.68 & 51423.36 & 251.5 & 256.5 & 275.0 & 271.2 & -3.8 \\
\hline "HC & $2 \mathrm{E}$ & 59868.65 & 51461.16 & 205.7 & 210.7 & 269.5 & 265.7 & -3.8 \\
\hline " $\mathrm{HC}$ & $2 F$ & 59867.82 & 51457.24 & 250.7 & 255.7 & 274.3 & 270.8 & -3.5 \\
\hline " $\mathrm{HC}$ & $6 \mathrm{~B}$ & 60149.18 & 51775.71 & 210.2 & 215.2 & 268.9 & 261.5 & -7.4 \\
\hline "HCA & 1 & 61242.75 & 51923.26 & 253.7 & 273.7 & 269.4 & 260.6 & -8.8 \\
\hline "HCA. & 2 & 61027.49 & 51707.50 & 242.0 & 273.4 & 270.2 & 262.1 & -8.1 \\
\hline " HCA. & 3 & 61269.49 & 52050.48 & 253.8 & 273.8 & 269.2 & 259.9 & -9.3 \\
\hline "HCA & 4 & 61080.70 & 51959.75 & 241.9 & 273.3 & 269.3 & 260.6 & -8.7 \\
\hline
\end{tabular}


Table F-2. Summary of Group Statistical Parameters (Continued)

\begin{tabular}{|c|c|c|c|c|c|c|c|c|c|}
\hline " $\mathrm{HCB}$ & 1 & $"$ & 61809.86 & 50683.36 & 222.6 & 252.6 & 263.6 & 260.4 & -3.2 \\
\hline " $\mathrm{HCB}$ & 2 & " & 61660.45 & 50574.96 & 239.9 & 269.9 & 268.1 & 262.9 & -5.2 \\
\hline " $\mathrm{HCB}$ & 3 & $"$ & 61740.10 & 50362.86 & 233.6 & 263.6 & 266.6 & 262.9 & -3.7 \\
\hline " $\mathrm{HCB}$ & 4 & $"$ & 61901.99 & 50477.10 & 235.9 & 265.9 & 264.5 & 260.8 & -3.7 \\
\hline " HET & 1D & " & 58616.55 & 51895.27 & 240.3 & 260.3 & 267.7 & 263.5 & -4 \\
\hline "HET & $2 \mathrm{D}$ & " & 58186.81 & 52045.60 & 239.7 & 259.7 & 258.5 & 256.0 & -2.5 \\
\hline "HET & 3D & " & 58220.83 & 52128.23 & 239.9 & 259.9 & 258.9 & 255.6 & -3.3 \\
\hline "HET & $4 \mathrm{D}$ & " & 58293.12 & 52198.95 & 239.5 & 259.6 & 259.2 & 255.7 & -3.5 \\
\hline " HHP & 1D & " & 58413.10 & 50996.42 & 260.4 & 269.9 & 271.2 & 269.3 & -1 \\
\hline " $\mathrm{HHP}$ & $2 \mathrm{D}$ & $"$ & 58647.26 & 50803.30 & 263.2 & 273.2 & 273.8 & 274.1 & 0.3 \\
\hline "HIW & IID & & 56711.83 & 52871.21 & 213.0 & 228.0 & 231.9 & 235.7 & 3.8 \\
\hline " HIW & 1MD & & 56725.89 & 52908.50 & 214.9 & 239.7 & 232.4 & 236.2 & \\
\hline " HIW & 1PD & & 56636.55 & 52924.42 & 215.5 & 240.5 & 231.9 & 235.6 & 3.7 \\
\hline "HIW & $2 \mathrm{D}$ & $"$ & 55178.32 & 53976.50 & 210.9 & 230.8 & 229.7 & 229.0 & -0 \\
\hline " $\mathrm{HOB}$ & $1 \mathrm{D}$ & " & 55284.63 & 53672.00 & 204.2 & 224.2 & 230.5 & 228.3 & -2.2 \\
\hline " НОВ & $2 \mathrm{D}$ & $"$ & 55595.50 & 53420.36 & 200.4 & 220.4 & 228.9 & 229.0 & \\
\hline " $\mathrm{HOB}$ & 3D & $"$ & 56238.78 & 52787.04 & 207.7 & 227.7 & 229.1 & 231.3 & \\
\hline " $\mathrm{HOB}$ & $4 \mathrm{D}$ & $"$ & 56545.37 & 52617.01 & 210.4 & 230.4 & 229.9 & 233.2 & \\
\hline " $\mathrm{HOB}$ & $6 \mathrm{D}$ & " & 55275.15 & 51204.47 & 186.9 & 196.9 & 207.1 & 206.4 & -0 \\
\hline " $\mathrm{HOB}$ & $7 \mathrm{D}$ & $"$ & 54438.67 & 52713.30 & 197.4 & 217.4 & 220.8 & 216.1 & -4 \\
\hline " HR3 & 11 & $"$ & 58112.36 & 51444.75 & 200.4 & 230.0 & 259.7 & 257.5 & \\
\hline "HR3 & 13 & $"$ & 58084.40 & 51702.80 & 205.1 & 234.8 & 258.8 & 254.9 & -3.9 \\
\hline "HR8 & 11 & $"$ & 57651.36 & 52097.77 & 207.9 & 237.6 & 246.2 & 246.0 & -0.2 \\
\hline "HR8 & 12 & " & 57392.25 & 51983.55 & 206.3 & 235.9 & 239.8 & 242.2 & \\
\hline " HR8 & 13 & " & 57317.15 & 51774.08 & 201.7 & 231.4 & 237.8 & 240.4 & \\
\hline " HR8 & 14 & " & 57595.58 & 51583.84 & 202.3 & 231.9 & 243.9 & 248.0 & \\
\hline "HSB & 65 & $"$ & 56647.98 & 52801.67 & 212.4 & 242.4 & 232.5 & 235.1 & \\
\hline "HSB & $65 c$ & " & 56665.66 & 52812.22 & 207.8 & 218.6 & 232.5 & 234.6 & \\
\hline "HSB & 66 & " & 55177.89 & 53117.82 & 198.1 & 228.1 & 224.7 & 225.4 & 0.7 \\
\hline " HSB & 67 & " & 56449.04 & 51902.78 & 200.7 & 221.6 & 223.3 & 222.9 & -0 . \\
\hline "HSB & 68 & " & 54963.81 & 52241.99 & 213.3 & 238.5 & 221.6 & 214.7 & -6 . \\
\hline "HSB & 69 & " & 54551.15 & 52349.03 & 199.0 & 227.8 & 219.4 & 212.9 & -6 \\
\hline "HSB & 70 & " & 54070.99 & 53534.77 & 205.7 & 235.7 & 223.9 & 219.5 & -4.4 \\
\hline "HSB & 71 & " & 53657.70 & 53897.63 & 204.8 & 234.8 & 224.0 & 217.7 & -6.3 \\
\hline "HSB & 83D & " & 56648.16 & 51986.31 & 198.7 & 225.2 & 224.8 & 226.8 & 2.0 \\
\hline "HSB & $84 \mathrm{D}$ & $"$ & 54436.38 & 52411.25 & 199.5 & 219.5 & 218.9 & 212.4 & -6 . \\
\hline "HSB & $85 c$ & & 57438.35 & 54041.12 & 214.2 & 224.2 & 238.7 & 239.5 & 0.8 \\
\hline "HSB & $86 \mathrm{D}$ & " & 54285.76 & 53402.43 & 206.6 & 236.6 & 223.5 & 220.6 & -2.9 \\
\hline "HSB1 & $.00 \mathrm{D}$ & $"$ & 56931.76 & 52381.69 & 216.9 & 236.9 & 233.5 & 236.1 & 2.6 \\
\hline "HSB1 & $.00 \mathrm{PD}$ & & 54436.51 & 52269.53 & 195.0 & 214.9 & 217.4 & 209.9 & -7.5 \\
\hline "HSB & $.01 \mathrm{D}$ & $"$ & 56718.21 & 52349.07 & 216.1 & 236.1 & 230.8 & 233.1 & 2.3 \\
\hline "HSB1 & $.02 \mathrm{D}$ & $"$ & 56511.84 & 52346.83 & 216.3 & 236.3 & 228.2 & 230.5 & 2.3 \\
\hline "HSB1 & $.03 \mathrm{D}$ & $"$ & 56360.00 & 5.67 & 213.7 & 224.7 & & 223.5 & -2 . \\
\hline "HSBI & $.04 \mathrm{D}$ & $"$ & 56080.13 & 51843.39 & 210.6 & 224.6 & 224.9 & 220.6 & -4 \\
\hline "HSB1 & $.05 \mathrm{D}$ & " & 55903.66 & 51967.39 & 211.8 & 230.9 & 225.3 & 221.8 & -3 \\
\hline "HSB1 & $.06 \mathrm{D}$ & " & 55732.90 & 52282.78 & 210.7 & 230.7 & 225.9 & 223.7 & -2 \\
\hline "HSB1 & $.07 \mathrm{D}$ & " & 55498.90 & 52300.62 & 215.1 & 235.1 & 224.7 & 222.1 & -2 \\
\hline "HSB1 & .08D & " & 55236.33 & 52347.64 & 212.0 & 232.0 & 223.5 & 219.6 & -3 \\
\hline "HSB1 & $.09 D$ & $"$ & 54981.42 & 52399.37 & 213.0 & 233.0 & 222.8 & 217.9 & -4 \\
\hline "HSBI & 100 & $"$ & 54793.39 & 52541.16 & 211.4 & 231.4 & 222.1 & 218.4 & 3 \\
\hline "HSBI. & $11 E$ & $"$ & 54643.22 & 52723.98 & 211.7 & 231.7 & 222.0 & 218.7 & \\
\hline "HSBI. & $12 \mathrm{E}$ & " & 54606.04 & 52970.91 & 211.7 & 231.7 & 222.5 & 220.5 & \\
\hline "HSBI. & $13 \mathrm{D}$ & $"$ & 54404.28 & 53152.93 & 216.2 & 236.2 & 222.5 & 220.2 & 2 \\
\hline "HSBI & $14 \mathrm{D}$ & $"$ & 54381.54 & 53333.10 & 212.8 & 232.8 & 223.3 & 221.1 & \\
\hline "HSB1 & $15 \mathrm{D}$ & " & 54357.27 & 53530.56 & 213.9 & 233.9 & 223.9 & 222.2 & \\
\hline "HSBI & $16 D$ & $"$ & 54355.82 & 53771.94 & 214.5 & 234.5 & 226.2 & 223.4 & \\
\hline "HSB1 & 170 & I" & 53510.12 & 53797.83 & 200.3 & 220.3 & 223.9 & 215.5 & \\
\hline "HS & $25 \mathrm{D}$ & $"$ & 56603.94 & 51862.91 & 199.4 & 219.4 & 221.3 & 225.0 & 3.7 \\
\hline $\mathrm{Ms}$ & 26D & " & 55040.55 & 51311.10 & 190.5 & 200.5 & 205.2 & 205.0 & -0.2 \\
\hline "HSBI & 270 & & 54789.02 & 51963.14 & 197.8 & 217.8 & 218.2 & 208.1 & -10.1 \\
\hline
\end{tabular}


Table F-2. Summary of Group Statistical Parameters (Continued)

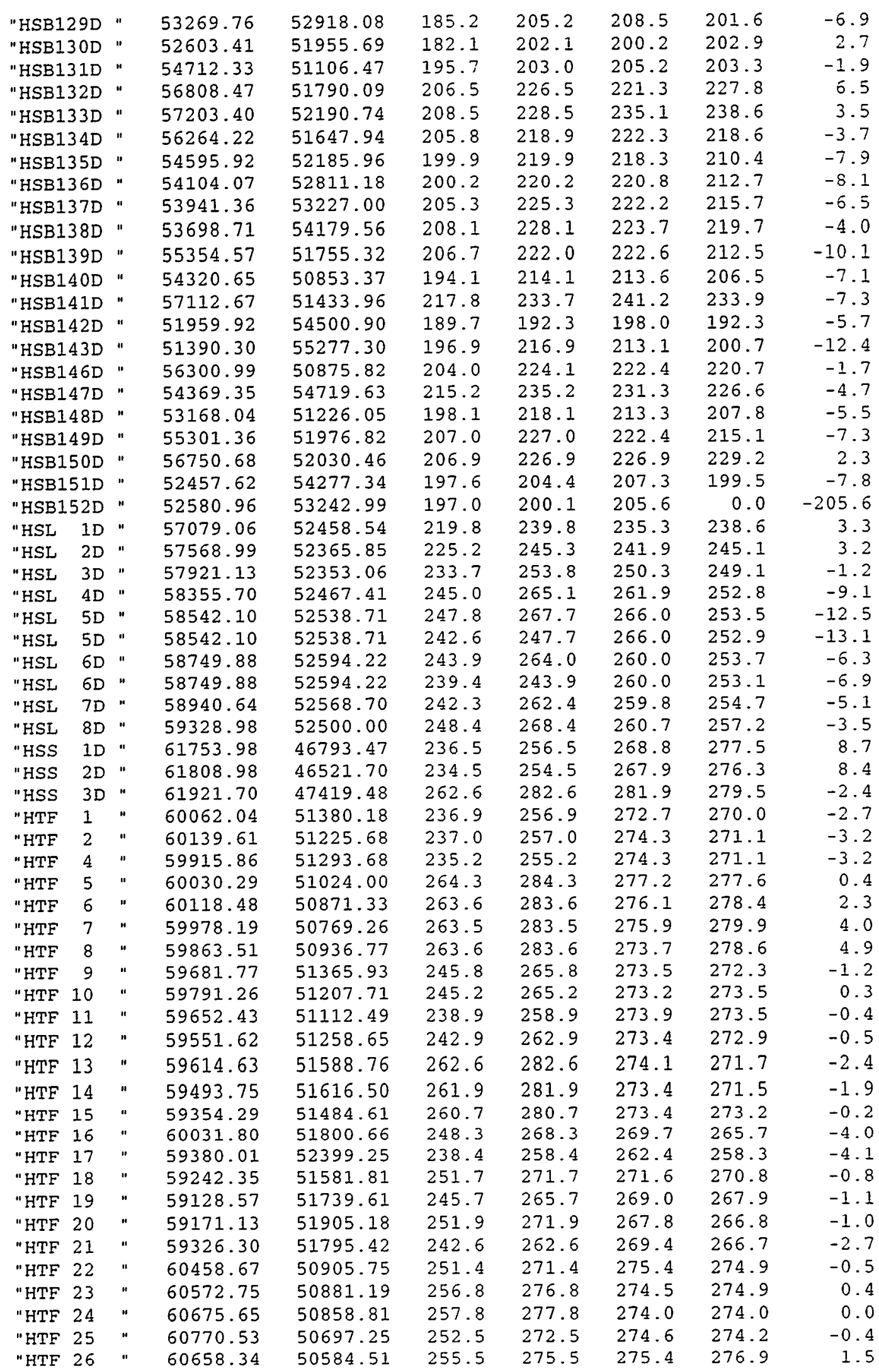


Table F-2. Summary of Group Statistical Parameters (Continued)

\begin{tabular}{|c|c|c|c|c|c|c|c|c|c|}
\hline "HTF & 27 & $"$ & 60500.00 & 50584.74 & 259.1 & 279.1 & 276.7 & 278.8 & 2. \\
\hline "HTF & 28 & $"$ & 60362.69 & 50636.52 & 251.9 & 271.9 & 275.8 & 277.7 & \\
\hline "HTF & 29 & $"$ & 60295.24 & 50804.00 & 259.9 & 289.9 & 275.6 & 277.8 & \\
\hline "HTF & 31 & $"$ & 60437.03 & 50280.18 & 246.7 & 266.7 & 275.6 & 279.1 & \\
\hline "HTF & 32 & $"$ & 60607.03 & 50380.63 & 251.1 & 271.1 & 274.7 & 278.2 & \\
\hline "HTF & 34 & $"$ & 59850.54 & 50810.81 & 251.7 & 271.7 & 275.6 & 277.7 & \\
\hline "HWP & 1D & $"$ & 57981.82 & 52244.65 & 239.9 & 249.9 & 245.2 & 250.8 & \\
\hline "HWP & $2 D$ & $"$ & 58090.42 & 52436.40 & 253.0 & 260.7 & 262.5 & 0.0 & 262 \\
\hline "HWS & $1 \mathrm{~A}$ & $"$ & 47062.15 & 47130.24 & 225.2 & 255.2 & 244.8 & 251.1 & \\
\hline "HWS & 2 & $"$ & 47150.77 & 47010.39 & 215.3 & 245.3 & 245.4 & 251.5 & \\
\hline "HXB & 1 & $"$ & 48433.00 & 42406.60 & 214.2 & 244.2 & 251.4 & 261.5 & 20 \\
\hline "HXB & 2 & $"$ & 48826.55 & 42646.82 & 212.1 & 242.1 & 252.6 & 262.8 & 10 \\
\hline " HXB & 3 & $"$ & 48596.18 & 42455.23 & 212.2 & 242.2 & 251.9 & 262.0 & 10 \\
\hline "HXB & $4 D$ & $"$ & 48519.48 & 42527.26 & 234.9 & 254.9 & 253.6 & 262.2 & \\
\hline "HXB & $5 D$ & $"$ & 48394.54 & 42453.62 & 234.2 & 254.2 & 252.7 & 261.7 & \\
\hline "K & $301 \mathrm{AP}$ & $"$ & 34880.17 & 38881.66 & 193.3 & 197.7 & 208.8 & 204.6 & -4 \\
\hline " K & $301 P$ & $"$ & 34699.85 & 38956.80 & 194.4 & 201.0 & 204.9 & 203.1 & -1 \\
\hline "KAB & 1 & $"$ & 34512.97 & 37703.87 & 194.0 & 224.0 & 205.9 & 207.1 & \\
\hline " KAB & 2 & $"$ & 34729.28 & 36998.69 & 198.6 & 228.6 & 209.9 & 207.7 & \\
\hline "KAB & 3 & $"$ & 34252.24 & 36483.51 & 193.0 & 223.0 & 204.1 & 202.7 & -1 \\
\hline "KAB & 4 & $"$ & 34008.71 & 37557.00 & 187.0 & 217.0 & 203.2 & 203.1 & -0 \\
\hline "KAC & 1 & $"$ & 37172.33 & 37252.49 & 199.0 & 229.0 & 219.3 & 216.3 & -3 \\
\hline "KAC & 2 & $"$ & 37251.77 & 37326.09 & 195.4 & 225.4 & 221.5 & 216.8 & \\
\hline "KAC & 3 & $"$ & 37286.28 & 37263.85 & 195.8 & 225.8 & 222.0 & 216.6 & -5 \\
\hline "KAC & 4 & $"$ & 37208.99 & 37128.67 & 178.0 & 208.0 & 218.1 & 215.4 & -2 \\
\hline "KAC & 5 & $"$ & 37270.51 & 37226.21 & 204.3 & 224.3 & 222.4 & 216.6 & -5 \\
\hline "KAC & 6 & $"$ & 37243.68 & 37209.62 & 204.6 & 224.6 & 222.3 & 216.5 & -5 \\
\hline "KAC & 7 & $"$ & 37150.77 & 37344.90 & 203.0 & 223.0 & 219.5 & 216.7 & -2 \\
\hline "KAC & 8 & $"$ & 37192.40 & 37216.54 & 192.3 & 212.3 & 221.2 & 216.0 & -5 \\
\hline "KAC & 9 & $"$ & 37152.62 & 37288.17 & 195.7 & 215.7 & 220.8 & 216.3 & -4 \\
\hline " KBP & $2 \mathrm{D}$ & " & 34610.95 & 36668.99 & 184.3 & 194.3 & 203.4 & 204.9 & \\
\hline " KCB & 1 & $"$ & 34207.66 & 38175.04 & 183.6 & 213.6 & 204.6 & 203.5 & -1 \\
\hline " KCB & 2 & $"$ & 34063.53 & 38391.13 & 187.7 & 217.7 & 202.8 & 201.6 & -1 \\
\hline " KCB & 3 & $"$ & 33829.55 & 38242.63 & 184.1 & 214.1 & 202.2 & 199.9 & -2 \\
\hline " KCB & 4 & $"$ & 33963.75 & 38025.59 & 188.9 & 218.9 & 205.5 & 202.2 & -3 \\
\hline " KCB & 5 & $"$ & 33764.06 & 38167.82 & 189.3 & 209.3 & 200.4 & 199.6 & -0 \\
\hline " KCB & 6 & $"$ & 33823.71 & 38365.23 & 188.7 & 208.7 & 201.0 & 199.4 & -1 \\
\hline "KCB & 7 & $"$ & 34486.92 & 38097.90 & 196.5 & 216.5 & 205.3 & 206.5 & \\
\hline " KDB & 1 & $"$ & 35214.96 & 38571.78 & 184.8 & 205.8 & 208.1 & 208.4 & \\
\hline "KDB & 2 & " & 35004.72 & 38470.07 & 182.5 & 203.5 & 206.7 & 207.6 & \\
\hline "KDB & 3 & $"$ & 35130.26 & 38328.17 & 184.2 & 205.4 & 207.5 & 208.8 & \\
\hline "KDB & 4 & $"$ & 34890.68 & 38371.73 & 189.2 & 209.2 & 206.5 & 207.7 & \\
\hline "KDB & 5 & $"$ & 34831.09 & 38655.12 & 188.5 & 208.5 & 204.9 & 206.0 & \\
\hline " KDT & $1 \mathrm{D}$ & $"$ & 35191.60 & 38682.66 & 193.7 & 213.7 & 208.1 & 208.3 & \\
\hline " KRB & 8 & $"$ & 35269.15 & 39422.20 & 195.8 & 215.8 & 208.5 & 203.6 & -4 \\
\hline " KRB & 13 & $"$ & 35054.23 & 39928.55 & 197.8 & 217.8 & 205.5 & 0.0 & -205 \\
\hline " KRB & $16 D$ & $"$ & 35354.26 & 39398.39 & 191.5 & 211.5 & 209.2 & 204.2 & -5 \\
\hline "KRB & 17D & $"$ & 35080.66 & 40027.41 & 186.8 & 206.8 & 205.9 & 196.1 & -9 \\
\hline " KRB & $18 D$ & $"$ & 35196.02 & 40122.82 & 185.8 & 205.8 & 204.5 & 196.0 & -8 \\
\hline "KRB & $19 D$ & $"$ & 35327.74 & 40153.30 & 186.8 & 206.8 & 203.8 & 196.8 & -7 \\
\hline " KRP & 1 & " & 37318.17 & 38629.26 & 207.0 & 237.0 & 218.4 & 219.3 & \\
\hline " KRP & 2 & $"$ & 37515.57 & 38546.00 & 199.2 & 229.2 & 219.1 & 220.2 & \\
\hline "KRP & 3 & $"$ & 37592.37 & 38269.08 & 207.5 & 237.5 & 219.1 & 220.6 & \\
\hline "KRP & 4 & $"$ & 37397.01 & 38427.35 & 188.7 & 218.7 & 218.3 & 219.4 & 1 \\
\hline " KRP & 5 & $"$ & 37048.11 & 38750.66 & 200.8 & 210.8 & 216.0 & 217.5 & \\
\hline " KRP & 6 & $"$ & 37009.08 & 38350.12 & 203.1 & 213.1 & 217.4 & 217.9 & \\
\hline " KRP & 7 & $"$ & 36699.81 & 38603.56 & 203.1 & 213.2 & 215.4 & 216.3 & \\
\hline " KRP & 8 & $"$ & 37116.32 & 38597.27 & 200.1 & 210.1 & 217.2 & 218.1 & \\
\hline " KRP & 9 & $"$ & 37210.32 & 38464.17 & 200.8 & 210.8 & 218.4 & 218.7 & \\
\hline " KSB & 1 & $"$ & 34608.12 & 38694.54 & 175.6 & 205.6 & 204.1 & 203.9 & 0 \\
\hline
\end{tabular}


Table F-2. Summary of Group Statistical Parameters (Continued)

\begin{tabular}{|c|c|c|c|c|c|c|c|c|c|}
\hline "KSB & 2 & $"$ & 34482.69 & 38601.79 & 173.8 & 203.8 & 203.8 & 203.5 & -0.3 \\
\hline "KSB & 3 & $"$ & 34429.71 & 38728.16 & 169.7 & 199.7 & 203.0 & 202.0 & -1.0 \\
\hline "KSB & $4 A$ & $"$ & 34579.07 & 38798.85 & 169.6 & 199.6 & 203.2 & 202.6 & -0.5 \\
\hline "KSB & $5 c$ & $"$ & 34792.85 & 38779.18 & 172.9 & 182.9 & 204.9 & 203.9 & -1.0 \\
\hline "KSB & $5 D$ & " & 34791.55 & 38770.15 & 194.5 & 214.5 & 204.5 & 205.3 & 0.8 \\
\hline "KSM & $1 \mathrm{D}$ & $"$ & 35147.98 & 38726.59 & 193.7 & 213.7 & 208.1 & 207.8 & -0.3 \\
\hline "KSS & 1D & $"$ & 33704.58 & 32460.67 & 157.4 & 177.5 & 174.3 & 175.3 & 1.0 \\
\hline "KSS & $2 \mathrm{D}$ & $"$ & 33719.14 & 31481.13 & 144.6 & 164.7 & 164.7 & 161.3 & -3.4 \\
\hline "LAC & 1 & $"$ & 44037.76 & 27687.88 & 191.1 & 221.1 & 216.5 & 217.6 & 1.1 \\
\hline "LAC & 2 & $"$ & 44009.27 & 27787.58 & 193.4 & 223.4 & 216.1 & 218.2 & 2.1 \\
\hline " LAC & 3 & $"$ & 43900.98 & 27679.23 & 190.7 & 220.7 & 216.6 & 216.7 & 0.1 \\
\hline "LAC & 4 & $"$ & 43985.08 & 27672.80 & 185.3 & 215.3 & 216.1 & 217.0 & 0.9 \\
\hline " LAC & 5DL & & 44096.56 & 27804.81 & 176.2 & 186.2 & 219.7 & 217.9 & -1.8 \\
\hline " LAC & $5 D U$ & & 44089.18 & 27786.44 & 207.9 & 227.8 & 219.5 & 218.9 & -0.6 \\
\hline "LAC & 6DL & & 43916.99 & 27748.31 & 175.9 & 185.9 & 217.9 & 216.4 & -1.5 \\
\hline "LAC & 6DU & & 43910.52 & 27728.93 & 201.7 & 221.7 & 219.0 & 217.3 & -1.7 \\
\hline "LAC & $7 \mathrm{DL}$ & & 43812.28 & 27590.94 & 177.4 & 187.4 & 215.1 & 214.7 & -0.4 \\
\hline " LAC & $7 \mathrm{DU}$ & & 43817.61 & 27607.80 & 204.9 & 224.8 & 218.1 & 215.9 & -2.2 \\
\hline "LAC & 8DL & & 43990.69 & 27552.51 & 180.4 & 190.4 & 217.5 & 215.7 & -1.8 \\
\hline " LAC & $8 \mathrm{DU}$ & & 43995.60 & 27571.30 & 199.8 & 219.8 & 218.1 & 216.7 & -1.4 \\
\hline " LAW & $1 F$ & " & 43161.80 & 27182.26 & 165.9 & 185.9 & 203.9 & 205.9 & 2.0 \\
\hline " LAW & $2 \mathrm{C}$ & $"$ & 42471.74 & 28401.16 & 171.2 & 191.2 & 209.2 & 210.8 & 1.6 \\
\hline " LAW & $3 C$ & $"$ & 45049.46 & 27858.57 & 194.9 & 214.9 & 235.2 & 224.1 & -11.1 \\
\hline "LBP & 1D & $"$ & 46902.24 & 30634.31 & 246.3 & 256.3 & 257.1 & 0.0 & -257.1 \\
\hline "LBP & $2 \mathrm{D}$ & $"$ & 46914.71 & 30844.84 & 241.9 & 251.9 & 256.1 & 245.8 & -10.3 \\
\hline " LuBP & $3 D$ & $"$ & 46453.56 & 30930.34 & 242.8 & 252.8 & 256.6 & 243.9 & -12.7 \\
\hline "LCO & 1 & $"$ & 43676.11 & 27723.24 & 195.8 & 225.8 & 214.8 & 215.6 & 0.8 \\
\hline "LCO & 2 & $"$ & 43784.81 & 27822.41 & 196.6 & 226.6 & 215.1 & 217.0 & 1.9 \\
\hline "LCO & 3 & $"$ & 43829.21 & 27695.61 & 196.3 & 226.3 & 229.1 & 216.4 & -12.7 \\
\hline "LCO & 4 & $"$ & 43729.76 & 27598.57 & 192.3 & 222.3 & 212.6 & 215.0 & 2.4 \\
\hline " LCO & 5DL & & 43560.94 & 27519.03 & 174.9 & 184.9 & 212.9 & 212.5 & -0.4 \\
\hline "LCO & 6DL & & 43613.61 & 27604.75 & 178.0 & 188.0 & 213.7 & 213.5 & -0.2 \\
\hline "LCO & $7 \mathrm{DL}$ & & 43719.92 & 27457.02 & 170.2 & 180.2 & 213.3 & 212.9 & -0.4 \\
\hline " LCO & 8DL & & 44170.42 & 28014.74 & 178.4 & 188.4 & 220.5 & 219.7 & -0.8 \\
\hline " LCO & 8DU & & 44151.94 & 28018.67 & 211.1 & 226.1 & 220.6 & 220.9 & 0.3 \\
\hline "LDB & 1 & $"$ & 43460.04 & 28472.85 & 185.0 & 215.0 & 216.9 & 218.7 & 1.8 \\
\hline " LDB & 2 & $"$ & 43675.04 & 28550.75 & 184.5 & 214.5 & 219.0 & 220.2 & 1.2 \\
\hline "LDB & 3 & $"$ & 43434.68 & 28664.71 & 199.3 & 219.3 & 218.5 & 219.7 & 1.2 \\
\hline " LDB & 4 & $"$ & 43198.42 & 28449.23 & 200.7 & 220.7 & 216.5 & 217.2 & 0.7 \\
\hline " LRP & 1 & $"$ & 42583.67 & 31380.70 & 185.8 & 215.8 & 209.1 & 215.9 & 6.8 \\
\hline " LRP & 2 & $"$ & 42626.81 & 31171.46 & 184.7 & 214.7 & 209.6 & 216.8 & 7.2 \\
\hline "LRP & 3 & $"$ & 42469.52 & 31185.16 & 191.4 & 221.4 & 209.4 & 215.9 & 6.5 \\
\hline " LRP & 4 & $"$ & 42400.72 & 31308.77 & 173.3 & 203.3 & 208.6 & 214.3 & 5.7 \\
\hline "LSB & 1 & " & 43415.55 & 27732.52 & 192.7 & 222.7 & 211.6 & 213.8 & 2.2 \\
\hline "LSB & 2 & $"$ & 43551.19 & 27776.17 & 195.0 & 225.0 & 212.4 & 215.1 & 2.7 \\
\hline "LSB & 3 & " & 43492.70 & 27956.99 & 196.6 & 226.6 & 217.2 & 216.1 & -1.1 \\
\hline "LSB & 4 & $"$ & 43266.79 & 27936.41 & 191.5 & 221.5 & 216.8 & 214.2 & -2.6 \\
\hline "MGA & 36 & " & 56426.67 & 54360.14 & 234.2 & 254.2 & 237.4 & 235.6 & -1.8 \\
\hline " MGC & 9 & $"$ & 54500.94 & 56270.36 & 217.3 & 237.3 & 229.4 & 227.6 & -1.8 \\
\hline "MGC & 11 & $"$ & 54632.54 & 56119.91 & 219.2 & 239.2 & 230.7 & 227.8 & -2.9 \\
\hline "MGC & 19 & $"$ & 55156.34 & 55515.60 & 230.6 & 234.6 & 232.0 & 0.0 & -232.0 \\
\hline "MGC & 32 & $"$ & 56009.88 & 54528.57 & 232.0 & 252.0 & 244.9 & 232.8 & -12.1 \\
\hline "MGC & 36 & $"$ & 56279.36 & 54222.66 & 234.4 & 254.4 & 235.8 & 234.5 & -1.3 \\
\hline "MGE & 9 & " & 54349.65 & 56142.01 & 218.1 & 238.1 & 228.8 & 226.8 & -2.0 \\
\hline "MGE & 21 & $"$ & 55134.33 & 55231.67 & 227.9 & 247.9 & 234.0 & 229.0 & -5.0 \\
\hline "MGE & 30 & $"$ & 55732.83 & 54540.13 & 229.3 & 249.3 & 235.7 & 231.4 & -4.3 \\
\hline "MGE & 34 & $"$ & 55995.47 & 54238.12 & 237.2 & 257.2 & 238.1 & 0.0 & -238.1 \\
\hline "MGG & 15 & " & 54596.53 & 55561.90 & 223.3 & 243.3 & 232.5 & 227.1 & -5.4 \\
\hline "MGG & 19 & $"$ & 54861.76 & 55257.10 & 226.0 & 246.0 & 232.3 & 228.0 & -4.3 \\
\hline "MGG & 23 & " & 55122.01 & 54954.38 & 227.1 & 247.1 & 235.0 & 228.9 & -6.1 \\
\hline
\end{tabular}


Table F-2. Summary of Group Statistical Parameters (Continued)

\begin{tabular}{|c|c|c|c|c|c|c|c|c|}
\hline "MGG & 28 & 55452.54 & 54568.21 & 230.3 & 250.3 & 235.3 & 0.0 & -235.3 \\
\hline "MGG & 36 & 55982.43 & 53952.59 & 232.5 & 252.5 & 237.5 & 0.0 & -237.5 \\
\hline "NBG & 1 & 53624.12 & 60472.79 & 200.9 & 232.3 & 224.5 & 221.8 & -2.7 \\
\hline "NBG & 2 & 53659.78 & 60260.13 & 203.6 & 233.6 & 225.0 & 223.7 & -1.3 \\
\hline "NBG & 3 & 53733.78 & 60080.63 & 202.1 & 233.5 & 217.5 & 224.5 & 7.0 \\
\hline "NPM & 1 & 52966.40 & 43082.52 & 257.1 & 277.1 & 287.1 & 276.7 & -10.4 \\
\hline " NPM & 2 & 54524.03 & 43675.02 & 244.2 & 264.2 & 271.6 & 272.6 & 1.0 \\
\hline "NPM & 3 & 51554.55 & 43337.43 & 247.2 & 267.2 & 274.4 & 272.5 & -1.9 \\
\hline "NPM & 4 & 53057.77 & 41764.52 & 256.7 & 276.7 & 284.2 & 278.8 & -5.4 \\
\hline "NPM & $19 \mathrm{~A}$ & 53821.23 & 43736.38 & 248.2 & 268.2 & 270.6 & 273.9 & 3.3 \\
\hline "NPM & $19 \mathrm{~B}$ & 53829.89 & 43745.89 & 217.7 & 227.7 & 268.7 & 272.5 & 3.8 \\
\hline "NPM & $19 \mathrm{C}$ & 53845.64 & 43737.74 & 193.5 & 203.5 & 267.7 & 271.9 & 4.2 \\
\hline "NPM & $34 \mathrm{~A}$ & 52141.34 & 41848.19 & 279.8 & 289.8 & 290.6 & 0.0 & -290.6 \\
\hline "NPM & $34 B$ & 52153.77 & 41839.82 & 225.6 & 235.6 & 271.0 & 275.4 & 4.4 \\
\hline "NPM & $34 \mathrm{C}$ & 52166.49 & 41832.31 & 181.8 & 191.8 & 267.6 & 274.3 & 6.7 \\
\hline "PAC & 1 & 58782.57 & 22820.40 & 253.9 & 283.9 & 284.7 & 275.5 & -9.2 \\
\hline "PAC & 2 & 59001.85 & 22757.84 & 247.9 & 277.9 & 271.0 & 274.0 & 3.0 \\
\hline "PAC & 3 & 58897.00 & 22839.32 & 252.9 & 282.9 & 271.3 & 274.9 & 3.6 \\
\hline "PAC & 4 & 58880.01 & 22750.72 & 250.6 & 280.6 & 284.4 & 274.7 & -9.7 \\
\hline "PAC & 5 & 58936.73 & 22806.44 & 255.1 & 275.1 & 275.1 & 274.7 & -0.4 \\
\hline "PAC & 6 & 58928.43 & 22827.02 & 255.2 & 275.2 & 274.6 & 274.8 & 0.2 \\
\hline "PBP & 10 & 58209.15 & 25056.48 & 269.1 & 279.1 & 280.3 & 277.8 & -2.5 \\
\hline " PBP & 2D & 57822.47 & 25005.93 & 262.8 & 272.8 & 278.4 & 277.9 & -0.5 \\
\hline "PBP & $3 \mathrm{D}$ & 57994.88 & 25094.07 & 268.9 & 278.9 & 279.8 & 278.2 & -1.6 \\
\hline " PCB & $1 \mathrm{~A}$ & 56813.22 & 21649.15 & 263.5 & 293.5 & 280.7 & 279.1 & -1.6 \\
\hline " $\mathrm{PCB}$ & $2 \mathrm{~A}$ & 56603.25 & 21523.26 & 257.8 & 287.8 & 279.5 & 278.8 & -0.7 \\
\hline " PCB & $3 \mathrm{~A}$ & 56466.82 & 21771.65 & 262.7 & 292.7 & 281.6 & 279.2 & -2.4 \\
\hline " PCB & $4 \mathrm{~A}$ & 56685.72 & 21863.14 & 262.9 & 292.9 & 279.7 & 279.4 & -0.3 \\
\hline " PDB & 2 & 56809.92 & 23208.82 & 247.7 & 268.7 & 277.9 & 278.2 & 0.3 \\
\hline "PDB & 3 & 57006.81 & 23196.72 & 248.1 & 269.1 & 278.1 & 278.4 & 0.3 \\
\hline "PDB & 4 & 56681.17 & 23176.89 & 266.2 & 286.2 & 278.9 & 279.1 & 0.2 \\
\hline "PDB & 5 & 56778.08 & 23822.35 & 264.2 & 284.2 & 277.7 & 278.6 & 0.9 \\
\hline " PRP & $1 \mathrm{~A}$ & 55518.77 & 25361.00 & 232.9 & 262.9 & 249.1 & 263.5 & 14.4 \\
\hline " PRP & 2 & 55719.03 & 25359.02 & 234.1 & 264.1 & 255.5 & 266.4 & 10.9 \\
\hline "PRP & 3 & 55617.66 & 25187.55 & 228.6 & 258.6 & 255.4 & 263.0 & 7.6 \\
\hline " PRP & 4 & 55808.30 & 25216.75 & 232.9 & 262.9 & 257.6 & 267.1 & 9.5 \\
\hline "PSB & $1 \mathrm{~A}$ & 56243.45 & 23437.80 & 257.4 & 287.4 & 276.5 & 277.9 & 1.4 \\
\hline "PSB & $2 \mathrm{~A}$ & 56022.03 & 23477.81 & 257.2 & 287.2 & 276.3 & 277.4 & 1.1 \\
\hline "PSB & $3 \mathrm{~A}$ & 55700.43 & 23533.29 & 256.5 & 286.5 & 275.2 & 276.2 & 1.0 \\
\hline "PSB & $4 \mathrm{~A}$ & 55448.71 & 23519.73 & 255.5 & 285.5 & 274.3 & 275.5 & 1.2 \\
\hline "PSB & $5 A$ & 55683.06 & 23374.12 & 262.3 & 292.3 & 275.7 & 276.8 & 1.1 \\
\hline " PSB & $6 \mathrm{~A}$ & 56043.26 & 23292.96 & 262.1 & 292.1 & 277.2 & 277.8 & 0.6 \\
\hline "PSB & $7 \mathrm{~A}$ & 56385.84 & 23340.06 & 259.0 & 289.0 & 276.9 & 278.3 & 1.4 \\
\hline "SBG & 2 & 63459.26 & 53546.40 & 205.9 & 235.9 & 237.8 & 244.2 & 6.4 \\
\hline "SBG & 3 & 63597.19 & 52627.33 & 206.6 & 236.6 & 237.5 & 244.8 & 7.3 \\
\hline "SBG & 6 & 62201.39 & 52821.17 & 208.1 & 238.1 & 244.5 & 251.8 & 7.3 \\
\hline "SCA & 2 & 63072.44 & 52892.94 & 215.9 & 245.9 & 242.2 & 249.0 & 6.8 \\
\hline " SCA & 3 & 62971.90 & 53025.44 & 220.3 & 240.3 & 241.3 & 249.2 & 7.9 \\
\hline "SCA. & $3 \mathrm{~A}$ & 62973.08 & 53031.02 & 267.1 & 272.4 & 271.1 & 0.0 & -271.1 \\
\hline "SCA. & 4 & 62942.99 & 52926.49 & 220.4 & 240.4 & 241.5 & 249.5 & 8.0 \\
\hline "SCA & $4 \mathrm{~A}$ & 62946.34 & 52924.45 & 265.3 & 274.0 & 268.8 & 0.0 & -268.8 \\
\hline "SCA & 5 & 63057.97 & 53143.73 & 223.7 & 243.7 & 241.3 & 248.6 & 7.3 \\
\hline "SCA & 6 & 62984.12 & 52764.09 & 221.3 & 241.1 & 242.0 & 249.6 & 7.6 \\
\hline "SLP & 1 & 62644.37 & 52071.80 & 228.0 & 248.0 & 245.1 & 252.4 & 7.3 \\
\hline & 2 & .45 & 51 & & & & & 6.8 \\
\hline "YSC & $1 \mathrm{D}$ & 65107.25 & 56877.04 & 216.8 & 236.8 & 221.3 & 220.9 & -0.4 \\
\hline $\mathrm{zz}$ & 2 & 52002.92 & 56201.42 & 214.0 & 214.5 & 218.7 & 219.4 & 0.7 \\
\hline$" z$ & 3 & 50252.68 & 56881.07 & 206.6 & 207.1 & 212.6 & 212.8 & 0.2 \\
\hline $\mathrm{z}$ & 8 & 50826.83 & 58348.05 & 213.6 & 214.1 & 218.9 & 221.1 & 2.2 \\
\hline$" z$ & 9 & 50061.53 & 59626.61 & 207.5 & 227.5 & 214.9 & 212.9 & -2.0 \\
\hline
\end{tabular}


Table F-2. Summary of Group Statistical Parameters (Continued)

\begin{tabular}{|c|c|c|c|c|c|c|c|c|c|}
\hline "Z & 12 & $"$ & 59296.96 & 50984.50 & 251.3 & 251.8 & 274.3 & 274.3 & 0.0 \\
\hline " 2 & 13 & $"$ & 59996.23 & 50413.54 & 256.6 & 257.1 & 275.2 & 279.6 & 4.4 \\
\hline$" z$ & 15 & $"$ & 61604.47 & 52133.04 & 253.8 & 254.3 & 263.7 & 258.2 & -5.5 \\
\hline$" z$ & 20 & $"$ & 42603.93 & 57478.90 & 173.4 & 193.4 & 184.7 & 180.2 & -4.5 \\
\hline$" 2$ & $20 B$ & $"$ & 42603.46 & 57483.39 & 175.6 & 195.6 & 190.7 & 180.3 & -10.4 \\
\hline " ZBG & 1 & $"$ & 64508.41 & 55382.39 & 220.0 & 240.1 & 234.0 & 234.7 & 0.7 \\
\hline " ZBG & $1 \mathrm{~A}$ & $"$ & 64523.68 & 55383.54 & 275.0 & 281.0 & 279.9 & 0.0 & -279.9 \\
\hline "ZDT & 1 & $"$ & 63022.32 & 50648.11 & 227.0 & 237.6 & 239.9 & 237.8 & -2.1 \\
\hline "ZDT & 2 & $"$ & 62979.45 & 50710.48 & 225.1 & 243.1 & 241.4 & 241.2 & -0.2 \\
\hline$" \mathrm{ZW}$ & 4 & $"$ & 55903.68 & 58318.78 & 229.2 & 239.7 & 232.2 & 232.7 & 0.5 \\
\hline$" \mathrm{ZW}$ & 5 & $"$ & 53700.74 & 56844.58 & 221.0 & 231.0 & 227.3 & 228.5 & 1.2 \\
\hline$" \mathrm{ZW}$ & 6 & $"$ & 51164.33 & 57791.21 & 216.7 & 227.2 & 220.2 & 222.7 & 2.5 \\
\hline "ZW & 7 & $"$ & 58470.42 & 52387.61 & 254.5 & 264.8 & 265.8 & 255.9 & -9.9 \\
\hline "ZW & 8 & $"$ & 61562.33 & 50095.99 & 254.1 & 264.1 & 270.8 & 268.0 & -2.8 \\
\hline$" \mathrm{ZW}$ & 9 & $"$ & 59712.09 & 52940.43 & 242.4 & 252.4 & 252.0 & 253.8 & 1.8 \\
\hline " $\mathrm{ZW}$ & 10 & $"$ & 61671.98 & 52538.16 & 242.2 & 252.2 & 249.7 & 255.8 & 6.1 \\
\hline " CMP & $10 D$ & $"$ & 47934.22 & 33150.84 & 209.6 & 229.6 & 229.8 & 235.9 & 6.1 \\
\hline "CMP & $11 D$ & $"$ & 47610.19 & 33296.80 & 209.5 & 229.9 & 223.3 & 234.4 & 11.1 \\
\hline " CMP & $14 \mathrm{D}$ & $"$ & 46762.01 & 34392.70 & 204.1 & 224.5 & 217.4 & 211.6 & -5.8 \\
\hline "CMP & $15 \mathrm{C}$ & $"$ & 46865.00 & 33346.32 & 220.6 & 250.6 & 244.5 & 234.5 & -10.0 \\
\hline "CMP & $30 D$ & $"$ & 47226.07 & 33625.65 & 211.6 & 231.6 & 228.0 & 228.8 & 0.8 \\
\hline "CMP & $32 D$ & $"$ & 48177.29 & 33934.12 & 218.6 & 228.6 & 220.8 & 0.0 & -220.8 \\
\hline "NPM & 2 & $"$ & 54524.03 & 43675.02 & 244.2 & 264.2 & 267.0 & 272.6 & 5.6 \\
\hline "NPM & 3 & $"$ & 51554.55 & 43337.43 & 247.2 & 267.2 & 267.6 & 272.5 & 4.9 \\
\hline "NPM & 4 & $"$ & 53057.77 & 41764.52 & 256.7 & 276.7 & 272.7 & 278.8 & 6.1 \\
\hline "NTN & 1 & $"$ & 40851.04 & 40382.75 & 212.4 & 232.4 & 233.7 & 238.2 & 4.5 \\
\hline "NTN & 2 & $"$ & 42194.02 & 41060.13 & 207.2 & 227.2 & 235.2 & 243.5 & 8.3 \\
\hline "NTS & 1 & $"$ & 36950.43 & 30056.38 & 164.3 & 184.4 & 180.4 & 184.4 & 4.0 \\
\hline "NTS & 2 & $"$ & 38877.07 & 29831.49 & 174.7 & 194.8 & 192.3 & 198.6 & 6.3 \\
\hline "NTW & 1 & $"$ & 33953.91 & 33448.01 & 168.9 & 188.8 & 183.6 & 186.3 & 2.7 \\
\hline "NTW & 2 & $"$ & 33179.95 & 34157.22 & 171.5 & 191.5 & 183.9 & 186.8 & 2.9 \\
\hline "NTW & 3 & $"$ & 35146.82 & 34486.17 & 176.7 & 196.6 & 191.8 & 194.8 & 3.0 \\
\hline "NTW & 4 & $"$ & 35314.22 & 33015.53 & 166.0 & 185.8 & 180.4 & 181.8 & 1.4 \\
\hline$* * \mathrm{GE}$ & ROUP & 4 & ** rms of & (FACT-data) & differ & : & 8.049 & & \\
\hline & & & avg of & (FACT-data) & diffe & : & -1.486 & & \\
\hline & & & avg of & |FACT-data| & differ & aces: & 5.188 & & \\
\hline & & & $\max$ of & $\{$ FACT-data $\}$ & diffe & ices: & -38.678 & & \\
\hline "BG & 91 & $"$ & 56069.82 & .49 & 205.4 & 235.4 & 218.6 & 224.5 & 5.9 \\
\hline "BG & 113 & $"$ & 58617.49 & 57478.99 & 196.4 & 216.4 & 217.1 & 216.1 & -1.0 \\
\hline "BG & 115 & $"$ & 57106.59 & 57592.61 & 198.9 & 218.9 & 215.8 & 224.7 & 8.9 \\
\hline " BG & 119 & $"$ & 56357.76 & 58300.26 & 209.2 & 229.2 & 215.4 & 225.8 & 10.4 \\
\hline "BG & 124 & $"$ & 56344.08 & 57802.53 & 214.8 & 234.8 & 231.8 & 230.7 & -1.1 \\
\hline " BGO & $10 \mathrm{~A}$ & $"$ & 56207.63 & 57372.71 & 111.1 & 121.1 & 170.6 & 157.6 & -13.0 \\
\hline "BGO & $11 \mathrm{DR}$ & & 55825.05 & 57499.11 & 213.1 & 233.0 & 230.1 & 231.2 & 1.1 \\
\hline "BGO & $12 \mathrm{DR}$ & & 55395.81 & 57575.32 & 212.7 & 232.8 & 219.6 & 230.9 & 11.3 \\
\hline " BGO & $17 D$ & $"$ & 55319.71 & 56328.91 & 204.0 & 224.0 & 230.8 & 229.1 & -1.7 \\
\hline "BGO & $19 D$ & $"$ & 55852.65 & 55960.45 & 196.8 & 216.8 & 234.2 & 230.2 & -4.0 \\
\hline "BGO & $19 \mathrm{DR}$ & & 55695.69 & 56167.61 & 196.7 & 216.7 & 231.3 & 229.0 & -2.3 \\
\hline "BGO & $20 A A$ & $"$ & 55859.63 & 55549.83 & 36.4 & 28.3 & 161.5 & 0.0 & -161.5 \\
\hline " BGO & $45 \mathrm{~A}$ & $"$ & 53558.72 & 56938.76 & 116.9 & 126.9 & 160.7 & 169.5 & 8.8 \\
\hline "BGO & $46 D$ & $"$ & 53265.93 & 56187.01 & 202.1 & 212.1 & 225.0 & 224.3 & -0.7 \\
\hline "BGO & $47 D$ & $"$ & 53696.69 & 55794.78 & 203.4 & 213.4 & 226.3 & 224.2 & -2.1 \\
\hline "BGO & $48 D$ & $"$ & 53858.59 & 55603.64 & 202.0 & 212.0 & 226.5 & 224.1 & -2.4 \\
\hline "BGO & $51 A A$ & $"$ & 56446.18 & 54569.76 & 31.1 & 39.2 & 168.2 & 165.9 & -2.3 \\
\hline "BGX & $3 D$ & $"$ & 57081.36 & 57976.03 & 201.6 & 221.6 & 214.6 & 223.0 & 8.4 \\
\hline "BRD & 4 & $"$ & 24671.03 & 42867.77 & 129.1 & 159.1 & 165.9 & 176.1 & 10.2 \\
\hline "BRR & $8 C$ & $"$ & 49605.56 & 59621.29 & 182.7 & 192.7 & 208.5 & 205.9 & -2.6 \\
\hline " CMP & 10 & $"$ & 47945.72 & 33146.25 & 188.8 & 218.8 & 220.1 & 222.1 & 2.0 \\
\hline
\end{tabular}


Table F-2. Summary of Group Statistical Parameters (Continued)

\begin{tabular}{|c|c|c|c|}
\hline CMP & 11 & " & 47606.72 \\
\hline "CMP & $14 \mathrm{C}$ & " & 46754.03 \\
\hline "FAB & 3 & " & 54303.61 \\
\hline "FBP & $5 D$ & " & 50857.86 \\
\hline "FBP & $11 D$ & " & 50538.90 \\
\hline "FC & $3 A$ & " & 57163.77 \\
\hline "FC & $4 \mathrm{~A}$ & " & 54252.64 \\
\hline "FC & $4 D$ & " & 54270.62 \\
\hline "FCB & 2 & " & 54221.13 \\
\hline "FNB & 6 & $"$ & 54152.82 \\
\hline "FSBI & $15 \mathrm{C}$ & $"$ & 48160.70 \\
\hline "FSBI & $22 \mathrm{C}$ & $"$ & 46937.44 \\
\hline "HAA & $1 A A$ & & 60549.35 \\
\hline "HAA. & $1 \mathrm{TA}$ & & 60543.75 \\
\hline "HAA & $2 A \mathrm{~A}$ & & 59126.82 \\
\hline "HAA & 3AA & & 58184.26 \\
\hline "HAA & $4 B$ & 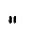 & 60007.73 \\
\hline "HC & $8 \mathrm{~A}$ & $"$ & 59290.18 \\
\hline " $\mathrm{HC}$ & $11 \mathrm{C}$ & $"$ & 60697.08 \\
\hline "HSB & $86 C$ & $"$ & 54275.70 \\
\hline "HSBI & $11 D$ & $"$ & 54648.99 \\
\hline "HSB1 & $12 \mathrm{D}$ & $"$ & 54613.42 \\
\hline "HSB1 & $18 \mathrm{~A}$ & $"$ & 54105.93 \\
\hline "HSB1 & $21 \mathrm{~A}$ & $"$ & 55545.03 \\
\hline "HSB1 & $23 A$ & $"$ & 56298.47 \\
\hline " HSB1 & 24AR & & 56699.16 \\
\hline "HSBI & $39 A$ & $"$ & 55334.77 \\
\hline "HSB1 & $45 \mathrm{D}$ & $"$ & 55706.59 \\
\hline "HSL & $6 B$ & $"$ & 58765.56 \\
\hline "KSS & $3 D$ & $"$ & 33990.18 \\
\hline "LAW" & $1 C$ & $"$ & 43197.56 \\
\hline "NBG & 4 & $"$ & 53989.69 \\
\hline "NBG & 5 & $"$ & 54172.29 \\
\hline "SBG & 1 & $"$ & 62305.00 \\
\hline "SBG & 4 & 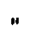 & 63077.06 \\
\hline "SBG & 5 & $"$ & 62537.22 \\
\hline "TIR & IL & $"$ & 15016.33 \\
\hline "YSC & $2 \mathrm{D}$ & $"$ & 65404.04 \\
\hline " $z$ & 18 & $"$ & 42445.86 \\
\hline "ZBG & 2 & $"$ & 66269.92 \\
\hline$" \mathrm{ZW}$ & 3 & $"$ & 57053.77 \\
\hline "CMP & $31 \mathrm{C}$ & $"$ & 47419.09 \\
\hline$" \mathrm{P}$ & $15 \mathrm{~A}$ & $"$ & 44409.31 \\
\hline$" P$ & $23 A$ & $"$ & 24677.32 \\
\hline
\end{tabular}

33311.24 34402.77

58131.15

60951.80

60922.99

59133.80

63347.03

63363.34

57666.65

61916.51

54697.60

56354.44

49375.76

49383.60

50741.06

51516.57

51880.30

57409.21

54058.07

53412.33

52716.01

52964.23

53618.85

52626.35

52634.89

52562.91

51753.59

51634.28

52607.86

31260.46

27174.96

60028.79

59991.30

53842.04

51408.75

51327.71

60212.77

56967.00

56486.58

54585.02

61222.21

34279.81

29159.29

34743.42

\begin{tabular}{rrr}
185.2 & 215.2 & 212.0 \\
185.1 & 215.1 & 212.4 \\
211.8 & 231.8 & 228.8 \\
192.6 & 212.6 & 205.2 \\
192.0 & 212.1 & 203.0 \\
54.2 & 26.5 & 175.5 \\
66.5 & -23.0 & 173.3 \\
146.4 & 151.4 & 151.0 \\
205.2 & 235.2 & 229.1 \\
200.6 & 210.6 & 208.7 \\
163.8 & 173.8 & 184.4 \\
160.0 & 170.0 & 199.7 \\
35.7 & 23.6 & 181.0 \\
35.6 & -19.8 & 180.7 \\
29.4 & 39.4 & 177.6 \\
9.2 & 16.5 & 175.0 \\
124.5 & 135.0 & 250.2 \\
65.9 & 16.3 & 175.6 \\
190.8 & 195.8 & 236.6 \\
189.4 & 199.4 & 223.6 \\
185.7 & 195.7 & 222.0 \\
188.3 & 198.3 & 222.8 \\
91.0 & 101.0 & 167.6 \\
88.3 & 98.3 & 171.6 \\
93.6 & 103.6 & 171.7 \\
94.6 & 104.6 & 172.0 \\
87.6 & 97.6 & 173.6 \\
184.2 & 194.2 & 220.5 \\
127.9 & 137.9 & 244.3 \\
139.3 & 159.3 & 163.8 \\
-27.8 & -29.0 & 176.2 \\
196.1 & 227.5 & 217.0 \\
194.9 & 226.4 & 217.8 \\
190.7 & 220.7 & 237.9 \\
185.6 & 215.6 & 240.9 \\
199.4 & 219.4 & 249.3 \\
65.7 & 67.7 & 93.2 \\
197.9 & 218.0 & 216.2 \\
159.9 & 160.4 & 184.2 \\
210.9 & 230.9 & 221.7 \\
194.6 & 205.1 & 200.7 \\
197.9 & 207.9 & 210.8 \\
-20.5 & -87.0 & 176.8 \\
-4.3 & -28.8 & 146.1 \\
& & \\
\hline 190
\end{tabular}


This page intentionally left blank 


\section{APPENDIX G. Uncertainty Analysis}

Four uncertainty cases were considered as summarized in the table below. For each case. numerous plots of the simulated groundwater flow results are provided for comparison to the nominal case. Discussion of the comparison is provided in the Section 4.3 of the main text.

GCU Kv

\begin{tabular}{|c|c|c|c|}
\cline { 2 - 4 } Recharge & $5 \times 10^{-4} \mathrm{ft} /$ day & $10^{-4} \mathrm{ft} /$ day & $2 \times 10^{-5} \mathrm{ft} /$ day \\
\hline $15 \mathrm{in} / \mathrm{yr}$ & - & Case 1 & - \\
\hline $12.5 \mathrm{in} / \mathrm{yr}$ & Case 3 & Nominal & Case 4 \\
\hline $10 \mathrm{in} / \mathrm{yr}$ & - & Case 2 & - \\
\hline
\end{tabular}


This page intentionally left blank 


\section{Simulation results for uncertainty case 1}

Uncertainty case 1 involves an increase in recharge of $20 \%$ to $15 \mathrm{in} / \mathrm{yr}$ over the reactor areas (Table 4-4). Summary calibration results are provided in Table 4-5. This appendix presents detailed simulation results for uncertainty case 1 for comparison to the nominal results shown in figures in the main text. The correspondence between figures for the nominal and uncertainty case 1 is as follows:

\begin{tabular}{|l|l|l|}
\hline Plot type & Nominal case & Uncertainty case 1 \\
\hline Head residual summary & Figure 4-1 & Figure G-1-1 \\
\hline Head residuals in Gordon aquifer & Figure 4-2 & Figure G-1-2 \\
\hline Head residuals in "lower" UTRA & Figure 4-3 & Figure G-1-3 \\
\hline Head residuals in "upper" UTRA & Figure 4-4 & Figure G-1-4 \\
\hline Kh in element layer 1 & Figure 4-5 & Figure G-1-5 \\
\hline Kv in element layer 2 & Figure 4-6 & Figure G-1-6 \\
\hline Kh in element layer 3 & Figure 4-7 & Figure G-1-7 \\
\hline Kh in element layer 4 & Figure 4-8 & Figure G-1-8 \\
\hline Kv in element layer 5 & Figure 4-9 & Figure G-1-9 \\
\hline Kh in element layer 6 & Figure 4-10 & Figure G-1-10 \\
\hline Kh in element layer 7 & Figure 4-11 & Figure G-1-11 \\
\hline Kh in element layer 8 & Figure 4-12 & Figure G-1-12 \\
\hline Gordon aquifer head & Figure 4-14 & Figure G-1-13 \\
\hline "Lower" UTRA head & Figure 4-15 & Figure G-1-14 \\
\hline "Upper" UTRA head & Figure 4-16 & Figure G-1-15 \\
\hline Head in aquifer containing water table & Figure 4-17 & Figure G-1-16 \\
\hline Water table & Figure 4-18 & Figure G-1-17 \\
\hline Seepage faces & Figure 4-22 & Figure G-1-18 \\
\hline Recharge/discharge & Figure 4-23 & Figure G-1-19 \\
\hline Example particle tracing & Figure 4-24 & Figure G-1-20 \\
\hline & & \\
\hline
\end{tabular}



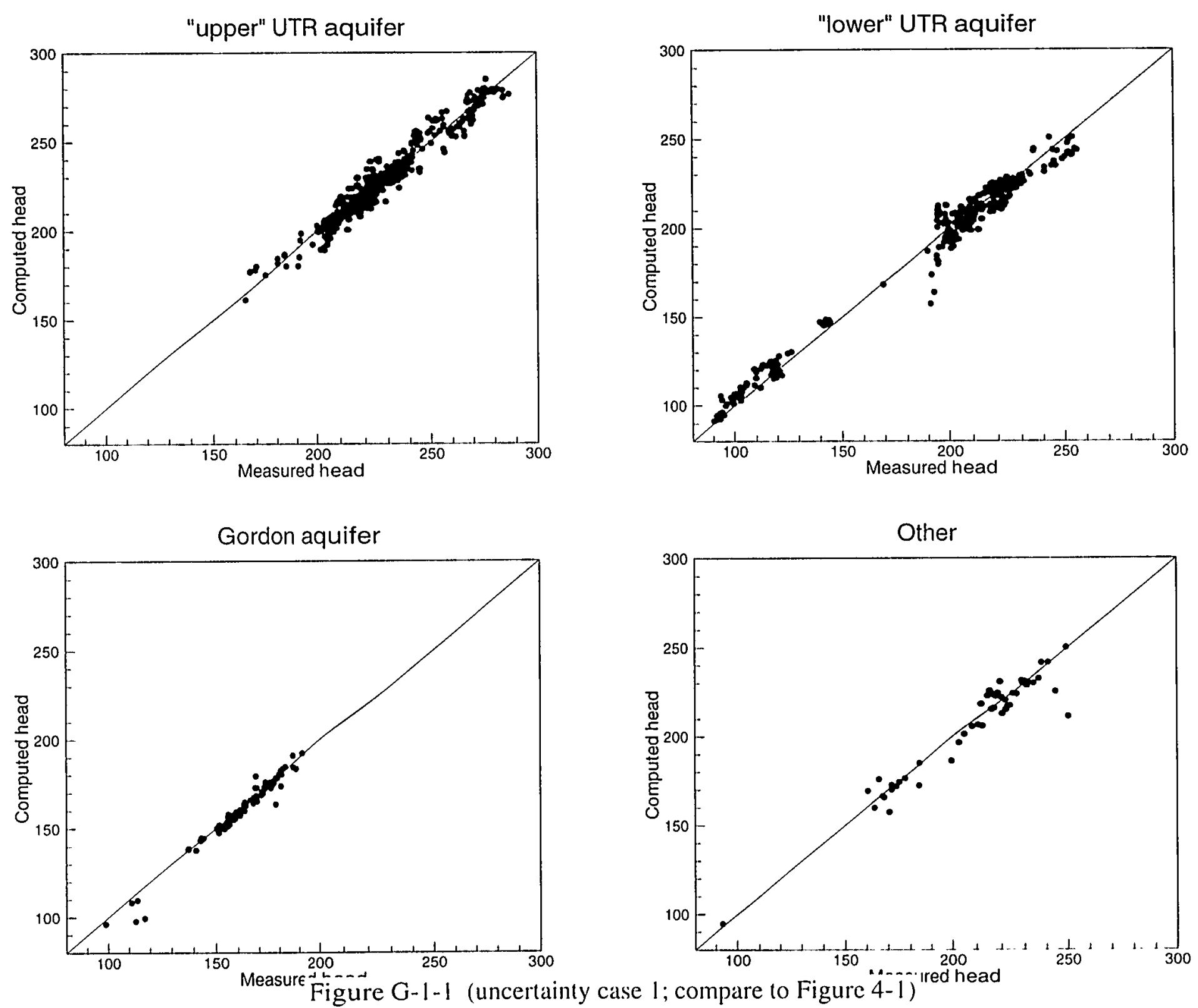


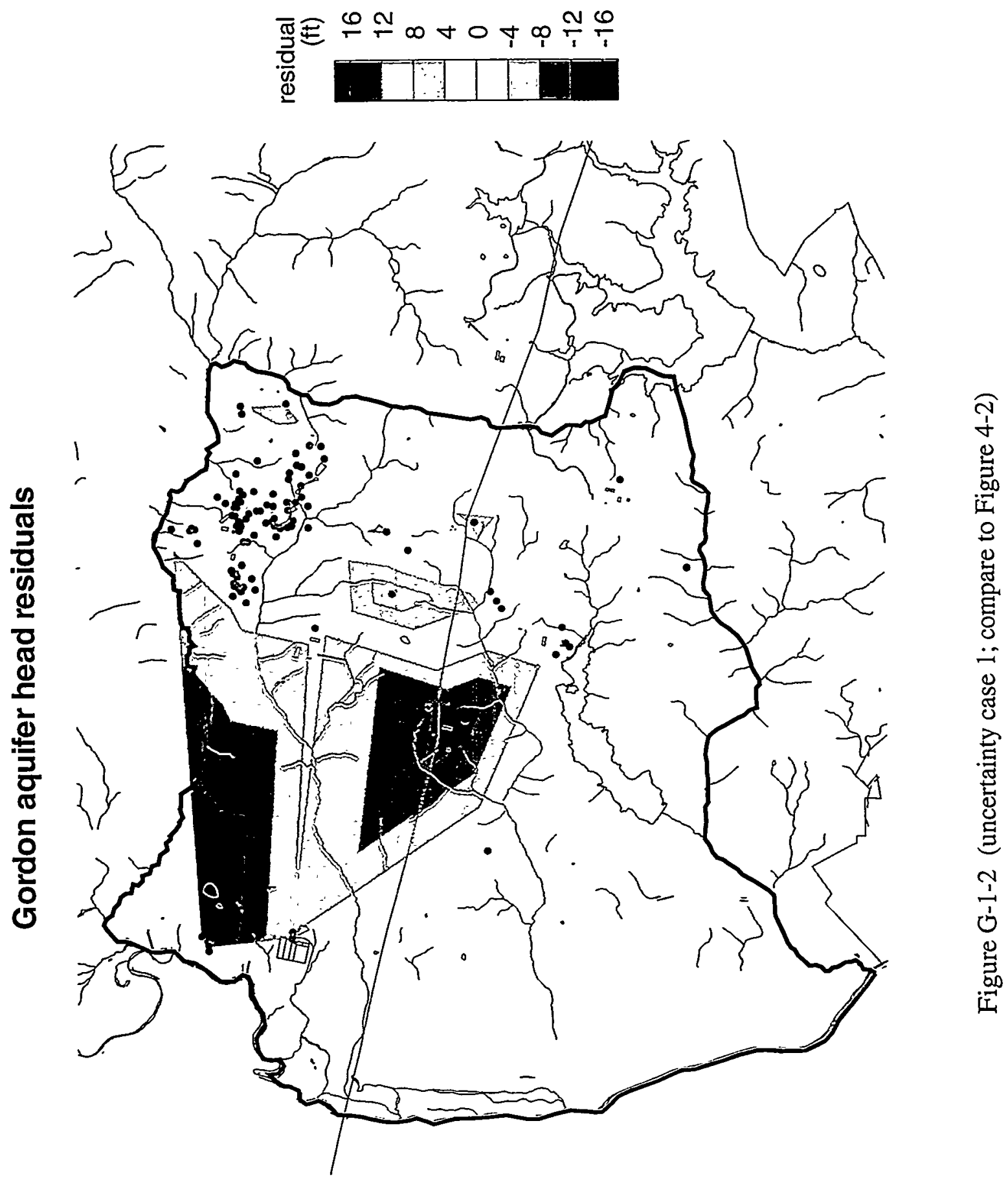




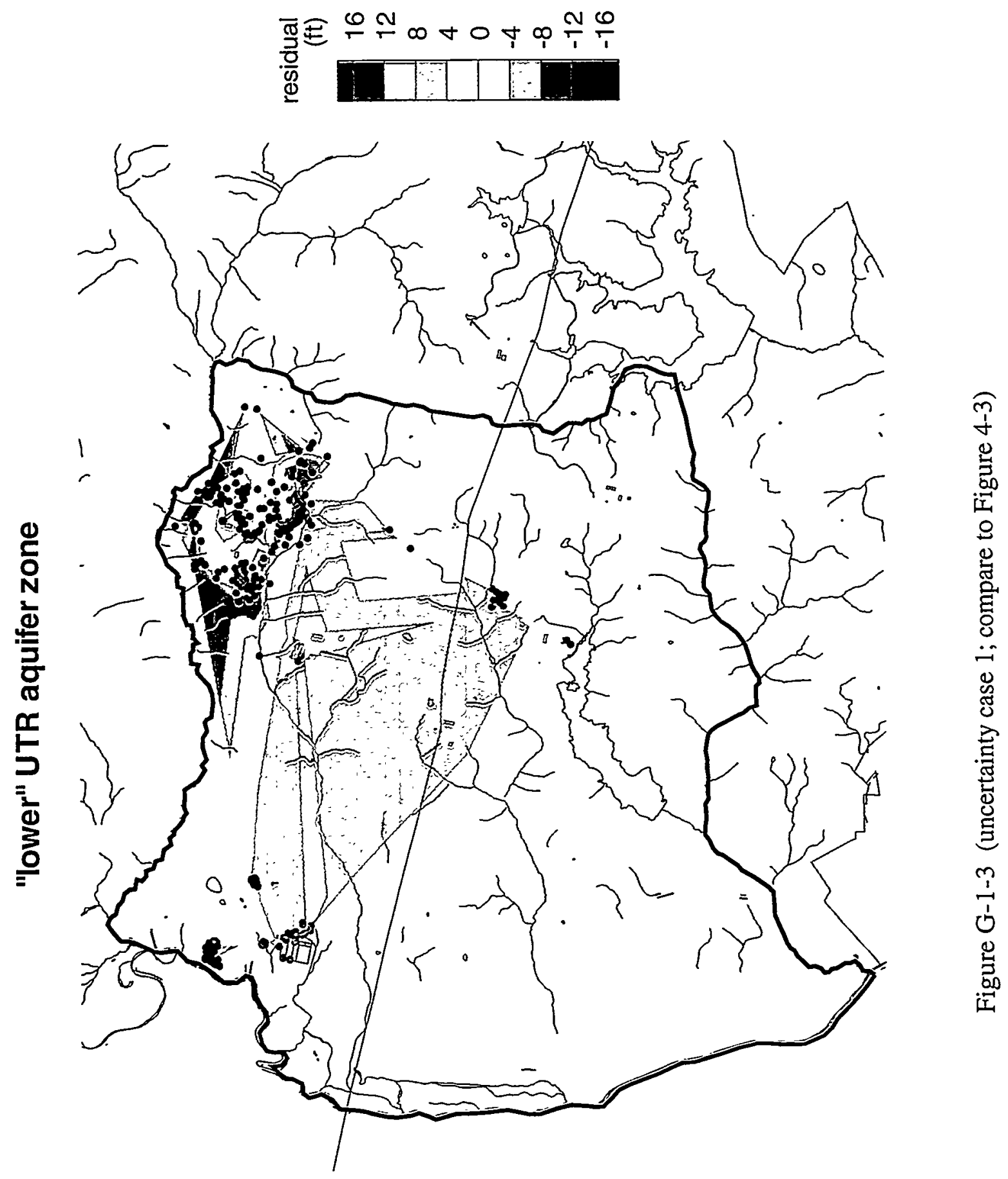




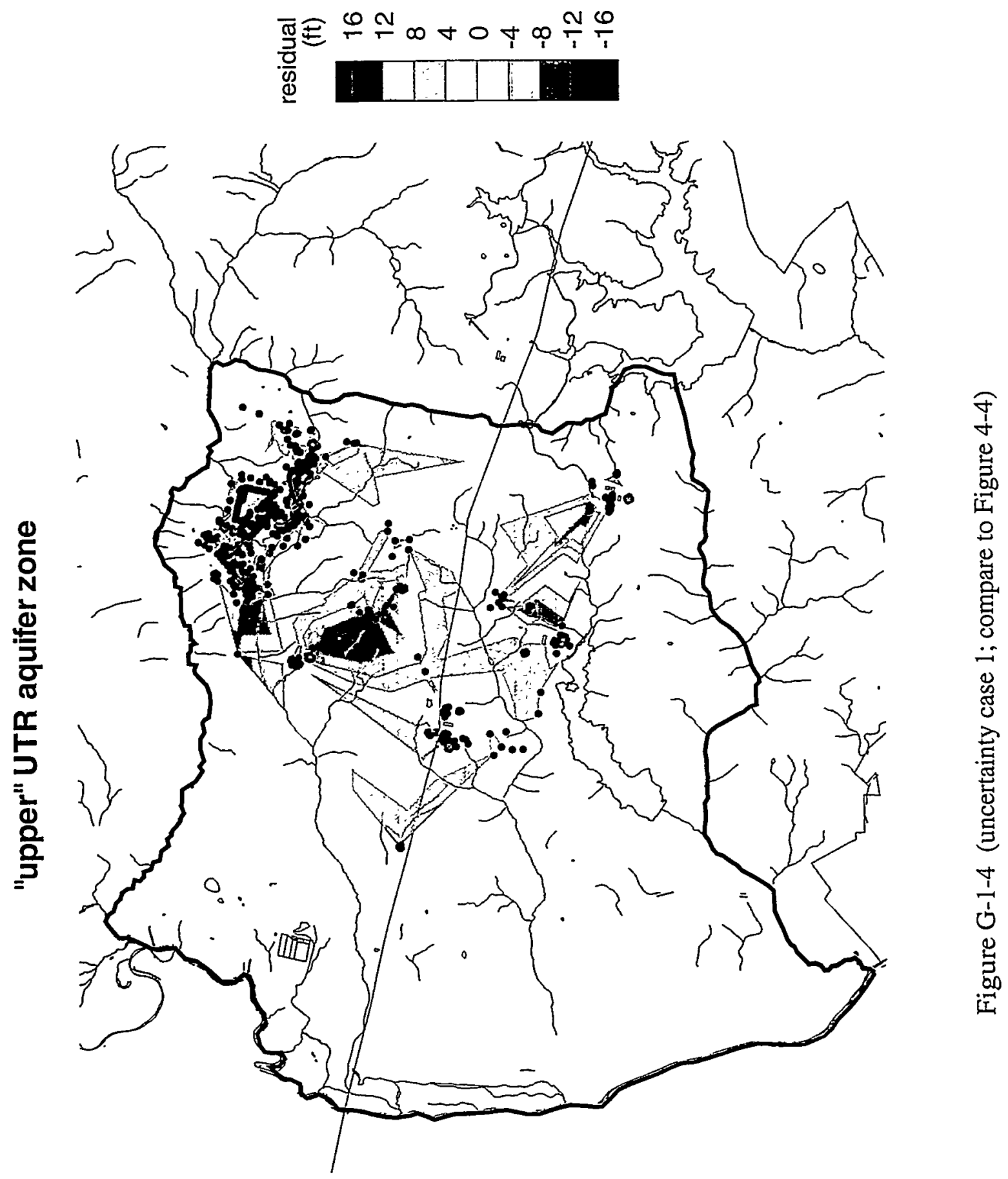




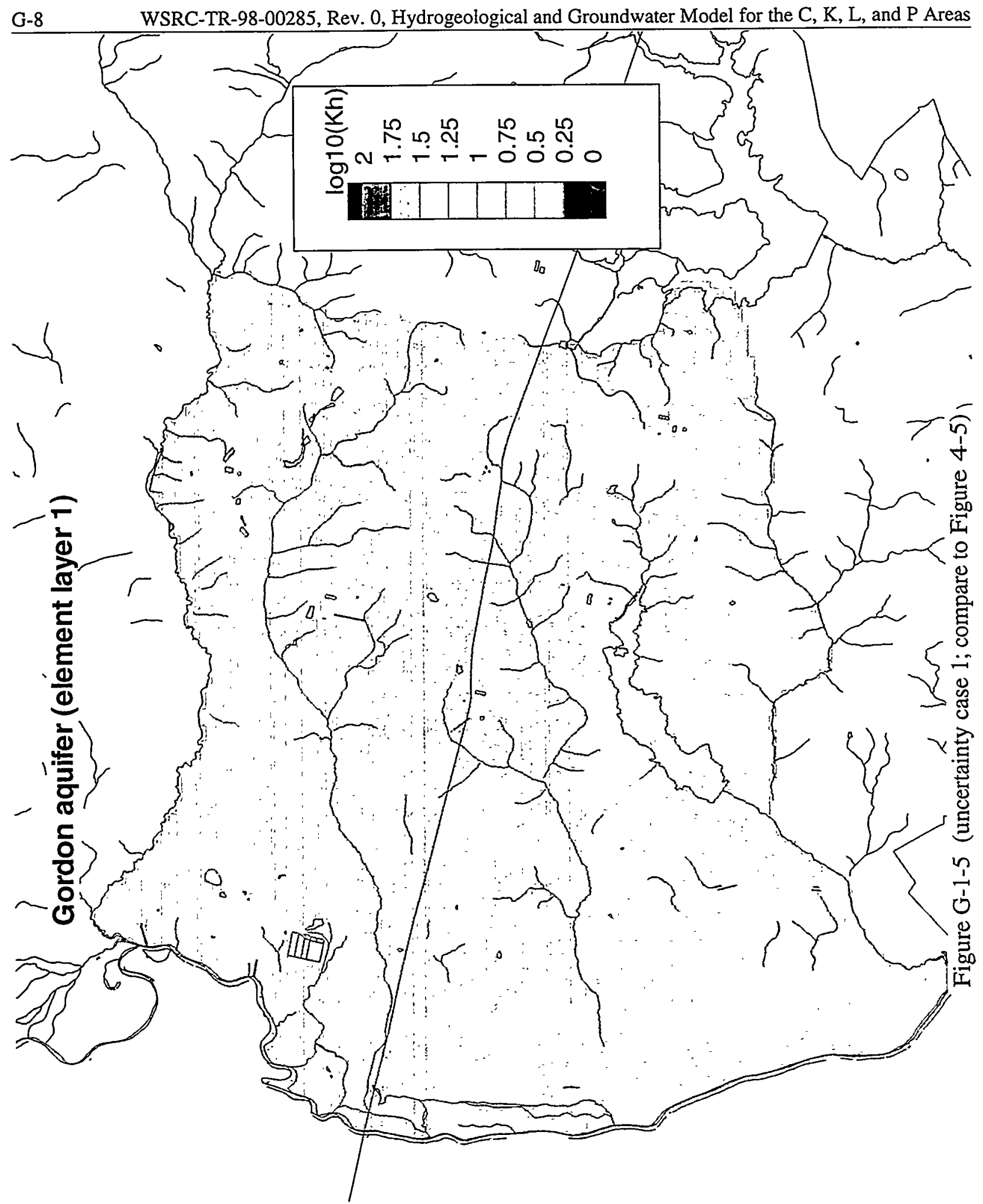


WSRC-TR-98-00285, Rev. 0, Hydrogeological and Groundwater Model for the C, K, L, and P Areas

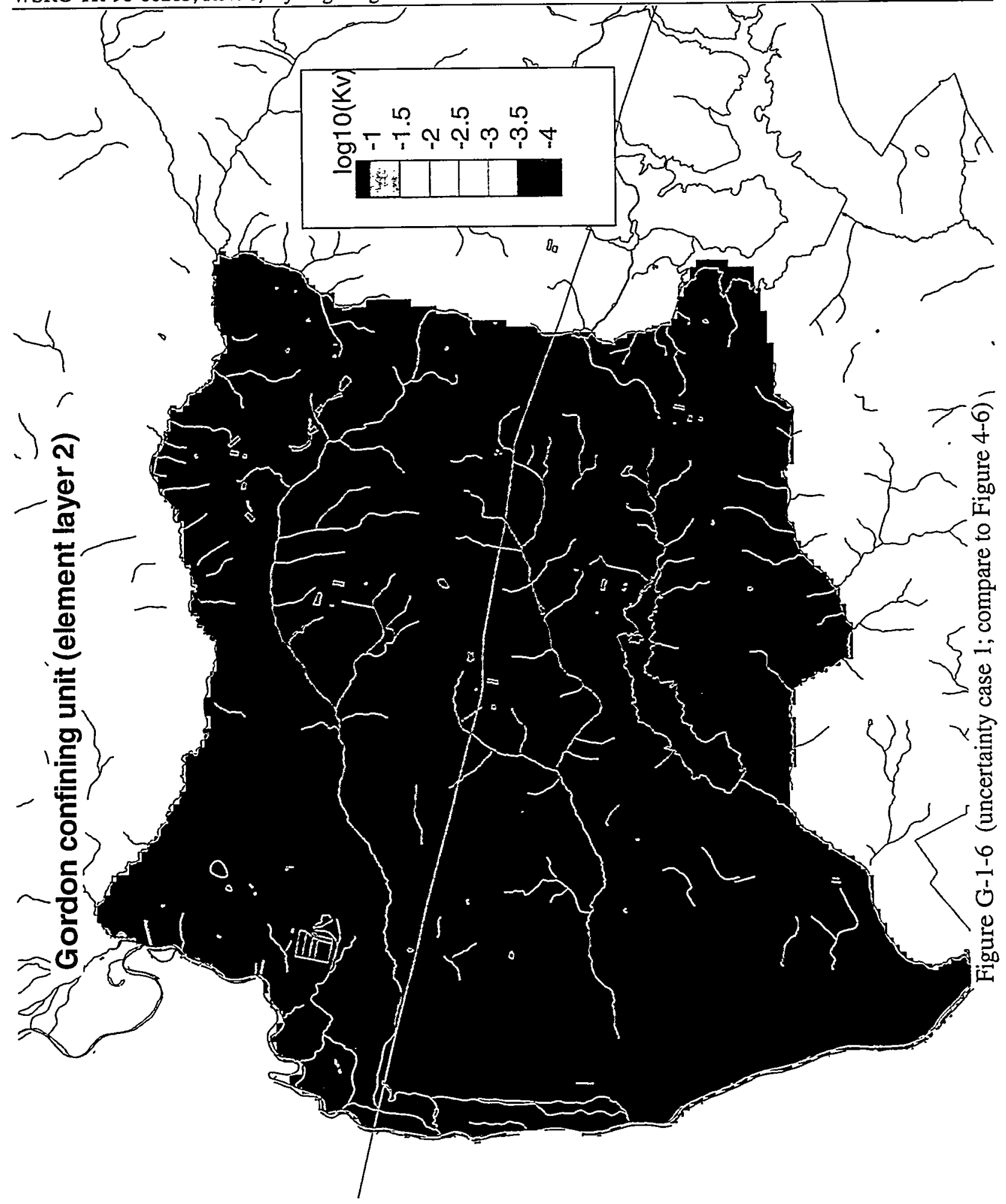




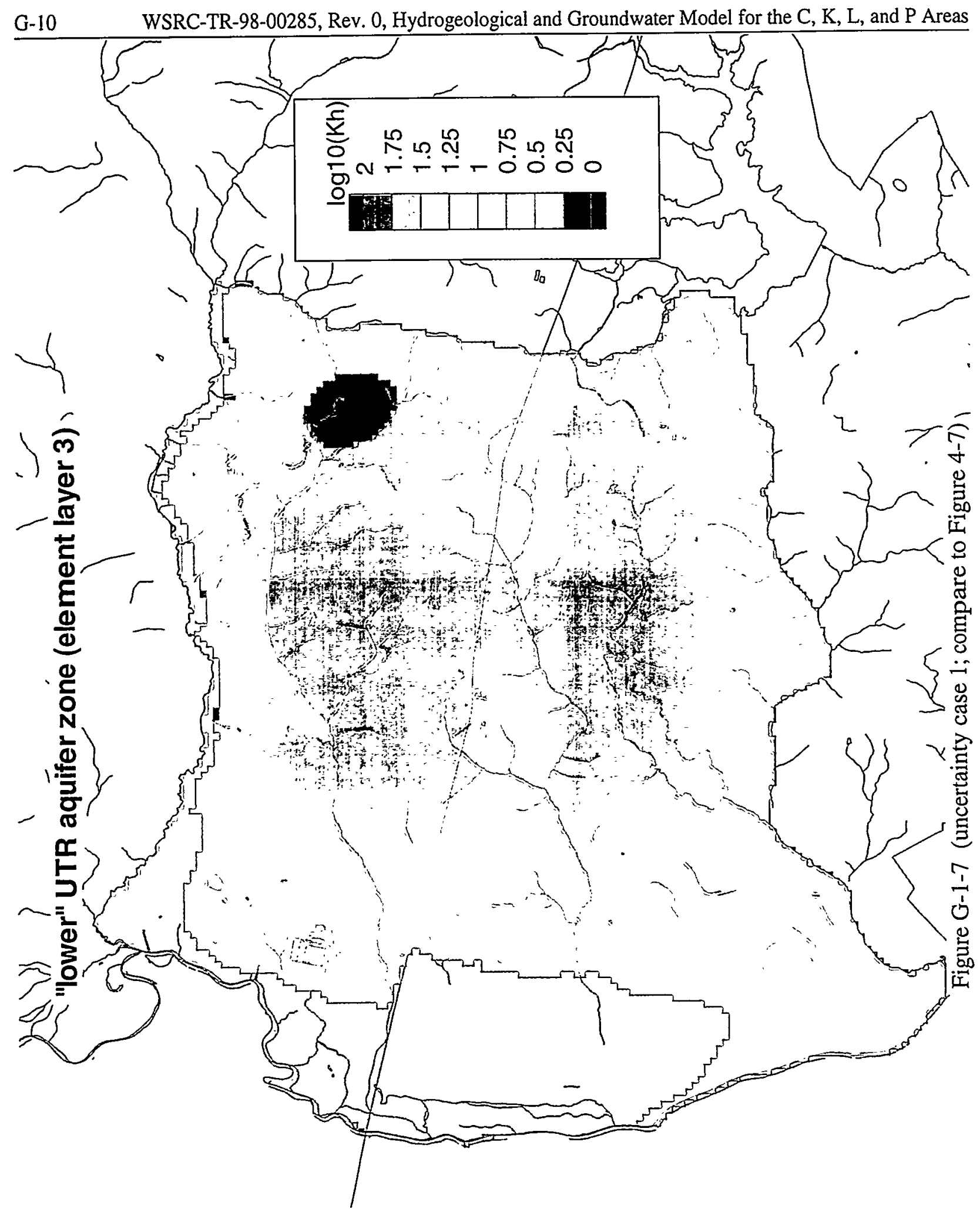




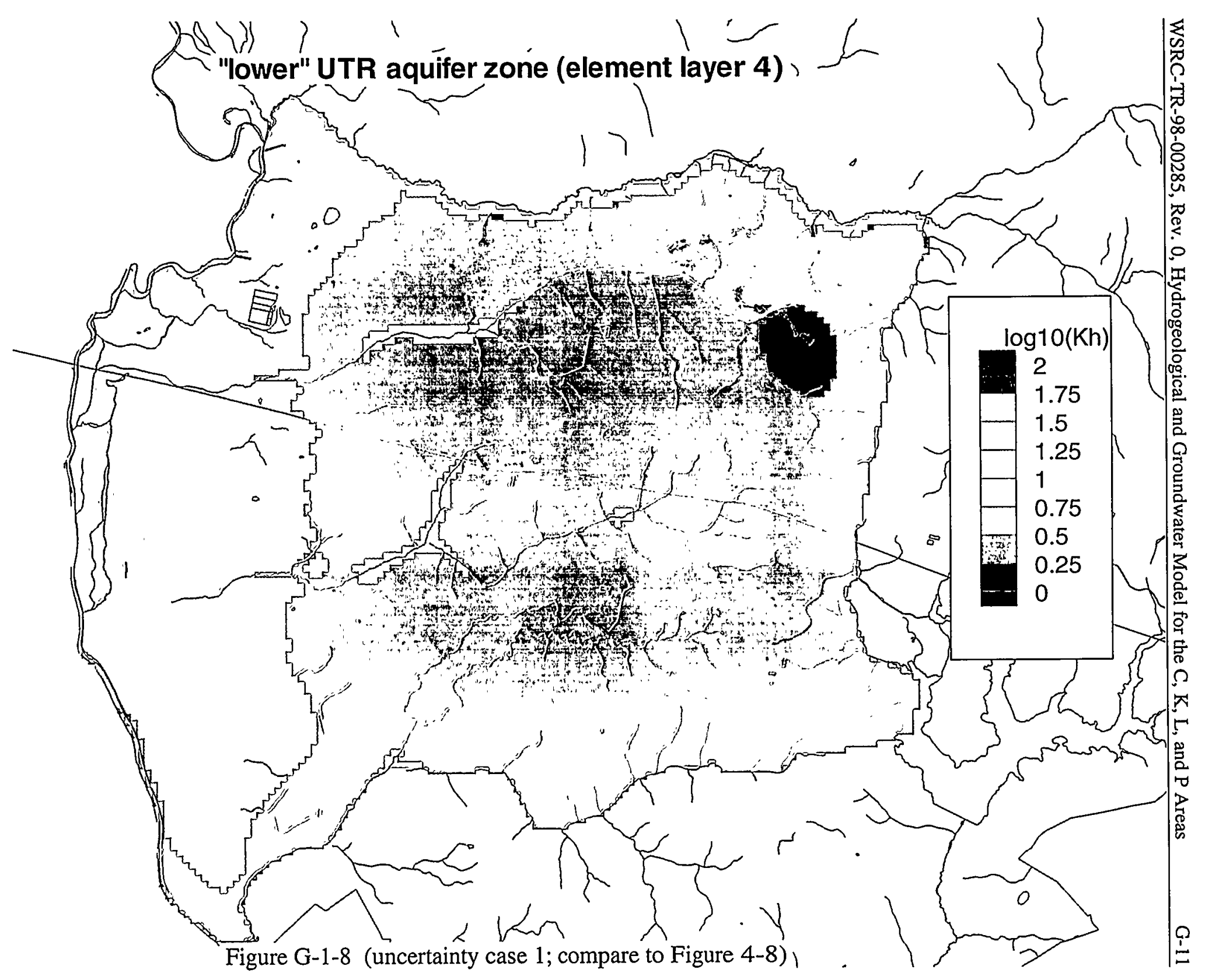




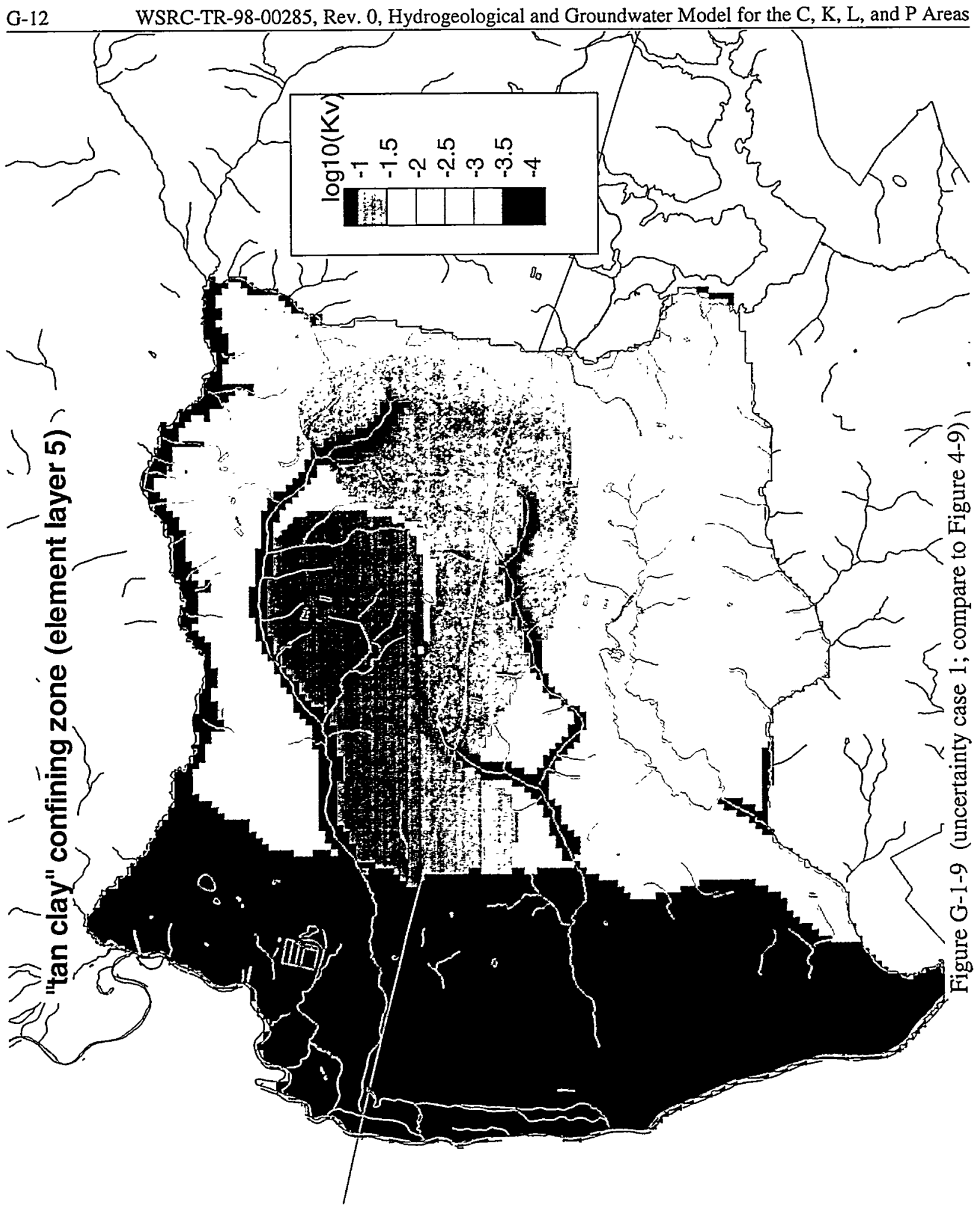




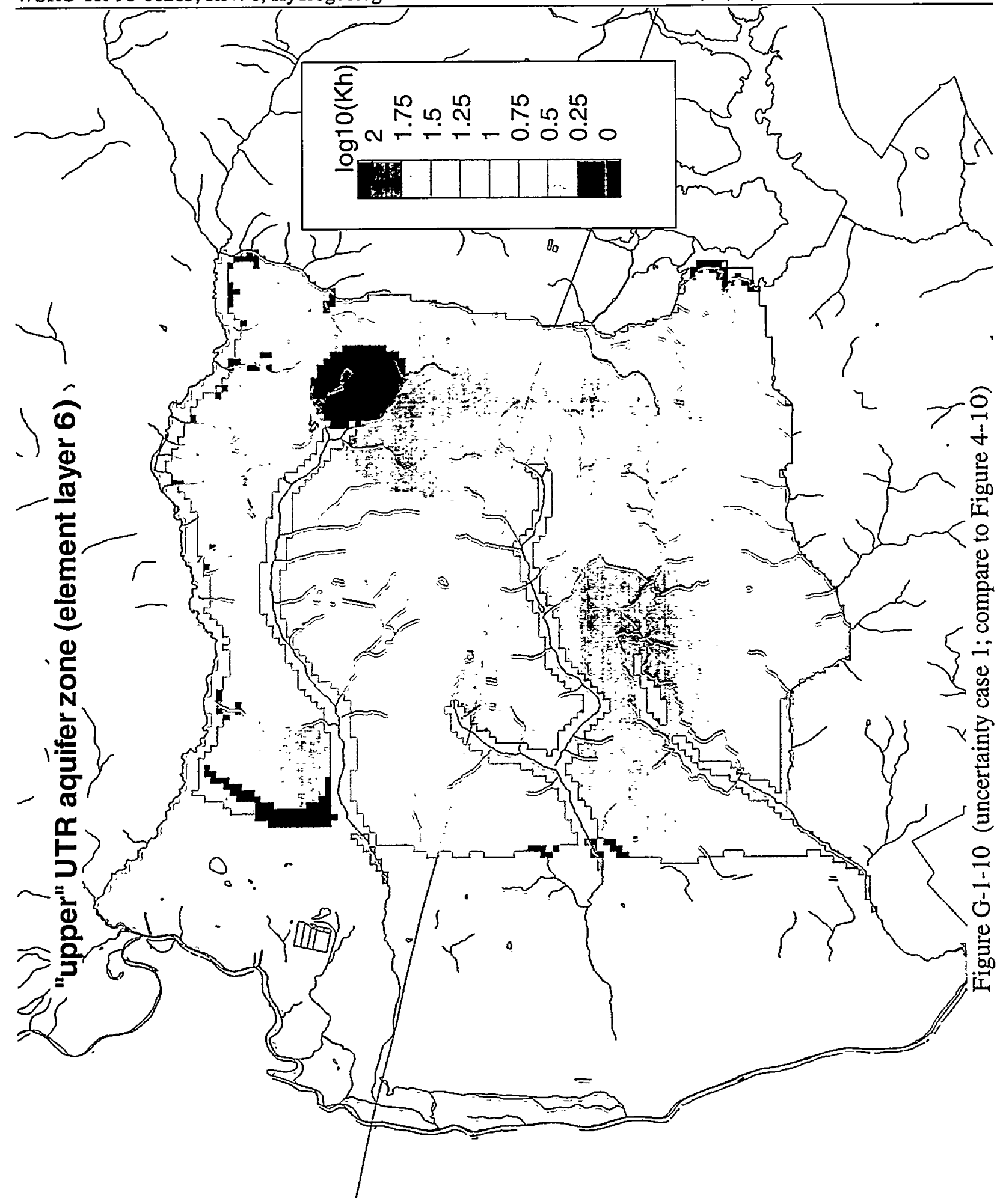




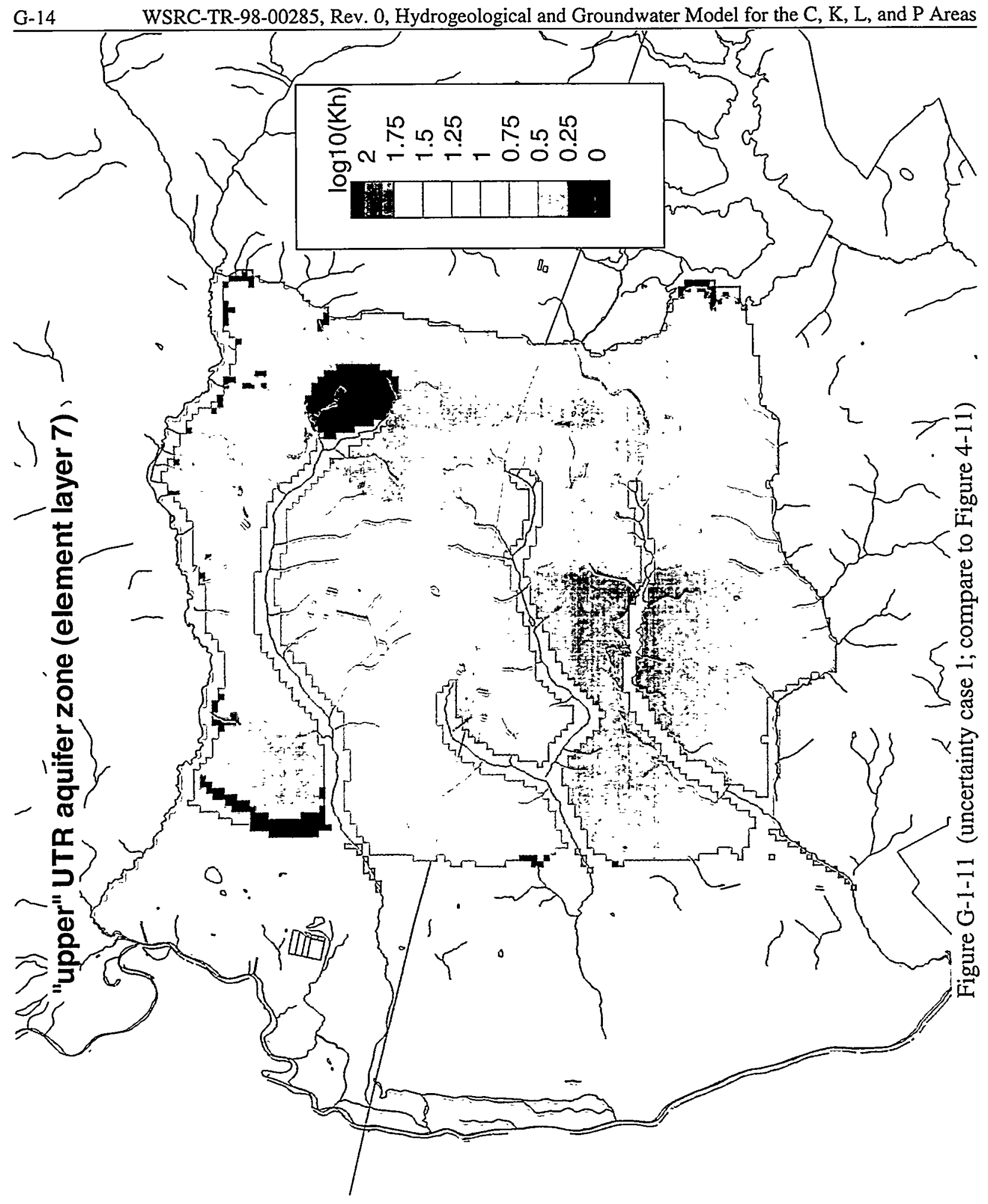




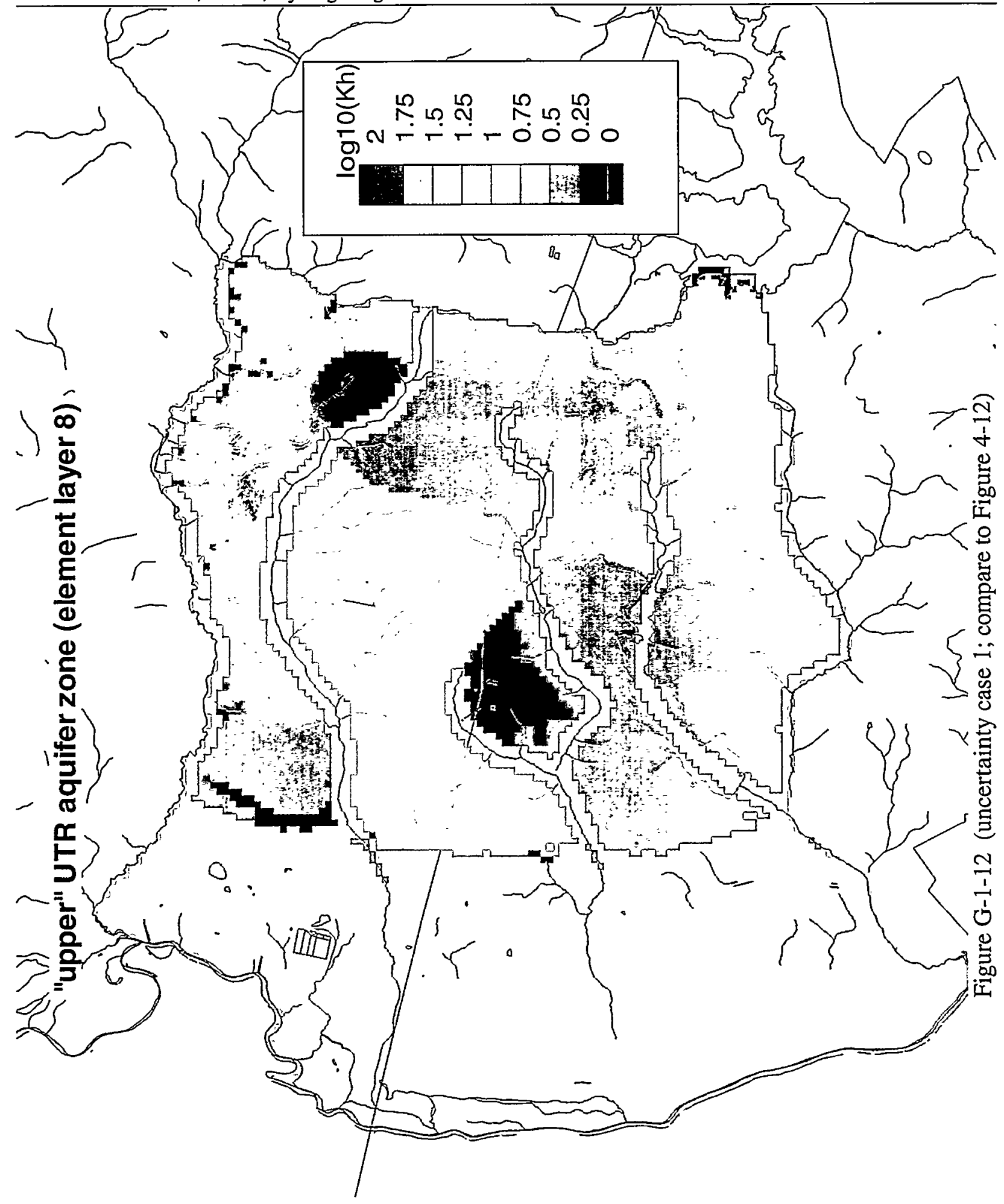




\section{Simulated hydraulic head in Gordon aquifer}

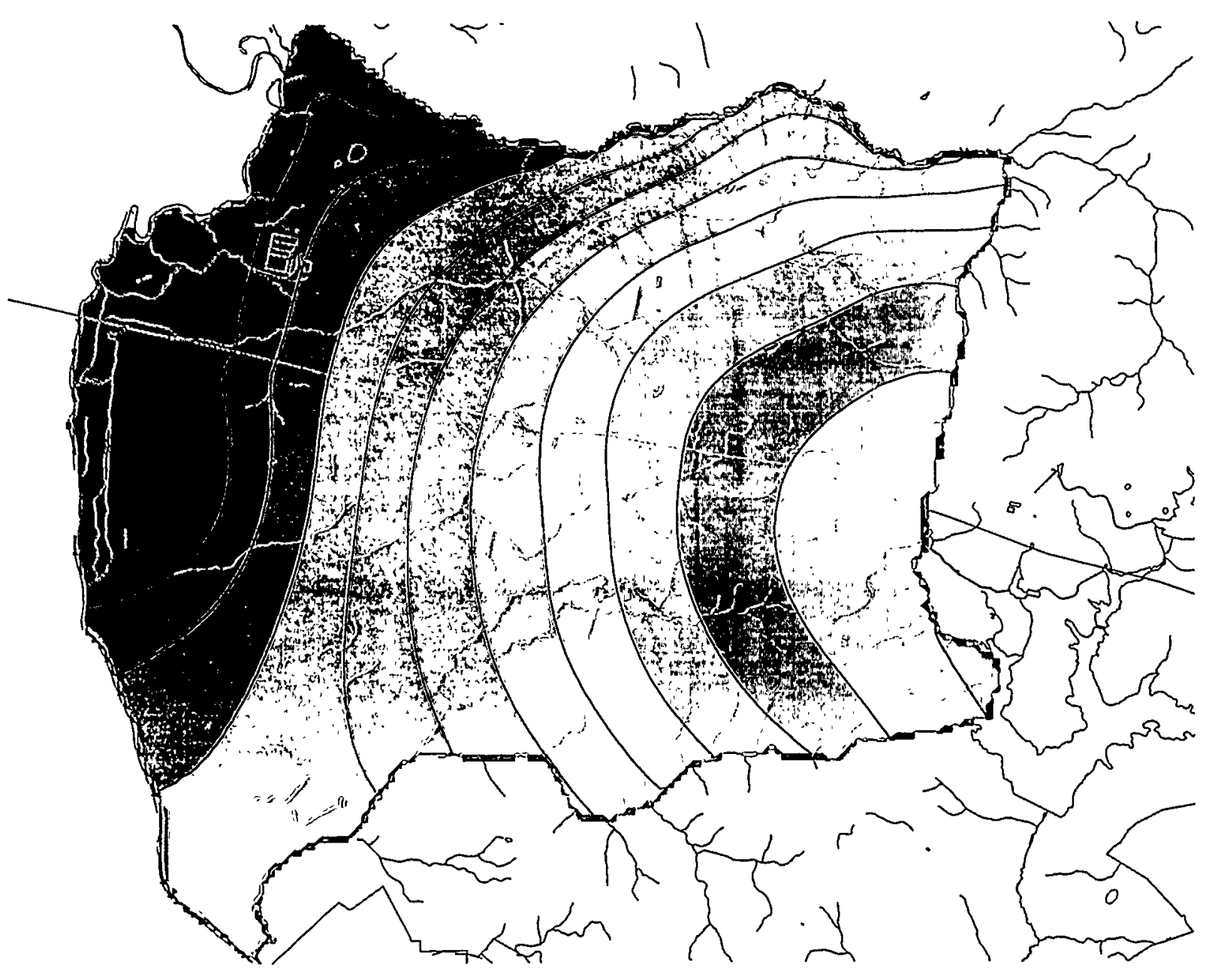


Simulated hydraulic head in "lower" UTR aquifer zone

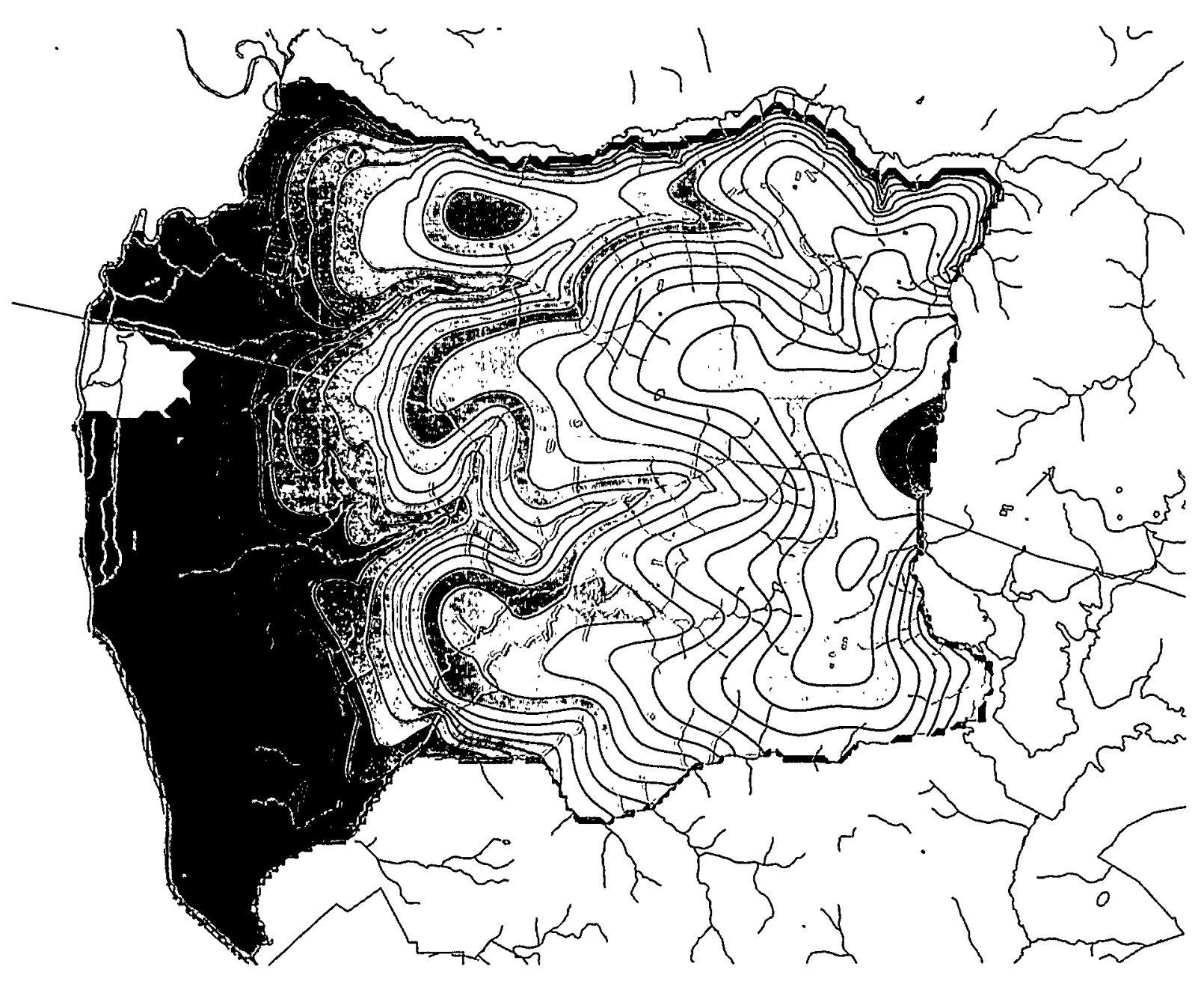


Simulated hydraulic head in "upper" UTR aquifer zone

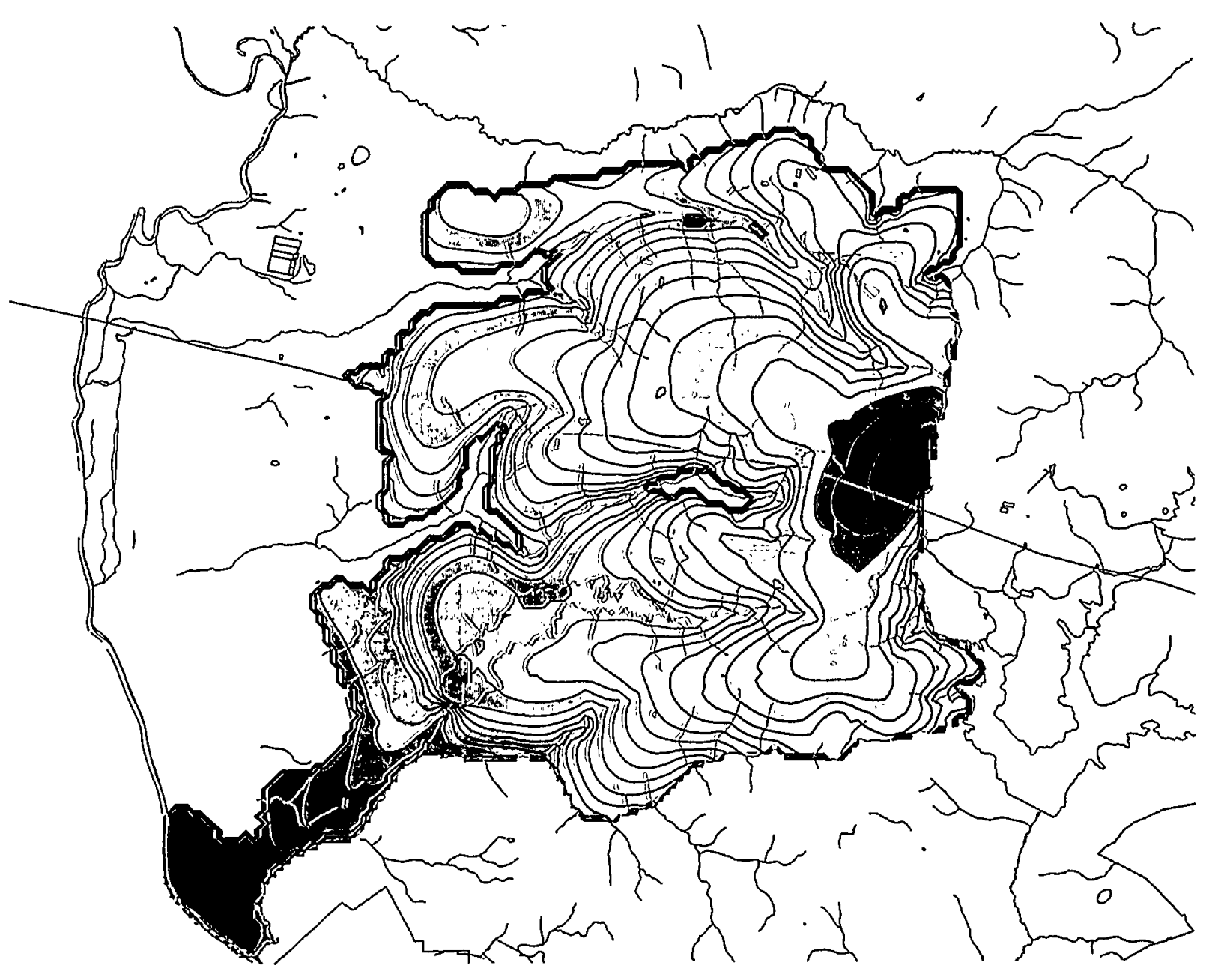

Figure G-1-15 (uncertainty case 1; compare to Figure 4-16) 


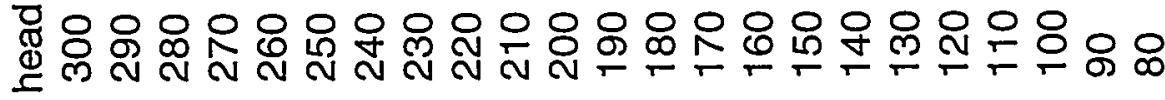

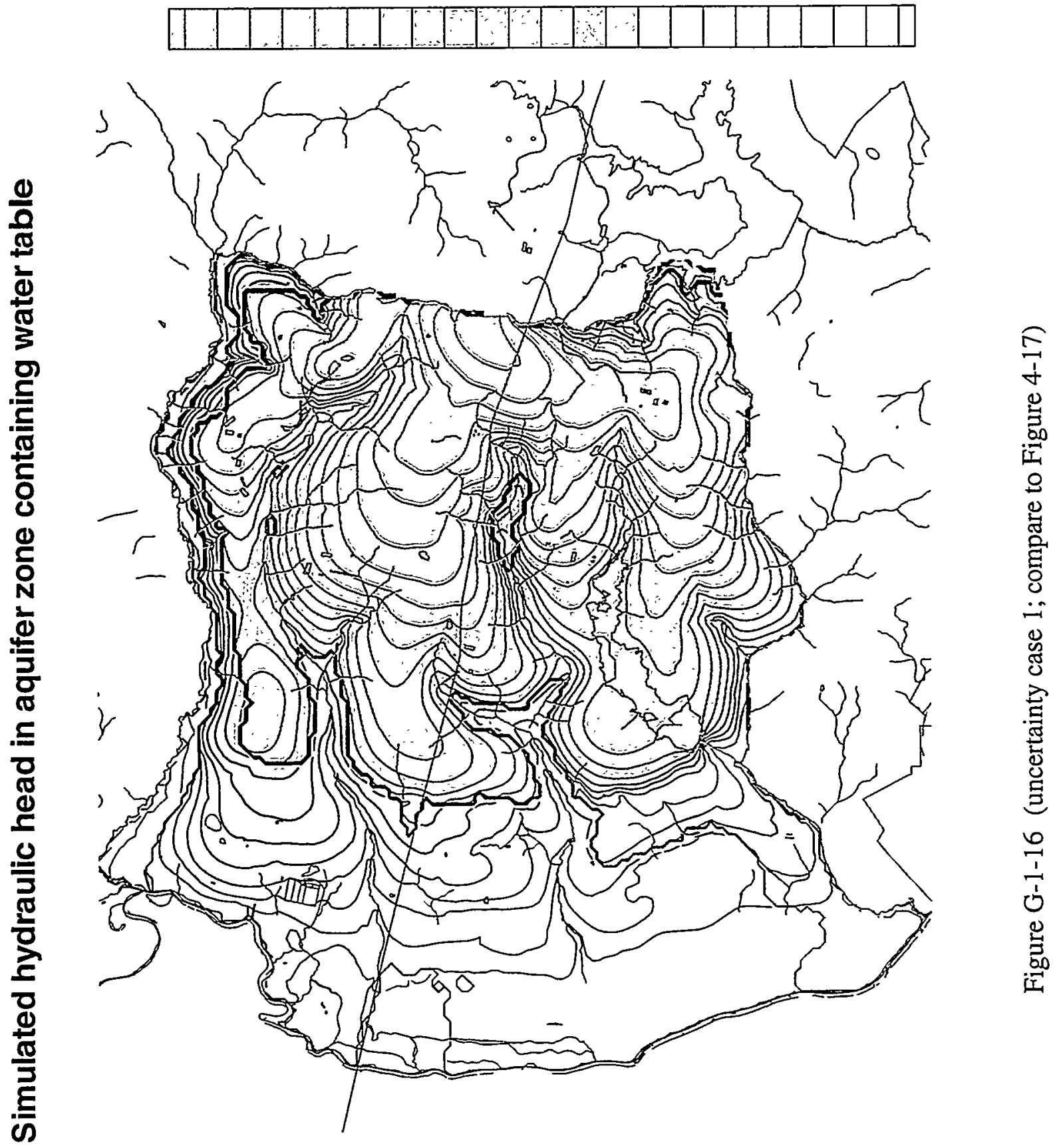




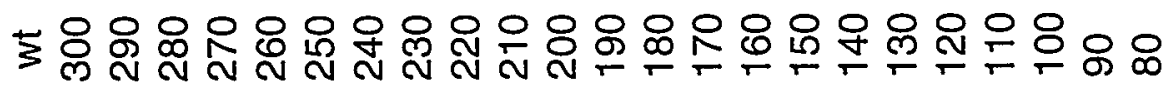

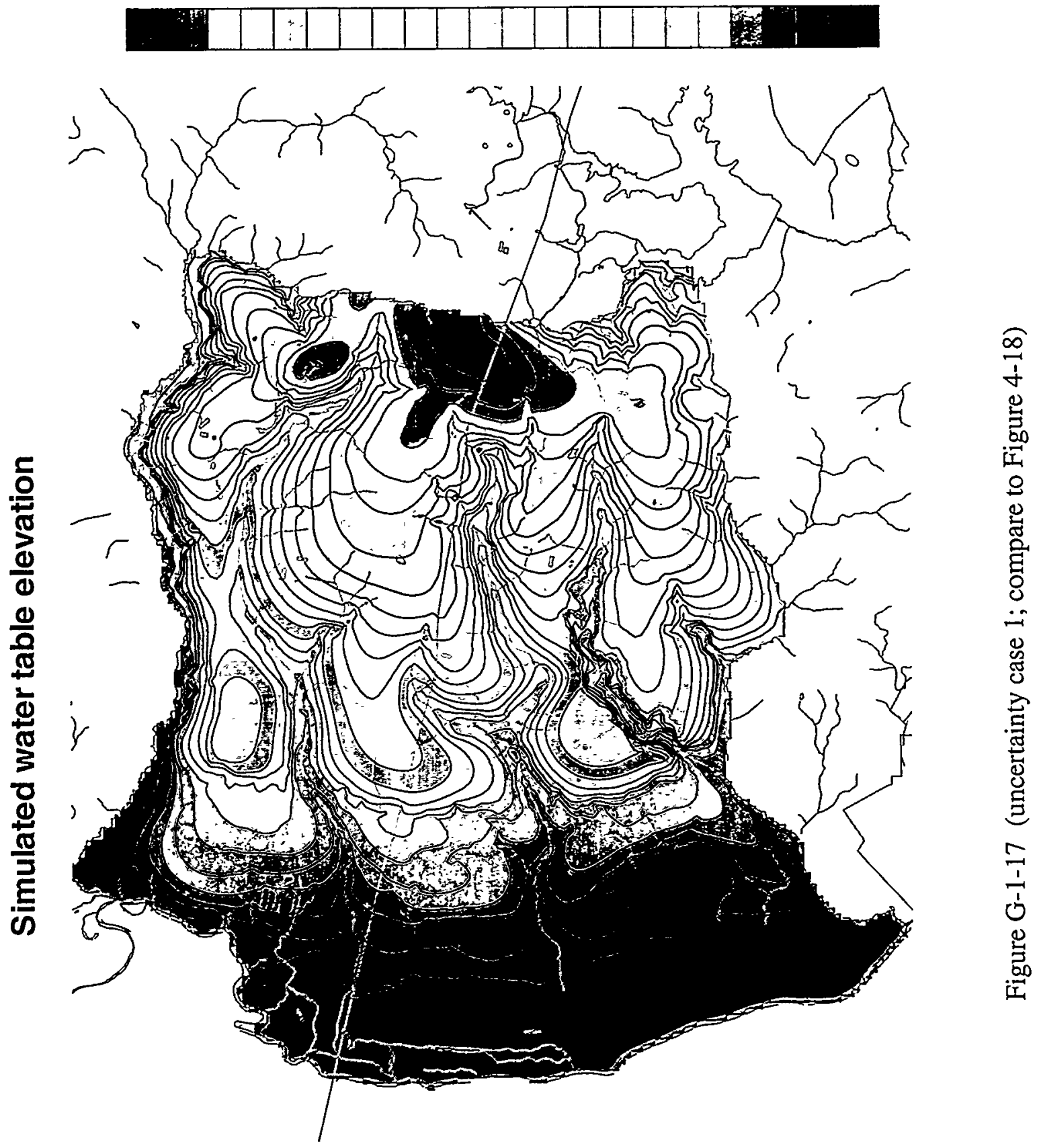




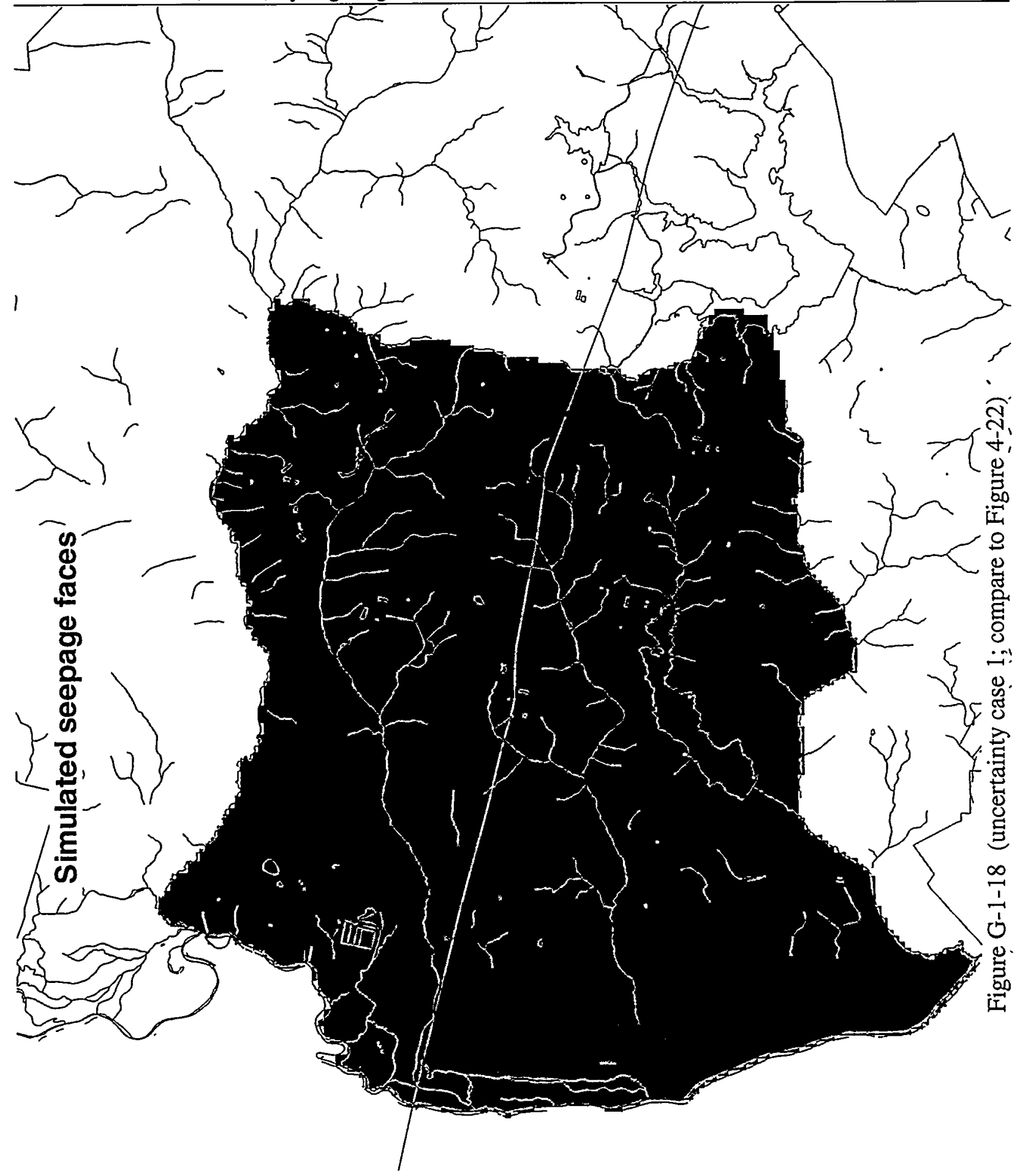




\section{Simulated groundwater recharge (discharge)}

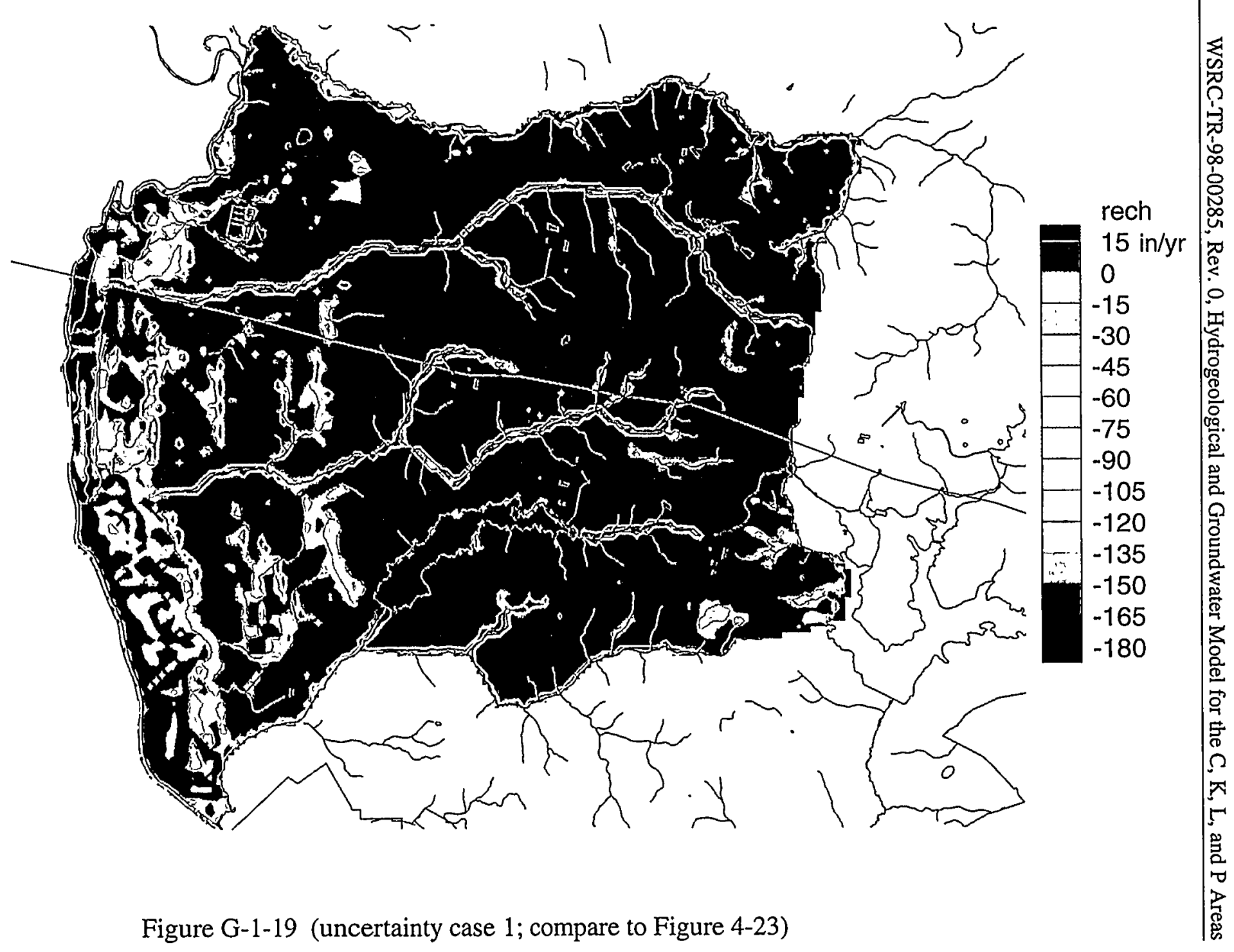




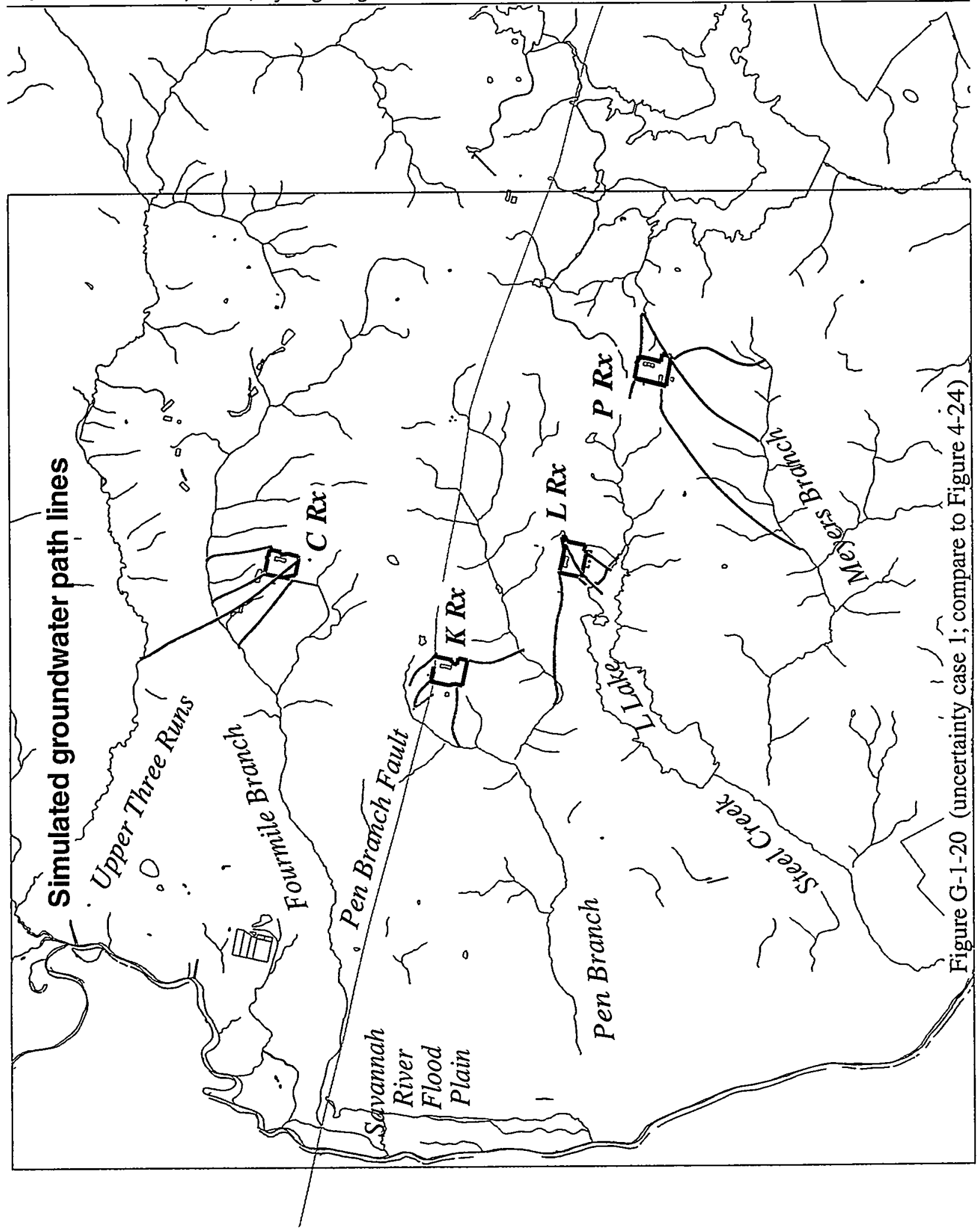


This page intentionally left blank 


\section{Simulation results for uncertainty case 2}

Uncertainty case 1 involves a decrease in recharge of $20 \%$ to $10 \mathrm{in} / \mathrm{yr}$ over the reactor areas (Table 4-4). Summary calibration results are provided in Table 4-5. This appendix presents detailed simulation results for uncertainty case 2 for comparison to the nominal results shown in figures in the main text. The correspondence between figures for the nominal and uncertainty case 2 is as follows:

\begin{tabular}{|l|l|l|}
\hline Plot type & Nominal case & Uncertainty case 2 \\
\hline Head residual summary & Figure 4-1 & Figure G-2-1 \\
\hline Head residuals in Gordon aquifer & Figure 4-2 & Figure G-2-2 \\
\hline Head residuals in "lower" UTRA & Figure 4-3 & Figure G-2-3 \\
\hline Head residuals in "upper" UTRA & Figure 4-4 & Figure G-2-4 \\
\hline Kh in element layer 1 & Figure 4-5 & Figure G-2-5 \\
\hline Kv in element layer 2 & Figure 4-6 & Figure G-2-6 \\
\hline Kh in element layer 3 & Figure 4-7 & Figure G-2-7 \\
\hline Kh in element layer 4 & Figure 4-8 & Figure G-2-8 \\
\hline Kv in element layer 5 & Figure 4-9 & Figure G-2-9 \\
\hline Kh in element layer 6 & Figure 4-10 & Figure G-2-10 \\
\hline Kh in element layer 7 & Figure 4-11 & Figure G-2-11 \\
\hline Kh in element layer 8 & Figure 4-12 & Figure G-2-12 \\
\hline Gordon aquifer head & Figure 4-14 & Figure G-2-13 \\
\hline "Lower" UTRA head & Figure 4-15 & Figure G-2-14 \\
\hline "Upper" UTRA head & Figure 4-16 & Figure G-2-15 \\
\hline Head in aquifer containing water table & Figure 4-17 & Figure G-2-16 \\
\hline Water table & Figure 4-18 & Figure G-2-17 \\
\hline Seepage faces & Figure 4-22 & Figure G-2-18 \\
\hline Recharge/discharge & Figure 4-23 & Figure G-2-19 \\
\hline Example particle tracing & Figure 4-24 & Figure G-2-20 \\
\hline & & \\
\hline
\end{tabular}



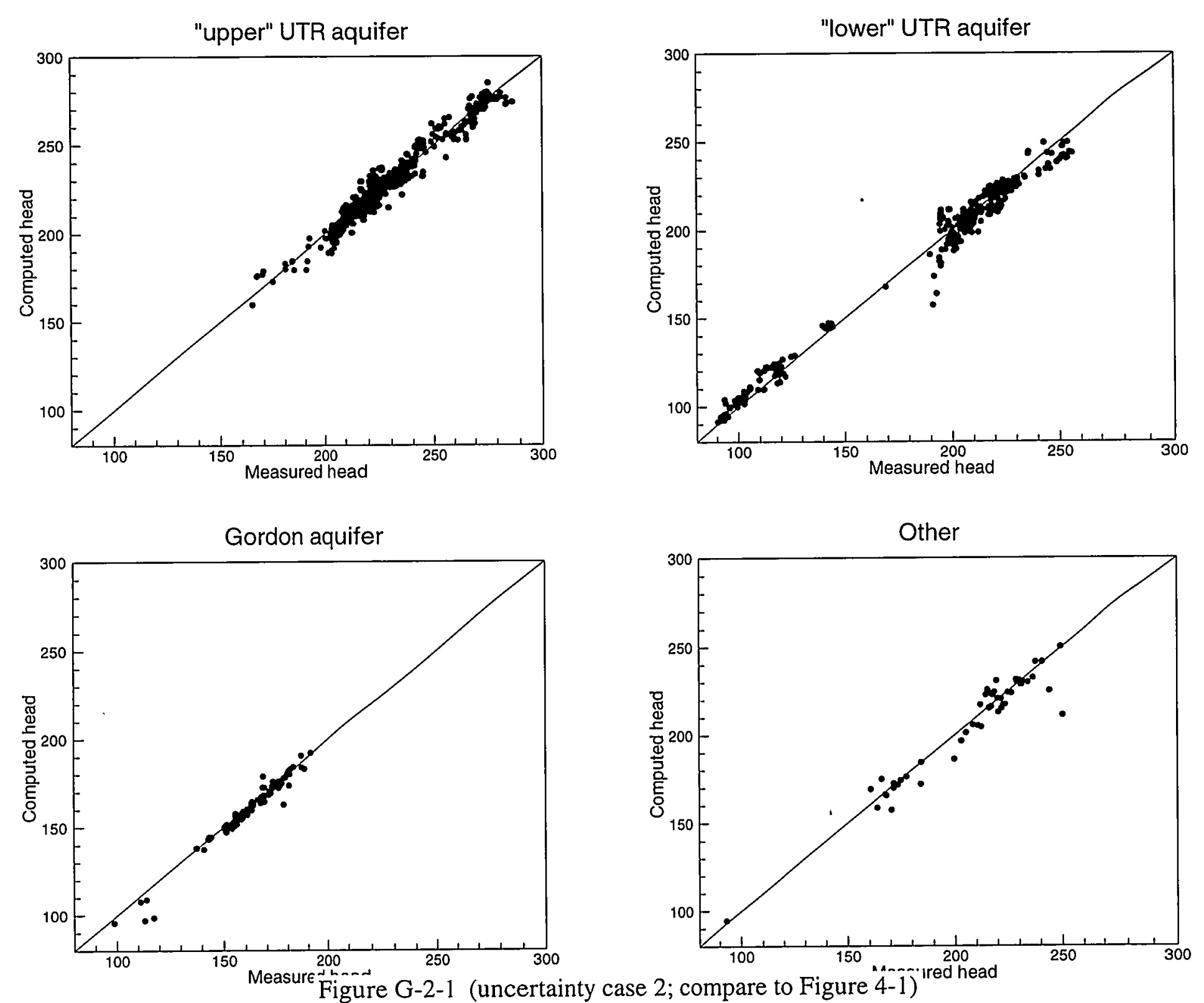


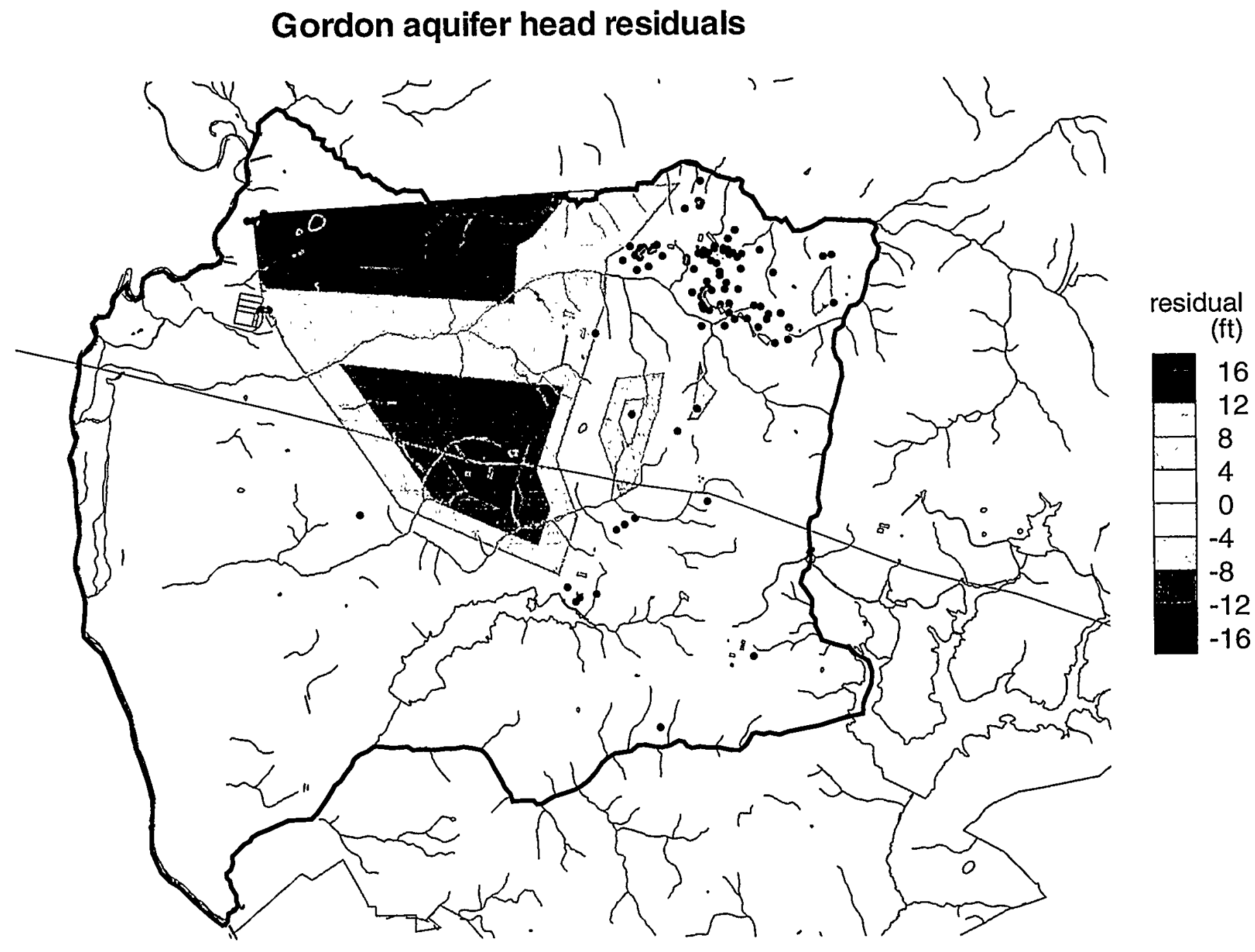

Figure G-2-2 (uncertainty case 2; compare to Figure 4-2) 


\section{"lower" UTR aquifer zone}

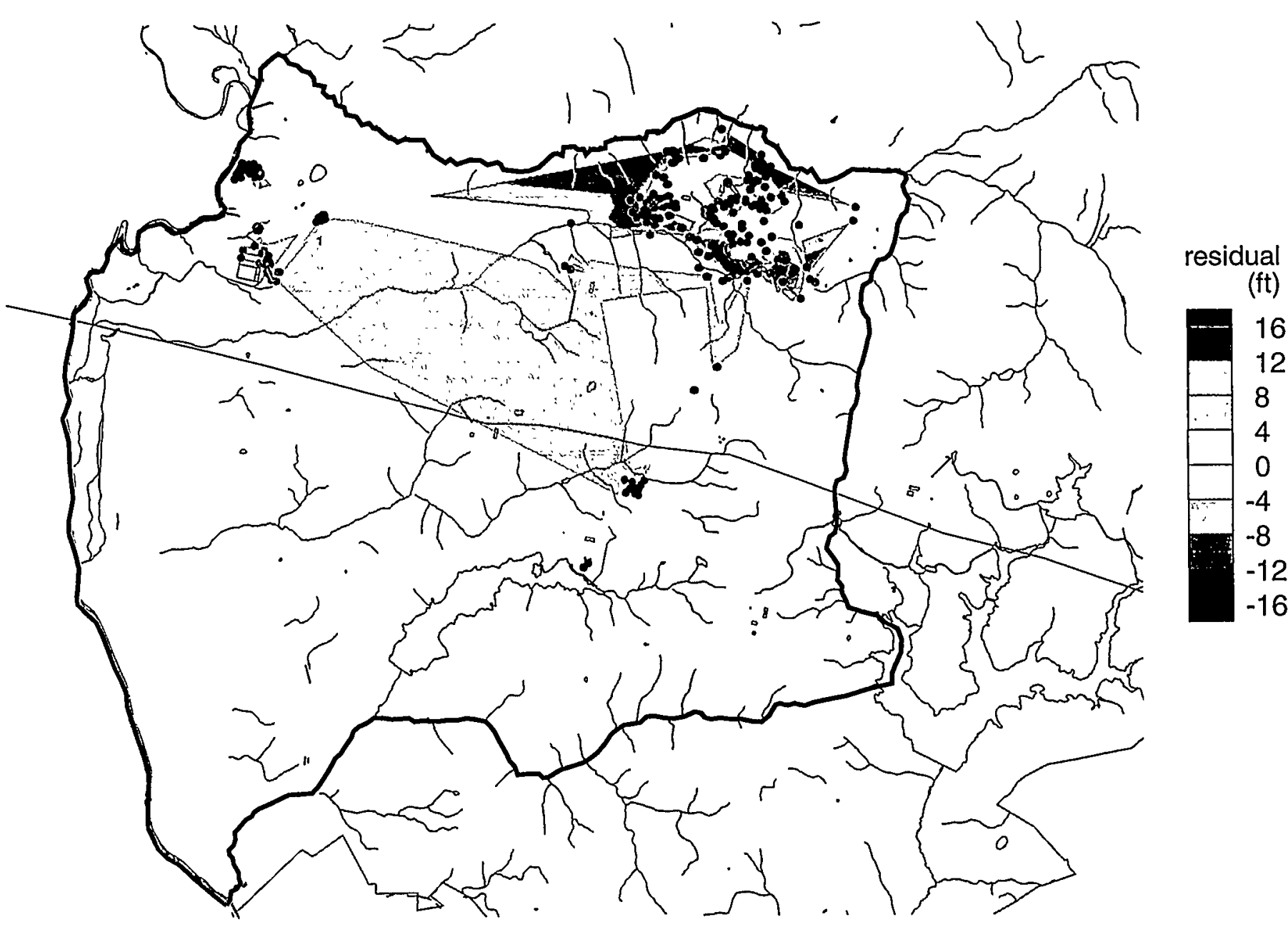

Figure G-2-3 (uncertainty case 2; compare to Figure 4-3) 


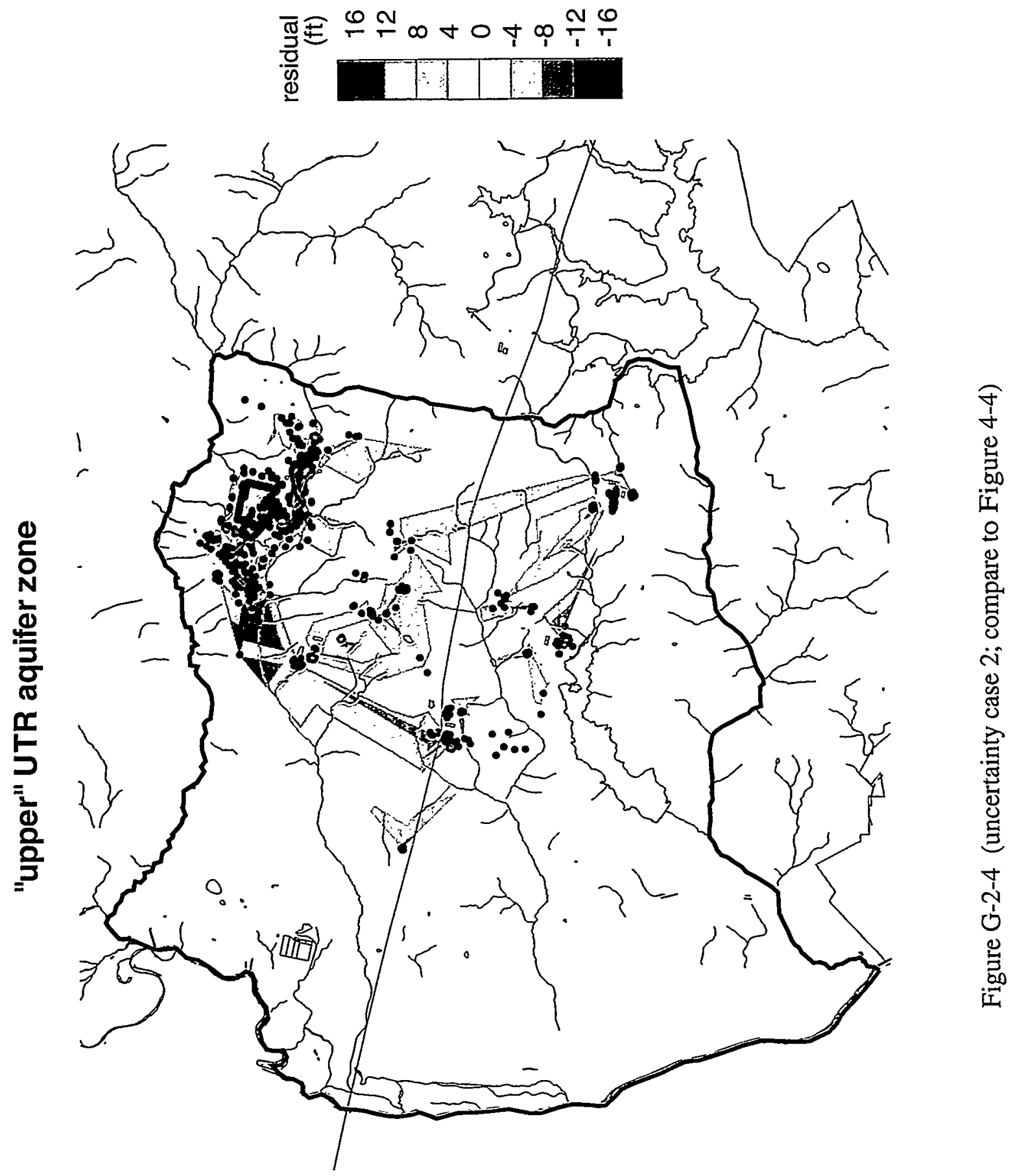




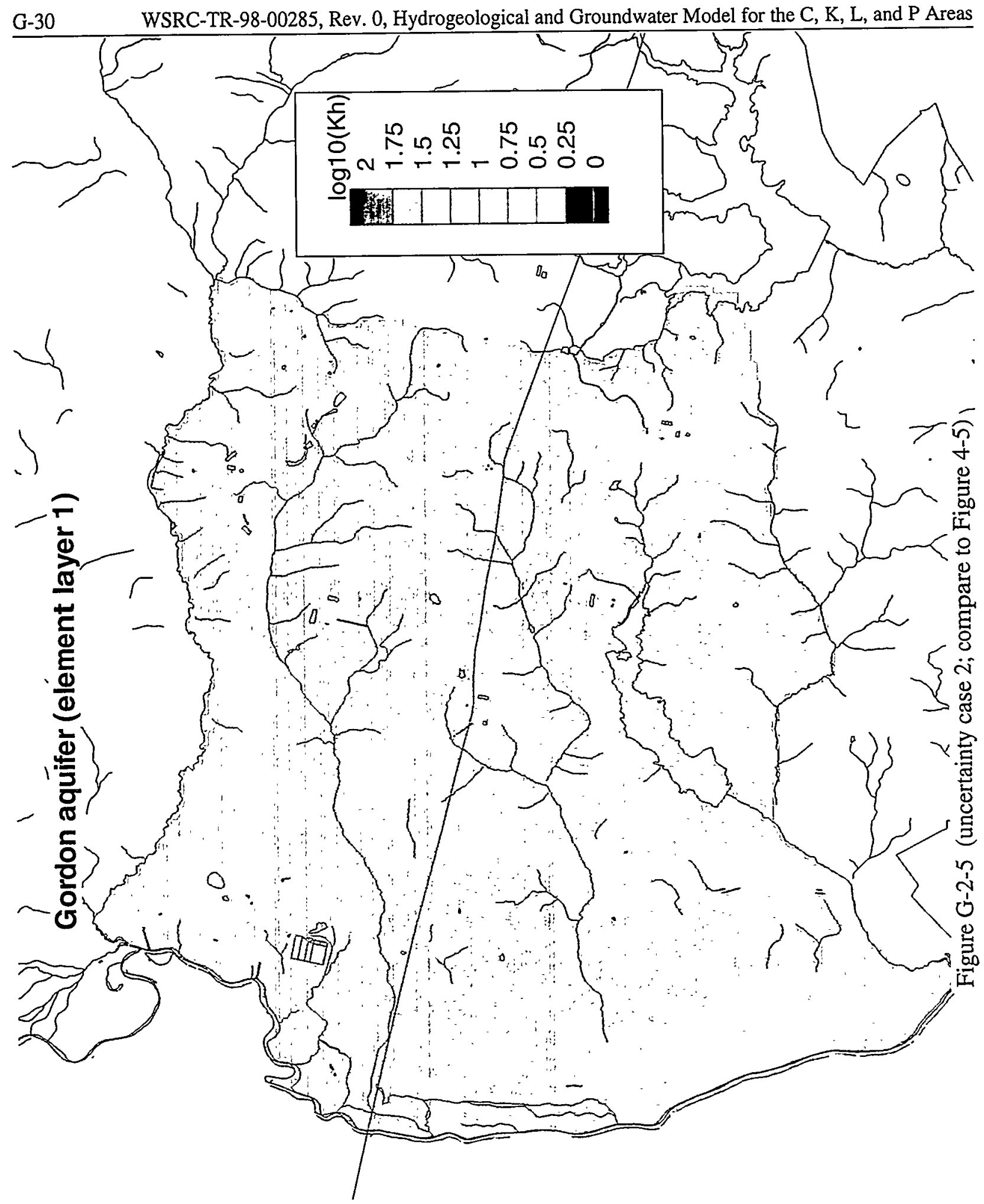




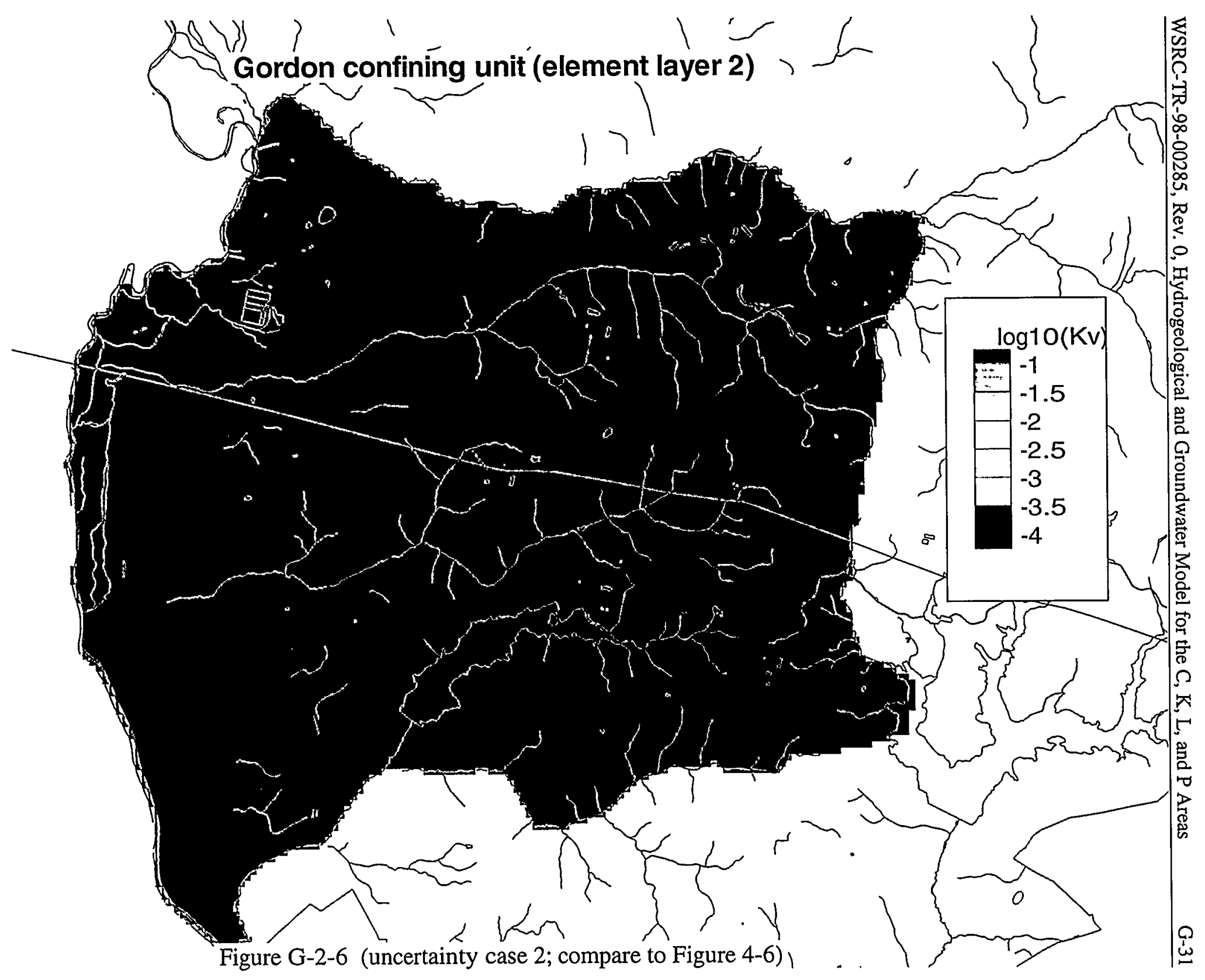




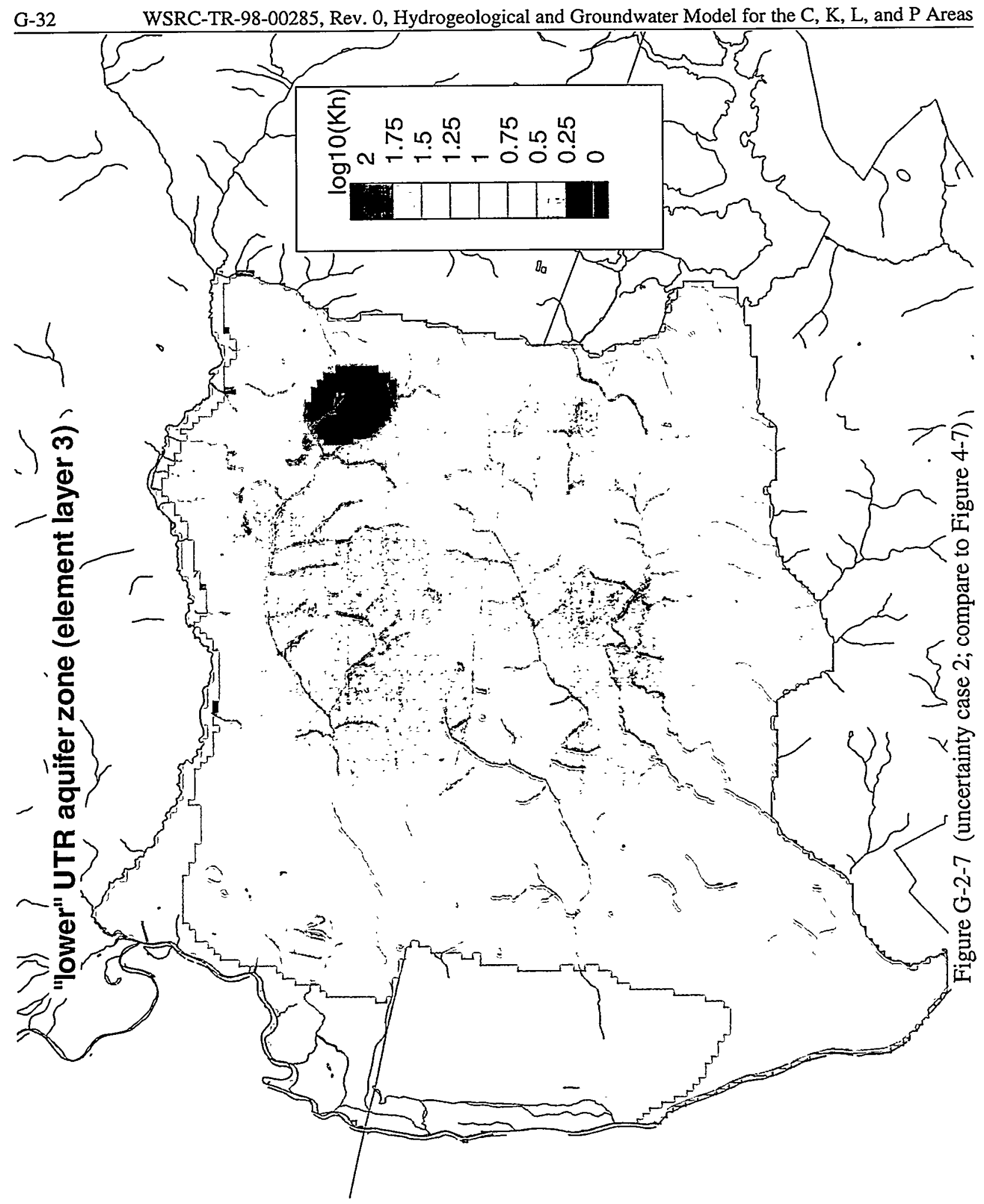




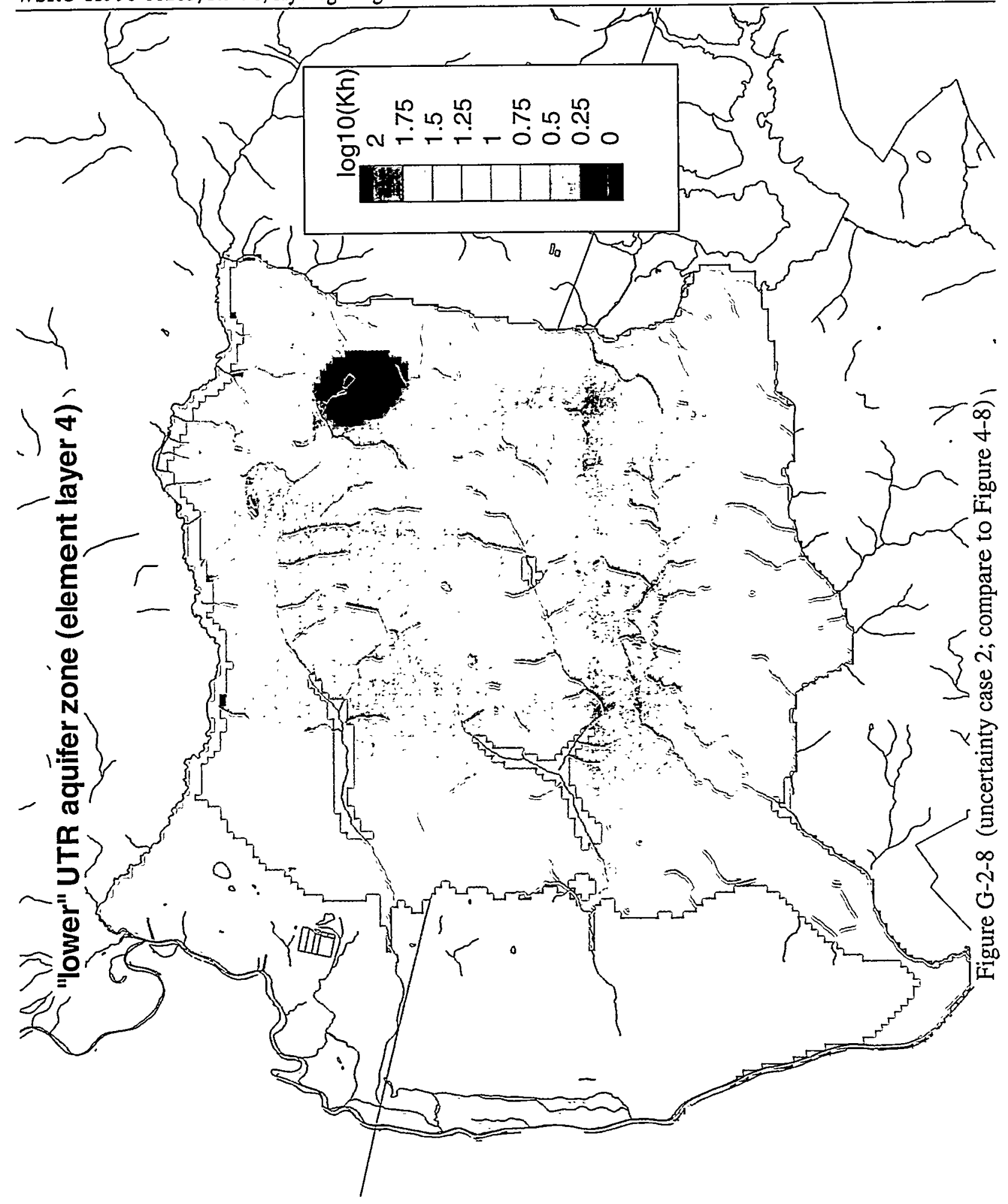




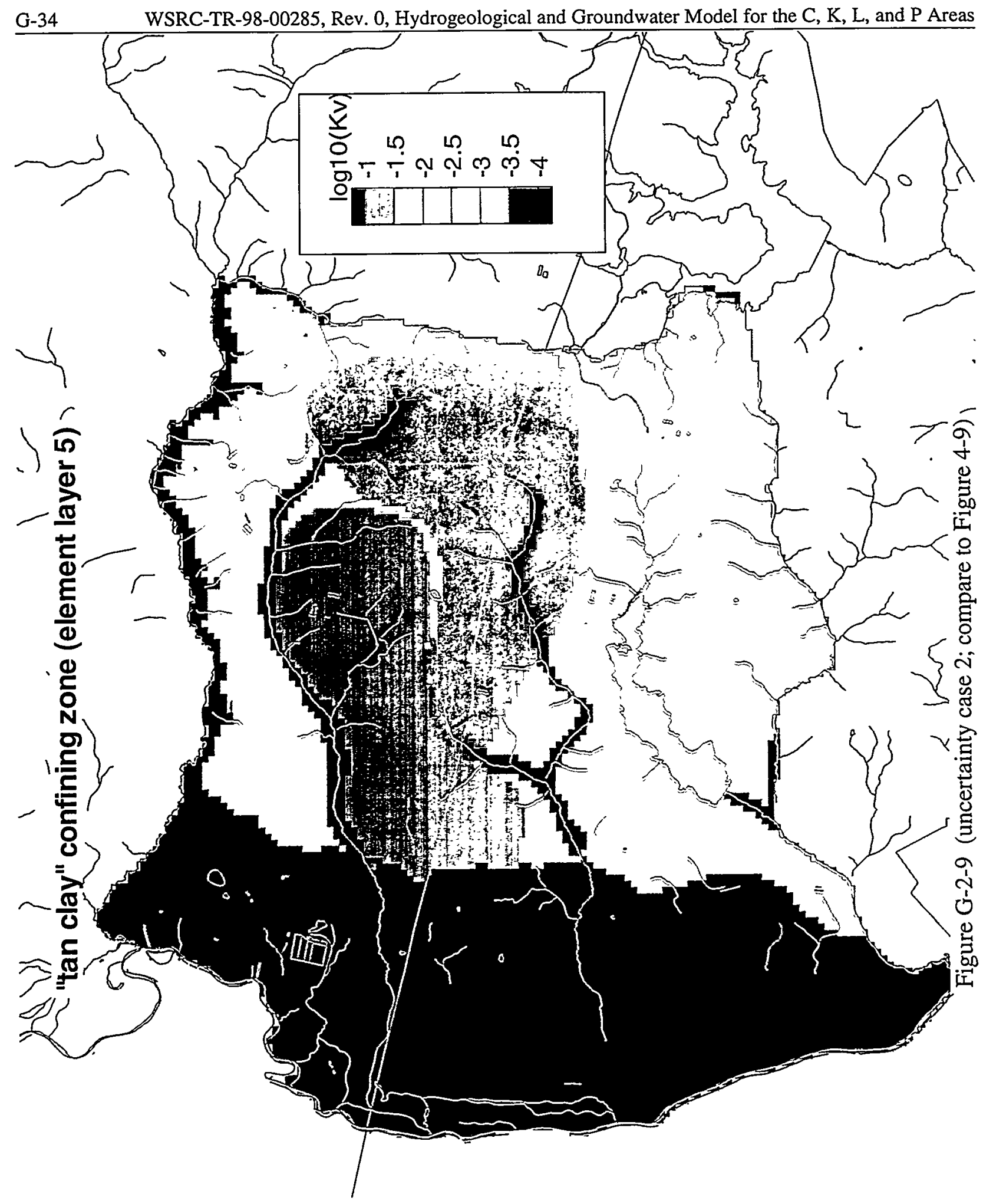




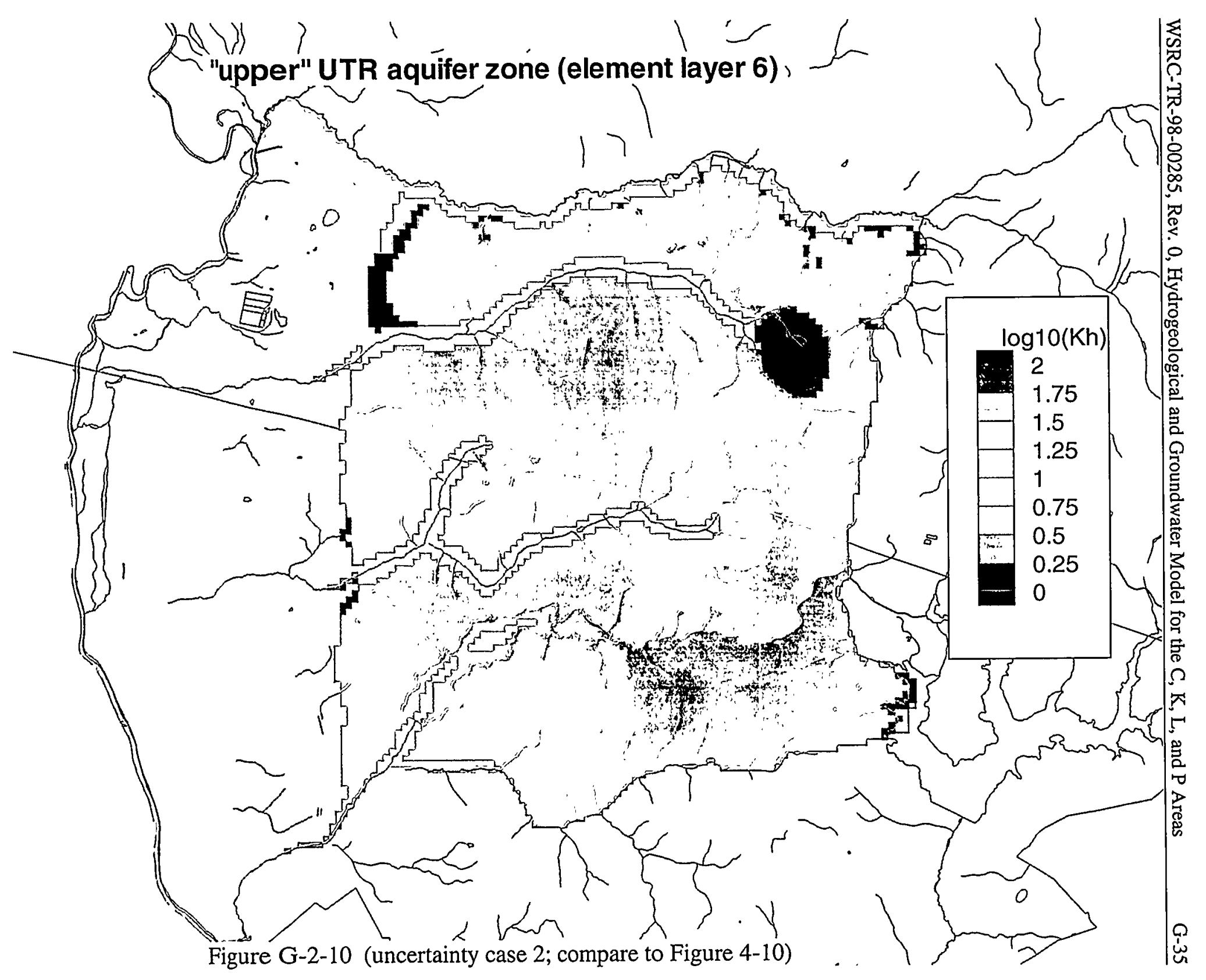




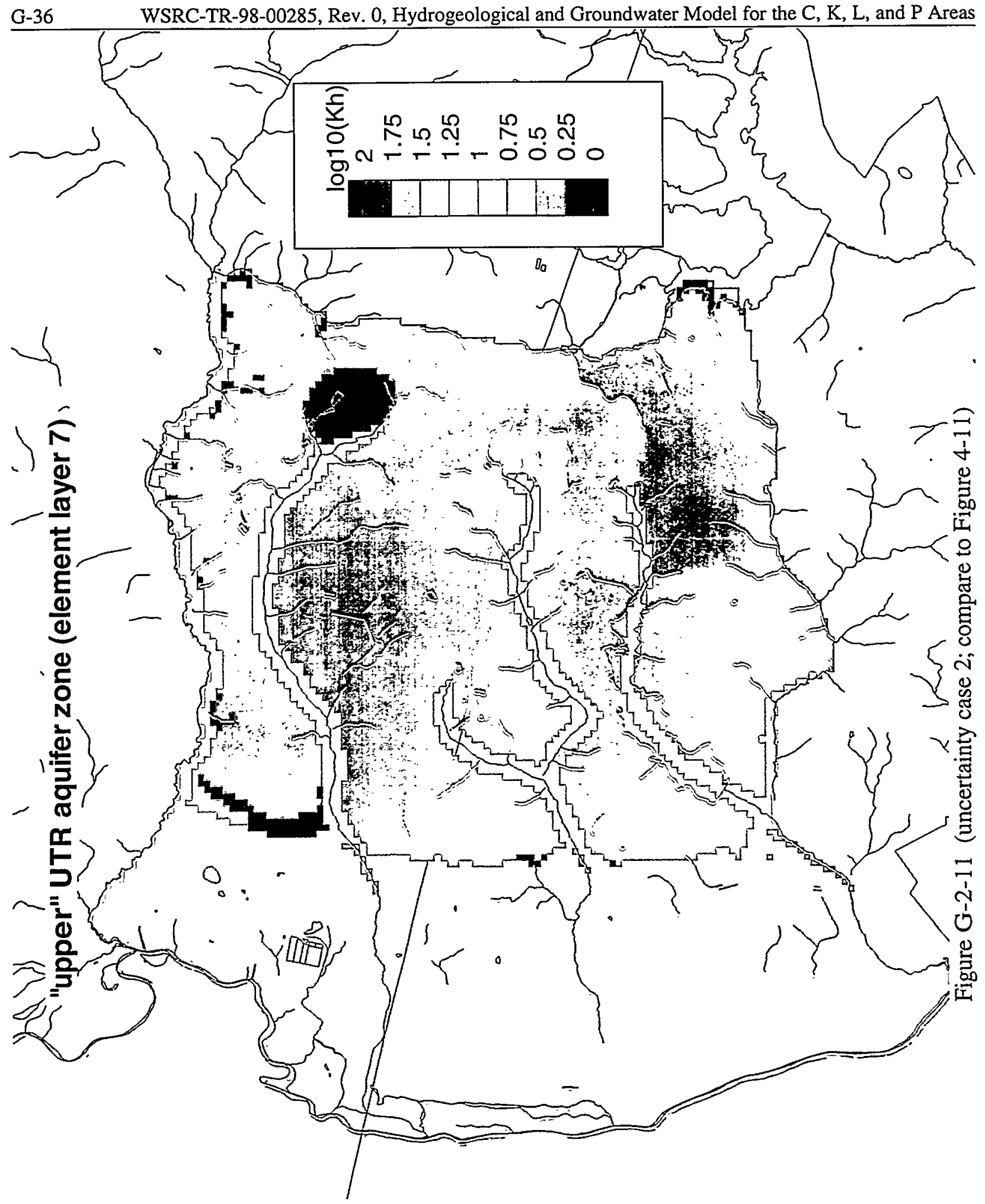




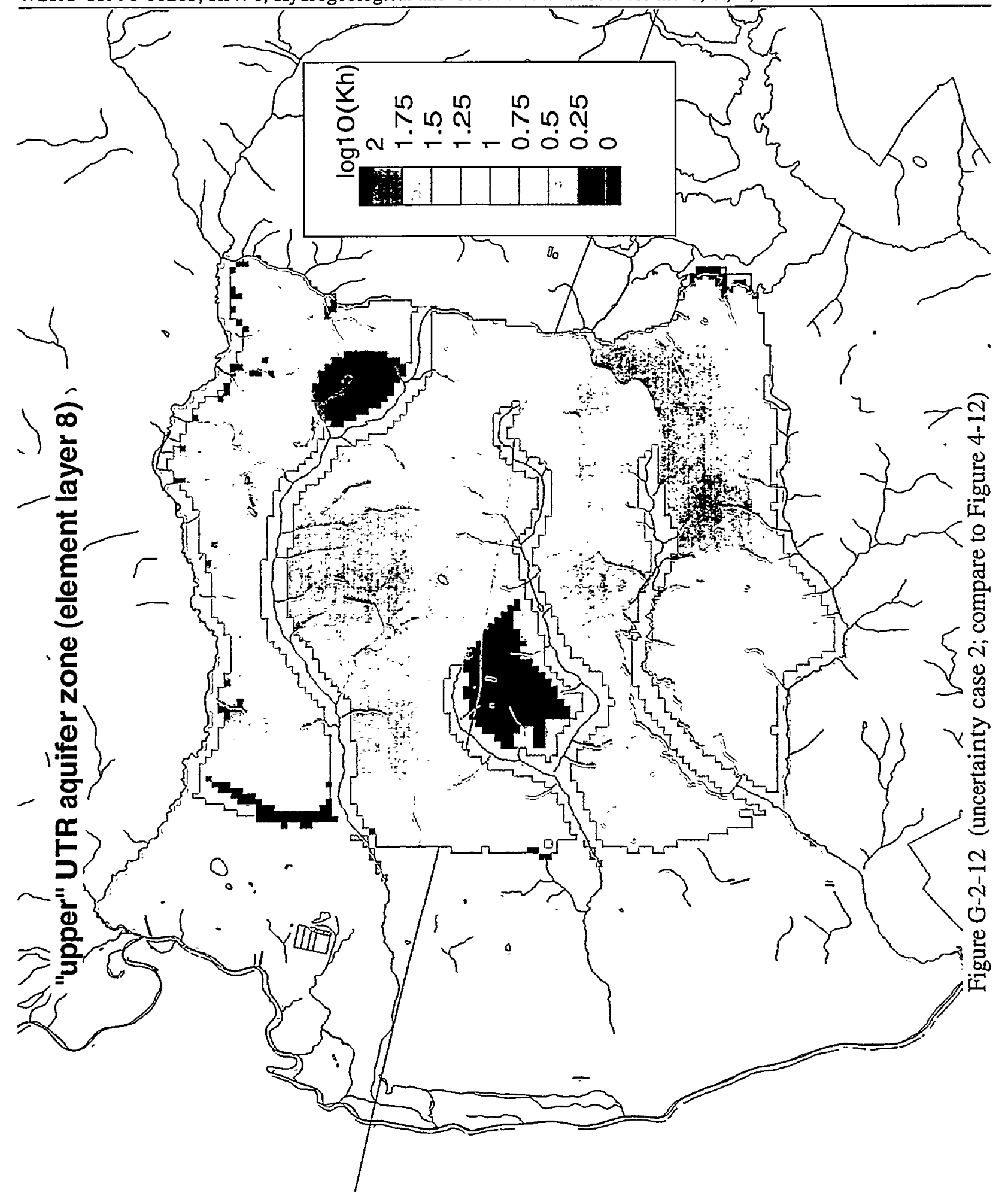




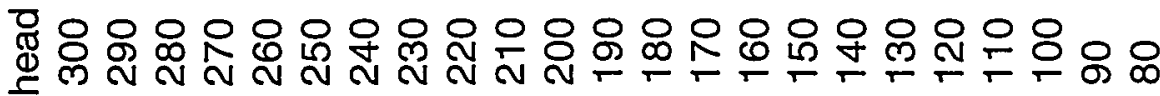
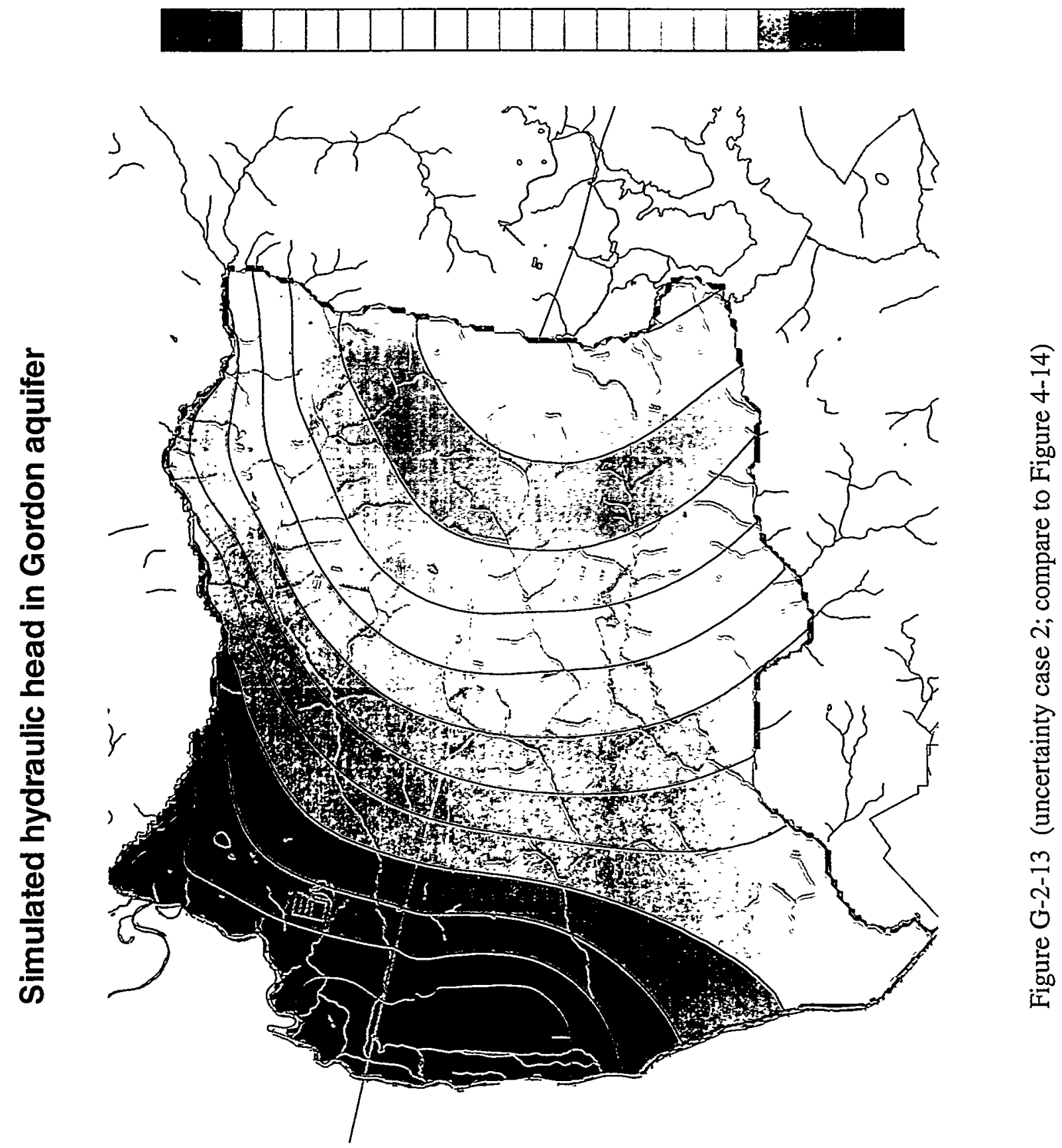


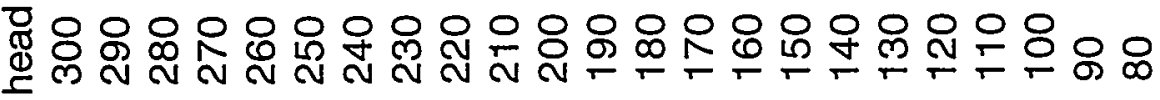
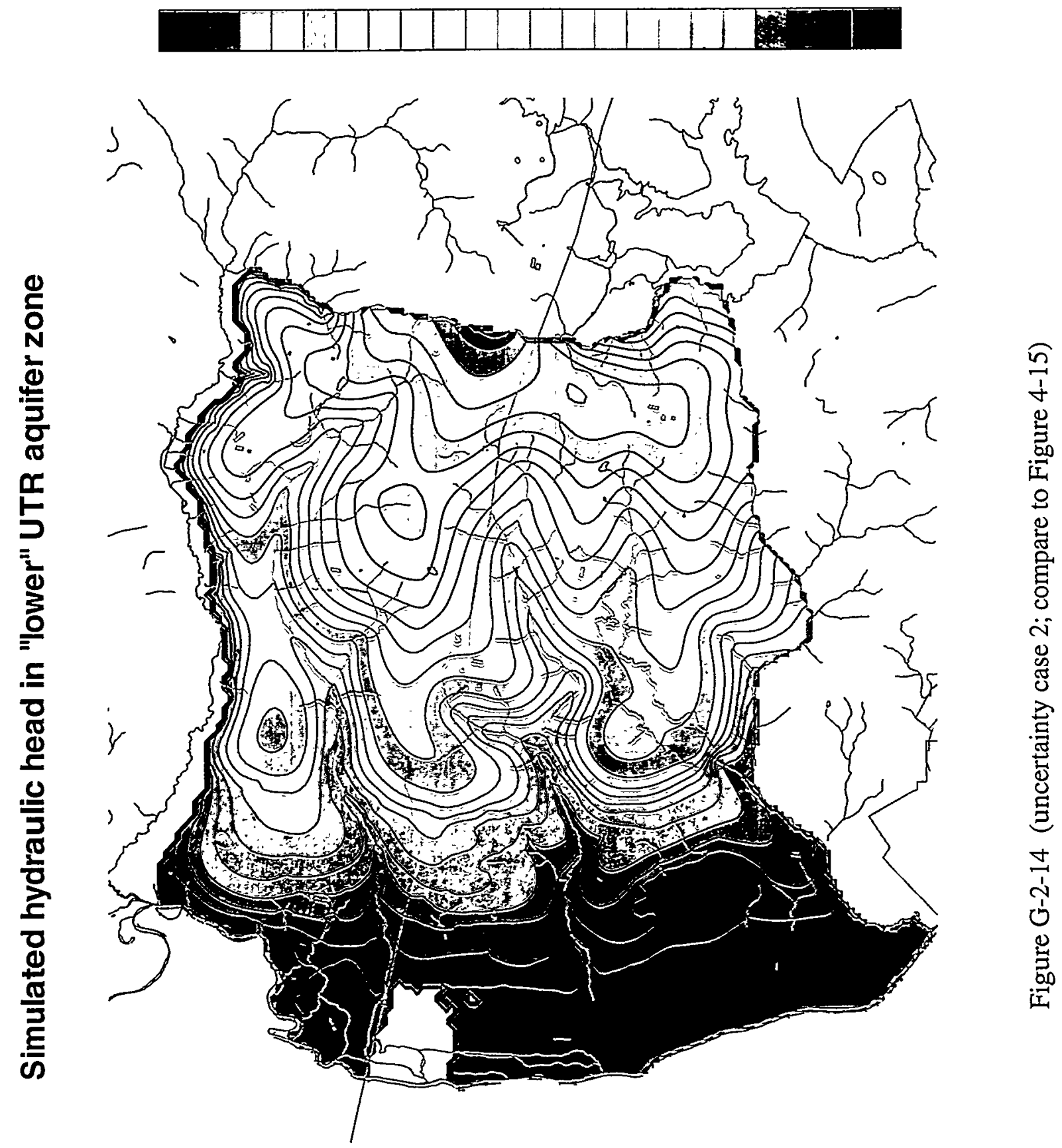


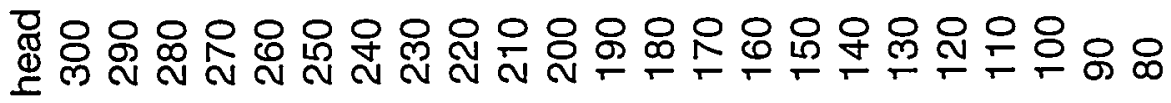
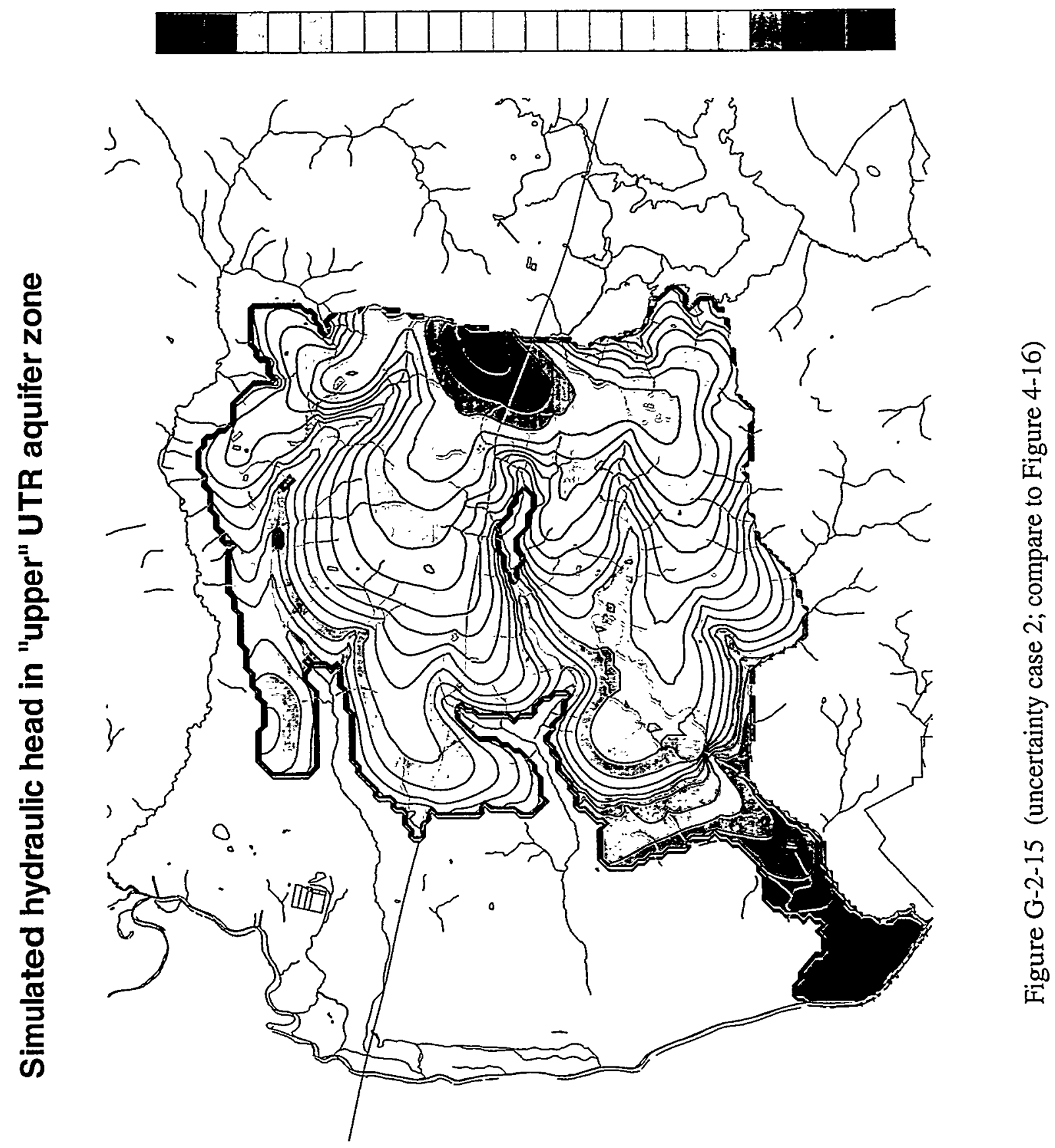


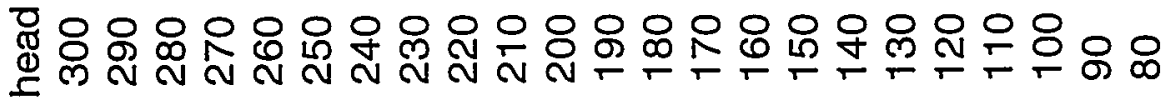

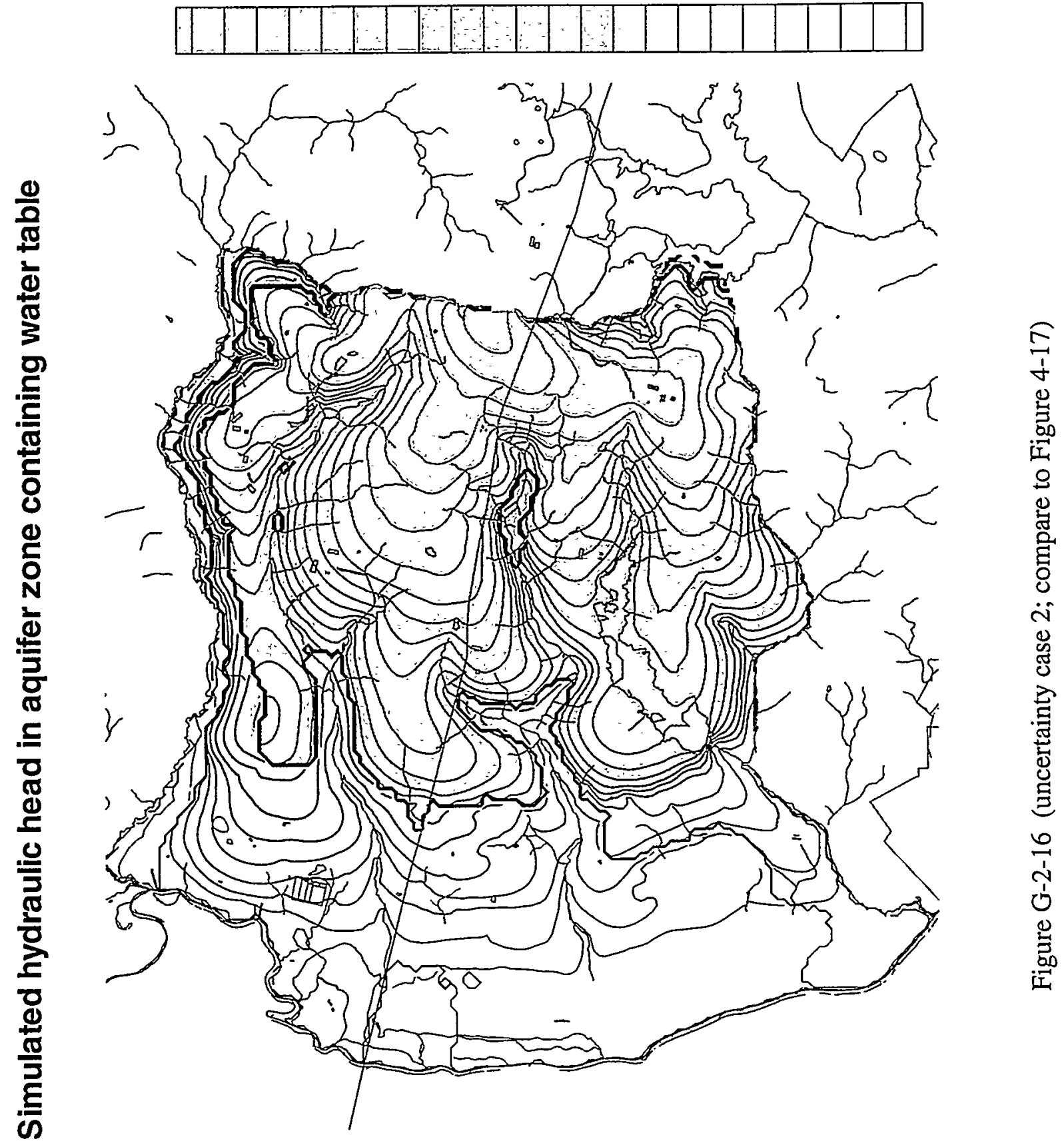




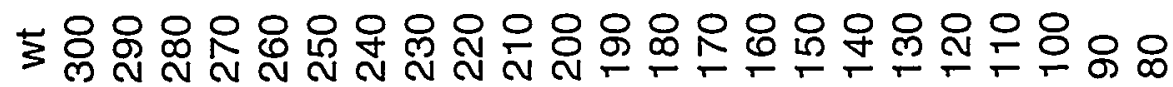

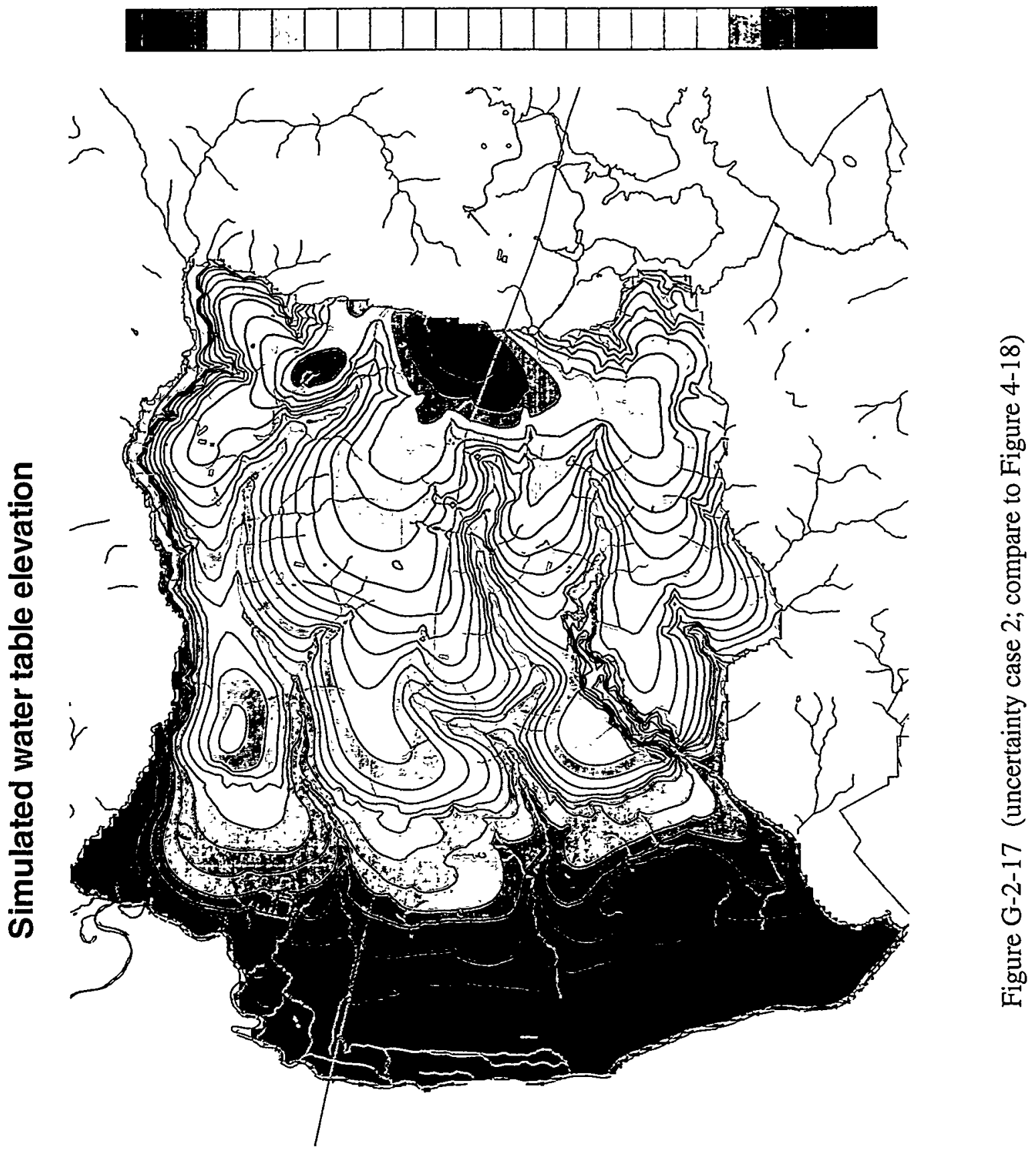




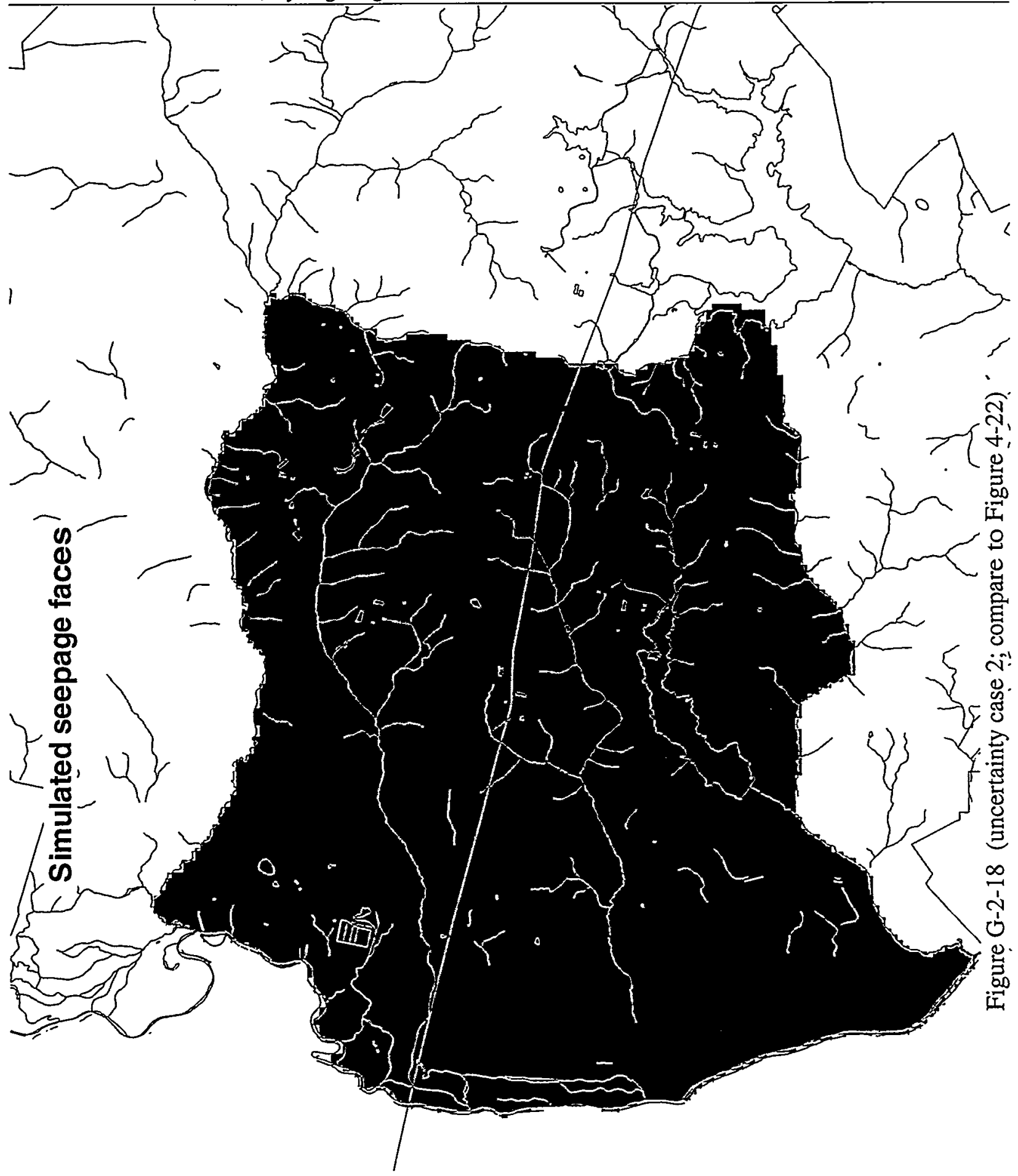



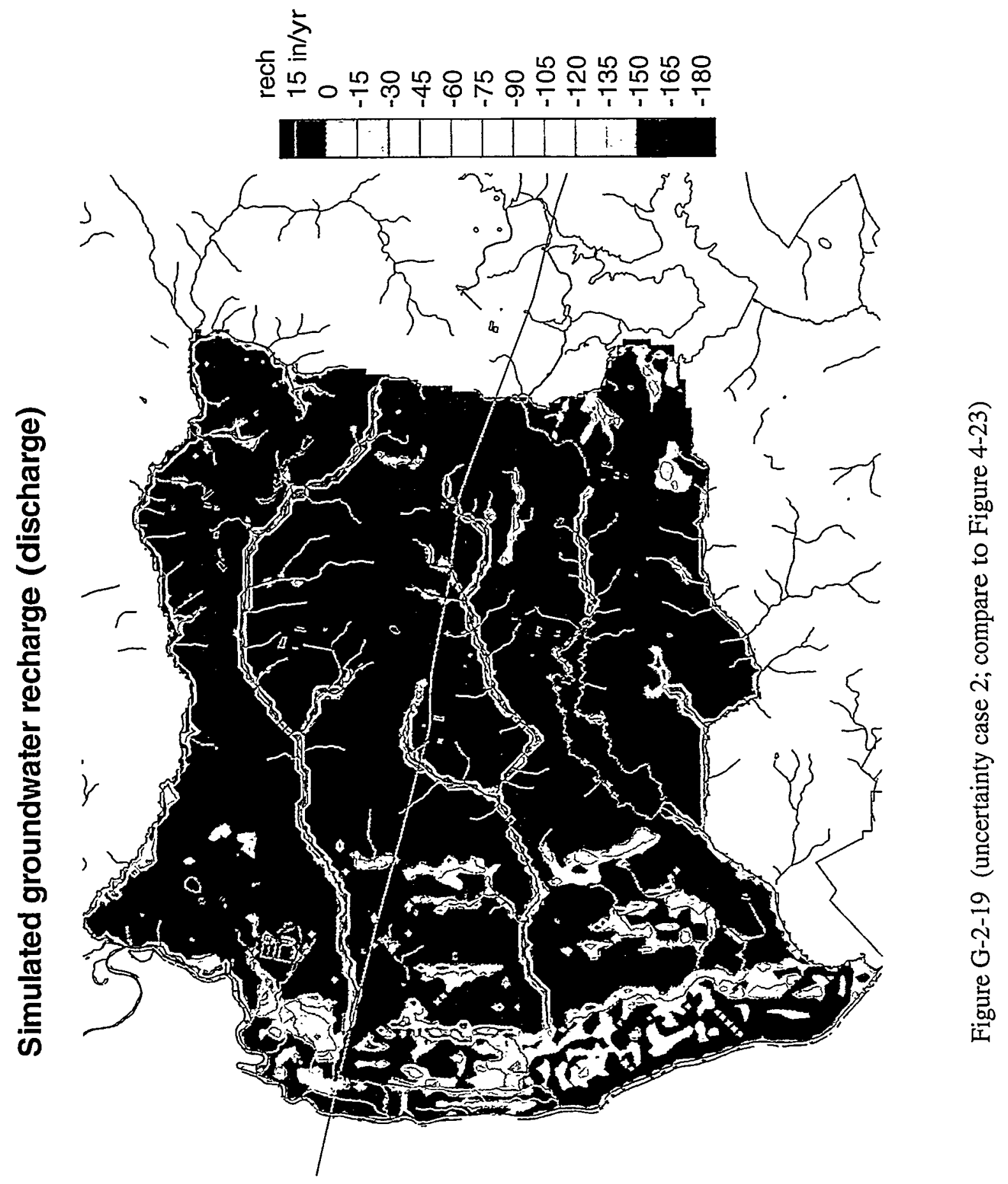


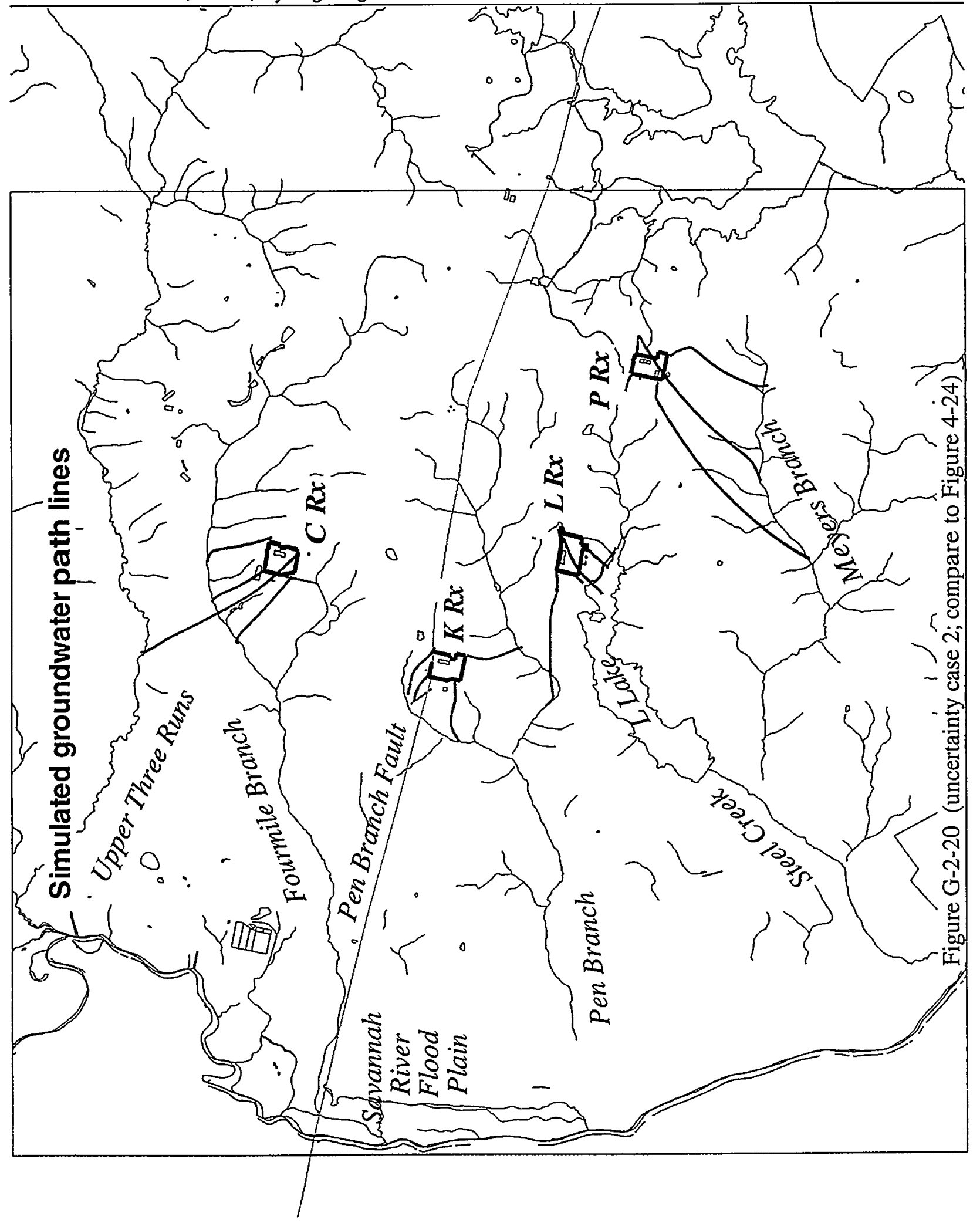


This page intentionally left blank 


\section{Simulation results for uncertainty case 3}

Uncertainty case 3 involves an increase in Gordon confining unit vertical conductivity by a factor of 5 to $5 \times 10^{-4} \mathrm{ft} /$ day (Table 4-4). Summary calibration results are provided in Table 45. This appendix presents detailed simulation results for uncertainty case 3 for comparison to the nominal results shown in figures in the main text. The correspondence between figures for the nominal and uncertainty case 3 is as follows:

\begin{tabular}{|l|l|l|}
\hline Plot type & Nominal case & Uncertainty case 3 \\
\hline Head residual summary & Figure 4-1 & Figure G-3-1 \\
\hline Head residuals in Gordon aquifer & Figure 4-2 & Figure G-3-2 \\
\hline Head residuals in "lower" UTRA & Figure 4-3 & Figure G-3-3 \\
\hline Head residuals in "upper" UTRA & Figure 4-4 & Figure G-3-4 \\
\hline Kh in element layer 1 & Figure 4-5 & Figure G-3-5 \\
\hline Kv in element layer 2 & Figure 4-6 & Figure G-3-6 \\
\hline Kh in element layer 3 & Figure 4-7 & Figure G-3-7 \\
\hline Kh in element layer 4 & Figure 4-8 & Figure G-3-8 \\
\hline Kv in element layer 5 & Figure 4-9 & Figure G-3-9 \\
\hline Kh in element layer 6 & Figure 4-10 & Figure G-3-10 \\
\hline Kh in element layer 7 & Figure 4-11 & Figure G-3-11 \\
\hline Kh in element layer 8 & Figure 4-12 & Figure G-3-12 \\
\hline Gordon aquifer head & Figure 4-14 & Figure G-3-13 \\
\hline "Lower" UTRA head & Figure 4-15 & Figure G-3-14 \\
\hline "Upper" UTRA head & Figure 4-16 & Figure G-3-15 \\
\hline Head in aquifer containing water table & Figure 4-17 & Figure G-3-16 \\
\hline Water table & Figure 4-18 & Figure G-3-17 \\
\hline Seepage faces & Figure 4-22 & Figure G-3-18 \\
\hline Recharge/discharge & Figure 4-23 & Figure G-3-19 \\
\hline Example particle tracing & Figure 4-24 & Figure G-3-20 \\
\hline
\end{tabular}



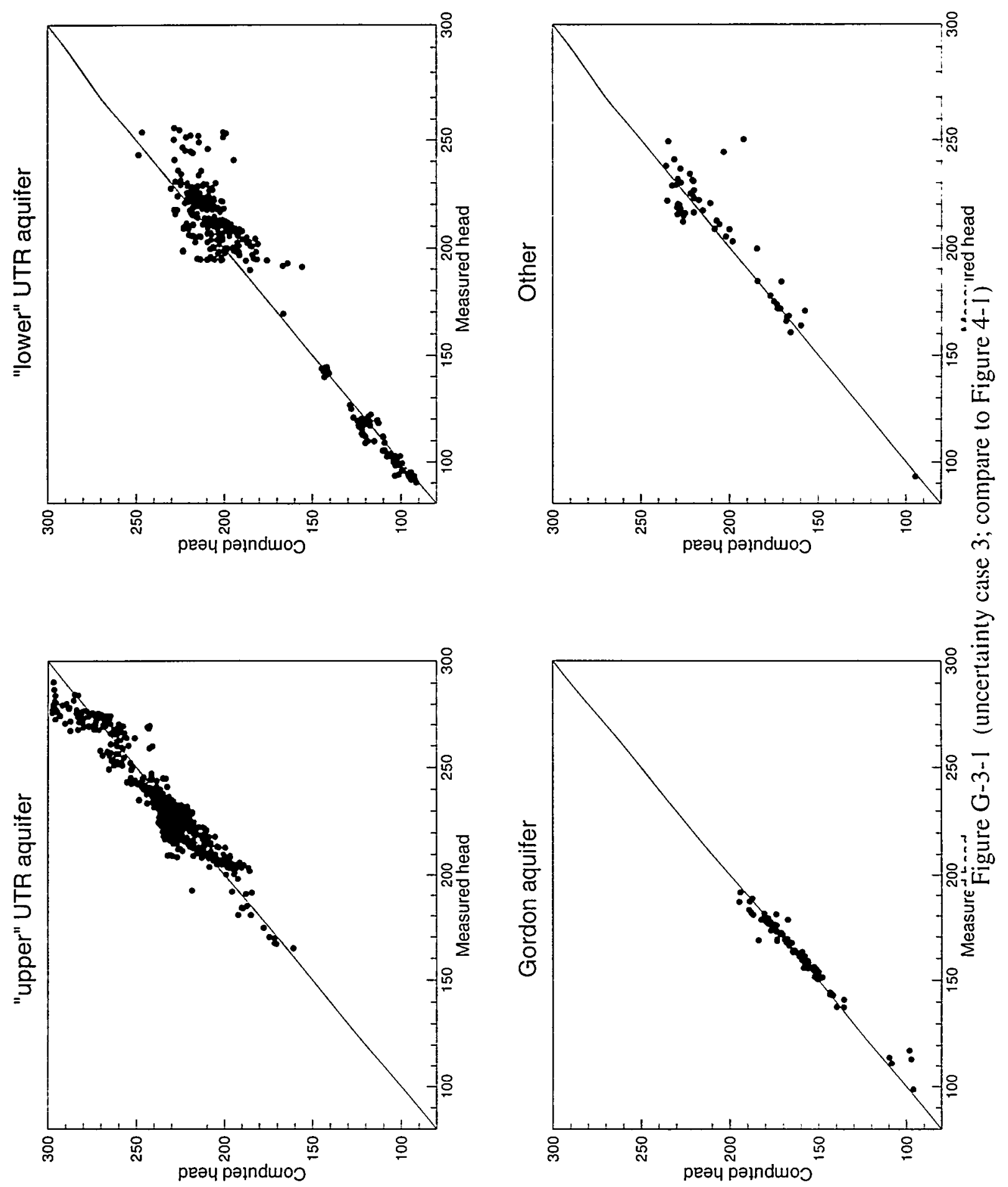

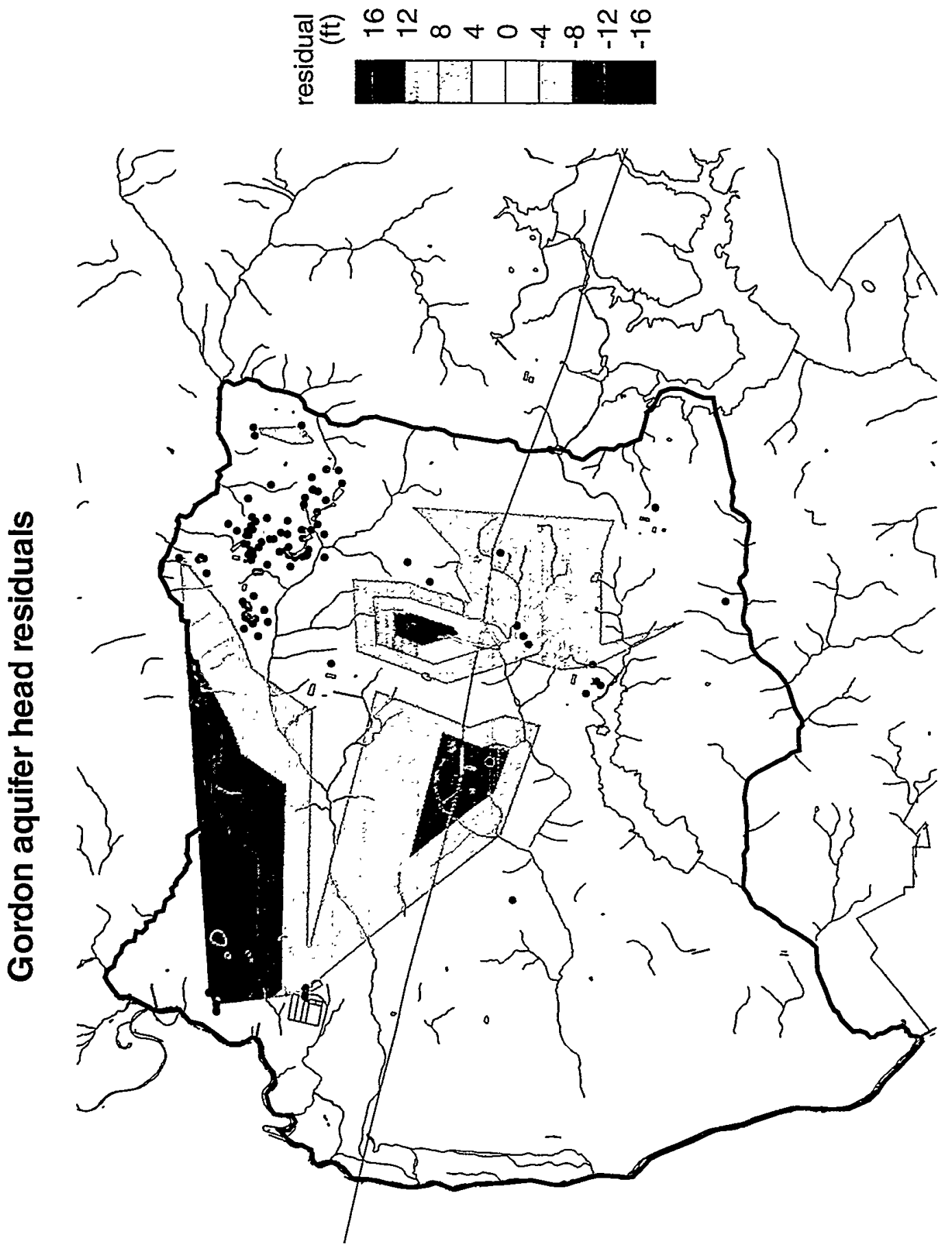

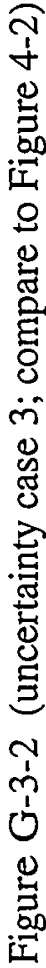


"lower" UTR aquifer zone

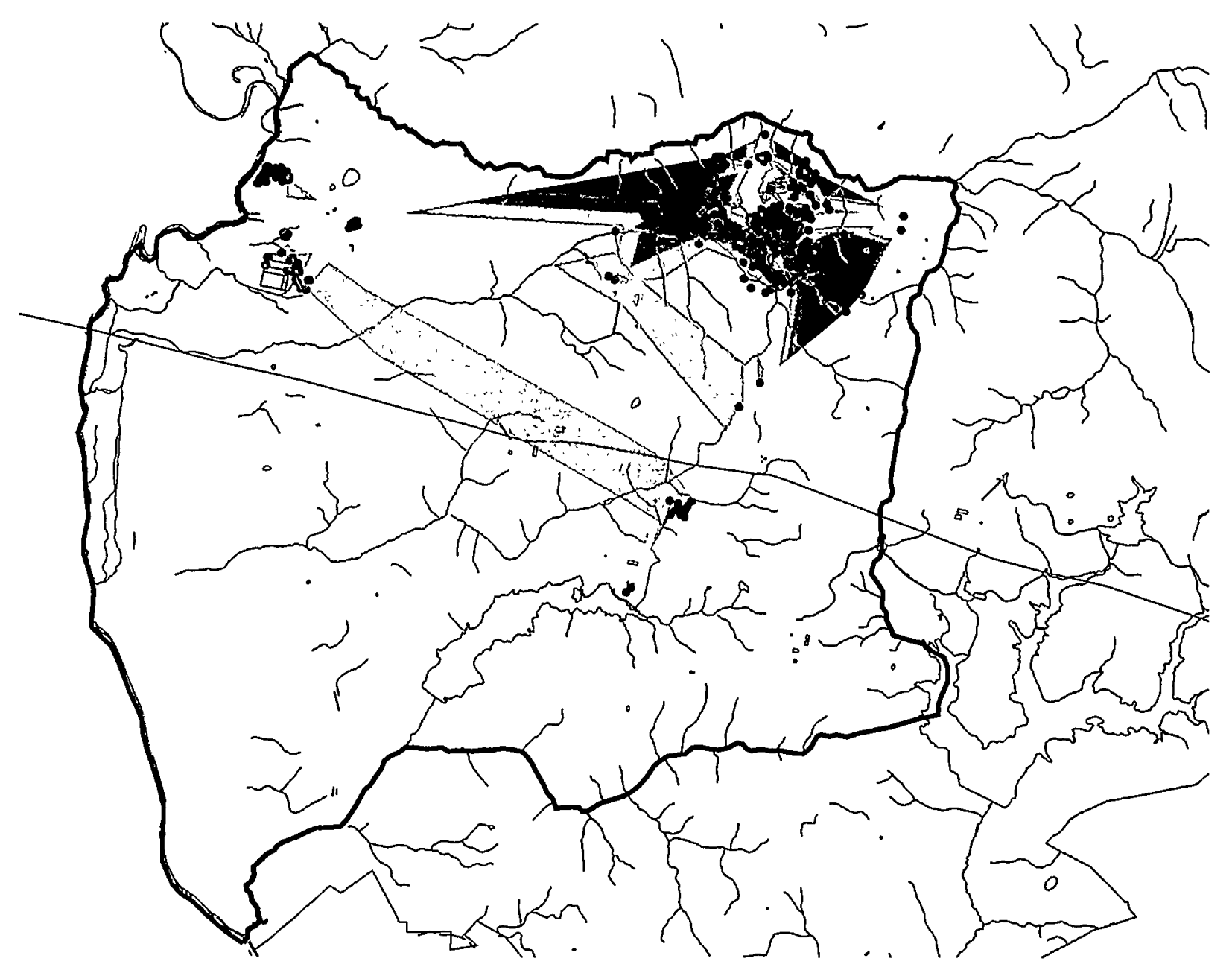

residual

(ft)

12

8

4
0

$-4$

Figure G-3-3 (uncertainty case 3; compare to Figure 4-3) 

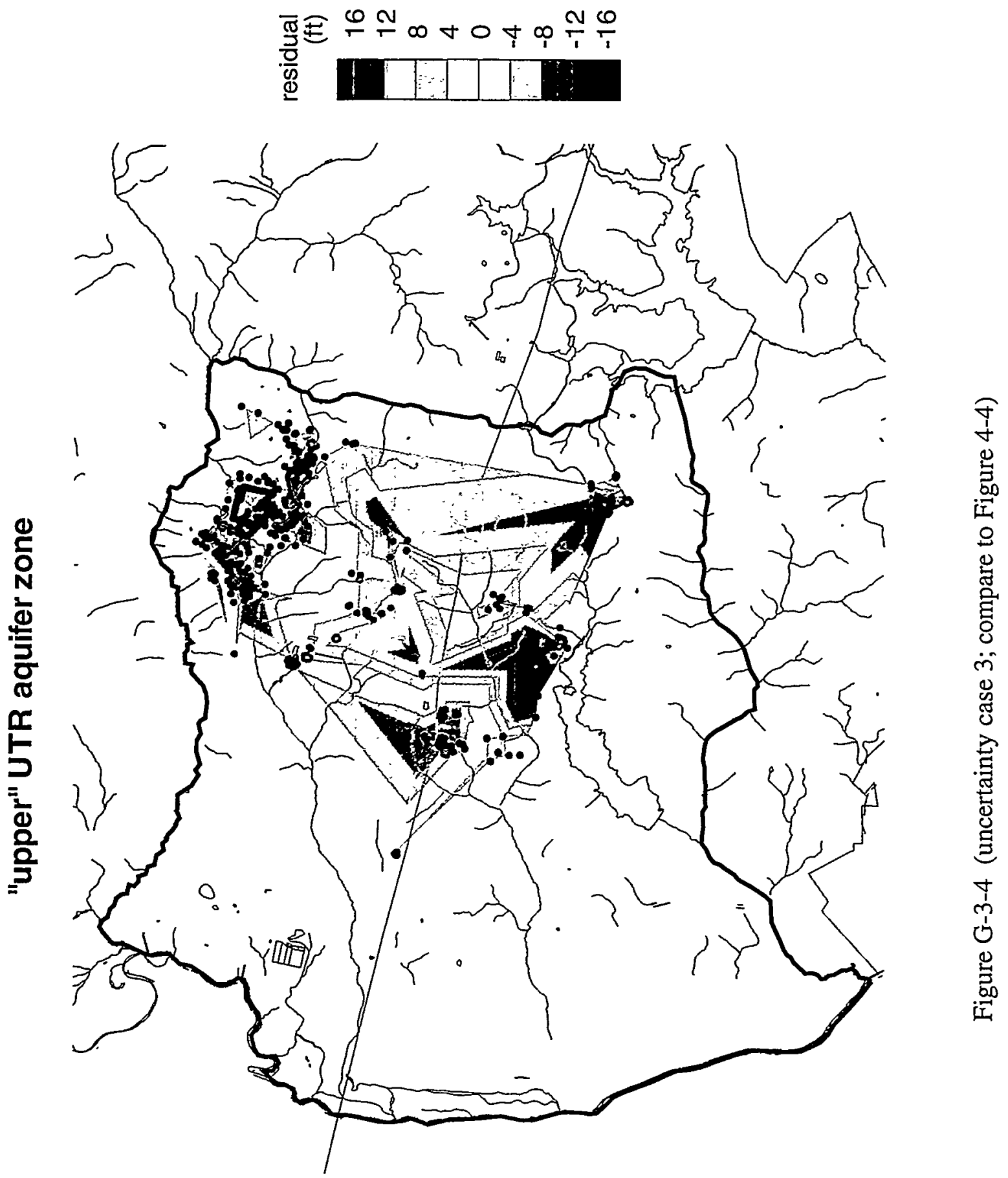


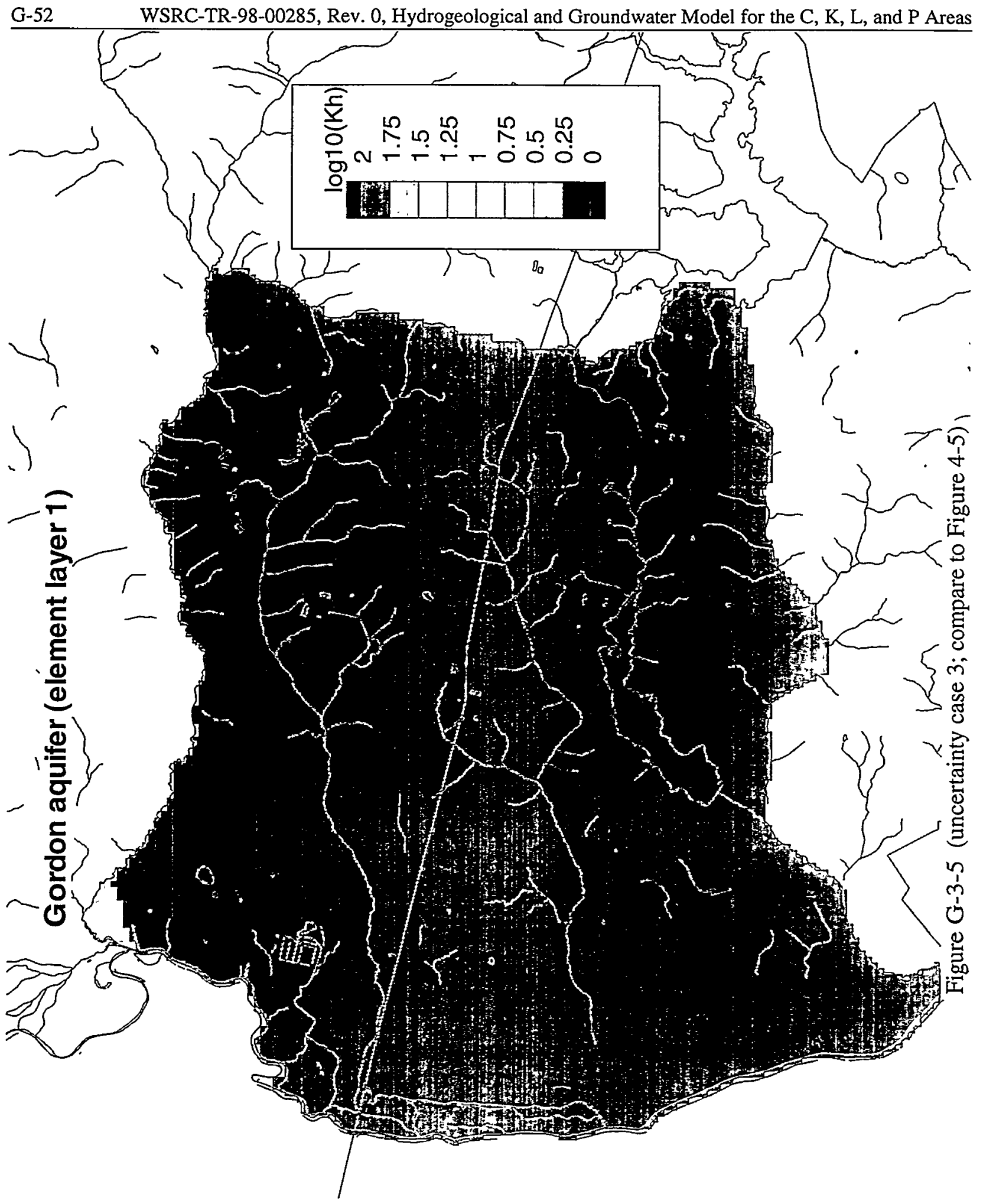




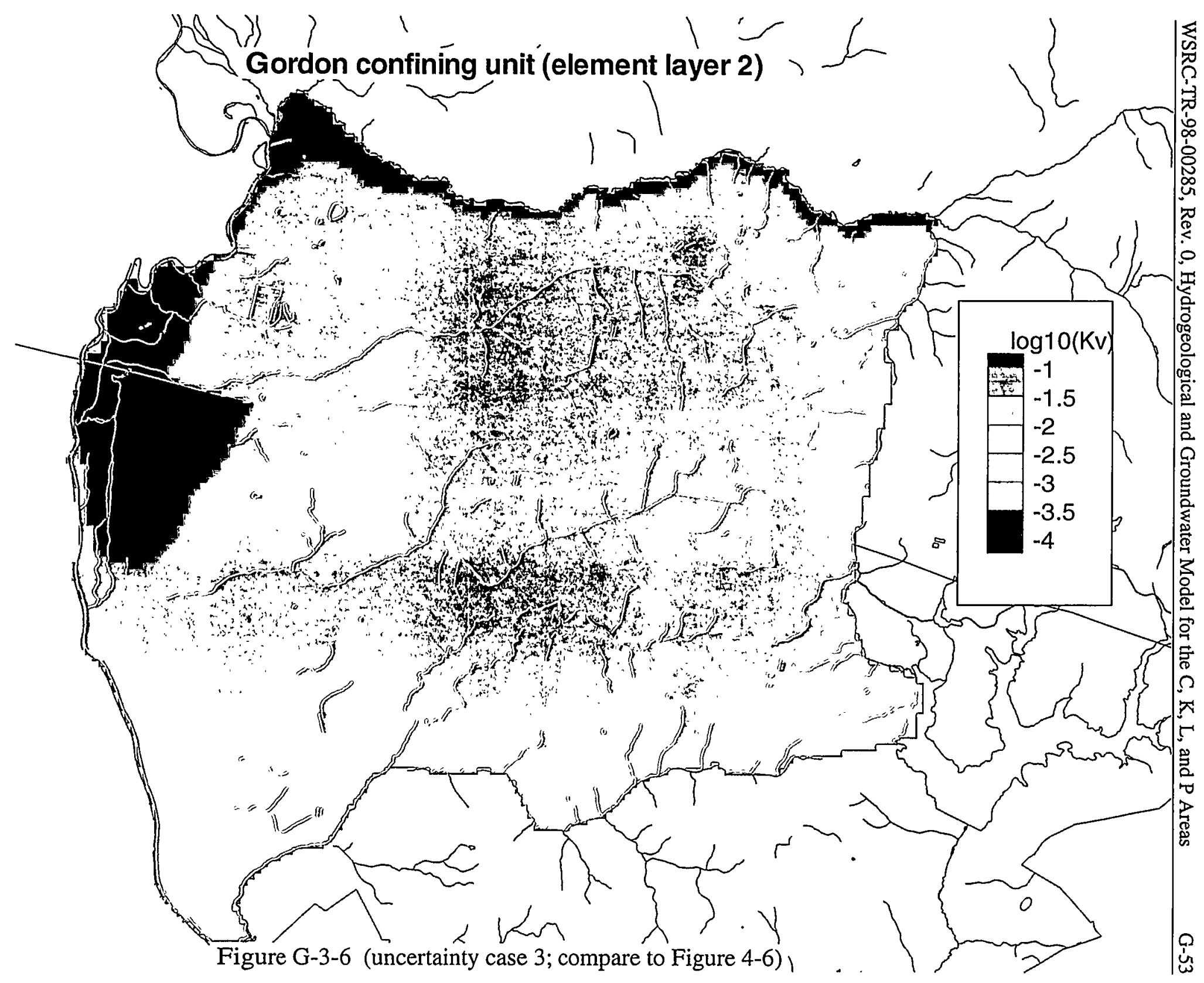


G-54 WSRC-TR-98-00285, Rev. 0, Hydrogeological and Groundwater Model for the C, K, L, and P Areas

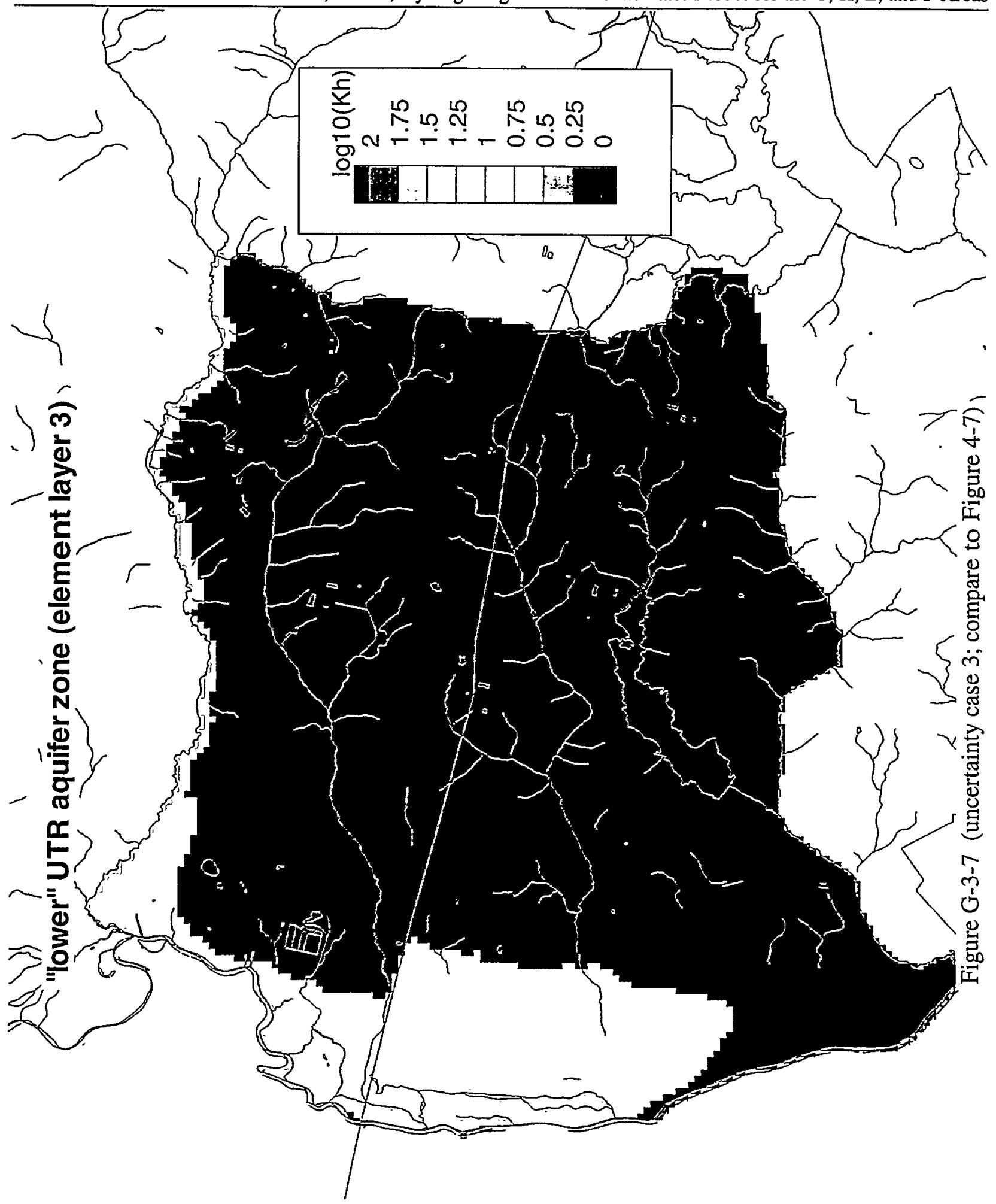




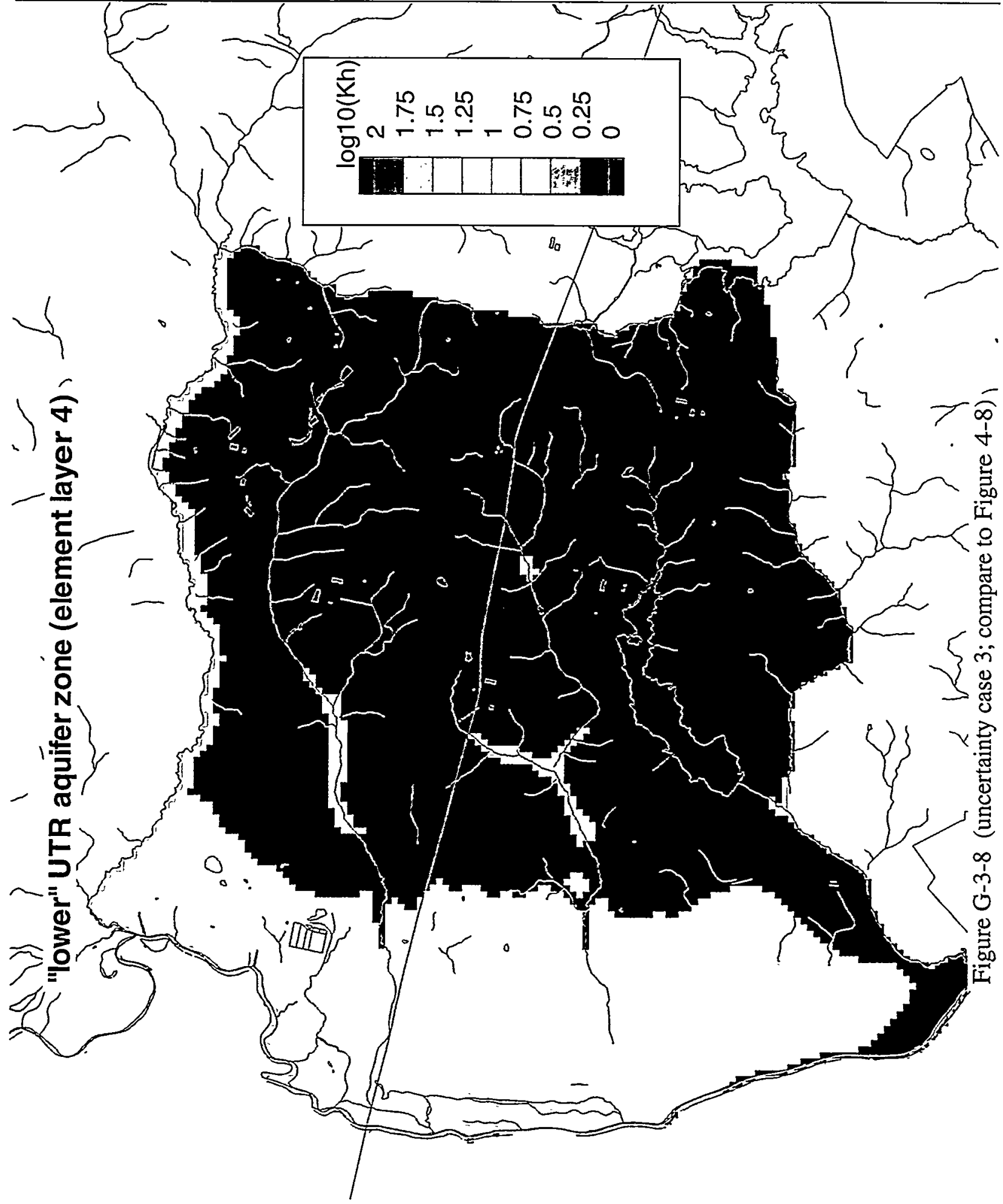




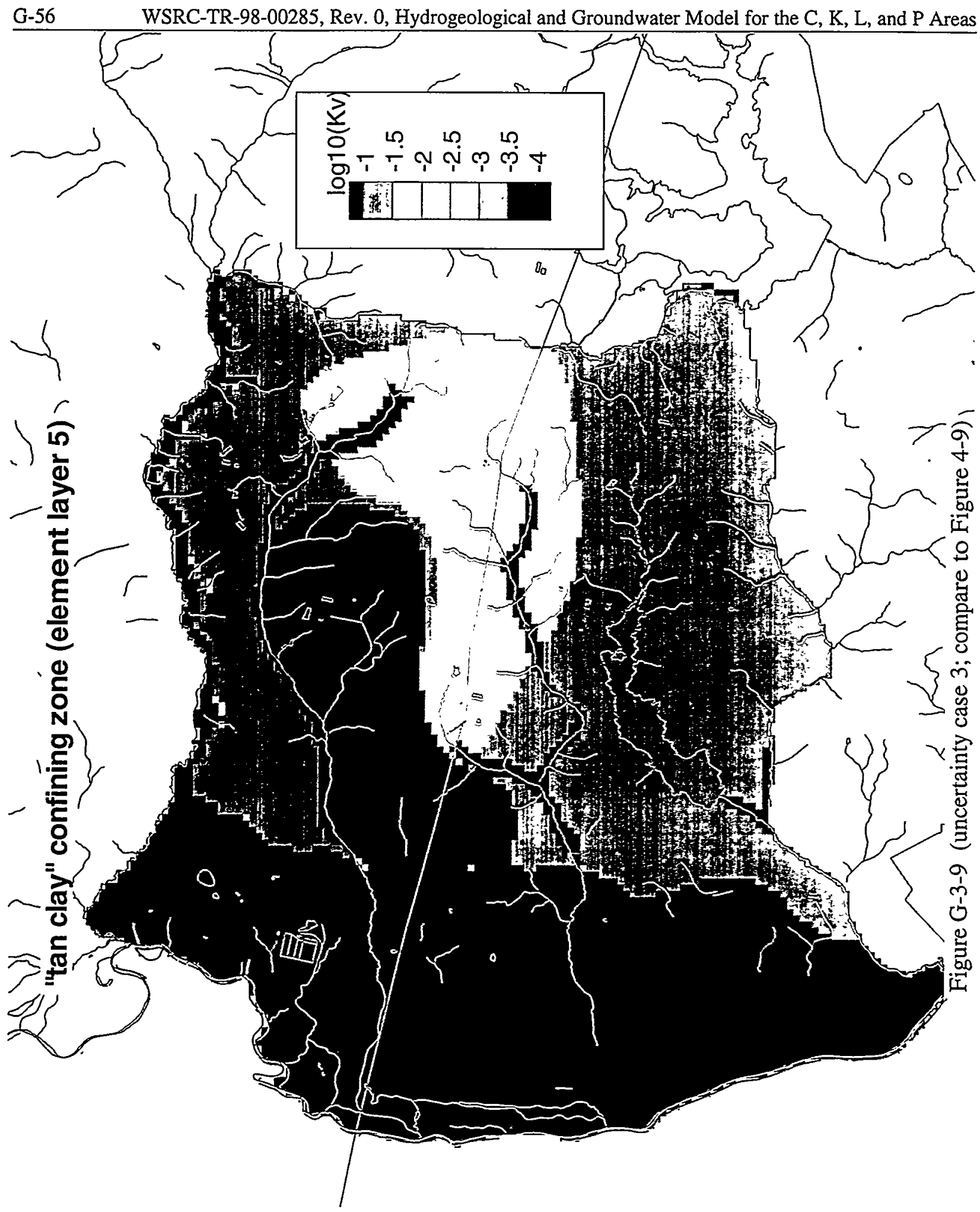




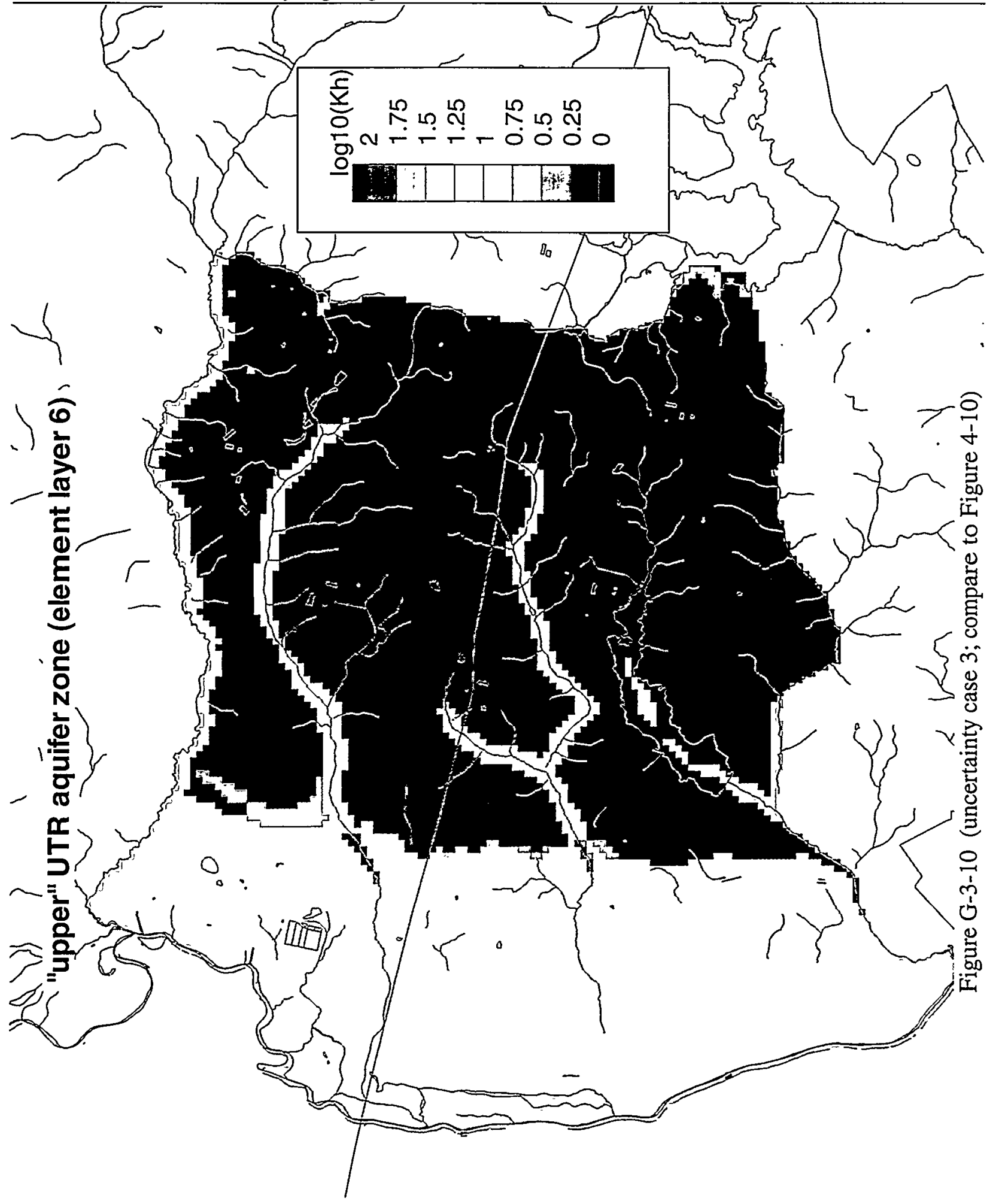




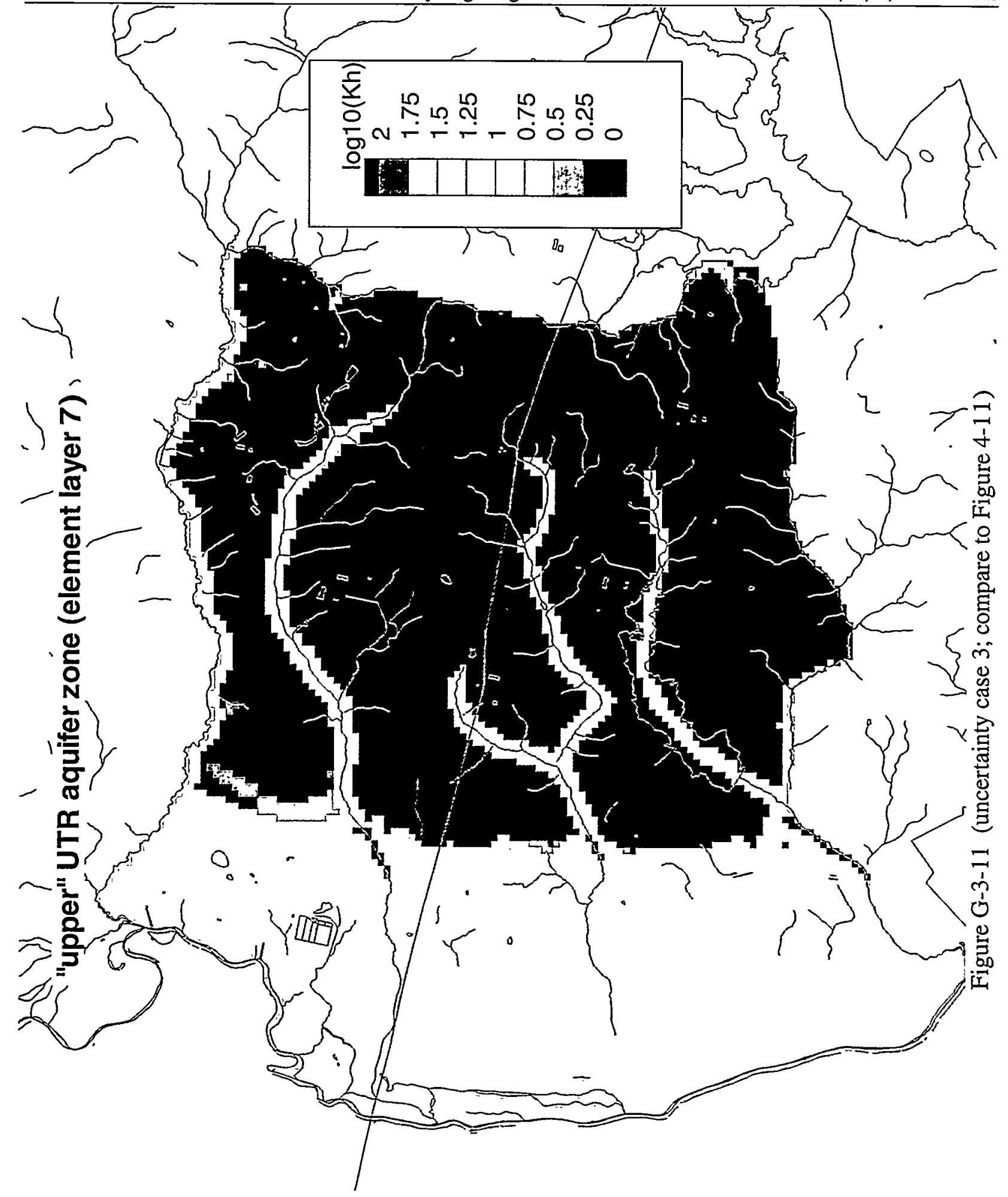




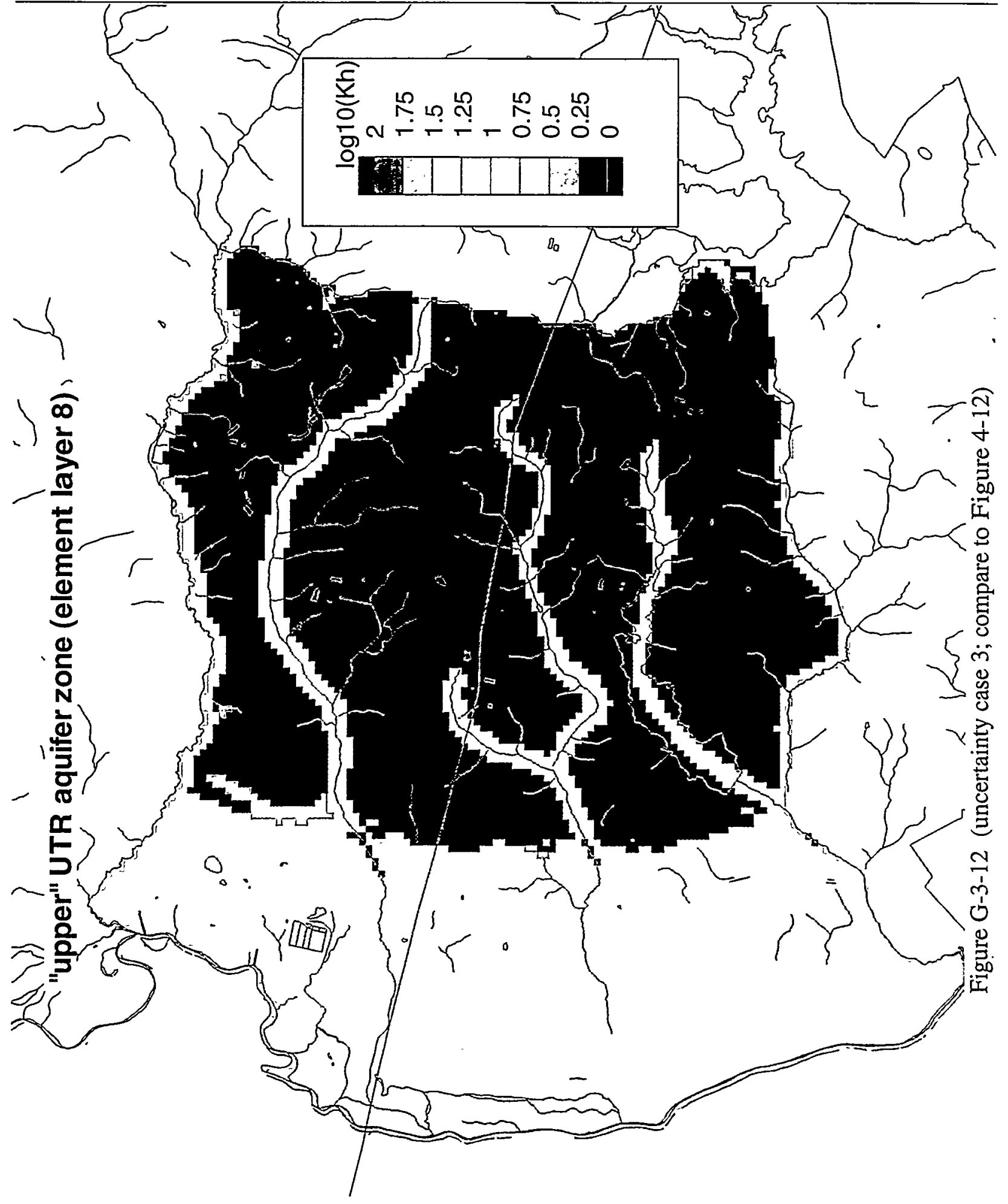


Simulated hydraulic head in Gordon aquifer

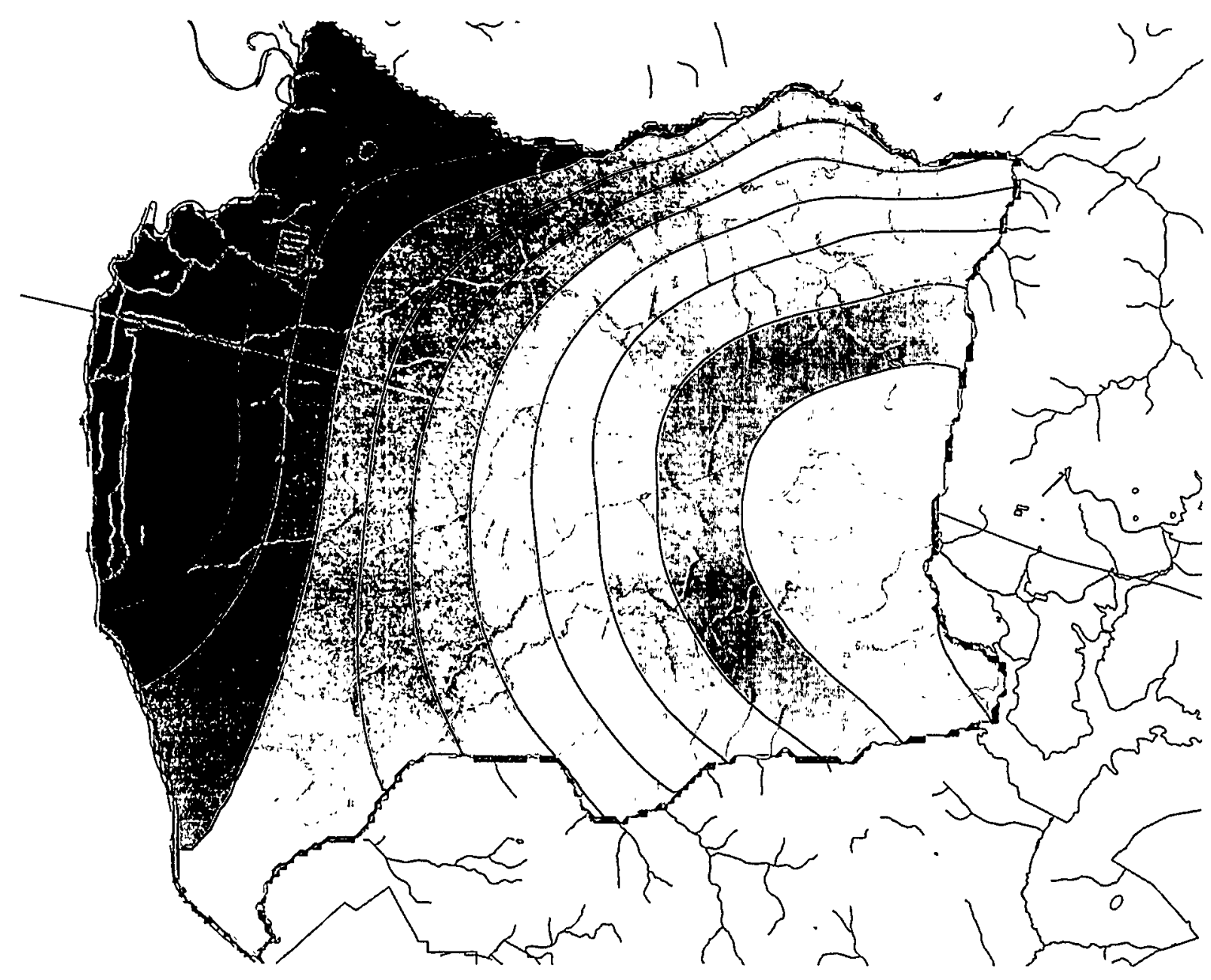

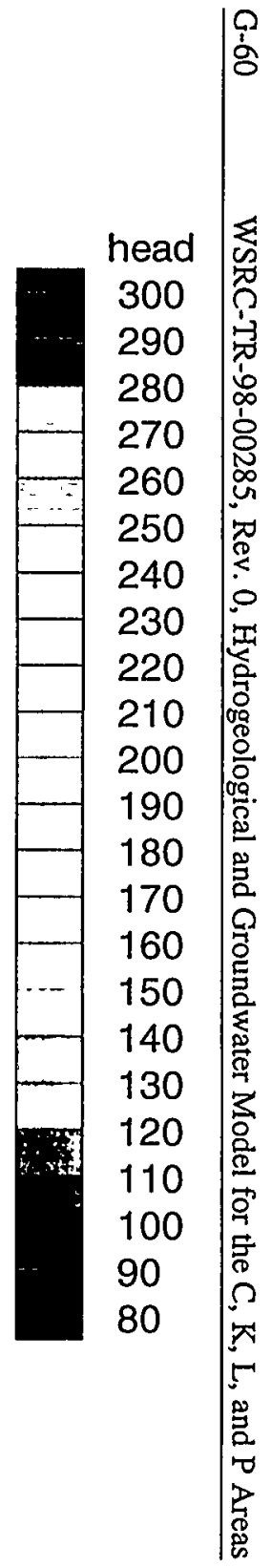

Figure G-3-13 (uncertainty case 3; compare to Figure 4-14) 


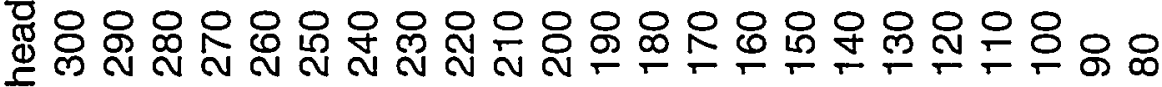
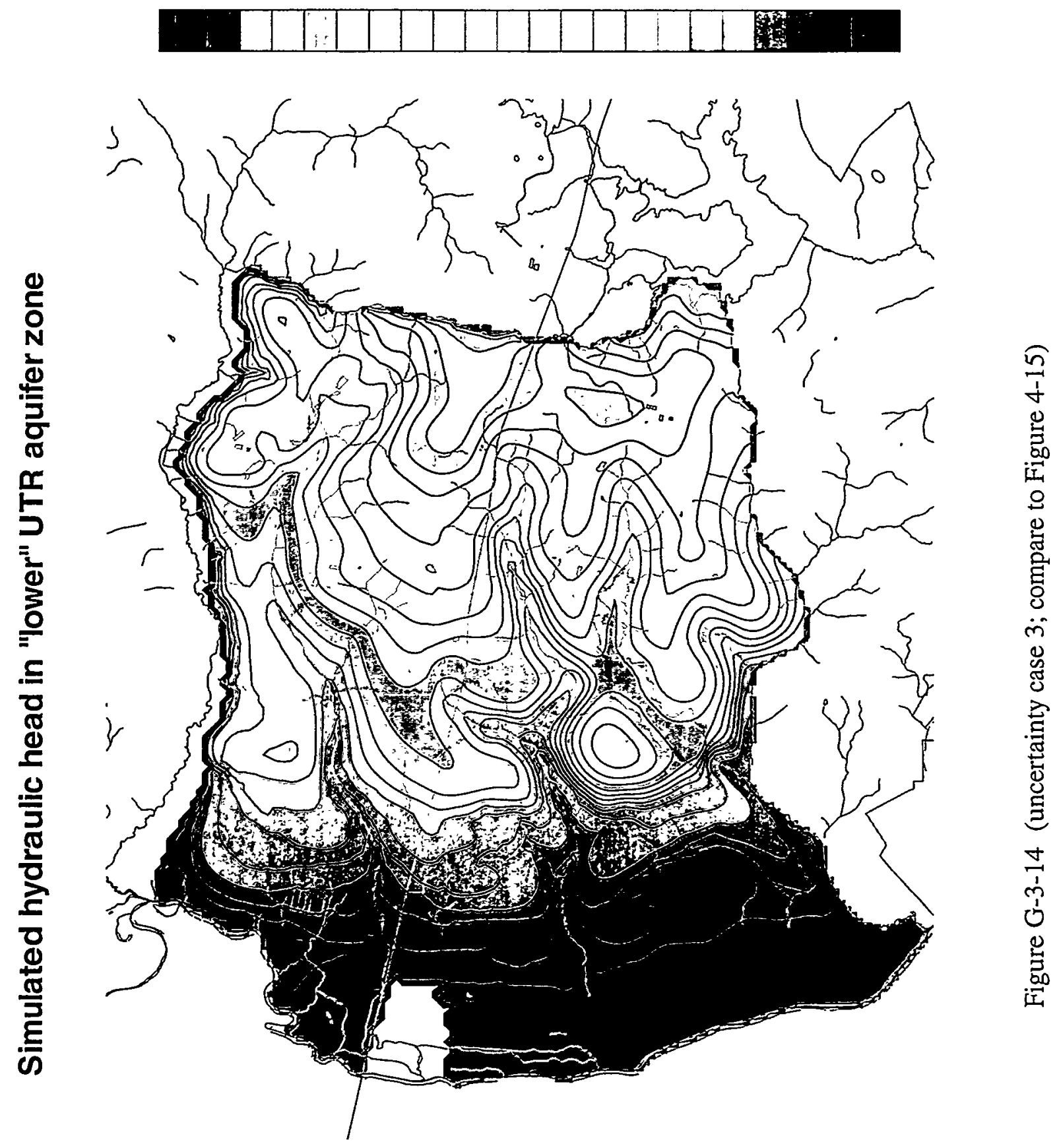
Simulated hydraulic head in "upper" UTR aquifer zone

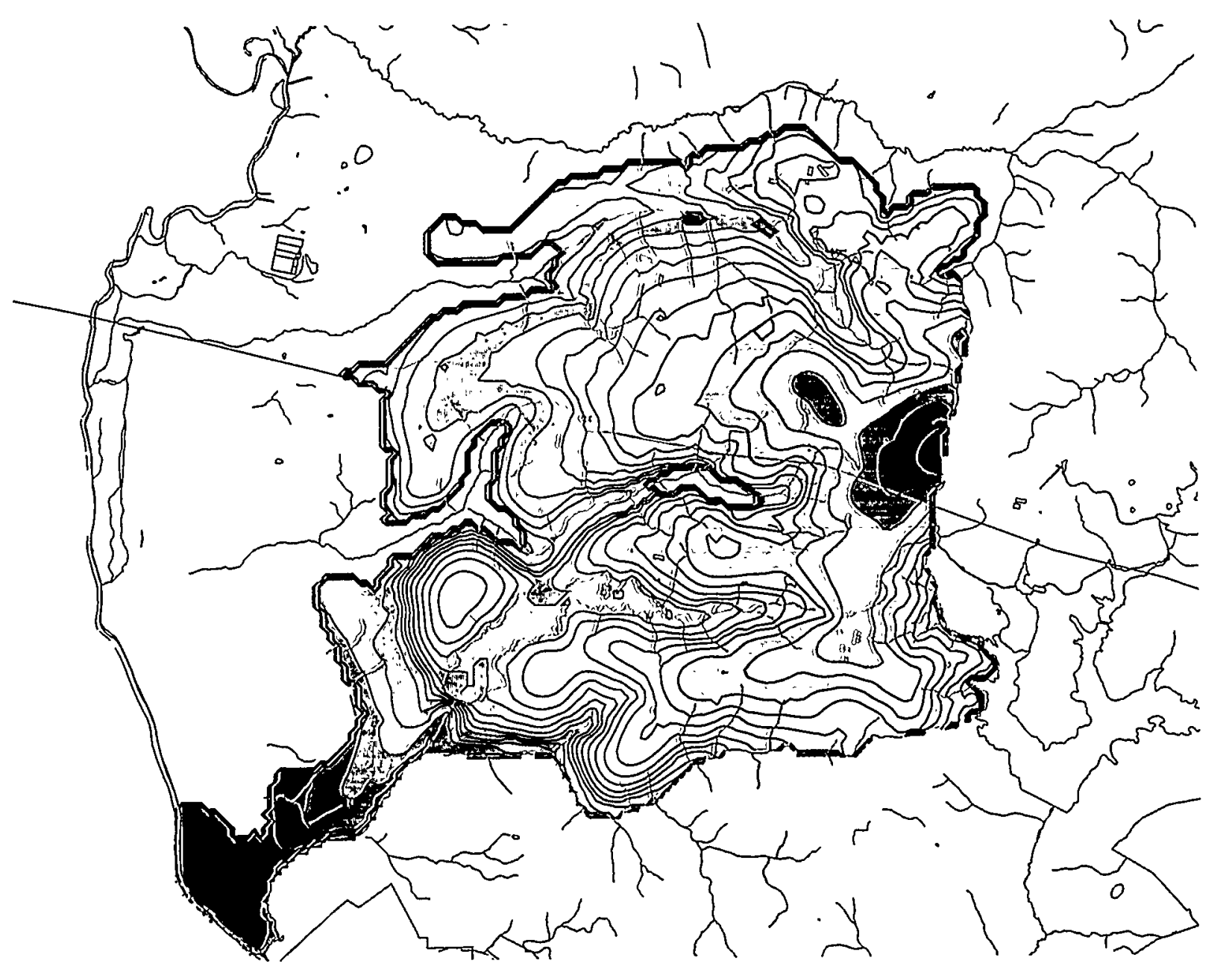




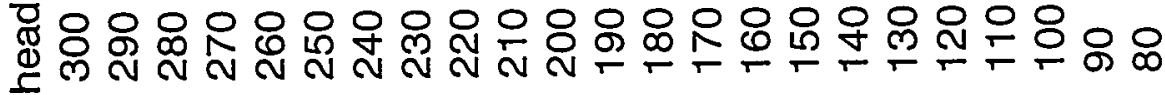

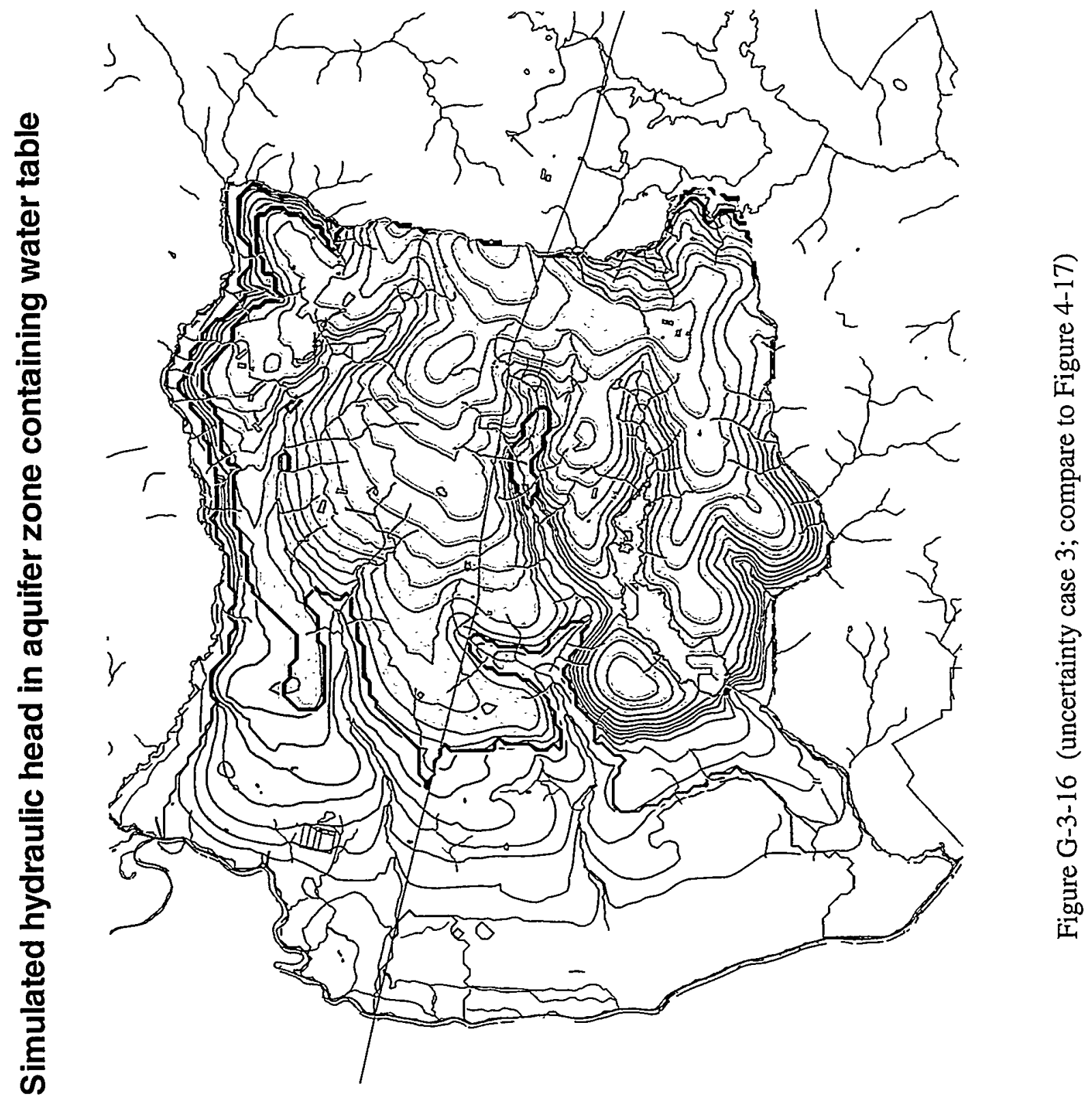




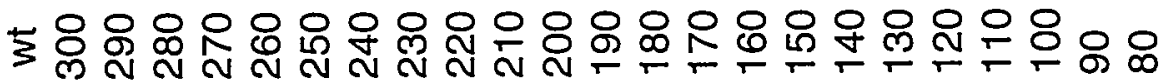

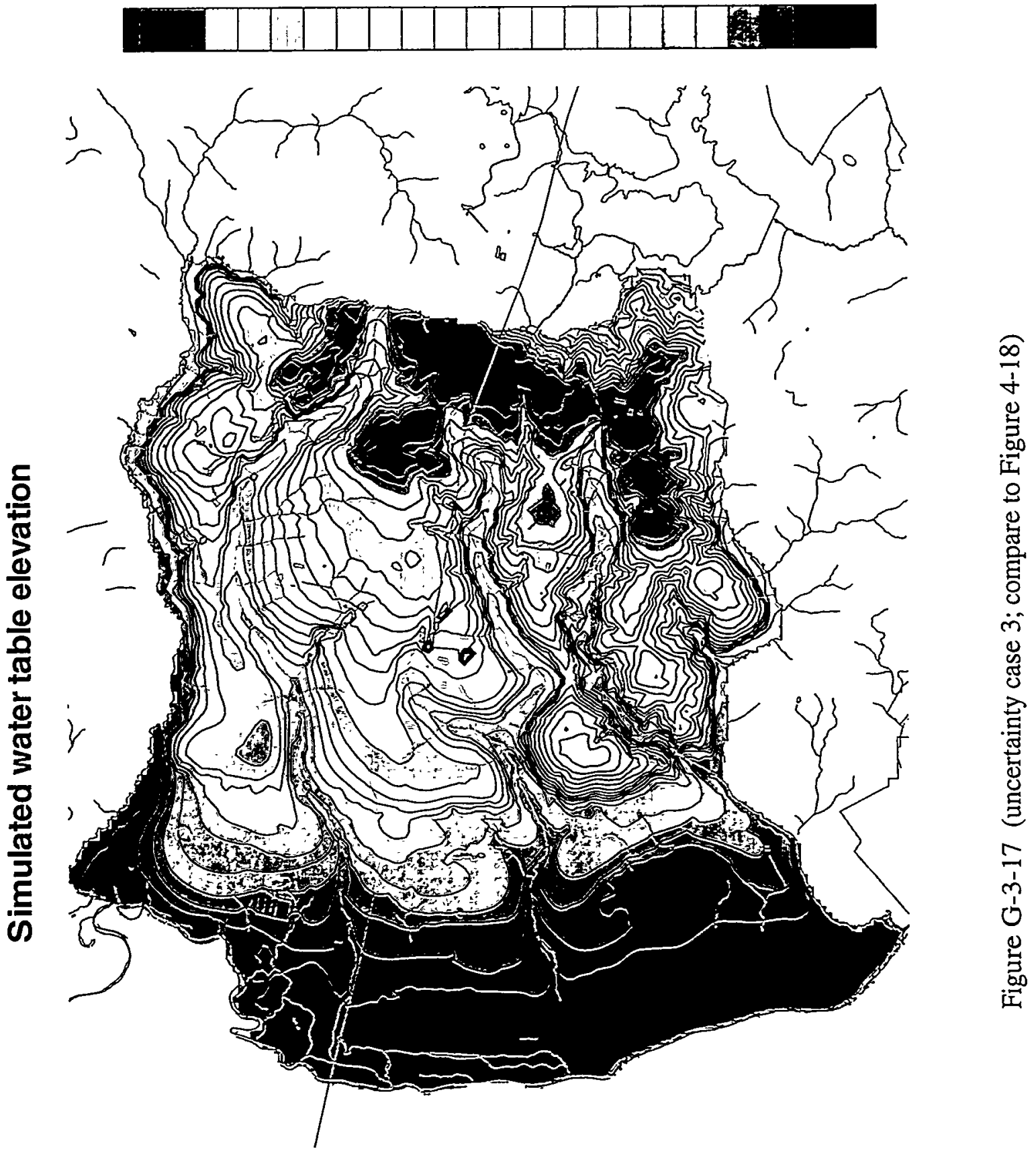




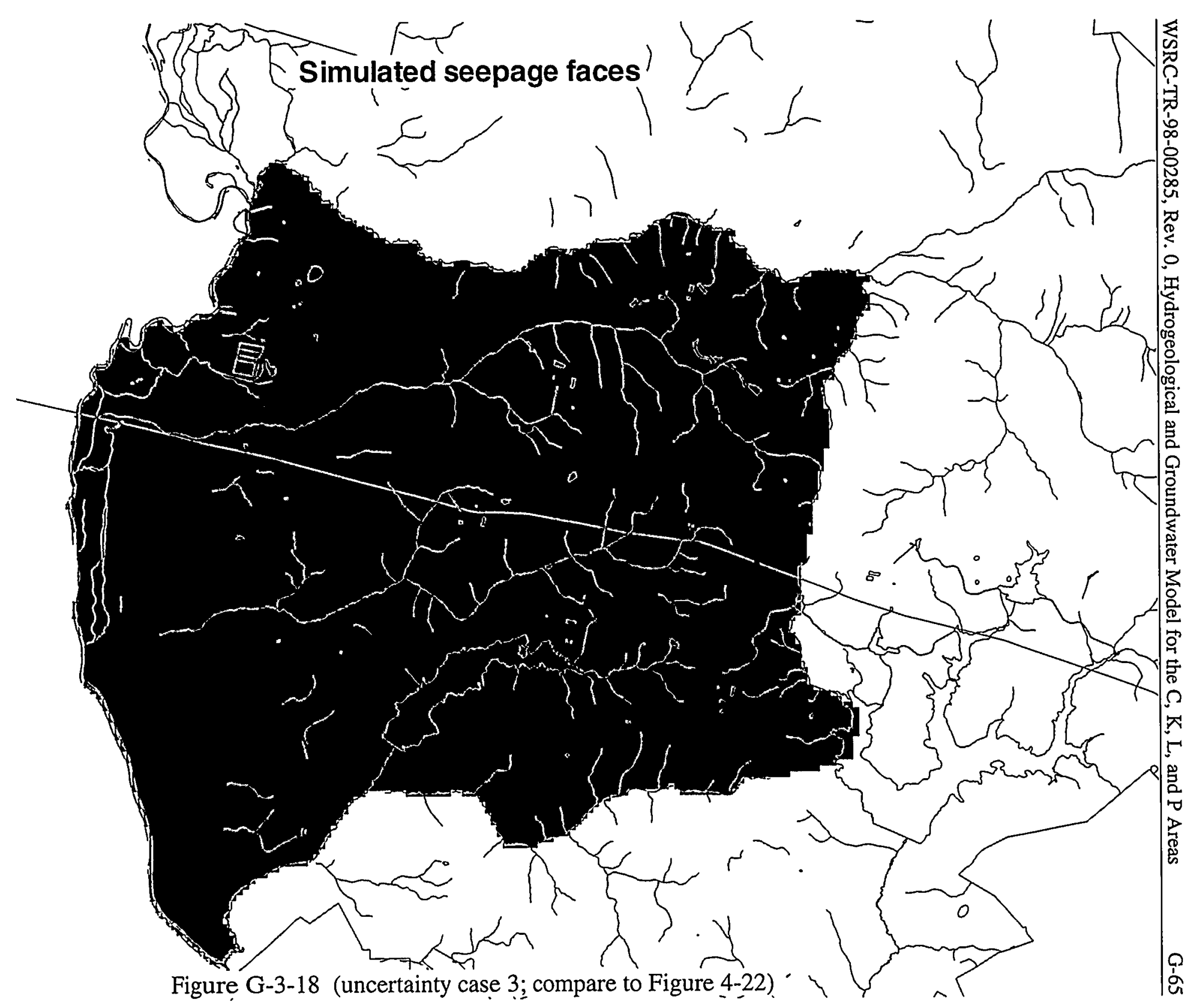




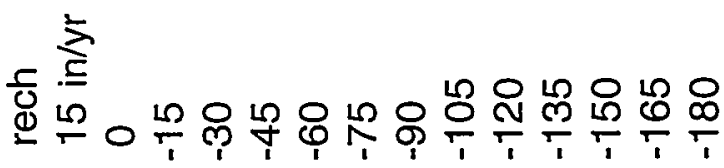
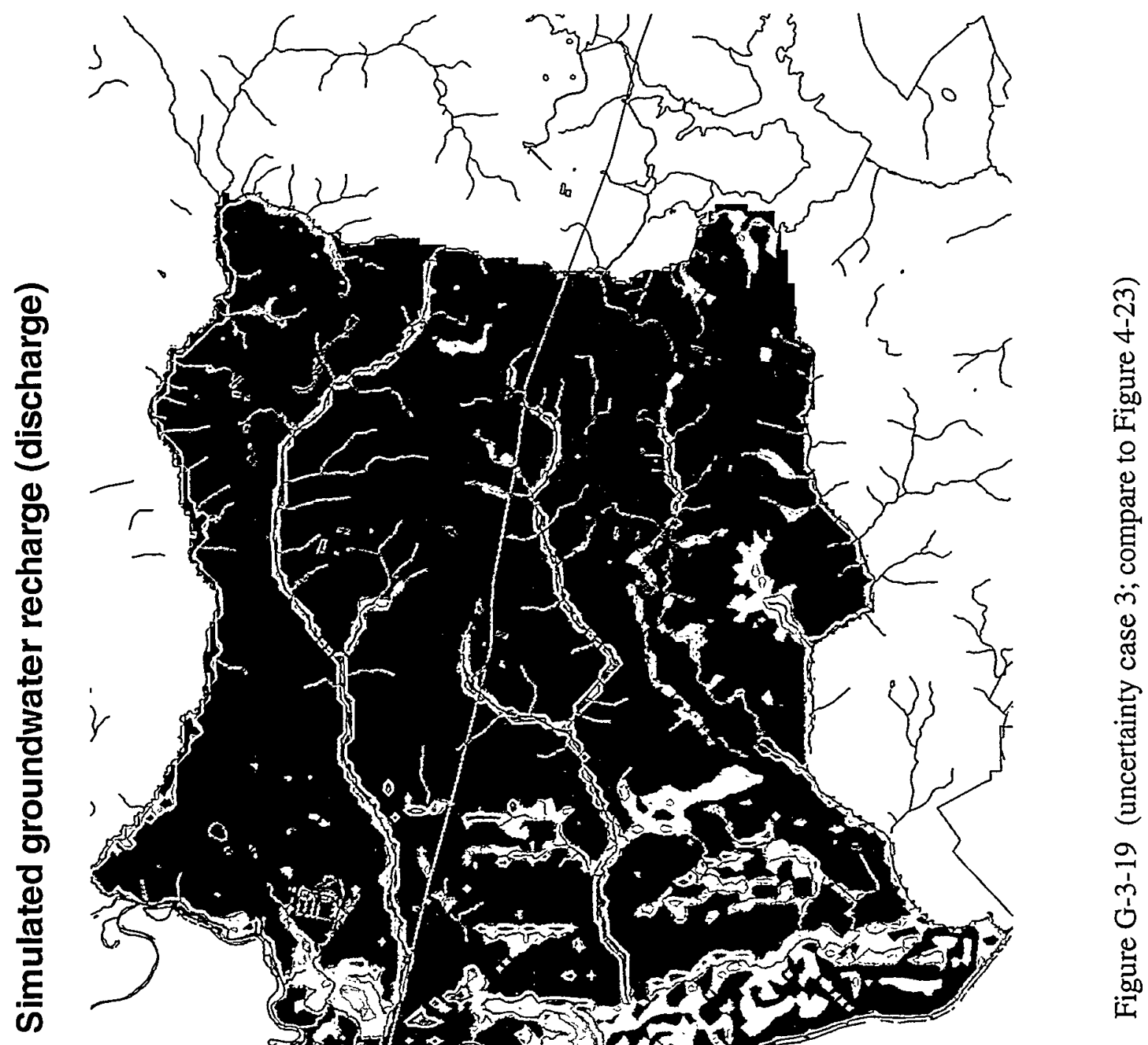


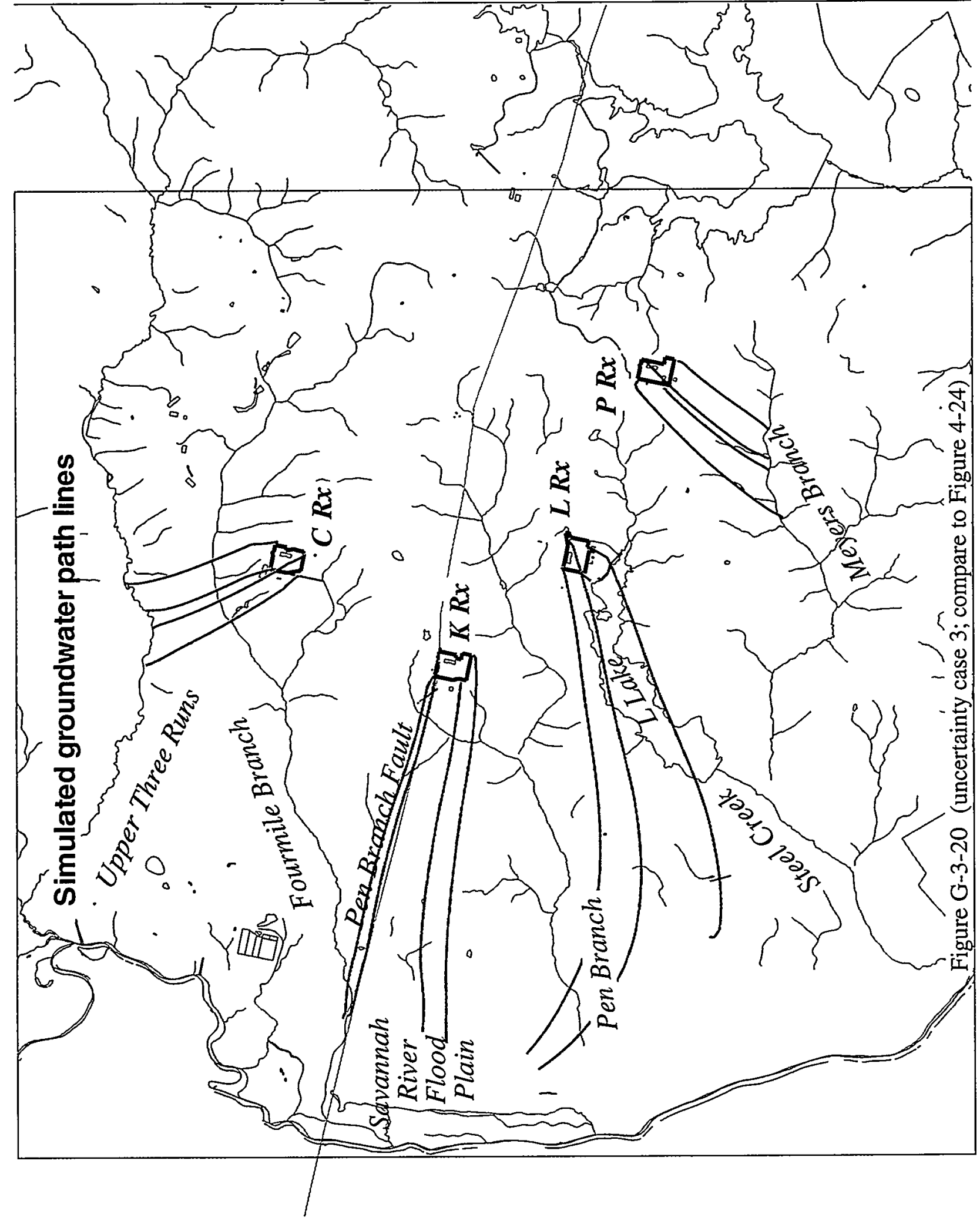


This page intentionally left blank 


\section{Simulation results for uncertainty case 4}

Uncertainty case 4 involves a decrease in Gordon confining unit vertical conductivity by a factor of 5 to $2 \times 10^{-5} \mathrm{ft} /$ day (Table 4-4). Summary calibration results are provided in Table 45. This appendix presents detailed simulation results for uncertainty case 4 for comparison to the nominal results shown in figures in the main text. The correspondence between figures for the nominal and uncertainty case 4 is as follows:

\begin{tabular}{|l|l|l|}
\hline Plot type & Nominal case & Uncertainty case 4 \\
\hline Head residual summary & Figure 4-1 & Figure G-4-1 \\
\hline Head residuals in Gordon aquifer & Figure 4-2 & Figure G-4-2 \\
\hline Head residuals in "lower" UTRA & Figure 4-3 & Figure G-4-3 \\
\hline Head residuals in "upper" UTRA & Figure 4-4 & Figure G-4-4 \\
\hline Kh in element layer 1 & Figure 4-5 & Figure G-4-5 \\
\hline Kv in element layer 2 & Figure 4-6 & Figure G-4-6 \\
\hline Kh in element layer 3 & Figure 4-7 & Figure G-4-7 \\
\hline Kh in element layer 4 & Figure 4-8 & Figure G-4-8 \\
\hline Kv in element layer 5 & Figure 4-9 & Figure G-4-9 \\
\hline Kh in element layer 6 & Figure 4-10 & Figure G-4-10 \\
\hline Kh in element layer 7 & Figure 4-11 & Figure G-4-11 \\
\hline Kh in element layer 8 & Figure 4-12 & Figure G-4-12 \\
\hline Gordon aquifer head & Figure 4-14 & Figure G-4-13 \\
\hline "Lower" UTRA head & Figure 4-15 & Figure G-4-14 \\
\hline "Upper" UTRA head & Figure 4-16 & Figure G-4-15 \\
\hline Head in aquifer containing water table & Figure 4-17 & Figure G-4-16 \\
\hline Water table & Figure 4-18 & Figure G-4-17 \\
\hline Seepage faces & Figure 4-22 & Figure G-4-18 \\
\hline Recharge/discharge & Figure 4-23 & Figure G-4-19 \\
\hline Example particle tracing & Figure 4-24 & Figure G-4-20 \\
\hline
\end{tabular}



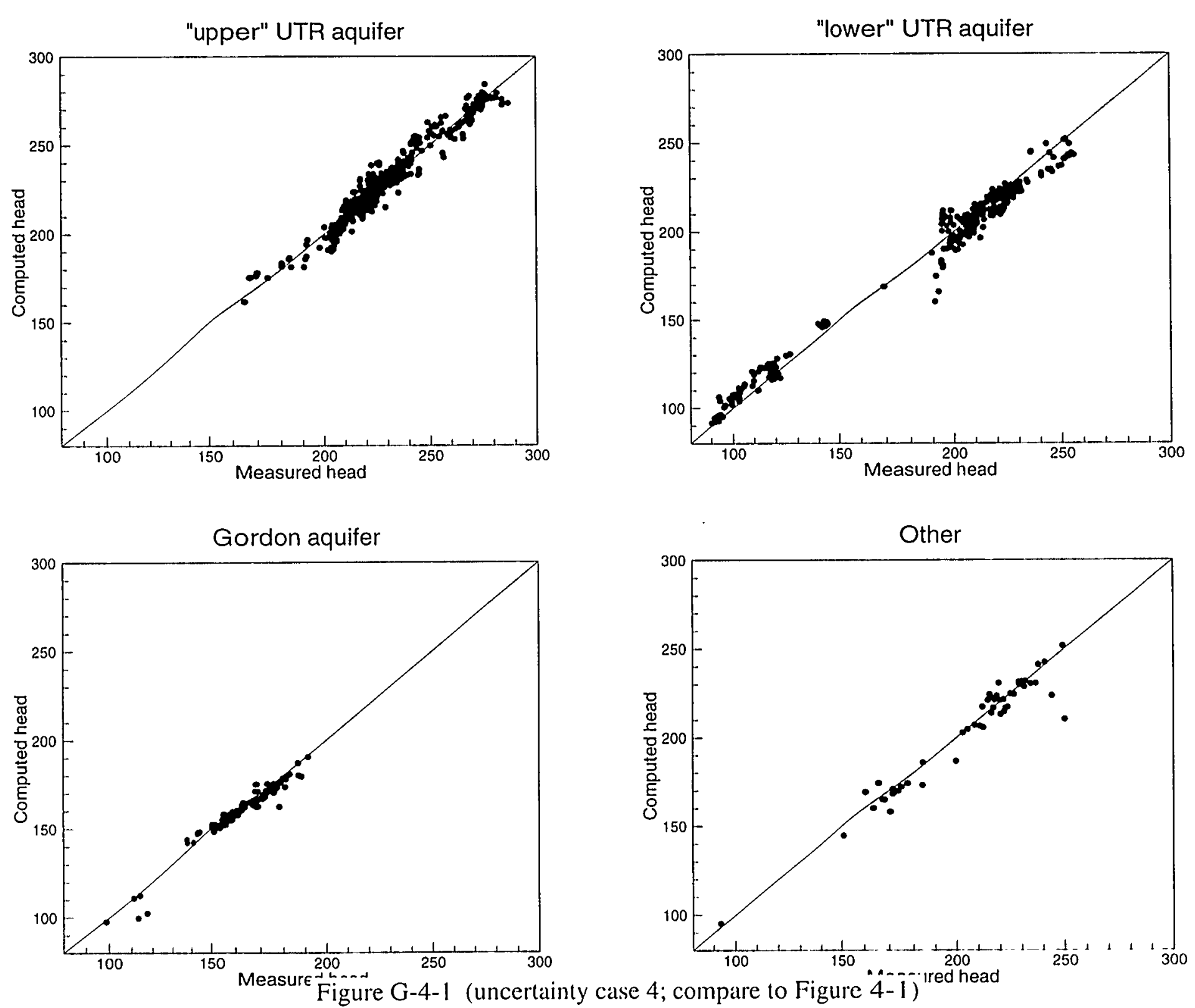


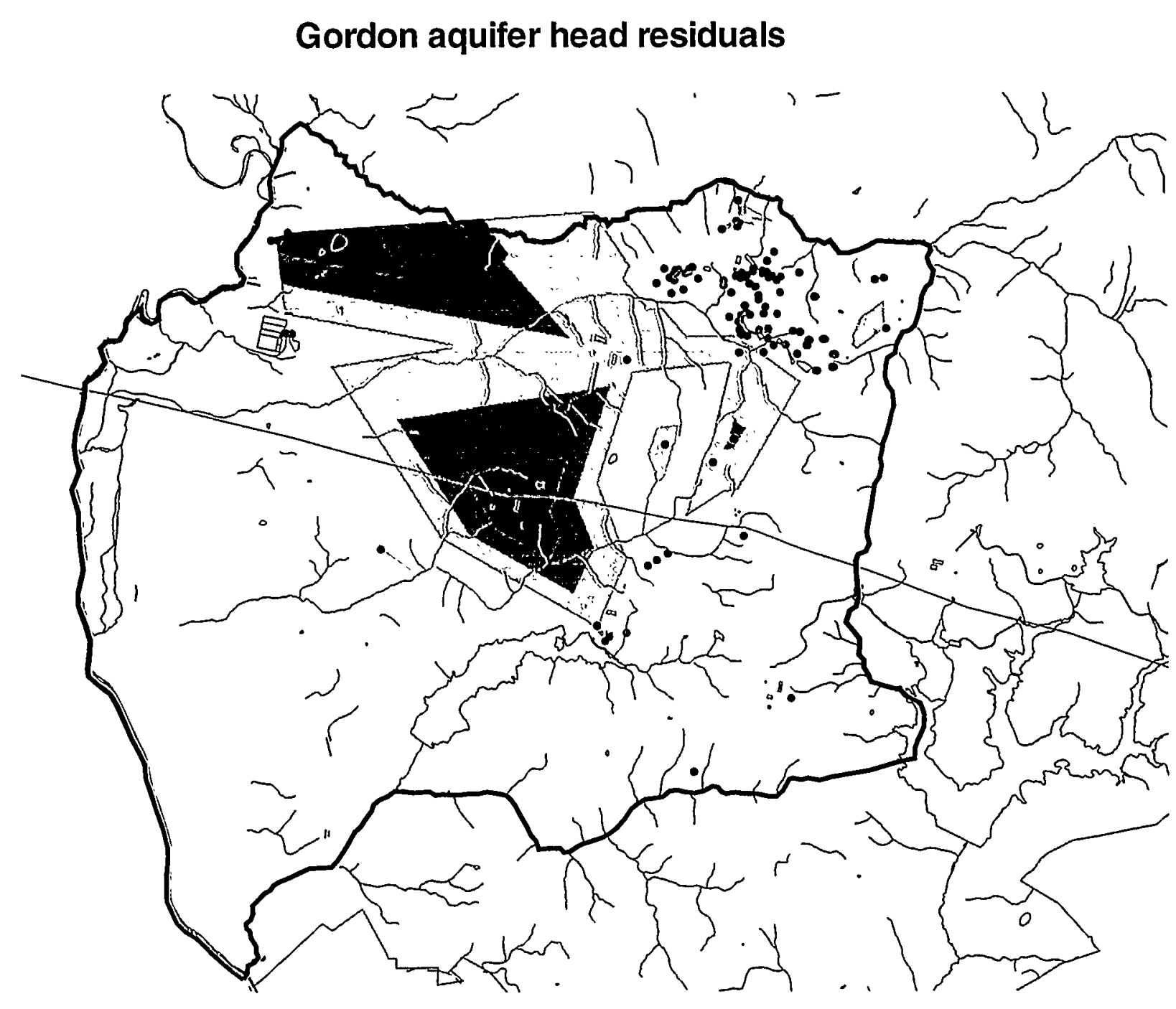

residual

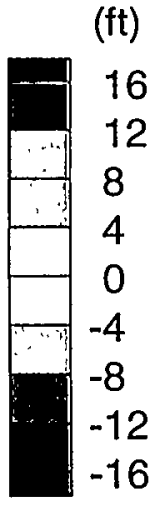

Figure G-4-2 (uncertainty case 4; compare to Figure 4-2) 


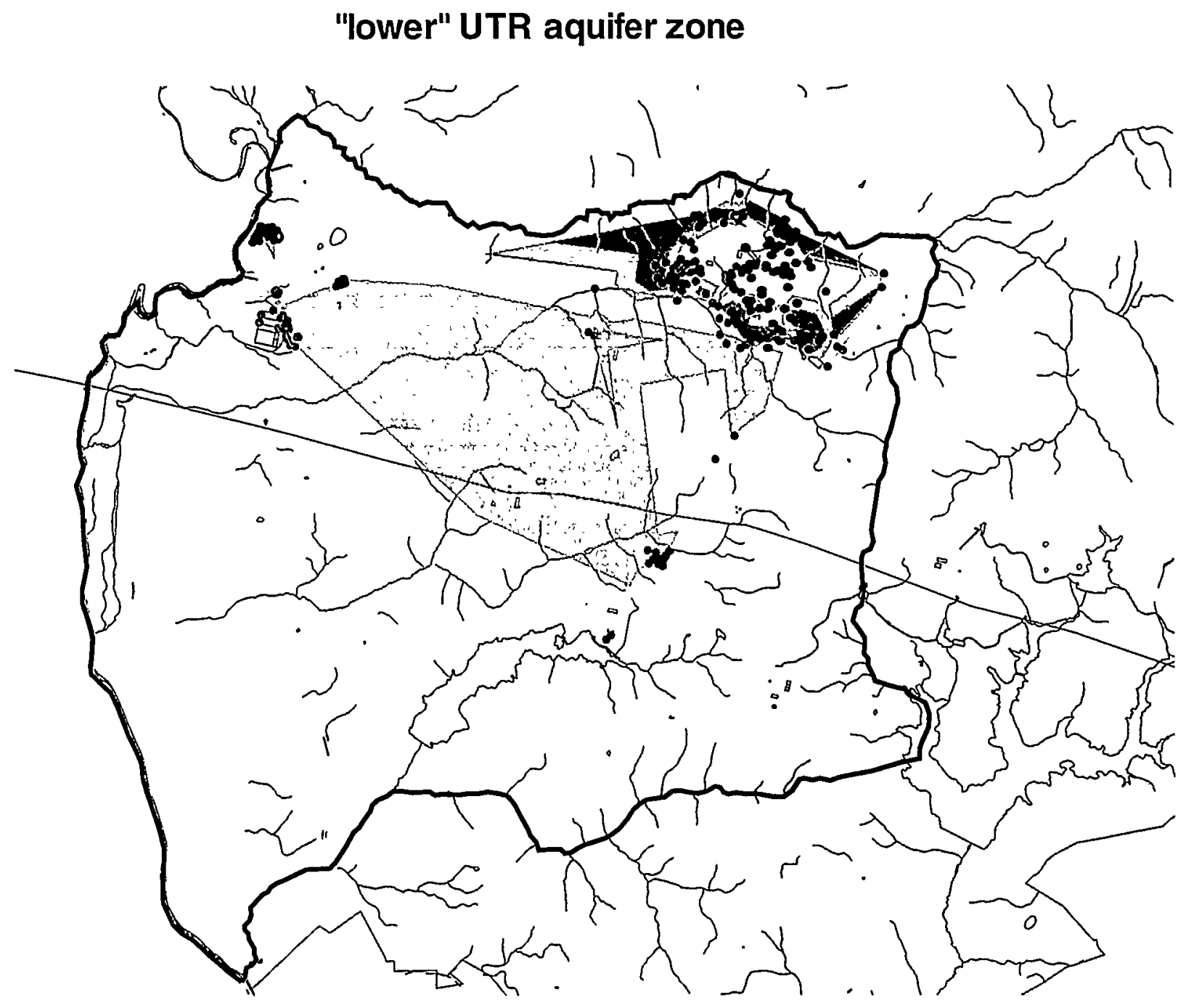

residual

(ft)

16

12

8
4
0
-4
-8
-1

$-16$

Figure G-4-3 (uncertainty case 4; compare to Figure 4-3) 


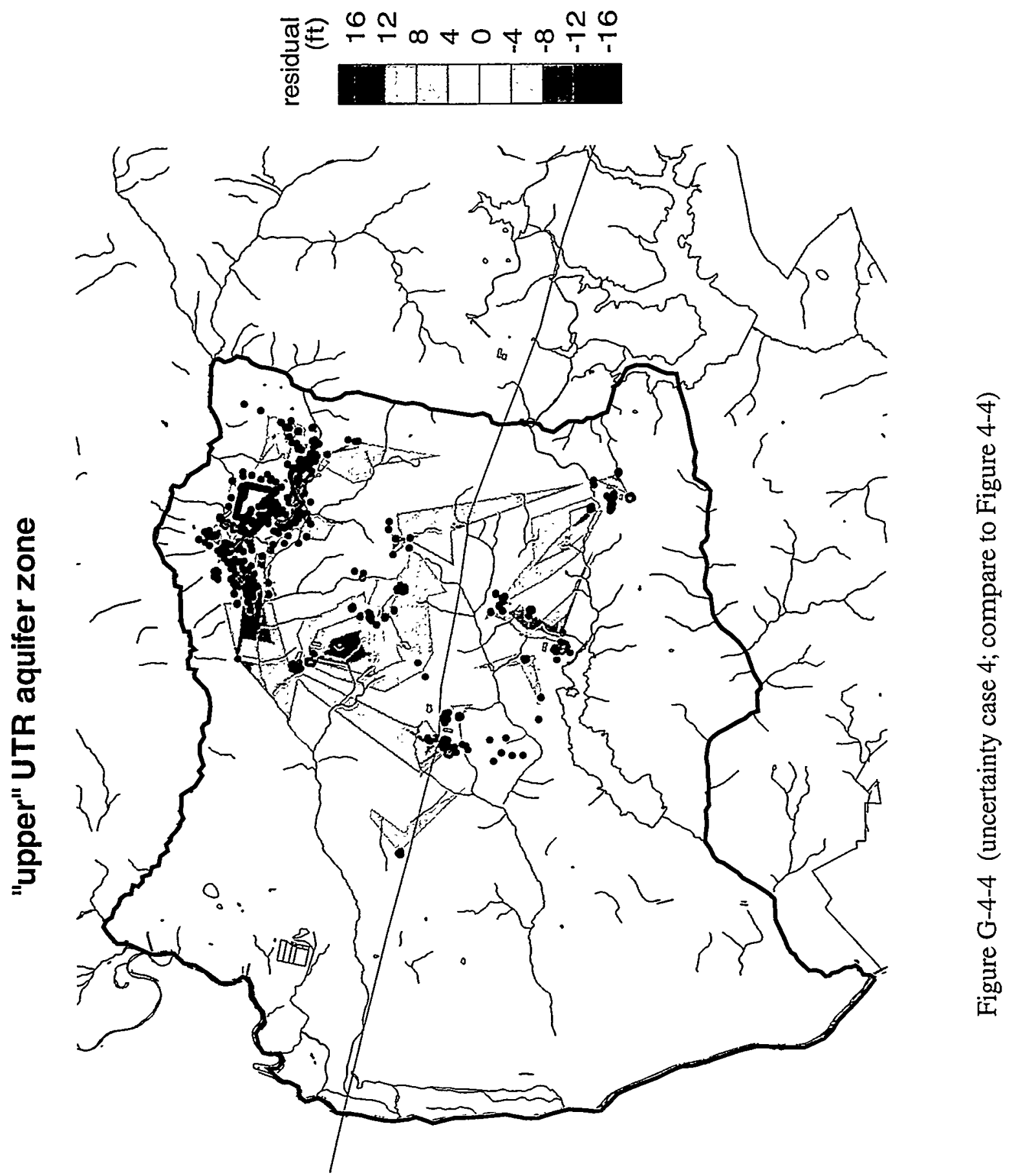




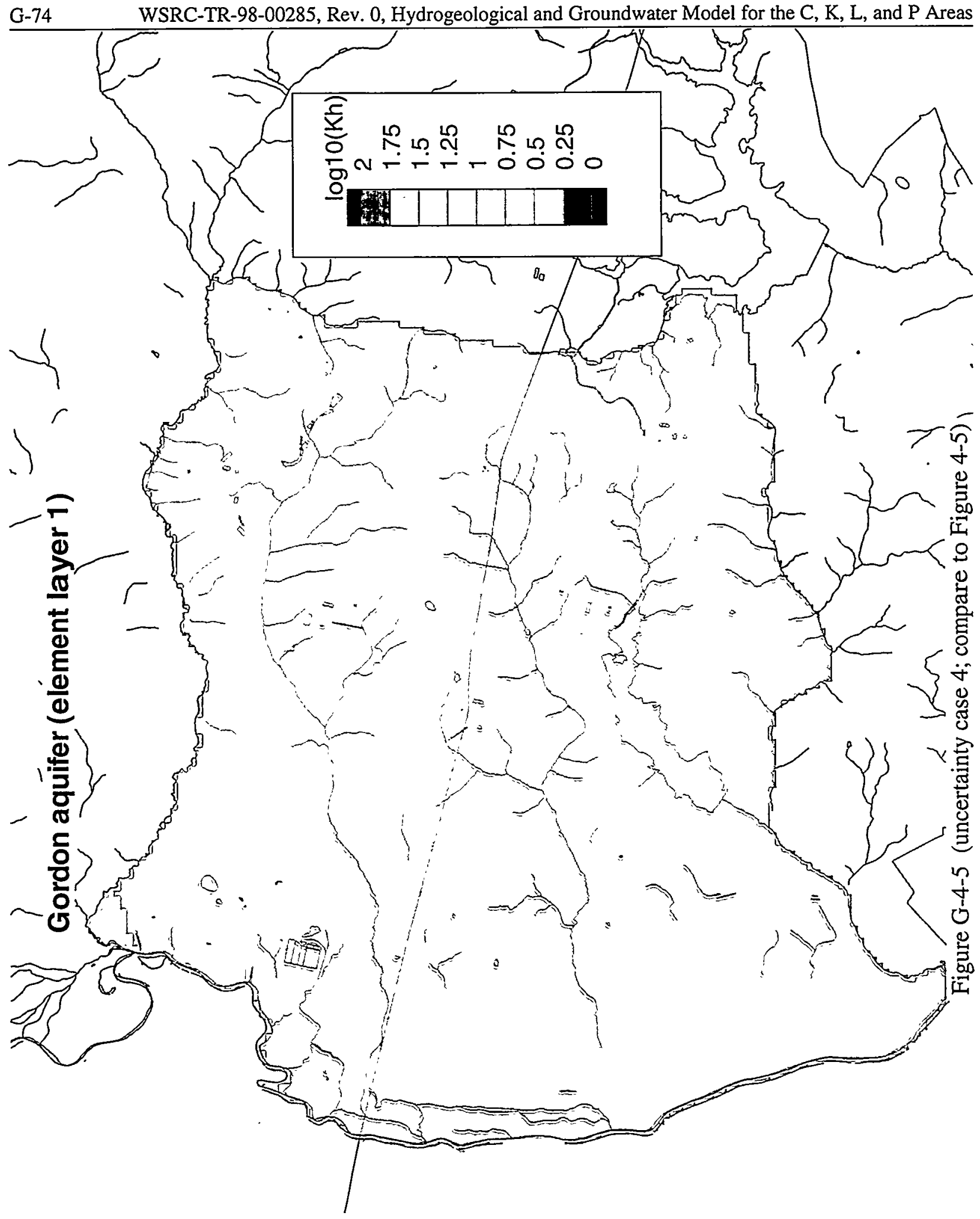




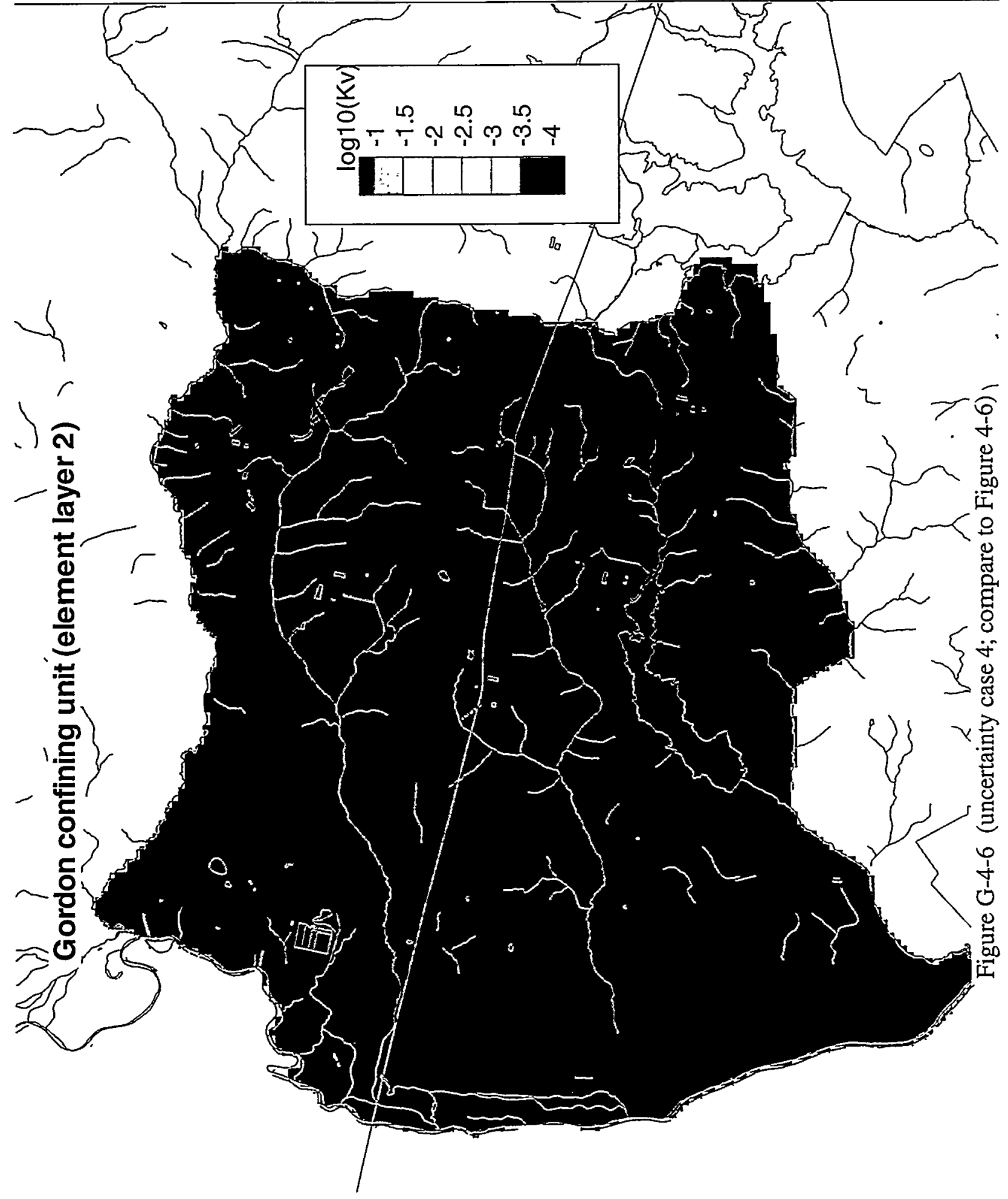




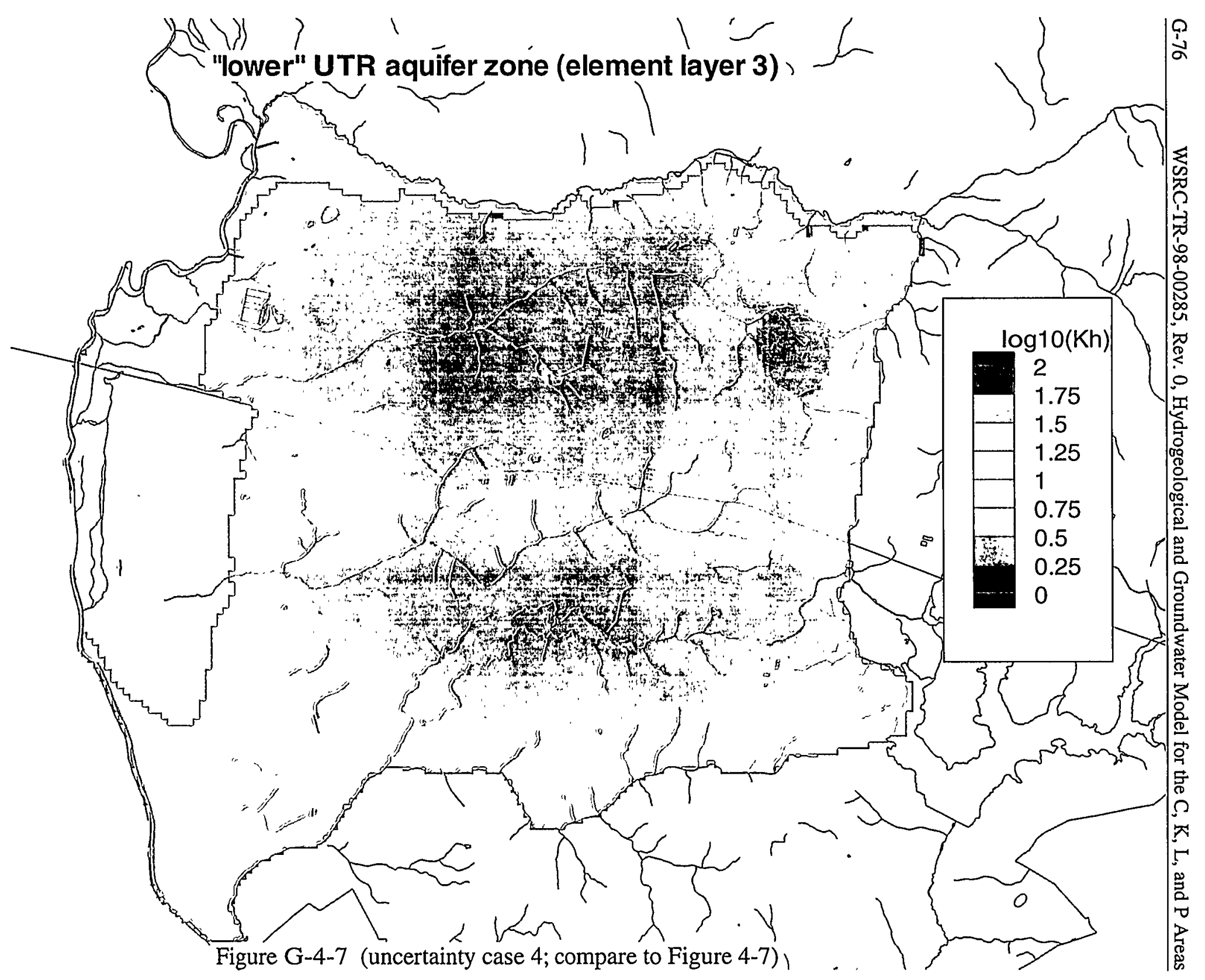




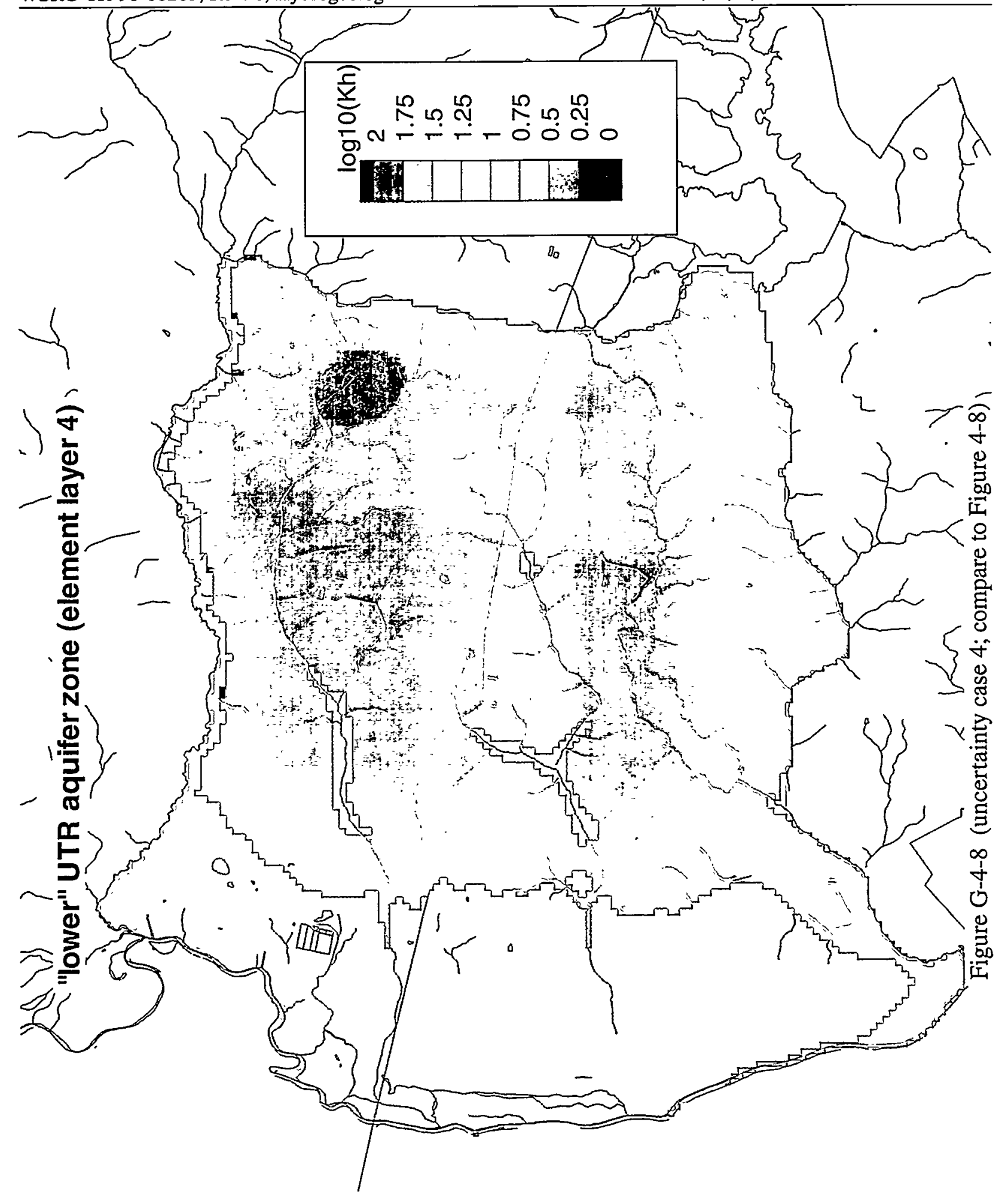




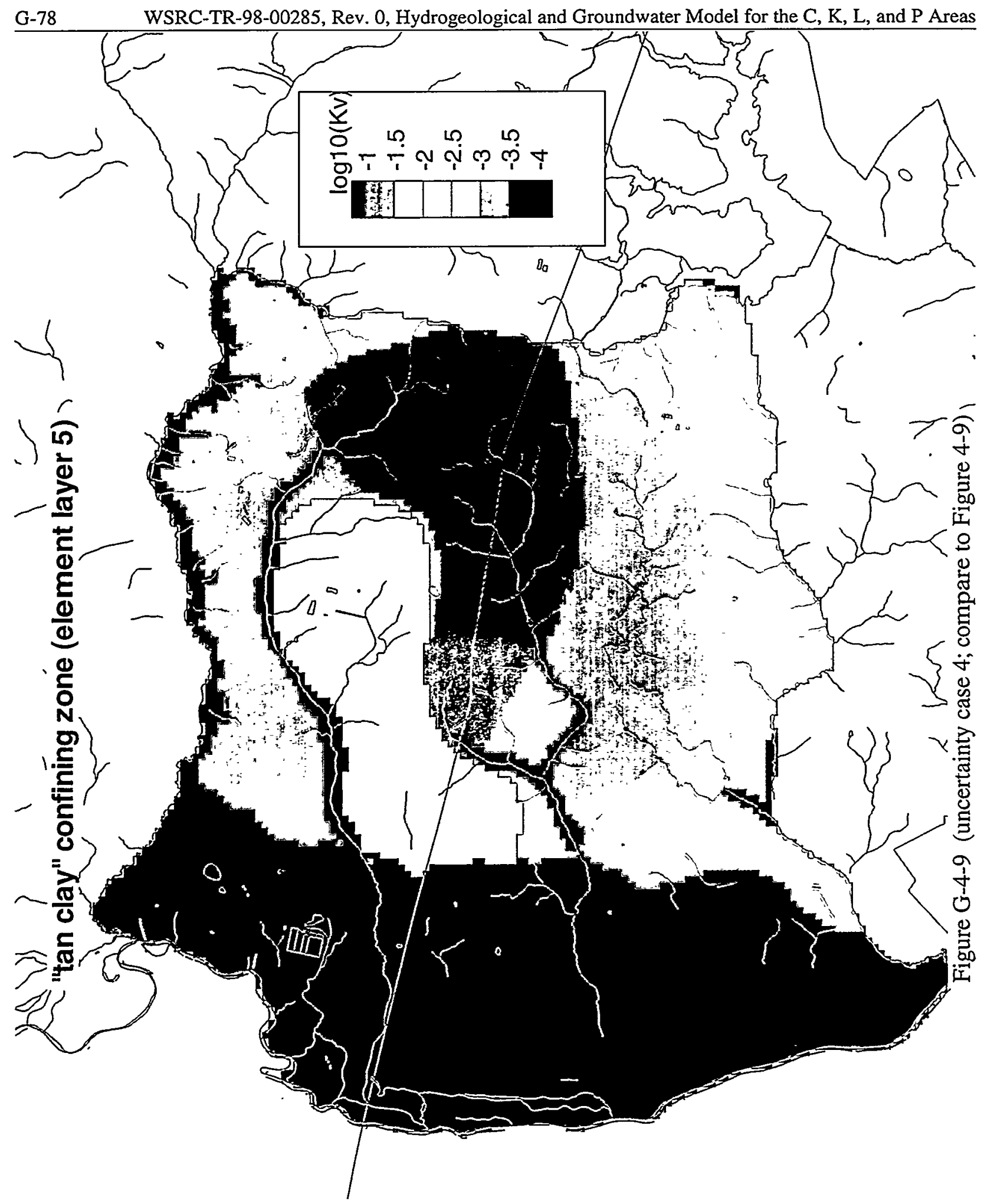




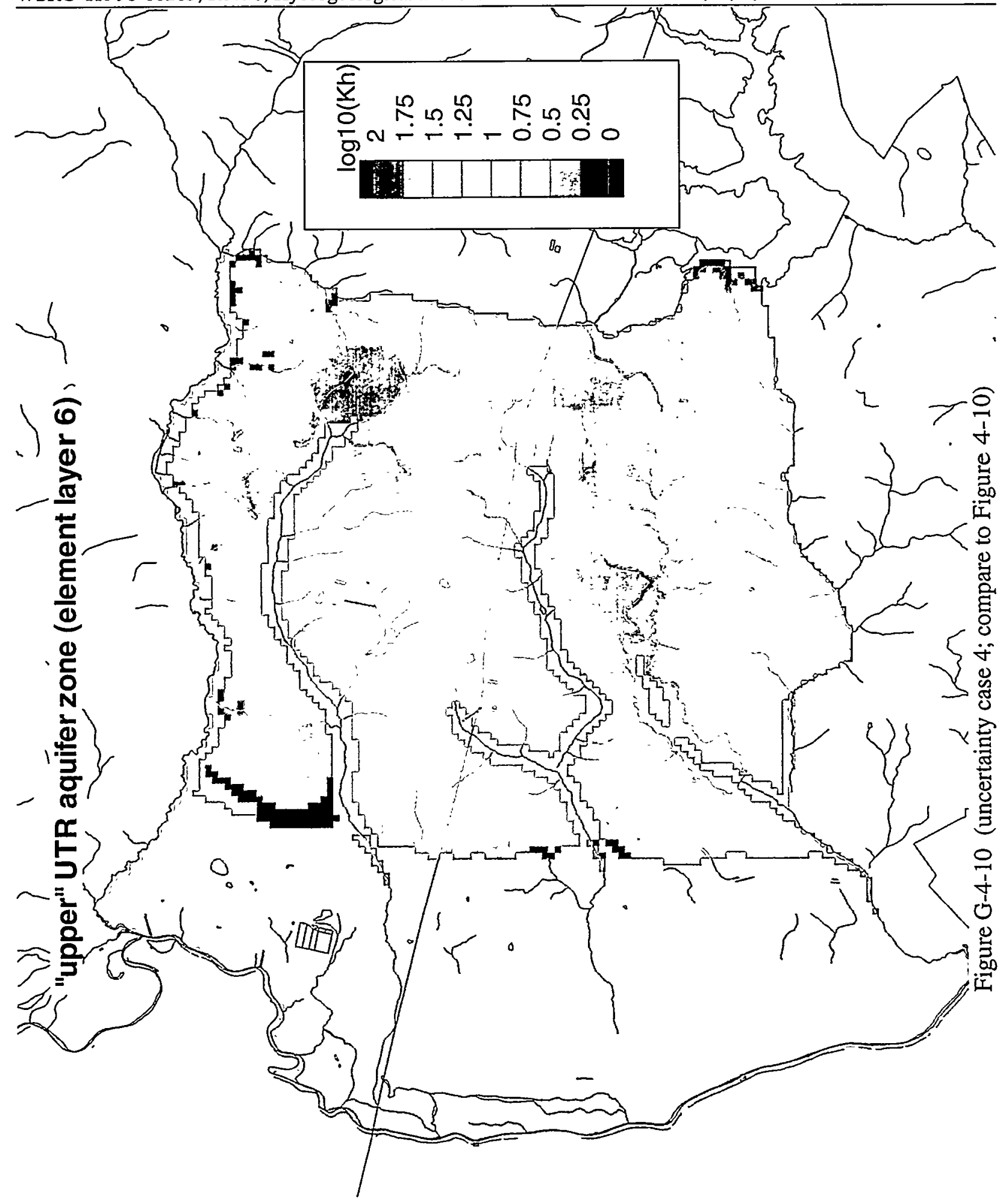




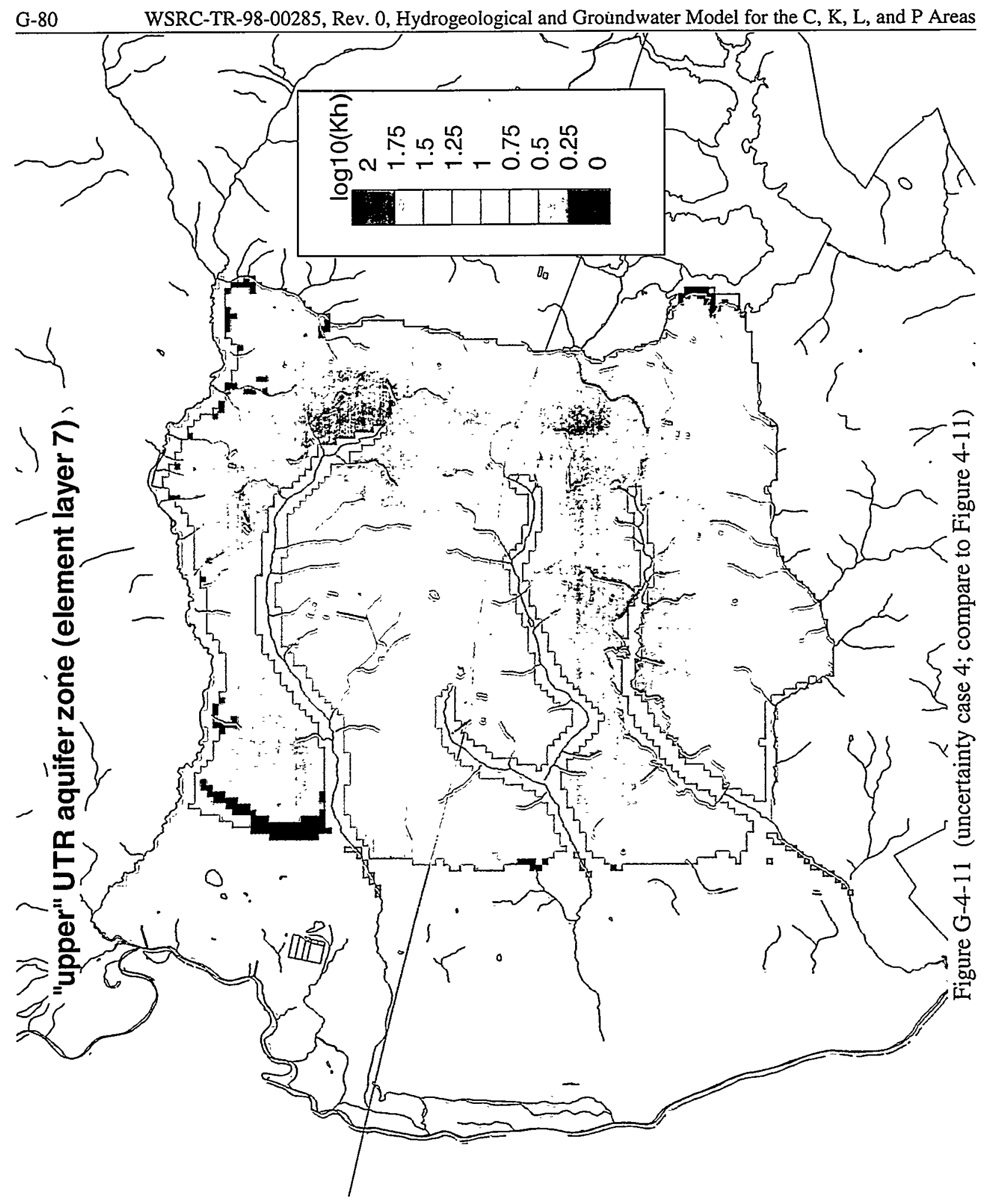




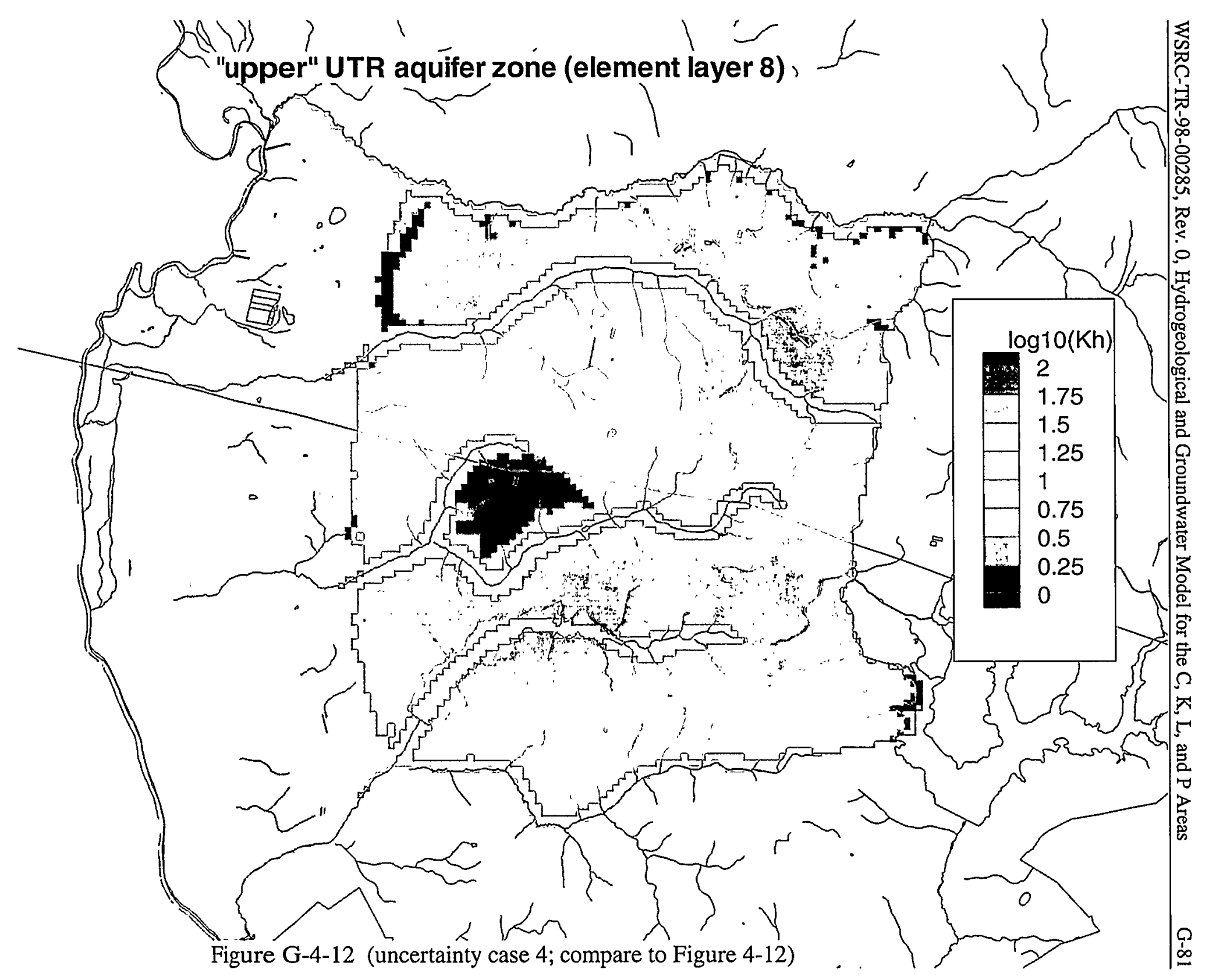




\section{Simulated hydraulic head in Gordon aquifer}

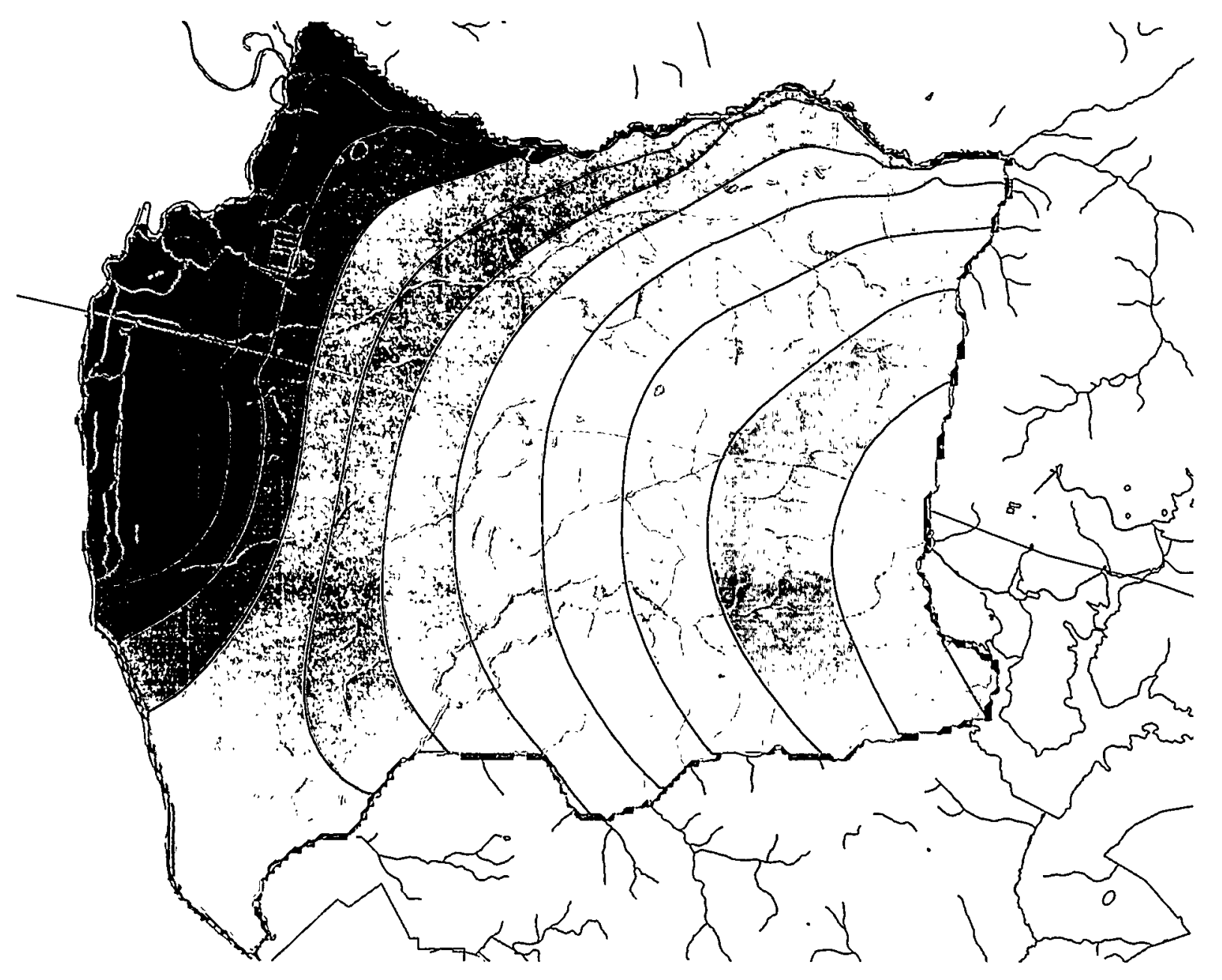




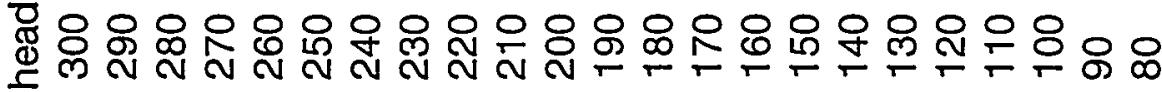

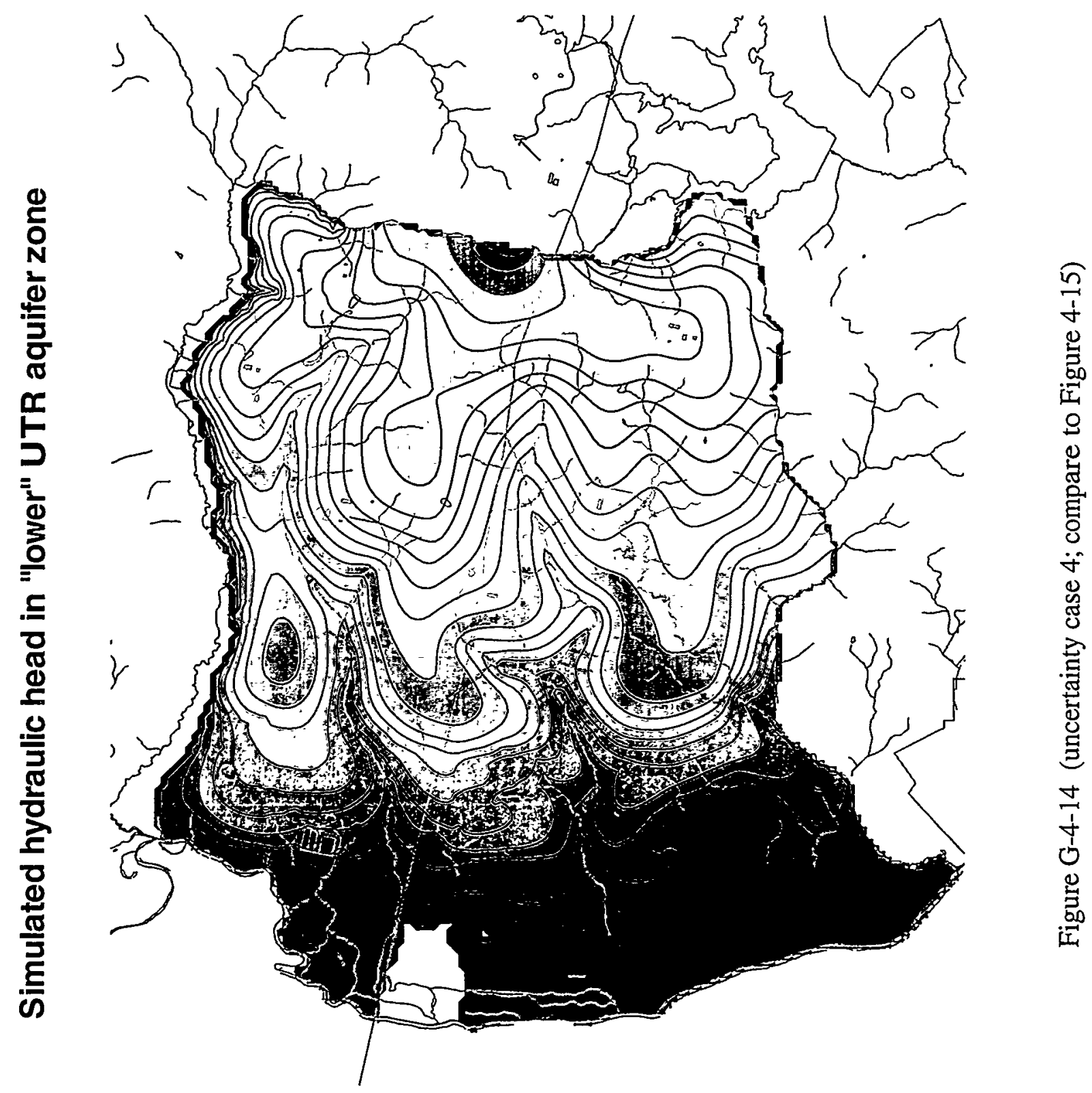


Simulated hydraulic head in "upper" UTR aquifer zone

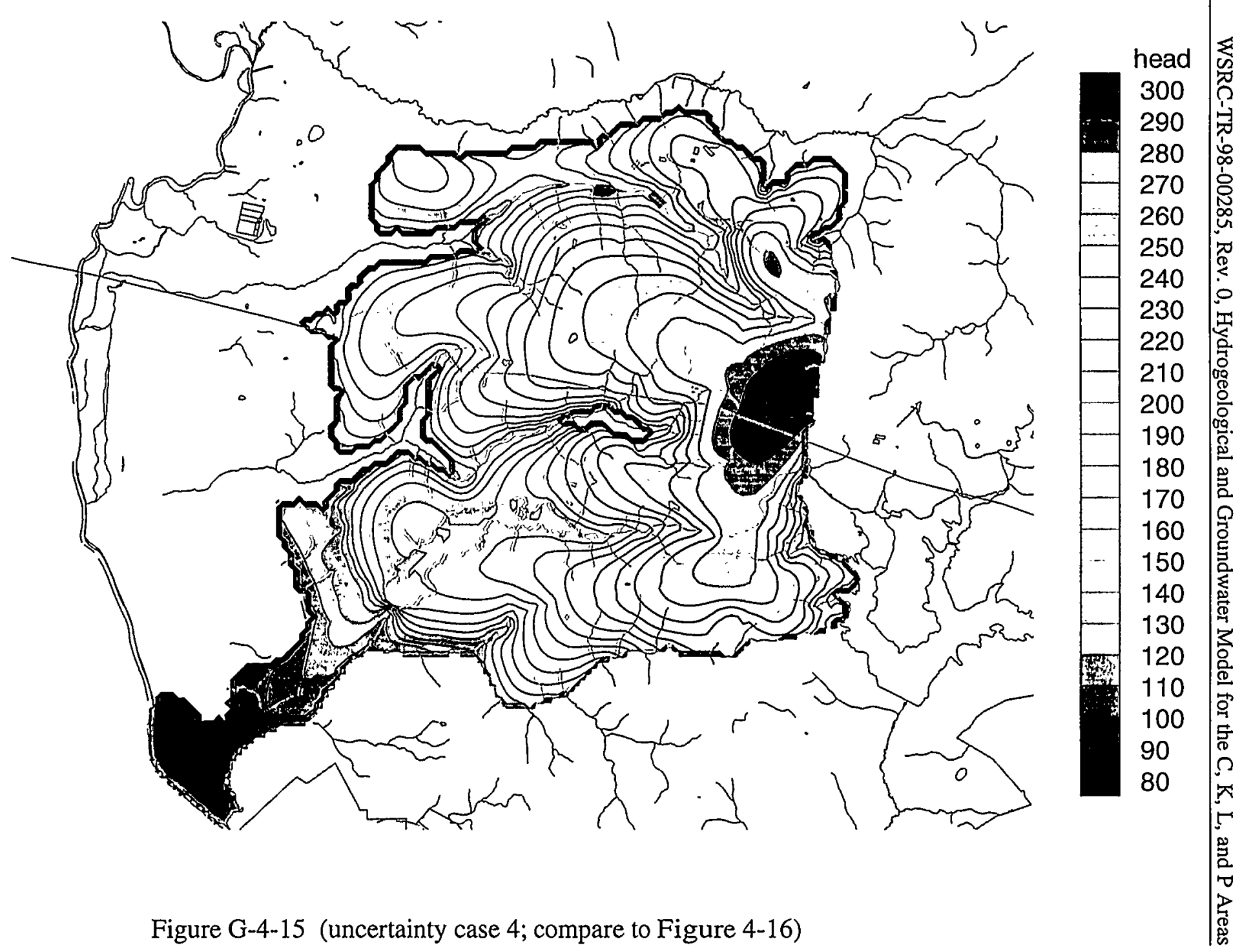




\section{Simulated hydraulic head in aquifer zone containing water table}

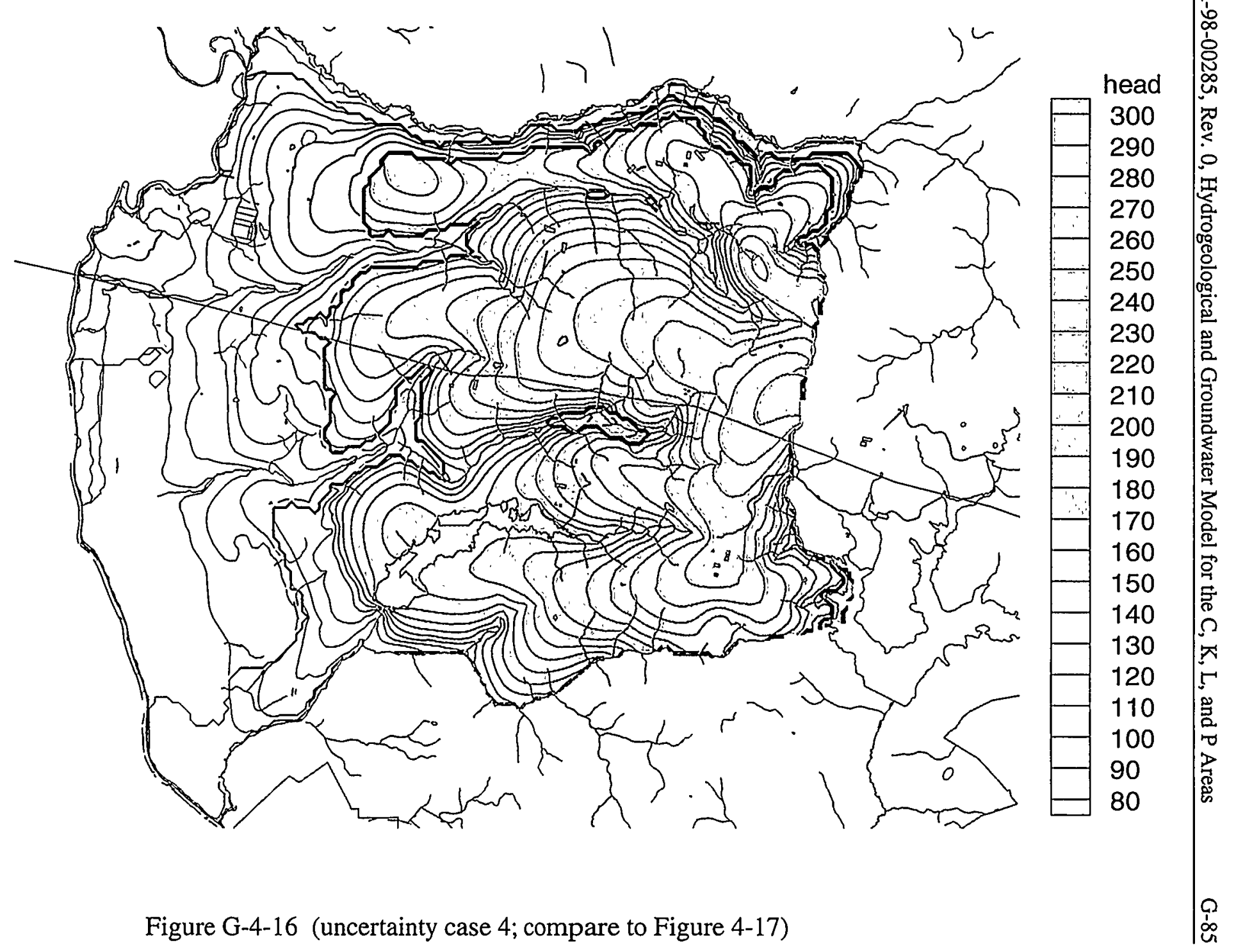




\section{Simulated water table elevation}

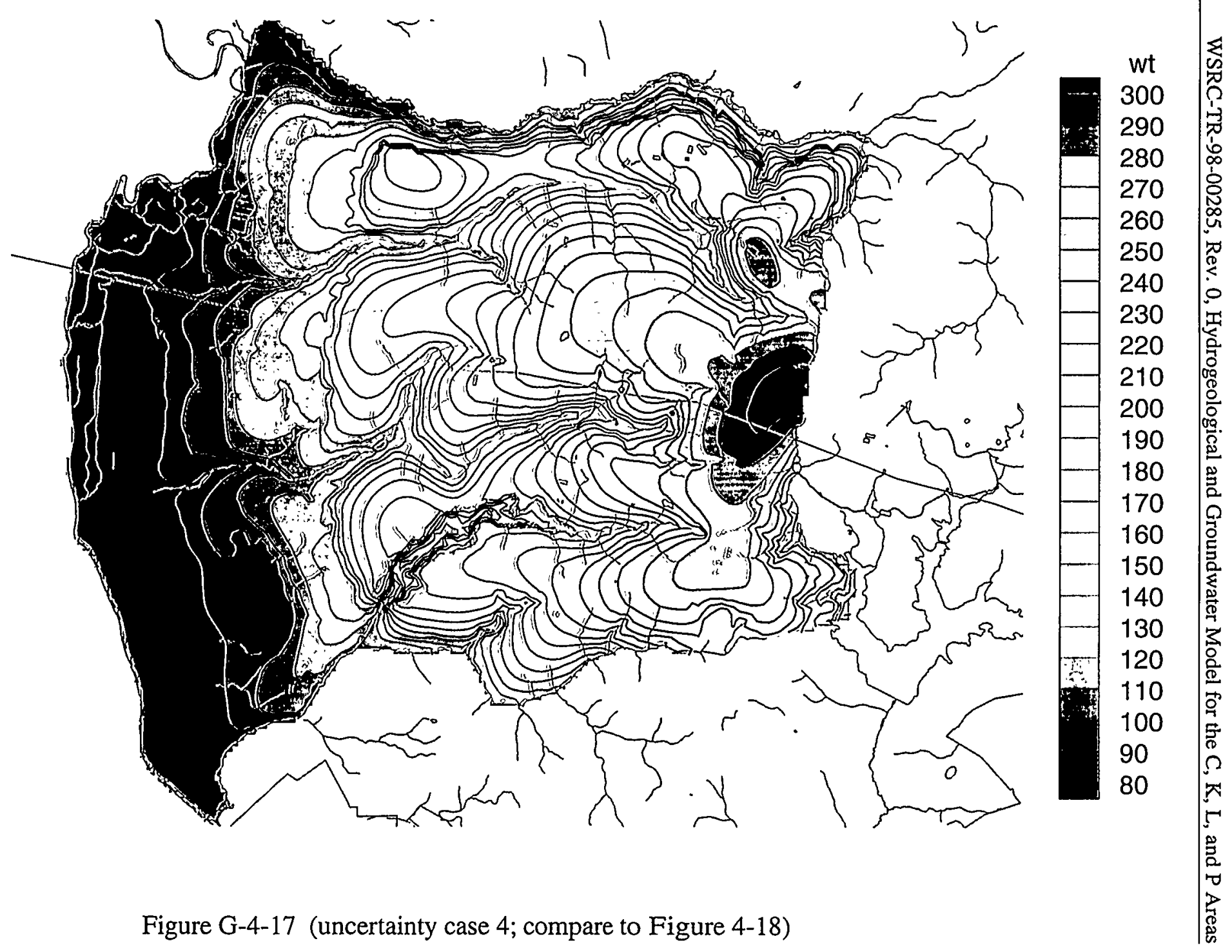




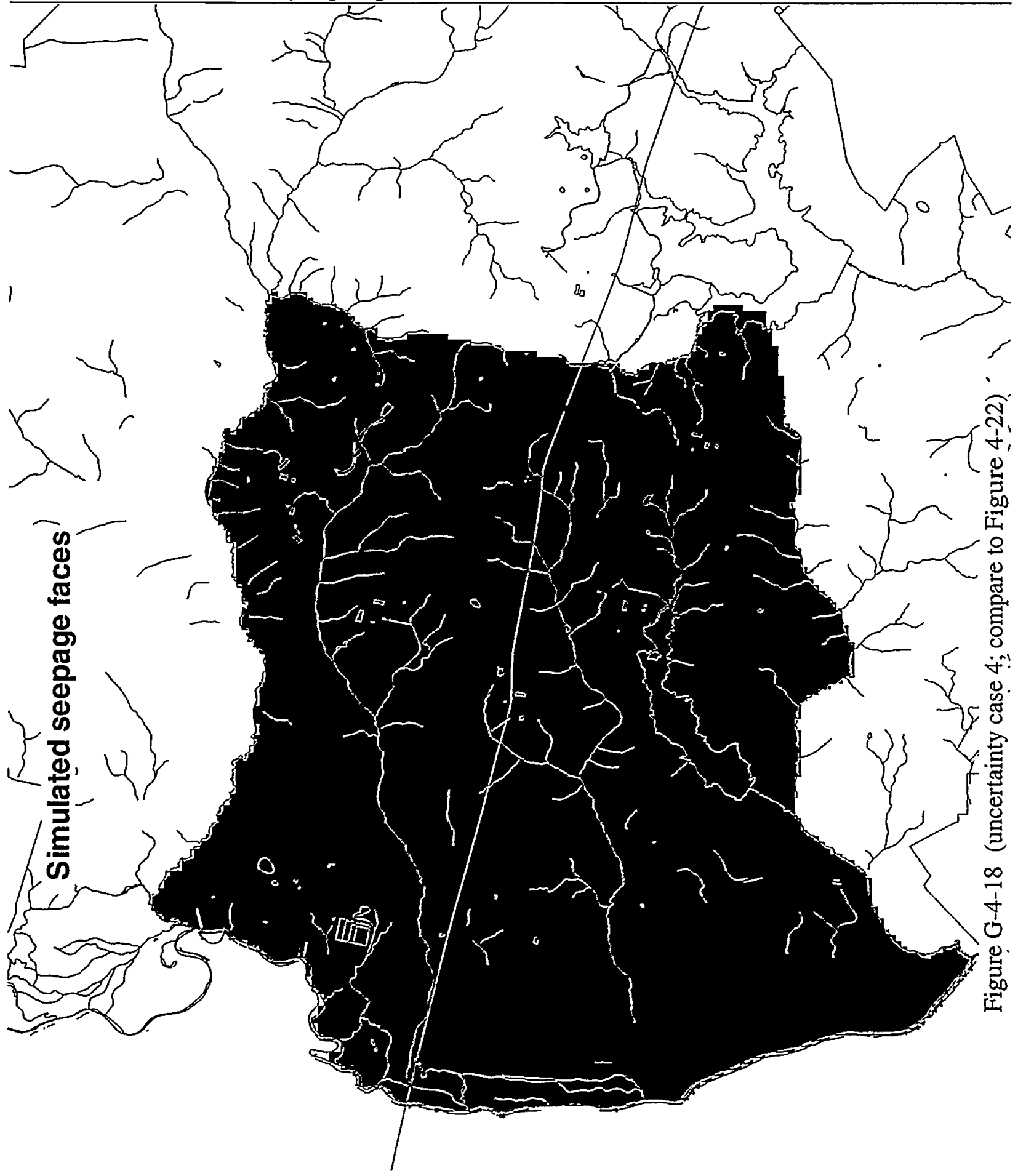




\section{Simulated groundwater recharge (discharge)}

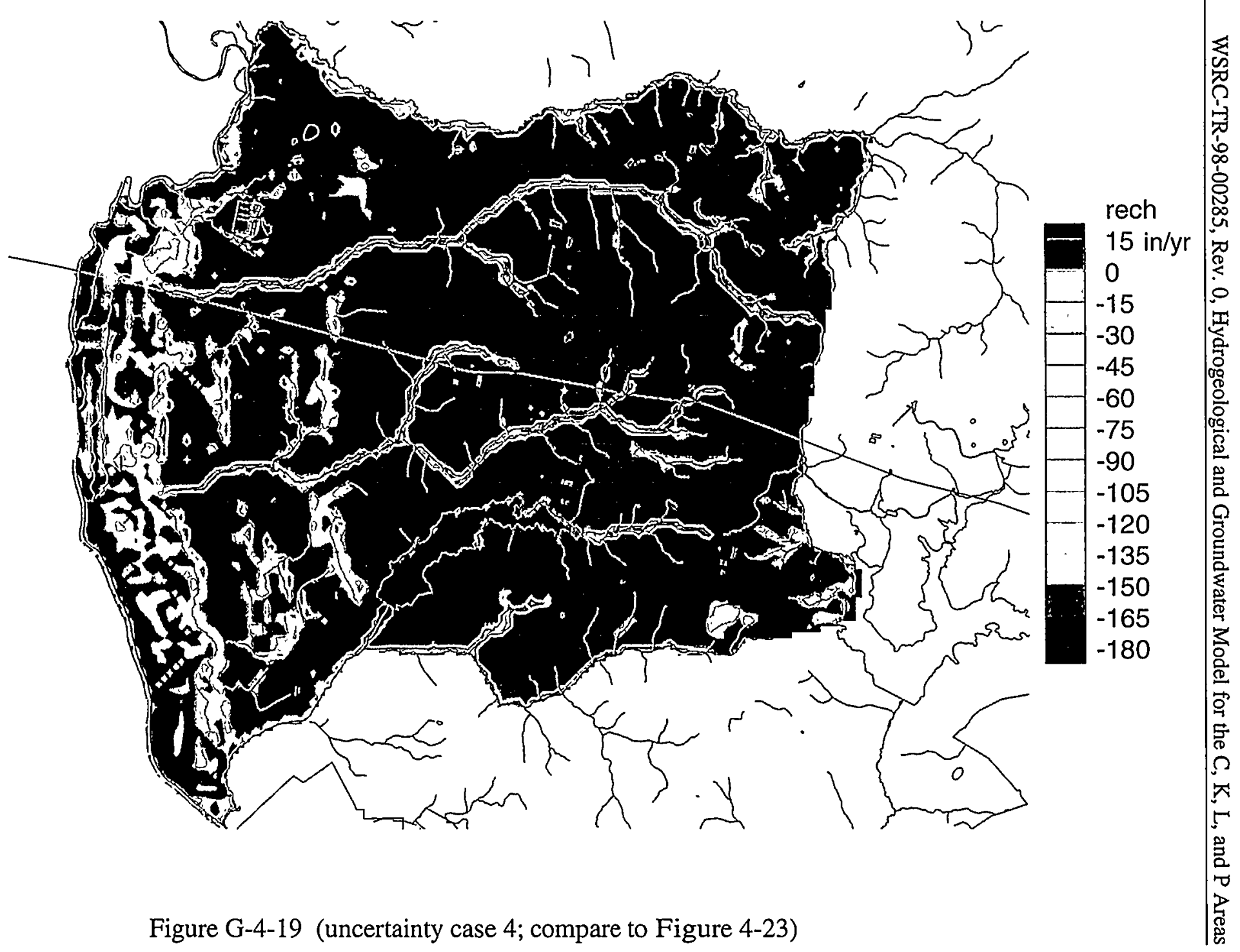


WSRC-TR-98-00285, Rev. 0, Hydrogeological and Groundwater Model for the C, K, L, and P Areas _ـ_ G-89

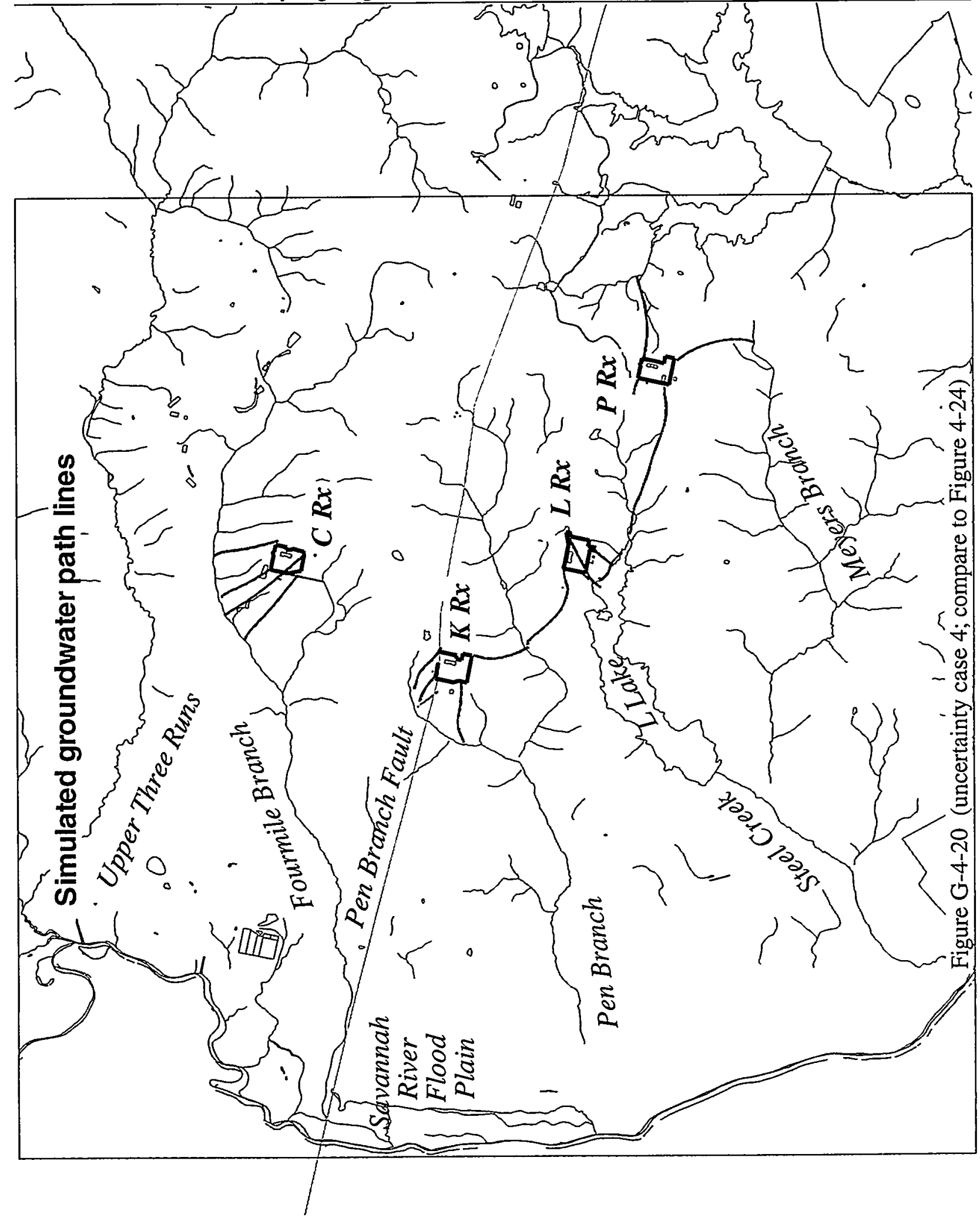


This page intentionally left blank 